University of Nebraska - Lincoln

DigitalCommons@University of Nebraska - Lincoln

1967

\title{
Paleotectonic Investigations of the Permian System in the United States
}

\author{
Edwin D. McKee \\ Stephen S. Oriel \\ Henry L. Berryhill \\ Eleanor J. Crosby \\ Donald A. Myers
}

See next page for additional authors

Follow this and additional works at: https://digitalcommons.unl.edu/usgspubs

Part of the Geochemistry Commons, Geology Commons, Geomorphology Commons, Hydrology Commons, and the Other Earth Sciences Commons

This Article is brought to you for free and open access by the US Geological Survey at DigitalCommons@University of Nebraska - Lincoln. It has been accepted for inclusion in Publications of the US Geological Survey by an authorized administrator of DigitalCommons@University of Nebraska - Lincoln. 


\section{Authors}

Edwin D. McKee, Stephen S. Oriel, Henry L. Berryhill, Eleanor J. Crosby, Donald A. Myers, George H. Dixon, Marjorie E. MacLachlan, Melville R. Mudge, Edwin K. Maughan, Richard P. Sheldon, Earl R. Cressman,

Thomas M. Cheney, Walter E. Hallgarth, and Keith B. Ketner 


\section{Paleotectonic Investigations of the Permian System in the United States}

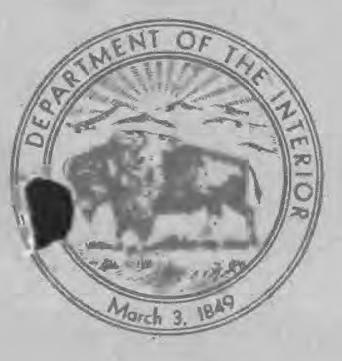

2.

)

GEOLOGICAL SURVEY PROFESSIONAL PAPER 515
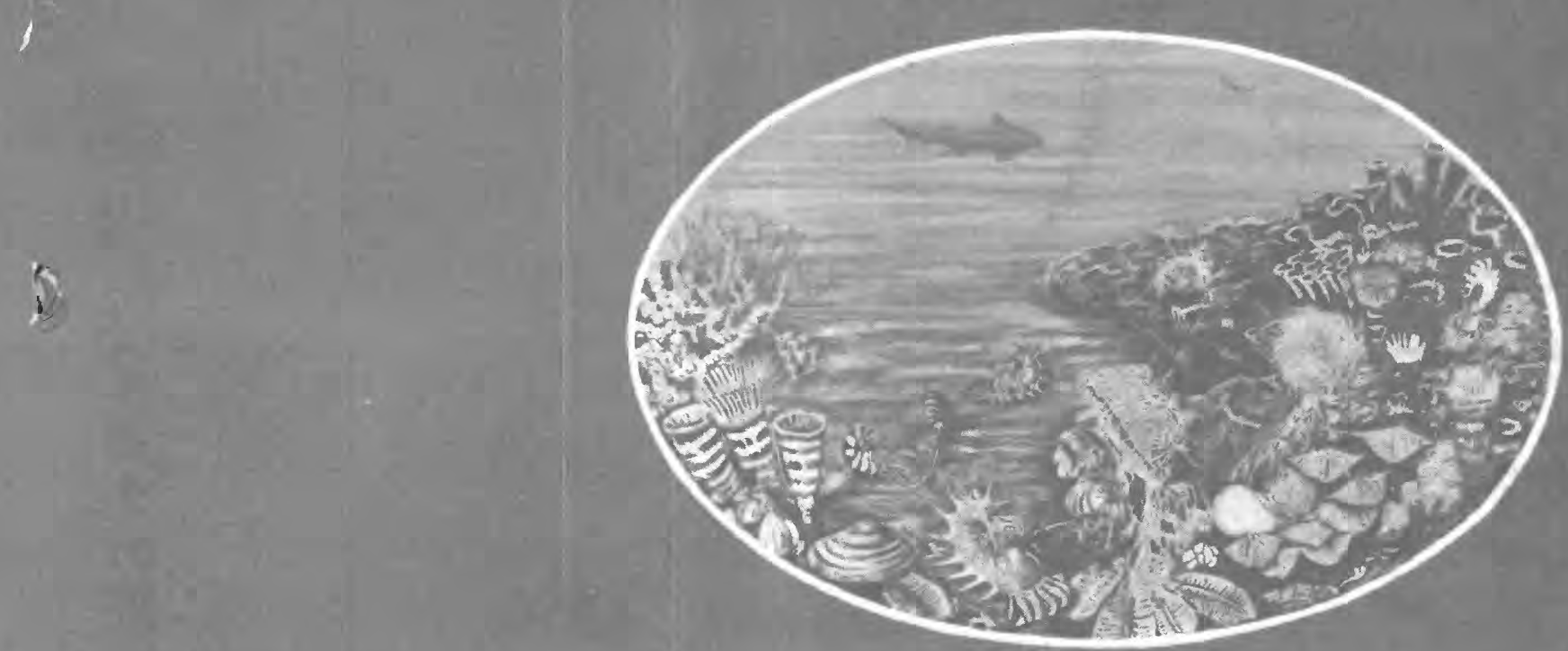
1 PERMIAN SYSTEM IN THE UNITED STATES 
RECONSTRUCTION OF SEASCAPE IN GLASS MOUNTAIN AREA, BREWSTER COUNTY, TEXAS, DURING MIDDLE PART (LEONARD) OF PERMIAN TIME

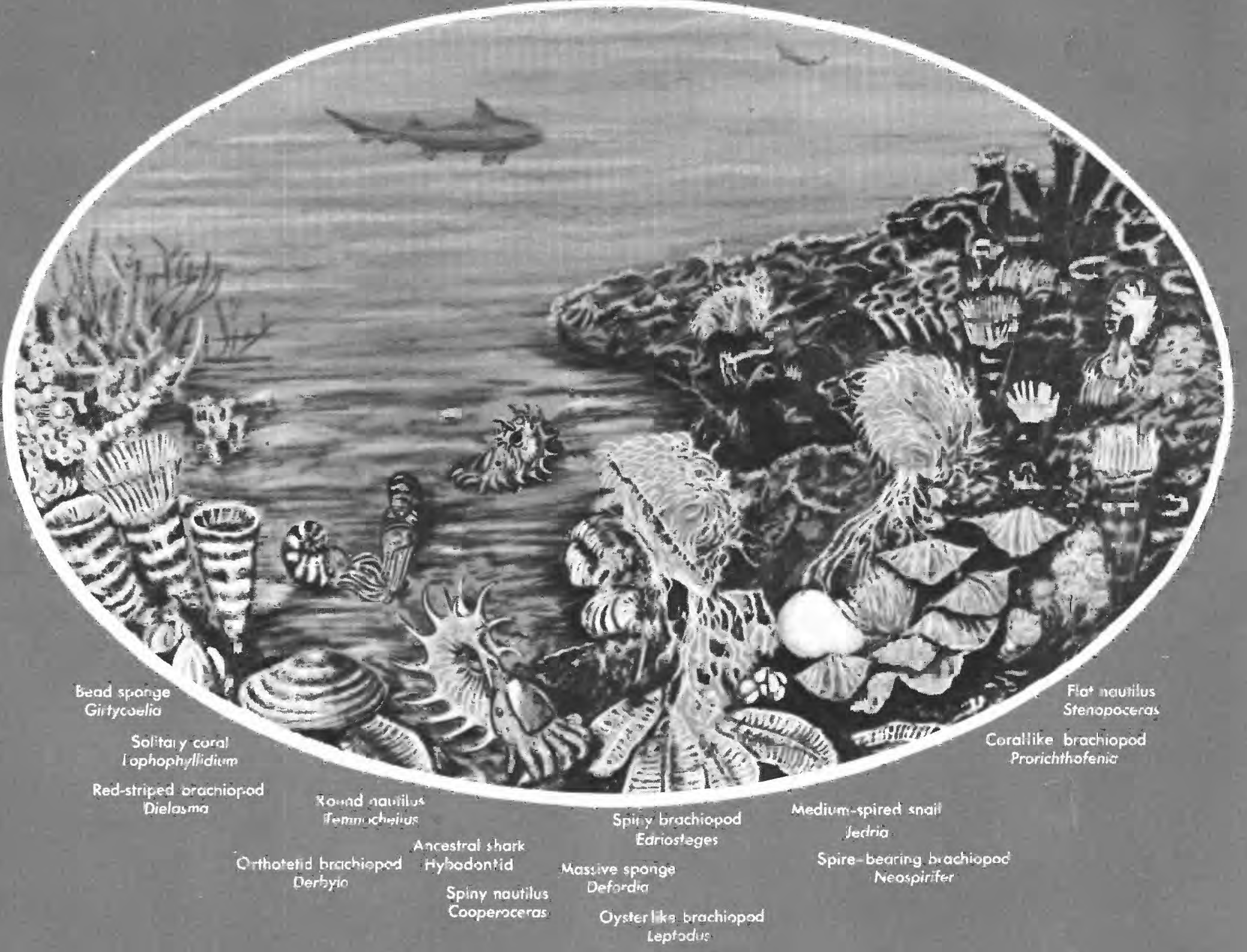

The reconstruction is based on a diorama prepared by George Marchard for the U.S. National Museum. Technical assistance for the reconstruction was furnished by G. Arthur Cooper and G. Edward Lewis. 


\section{Paleotectonic Investigations}

of the Permian System in the United States

By E. D. McKEE, S. S. ORIEL, and others

GEOLOGICAL SURVEY PROFESSIONAL PAPER 515

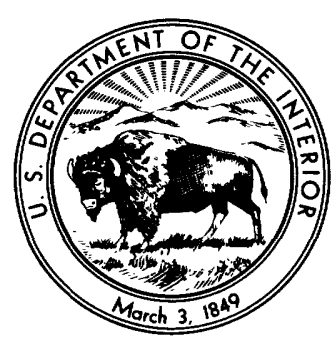




\title{
UNITED STATES DEPARTMENT OF THE INTERIOR STEWART L. UDALL, Secretary GEOLOGIGAL SURVEY William T. Pecora, Director
}

Library of Congress catalog-card No. GS 67-194

\author{
First printing 1967 \\ Second printing 1968
}

For sale by the Superintendent of Documents, U.S. Government Printing Office Washington, D.C. 20402 - Price \$4 (paper cover) 


\section{PREFACE}

This professional paper is a supplementary volume to "Paleotectonic Maps of the Permian System" by McKee, Oriel, and others (1967), published by the U.S. Geological Survey as Miscellaneous Geologic Investigations Map I-450. The I-450 publication consists of 20 plates-isopach and lithofacies maps, cross sections to accompany the maps, and interpretive and environmental maps-and a summary of available geological information on each part of the Permian Period, an interpretation or reconstruction of Permian history, and brief discussions of environment, tectonics, and other significant features. The present volume explains and documents the maps and conclusions presented there. This study of the Permian System was made by 15 geologists, who were individually responsible for coverage of 18 regions. These authors are:

Henry L. Berryhill, Jr.

Thomas M. Cheney

Earl R. Cressman

Eleanor J. Crosby

George H. Dixon
Walter E. Hallgarth

Keith B. Ketner

Marjorie E. MacLachlan

Edwin K. Maughan

Edwin D. McKee
Vincent E. McKelvey

Melville R. Mudge

Donald A. Myers

Steven S. Oriel

Richard P. Sheldon

The Permian System of the 18 regions is described in 11 chapters. Each chapter presents an analysis of the basic data used, points out significant trends, and presents an interpretation, as well as alternative explanations where each occur, for the region concerned. The chapters and accompanying illustrations were coordinated and assembled by E. J. Crosby, E. D. McKee, W. W. Mallory, E. K. Maughan, and S. S. Oriel.

Descriptive and documentary data are organized according to region, from east to west, and according to chronological sequence. Each chapter discusses, in order, rocks that underlie the Permian, the several intervals or divisions of the Permian (from oldest to youngest (table 1, in pocket) ), and, finally, the rock units that directly overlie the Permian. Stratigraphic problems, the nature of contacts, trends in thickness and lithology, possible sources of sediment, environments of deposition, and paleotectonic implications of each interval are treated in that order.

It is necessary to divide the Permian System to prepare meaningful lithofacies-thickness maps. The system includes thick sequences of rocks of diverse origins, resulting from multiple geologic events, so a lithofacies map for the entire system would be largely unintelligible.

In this paper, as in I-450, the primary division of the Permian System is threefold: intervals A, B, and C-D, in ascending order (table 1, in pocket). An interval is composed of assemblages of members, formations, and groups that lie mainly between recognizable lithologic contacts which may not and commonly do not coincide with isochronous surfaces. Use of the informal term "interval" and the means for recognizing interval boundaries were discussed by McKee and others $(1959$, p. 5). The intervals can be recognized nearly everywhere that they occur in the United States, so that comparison of genetically related events can be made between areas.

The third major division of the Permian System has been given a two-letter designation because of unsolved problems regarding precise age assignments of uppermost Permian units. Strata above those assigned to interval B cannot be subdivided consistently in much of the western interior. In west Texas and southeastern New Mexico, however, such strata are commonly separated into two units, the Guadalupe and Ochoa Series, here designated as intervals $\mathrm{C}$ and $\mathrm{D}$, respectively. A principal unanswered question is whether rocks in interval 
C-D in other parts of the country are correlative with rocks in interval $\mathrm{C}$ or in both intervals $\mathrm{C}$ and $\mathrm{D}$ in west Texas.

Assignment of rocks to the Permian intervals adopted here is based largely on relations shown in the Permian correlation chart of the Committee on Stratigraphy of the National Research Council (Dunbar and others, 1960). The authors are particularly grateful to the Permian Subcommittee and to Carl O. Dunbar, chairman, for providing a manuscript copy of this chart and the accompanying text prior to publication.

Some interval assignments in this paper suggest age relations different from those indicated on the correlation chart. Most such differences stem from problems in Permian correlation that are discussed by Dunbar and others (1960, p. 1773-1778). These involve both nonfossiliferous rocks whose stratigraphic positions and relations are not known precisely and fossiliferous rocks whose faunal zones cannot be related directly to the standard assemblage zones most commonly used in Permian correlations. These and related problems, as well as resulting divergent interpretations, are reviewed in the discussions on each interval.

A general correlation of Permian rock-stratigraphic units in the United States exclusive of Alaska and Hawaii is given in table 1 (in pocket). Relative stratigraphic positions are shown within columns, each of which is made for a large area. Rock units in this chart are arranged in horizontal rows corresponding to the Permian intervals. Few details of correlation are attempted in this chart; overlap, facies change, and intertonguing stratigraphic relations are barely suggested, and the time span represented by each formation is shown only in a general way. Attempts to depict such relations more precisely are made in a correlation chart prepared by Dunbar and others (1960).

In table 1 and throughout this paper, stratigraphic names that have not been adopted by the U.S. Geological Survey and those for which there has been no occasion for official action are shown in italics. Drillers' terms and names of rock units that are defined by economic significance are italicized also.

Stratigraphic names adopted by the Geological Survey are not italicized, but where such names are applied locally to rock units that are either definitely not or probably not the same as those of the type area, the names are enclosed in quotation marks.

The authors are indebted to many individuals and organizations for basic data and ideas. Especially noteworthy contributions have been made by those listed below (affiliations as of December 1960) : W. L. Adkison, E. H. Baltz, W. M. Cady, L. V. Davis, C. L. Jones, W. R. Keefer, P. B. King, J. D. Love, C. B. Read, C. A. Sandberg, and J. M. Schopf of the U.S. Geological Survey; H. G. Hershey, Iowa Geological Survey; E. D. Goebel and D. F. Merriam, Kansas Geological Survey, anḍ J. D. McNeal, Kansas Highway Department; R. A. Bieberman and R. W. Foster, New Mexico Bureau of Mines and Mineral Resources; W. M. Laird, North Dakota Geological Survey; R. J. Bernhagen, R. A. Brant, and G. H. Denton, Ohio Geological Survey; R. L. Fay, W. E. Ham, and Louise Jordan, Oklahoma Geological Survey; Carlyle Gray and W. R. Wagner, Pennsylvania Geological Survey; A. F. Agnew, South Dakota Geological Survey, and J. P. Gries, South Dakota School of Mines; P. T. Flawn, Texas Bureau of Economic Geology; P. H. Price, Thomas Arkle, Jr., and W. R. McCord, West Virginia Geological Survey; H. D. Thomas, Wyoming Geological Survey ; J. W. Harshbarger, University of Arizona; John Chronic and W. O. Thompson, University of Colorado; C. C. Branson, University of Oklahoma; R. K. DeFord, University of Texas; D. W. Boyd, University of Wyoming; C. O. Dunbar, Yale University; Well Sample Laboratory, Museum of Northern Arizona; J. R. Clair; H. N. Frenzel; E. W. Owen; John Green and J. G. Mitchell, American Stratigraphic Co.; A. E. Dufford, H. L. Ellinwood, and C. J. McGinnis, The California Co.; W. R. Atkinson and H. R. Wingerter, Colorado Oil \& Gas Corp.; J. W. Strickland, Continental Oil Co.; M. S. Houston, Eldorado Refining Co.; Don Gilkison and R. C. Norman, Gulf Oil Corp.; J. B. Coughman, R. D. Holt, T. A. McCarty, R. I. Roth, J. W. Skinner, and G. L. Wilde, Humble Oil \& Refining Co.; J. D. Davis, Kansas Sample Log Service; D. W. Franklin, Ohio Oil Co.; Lloyd Pray, Ohio Oil Research Center; R. V. Hollingsworth and H. L. Williams, Paleontological Laboratory, Inc.; N. T. Brasher, E. D. 
Clements, J. J. Gill, R. C. Linden, and G. J. Verville, Pan American Petroleum Corp.; R. G. Clausing and J. K. Curry, Panhandle Eastern Pipe Line Co.; E. R. Hill, P. H. Kolm, and W. W. West, Permian Basin Sample Laboratory; O. E. Childs, W. W. Mallory, and Addison Young, Phillips Petroleum Co.; J. C. Maher, Pure Oil Co.; M. L. Peterson and D. L. Baars, Shell Oil Co.; A. L. Bowsher, Sinclair Oil \& Gas Co.; W. F. Bailey, Skelly Oil Co.; J. E. Adams and William McBee, Jr., Standard Oil Co. of Texas; R. B. Totten, Sun Oil Co.; B. J. Cunningham and I. D. Taylor, Texas Panhandle Sample Log Service. 
-

, 


\section{CONTENTS}

\section{)}

[Ietters designate the separate chapters]

(A) Allegheny region, by Henry L. Berryhill, Jr.

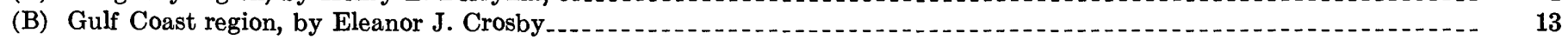

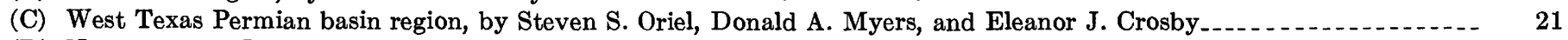

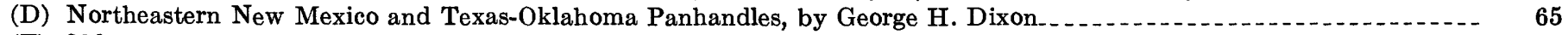

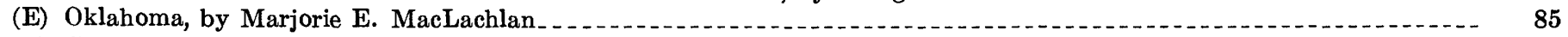

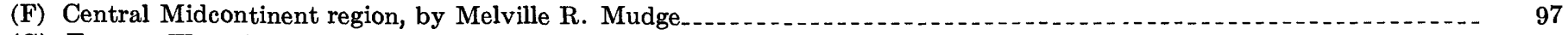

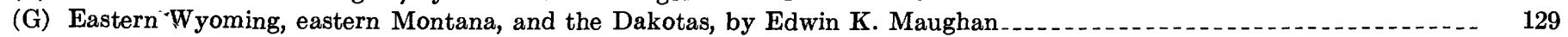

(H) Middle Rocky Mountains and northeastern Great Basin, by Richard P. Sheldon, Earl R. Cressman, Thomas M. Cheney, and Vincent E. McKelvey.

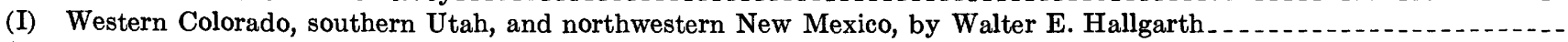

(J) Arizona and western New Mexico, by Edwin D. McKee...

(K) West Coast region, by Keith B. Ketner.

References cited.

Index 
$r$

, 


\section{Paleotectonic Investigations}

of the Permian System

in the United States

Chapter A. Allegheny Region

$B y$ HENRY L. BERRYHILL, JR.

GEOLOGICAL SURVEY PROFESSIONAL PAPER 515-A

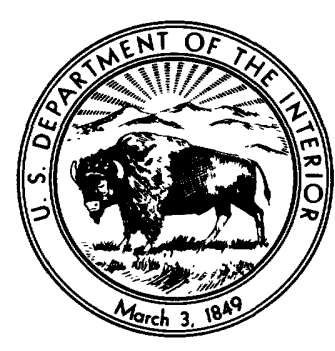




\section{CONTENTS}

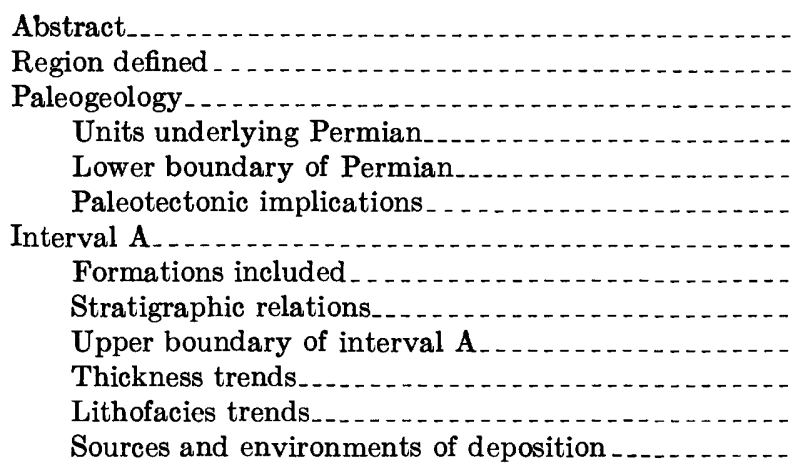

\begin{tabular}{r|} 
Page \\
1 \\
1 \\
2 \\
2 \\
2 \\
2 \\
2 \\
2 \\
2 \\
3 \\
3 \\
3 \\
4 \\
\end{tabular}

Interval A-Continued

Sources and environments of deposition-Continued

Lakes... . -

Swamps _. . -

Fluvial-delta plains . .

Environmental relations. ........

Source areas . . . .

Climate. . . . .

Paleotectonic implications............

Geologic units directly above Permian System ........

Paleotectonic implications. . . . . . . . . . . .

Page

Permian(?) areas in eastern United States and Iowa

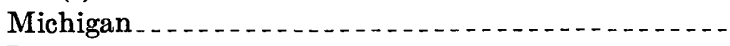

Iowa

\section{ILLUSTRATIONS}

Plate 1. Maps and section showing special features of the Dunkard Group, Allegheny Plateau. Page

Figure 1. Map showing counties in Maryland, Pennsylvania, Ohio, and West Virginia referred to in text............

2. Columnar sections showing cyclic character of Dunkard Group and position of Washington coal bed in Ohio and West Virginia 



\title{
PALEOTECTONIC INVESTIGATIONS OF THE PERMIAN SYSTEM IN THE UNITED STATES
}

\section{ALLEGHENY REGION}

\author{
By Henry L. Berryhill, Jr.
}

\begin{abstract}
Two places in the Allegheny region contain rocks of Permian age: a synclinal area of elliptical outline in eastern Ohio, southwestern Pennsylvania, and northwestern West Virginia known as the Dunkard basin; and a very small area in the George's Creek basin of western Allegany County, Md.

In the Allegheny region, rocks of Early Permian age cannot easily be separated from rocks of Late Pennsylvanian age because of lithologic and paleontologic gradation. In this paper the gradational zone, considered to be Late Pennsylvanian and Early Permian in age, is included with the Permian. The nomenclature and age assignments used for the Upper Pennsylvanian and Lower Permian rocks of the Allegheny region are those that were employed prior to 1962 .

Rocks of latest Pennsylvanian and Early Permian age make up the Dunkard Group, which has been divided into the Washington Formation of Late Pennsylvanian and Permian age and the Greene Formation of Early Permian age.

Rocks of the Dunkard Group are similar to those of the underlying Pennsylvanian Monongahela Formation, a cyclically bedded sequence of impure sandstone, siltstone, impure limestone, and small amounts of mudstone and coal. In the Dunkard Group they are largely detrital. Mudstone is more abundant than sandstone, in general, but the proportion of sandstone increases from northeast to southwest. The marginal pattern on the lithofacies map shows protuberances of coarse detrital rock oriented toward the axis of the Dunkard basin. Marly limestone beds and coal beds are thickest and most abundant at the northeast end of the basin. Red mudstone is abundant in the southern half and is absent in the northernmost part.

The Upper Pennsylvanian and Permian rocks are continental deposits believed to have accumulated in closely associated lacustrine, swamp, fluvial, and delta-plain environments. Younger rocks, other than Quaternary alluvium, are absent throughout the area.
\end{abstract}

\section{REGION DEFINED}

Allegheny region, as used in this paper, includes all the Allegheny Plateau and also the southern part of the Allegheny Mountain section in the Appalachian Plateaus province (Fenneman, 1938, p. 279-304). In this region, rocks of Early Permian age cannot easily be separated from rocks of Late Pennsylvanian age because of lithologic and paleontologic gradation (further discussion in $\mathbf{I}-450$ ). The gradational zone is here included with the Permian. The nomenclature and age assignments for the Upper Pennsylvanian and Lower Permian rocks of the Allegheny region are those in usage prior to 1962 .

Two areas in the Allegheny region contain rocks of Late Pennsylvanian and Permian age. The largest is a synclinal area of elliptical shape in eastern Ohio, southwestern Pennsylvania, and northwestern West Virginia in the Allegheny Plateau, known as the Dunkard basin (pl. 1 $A$ ). A second and smaller area is in the Georges Creek basin of western Allegany County, Md., in the Allegheny Mountains (fig. 1); it contains three very small exposures of uppermost Pennsylvanian and lowest Permian rocks.

Permian rocks of the Allegheny region form the Dunkard Group, a sequence of continental deposits that accumulated in closely related lacustrine, swamp, and fluvial-delta-plain environments. Younger rocks,

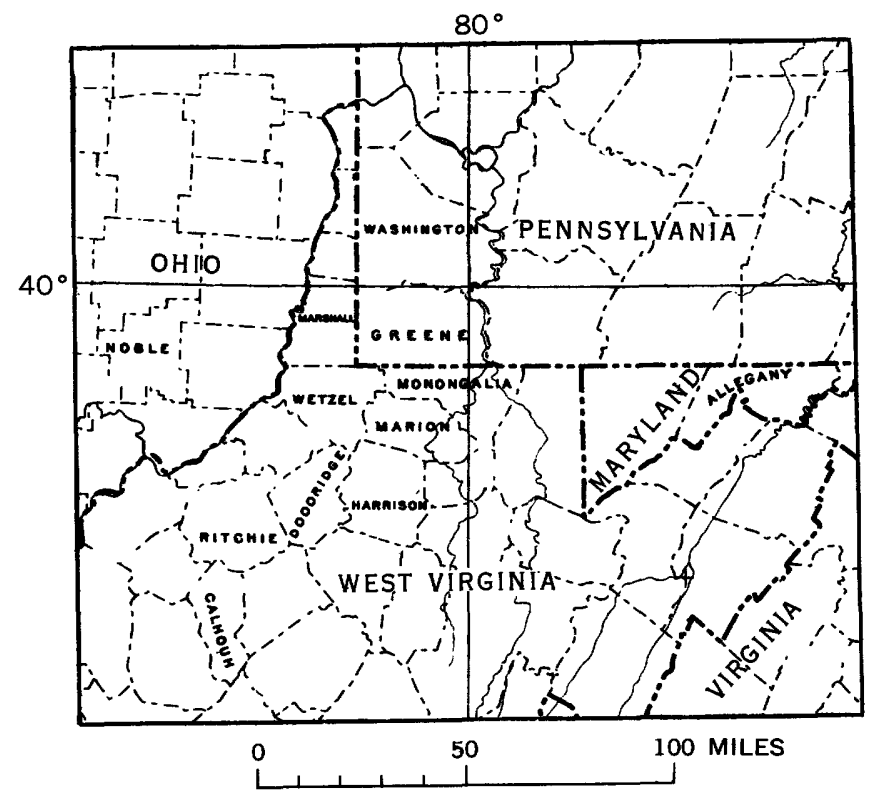

Figure 1.-Counties in Maryland, Pennsylvania, Ohio, and West Virginia referred to in text. 
other than Quaternary alluvium, if ever present, have been removed by erosion.

\section{PALEOGEOLOGY}

\section{UNITS UNDERLYING PERMIAN}

In the Dunkard basin and in western Maryland, rocks of the Washington Formation, considered transitional in age between latest Pennsylvanian and Permian, conformably overlie the Monongahela Formation of Late Pennsylvanian (Virgil) age. The Monongahela Formation is a cyclically bedded sequence of impure sandstone, siltstone, and impure limestone, and small amounts of mudstone, claystone, and coal. Its uppermost unit throughout a large part of the Dunkard basin is the Waynesburg coal bed. This bed averages $1-4$ feet in thickness in the northern half of the basin but thins to less than 1 foot toward the southwest. The Waynesburg coal is absent in much of the southern quarter of the Dunkard basin, where the Washington Formation rests conformably, in places, on a thin clay bed and, elsewhere, on the Gilboy Sandstone Member of the Monongahela Formation.

In western Maryland the top of the Monongahela Formation is considered to be a thin coal bed that has been correlated with the Waynesburg coal of the Dunkard basin (Berryhill and de Witt, 1955).

\section{LOWER BOUNDARY OF PERMIAN}

The top of the Waynesburg coal bed marks the lower boundary of transitional Pennsylvanian and Permian rock in the Dunkard basin and in Allegany County, Md., and is arbitrarily used as the base of the system. Little stratigraphic significance can be attributed to this boundary, however, because rock sequences both above and below contain similar cyclic beds. Field recognition of the boundary is not difficult over most of the northern part of the Dunkard basin, where the Waynesburg caal is prominent, but in other parts, where the coal is either thin or absent, the boundary is not readily apparent.

Originally, a Monongahela Series and an Upper Barren Group, the present Dunkard Group, were described by Rogers (1858, p. 14-20), who put the boundary between these units 40-50 feet higher than the present one at the base of the Waynesburg Sandstone Member of the Washington. These units were differentiated on the basis of gross lithologic character, such as a general lack of minable coals in the higher strata, and not on age difference. The boundary was later lowered to its present position on paleobotanical evidence (Fontaine and White, 1880). Fossil plants in the Cassville Shale Member, just above the Waynesburg coal in West Virginia, were considered by Fon- taine and White to have Permian affinities; however, the systemic boundary has been the subject of controversy for many years. Some paleobotanists have questioned the original floral interpretations and have suggested raising the boundary.

\section{PALEOTECTONIC IMPLICATIONS}

Permian and Pennsylvanian Systems in the Dunkard basin and in western Maryland are conformable and gradational. Deposition was continuous from one period to the next, which indicates a relatively constant sinking of the negative area.

\section{INTERVAL A}

\section{FORMATIONS INCLUDED}

Rocks of latest Pennsylvanian and Early Permian age in the Allegheny region are assigned to interval $\mathbf{A}$. In the Dunkard basin and in western Maryland these rocks make up the Dunkard Group, which has been divided into the Washington Formation of Late Pennsylvanian and Permian age and the Greene Formation of Early Permian age.

\section{STRATIGRAPHIC RELATIONS}

The Upper Barren Series, now called the Dunkard Group, was first divided (Stevenson, 1876, p. 34-56) into the Washington County and Greene County Groups, with the boundary between them at the top of the Upper Washington Limestone. Subsequently, these group names were abandoned and they became the Washington and Greene Formations, respectively, which have been further subdivided into a total of 48 members and beds. The large number of members recognized is a reflection of the cyclic pattern of deposition.

The Washington County Group was separated from the overlying Greene County Group by Stevenson because of a greater abundance of limestone in the lower part of the section as exposed in Washington County, Pa. These limestone beds are progressively thinner southward, however, and are absent over most of the southern part of the Dunkard basin, so that a regional twofold differentiation is made difficult on this basis.

Lateral variations in lithology within the Dunkard Group are more pronounced than gross vertical differences. As a result of facies changes, individual components of the sedimentary cycles intertongue. Coal beds are the most extensive and also the most diagnostic key units. Certain limestone units have diagnostic features within limited areas; but throughout the basin, lithologic types recur vertically so many times that stratigraphic position is difficult to ascertain except where diagnostic coal beds are present. In areas where the coals are either very thin or absent, a sequence consisting of a combination of two or more 
sedimentary cycles must be traced carefully if reliable correlations are to be made.

Rocks of the Greene Formation are believed to be equivalent to Permian rocks of early to middle Wolfcamp age in the central and southwestern parts of the United States (Dunbar and others, 1960). Rocks of the Washington Formation are probably of late Virgil to early Wolfcamp age.

\section{UPPER BOUNDARY OF INTERVAL A}

The top of the Greene Formation is a surface of Recent erosion, so the stratigraphic record of rocks younger than the Greene Formation has been destroyed.

\section{THICKNESS TRENDS}

Rocks of the Dunkard Group are remnants of a once thicker and more extensive sequence preserved in shallow synclines. Thickness trends for this group can be inferred only by comparison with the thickness trends of components or units within it which have not been appreciably eroded.

Because the top of the Washington Formation is preserved across much of the Dunkard basin, rocks of this formation were used in inferring thickness trends for the entire Dunkard Group. The thickness of the Washington Formation increases eastward from slightly less than 250 feet along the west side of the Dunkard basin to more than 400 feet locally near the northeast side, in Greene County, Pa., and in Monongalia and Marion Counties, W. Va. (pl. 1E). The rate of increase averages about $31 / 2$ feet per mile, but it is not uniform because of local variations across shallow northeast-trending flexures that parallel the main axis of the basin.

Trends within the Washington Formation suggest that the unit was thickest east of the present area of the Dunkard Group. To corroborate the pattern suggested by the thickness of the Washington Formation, an isopach map has been prepared (pl. $1 F$ ) which shows the thickness of the lower part of the formation between the top of the Waynesburg coal bed and the base of the Washington coal bed. This interval was selected because of the correlative value of the coal beds at its base and top, as the Washington coal bed is a far more extensive marker than the limestone at the top of the Washington Formation.

Eastward thickening of the lower part of the formation confirms the trend for the entire formation except in one area. Rocks of this unit, like those of the formation as a whole, thicken progressively toward the east-central margin of the Dunkard basin in Doddridge and Ritchie Counties, W. Va., but from there they thin toward the southeast (pl. $1 D$ ). Thus, the trend of the lower part suggests that the thickest ac- cumulation of sediment was within the present Dunkard basin. Sediments as originally deposited probably thinned gradually southeastward from the eastern part of the present Dunkard basin, and loci of thickening may have been in shallow northeast-trending structural depressions and in alluvial fans that lay east of the present area of Dunkard rocks.

\section{LITHOFACIES TRENDS}

Rocks of the Dunkard basin are largely detrital and, in general, mudstone is more abundant than sandstone. The ratio of sandstone to mudstone increases from northeast to southwest, ranging from an average of $1: 3$ to an average of $1: 1$. Grain size increases unevenly from northeast to southwest (pl. 1A). This unevenness is caused by the presence of coarse-grained detrital rocks along the west and southeast margins of the Dunkard basin. The marginal pattern on the lithofacies map is that of protuberances of coarse detrital rock oriented toward the axis of the Dunkard basin. A north-trending belt of coarse-grained rock traverses the central part of the basin (pl. 1A). Northeastward from this belt is a lobate area, also of coarse-grained rock, that parallels the axis of the basin. Presumably, when the relatively coarse sediments reached the lowest part of the elongate basin, they tended to spread laterally along the northeast-trending axis.

Detrital rock composed of coarse-grained, and in part pebbly, sandstone occurs mainly in the southwestern part of the Dunkard basin in the Waynesburg and Mannington Sandstone Members of the Washington that lie between the Waynesburg and Washington coal beds. Northwest-trending Y-shaped belts containing coarse pebbly sandstone (pl. $1 F$ ) include most of the coarse-grained to pebbly sandstone in the lower part of the Washington Formation, as well as the coalesced sandstones that locally form a continuous unit between the Waynesburg and Washington coal beds. Lenses of pebbly sandstone above the Washington coal bed are more sporadic than the pebbly sandstone beds of the Waynesburg and Mannington Members in the southern Dunkard basin.

Marly limestone beds are locally abundant at the northeast end of the Dunkard basin. They are interbedded with calcareous mudstone and with fine-grained sandstone.

Coal beds are thickest and most numerous in the northern part of the Dunkard basin in a border zone between the relatively coarse grained rock to the southwest and the finer grained, calcareous rock to the northeast (pl. $1 C$ ).

The mudstone in the southern half of the Dunkard basin is mostly red brown, whereas that in the north- 
ern half is more commonly olive gray. Red brown seems to be most pronounced in areas where mudstone exceeds sandstone in a ratio of about $2: 1$. The amount of red-brown mudstone in rocks of the southern part of the basin is shown by percentage on plate $1 B$.

Plate $1 A$ shows the gross lithology of the Dunkard Group but not the cyclic character. Figure 2, however, shows the characteristic repetitive nature of the relatively thin sheets of sandstone, mudstone, claystone, limestone, and coal that make up the group. In a given area these diverse lithologic units commonly recur in orderly groupings that are considered to be sedimentary cycles. These cycles average about 40-50 feet each in thickness. Each facies within a cycle changes in the same manner as does the group as a whole. Impure limestone beds, which are thickest and most numerous in the northern part of the basin (fig. 2, Ohio), thin southward, the same direction in which sandstone sheets thicken (fig. 2, West Virginia).

The gross lithology of the Dunkard Group in western Maryland is similar to that in the north half of the Dunkard basin except that the limestone and coal beds are thinner. In addition, red beds are scarce, and coarse detrital rocks are absent except in the southernmost of three localities that contain Dunkard rock. The basal unit in that area is a thick pebbly to conglomeratic sandstone.

\section{SOURCES AND ENVIRONMENTS OF DEPOSITION}

Rock types, fauna, and sedimentary structures suggest that rocks of the Dunkard Group probably formed from continental deposits that accumulated in three general and overlapping environments: lake, swamp, and fluvial-delta plain ( pl. 1G). Deposition probably took place under both fresh- and brackish-water conditions in the shallow landward part of an elongate estuarine embayment. Though drainage of the depositional area was probably into the sea, extreme shallowness of water and remoteness from the ocean may have precluded marine incursions.

Because the Dunkard Group is far removed from rocks of comparable age, this group can be related only with difficulty to the paleogeography of the time. The widespread occurrence of Upper Pennsylvanian and Lower Permian rocks to the southwest of the Dunkard basin and their absence to the northwest suggest that a Late Pennsylvanian and Early Permian epicontinental sea was to the southwest. The position of thick limestone beds in the Dunkard basin, north of the sandstone and red mudstone, however, suggests that the basin possibly drained northeastward rather than southwestward.
LAKES

Sequences of thin- to medium-bedded impure limestone and interbedded calcareous mudstone at the north edge of the present Dunkard basin in south-

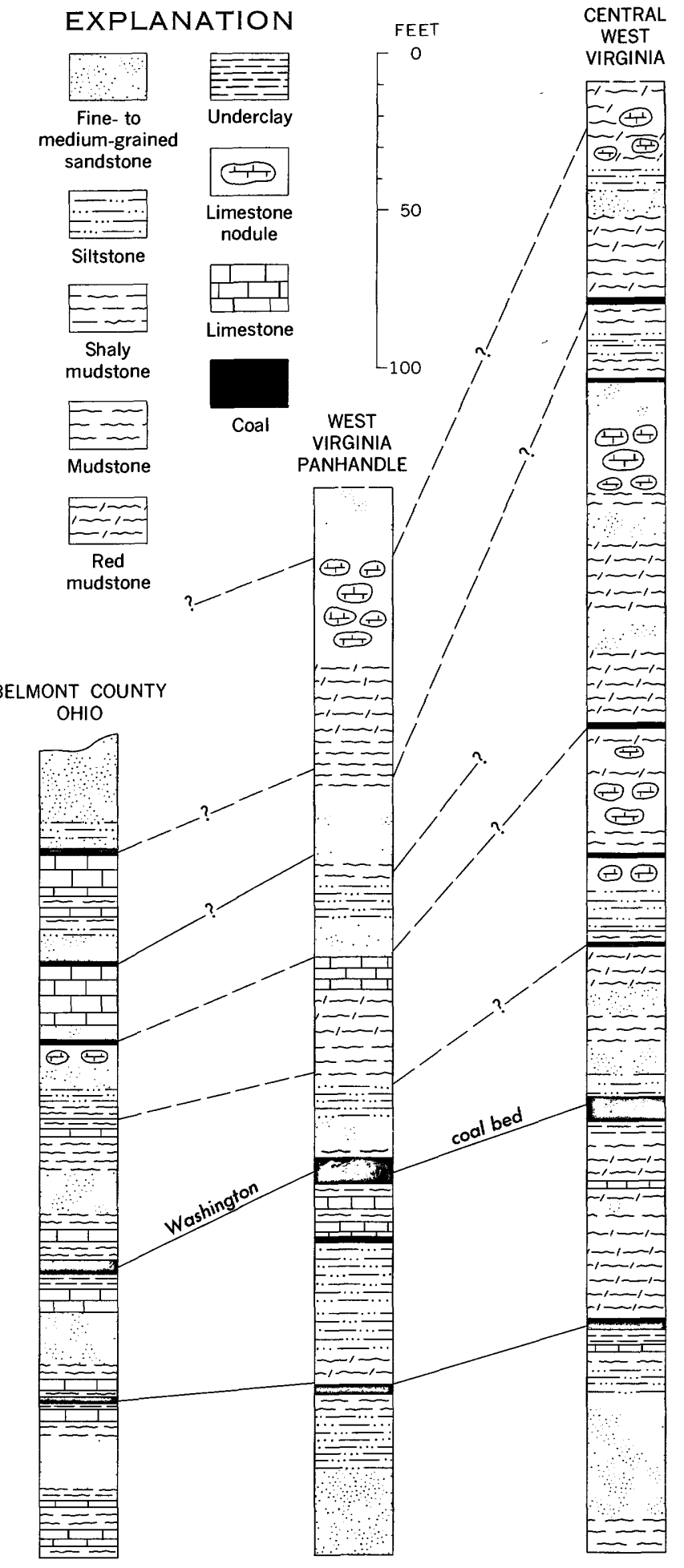

FIGURE 2.-Columnar sections showing cyclic character of Dunkard Group and position of Washington coal bed in Ohio and West Virginia. 
western Pennsylvania are believed to be principally lacustrine deposits. The coal beds represent periods when the lakes became filled and swamp conditions prevailed. The kinds of fossils, both invertebrate and vertebrate, in the limestone and associated calcareous mudstone support these inferences.

Invertebrates include small gastropods, small pelecypods, and very small smooth-shelled ostracodes, some of which have been referred to Carbonita (Kellett, 1943, p. 616). Other specimens identified are Lingula permiana (Stauffer and Schroyer, 1920, p. 143), Spirorbis and Estheria (?). Most of these seem to be fresh-water forms, but Lingula permiana, found only in a thick parting in the Washington coal bed, and possibly Spirorbis, may be exceptions. The areal distribution of Lingula permiana is not well known, but this brachiopod and also Spirorbis may indicate brackish water (Weller, 1957, p. 333; Cross and Schemel, 1956, p. 51).

\section{SWAMPS}

Most of the vertebrate fossils in the Dunkard strata are fragmented fish remains, but skeletal parts of amphibians and reptiles have also been found. Vertebrates of the Dunkard Group were listed by Romer (1952, p. 49-98), who interpreted the environment (p. 103) as "a flat, well-watered coastal region with abundant swamps and lagoons; a region ecologically ideal for an abundant fauna of fresh-water fishes and aquatic or swamp-dwelling tetrapods, but with relatively few dry land areas in which the more purely terrestrial types of amphibians and reptiles could flourish in any numbers."

Amphibian and reptile remains are relatively scarce. The fluctuating Dunkard environment was probably the controlling factor that limited population and diversity of both aquatic and terrestrial forms. Paucity of terrestrial vertebrate remains does not necessarily rule out the abundance of vertebrate animals, for such remains are not often preserved.

Limestone of inferred lacustrine origin thins southwestward and intertongues with mudstone, in part red, and with fine-grained sandstone and coal. These strata accumulated in a zone probably intermediate between lake and fluvial-delta plain, where the persistence of swamps is indicated by the aggregate thickness of coal (pl. $1 C$ ). The thickest coal probably formed on the side of the swamp nearest the lacustrine deposits. Red mudstone intertongues with swamp deposits but is especially typical of strata formed on a fluvial-delta plain. The distribution of this mudstone and the percentage of red mudstone relative to total thickness of Dunkard rocks is shown on plate $1 B$.

\section{FLUVIAL-DELTA PLAINS}

Rocks attributed to the fluvial-delta plain are, in general, pebbly to fine-grained sandstone, and mudstone believed to have accumulated mainly on flood plains and in relatively thin deltaic fans. Because of low gradient, which caused streams to meander and flood-plain deposits to overlap, most of the detrital units are composite sheetlike bodies that include channel, flood-plain, and deltaic features. Thin tongues of limestone probably of lacustrine origin are interbedded with the fluvial-plain deposits, but the limestone is impure and lenticular, as are the coal beds.

\section{ENVIRONMENTAL RELATIONS}

Natural lines of demarcation between the three principal environments represented by Dunkard rocks do not exist, as rocks of these environments are intertongued.

The general vertical cyclic repetition across the Dunkard basin-coal, mudstone, sandstone, mudstone, impure limestone, and underclay, in that order-indicates that the environment fluctuated many times from lacustrine to fluvial plain to coal swamp. The extensiveness of many of these units indicates that the area receiving sediments was very flat. The fluctuations were probably caused by regional tectonic movements and by climatic variations that controlled the influx of water and sediment.

Because of the flatness, even a slight increase in water influx must have inundated much of the basin and converted it into a broad shallow lake. Conversely, periodic floods of detritus resulted in the building of broad fluvial-delta plains that reduced and filled the lake. During stable periods, swamps covered large parts of the basin and vegetal material accumulated.

Each of the three environments described seems to have produced a characteristic type of rock. Thus, the lacustrine phase of the sedimentary cycle is characterized by impure limestone, the fluvial-delta plain phase by detrital rock, and the swamp phase by relatively thick coal. Shallowness of water is strongly suggested by desiccation cracks in many of the limestone beds. At times much of the Dunkard basin surface was a mudflat.

\section{SOURCE AREAS}

Scarcity of conglomerate and very coarse grained sandstone, except in the lower part of the Dunkard Group (pl. $1 F$ ), suggests that either source areas were distant or the climate was sufficiently humid to allow deep weathering. The principal source area seems to have been to the southeast; a subsidiary source apparently lay to the north. 
Interpretations of the nature of source areas must be based upon the mineralogy of the sandstone, which is mostly subgraywacke according to the definition of Pettijohn (1949, p. 256). This sandstone consists mainly of quartz grains but also contains feldspar, abundant mica, some rock fragments, and a clayey matrix. Commonly present in the base of the sandstone units are casts of logs and of other vegetal debris. The inferred southeastern source area probably consisted of older Paleozoic sedimentary, volcanic, metamorphic, and granitic igneous rocks, but the rocks of the northern source area probably included Precambrian granites and metamorphic rocks as well as some Paleozoic sedimentary rocks. The detritus seems to have been transported with little winnowing, from source areas across broad piedmont plains.

\section{CLIMATE}

Climate in the Allegheny region during Dunkard deposition was humid, as indicated by abundance and type of fossil flora. The formation of red beds in the Dunkard Group is probably a function of position of the sediments relative to water level during and soon after deposition. The position of the red beds on the fluvial-delta plain between the lacustrine limy sediments and the deltaic sands suggests deposition in a part of the basin where water level fluctuated and repeatedly exposed surface and near-surface sediments to drying. Conditions alternating from wet to dry would have been very favorable for oxidation and formation of red sediments. No aspect of the fauna or flora, or of the rock itself, has been recognized as a reliable indicator of temperature range during Dunkard time.

\section{PALEOTECTONIC IMPLICATIONS}

The large quantity of detrital rock in the Dunkard Group came from rising land areas both to the north and to the southeast, bordering a basin in which subsidence was barely sufficient to accommodate the influx of sediments. Cyclic repetition of the various lithologies resulted from recurrent elevation of source areas, from fluctuation in amount of precipitation, or from a combination of these factors and perhaps others.

Recurrence of sedimentary rock types has been explained in several ways. Most explanations are variations of either the diastrophic control theory of Weller (1956) or the climatic and sea-level control theory of Wanless and Shepard (1936). According to the diastrophic control theory, recurring uplift and submergence, both of the basin and of the source areas, controlled the influx of sediments, with the sandstone representing times of uplift in source areas. The cli- matic and sea-level control theory infers a more or less continuous subsidence of the basin accompanied by rhythmic falling and rising of sea level, attributed to changes in the amount of ocean water stored on land in continental glaciers. According to this theory, sand was deposited during times of glaciation as channel fillings and coalescing deltaic fans on a broad piedmont that lay between the source areas and the restricted basins.

Basic components of the Dunkard cycles-impure limestone, impure sandstone, and coal-represent three related types of environment. Changes from deposition of one type of sediment to another probably resulted from fluctuations in inflow of both detritus and water, causing shifts in the lake shoreline. Fluctuations of inflow possibly resulted from cyclic changes in precipitation. Rainfall throughout what was possibly an elevated, plant-covered, and deeply weathered source area is believed to have been abundant at all times, but it may have reached periodic maximums of tremendous proportions. During times of greatest rainfall, deep soil and saprolite, as well as fresh detritus, were transported, in successive flood stages, across both the piedmont plains and the basin. Sedimentary features of the sandstone, such as extensive scour bottoms, angular fragments scoured from the underlying stratum, and extensive structureless lenses, attest to rapid transport of great quantities of sediments by large volumes of water.

Although the shape, size, and depth of the Dunkard basin changed periodically, the main streams or drainage systems entering it seem to have followed the same general courses for long periods. Thus the lobate and digitate sandstone areas shown on plate $1 A, F$, outline drainageways that seem to have persisted during much of Dunkard time.

\section{GEOLOGIC UNITS DIRECTLY ABOVE PERMIAN SYSTEM}

Except for Quaternary alluvial deposits, there is no evidence of post-Early Permian deposition in the Dunkard basin. Extensive deposits younger than Early Permian, if ever present, have been removed by erosion.

\section{PALEOTECTONIC IMPICATIONS}

Tectonic movements that caused both the gradual sinking of the depositional basin and the uplift of areas that supplied sediment to the basin seem to have ceased after Early Permian time. With the filling of this Early Permian continental basin, which was a last remnant of the Appalachian geosyncline, the sedimentary record of the Paleozoic Era was brought to a close in eastern North America. 
PERMIAN(?) AREAS IN EASTERN UNITED STATES AND IOWA

Sporadic patches of gypsum-bearing red rocks that are presumably remnants of once more extensive deposits occur in the central part of the Michigan basin and in the northern part of Webster County, Iowa. These rocks are sparsely fossiliferous; they are assumed to be Permian(?) because of their lithology and stratigraphic position.

Rocks in New Hampshire that make up the White Mountain Plutonic-Volcanic Series were at one time considered to be Late Permian on the basis of radioactive age determinations of 186 million years (Lyons and others, 1957 , p. 540; Cady, 1960, p. 563-564). Results from more recent radioactive dating (Faul, 1961), however, and revision of the geologic time scale (Kulp, 1961) indicate either a Triassic or Jurassic age for these rocks.

\section{MICHIGAN}

The Permian(?) rocks of central Michigan are unnamed unfossiliferous red beds consisting of claystone, mudstone, sandstone, and some gypsum (Cohee and others, 1951). These strata, which unconformably overlie rocks ranging in age from Mississippian to Middle Pennsylvanian, apparently accumulated as terrestrial deposits in local topographic lows, and their thickness ranges from as much as 400 feet in north- eastern Mecosta and southeastern Clare Counties to 100 feet or less elsewhere. The Permian(?) rocks are everywhere concealed by Pleistocene glacial deposits, and their presence is known only from drill holes.

\section{IOWA}

Permian(?) rock in Iowa, called the Fort Dodge Formation, crops out in isolated patches in the vicinity of Fort Dodge, northern Webster County. The formation is massive gypsum overlain by red clayey mudstone and sandstone and has a maximum thiclmess of less than 100 feet (Hale, 1955, p. 136). This rock in most places rests unconformably on the Pennsylvanian Des Moines Series but in some places rests on the Ste. Genevieve Limestone and the St. Louis Limestone of the Mississippian Meramec Series (Hale, 1955 , p. 134-138). Lenses of limestone conglomerate whose pebbles contain fossils of Des Moines age lie beneath the gypsum and are included in the Fort Dodge Formation.

Parts of the Fort Dodge Formation have variously been considered as Early Cretaceous, Miocene, Pennsylvanian, and Permian in age. A Permian age assignment was favored by Wilder (1902, p. 99-114; 1924, p. 168-177) because of the resemblance to the Permian gypsiferous red beds of Kansas. The unit is currently classed as Permian(?). 



\section{Paleotectonic Investigations}

of the Permian System

in the United States

Chapter B. Gulf Coast Region

By ELEANOR J. CROSBY

GEOLOGICAL SURVEY PROFESIONAL PAPER 515-B

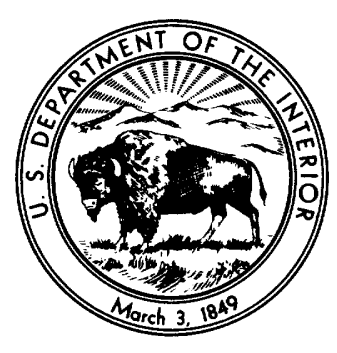





\section{CONTENTS}
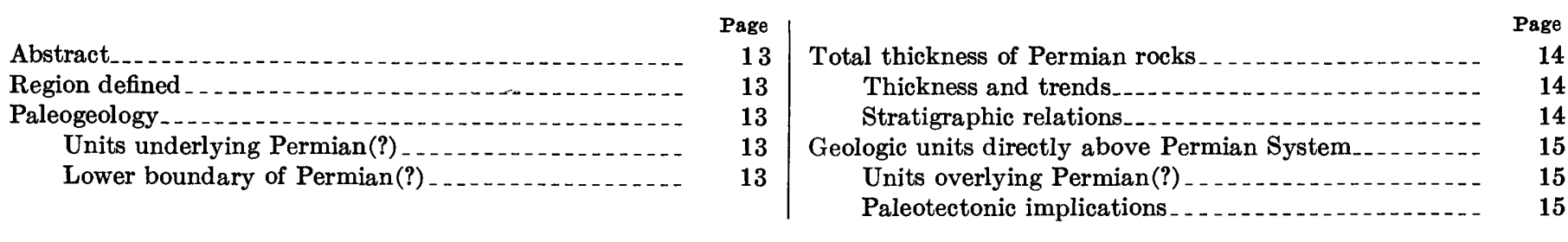

Page

14

Abstract__.

13

13

13

13

Units underlying Permian(?)

13

\section{ILLUSTRATIONS}

Figure 3. Map showing thickness of Eagle Mills Formation in southern Arkansas, northern Louisiana, western Mississippi, and northeastern Texas._. 


\title{
PALEOTECTONIC INVESTIGATIONS OF THE PERMIAN SYSTEM IN THE UNITED STATES
}

\section{GULF COAST REGION}

\author{
By Eleanor J. Crosby
}

\begin{abstract}
In a roughly arcuate area extending from western Mississippi through southern Arkansas and northern Louisiana to northeastern Texas, a southward-thickening wedge of red mudstone, red and gray sandstone, and some anhydrite is designated as the Eagle Mills Formation. It has variously been referred to the Permian, Triassic, and Jurassic Systems; in this paper its age is given as Permian(?).

The Eagle Mills is entirely a subsurface unit. It overlies folded Pennsylvanian and possibly older Paleozoic rocks, at least along its north edge, and it is overlain by rocks of Jurassic(?), Jurassic, and Cretaceous age in successive northward overlappings. Limited available data suggest that the Eagle Mills at its south limit may be downfolded or faulted against older rocks near the Arkansas-Louisiana boundary.
\end{abstract}

\section{REGION DEFINED}

The central Gulf Coast region, defined in terms of the extent of red beds of the Eagle Mills Formation of possible Permian age, ${ }^{1}$ includes southern Arkansas, the northernmost edge of Louisiana, part of northeastern Texas, and part of western Mississippi. The roughly arcuate, eroded north edge of the Permian(?) rocks follows the trend of the Ouachita Mountains across western Arkansas and eastern Oklahoma and their continuation, the buried southwest-trending Ouachita structural belt, in northeastern Texas. Controlling factors at the south edge of the southward-thickening Dermian(?) are not known.

\section{PALEOGEOLOGY}

\section{UNITS UNDERIYING PERMTAN(?)}

In northeastern Texas, southern Arkansas, adjacent Mississippi, and northern Louisiana, the presence of Paleozoic units older than Permian is inferred below rocks assigned to the Eagle Mills Formation of Permian(?) age. The Eagle Mills is used in the restricted sense of Hazzard, Spooner, and Blanpied (1947), ex-

${ }^{1}$ Fossil evidence for a probable Triassic age for the Eagle Mills Formation is given by Scott, Hayes, and Fietz (1961) in a paper published after completion of this text. The impression of a leaf of Macrotaeniopteris magnifolia, recovered from the Eagle Mills in Humble Oil and Refining Co. 1 Royston, sec. 31, T. 10 S., R. 24 W., Hempstead County, Ark., was identified by Dr. Erling Dorf as "of late Triassic or early Jurassic age, more probably the former." cluding strata now assigned to the Werner and Louann Formations. One well is known to have reached the base of the Eagle Mills; a few have bottomed in igneous rock intrusive into it. Nearly all information on the older rocks has been obtained from their lateral extensions beyond the present limit of the Eagle Mills. Available data are shown on plate 2 of $I-450$.

North and west of the limits of Permian(?) strata, Jurassic and Cretaceous formations directly overlie folded and metamorphosed Paleozoic sedimentary rocks of the Ouachita belt. Folded Paleozoic rocks near the north edge of the Permian(?) in southern Arkansas and locally in northeastern Texas consist of hard sandstone and black carbonaceous mudstone resembling Mississippian or Pennsylvanian rocks of the Ouachita Mountains (Weeks, 1938, p. 962) in southwestern Arkansas and southeastern Oklahoma.

Rocks of possible pre-Permian age south of the Eagle Mills are known from only two wells. In central-southern Arkansas (Gulf Refining Co. 49 Werner, sec. 5, T. 15 S., R. 7 W.), steeply dipping mudstone, altered to hornfels by intrusive diabase and believed to be older than the Eagle Mills, underlies conglomeratic red beds assigned to the Werner Formation, which overlies the Eagle Mills to the north. In northeastern Louisiana (Union Producing Co. 1-A Tensas Delta, sec. 8, T. 22N., R. 4 E.), red beds of the Werner lie without apparent angular discordance on unmetamorphosed dark mudstone and subordinate sandstone, limestone, red beds, and anhydrite of the Morehouse Formation. The Morehouse has been dated as late Paleozoic, probably not older than Pennsylvanian, on faunal evidence (Imlay and Williams, 1942) and as Middle or Late Pennsylvanian on spore determinations (Hoffmeister and Staplin, 1954).

\section{LOWER BOUNDARY OF PERMIAN(?)}

The lower boundary of the Permian(?) in the central Gulf Coast region is assumed to be at the base of the dominantly red rocks assigned to the Eagle Mills Formation. At its north edge the Eagle Mills wedges 
out above folded older Paleozoic rocks. In other parts of the area the depth and nature of the lower boundary are unknown.

\section{TOTAL THICKNESS OF PERMIAN ROCKS THICKNESS AND TRENDS}

Figure 3 shows the total thickness of Permian rocks -the Eagle Mills Formation (restricted) -in the Gulf Coast region. The original thickness of the Eagle Mills is unknown. The formation has been beveled by erosion at least along its north margin, and its base has not been reached to the south, although more than 4,600 feet of red beds and associated sandstones has been penetrated in southeastern Arkansas. The zero isopach in figure 3 marks the approximate edge of the formation. Near this south edge, figures given for partial thickness of the restricted Eagle Mills include undetermined thicknesses of the red-bed member of the overlying Werner Formation (Hazzard and others, 1947, p. 486).

Available lithologic data are inadequate for recognition of lithofacies patterns in the Eagle Mills. The formation consists dominantly of red mudstone, lesser amounts of red and gray sandstone, and a little anhydrite.

\section{STRATIGRAPHIC RELATIONS}

The north margin of the Eagle Mills, in Arkansas and along its possible continuation in eastern Texas, is the eroded edge of a southward-dipping unit that once extended farther north over folded Paleozoic rocks of the Ouachita belt. The age of the formation and the nature of the southern, more deeply buried part are controversial. Neither the red beds of the restricted Eagle Mills nor the closely associated red beds, anhydrite, and salt currently designated as the Werner and Louann Formations have yielded identifiable fossils. The Morehouse Formation in northeastern Louisiana, another element in all interpretations of the Eagle Mills, has been dated as Pennsylvanian on spores from the only well in which the formation has been recognized. All four formations are restricted to the subsurface, below Upper Jurassic and younger rocks.

The Eagle Mills has been classed variously as Permian, Triassic, or Jurassic. Permian age has been suggested by those who regard the upper part of the northern red beds as grading southward into anhydrite and salt considered to be of that age. The entire unit, so conceived, has been called Permian(?) on the basis

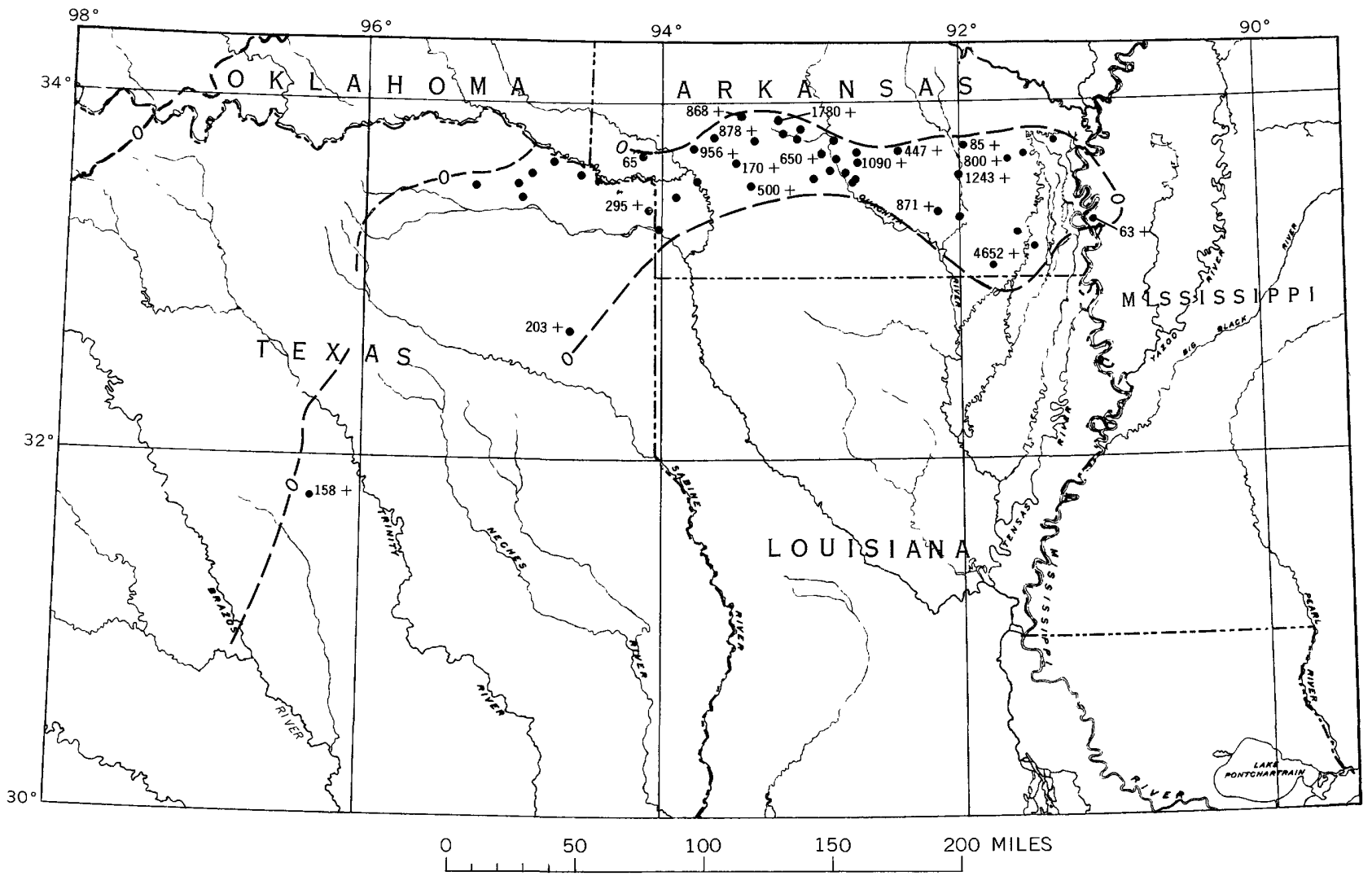

FIGURE 3.-Thickness, in feet, of Eagle Mills Formation in southern Arkansas, northern Louisiana, western Mississippi, and northeastern Texas. Zero isopach dashed because of poor control. O, Permian rocks present, but control inadequate for more than zero isopach. 
of comparison with red beds and salt of the Permian of west Texas, Oklahoma, and Kansas (Weeks, 1938, p. 962).

Permian age also is assigned to both red beds and saline deposits by Hazzard, Spooner, and Blanpied (1947, p. 483-503). However, they restrict the name Eagle Mills to red beds in the type well (Amerada Petroleum Co. 1 Eagle Mills, sec. 11, T. 12 S., R. 16 W.) near the northern limit of the formation in Arkansas, and to equivalent strata. They define as the Werner Formation red beds and anhydrite that they consider to be unconformable above the restricted Eagle Mills and that lie south of the Eagle Mills type locality. Above the anhydrite is the Louann Salt.

In northeastern Louisiana the Eagle Mills is missing. Less than 50 feet of red beds between the Morehouse Formation and the overlying anhydrite and salt is assigned to the Werner Formation by Hazzard, Spooner, and Blanpied (1947). Less than 20 miles to the northeast, the evaporitic rocks are underlain by more than 4,600 feet of red beds and sandstone of the Eagle Mills and Werner Formations, the base of which was not reached in drilling. The Eagle Mills is interpreted by Hazzard, Spooner, and Blanpied as older than the Morehouse and extending southward beneath it. This interpretation, however, predates recognition of Pennsylvanian spores in the Morehouse (Hoffmeister and Staplin, 1954).

The relation between the Morehouse and the thick restricted Eagle Mills to the north may be explained (according to Imlay and others, 1948, p. 1760) by faulting or folding of the Eagle Mills before deposition of the Werner Formation. In this interpretation it is assumed that the Eagle Mills is younger than the Morehouse.

A Jurassic age has been suggested for the Eagle Mills and the overlying red beds and salt of the Werner and Louann Formations because of lithologic similarity to red beds and salt of probable Jurassic age in eastern Mexico (Imlay and others, 1948, p. 17581760). Finally, recent study of the red beds of Tamaulipas, Mexico (Mixon and others, 1959), suggested a possible Triassic age. An angular unconformity separates into two units the sequence at Tamaulipas, dated by Imlay and others as probably Jurassic; plant remains of probable Triassic age occur near the top of the lower unit; this unit may be correlative, at least in part, with the Eagle Mills (Mixon and others, 1959).

In this paper the Eagle Mills is assigned provisionally to the Permian. The formation cannot, however, be dated with certainty more closely than younger than Early Pennsylvanian and older than part of the Late Jurassic.

\section{GEOLOGIC UNITS DIRECTLY ABOVE PERMIAN SYSTEM} UNITS OVERLYING PERMIAN(?)

The Permian(?) of the central Gulf Coast is overlain by rocks of possible Late Jurassic, known Late Jurassic, and Cretaceous age. In this paper, the red beds, anhydrite, and salt of the Werner and Louann Formations, overlying the Eagle Mills Formation, are considered provisionally as of Jurassic age (MacLachlan, in McKee and others, 1959, p. 1; I-450, pl. 8).

North and northwest of the limits of the Werner and Louann, poorly defined belts of Upper Jurassic rocks lie on Permian(?) rocks. Locally, the Cotton Valley Group, youngest unit of Late Jurassic age in the central Gulf Coast region, occurs immediately above the Eagle Mills in an area where older units would normally overlie the Permian(?). Along its north edge the Permian(?) is overlain by Lower Cretaceous rocks in Texas and western Arkansas and by Upper Cretaceous gravels in central and eastern Arkansas.

\section{PALEOTECTONIC IMPLICATIONS}

Events at the end of Eagle Mills time cannot be reconstructed with confidence. An extensive evaporite basin may have formed in and south of the known area of Eagle Mills deposition after or perhaps during the later stages of Eagle Mills accumulation. Formations of Jurassic and Cretaceous age overlapped both evaporitic deposits and older red beds of the Eagle Mills. Irregular distribution of various younger units directly above the Eagle Mills indicates that the Permian(?) was warped and locally exposed within the Mesozoic Era. Normal faulting in southwestern Arkansas accompanied regional southwestward tilting and exposure of the Eagle Mills in eastern Arkansas at the end of Early Cretaceous time. After the close of the Mesozoic, however, the Permian(?) rocks remained covered by deposits of shallow, fluctuating Gulf Coast seas and of the adjoining marginal areas. 



\section{Paleotectonic Investigations}

of the Permian System

in the United States

Chapter C. West Texas Permian Basin Region

By STEVEN S. ORIEL, DONALD A. MYERS, and ELEANOR J. CROSBY

GEOLOGICAL SURVEY PROFESIONAL PAPER 515-C

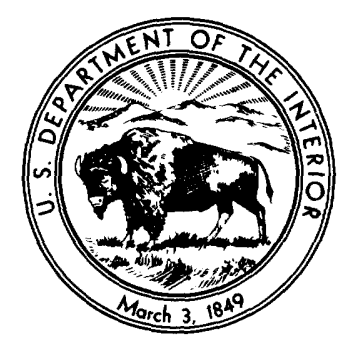


FigdRE 12-17. Maps showing thicknesses of rocks in west Texas and southeastern New Mexico:

12. Interval A

14. Interval $\mathrm{C}-\mathrm{D}$

15. Interval $\mathrm{C}_{-}$

16. Interval $\mathrm{D}$

17. Permian rocks (total)

18. Map showing geologic units directly above Permian System in west Texas and southeastern New Mexico _.. 59

\section{TABLE}

Table

1. Generalized chart showing stratigraphic units in major Permian subdivisions 


\title{
PALEOTECTONIC INVESTIGATIONS OF THE PERMIAN SYSTEM IN THE UNITED STATES
}

\section{WEST TEXAS PERMIAN BASIN REGION}

\author{
By Steven S. Oriel, Donald A. Myers, and Eleanor J. Crosby
}

\begin{abstract}
Synthesis of available stratigraphic information indicates that major tectonic elements infiuencing sedimentation in west Texas and adjoining regions during the Permian Period were fully developed late in Pennsylvanian or very early in Permian time.

Dominant in earliest Permian time was the northward thrusting of the Ouachita-Marathon structural belt, an event which marked the culmination of orogeny along the south edge of the Permian basin and the shedding of a large volume of detritus northward into the Val Verde trough. North of this trough the region was divided by positive elements into platforms and intervening basins. Early in Wolfcamp time, sinking of the Delaware and Midland basins and of the Val Verde trough exceeded the rate of deposition. This situation favored formation of stagnant-water deposits, and produced bold submarine relief along the Central Basin platform, which periodically stood above sea level. Thicknesses of strata differ greatly from place to place, but greatest accumulations were in the basins.

During Leonard time stratigraphic thicknesses more uniform than before suggest that the region subsided rather evenly. Inherited physiographic features such as platforms, shelves, basins, and the margins between them, however, were still sharply demarcated by distinctive facies. On basin margins marked relief was maintained by rapid deposition of carbonate rocks, whereas the basins as a whole, though large and continually sinking, received insufficient detritus to fill completely.
\end{abstract}

In Guadalupe time the central part of the Delaware basin continued to deepen and euxinic conditions persisted, but the Midland basin gradually became filled and assumed the aspects of adjoining shelves and of the Central Basin platform. In it conditions were favorable for the deposition of evaporites. Growth of almost continuous reefs and banks around the periphery of the Delaware basin effectively reduced marine circulation on shelves and platforms. Relative tectonic stability resulted in lateral as well as vertical growth of reefs, maintenance of barriers, the formation of thick deposits of evaporites.

In latest Permian time formation of a barrier, possibly a reef sill, in the southern part of the region sharply reduced circulation and resulted in rapid deposition of a great volume of evaporites. Marked tectonic stability, except for relatively great regional sinking, permitted maintenance of the barrier and of an evaporite pan in which the sequence of precipitation proceeded to the stage in which bittern salts settled. The evaporites were subsequently blanketed by uniformly thin and very fine grained red beds whose nearly conformable relation to overlying Upper Triassic detrital rocks implies continued regional stability.

\section{REGION DEFINED}

The west Texas Permian basin region includes the southeast quarter of New Mexico and parts of Texas south and southwest of the Texas Panhandle (fig. 4). The region, locally known as the Permian basin, was the site of epicontinental inundations during most of Permian time. During earliest Permian time, the Ouachita-Marathon structural belt shed a large volume of detritus northward into the Val Verde trough. North of this trough, the region was divided by positive elements into platforms and intervening moderately deep basins. The platforms or shelves, the basins, and the margins between them are sharply demarcated by distinctive facies. Restrictions in marine circulation, especially during latter parts of Permian time, resulted in the accumulation in this region of especially thick and varied saline deposits.

\section{PALEOGEOLOGY \\ UNITS UNDERLYING PERMIAN}

Rocks beneath the Permian System in west Texas range in age from Precambrian to Pennsylvanian (fig. 5). In general, the oldest rocks directly underlie the Permian in structurally positive areas such as the Central Basin platform, the Diablo platform, and the Pedernal positive element. Pennsylvanian rocks are most extensively preserved in the Midland and Delaware basins, in the Val Verde trough, and on the Northwestern and Eastern shelves. They are also reported from the Chinati Mountains (fig. 6) and from a few boreholes in the little-explored Marfa basin (fig. 7). The Pennsylvanian and Permian sequence of the Marfa basin may continue under younger rocks southwestward into the Placer de Guadalupe and Sierra del Cuervo areas of Chihuahua (fig. 4), where Pennsylvanian(?) rocks are reported below Lower Permian rocks (Ramirez and Acevedo, 1957; Flawn and DiazGonzales, 1959; Bridges and DeFord, 1961). 


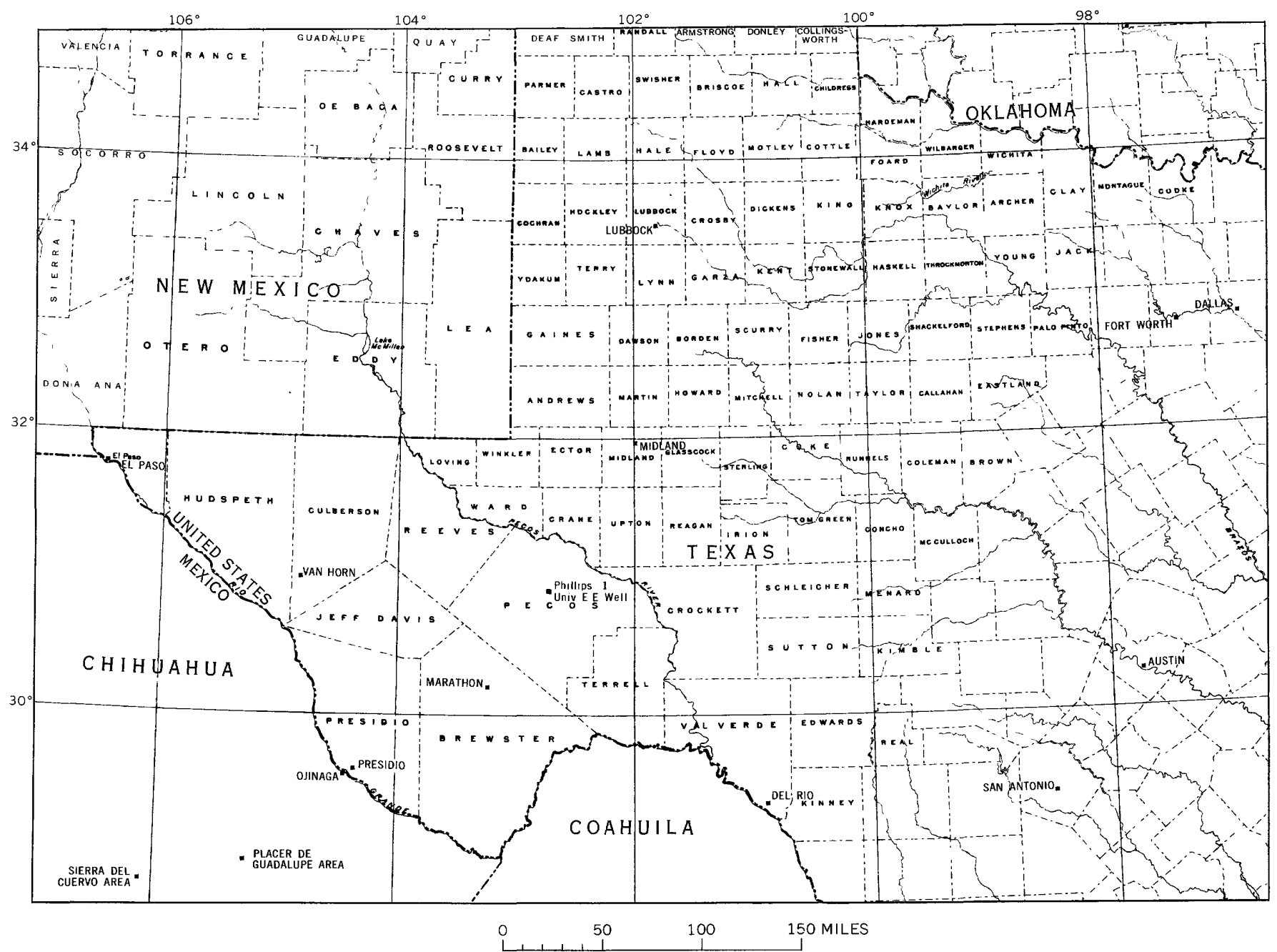

Figure 4.-Central and west Texas and southeastern New Mexico localities referred to in text. Counties named on map are underlain in whole or in part by Permian rocks.

Units shown on the paleogeologic map (fig. 5) of the region are for the most part time stratigraphic rather than rock stratigraphic, which conforms with common regional practice.

\section{PENNSYLVANIAN UNITS}

Assignment of rocks beneath the Permian to subdivisions of the Pennsylvanian System has been based largely on fusulinid data obtained from reports of the Paleontological Laboratory in Midland, Tex., and from some petroleum companies. Reliance on paleontologic information is necessary because facies changes in Pennsylvanian rocks within the region are numerous and, in places, abrupt. Moreover, in many places no readily apparent lithologic basis is evident for separating rocks of one series from similar rocks of another. Individual key beds are utilized locally for correlation by lithology. Although spore studies are being used increasingly for stratigraphic division of the Pennsylvanian System, results of these studies have not been available to us.

In the shelf areas of the west Texas region, uppermost Pennsylvanian rocks beneath the Permian System are assigned by Texas geologists to the Cisco Series and are shown in figure 5 and on plate 2 of I-450 as rocks of Virgil age. This series is extensively represented by limestone on the Northwestern shelf and on the east side of the Central Basin platform. Limestone is also the dominant rock along the Horseshoe atoll (Myers and others, 1956, p. 11, 28; Stafford, 1959, p. 8). However, the Cisco Series consists of both mudstone and limestone, and some interbedded sandstone along the Eastern shelf, and underlies the Permian System with apparent conformity. Permian rocks overlap the Cisco Series and lie on rocks of the Canyon and Strawn Series of Missouri and Des Moines age, respectively, at the south end of the Central Basin platform. 


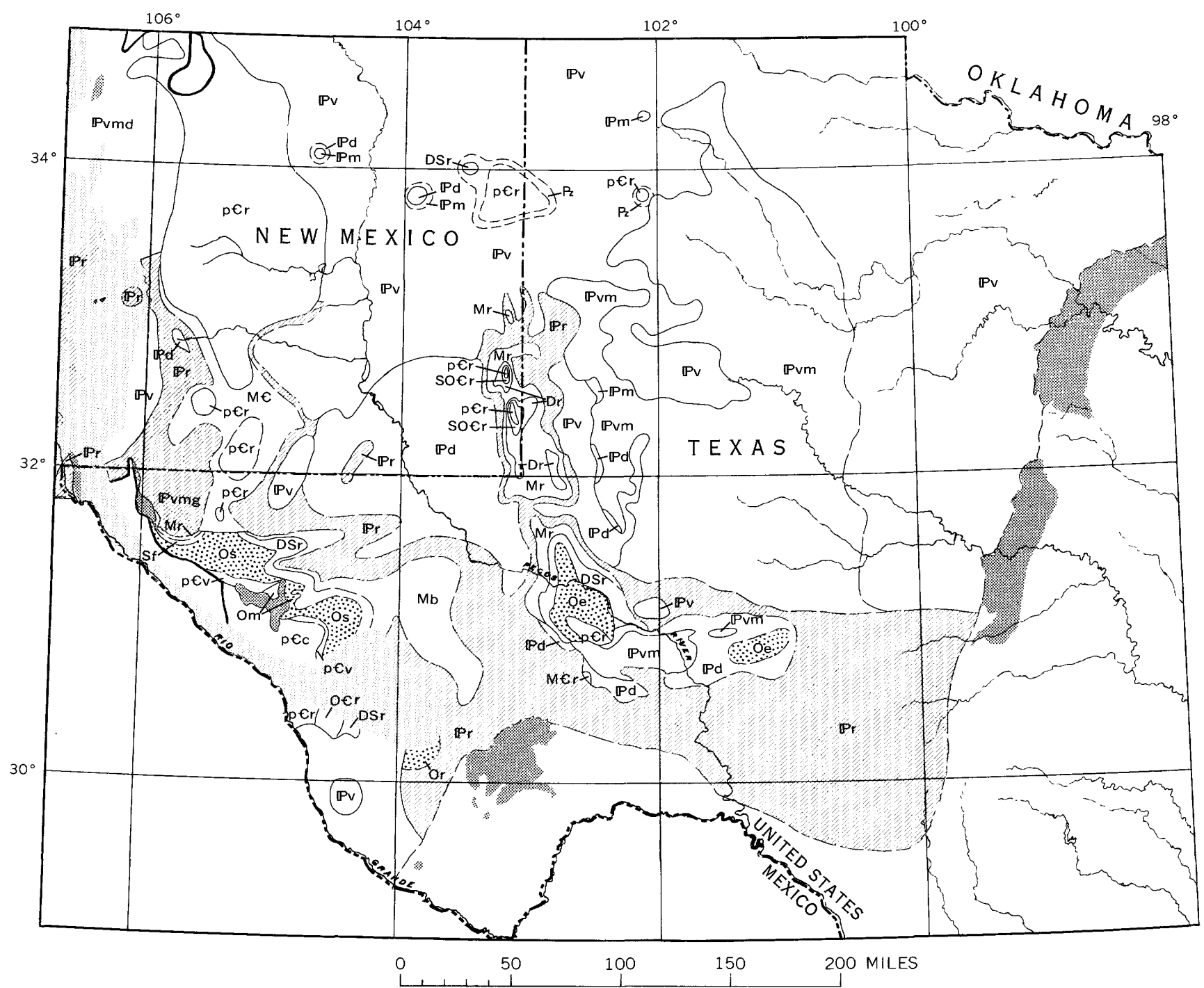

Figdre 5.-Geologic units directly beneath Permian System in west Texas and southeastern New Mexico. P, Paleozoic rocks. Pennsylvanian rocks: $\mathbb{P r}$, undivided (line pattern); $\mathbb{P s c}$, Sangre de Cristo Formation (part); $\mathbb{P} v m d$, Madera Limestone, Pvmg, Magdalena Group, and $\mathbb{P} v$, undivided, all of Virgil age; $\mathbb{P} v m$, undivided, of Virgil and Missouri age; $\mathbb{P m}$, undivided, of Missouri age; $\mathbb{P d}$, undivided, of Des Moines age. Mississippian rocks: Mr, undivided; Mb, Barnett Shale. MEr, Mississippian through Cambrian rocks. Dr, Devonian rocks. DSr, Devonian and Silurian rocks. Sf, Silurian Fusselman Dolomite. SOCr, Silurian, Ordovician, and Cambrian rocks. Ordovician rocks (stipple pattern): Or, undivided; Oe, Ellenburger Group; Om, Montoya Limestone; Os, Simpson Group. O€r, Ordovician and Cambrian rocks. $p \in_{V}$, Precambrian(?) Van Horn Sandstone. Precambrian rocks: $p €_{r}$, undivided; p€c, Carrizo Mountain Formation. Dark pattern, areas where rocks older than Permian are exposed; light pattern, areas where Permian rocks have not been penetrated. Contacts between stratigraphic units dashed where uncertain. Limit of Permian rocks shown by heavy line; dashed where uncertain.

Rocks of Virgil age are locally present along the west margin of the region. In the Hueco Mountains (fig. 6), for example, the uppermost part of the Magdalena Group at one locality has yielded fusulinids of Virgil age (King, P. B., and others, 1945). An angular unconformity separates the two systems there, however, and Permian rocks in adjoining areas rest on successively older Pennsylvanian rocks of the Magdalena. A similar situation exists in the Franklin Mountains and the Sierra Diablo. For this reason, these units below the Permian are shown in figure 5 as Pennsylvanian undivided.

In the Glass Mountains area (fig. 6), south of the Val Verde trough, rocks directly beneath the Permian are mapped as Pennsylvanian undivided because of the stratigraphic complexity produced by deformation and erosion in the Late Pennsylvanian and very early in the Permian. Permian rocks rest on (1) the Tesnus Formation of Mississippian and Pennsylvanian age and the Dimple Limestone of Middle Pennsylvanian 


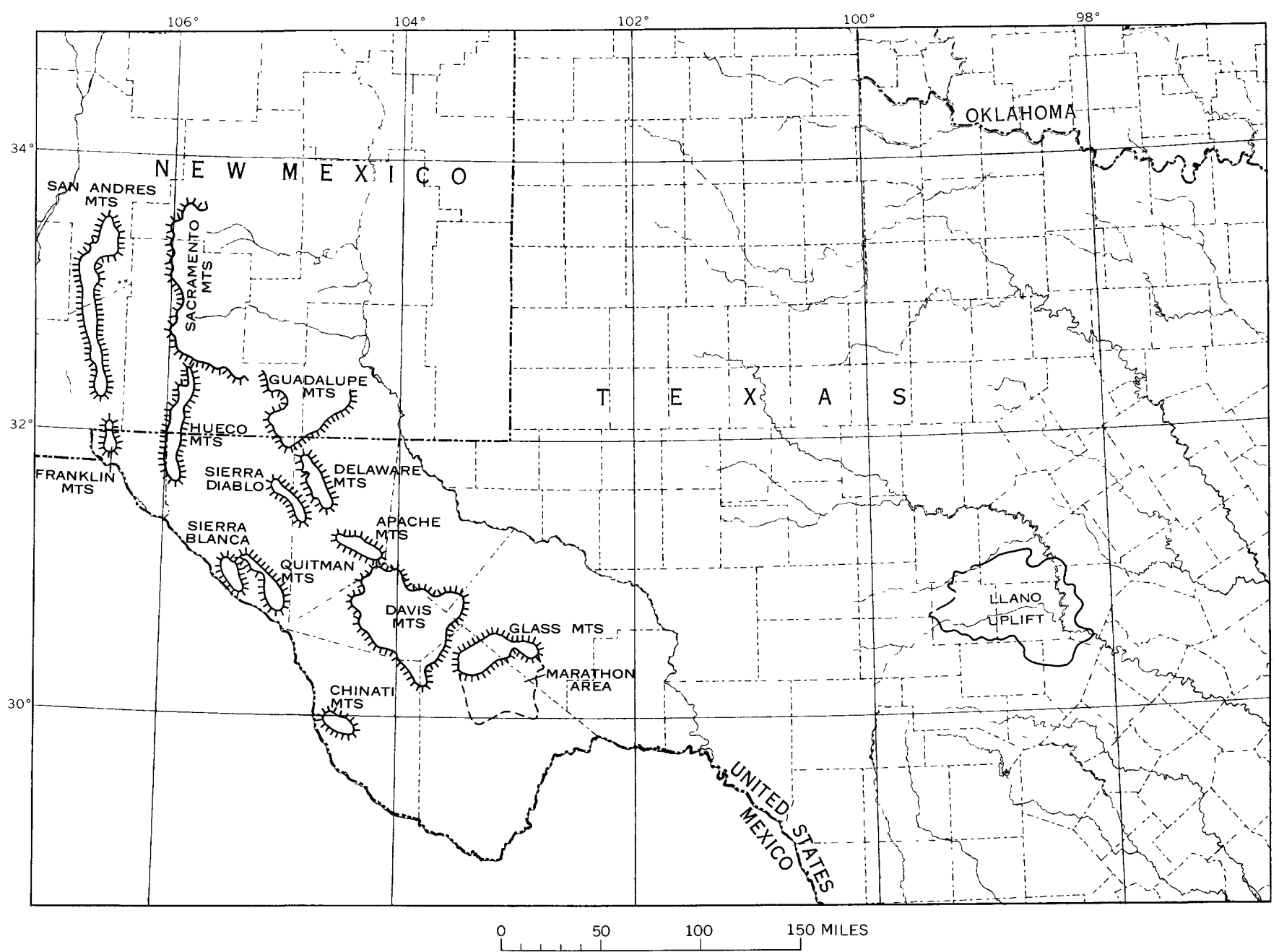

Figure 6.-Geographic features in central and west Texas and southeastern New Mexico mentioned in text.

age along the central part of the Glass Mountains escarpment, (2) the Haymond Formation of Middle Pennsylvanian age at the far east end of the mountains, (3) the shallow-water, type Gaptank Formation of Middle and Late Pennsylvanian age in the northeastern Glass Mountains, and (4) a thick Gaptank sequence of deeper water mudstone and sandstone in the western Glass Mountains area. The significance of the Gaptank in determining the base of the Permian in this area is discussed below.

The precise age of the uppermost Pennsylvanian beds in the Midland and Delaware basins and the Val Verde trough is not established. The section in both basins consists of a hundred to several hundred feet of very dark gray mudstone underlain by locally cherty limestone with some gray mudstone. The limestone is assigned to the Strawn Series and contains fusulinids of early Des Moines age. The dark-gray mudstone was formerly assigned a Wolfcamp age be- cause fusulinids of that age had been reported from the unit in several wells.

Recent detailed studies of the dark-gray mudstone unit in the Midland basin indicate that at least some earlier reported Wolfcamp fossils apparently were from caved cuttings of rocks above the mudstone. Fusulinids of Virgil, Missouri, and late Des Moines age are reported by the Paleontological Laboratory from the mudstone unit in several boreholes within the Midland basin. ${ }^{1}$ Furthermore, near the margins of the basin the thin mudstone unit is believed to intertongue with limestone beds of the thicker fossiliferous Upper Pennsylvanian sequence of the shelf areas (Adams and others, 1951, p. 2604; Rall and Rall, 1958, p. 860-861). The thinness of the mudstone unit and the sparsity of fossils in it are attributed to deposition in a deep marine "starved basin" (Adams and others, 1951, p.

1 Texas loc. Nos. on pl. 1 of I-450; 1535, 1537 (Howard County) ; 670 (Crosby County); 1408 (Kent County); 1524 (Martin County); and 1542 (Mitchell County). 


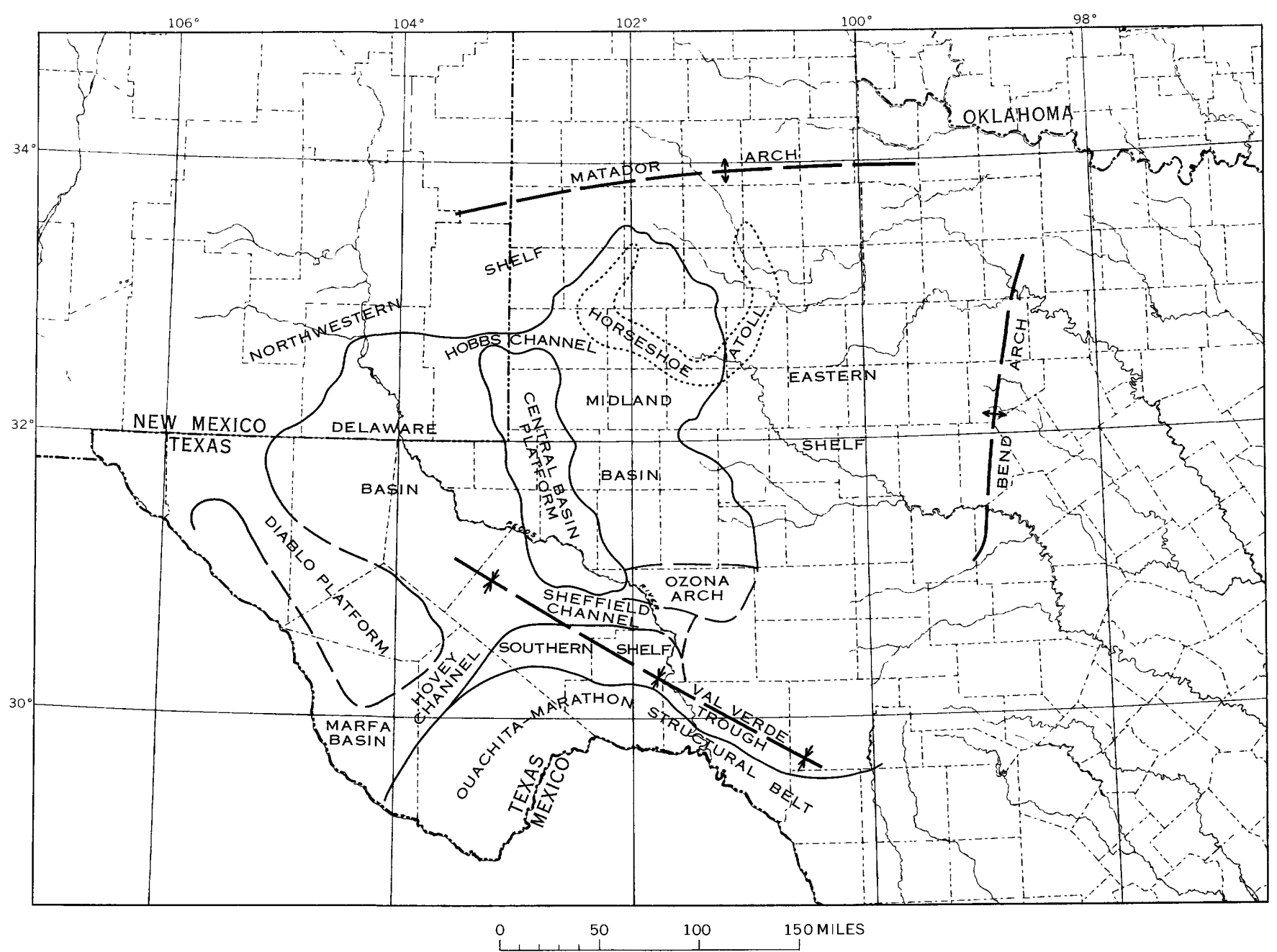

Figure 7.- Tectonic elements in central and west Texas and southeastern New Mexico in late Paleozoic time.

2604) that persisted at least through Late Pennsylvanian time. In the Midland basin, therefore, the dark-gray mudstone unit above the Strawn limestone is mainly Late Pennsylvanian and is shown in figure 5 as of Missouri and Virgil age.

Drilling in the Delaware basin and the Val Verde trough has been far less intensive than in the Midland basin, and detailed stratigraphic relations have yet to be established. A dark-gray mudstone unit above the Strawn Limestone in the Delaware-Val Verde area was included in the Wolfcamp Series in earlier publications (Roswell Geol. Soc., 1953; Bruce, 1954) but is assigned to the Cisco and Canyon Series in a more recent geologic section (Roswell Geol. Soc., 1958). This unit, like the similar mudstone above the Strawn Limestone in the Midland basin, may have been deposited in a deep marine "starved basin" (Vertrees and others, 1959, p. 68) of Late Pennsylvanian age. However, most of the fusulinids reported thus far from the mudstone unit in the Delaware basin have been assigned a Wolfcamp age (Williams, H. L., 1959, p. 97).

The dark-gray mudstone unit, where present in the Delaware basin and Val Verde trough, is included in this paper with the Wolfcamp Series in interval A, and the rocks beneath the Permian System are shown as of Des Moines age (fig. 5). These ages conform with reports of the Paleontological Laboratory. Moreover, this mudstone unit commonly cannot be separated on a regional basis from overlying rocks in interval $\mathbf{A}$.

It is likely that Wolfcamp fossils caved from the overlying very thick detrital rocks have been recovered with rotary samples from the mudstone unit, which is rarely cored. On the other hand, some Permian fusulinids have been obtained from limestone immediately above the Strawn Limestone, so that at least locally Wolfcamp rocks rest upon Middle Pennsylvanian rocks. 
In the Chinati Mountains of the western Marfa basin, Permian rocks crop out in several isolated areas. Their base is mostly not exposed or is destroyed by igneous intrusions. At a few places they are known to be underlain by limestone, sandstone, and mudstone of the Cieneguita Formation of Middle and Late Pennsylvanian age (Skinner, J. W., 1940, p. 185).

Rocks of late Early and early Middle Pennsylvanian age, as well as some of Late Pennsylvanian age, are present in the west Texas Permian basin. Where they lie directly beneath the Permian System, they are shown in figure 5 as Pennsylvanian rocks undivided.

\section{OLDER PALEOZOIC UNITS}

Pre-Pennsylvanian rocks that are directly beneath the Permian System in west Texas include limestone, siliceous limestone, and black mudstone of Mississippian age; the "Woodford Shale" and Caballos Novaculite of Mississippian and Devonian age; limestone, cherty limestone, and dolomite of Devonian age; a unit consisting mainly of the Fusselman Dolomite of Silurian age but locally including rocks of adjoining systems; the Montoya Limestone, Simpson Group and Ellenburger Group of Ordovician age; sandstones of Cambrian or Cambrian and Ordovician age; and Precambrian rocks of several lithologies. The Van Horn Sandstone is shown in this paper as Precambrian(?) (King, P. B., and Flawn, 1953, p. 95). These and other named units are described by P. B. King (1937, 1965), Laudon and Bowsher (1941), Lloyd (1949), T. S. Jones (1953), Flawn (1956), Barnes and others (1959), Jicha and Lochman-Balk (1958), Galley (1958), and others.

The complex distribution of Paleozoic and Precambrian rocks beneath the Permian System on the Central Basin platform is generalized considerably in figure 5. Permian strata rest with angular unconformity on faulted and folded older rocks. Detailed relations of these faults and folds have been ascertained only in intensively drilled producing areas but were illustrated by Elam (1957, p. 9), Van den Bark (1957a, p. 113), Osborne (1957, p. 168), Watson and Bentz (1957, p. 188-189), Cooper and Ferris (1957, p. 361), and LeBlond (1957, p. 405). Geophysical evidence suggests that a high-angle reverse fault offsets basement rocks along the west side of the Central Basin platform (Cohee and others, 1961), but the fault may fade out in overlying strata and is not shown in figure 5 .

Paleogeologic relations in the Sierra Diablo area, in eastern Hudspeth and western Culberson Counties of west Texas (figs. 4, 5), are generalized from a map by P. B. King (King and Flawn, 1953, pl. 19C) and are extended laterally on the basis of sparse subsurface data. In this area, too, details of known structural features (including faults) cannot be shown on the present scale, but a regional easterly to southeasterly strike of pre-Permian strata is evident.

Rocks beneath the Permian System exposed in the Pump Station Hills of north-central Hudspeth County, Tex., are assigned a Precambrian age (King, P. B., 1942 , p. 678 ; King, P. B., and Flawn, 1953, p. 123 ; Stead and Waldschmidt, 1953, p. 73). The hills are south of the south end of the Pedernal positive element in New Mexico (fig. 75) and probably represent its southern extension. The axis may continue southward into the area of pre-Permian deformation on the Diablo platform, as depicted by P. B. King (1942, p. 678), and as shown in figure 5, although drilling has not yet established this.

\section{LOWER BOUNDARY OF PERMIAN}

In many parts of the region, Permian strata are underlain by lithologically similar Pennsylvanian rocks and the boundary between them is difficult to recognize, except on the basis of fusulinid age determinations (Soc. Econ. Paleontologists and Mineralogists, 1957 , p. $39-98)$.

The base of the Permian is clear in the structurally positive areas where Pennsylvanian rocks are absent. In many parts of the Central Basin platform, the Permian overlies distinctive middle to lower Paleozoic or Precambrian rocks (Van den Bark, 1957b, p. 233; LeBlond, 1957, p. 404). In some areas the base of the Permian is marked by a thin detrital unit of variegated mudstone, sandstone, and chert sandstone derived from the older rocks. In parts of the Central Basin platform, however, similar detrital units occur locally both at the base of the Pennsylvanian and within the carbonate sequence of Wolfcamp age.

An angular unconformity at the base of the Permian is conspicuous in the Sierra Diablo region and present in the Pump Station Hills and along the southern part of the Pedernal positive element. The detrital unit near and at the base of the Permian System in the western part of the basin, exposed in the Hueco Mountains and the Sierra Diablo, is called the Powwow Member of the Hueco Limestone (King, P. B., and Flawn, 1953, p. 98).

In the western part of the Glass Mountains, an angular unconformity occurs at the base of the Wolfcamp Formation; however, Pseudoschwagerina has been recognized in rocks mapped as Gaptank Formation below the unconformity. In one place they occur in rock below an intervening thrust plate of pre-Permian rocks. The unconformity is, therefore, within the Per- 
mian System as defined in terms of fusulinid zones. The base of the system in this area cannot be consistently recognized in terms of changes in lithology.

In many stratigraphic sections in the Midland basin, the lower boundary of the Permian System is placed at the top of or within the dark-gray mudstone unit that overlies the Strawn Limestone (Caussey, 1957, p. $147)$; the horizon chosen at many localities is at the top of a sandstone lentil about 200 feet above the Strawn Limestone. In the Delaware basin and Val Verde trough, however, the boundary is placed at the base of several hundred feet of dark-gray mudstone that overlies the Strawn Limestone (Vertrees and others, 1959, p. 68). Part or all of this mudstone, however, may be Pennsylvanian. In the eastern part of the area, layers or reefs of Pennsylvanian limestone that are progressively younger (Missouri to Virgil) toward the Eastern shelf intertongue with mudstone and sandstone (Rall and Rall, 1958). However, in southwestern Sutton County fusulinids of Wolfcamp age (in place?) were recovered within 100 feet of the Strawn Limestone.

No lithologic basis of recognizing the Pennsylvanian-Permian boundary is apparent on the Northwestern shelf, along the east margin of the Central Basin platform, or in the area of the Horseshoe atoll (fig. 7), in the northern Midland basin, where limestones of Late Pennsylvanian and Wolfcamp ages are much alike. Moreover, in some parts of the Midland and Delaware basins, detrital rocks of Permian age overlie similar rocks of Pennsylvanian age. In these places, therefore, the systemic boundary is placed between horizons from which fusulinids indicative of the respective ages have been reported.

On the Eastern shelf, the base of the Permian rests upon the Chaffin Limestone Member of the Thrifty Formation (Cisco Group) and its lateral equivalents (Eargle, 1960).

The base of interval A in the Chinati Mountains in the western Marfa basin is at the base of the Alta Formation, although some Pennsylvanian strata may be included in the unfossiliferous mudstone of the Alta (Skinner, J. W., 1940; Rix, 1953a, b, c).

\section{PALEOTECTONIC IMPLICATIONS}

Most of the major tectonic elements that influenced sedimentation in west Texas and adjoining regions during the Permian Period were fully developed late in Pennsylvanian or very early in Permian time.

Major crustal instability within the west Texas Permian basin, before oldest Permian strata were deposited, is clearly recorded in the marked angular unconformities shown on the paleogeologic map (fig. 5).
Fossils for bracketing many of the tectonic episodes, however, are sufficient to permit age assignments no more precise than Middle or Late Pennsylvanian to Early Permian.

\section{OUACHITA-MARATHON BELT}

One of the most extensive tectonic elements of the Southwestern United States, active at or near the end of the Pennsylvanian Period, was the western part of the Ouachita-Marathon structural belt, along the south margin of the Val Verde trough. The belt contains structural features of possible Early Pennsylvanian to Early Permian age. The present edge of Permian rocks (fig. $8 ; \mathrm{I}-450$, pl. 3 ) differs only slightly from the boundary of the structural belt (fig. 9, inset). Within at least the western part of the arc of the orogenic front, strata formed in an Early Pennsylvanian trough, and earlier Paleozoic formations beneath were folded and thrust, mainly northward, at intervals throughout Pennsylvanian time and very early in Permian time. Mountainous areas created by these deformations furnished much of the detritus that filled the Val Verde trough.

The southeastern part of the south margin of the Val Verde trough may have been established early in Pennsylvanian time. In that area, an overthrust sheet of metamorphosed rock of the Ouachita structural belt overlies Precambrian metavolcanic rocks of the Devils River uplift, a northwestward-trending positive element that was intermittently active from early $\mathrm{Pa}$ leozoic through at least Cretaceous time (Flawn, 1959, p. 74-77). Metamorphic rock fragments derived from the thrust sheet were deposited with sediment of early Middle Pennsylvanian (Atoka) age northeast of the thrust belt and the Devils River positive element (Flawn, 1959, p. 77). Not enough data are available to indicate whether deep-trough development north of the Devils River uplift began in Middle Pennsylvanian time or later, but the resistant mass of the uplift seems to have set a northeastern limit to intensive folding and overthrusting by this date.

Times when deformation northwest of the Devils River uplift took place also are not definitely known. The youngest deformed and slightly metamorphosed rocks between the Devils River and Marathon uplifts may be equivalent to the Tesnus Formation of the outcrops (P. T. Flawn, written commun., 1960). Later Pennsylvanian time may be represented by unaltered dark mudstone and fine-grained sandstone, recorded in a few wells just north of the orogenic front; it may be more completely represented in the Val Verde trough area in the Lower Strawn Limestone and overlying dark mudstone unit, which is a few hundred feet 

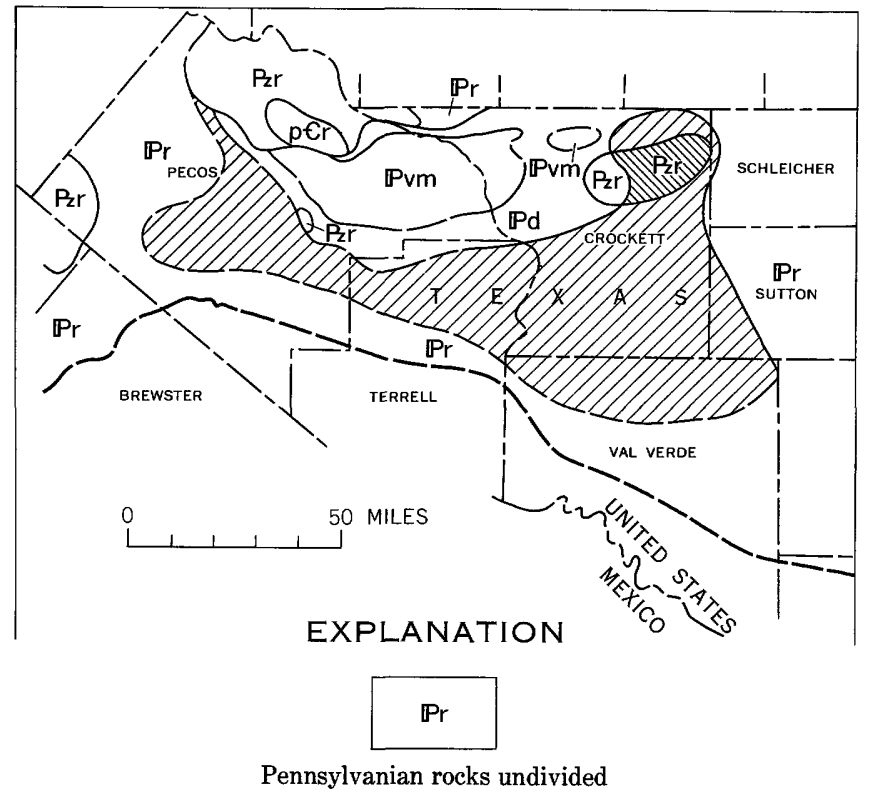

Pvm

Rocks of Virgil and Missouri age

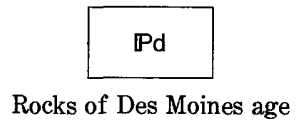

Pzr

Paleozoic rocks older than Pennsylvanian

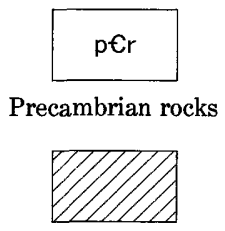

Area where strata assigned to Permian System in this report overlie limestone of early Des Moines age and may include Pennsylvanian rocks of "starved basin facies"

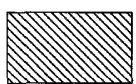

Area where strata assigned to Permian System in this report overlie Ellenburger Group and may include a thin Pennsylvanian unit

\footnotetext{
Contact between stratigraphic units Dashed where control is poor

Present limit of Permian rocks Dashed where control is poor
}

Figure 8.- Val Verde trough area, west Texas, showing stratigraphic units underlying interval A. thick at most. The absence of known thick or coarsegrained detrital deposits of Middle or Late Pennsylvanian age suggests that land south of this central segment of the Val Verde trough remained too low to supply a large volume of sediment until very early in Permian time.

Deformation in the western part of the Val Verde region is recorded in Paleozoic rocks exposed in the Marathon area. Lower Pennsylvanian and underlying rocks, formed in older troughs to the south, were deformed and uplifted in Middle and Late Pennsylvanian and earliest Permian times. They supplied detritus to a foredeep, whose strata have been mapped as the Gaptank Formation in the western Glass Mountains, and to an unstable shelf, as recorded in the Gaptank and Wolfcamp Formations of the eastern Glass Mountains. Destruction of this later trough very early in the Permian is demonstrated by a northwestward thrust of lower Paleozoic rocks upon which conglomerate and other shallow-water strata of the Wolfcamp Formation were deposited unconformably. These data support migration of belts of deformation and deposition in the Ouachita-Marathon structural belt from the inner (southern) part of the system toward the foreland (Flawn and others, 1961).

\section{BASINS AND TROUGHS}

The Delaware and Midland basins were well developed before Permian sedimentation began. The presence of normal marine sedimentary rocks in the lower part of the Strawn Series indicates that seas were still shallow in both basins, although the deepest part of the later Delaware basin was foreshadowed by the earlier "Tobosa basin" (Galley, 1958). By Late Pennsylvanian time, however, both basins were probably topographically and structurally deep (Adams and others, 1951). Only the northern part of the Midland basin remained a relatively shallow platform, on which grew the Horseshoe atoll (fig. 7).

In the Val Verde area, southeast of the Delaware basin and north of the Ouachita-Marathon belt, and in outcrops at the base of the Gaptank Formation of the Glass Mountains, the presence of widespread limestone suggests a fairly stable foreland early in Des Moines time. Through the remainder of Pennsylvanian time, dominantly carbonate deposition, presumably in shallow water, continued on the north edge of the Val Verde area, and the sea transgressed across a positive element of older rocks, the south end of the Central Basin platform. In contrast, deposition of a thin unfossiliferous mudstone-the "starved-basin" 
facies-south of the area of carbonate deposition may indicate deeper water accompanying downwarping in the incipient Val Verde trough.

Deposition of much detritus, as well as limestone, in the Marathon area and the Chinati Mountains.area (Gaptank and Cieneguita Formations) suggests that these areas bordered high southern and western source areas during Middle and Late Pennsylvanian time.

Near the beginning of Permian time, the Val Verde trough was abruptly deepened and its north side irregularly steepened opposite the Marathon salient of the southern structural belt. The slope thus formed lay along the southwest margin of the developing Central Basin platform and, to the east, passed into the broad south flank of the Ozona arch in Crockett County. That the north flank of the trough was not a slope of simple linear trend is evident from the isopach map of interval A (fig. 12).

Large-scale faulting, believed to be of Pennsylvanian age, is recognized in several areas of deep drilling along the north flank of the Val Verde trough; sagging along these zones of weakness during Permian deepening of the trough seems probable (Vinson, 1959; Hester and Holland, 1959). The Phillips 1 University $\mathrm{EE}$ well (loc. 2254, I-450, pl. 1) penetrated a section described as "located in a structurally complex zone of multiple faulting, including high-angle reverse faults and possibly some overturning, which separates the Fort Stockton high from the Val Verde geosyncline" (Young, 1960, p. 104). The deformation observed in the University EE well is interpreted (Young, 1960, fig. 65) as having affected lowest Permian rocks in the Val Verde trough.

\section{PLATFORMS}

Though relatively small in area, the deformed Central Basin and Diablo platforms affected sedimentation throughout Permian time. Ascertaining the precise times of deformation of these elements, however, is difficult.

Deformation on the Diablo platform consisted of uplift, folding, and faulting. Uplift was greater in the south than the north, in the Carrizo MountainVan Horn area (fig. 4) where subsequent erosion breached Precambrian rocks.

Pebbles and cobbles in the Powwow Member of the Hueco Limestone attest to deformation and erosion of parts of the Diablo platform; in places the underlying surface has several hundred feet of relief (King, P. B., and Flawn, 1953; Hay-Roe, 1957). Fusulinids in beds above the unconformity are considered by Henbest to characterize "bed 14" and higher parts of the Wolfcamp Formation at its type section (King, P. B., 1965), so that oldest Permian strata in the Sierra Diablo area may be of late Wolfcamp age. Youngest rocks beneath the unconformity are possibly of Middle Pennsylvanian age. Detritus as coarse as sand is moderately abundant in Permian rocks of interval $\mathbf{A}$ in the adjoining Delaware basin, whereas such detrital sediment is not apparent in Upper Pennsylvanian rocks. The Diablo platform may have been deformed in either Late Pennsylvanian or Early Permian or both, but topographic relief and the presence of coarse detritus favor Early Permian.

The fault shown northeast of the Diablo platform in southern Reeves County is a diagrammatic representation of a little understood structure in a very sparsely drilled area. The contact between rocks depicted in figure 5 and the Permian may be an unconformity on older rocks that were faulted in pre-Permian time. If, however, the Permian in at least one of the boreholes in the area (Balmorhea Ranch, loc. $2084, \mathrm{I}-450, \mathrm{pl} .1$ ) is in fault contact with the older rocks, as seems likely, then deformation occurred after earliest Permian deposition. The fault parallels faulting known in post-Permian rocks southwest of the Balmorhea Ranch area, along the northeast margin of the Diablo platform.

The Central Basin platform probably assumed its present structural configuration early in Permian time. During most of Paleozoic time the site of the platform was close to but east of the axis of the "Tobosa basin" (Galley, 1958, p. 408, 409, 412, 416), but early in Pennsylvanian time the southern part of the area became structurally positive and formed part of the Pecos arch (Galley, 1958, p. 418). The platform had developed in embryonic form in latest Middle Pennsylvanian time (Adams and others, 1951). There seems to be no control of the position of the platform in the pattern of basement rocks (Flawn, 1956, pl. 3).

Folds and faults formed during uplift of the Central Basin platform affect rocks as young as Late Pennsylvanian. Strata of Wolfcamp age lie unconformably on these structural features but are thin or even absent in places and probably were deposited late in Wolfcamp time. The platform was probably deformed during the early part of the Permian (Lloyd, 1949, p. 63).

A large volume of Paleozoic and Precambrian rocks was removed from the Central Basin platform during and after uplift and before deposition of lowest 
Permian strata, but there is little evidence of this debris in surrounding areas. Along the west margin of the Central Basin platform present structural relief is about 4,000 feet and along the east margin about 1,500 feet. Similar topographic relief in Late Pennsylvanian or earliest Permian time would have produced much coarse detritus, but such is not now evident in rocks of Wolfcamp age. Most of the eroded material, however, was easily weathered Paleozoic carbonate rock (Lloyd, 1949, p. 63).

Erosion may have kept pace with uplift so that the top of the platform did not rise appreciably above base level. Rock removed may have been distributed through the large volume of detrital rocks, including numerous sandstone beds, now present in Wolfcamp strata in adjoining basins.

\section{SHELVES}

The Northwestern shelf was well developed before the onset of Permian time, as shown by the abundance of shelf limestones, including numerous reefs of Virgil age (fig. 5), along its present trend. This tectonic element may have originated in early Paleozoic time, when it formed the north margin of the early "Tobosa basin" (Galley, 1958, p. 423).

The Eastern shelf, too, was well developed by Late Pennsylvanian time. Permian strata were deposited upon a slightly southwestward-sloping surface underlain by Upper Pennsylvanian strata. This surface was relatively smooth except where reefs rose above it (Myers and others, 1956, p. 34).

\section{INTERVAL A FORMATIONS INCLUDED}

Stratigraphic units in the west Texas Permian basin region assigned to interval $\mathrm{A}$ include many compositions and facies. Diversity in rock type is indicated by the abundance of stratigraphic names used in the region. These include the Hueco Limestone, the Dean Sandstone, the Third Bone Spring sand, the Alta Formation, the Pueblo and Moran Formations, and the lower part of the Putnam Formation of the Wichita Group. Individual formations, such as the Wolfcamp and some of the aforementioned units, also include diverse rock types. Likewise in interval $\mathbf{A}$ are many unnamed subsurface units of contrasting rock types to which a Wolfcamp age is ascribed.

\section{INTERVAL A IN THE GLASS MOUNTAINS}

The Wolfcamp Formation was named for typical exposures in the Wolf Camp Hills in the eastern Glass Mountains, but the Gaptank Formation which underlies it at this locality is similar lithologically, and the distinction between them was made on the basis of the assumption that the faunas of the Wolfcamp herald the beginning of the new Permian Period. The elusiveness of this criterion is illustrated by divergences in opinion and among individuals as to where the boundary should be placed. Bose (1917) originally called attention to the distinctive ammonites of the Uddenites zone, which he and Udden supposed marked the base of the formation; Beede and Kniker (1924) later emphasized the significance of the pseudoschwagerinids, which occur a little higher. The $U d$ denites zone is now restricted to the upper part of the Gaptank, and the base of the Wolfcamp in the type area is now drawn on the basis of fusulinids (especially the pseudoschwagerinids), with some differences of opinion as to the exact position within a few feet of beds.

A revision of the Wolfcamp in the Glass Mountains was proposed by Ross (1959a, b), who divided it into a Neal Ranch Formation below and a Lenox Hills Formation above, with type sections established in the central and western Glass Mountains, respectively. In the eastern Glass Mountains the Neal Ranch corresponds virtually to the Wolfcamp Formation of current usage, with the exclusion of the gray limestone member at the base, and the Lenox Hills consists of the lower few hundred feet of the unconformably overlying Hess Limestone Member of the Leonard Formation of current usage. In this paper, however, the Wolfcamp Formation is used as defined by P. B. King (1930, 1937, 1942).

In the western part of the Glass Mountains, basal relations of the Wolfcamp Formation are markedly different from those farther east. The formation lies with angular unconformity on highly disturbed strata, mapped as Gaptank Formation, some of which are apparently only a little older than the Wolfcamp. These were laid down on a foreland sequence of earlier Paleozoic rocks and were overridden for many miles by a thrust plate of the Marathon sequence of earlier Paleozoic rocks. The Wolfcamp Formation was deposited on the eroded edges of the thrust plate (fig. 9).

The disturbed strata in the western Glass Mountains area contain fossils of a wide variety of Pennsylvanian ages, but mainly Des Moines and younger (King, P. B., 1937, p. 80-82). Recently some exposures have yielded fusulinids considered to be of Permian age; these included Schwagerina, Pseudoschwagerina, and Triticites (West Texas Geol. Soc., 1952 , p. $26-27$; 1957 , p. 14). Similar fossils were reported in a well which was drilled through the thrust plate into the overridden rocks (Hull, 1957b). How much of the Gaptank Formation of this area is 


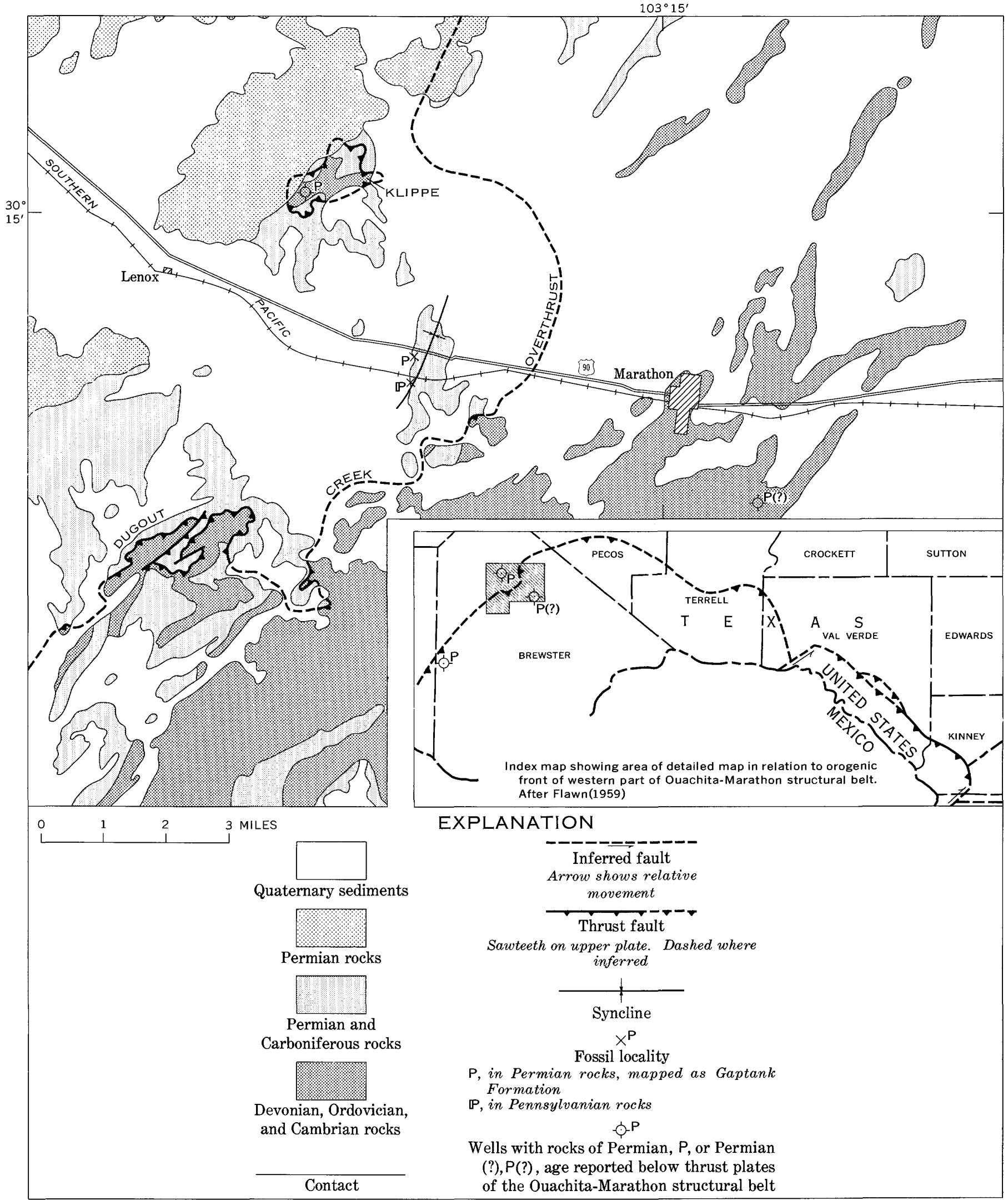

Figure 9.- Marathon area, west Texas, showing sources of evidence for Permian age of late deformation along western front of Ouachita-Marathon structural belt. Geology modified from P. B. King (1937). 
Permian is undetermined, but the presence of Permian fossils indicates that deformation in the western Glass Mountains occurred in earliest Permian rather than latest Pennsylvanian time.

This deformation, which occurred very early in the Permian, may persist for considerable distances northeast and southwest of the exposures in the Glass Mountains. A well (loc. 2220, I-450, pl. 1) drilled to the southwest is reported to have passed through a thrust plate of lower Paleozoic rocks into Upper Pennsylvanian or lowest Permian rocks like those in wells near Marathon (P. T. Flawn, written commun., 1960; fig. 9, this paper). Eastward, the deformed Upper Pennsylvanian and lowest Permian rocks may extend under the Glass Mountains, north of the type area of the Wolfcamp, in continuity with similar rocks of the Val Verde trough.

\section{BASIN ARTAS}

North and east of the Glass Mountains area, thick subsurface sequences of detrital rock, similar to the deformed rocks beneath the Wolfcamp Formation in the western Glass Mountains, are also included in interval A. These rocks, containing fusulinids commonly assigned to the Pseudoschwagerina Assemblage Zone, are mainly dark-gray and brown mudstone, white to gray quartzitic sandstone, and some tan to brown, mainly fragmental limestone (Vertrees and others, 1959, p. 68; Soc. Econ. Paleontologists and Mineralogists, 1957, p. $88-95)$.

In the central and northern parts of the Delaware basin, rocks commonly assigned to the Bone Spring Limestone (discussed more fully in the section on interval B, p. 37-38) include mainly brown to darkbrown partly argillaceous limestone, dark-gray to brown mudstone, and white to brown medium- to finegrained sandstone. Much of the sandstone occurs in three regionally extensive blanket deposits that are locally referred to as the First, Second, and Third Bone Spring sands (Roswell Geol. Soc., 1958; Jones, T. S., 1949; Vertrees and others, 1959, fig. 3).

Below the basal or Third Bone Spring sand, which is included in interval $\mathbf{A}$, the proportion of limestone in the predominantly detrital sequence increases toward the margins of the basins, probably by intertonguing rather than by gradation. The proportion of sandstone increases southward toward the Val Verde trough. The thick sequences of strata in the Delaware basin and Val Verde trough have not been subdivided lithologically.

Rock types in the Midland basin are similar to those in the Delaware basin. Here, however, the upper part of the section, beneath the Dean Sandstone, consists mainly of dark argillaceous locally cherty limestone and interbedded dark-gray to brown mudstone, whereas the lower part of the sequence is dominantly dark mudstone and thin units of fossiliferous limestone and fine-grained argillaceous sandstone. Thin unnamed lithologic units can be traced within the basin (Jones, T. S., 1949; Davis, H. E., 1953). The proportion of limestone increases northward and westward along the periphery of the basin.

The Dean Sandstone was named from the Gulf Oil Corp. 1 Dean well in Dawson County, but the type section is another well in the same county (McLennan and Bradley, 1951). The unit occurs in most of the Midland basin and is mainly composed of white, gray, and brown fine-grained sandstone to siltstone but includes streaks of $\tan$ to brown to dark-gray mudstone. It can be traced southward across the Ozona arch; or the southern threshold of the basin, and perhaps somewhat farther.

In the Chinati Mountains in the western part of the Marfa basin, Permian rocks occur in a few places, but data on subdivisions are inadequate for showing thickness in figure 12. Interval A includes the unfossiliferous mudstone and overlying sandy mudstone of the Alta Formation (Udden, 1904) and the transition zone of limy and sandy mudstone at the base of Udden's Cibolo Formation. The transition zone contains abundant fusulinids of Wolfcamp age (Skinner, J. W., 1940, p. 185; Rix, 1953c, p. 52).

Rocks of Wolfcamp age have also been identified in a few wells within the Marfa basin.

\section{SHOTIF AREAS}

Limestone and red detrital rocks on shelf areas of the west Texas Permian basin region contrast with the dark-gray detrital rocks of the basin areas.

The Hueco Limestone, named for exposures in the Hueco Mountains (Richardson, 1904, p. 32-38), crops out extensively along the westernmost part of the Permian basin, where it consists dominantly of limestone and dolomite but includes detrital strata. The name is now restricted to that part of the original formation that includes the "Hueco fauna" (King, 1934, p. 741-742). In westernmost Texas, near El Paso, the formation consists of four members: the Powwow Conglomerate Member, an unnamed limestone member, the Deer Mountain Red Shale Member, and an unnamed upper limestone member. Only the lower three units are included in interval $A$; the upper unit is assigned here to interval B.

Limestone is dominant in interval $\mathbf{A}$ on the Northwestern shelf and on much of the Central Basin platform (Soc. Econ. Paleontologists and Mineralogists, 1957, p. 39-44, 51-56, 63-72). The names Hueco Limestone and Wolfcamp limestone have been applied 
to these. On the Northwestern shelf the rocks have been subdivided into two cherty limestone units separated by interbedded limestone and red, green, and gray mudstone. The detrital layers thicken northward, where they include sandstone; southward thinning of mudstone is accompanied by a change from red to green. The carbonate rocks also include local dolomite along the Central Basin platform. Along the margins of the shelf areas, medium- to dark-gray mudstone layers intertongue with the limestone.

On some parts of the Central Basin platform, interval A consists of only a thin unit informally designated as the detrital zone. It is mainly red mudstone but locally includes poorly sorted sandstone and fine conglomerate. On other parts of the platform, the detrital unit underlies a thin sequence of limestone also assigned to interval $\mathbf{A}$.

On the Eastern shelf (figs. 7, 10), interval A includes the Pueblo and Moran Formations and part of the Putnam Formation. The formations extend westward into the Midland basin, where they merge into a sequence consisting of (1) discontinuous beds of gray mudstone, locally containing as much as 60 percent limestone, (2) thin discontinuous beds of sandstone, and, in some places, (3) massive limestone units (fig. 11). In parts of the Midland basin massive limestone units occupy all of interval $A$.

\section{UPPER BOUNDARY OF INTERVAL A}

Lithologic contacts chosen as the top of interval A in most parts of the west Texas Permian basin are at or very close to the top of the Wolfcamp Series as

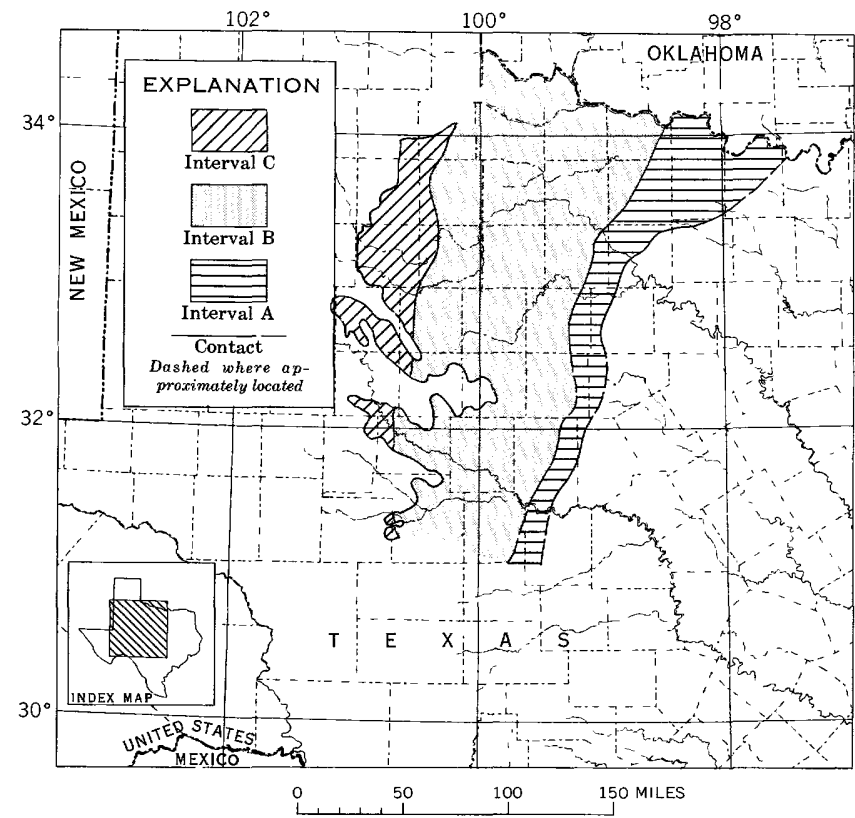

Figure 10.-Eastern shelf area of Texas showing extent of exposures of Permian intervals $\mathrm{A}, \mathrm{B}$, and $\mathrm{C}$.

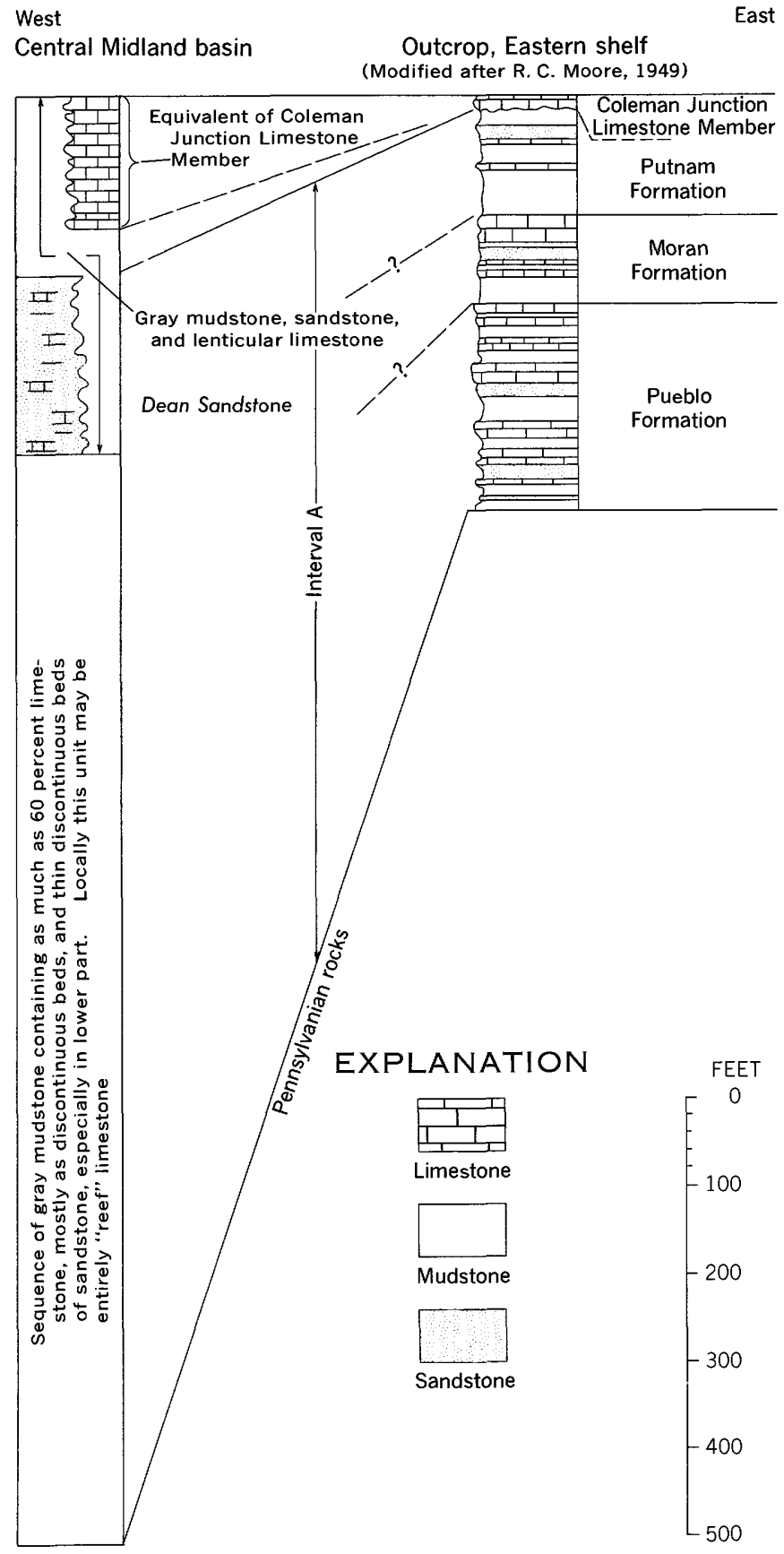

Figure 11.-Relations between interval $A$ in the central part of the Midland basin and in the outcrop area on the Eastern shelf, west Texas Permian basin.

determined from available fusulinid data. In parts of the region, however, lack of data necessitates the use of an arbitrary boundary.

\section{BASIN AREAS}

In the Glass Mountains the upper boundary of interval $\mathbf{A}$ is at the top of the Wolfcamp Formation. Elsewhere in the Val Verde area, the top of the interval is located on the basis of scattered fossil evidence and 
on projection of lithologic units. Correlations are especially uncertain in the southern and eastern parts of the Val Verde trough.

The Third Bone Spring sand in the Delaware basin has been assigned variously to the Leonard (Jones, T. S., 1949) and the Wolfcamp (Roswell Geol. Soc., 1958) Series but in this publication is included in interval A. Fusulinids in limestone samples from directly above and within the sandstone (for example, Richardson and Bass Legg 1, Eddy County, and Stanolind Buffalo unit 1, Lea County, N. Mex.) are assigned (Paleont. Lab., unpub. repts.) a Wolfcamp age, whereas fusulinids of Leonard age are reported in limestone as low as 30 feet above the sandstone. The top of the sandstone seems the most practicable and recognizable lithologic contact for use as the top of the interval, although the series boundary is somewhat higher.

Above the Dean Sandstone (fig. 11) in the west half of the Midland basin about 200 feet of mudstone and minor lenticular limestone underlie the Spraberry Sandstone (McLennan and Bradley, 1951), the next higher named unit. Throughout most of the area the Dean Sandstone contains fusulinids of Wolfcamp age; the Spraberry Sandstone contains fusulinids of Ieonard age. Between the Dean and Spraberry Sandstones are sparse fusulinids which have been identified as of Leonard age at some localities, and as of Wolfcamp age at others; but most of the fusulinids are Leonard types. The top of the Dean Sandstone has arbitrarily been selected as the top of interval A.

The Dean Sandstone grades laterally into mudstone and silty mudstone in the east half of the Midland basin. The change in facies is near the west edge of the Coleman Junction Limestone Member of the Putnam Formation. In a small area of overlap, this member lies less than 100 feet above the Dean Sandstone (Myers and others, 1956). The base of the Coleman Junction Limestone Member is the first persistent mappable unit above the Dean in the area. Therefore, this base is used as the top of interval A on the Eastern shelf, although the Coleman Junction includes Wolfcamp fusulinids and the Admiral Formation, above the Putnam, contains Wolfcamp ammonites (Plummer and Scott, 1937).

In the Marfa basin, the top of interval $\mathbf{A}$ is drawn at the upper limit of Wolfcamp fusulinids as reported from wells. It is considered to be at the top of the transition zone of the Cibolo Formation in outcrops in the Chinati Mountains.

\section{SHELF AREAS}

On the Northwestern shelf and on much of the Central Basin platform, the top of the Wolfcamp Series lies within a carbonate sequence. At numerous localities limestone referred to as the Hueco or Wolfcamp limestone contains fusulinids assigned a Wolfcamp age (Paleont. Lab., unpub. repts.). The relatively few fossils found in an overlying dolomite unit are regarded (Roswell Geol. Soc., 1958) as of Leonard age (for example, in Buffalo Oil 25 Baish, Lea County; Wilshire 33-16 G. M. Cox and others, Andrews County). The contact between the dolomite and the limestone has therefore been used as the upper boundary of interval A. In a few boreholes (such as Great Western Drilling-Wilshire 1 Grayburg deep unit, Eddy County), however, fusulinids of Wolfcamp age are found in the lower part of the dolomite; also, the dolomite locally includes some limestone near its base. This limestone probably intertongues with the dolomite, and the contact between units is time transgressive. Despite this, the limestone-dolomite contact is used as the top of interval A.

The age of the upper part of the Hueco Limestone has been in question in its type area in westernmost Texas and in southeastern New Mexico (King, P. B., and others, 1945) and elsewhere. The comparatively young aspect of fusulinids in uppermost strata of the unit in the Franklin and Hueco Mountains indicates a Leonard(?) age (Ross, 1959a), although it has been proposed that the Wolfcamp Series be redefined to include these strata (Thompson, M. L., 1954, p. 19). Regional stratigraphic relations are interpreted as indicating intertonguing of the upper parts of the Hueco Limestone and the Abo Sandstone of the Sacramento Mountains. Although the relation of the uppermost tongue of the Abo Formation to the Deer Mountain Red Shale Member of the Hueco is disputed (Pray, 1954, p. 101; Bachman and Hayes, 1958, p. $697)$, the limestone above the red mudstone of the Abo is regarded as of Leonard age. All the Abo along the west flank of the Sacramento Mountains is included in interval $\mathbf{A}$ in this paper. Use of the top of the Deer Mountain Red Shale Member of the Hueco as the top of interval $\mathbf{A}$ seems to be consistent with boundaries selected in adjoining parts of New Mexico.

\section{THICKNESS TRENDS}

The greatest thickness of rocks assigned to interval $A$ in the west Texas Permian basin region is nearly 15,000 feet (fig. 12), in the east half of the Val Verde trough, but some Pennsylvanian rocks may be included. The interval thins north ward to less than 5,000 feet in the Midland basin and, in general, northwest- 
ward into the Delaware basin, where thicknesses exceed 5,000 feet only locally. Thicknesses on shelves and platforms are less than 1,000 feet.

In the Glass Mountains, on the south flank of the Val Verde trough, the exposed Wolfcamp Formation is 250-700 feet thick; thick rocks of probable Permian age but older than the exposed Wolfcamp Formation are present at least locally in the subsurface. East of the Glass Mountains, several wells along the south edge of the Val Verde trough have penetrated rocks that may be Pennsylvanian or Permian. No thickness can be assigned to the Permian here, and its relation to the folded and faulted Pennsylvanian and older rocks of the Ouachita-Marathon structural belt (inset, fig. 9) has not been determined. The present edge of interval $\mathbf{A}$ as shown on the south side of the Val
Verde trough in figure 12 may be close to the depositional limit.

The maximum thickness shown for interval $\mathbf{A}$ in the southeastern part of the Val Verde trough may be in tilted beds; farther northwest, close to the axis of the trough where the beds are nearly flat, more than 12,000 feet is assigned to the interval. Less than 35 miles north, interval A is absent and presumed not to have been deposited on the south end of the Central Basin platform.

In the northeastern part of the region, interval $\mathbf{A}$ thickens westward and southwestward from less than 700 feet in the outcrop belt on the Eastern shelf to 4,000 feet. West of this area, along the edge of the Central Basin platform, the interval again thins to less than 1,000 feet. Farther north, however, in Lub-

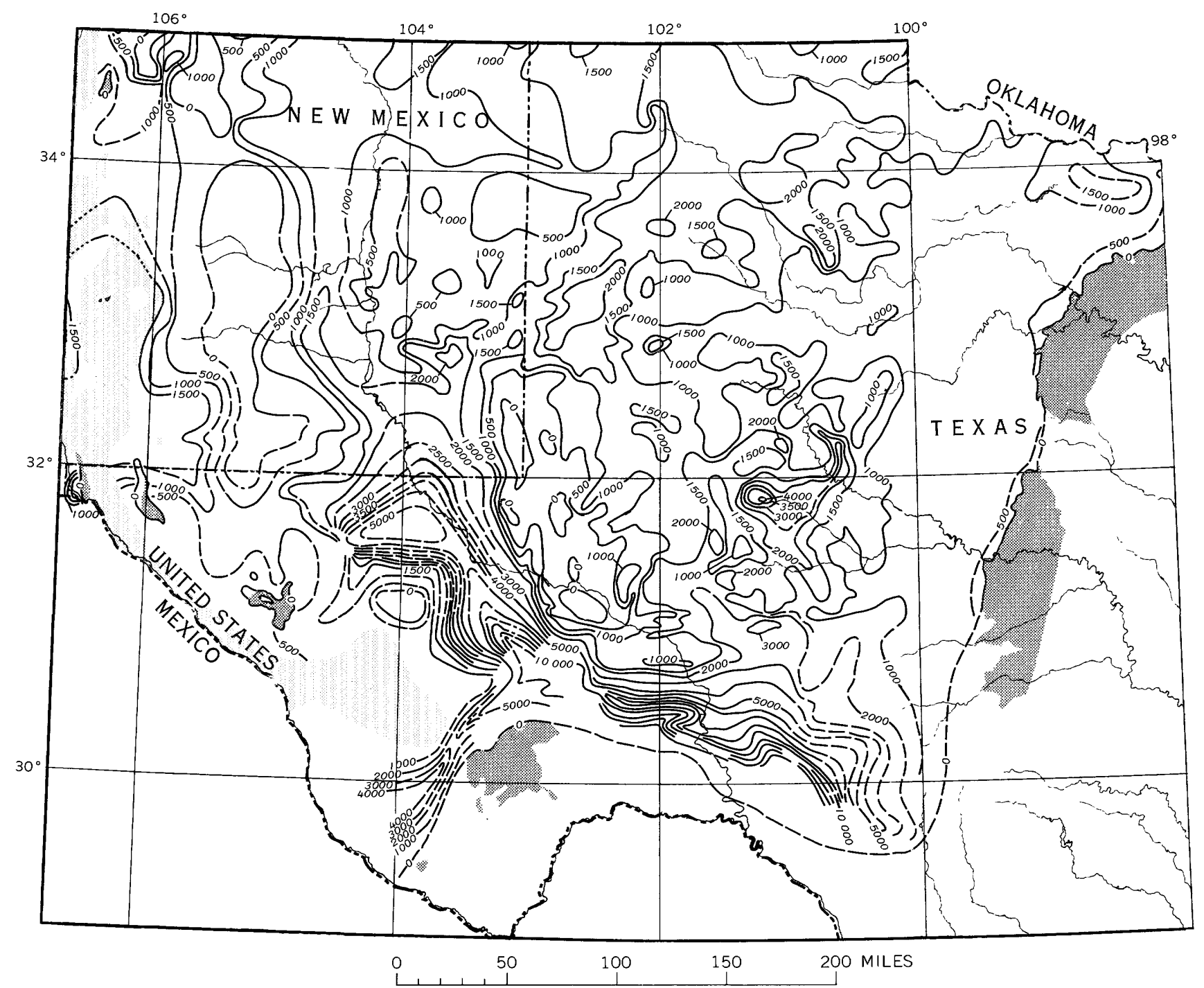

FIGURE 12.-Thickness of interval A in west Texas and southeastern New Mexico. Isopach intervals 500 and 1,000 feet. Isopachs dashed where control is poor, dotted where Permian rocks have not been penetrated by drill. Dark pattern, areas where rocks older than interval $\mathrm{A}$ are exposed; light pattern, areas where rocks younger than interval $\mathrm{A}$ have not been penetrated. 
bock County (fig. 4), the thickness is more than 2,000 feet near the edge of the Northwestern shelf.

Thickness of interval $\mathbf{A}$ in the Marfa basin is little known, but southward thickening to more than 5,000 feet is indicated in the Chinati Mountains and in a few wells.

Uncertainties regarding stratigraphic assignments account for local irregularities of isopachs within the Permian basin region, and for minor discrepancies between maps included here and in other publications (for example, Galley, 1958, fig. 24). In dispute, for example, is the age of limestone in the basal part of Permian strata on some parts of the Central Basin platform. In western Ector County, all these strata are assigned a Leonard age by Scobey (1951), whereas 300-500 feet of them is assigned a Wolfcamp age by Galley (1958, fig. 24), Van den Bark (1957b, p. 233), and Cooper and Ferris $(1957$, p. 360). Only the basal part of the sequence, assigned a Wolfcamp age by these authors, is included in interval $\mathbf{A}$.

\section{LITHOFACIES TRENDS}

Interval $\mathrm{A}$ in the west Texas Permian basin is dominantly limestone on platforms and shelves (except on the Eastern shelf) and dark-gray mudstone in the basins (King, P. B., 1942, p. 735; Galley, 1958, figs. 25, 27). Principal tectonic elements are fairly well outlined by lithofacies patterns ( $\mathrm{I}-450, \mathrm{pl} .3)$ and would be even more prominent if red and dark-gray mudstone were distinguished (King, P. B., 1942, figs. $26,27)$.

Coarser detrital rocks-sandstone and in a few places conglomerate-form a significant part of the interval along the south margin of the Val Verde trough, the west edge of the Delaware basin, and in the northeastern part of the outcrop belt on the Eastern shelf (fig. 10; Montague County, fig. 4).

Interval A of the Eastern shelf as a whole is dominantly fine detrital rocks, but areas of dominant carbonate rock are present here and within the mudstone facies of the adjoining Midland basin. Local areas of relatively pure limestone on the shelf and in the basin originated as reefs.

\section{SOURCES AND ENVIRONMENTS OF DEPOSITION}

Abundant marine fossils indicate that most of the rocks of interval $\mathrm{A}$ in the west Texas Permian basin are marine and represent a variety of environments. Some deposition occurred in marginal or even continental environments. Major sources of sediments were south, southwest, northeast, and north of the basin; a few areas within the basin also furnished detritus.

\section{SOURCES}

Much mud and sand and some coarser detritus were supplied to the Val Verde trough from the OuachitaMarathon structural belt to the south. Part of this sediment was carried into the Delaware basin, where the amount and coarseness of sand decrease north westward (I-450, pl. 3). The Diablo platform contributed fine to coarse sediment northeastward to the Delaware basin and southward to the Marfa basin. Small quantities of mud moved toward the Delaware basin from the Pedernal positive element, west of the basin, and from more remote northwestern sources.

Arkosic sandstone, cherty conglomerate, and sandy mudstone on the Eastern shelf, near the Texas-Oklahoma boundary, were derived from a northeastern uplift, possibly part of the Arbuckle Mountains positive area. Lesser source areas probably existed southward along the Bend arch.

Basal red detrital deposits on the Central Basin platform and on the Diablo plateau were derived from underlying rocks in areas exposed to weathering during Early Permian time.

\section{HNVIRONMENTS OF DEPOSITION}

Dark-gray or black mudstone in the Delaware basin and Val Verde trough probably was deposited under reducing conditions in stagnant, possibly deep water (King, P. B., 1942, p. 737). Similar dark mudstone is present in the Midland basin.

Although data are inconclusive, the great volume of detrital material in the Val Verde trough may have been deposited in deep water by turbidity currents initiated by tectonic activity along the north front of the Ouachita-Marathon belt. Increased amounts of limestone in the upper part of the interval suggest decreased depth of water in later Wolfcamp time, but near-shore deposits have been identified in this area only in the western Glass Mountains.

Limestones on the shelves and platforms north and west of the Delaware and Midland basins were deposited in relatively shallow and well-aerated water. Few reefs were formed, in contrast to the abundant reefs of later Permian time, but some occur along the basinward margins of the shelves and above reefs of Late Pennsylvanian age, as in the Horseshoe atoll within the Midland basin. These reefs formed in clear, well-circulated but not turbulent water in a uniformly warm climate. On the shelves wedges of red detritus thickening northward to northwestward indicate rapid deposition and proximity to source areas rather than oxidizing conditions at the site of deposition; green mudstone prevails farthest away from the sources. 
Sedimentation on the Eastern shelf probably occurred mainly in shallow marine waters or estuaries. Fossiliferous marine mud and calcium carbonate were deposited during recurrent inundations. Thin. coal beds are interbedded with mudstone in some areas, and plant debris and fossil wood occur in channel sandstone and conglomerate near the base of the interval. Near the northeastern source of sediments, arkosic sand and cherty.gravel were deposited under nonmarine conditions.

\section{PALEOTECTONIC IMPLICATIONS}

Major tectonic elements of Early Permian time in west Texas and southeastern New Mexico (fig. 7) were inherited from the Pennsylvanian and continued to grow. Movements in earliest Wolfcamp time sharpened the contrast between positive and negative elements, but later downwarping affected shelves and platforms as well as troughs and basins.

The great volume of sediment poured northward into the Val Verde trough, and the northward thrusting of pre-Permian rocks near the Glass Mountains in earliest Permian time marked the culmination of orogeny at the south edge of the Permian basin. No later large-scale deformation occurred in this section of the Ouachita-Marathon structural belt. Arkose and conglomerate throughout interval $\mathrm{A}$ in the northeastern part of the Eastern shelf imply continuing rise of a positive area northeast beyond the shelf. Other earlier source areas were submerged or at least were no longer rising by late Wolfcamp time.

Through the early part of Wolfcamp time the rate of sinking of the Delaware and Midland basins and the Val Verde trough exceeded the rate of deposition and produced bold submarine relief along the Central Basin platform. The platform stood only slightly above sea level but was uplifted sporadically, possibly in isostatic response to load-induced downwarping in the ajdoining basins. Later downwarping spread the sea across this region and also across the Diablo platform and much of the Northwestern and Eastern shelves. Alternation of marine and nonmarine strata on the Eastern shelf indicates that the transgression was intermittent.

\section{INTERVAL B}

\section{FORMATIONS INCLUDED}

In the west Texas Permian basin, the great range in rock types in interval B represents marked lateral facies changes. Some of these facies occur within single formations, such as the Leonard in the type area; others are differentiated by separate formation names. Rock units in interval $\mathrm{B}$ are shown in table 1.
Local subsurface rock units that are referred to informally under various designations (discussed below) are included.

\section{GLASS MOUNTAINS AREA}

Exposures of the Leonard Formation in the Glass Mountains (Udden and others, 1916, p. 51; Udden, 1917, p. 43-48; King, P. B., 1930, 1937) formed the basis for definition of the Leonard Series (Adams and others, 1939, p. 1675). "The Leonard formation in the western half of the Glass Mountains is a succession of siliceous shales, sandstone, and thin to thick interbedded limestones. Eastnortheastward along the outcrop, these interfinger with limestone reefs, which change in turn into thin-bedded, back-reef limestones. The reef and back-reef deposits are the Hess limestone member" (King, P. B., 1942, p. 651), which grades into mudstone, sandstone, and limestone in the easternmost Glass Mountains. The basal part of the Hess Member as described by King extends into the western Glass Mountains as a partly conglomeratic unit below the main body of the Leonard; in the eastern mountains, the Hess is overlain by about 300 feet of strata similar to the upper part of the formation to the west. The lower 250-300 feet of the Hess Member in the eastern Glass Mountains has been excluded by Ross $(1959 a, b ; 1960)$ from the Leonard Formation (a rock-stratigraphic unit by original definition) because it contains Wolfcamp fusulinids, including Pseudoschwagerina. The usage of King has been followed in this report.

\section{BASIN AREAS}

The Bone Spring Limestone as now recognized represents the basin facies of interval $B$ in the Delaware basin and in its southeastward extension, which is the northwest end of the Val Verde trough. This formation, as previously defined (Blanchard and Davis, 1929, p. 961 ; King, P. B., 1948, p. 13-24), included rocks of several facies; however, the name is now restricted to a sequence composed dominantly of black limestone. The Victorio Peak and Cutoff, once considered members of the Bone Spring, consist mainly of other rock types which are mappable and have been raised to formation status (King, P. B., in I-450, p. 41, 42).

Where exposed near the margin of the Delaware basin, as in the Delaware Mountains and in the Sierra Diablo, the Bone Spring Limestone is thin-bedded black and dark-gray fine-grained argillaceous bituminous limestone and some dark-gray, brown, and black mudstone, buff to light-gray sandstone, and dark chert nodules and beds. Fossils are sparse except in some 
lenses of relatively coarse grained limestone. Unusual primary structures, including wedge-shaped masses with discordant bedding, and folded and contorted bedding were described by P. B. King (1948, p. 15) and by Newell and others $(1953$, p. $86-88)$. The sandstone units are all less than 10 feet thick, whereas mudstone units are as much as several hundred feet thick.

In the Delaware basin, in outcrop and subsurface, the formation is thicker than along the margins and includes more detritus, particularly dark-colored mudstone. A few thick blanketlike sandstone units as much as several hundred feet thick also extend throughout the basin and form the First and Second Bone Spring sands of local usage (Roswell Geol. Soc., 1958). The Third Bone Spring sand, as discussed above, is assigned in this paper to interval $\mathrm{A}$.

Rocks in the Midland basin (fig. 7) assigned to interval B are between the top of the Dean Sandstone (McLennan and Bradley, 1951) and the base of the San Andres Limestone. The interval thus includes rocks equivalent to the upper part of the Wichita Group, the Clear Fork Group, and the lower part of the Pease River Group at the top.

Rocks equivalent to the upper part of the Wichita Group consist of mudstone, a little sandstone and less limestone. Beneath this unit is 200 feet of mudstone, assigned to interval $A$. Sandstone is confined to the Spraberry Saristone of McLennan and Bradley (1951). The Spraberry comprises two sandstone members, each about 300 feet thick, separated by about 250 feet of interbedded dark-gray and brown calcareous mudstone and muddy limestone. The sandstone members are very fine grained sandstone and siltstone with much interbedded dark-gray and brown limestone and dark-gray to black mudstone. The upper and lower sandstone members of the Spraberry may be equivalent to the First and Second Bone Spring sands in the Delaware basin (McLennan and Bradley, 1951, p. 907), but their only physical connection would be in the Sheffield channel, where interval $B$ is sandy throughout.

From the south end of the Midland basin, the thin unnamed mudstone at the base of interval B and the overlying Spraberry Sandstone extend across the Ozona arch, but they lose their identity on the north flank of the Val Verde trough, and rocks of interval $B$ are undivided beyond.

Rocks in the Midland basin equivalent to the Clear Fork Group are mainly limestone and dolomite. Lenses of mudstone and sandstone occur, especially toward the base, and in places all the unit is sandstone.
The uppermost part of interval $B$ in the Midland basin is mainly carbonate, but the "Glorieta Sandstone" of subsurface usage forms lenses in the upper part and is probably equivalent to the lower part of the Pease River Group.

The Briggs Formation (Albritton, 1938, p. 17531757), here assigned to interval $\mathrm{B}$, occurs in the Malone and Quitman Mountains (Marfa basin area) of south-central Hudspeth County. It is composed mainly of anhydrite and gypsum but includes gray to black and buff limestone and dolomite in single laminae or in thick beds.

Other rocks of Leonard age (Albritton and Smith, 1965 ), assigned to interval B, are in the Finlay Mountains, about 8 miles to the north and across a thrust fault. These rocks comprise mainly conglomerate, mudstone, and marlstone but include limestone and dolomite.

In the Chinati Mountains of Presidio County, interval B consists of the Cibolo Formation (Udden, 1904, p. 18-21), excluding the basal zone of Wolfcamp age. At the northwest end of the mountains, in the Pinto Canyon area, rocks of interval B occur in the lower part of the Pinto Canyon Formation (Amsbury, 1958). Rocks of interval B have also been identified in a few drill holes in the Marfa basin.

\section{MARGINAL BELTS}

Along the margins of the Delaware basin, the upper part of the Bone Spring Limestone grades laterally into the Victorio Peak Limestone (King, P. B., 1965). Its marginal facies is light-gray thick-bedded fossiliferous limestone, with some chert and sandstone. This passes shelfward into thin-bedded sparsely fossiliferous dolomite.

The lower part of the Bone Spring Limestone, like the upper, grades laterally into thick-bedded gray limestone along the margins of the basin. Well displayed in exposures in the Sierra Diablo, the gray limestone differs somewhat from rocks in the Victorio Peak Limestone and overlaps unconformably on the Hueco Limestone (King, P. B., 1965).

Along the basin margin the Victorio Peak Limestone is succeeded by the Cutoff Shale, here included in interval $B$ although its age is in doubt. The Cutoff includes thin-bedded platy gray to black limestone, brown siliceous or sandy mudstone, and thin-bedded fine-grained sandstone (King, P. B., 1965).

Units in the Midland basin sequence grade laterally northward and westward into almost pure limestone and dolomite along the peripheries of the Central Basin platform and the Northern shelf. 


\section{SHELF AREAS}

Away from the Delaware basin, rocks of interval $B$ grade laterally into light-colored dolomite. On the Northwestern shelf and on the Central Basin platform the dolomite is almost 3,000 feet thick with a few thin sandstone units. A tripartite unit, referred to locally as the "Glorieta" or "San Angelo Sandstone," forms the top of interval B and consists of two sandstone layers, separated by dolomite. The name "San Angelo" has been applied (Jones, T. S., 1953, p. 37) to the whole unit and the name "Glorieta" restricted to the upper sandstone layer. Use of either name is of doubtful validity; the type Glorieta Sandstone in central New Mexico pinches out and does not extend into southeastern New Mexico, and the lateral continuity with the San Angelo has not been proved.

Somewhat below the middle of the dolomite sequence is an extensive but thin sandstone bed, variously called the Tubb sand, the Fullerton sandstone (Moore, J. H., 1944, p. 1542), and the Drinkard Sandy Member of the Yeso Formation (King, R. E., 1945, p. 13; Jones, T. S., 1953, p. 34).

Application of the name "Clear Fork Group" is extended from the Eastern shelf (discussed below) to the Central Basin platform and to the Northwestern shelf, where it is applied to dolomite below the tripartite unit, both above and below the Tubb, Fullerton, or Drinkard. However, the name Yeso, derived from the northwest in central New Mexico, has been considered more suitable (King, R. E., 1945, p. 12). The dolomite resembles neither the type Clear Fork, nor the type Yeso, both of which are much more varied. The lower part of the dolomite sequence has been called the "Wichita Group" and the "Abo Formation"; the boundary between this part and the beds above is indefinite and commonly selected on electric logs. Where the name "Wichita Group" is used for rocks of the lower part of interval B, it is not commonly applied to the Wolfcamp rocks beneath, although the group includes both Wolfcamp and Leonard rocks in the type area.

The lower part of the shelf and platform sequence grades northward from almost pure dolomite into gray and green mudstone and finally into red mudstone with interbedded anhydrite, dolomite, and a little sandstone. This has been called the "Abo Formation" although it is clearly separated from and is stratigraphically higher than the type Abo. The upper part of the sequence also grades northward into red mudstone, sandstone, and anhydrite assigned to the Yeso Formation. The sandstone units in the dominantly dolomite sequence described above have been interpreted as detrital tongues of the Yeso Formation.
On the Eastern shelf, the Wichita Group contains the following, in descending order:

Lueders Limestone

Clyde Formation

Belle Plains Formation

Admiral Formation

Putnam Formation (in part)

The cherty Coleman Junction Limestone Member is the only part of the Putnam Formation included in interval B, although it is of Wolfcamp age. The base of the Coleman Junction has been used as the base of interval $\mathrm{B}$ because it is the only consistently recognizable horizon in this part of the sequence. The Admiral Formation is mainly gray mudstone and cherty limestone with some dolomite. The Belle Plains, Clyde, and Lueders Formations are dominantly carbonate with minor gray mudstone.

The overlying Clear Fork Group has been divided into the following, in descending order:

\section{Choza Formation \\ Vale Formation \\ Arroyo Formation}

The Choza and Vale Formations are mostly red mudstone with anhydrite, some dolomite, and lenses of sandstone. The lower half of the Vale is mostly red mudstone; The Arroyo Formation is mostly dolomite with gray and red mudstone, lenses of sandstone, and some anhydrite near the base.

The San Angelo Sandstone, an approximate lateral equivalent to the "Glorieta Sandstone," belongs to the lower part of the Pease River Group. It is a sequence of conglomerate, sandstone, and brightly colored mudstone. The upper part of the Pease River Group or "Blaine of Texas" (included in interval B east of the arbitrary red line of $\mathrm{I}-450, \mathrm{pl} .4$ ) consists, in ascending order, of (1) varicolored mudstone and dolomite, (2) dolomite, gypsum, mudstone, and calcareous sandstone or siltstone, and (3) red mudstone, anhydrite and gypsum, and dolomite. This upper part of the Pease River is equivalent to the Flowerpot Shale, Blaine Gypsum, and Dog Creek Shale of the El Reno Group in Oklahoma to the north.

These units of the Eastern shelf are not recognizaable in the subsurface of the Midland basin because of changes in facies.

\section{UPPER BOUNDARY OF INTERVAL B}

The top of interval $B$ coincides approximately with the boundary between the Leonard and Guadalupe Series. As equivalents of this series boundary are difficult to recognize in the west Texas Permian basin, there are some discrepancies in the top of the interval 
as used here. Part of the difficulty results from apparent discrepancies between stratigraphic ranges of different fossils.

\section{GLASS MOUNTAINS AREA}

The top of interval $B$ in the Glass Mountains is at the conformable contact between the Leonard Formation and the overlying Word Formation. The Word is assigned a Guadalupe age, with recognition of the possibility that the first (basal) limestone member of the formation may be older than the basal part of the Delaware Mountain Group (Guadalupe Series) farther north. The upper boundary of the Leonard Formation approximates the upper limit of the zone of Parafusulina in its small and intermediate forms, which contrast with larger Guadalupe forms in the Word, and the zone of the ammonoid Perrinites hilli. Perrinites hilli, however, extends into the first limestone member of the Word, as does the Leonard brachiopod Dictyoclostus bassi.

\section{BASIN AREAS}

In the subsurface of most of the Delaware basin, the boundary between the Delaware Mountain Group above and the Bone Spring Limestone below is sharp and easily recognized, and hence serves as the top of interval B. Some wells, however, penetrate a 400 foot-thick sandy unit above the Bone Spring Limestone which contains fusulinids of Leonard age (Amerada Petroleum Corp. 2 Record in Lea County, Paleont. Lab., unpub. rept., 1954). Either the Leonard fusulinids in the sandstone may have been redeposited in sediments of Guadalupe age, or the upper part of the Bone Spring Limestone grades into rocks similar to the Delaware Mountain Group. The first alternative seems the more likely, and the lithologic boundary is used as the top of interval B.

In exposures in the Delaware Mountains, in the northern part of the Delaware basin, the top of interval B is also placed between the Bone Spring Limestone and the Delaware Mountain Group. At the base of the latter is the Pipeline Shale (Warren, 1955, p. 11) Member of the Brushy Canyon Formation, formerly correlated with the Cutoff Shale northwest of the Bone Spring flexure.

In the basin area north of the Glass Mountains, the top of interval B is placed at the top of the Bone Spring Limestone where recognizable, and farther southeast the boundary is determined on the basis of fusulinids, where these have not been destroyed by dolomitization.

Along the western part of the Midland basin are several thick bodies of sandstone in different parts of the sequence. Sparse fusulinids indicate that all the sandstone bodies at some localities are of Guadalupe age, but at other localities, the lower sandstones are Leonard. Some anomalous features of isopachs in figure 13 may arise from inconsistent correlations in this area.

In the eastern part of the Midland basin, the upper boundary of interval $B$ has been placed at the base of the San Andres Limestones, considered the basal unit of interval $\mathrm{C}$.

South of the Midland basin and the Eastern shelf, in the eastern part of the Val Verde trough, the boundary between intervals $\mathrm{B}$ and $\mathrm{C}$ is arbitrary; but toward the east all of interval $\mathrm{C}$ has been removed by pre-Cretaceous erosion. Westward across the north side of the trough the dominant mudstone has been included in interval $\mathrm{B}$, and the overlying dominant carbonate is assigned to interval $C$. In a few wells this division is confirmed by occurrence of Leonard and Guadalupe fusulinids.

The location of the upper boundary of interval $B$ is very uncertain in the Sheffield channel, southeast and south of the Central Basin platform. Limited fusulinid evidence suggests, however, that the lower part of the channel sandstone is Leonard in age.

In the Chinati Mountains, in the Marfa basin, the top of interval B is the contact between the Cibolo and Ross Mine Formations. In the northwestern part of the mountains, the Pinto Canyon Formation is of both Leonard and Guadalupe age.

In the Malone and Finlay Mountains in westernmost Texas, the Briggs Formation and other beds of Leonard age are well dated and are overlain by Mesozoic rocks; no strata of Guadalupe age seem to be preserved.

\section{MARGINAL BELTS}

Along the margins of the Delaware basin, the top of the Victorio Peak Limestone, or Cutoff Shale where present, is the top of interval B. In subsurface along much of the periphery of the basin, however, carbonate at the top of the Victorio Peak Limestone is difficult to distinguish from similar carbonate of Guadalupe age, except where fusulinid data have been reported by the Paleontological Laboratory.

\section{SHELF AND PLATFORM AREAS}

On the shelves and platforms, away from the margins of the Delaware basin, the top of interval B is at the contact between the "Glorieta" or "San Angelo Sandstone," of subsurface usage, and the overlying San Andres Limestone.

The age of the San Andres Limestone and its stratigraphic relation to rock units in other regions have long been controversial. As the limestone contains Perrinites hilli and seems to be a lateral equiva- 
lent of the Kaibab Limestone, the San Andres has been assigned a Leonard age by many geologists. The presence in the San Andres of Parafusulina rothi and the presumed lateral continuity of the "Blaine of Texas" with the San Andres on the other hand, have led other geologists to assign both the San Andres and the "Blaine" a Guadalupe age.

Recent studies in southeastern New Mexico (Boyd, 1958, p. 74-79; Hayes, 1964) has shown that much of the San Andres Limestone is laterally continuous with the sandstone tongue of the Cherry Canyon Formation; hence, part of the San Andres is equivalent to the lower part of the Delaware Mountain Group (Guadalupe age). Lower strata of the San Andres, on the other hand, are equivalent to the Cutoff Shale (age uncertain) and possibly to the uppermost beds of the Victorio Peake Limestone (Leonard age). The Guadalupe-Leonard Series boundary (Boyd, 1958, p. 67), therefore, probably lies a little above the base of the San Andres Limestone. As no lithologic basis is evident for separating the basal part from beds of Guadalupe age, all the San Andres Limestone in the west Texas Permian basin region is here assigned to interval $\mathrm{C}$.

The age of the Cutoff Shale is equivocal. The unit contains fusulinids of Guadalupe age (Warren, 1955, p. 12), and ammonoids of Leonard age (Boyd, 1958, p. 59). Moreover, its stratigraphic relation to welldated units is uncertain (King, P. B., 1965). The Cutoff is included here with rocks of Leonard age, and its top is used as the top of interval B.

The San Andres Limestone as used on the Central Basin platform is probably more inclusive than at the surface west of the Delaware basin; the upper boundary of the formation, in particular, is not consistently chosen. Fossils are scarce in the dominantly dolomite unit. Nevertheless, available data suggest that the Guadalupe-Leonard Series boundary is not far from the base of the San Andres Limestone on the east side of the Central Basin platform. As the base of the formation is a relatively sharp and easily recognized lithologic contact, it is used as the top of interval B.

Along the Eastern shelf, east and northeast of an arbitrary line shown in red on plate 4 of I-450, the upper boundary of interval B is placed at the top of the Pease River Group and is equivalent to the boundary at the top of the $\mathrm{El}$ Reno Group in Oklahoma.

Along the outcrop on the Eastern shelf (fig. 10), rocks of the Trinity Group (Lower Cretaceous) and the Seymour Formation (Quaternary) locally rest on interval B.

\section{THICKNESS TRENDS}

Maximum thicknesses of interval $B$ in the west Texas Permian basin region exceed 4,000 feet and occur in two northward-trending belts along the east and west margins of the Delaware basin and in the southern part of the Midland basin (fig. 13). Elsewhere in these basins the rocks are 3,000 feet thick or less.

In the shelf area west and north of the Delaware basin, thicknesses exceed 3,000 feet, and along northward- and eastward-trending belts in Eddy and Lea Counties, N. Mex., near the periphery of the basin, they are more than 3,500 feet. These belts coincide with the "Abo reef trend" recently drilled for oil. West of the northward-trending belt, interval $B$ is thin because of recent erosion.

Near the southwest side of the Delaware basin, along the southwest boundary of Reeves County, irregularities in thickness reflect tectonic control in a northwest-trending belt that includes the Victorio flexure and the Hovey anticline (King, P. B., 1942, p. 723). Isopachs in this area may not be accurate because of sparse control.

More than 4,000 feet of interval B occurs in the south-central part of the Midland basin. This area is elongated northward and has two conspicuous extensions to the north and northwest. Other areas of notable variations in thickness occur in the western and northwestern parts of the Midland basin.

Rocks of interval B thin from the Midland basin to less than 2,000 feet on the Eastern shelf, partly as a result of erosion.

In the Val Verde trough interval B varies only moderately in thickness (average $2,000-3,000 \mathrm{ft}$.), in contrast with the extreme variations in underlying interval A. Somewhat greater thicknesses occur along the southwest edge of the Central Basin platform, south of the Sheffield channel, and south of the Midland basin in western Schleicher and Sutton Counties. Pre-Cretaceous erosion has truncated the interval to the south and east.

In the Marfa basin the maximum thickness assigned to the interval is about 2,300 feet. This thickness was penetrated in a well in the northeastern part of the area.

\section{IITHOFACIES TRENDS}

Lithofacies patterns of interval B (I-450, pl. 4; King, P. B., 1942, p. 739, 742) coincide closely with broad tectonic elements. Carbonate rocks dominate on shelves northwest, west, and south of the basins and on the Central Basin platform. Detritus is more abundant than carbonate in the Delaware and west- 


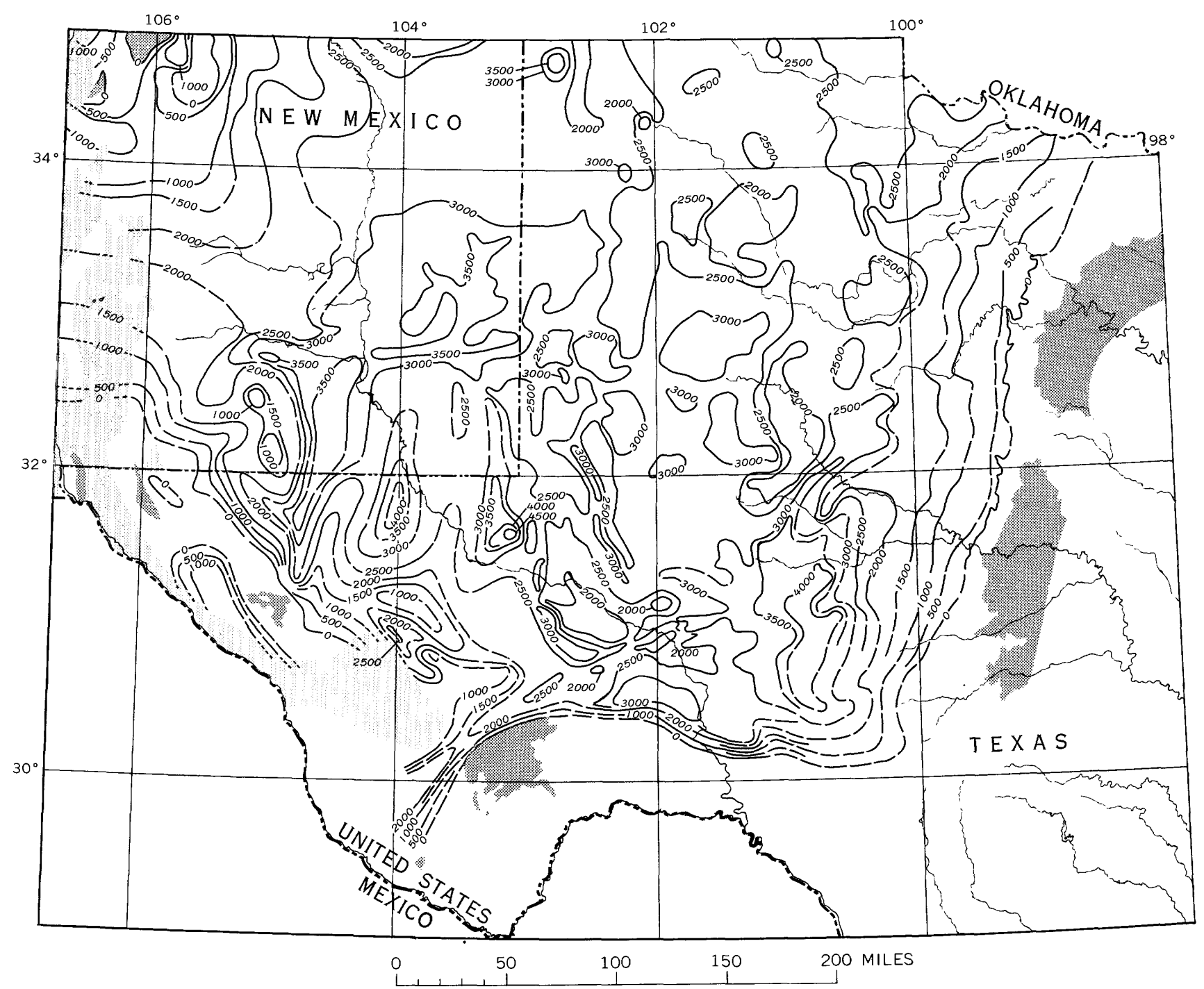

Figure 13.-Thickness of interval B in west Texas and southeastern New Mexico. Isopach intervals 500 and 1,000 feet. Isopachs dashed where control is poor, dotted where Permian rocks have not been penetrated by drill. Dark pattern, areas where rocks older than Permian are exposed; light pattern, areas where rocks younger than interval B have not been penetrated.

ern Midland basins, along the east margin of the Midland basin, and northward toward the Texas Panhandle and northeastern New Mexico.

Detrital components in the basins are dominantly dark-gray, brown, and black mudstone and lightcolored sandstone. Detritus of the north and east margins of the region, however, consists mostly of red mudstone, with some sandstone, and, in the north, some anhydrite.

Within the Delaware basin, detrital components of the interval are greater toward the south but are dominantly mudstone, whereas they change to sand- stone northward. Similar trends are evident in the detrital components of the western Midland basin.

About half the Midland basin and Eastern shelf area is occupied by carbonate rock together with various amounts of mudstone and sandstone. In the northeastern part of the Eastern shelf, mudstone and interbedded sandstone grade southwest and west into mudstone, which grades progressively toward the Midland basin into carbonate rock. The contrast between the carbonate facies of the basin and the detrital facies of the shelf is accentuated by the inclusion, 
east of the red line on plate 4 of $I-450$, of the upper part of the Pease River Group ("Blaine of Texas").

Along the south margin of the Permian basin, in the Val Verde trough, lithofacies trends of interval B contrast sharply with those of interval A. Carbonate rock of interval $B$ extends across much of the trough where detrital strata predominate in interval $A$. The apparent transition eastward from carbonate to detrital facies on the map is largely a result of preCretaceous truncation. Between the carbonate rock of the Southern shelf and the Central Basin platform, a narrow band of mudstone and sandstone marks the Sheffield channel.

Lithofacies trends in the Marfa basin cannot be plotted from the data available.

Lithofacies patterns used (I-450, pl. 4) do not show differences between red and dark-colored mudstones, or distinguish limestone from dolomite. A map showing the limestone-to-dolomite ratio of interval $B$ in the Permian basin region (pl. $2 A$ ) depicts the major tectonic elements somewhat more sharply. Dolomite dominates on the shelves and platform, whereas limestone is the main carbonate component in the basins. The margins between the basins and the shelves are belts of intermixing close to the line where the ratio of limestone to dolomite is $1: 1$. Also well shown on the map are the Sheffield channel south of the Central Basin platform and the Hobbs channel separating the platform from the Northwestern shelf.

\section{SOURCES AND ENVIRONMENTS}

Strata of interval B in the Permian basin were largely deposited under marine conditions; however, some strata were formed in restricted-marine or marginal environments. The great range in marine rock types probably reflects differences in depth of water, circulation, and the amount of detritus.

\section{BASIN ENVIRONMENTS}

Poor circulation and fairly deep water deficient in oxygen are inferred for the Delaware basin because of the abundance of organic matter (accounting for dark colors), the paucity of fossil remains except for a few free-swimming forms, the preservation of fragile fossils and thin laminae, and the abundance of pyrite (King, P. B., 1948, p. 26; Newell and others, 1953, p. $49-57,190,197-199)$. Rather deep water is further indicated by submarine slopes needed to account for slump structures in the Bone Spring Limestone along the basin margin (Newell and others, 1953, p. 86-89). The great extent of laminae and wide distribution of sponge spicules may have resulted from deposition by turbidity currents associated with the submarine slides
(Newell and others, 1953, p. 197; Rigby, 1957). During Leonard time the Delaware basin may have been about 500 feet deep (Newell and others, 1953, p. 190).

Rock types in interval $B$ in the western part of the Midland basin are similar to those of the Delaware basin; hence, depositional conditions may have been similar.

In the central part of the Val Verde trough, at least in later Leonard time, current-borne detritus was apparently mixed with carbonate deposits in the narrow Sheffield channel, between areas of nearly pure carbonate accumulation on the Southern shelf and on the Central Basin platform.

The range in rock types in interval $B$ in southcentral Hudspeth County suggests diverse conditions of deposition in the northern part of the Marfa basin. The dominant detrital components and the presence of cut-and-fill structures, slump structures, and contorted bedding in exposures in the Finlay Mountains indicate submarine slides from the southwest flank of the Diablo platform into the Marfa basin (Albritton and Smith, 1965). The Briggs Formation exposed in the Malone Mountains, on the other hand, probably "was deposited as a result of recurrent partial evaporation of lagoonal waters largely cut off from an open sea which lay a few miles to the north during Leonard (Permian) time" (Albritton, 1938, p. 1757). The evaporite sequence has been thrust from its site of deposition northeastward toward the Finlay Mountains for a distance of at least 15 miles (Albritton and Smith, 1965).

In the northwestern Chinati Mountains in northern Presidio County, the Pinto Canyon Formation (lower part) is mainly thin- to medium-bedded chert and limestone, interbedded with units of thin mudstone and fossil debris; part of the Pinto Canyon includes large blocks of chert and limestone interpreted as submarine slide blocks (Amsbury, 1958) and suggestive of platform-margin conditions similar to those inferred in the Finlay Mountains. Toward the southeast, the Cibolo Formation consists of thin-bedded limestone, mudstone, and sandstone, overlain by massive dolomitic limestone that suggests a reef deposit ( Rix, $1953 \mathrm{a}, \mathrm{b}, \mathrm{c}$ ) ; to the north, the interval consists of mudstone, sandy mudstone, and lenses of coarse sandstone, overlain by thin limestone (King, R. E., 1930 , p. 17 ; Rix, 1953a, b, c), which may extend shoreward from the reef. Relations between depositional environments represented by rocks in the several outcrop areas of the Chinati Mountains and in the adjoining deep-water Marfa basin are not fully understood. 
MARGINAL REFF AND BANK ENVIRONMENTS

Water along the margins of the Delaware basin was probably shallow, clear, well aerated, and favorable to the proliferation of life, as indicated by abundant fossil remains (King, P. B., 1948, p. 27).

The Victorio Peak Limestone, in the upper part of interval $\mathrm{B}$, formed as a limestone bank deposit rather than as a reef. No reef-forming organisms occur in place; there is no reef talus; and textures and primary structures suggest bank sedimentation (Newell and others, 1953, p. 94-95). Comparable rocks probably formed along most of the margins of the Delaware and Midland basins, although reefs may have grown locally in these areas.

The origin of some rocks in the lower part of interval $B$ in marginal areas of the basin is not yet known. Rocks along the north and northwest margins of the basin are commonly referred to as the "Abo reef," but data on their lithologic character and texture have been made available only by very recent drilling and have not yet been described and evaluated.

Depositional patterns of interval B along the southern part of the west Texas Permian basin region were notably different from those of interval A. The increase in area of carbonate deposition across part of the axial trend of the older Val Verde trough presumably resulted from reduced elevation and perhaps greater distance of sources of detritus in the Marathon folded belt. Clear evidence of the lateral sequence of depositional environments is available only near the Glass Mountains. Here the sequence included (1) basin deposits typical of the Bone Spring northwest of the mountains, (2) basin margin deposits of siliceous mudstone, sandstone, and thin limestone beds in the western Glass Mountains, (3) reefs in the massive limestone of the central part of the mountains, (4) back-reef thin-bedded dolomitic carbonate rocks and interbedded detrital deposits of the eastern mountains, and (5) marginal deposits of intertonguing red and green mudstones and back-reef carbonate rocks.

\section{SHELF AND PLATFORM ENVIRONMENTS}

Interval $\mathrm{B}$ on the shelves and platform consists almost entirely of light-colored dolomite and a few thin extensive sandstone units. As these rocks are nowhere exposed, their primary structures and textures cannot be studied. They grade northward and northwestward into the "Abo" and Yeso sequence, which includes abundant anhydrite and red mudstone, as well as some sandstone and some salt. The abundance of evaporites to the north suggests that dolomite may have been the initial deposit of saline waters controlled by a belt of shoaling along the basin margins. As the waters flowed down the shelfward slope, away from the shoals, into extensive lagoonal areas, they probably became supersaline (Newell and others, 1953, p. 122).

The upper part of interval B on the Eastern shelf was probably a deltaic and estuarine deposit. In the south, in Foard County (fig. 4), copper ore in the San Angelo Sandstone "is associated in its main aggregations with fossil wood and plants, which are largely charcoal-like masses of trunks and stems" (Beede and Christener, 1926, p. 38). The fossil plants are in aggregates or "drifts," which are suggestive of waterborne accumulation.

Ammonites occur in dolomite in the upper part of the Pease River Group (assigned to interval B east of the arbitrary red line on pl. 4 of $\mathrm{I}-450$ ) according to Clifton (1944). The upper part of the group consists of red beds, dolomite, and anhydrite and probably represents mostly a near-shore shallow-water deposit, formed during alternating periods of normal sea stand, restricted circulation and, possibly, emergence.

Anhydritic dolomite and red mudstone in the Clear Fork Group on the Eastern shelf suggest deposition in an environment of shallow water, periodic emergence, and an arid climate.

\section{SOURCES OF DETRITUS}

The source of detritus in the Delaware Basin is not established. The high proportion of sandstone in the northern part of the basin suggests a northern source. On the other hand, the increase southward in the ratio of all detritus to carbonate rock ( $\mathrm{I}-450$, pl. 4), and the presence of coarse sandstone and conglomerate in the Glass Mountains area, suggest sources in the opposite direction, possibly related to uplifts such as that of the Marathon folded belt (King, P. B., 1948, p. 26). Northern sources may well have been as far distant as the ancestral Rocky Mountains (Newell and others, 1953, p. 60).

Most detritus in interval $\mathrm{B}$ in the eastern part of the region probably came from the northeast. Sandstone within dolomite and limestone in a southeasttrending belt in the northwestern part of the Midland basin suggests a secondary source to the northwest. Derivation of detritus in the Midland basin from the north is supported by northward coarsening of sand grains in the Spraberry Sandstone. Moreover, the increase of detrital rocks in the southeastern part of the basin suggests a minor southern or eastern source. 
Tracing of the coarse siltstone of the Spraberry southward from the Midland basin indicates that part of the detritus of interval B entered the southeasternmost part of the west Texas Permian basin from the north.

Carbonate deposition of the Southern shelf probably did not reach the eastern part of the Val Verde area. Even allowing for erosional beveling of the upper surface of interval $B$ in the south and east, it seems likely that a southern or southeastern source area persisted through the greater part of Leonard time.

Silt and sand of the Sheffield channel may have come through the Hovey channel, west of the Glass Mountains, from undetermined southern sources, or they may have come in part through still-undiscovered current channels across the Southern shelf.

\section{PALEOTECTONIC IMPLICATIONS}

The west Texas Permian basin was relatively quiescent during Leonard time. Most major tectonic elements evident earlier in Permian time continued to influence sedimentation. High relief (mainly submarine) along the margins of the Delaware basin and the west side of the Midland basin was inherited from earlier structural features but was maintained by sedimentation rather than by differential tectonic movement.

The relative uniformity of thicknesses of interval $\mathrm{B}$ (I-450, pl. 15E, section $\mathrm{Q}-\mathrm{Q}^{\prime}$ ), despite marked facies changes across shelves and basins, is significant when contrasted with the great increases in thicknesses from shelves to basins in other intervals ( $\mathrm{I}-450$, pls. 3,5$)$. Despite submarine relief along the margins of the Delaware basin, basin deposits are not inordinately thicker than shelf deposits. Indeed, interval B is thicker on parts of the Northwest shelf than in parts of the adjoining basin. Comparable shelf and basin facies are evident in intervals $\mathrm{A}$ and $\mathrm{C}$, yet basin strata of these intervals are notably thicker than shelf deposits. The present thicknesses in interval B can scarcely have been determined by differences in compaction between muddy limestone (Pray, 1960) of the basin and carbonate rock of the shelf.

Available evidence suggests that much of the west Texas Permian basin subsided rather uniformly during Leonard time. Marked bottom relief was maintained by rapid deposition of carbonate rocks on the basin margins while the basin was semistarved, or at least not well nourished. Although the basin was large and continually sinking, the detritus furnished was insufficient to fill it, and therefore it was maintained by regional and not differential subsidence.
No major deformation or uplift of positive areas occurred in nearby regions during Leonard time. Orogeny in the Ouachita-Marathon belt had ceased although this belt probably had sufficient relief to continue to supply detritus northward (King, P. B., 1948, p. 26). Local uplifts are suggested by the conglomerates of the Leonard Formation in the Glass Mountains. The extension of limestone and dolomite across a shelf, forming part of the area of deep subsidence of the earlier Val Verde trough, implies a marked decrease in disturbance south of the west Texas Permian basin.

Other large positive elements, such as the Central Basin platform and the Pedernal positive element, exposed to weathering during parts of Wolfcamp time, were buried by sediments by Leonard time. The great extent of rocks assigned to interval B suggests that detritus must have been derived from distant sources such as the ancestral Rocky Mountains.

Formation of the Bone Spring flexure late in Leonard time is supported by stratigraphic data (King, P. B., 1948, p. 18-19; Newell and others, 1953, p. 22, fig. 10). The Victorio and Babb flexures, farther south, are also believed to have been active at this time (King, P. B., 1965).

In the Eastern shelf-Midland basin area, sediments formed in a subsiding region; greatest subsidence was in the south-central part. The center of accumulation had migrated 40-50 miles south from that of interval A. The distribution of relatively coarse textured detrital rocks implies simultaneous emergence of a landmass to the northeast and small areas to the south.

The Marfa basin in westernmost Texas apparently continued to be a negative element through Leonard time, but its form and extent are unknown. Detrital rocks of interval B in the Chinati Mountains indicate a source area that was probably residual from earlier uplift in the southern part of the Diablo platform. Reef and slump deposits, suggesting a seaward slope, indicate a south or southwest edge of the platform and imply an adjoining basin.

Evidence for a northern arm of the Marfa basin west of the Diablo platform (I-450, pl. 4), is found only in rocks of Leonard age. Remnants of these rocks on the northern part of the platform suggest that the area was covered by marine sediments during Leonard time. The southwestern limit of the northern arm of the basin may have been along the present course of the Rio Grande (Albritton and Smith, 1965). The negative element represented by the Marfa basin may have extended southwestward into Mexico, as suggested by the presence of rocks of Leonard age in the Placer de Guadalupe area. 
INTERVAL C-D

Aggregate thicknesses of intervals $\mathrm{C}$ and $\mathrm{D}$ are shown in figure 14, although the intervals are discussed separately below.

INTERVAL C FORMATIONS INCLUDED

Interval $\mathrm{C}$ in the west Texas Permian basin region includes the Delaware Mountain Group in the Delaware basin and all rock units believed to be laterally equivalent to or correlative with this group. Discrepancies arising from possibly inconsistent recognition of the base of the interval are discussed elsewhere (I-450, p. 31).
BASIN AREAS

Exposures of the Delaware Mountain Group consist mainly of sandstone but include dark mudstone, limestone, chert, and a few bentonite beds. The Brushy Canyon Formation at the base differs from the overlying Cherry Canyon and Bell Canyon Formations in coarser texture, absence of rocks other than sandstone, and in its primary structural features. These features include cross stratification in the beds of medium-grained sandstone, oscillation ripple marks, and oriented fusulinids, all indicative of agitated water (King, P. B., 1948, p. 31) ; strata in the overlying formations are fine-grained sandstone to siltstone and are mainly very thinly laminated (p. 34,

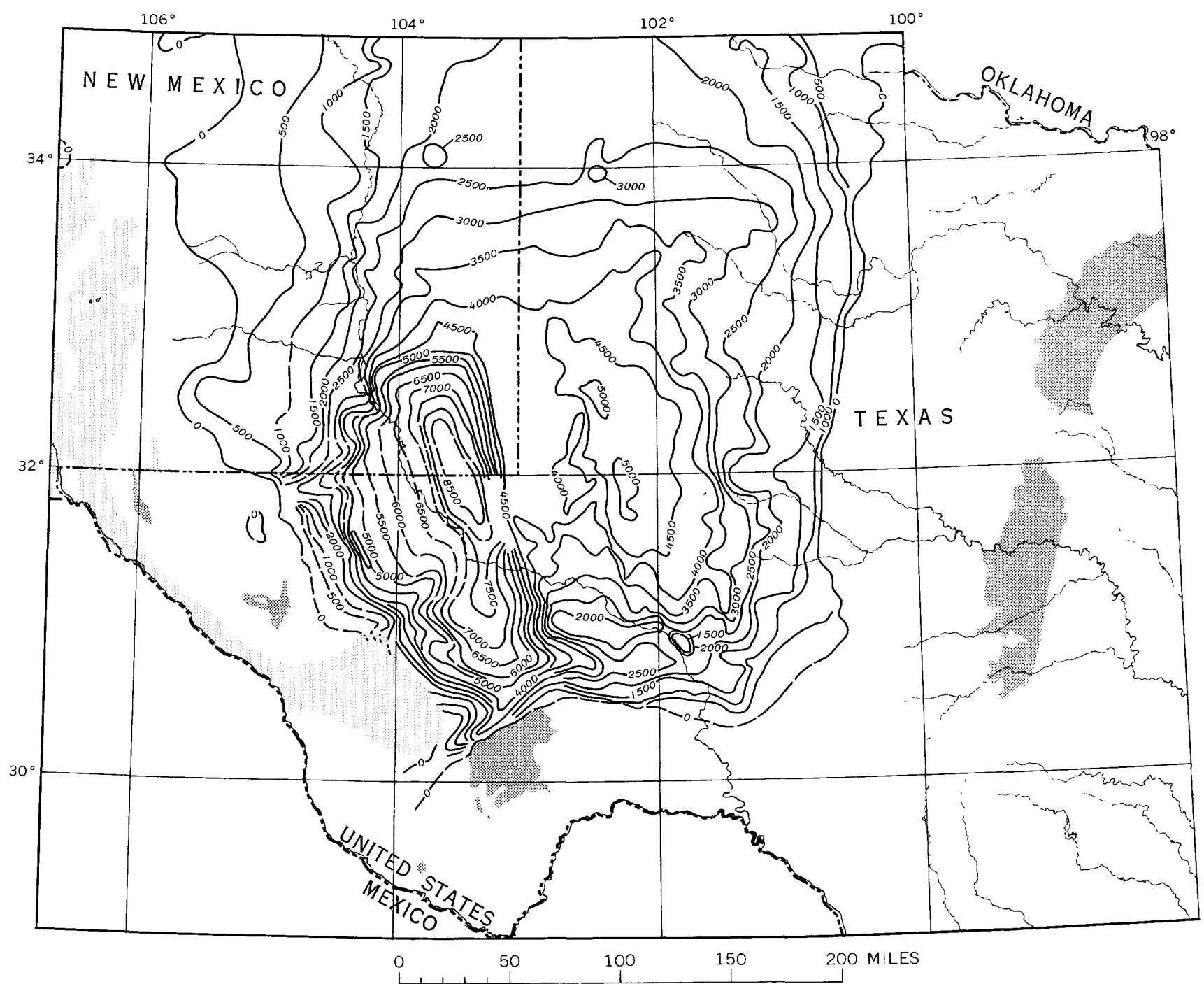

Figure 14.-Thickness of interval C-D in west Texas and southeastern New Mexico. Isopach interval 500 feet. Isopachs dashed where control is poor, dotted where Permian rocks have not been penetrated by drill. Dark pattern, areas where rocks older than Permian are exposed; light pattern, areas where rocks younger than interval C-D have not been penetrated. 
54). The Pipeline Shale (Warren, 1955, p. 11) is now regarded as a basal member of the Brushy Canyon Formation (King, P. B., 1965) and is assigned to interval C. The Brushy Canyon Formation terminates as a wedge along the Bone Spring flexure. The lower part of the Cherry Canyon extends across it well into the shelf area; the upper part of the Cherry Canyon and the Bell Canyon intertongue laterally with reef deposits along the margin of the basin.

All three formations of the Delaware Mountain Group grade into finer grained sandstone and siltstone in the subsurface; dark-gray, brown, and black mudstone and argillaceous limestone are also more abundant than in exposures along the flank of the basin. However, the three formations or their inferred equivalents have been identified in a few deep boreholes along the southeastern part of the Delaware basin, north of the Glass Mountains. Relatively few boreholes have been drilled much below the Lamar Limestone Member near the top of the Bell Canyon Formation.

\section{MARGINAL BELTS}

The upper two formations of the Delaware Mountain Group change westward into reef facies which form the Goat Seep and Capitan Limestones. Similar carbonate rocks, mainly dolomite, occur in subsurface around almost the entire periphery of the Delaware basin and, in the lower part of the interval, along the west margin of the Midland basin. A distinction between reef, reef talus, and other varieties of marginal deposits is difficult to make on the basis of data from most boreholes. Also, the base of the Capitan Limestone is difficult to recognize where the unit rests on older carbonate rocks. Nevertheless, reefs are inferred to be present between the southwest margin of the Central Basin platform and the Glass Mountains.

Thick massively bedded carbonate rocks along the margins of the basins grade shelfward into thinbedded dolomite. Units assigned to interval $\mathrm{C}$ along the shelves include the San Andres Limestone, the Grayburg and Queen Formations, and rocks formerly assigned to the Carlsbad Limestone or Group but now included in the upper part of the Artesia Group (Tait and others, 1962). Farther shelfward, strata in the upper part of the interval include detrital and evaporitic rocks. Belts parallel to the margin or reef front of the western Delaware basin are formed of successive facies of (1) dolomitized coquina and calcarenite, (2) pisolites, (3) fine-grained dolomite, (4) evaporites, and (5) terrigenous red detritus (Newell and others, 1953 , p. 46 ).
Interval $\mathrm{C}$ in the Glass Mountains includes the Word Formation of early Guadalupe age and the Altuda Formation, Capitan Limestone, and Gilliam Limestone of later Guadalupe age (King, P. B., 1942, p. 654-662). In the western part of the mountains, the Word Formation is composed of about 1,000 feet of siliceous mudstone, sandstone, and thin-bedded limestone, with a persistent basal (first) limestone member. Eastward the mudstone intertongues with limestone beds and with an upper massive reef unit, the Vidrio Limestone Member, so that in easternmost exposures the formation is nearly all cherty dolomite.

Formations in the upper part of the Guadalupe Series in the Glass Mountains are facies units, comparable to facies of the underlying Word. Siliceous mudstone and sandstone of the Altuda Formation constitute a basin-margin deposit exposed west of the massive reef facies of the Capitan Limestone, which grades eastward into the back-reef facies of the Gilliam Limestone. Thin-bedded dolomite of the Gilliam is interbedded with sandstone above and below and with some red and blue mudstone and gypsum (King, P, B., 1930, p. 76). A persistent sandstone at the top has been correlated with the Yates Sandstone in the subsurface to the north and northeast.

In the Chinati Mountains of the Marfa basin area, rocks of marginal facies of both Word and Capitan age are present (Skinner, J. W., 1940, p. 186-187). The name Ross Mine Formation has been applied to the Word equivalent and Mina Grande Formation to the Capitan equivalent (Rix, 1953a, c). The Pinto Canyon Formation (Amsbury, 1958) at the northwest end of the mountains contains equivalents of the Ross Mine in its upper part.

\section{SHERT ARTAS}

Interval $\mathrm{C}$ on the shelves and Central Basin platform includes the San Andres Limestone and the overlying Artesia Group (Tait and others, 1962). The Artesia Group includes the Grayburg Formation, the Queen Sandstone, the Seven Rivers Formation, the Yates Sandstone, and the Tansill Formation (Boyd, 1958, p. 27-32; Jones, 1953, p. 39-40; Hayes, 1964).

All the San Andres Limestone in the Permian basin region is included in interval $\mathrm{C}$, although its basal part may be of Leonard age. Part of the formation has been demonstrated to be the shelfward equivalent of the lower part of the Cherry Canyon Formation (Boyd, 1958, p. 74-78; Hayes, 1959), but other strata in the unit may have formed at the same time as the Brushy Canyon Formation (Hayes, 1964). The San Andres is mainly dolomite but includes limestone near its base and, in places, chert. It extends many miles 
PALEOTECTONIC INVESTIGATIONS OF THE PERMIAN SYSTEM IN THE UNITED STATES

farther shelfward than the overlying Artesia Group before grading into evaporitic and detrital rocks. Chert or limestone in the formation generally do not form persistent horizons; hence, subdivision is not practicable. An extensive tongue of limestone occurs on the Central Basin platform, however, and its base seems to be a laterally consistent horizon, but only in the platform area. The San Andres Limestone of many subsurface sections probably includes correlatives of the Grayburg Formation.

The top of the Queen Sandstone in the subsurface may be the same as the Shattuck Member of the Queen Sandstone in outcrop, which apparently grades into the upper part of the Goat Seep Limestone (Newell and others, 1953, p. 45, figs. 26, 27). The Seven Rivers and higher formations of the Artesia Group are, therefore, probably equivalent to the Capitan Limestone and Bell Canyon Formation of the marginal and basin areas.

The tops of the Yates and Queen Sandstone have long been used as key horizons for preparation of structure contour maps (Jones, 1953, p. 39-40), but they do not seem to be consistently recognizable in all parts of the region.

The San Andres Limestone and formations of the Artesia Group can be recognized and traced southward along the Central Basin platform nearly to its end. South of the platform, sandstone of the Sheffield channel intervenes between northern and southern areas of carbonate deposits of early to middle Guadalupe age. In this area, evaporitic deposition did not start until late Guadalupe time.

Units of interval $\mathrm{C}$ in the Midland basin largely resemble those on the shelves. They are the same as those on the Central Basin platform from the top of the Tansill Formation down to dolomite in the upper part of the San Andres Limestone. The basal part of the sequence, however, is dominantly fine-grained sandstone and siltstone, light- to dark-colored limestone, and dark mudstone, all of which are very similar to rocks in the upper part of interval B in the Midland basin.

The San Andres Limestone thins eastward across the Midland basin, and detrital and evaporitic rock proportions increase progressively. On the Eastern shelf, part of the formation grades into the upper three formations of the Pease River Group: the Flowerpot Shale, Blaine Gypsum, and Dog Creek Shale, collectively referred to as the "Blaine of Texas." East of an arbitrary line $(\mathrm{I}-450, \mathrm{pl} .6)$, these formations are assigned to interval $\mathrm{B}$.

Along the east margin of the Permian basin, only the Whitehorse Group undifferentiated is assigned to interval C. The group is dominantly sandstone, anhydrite or gypsum, and halite but includes some dolomite and red mudstone. Oklahoma divisions of the group are poorly recognizable in Texas.

\section{UPPER BOUNDARY OF INTERVAL C}

The top of interval $\mathrm{C}$ in the west Texas Permian basin coincides with the top of the Guadalupe Series. The tops of the Tansill Formation on the shelves and in the Midland basin, of the Capitan Limestone in marginal areas, of the Lamar Limestone Member of the Bell Canyon Formation in the Delaware basin, and of the Whitehorse Group on the Eastern shelf form the interval and series boundaries. Overlying formations are the Castile Formation in the Delaware basin and the Salado Formation elsewhere.

The general relations of the upper part of the Artesia Group, or the former Carlsbad Limestone, to the Capitan Limestone and to the Bell Canyon Formation are clear (King, P. B., 1948, p. 53-68, pls. 6, 7, 15, 17; Newell and others, 1953 , p. 25-47), but the precise relations of these upper contacts are unclear (King, P. B., 1948, p. 68). The uppermost several hundred feet of the Capitan Limestone is younger than the Lamar Limestone Member of the Bell Canyon Formation and may have been deposited at the same time as basal strata of the Castile Formation, above the Delaware Mountain Group in the basin (Newell and others, 1953, p. 47; Jones, C. L., 1954, p. 108-109). The top both of the Tansill Formation of the Artesia Group and of the Capitan Limestone, therefore, may be somewhat younger than that of the Delaware Mountain Group. An alternative interpretation is that uppermost strata of the Tansill and Capitan are equivalent to sandstone above the Lamar Member in the Delaware Mountain Group (King, P. B., 1948, p. 68). A few geologists have proposed that most or all of the Castile Formation is laterally equivalent to the Capitan Limestone (Baker, C. L., 1920, p. 116-117; Cave, 1954; Moore, G. W., 1959), but the evidence is not convincing. Location of the top of interval $\mathrm{C}$ and of the Guadalupe Series is based entirely on physical stratigraphy and on lithology, because Permian rocks above the top of interval $\mathrm{C}$ are almost devoid of fossils.

The upper boundary of interval $\mathrm{C}$ in the Glass Mountains is at the top of the rocks of known Guadalupe age-the Altuda, Capitan, and Gilliam Formations-which are seemingly conformable with the overlying Tessey Limestone of the Ochoa Series. An equivalent of the Tansill Formation of the subsurface may occur in the basal part of the Tessey, but it has not been separated as a mappable unit (King, P. B., 1942 , p. 658$)$. 
Northeast of the Glass Mountains and east of the Delaware basin, interval $\mathrm{C}$ includes strata to the top of the Tansill Formation or to an estimated equivalent point above the Yates Sandstone. The boundary in the eastern and southeastern marginal zones is an erosion surface overlain mostly by Cretaceous rocks and, in a very small area, by Triassic rocks.

\section{THICKNESS TRENDS}

Interval $\mathrm{C}$ is thickset in the Delaware basin; there it exceeds 5,500 feet (fig. 15). It is $3,000-4,000$ feet thick along the margins of the basin and gradually thins northward on the Northwestern shelf to less than 3,000 feet, and southward on the Central Basin platform to less than 2,000 feet. The greatest thickness in the western part of the Midland basin is slightly more than 3,500 feet. Along both the west and east margins of the west Texas Permian basin region the interval is truncated by erosion.

In the western part of the Delaware basin belts of thinning and intervening belts of thickening trend eastward to southward. In east-central Eddy County these coincide with sharp bends of the reef front which were formed during Guadalupe time (pl. $2 C$ ). These bends include the one at the Huapache fault zone (Hayes, 1964).

A northwestward-trending belt of thickening in northeastern Jeff Davis County coincides with the northeast margin of Diablo platform; it lies near the Hovey anticline and the faults on the north side of the Apache Mountains (King, P. B., 1949).

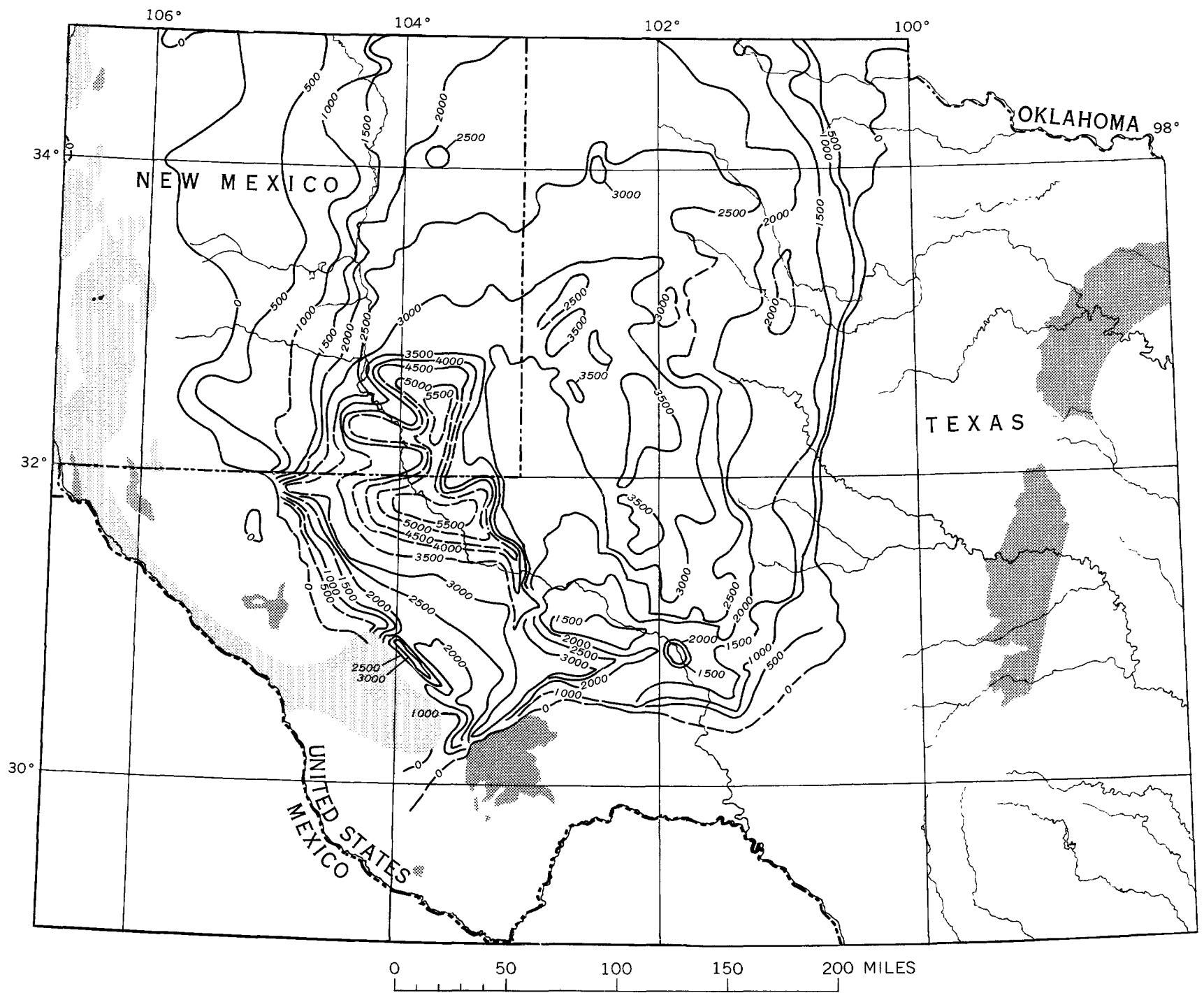

FIGURE 15.-Thickness of interval $\mathrm{C}$ in west Texas and southeastern New Mexico. Isopach interval 500 feet. Isopachs dashed where control is poor. Dark pattern, areas where rocks older than Permian are exposed; light pattern, areas where rocks younger than interval $\mathrm{C}$ have not been penetrated. 
From the eroded east edge of the Val Verde area, interval $\mathrm{C}$ thickens westward through the area of the Sheffield channel, northwestward along the edge of the Central Basin platform, and southwestward into the Glass Mountains area. The interval thickens from 1,400 feet at the south end of the Central Basin platform to 3,500 feet beyond the platform. It may be only a few hundred to a thousand feet thick in the outcrop area of the Marfa basin.

\section{LITHOFACIES TRENDS}

The variations in composition of interval $\mathrm{C}$ in the west Texas region are closely related to structural elements. On the Delaware basin and the Eastern shelf detrital rock is predominant, whereas on marginal belts carbonate rock is predominant. On shelves other than the Eastern shelf, and on platforms (I-450 pl. 6), mixed carbonate and evaporite rock are predominant.

South of the Central Basin platform, in the Val Verde area, interval $C$ consists of a lower unit in which carbonate exceeds anhydrite and an upper, more evaporitic unit containing much anhydrite and, locally, rock salt. Transition from the lower to the upper unit seems to be higher southwestward across the area. Along the southeast margin of interval $\mathrm{C}$, absence of anhydrite is due to truncation.

Sandstone was concentrated around the south end of the Central Basin platform because of sinking of the Sheffield channel during deposition of the lower part of the interval. Sandstone forms less than 30 percent to more than 80 percent of the rocks equivalent to the San Andres or Word in the channel area, in contrast to less than 5 percent on the platform and along the Southern shelf. Sandstone in the upper part of the interval is somewhat more uniformly distributed; maximum amounts are below 25 percent in the western part of the Val Verde area and in most of the eastern part.

Lithofacies patterns reveal the gross outlines of basin and shelf areas but mask the trend of the reefs that separated them. Reefs of Word and Capitan age in the Glass Mountains and in subsurface along part of the west side of the Central Basin platform grew progressively outward and upward from the shelf and platform areas. The west end of the Sheffield channel was probably closed by coalescing of the southern and northern reefs or by formation of a supplemental reef between the two. This is indicated by an evaporitic facies across the channel area in the upper part of the interval and also by the north-south trend of the Delaware basin margin as shown by con- tours on a horizon near the top of rocks of Guadalupe age (King, P. B., 1942, pl. 1).

The reef facies between the Central Basin platform and the Southern shelf cannot now be outlined, and the reef zone is presumably too thin to appear as a distinct unit on the lithofacies map (I-450, pl. 6). The upper and outer limit of the reef probably lies within a belt of carbonate rock, mudstone, and sandstone that crosses the west end of the Sheffield channel (fig. 7).

In the southern Chinati Mountains (Marfa basin), where the thin-bedded muddy Ross Mine Formation of Word age is overlain by massive dolomitic limestone of the Mina Grande Formation, a Capitan equivalent, descriptions of the rocks suggest a basinedge facies succeeded by a reef comparable to that in the Glass Mountains.

If only the lower part of interval $\mathrm{C}$ in the west Texas region is considered, the ratio of limestone to dolomite is greatest in the Delaware and Midland basins (pl. $2 B$ ), as in interval B (pl. $2 A$ ). Dolomite is dominant on the shelves and platforms. The belt of mixing, in which proportions of limestone and dolomite are nearly equal, is narrow and marks the position of the margins of the Delaware basin during deposition of the San Andres Limestone and lateral equivalents. Widespread areas of mixing are evident in the Midland basin area as well as on parts of the Central Basin platform; they indicate partial inundation of the platform by normal, rather than somewhat saline, sea water.

\section{SOURCES AND ENVIRONMENTS}

\section{MARGINAI RHEFS}

Parts of interval C exposed in the Guadalupe Mountains and other ranges on the west margin of the Delaware basin clearly are classic examples of ancient reefs. Data supporting the reef origin of these limestones are summarized by P. B. King (1948, p. 38-40, 48-53, 5964, 75-87), Adams and Frenzel (1950, p. 302-307), Newell and others (1953, p. 105-114; 1957), and McKee, Oriel, and others ( $\mathrm{I}-450)$.

Basinward growth of the reef zones is shown on plate $2 C$. This illustration shows the several positions of the marginal belts for different parts of interval C. When it is compared with plate $2 A$, the gradual diminution in size of the Delaware basin becomes obvious. Moreover, the filling and ultimate destruction of the Midland basin is shown on plate $2 C$; here only the lower part of interval $\mathrm{C}$ is of basin facies. Also shown is the gradual exclusion of normal marine waters from the eastern two-thirds of the Val Verde area, south of the Central Basin platform. 
Outcrops in the Chinati Mountains are suggestive of continuous normal marine conditions in the area of the Marfa basin from Word through Capitan time.

\section{BASIN ENVIRONMENTS}

Exposures of the lower part of the Delaware Mountain Group contain many features suggestive of deposition in shallow well-aerated sea water, but rock toward the center of the Delaware basin more likely formed in considerably deeper and even stagnant water. The upper part of the group, both within the basin and along its margins, is also interpreted as having formed in deep water. Sea-bottom relief along the margins of the basin was probably low in the early part of Guadalupe time but moderate to great in middle and late Guadalupe time.

\section{SHFTL EVAPORITES}

As sea water crossed the marginal belt, which was composed largely of reef rock, and flowed shelfward, salinity increased, as it had during Leonard time. The higher salinity resulted in deposition of evaporite many miles shelfward during formation of the lower part of interval $\mathrm{C}$ and closer to the reefs during formation of the upper part of interval $\mathrm{C}$.

Dolomite shelfward of the marginal belt is considered by some geologists to be the product of penecontemporaneous replacement, but the pisolite facies, which is composed wholly of dolomite, is not explained (Newell and others, 1953, p. 181). A possible mode of replacement is seepage refluxion (Adams and Rhodes, 1960). Marginal reefs and banks prevented free refluxion of lagoonal waters and produced heavy brines that displaced connate waters and seeped slowly downward through carbonates, replacing them below the lagoon floor.

The view that very fine grained dolomite in the back-reef area was precipitated directly (King, P. B., 1948, p. 88; Adams and Frenzel, 1950, p. 304) is supported by evidence that dolomite is now forming in an analogous environment in lagoons of southern Australia (Alderman and Skinner, 1957; Skinner, 1960). On the other hand, partial to complete dolomitization of rocks in and adjacent to the reef zones is not debated (King, P. B., 1948, p. 88; Adams and Frenzel, 1950, p. 304 ; Newell and others, 1953, p. 178180).

Although the Castile Formation is excluded from interval $\mathrm{C}$, difficulties arise if the basal part of the formation is correlated with the upper part of Capitan and Artesia strata. This correlation has not been universally accepted because the formation of evaporite rock on both sides of a reef complex is considered unlikely. Nevertheless, evidence of physical stratig- raphy supports this correlation (Newell and others, 1953, p. 47; Jones, C. L., 1954, p. 108-109).

Density stratification of water in the Delaware basin may have permitted continued growth of the Capitan reef while evaporites of the basal part of the Castile Formation were deposited. As sea water evaporated its density and salinity increased, but the denser liquid settled in the basin. Salinity in the deep part of the basin may have increased sufficiently to permit deposition of laminated calcite and anhydrite at the same time as a surface layer of nearly normal salinity permitted continued growth of the reef and furnished sea water to the lagoons behind the reef. However, this process probably ceased when halite began to precipitate during deposition of the lower part of the Castile Formation. Halite deposition may well have been induced by restriction of the entry of normal sea water into the Delaware basin, either by lowering of sea level or by local differential tectonic movements; reef building may have ceased because of increased salinity (Kroenlein, 1939, p. 1684) or because the basin margins were no longer submerged (Lloyd, in Kroenlein, 1939, p. 1693).

In summary, the sequence of facies represented in interval $\mathrm{C}$ in the Permian basin region includes dark mudstone and limestone of euxinic environment in the basin, grading laterally into tongues of coquinoid limestone, reef debris, reef rock, calcarenite, pisolites, dolomite, anhydrite, salt, mixed salt, anhydrite and carbonate rock, and finally red beds and arkose near the ancient source areas. The broad extensive lagoonal belt behind the reef may have served as an evaporating pan for sea water that continued to be replenished over the circulation-restricting reef.

\section{SOURCES OF DETRITU'S}

Sparsity of detritus in peripheral belts around the Delaware and Midland basins has raised questions regarding possible sources of sand in the basins. The dominance of sandstone in the northern part of the Delaware basin $(I-450, \mathrm{pl} .6)$, the presence of pockets and lenses of sandstone in reefs bounding the basin (Newell and others, 1953, p. 107), the decrease in grain size of sandstone from shelf to basin (except within the Brushy Canyon Formation, where marginal barriers were probably low), the distribution and relative abundance of feldspar grains in the northern part of the Delaware basin, as well as other features, indicate that sand sources were behind barrier reefs surrounding the basin.

The sand of the west Texas Permian basin was probably derived from feldspathic and garnetiferous rocks in the ancestral Rocky Mountains and possibly from 
the ancestral Wichita Mountains (Hull, 1957a). Sand grains may be sparse in the reef zone because detritus was flushed through surge channels in this belt (T. F. Stipp, oral commun.). The form of some surge channels may still be preserved between reef knobs, as suggested by Stipp and Haigler (1656). Sparse detritus trapped in the reef belt was apparently masked by thick rapidly formed carbonate deposits (Hull, $1957 \mathrm{a}$, p. 305).

Some of the detritus in the west Texas Permian basin may have come from subsidiary southern and eastern sources. The predominance of detrital rocks in places along the south and east margins suggests these sources.

Some sand and mud from southern sources may have moved northward through the Hovey channel, west of the Glass Mountains, into the Delaware basin and the Sheffield channel. The presence of mudstone and sandstone, in part conglomeratic, at the base of the Grayburg Formation in north-central Crockett County suggests a near-shore environment in the eastern part of the Val Verde area (Page and Adams, 1940, p. 59$60)$. Low marginal lands both south and east may have furnished detrital components of the upper part of interval $\mathrm{C}$.

Eastern sources apparently lay in two directions. Mud, sandy mud, and some sand were derived from the northeast, probably from Oklahoma. The prevalence of sandstone and mudstone along the southern part of the Eastern shelf also supports the southeastern source inferred for the eastern part of the Val Verde area.

\section{PALEOTECTONIC IMPLICATIONS}

During deposition of interval $\mathrm{C}$ major tectonic elements were modified considerably. Thus the Midland basin largely lost its basin character and assumed aspects of adjoining shelves and the Central Basin platform.

The depth of the central part of the Delaware basin continued to be optimum for euxinic conditions, as during the preceding Leonard time, but the west margin was no longer an abrupt topographic front early in Guadalupe time. The former steep peripheral relief of the basin was largely buried by a flood of relatively coarse detritus, much of which was deposited in shallow water. Regional subsidence resulted in encroachment of basin detrital units upon the shelf (sandstone tongue of the Cherry Canyon Formation). The Delaware basin area, therefore, was relatively quiescent early in Guadalupe time, although tectonism in distant areas can be inferred from the flood of sand which reached this basin.
During middle Guadalupe time the center of the Delaware basin sank more than its margins, and marginal areas buckled locally. Reef and bank deposition continued under these conditions, as in Leonard time. After deposition of the Goat Seep and Vidrio began, sedimentation, largely by organisms, caught up and kept pace with regional sinking, and a steep but submerged marginal topographic front formed again.

The Goat Seep and the Capitan Limestones reduced marine circulation more effectively than their earlier counterparts. Once a continuous sill had been built up around the Delaware basin, extensive deposition of evaporites, rather than of carbonates (San Andres Limestone), was promoted on the shelves and took place nearer the marginal belts than at any time during the Leonard. The maintenance of barriers and the thickness of evaporites also reflect tectonic stability.

Reef growth during late Guadalupe time was greater laterally than vertically, which indicates that regional sinking did not keep pace with sedimentation in the peripheral belts. On the other hand, the detritus carried in was insufficient to fill the basin completely; sinking continued to exceed sedimentation, as indicated by euxinic conditions in the middle of the basin.

Conditions in the Midland basin differed from those in the Delaware basin. The introduction of great volumes of sand and mud into the Midland basin in late Leonard and early Guadalupe time was not accompanied by differential sinking; therefore, the basin filled. Moreover, the Sheffield channel, as a marine passageway, was destroyed by sedimentation. By late early Guadalupe time the formerly deep Midland basin was shallow, and evaporite deposits, characteristic of the shelves and the Central Basin platform, spread extensively over the area. The Midland basin was therefore relatively stable, although evidence of an early flood of detritus implies a distant area of uplift.

The Val Verde trough and Marfa basin areas were probably also stable. Some warping in the eastern part was perhaps accompanied by brief emergence of marginal zones. Maximum subsidence, extending from the southeastern Delaware basin into the Sheffield channel, was probably early in Guadalupe time. Slight uplift may explain thinning of carbonate rock over part of the south end of the Central Basin platform.

Detritus deposited on the Eastern shelf suggests uplift of inferred source areas. Positive areas of low to moderate relief were probably close to the southern part of the shelf. Northeastern source areas were probably more distant. 
INTERVAL D

\section{FORMATIONS INCLUDED}

Rock units assigned to interval $\mathrm{D}$ are, in ascending order, the Castile, Salado, and Rustler Formations and the Dewey Lake Redbeds. The Dewey. Lake includes strata formerly assigned to the Pierce Canyon Redbeds. Whether Dewey Lake Redbeds are of Permian or of Triassic age has been disputed.

Interval $\mathrm{D}$ includes perhaps the thickest and most extensive evaporite rock sequence in North America. Although the sequence has been penetrated by many boreholes, details are poorly known except in the few holes where cores have been taken, partly during exploration for potash.

The Castile Formation (Richardson, G. B., 1904, p. 43 ) is confined to the Delaware basin and consists mainly of anhydrite, although it includes calcite and two very extensive layers and several tongues of halite (I-450, pl. 6, inset, section $\left.B-B^{\prime}\right)$. The lower part of the formation consists of distinctively banded lightgray anhydrite and brown bituminous limestone laminae. Toward the margins of the basin, the basal part of the banded unit grades reefward into laminated limestone and the upper part into massive anhydrite (Jones, C. L., 1954, p. 109). The upper part of the Castile Formation is light-gray massive anhydrite which grades laterally into the basal part of the Salado Formation by wedging of anhydrite tongues northeastward into salt (Jones, C. L., 1954, p. 109; Moore, G. W., 1960, p. 131). The level at which the contact between these formations is placed depends on the abundance of anhydrite below and salt above.

The Salado Formation (Lang, 1935, 1939) is dominantly halite but includes abundant anhydrite and some mudstone, sandstone, and a suite of salts that includes polyhalite $2 \mathrm{CaSO}_{4} \cdot \mathrm{MgSO}_{4} \cdot 2 \mathrm{H}_{2} \mathrm{O}$ ), kieserite $\left(\mathrm{MgSO}_{4} \cdot \mathrm{H}_{2} \mathrm{O}\right)$, glauberite $\left(\mathrm{CaSO}_{4} \cdot \mathrm{Na}_{2} \mathrm{SO}_{4}\right)$, sylvite $(\mathrm{KCl})$, carnallite $\left(\mathrm{KCl} \cdot \mathrm{MgCl}_{2} \cdot 6 \mathrm{H}_{2} \mathrm{O}\right)$, langbeinite $\left(\mathrm{K}_{2} \mathrm{SO}_{4} \cdot 2 \mathrm{MgSO}_{4}\right)$, kainite $\left(\mathrm{KCl} \cdot \mathrm{MgSO}_{4} \cdot 3 \mathrm{H}_{2} \mathrm{O}\right)$, and leonite $\left.\mathrm{K}_{2} \mathrm{SO}_{4} \cdot \mathrm{MgSO}_{4} \cdot \mathrm{H}_{2} \mathrm{O}\right)$. Principal lithologic types form cycles consisting of a detrital layer, a sulfate, a halite, and a mixed halite-detrital layer, in ascending order, with gradational contacts (Jones, C. L., 1954, p. 110). The formation includes several widely recognized but thin named members (Adams, 1944, p. 1610-1611). The Salado Formation extends beyond the limits of the Castile across most of the Permian basin; its thickness and lithofacies vary unpredictably because of leaching of its several soluble components.

The Rustler Formation (Richardson, G. B., 1904, p. 44) consists mainly of anhydrite and halite but also contains dolomite, limestone, siltstone, and sandstone. Some of the dolomite is oolitic in the marginal and shelf areas. Within the Delaware basin, limestone and dolomite increase southward and southwestward, at the expense of salt and anhydrite. The top of the Rustler Formation is clearly marked and has been used as a datum for structural maps.

The Dewey Lake Redbeds (Page and Adams, 1940, p. $62-63$; Adams, 1929 , p. 1052) are dominantly uniform orange-red siltstone but include disseminated sand grains, sandstone beds, and some mudstone. Gypsum forms cement, secondary crystals, and veins.

The name Pierce Canyon Redbeds (Lang, 1935, p. 262-264) was used for a unit of red siltstone in southeastern New Mexico and adjoining parts of Texas; this unit is regarded as the same as the Dewey Lake Redbeds in west Texas (Miller, D. N., Jr., 1955).

The Tessey Limestone (Udden, 1917, p. 53) is assigned to interval D, although its basal part may be of Guadalupe age. Where exposed in the northern Glass Mountains it is relatively unfossiliferous, massive to indistinctly bedded dolomite, approximately 1,000 feet thick (King, P. B., 1937, p. 106). Much of the Tessey is believed to grade northward into the much thicker evaporitic sequence of the Salado and Rustler Formations in the Delaware basin.

The Tessey contains the pelecypod Pleurophorus (King, P. B., 1942, p. 662-663), but no other fossils have been reported. It is considered to be part of the Ochoa Series because it overlies the Altuda, Capitan, and Gilliam Formations of late Guadalupe age, and because the upper part of the Gilliam and basal part of the Tessey seem to correspond to the Yates Sandstone and Tansill Formation.

No rocks equivalent to those of the Ochoa Series are known southwest of the Glass Mountains within the United States. Two wells drilled in eastern Chihuahua, Mexico, near Ojinaga and across the Rio Grande from Presidio, Tex., penetrated about 8,500 feet of mudstone and limestone with interbedded anhydrite, gypsum, and rock salt, below rocks of Jurassic or possibly Triassic age. The evaporitic sequence has been called Permian (?) on the basis of comparison with Ochoa lithology in Texas (Ramirez and Acevedo, 1957, p. 663-665), but the evaporites may be of Mesozoic age. About 150 miles southeast of the Ojinaga area, near Las Delicias in southwestern Coahuila, 220 feet of gray marine mudstone overlying rocks of Guadalupe age has been considered to be possibly of Ochoa age (King, R. E., and others, 1944, p. 19). It contains the fusulinid Polydiexodina mexicana and the ammonoid Kingoceras, which are not known from any other locality and which are considered younger than 
the most closely related forms from the Guadalupe Series and its equivalents in the United States.

\section{UPPER BOUNDARY OF INTERVAL D}

The Permian age of most of the rocks assigned to interval $\mathrm{D}$ and to the Ochoa Series has been established by fossils found in the Rustler Formation in Culberson County, Tex. (Donegan and DeFord, 1950; Walter, 1953). No fossils have been reported from the Dewey Lake Redbeds. The last age assignment of the Pierce Canyon Redbeds by the U.S. Geological Survey, before the name was abandoned in favor of the Dewey Lake, was Permian or Triassic. The redbed unit has traditionally been assigned a Permian age on the basis of physical stratigraphy: it is thought to overlie conformably the Rustler Formation and underlie unconformably the Dockum Group; it was apparently deposited in a large standing body of water, as were the underlying strata, and not in streams, as were the overlying beds. In the absence of information to the contrary, the red-bed unit is included in interval $D$ although its age admittedly is not known.

Physical criteria can be used for distinguishing red beds included in the Permian from those of the Dockum Group (Adkins, 1924, p. 28 ; Adams, 1929, p. 1052 ; Miller, D. N., Jr., 1955), but the top of the Dewey Lake Redbeds is generally assigned on the basis of geophysical logs (for example, Roswell Geol. Soc., 1958; Van den Bark, 1957 a, p. 111, and other reports in the same volume).

In some parts of the Permian basin region, interval $\mathrm{D}$ is unconformably overlain by Cretaceous or Cenozoic strata with slight to moderate angular discordance. In most parts of the region, rocks directly beneath this erosional surface are the Dewey Lake Redbeds; but in places they are the Rustler or Salado Formations.

\section{THTCKNESS TRENDS}

Interval $\mathrm{D}$ is slightly more than 5,000 feet thick in the central part of the Delaware basin and more than 4,000 feet thick in a north-trending belt within the basin (fig. 16). The rocks thin to about 1,000 feet on the shelf areas and to about 1,500 feet in the Midland basin. Along the eroded edges of the sequence around the periphery of the Permian basin there is marked irregular thinning.

Local irregularities in thickness, as along the margins of the Central Basin platform and along the west and north margins of the Permian basin region, result from leaching of the more soluble beds. Local belts of thinning near the margins of the basin, as the east trending belt in west-central Reeves County, are areas eroded before deposition of Upper Triassic and Cre- taceous strata (fig. 18). Irregular thickness along the southern part of the Central Basin platform is the result of both leaching and erosion.

The Tessey Limestone has a maximum thickness of about 1,000 feet in the Glass Mountains.

\section{LITHOFACIES TRENDS}

Units assigned to interval $\mathrm{D}$ are not described from enough boreholes to permit satisfactory reconstruction of lithofacies trends. In many areas, lithofacies are interpolated from the few available data; in some, data are too sparse to permit interpolation, and lithofacies for these areas are not shown $(\mathrm{I}-450, \mathrm{pl} .6$, inset).

Interval $\mathrm{D}$ is composed mainly of evaporites, mostly anhydrite and halite. Halite is dominant north of the Delaware basin, where the Salado Formation makes up the bulk of the unit. Total thicknesses of salt are greatest, however, within the Delaware basin, but presence of the Castile Formation reduces the relative proportion of salt in the interval. Local differences in the proportion of salt, as along the north and east margins of the Delaware basin, reflect postPermian leaching.

The proportion of carbonate rock to other types increases southwestward and southward, and the proportion of detrital rocks increases eastward and northeastward.

Detrital rocks on the Eastern shelf include both sandstone and mudstone, but the sandstone is more abundant on the southern than on the northern part of the shelf. Sandstone is also moderately abundant along the eastern part of the south margin of the region.

Dolomite is not a major rock component of interval $D$ except in the Tessey Limestone, which lies in and north of the Glass Mountains.

\section{SOURCES AND ENVIRONMENTS}

The greater part of interval D in the west Texas Permian basin region is clearly the product of the evaporation of sea water, somewhat modified by later events and processes. The sequence of strata in the interval records the increasing salinity and density of brine. Geochemical studies of brines indicate that an extremely large volume of water was evaporated.

The deposits accumulated in an interior basin connected to the ocean on the southwest or south by numerous inlets (Moore, G. W., 1960, p. 130) across a partially obstructing sill or barrier. The sill may have been a reef (King, P. B., 1942, p. 752, 759) on the seaward side of the near-margin deposits now preserved as the Tessey Limestone, or perhaps sand dunes 


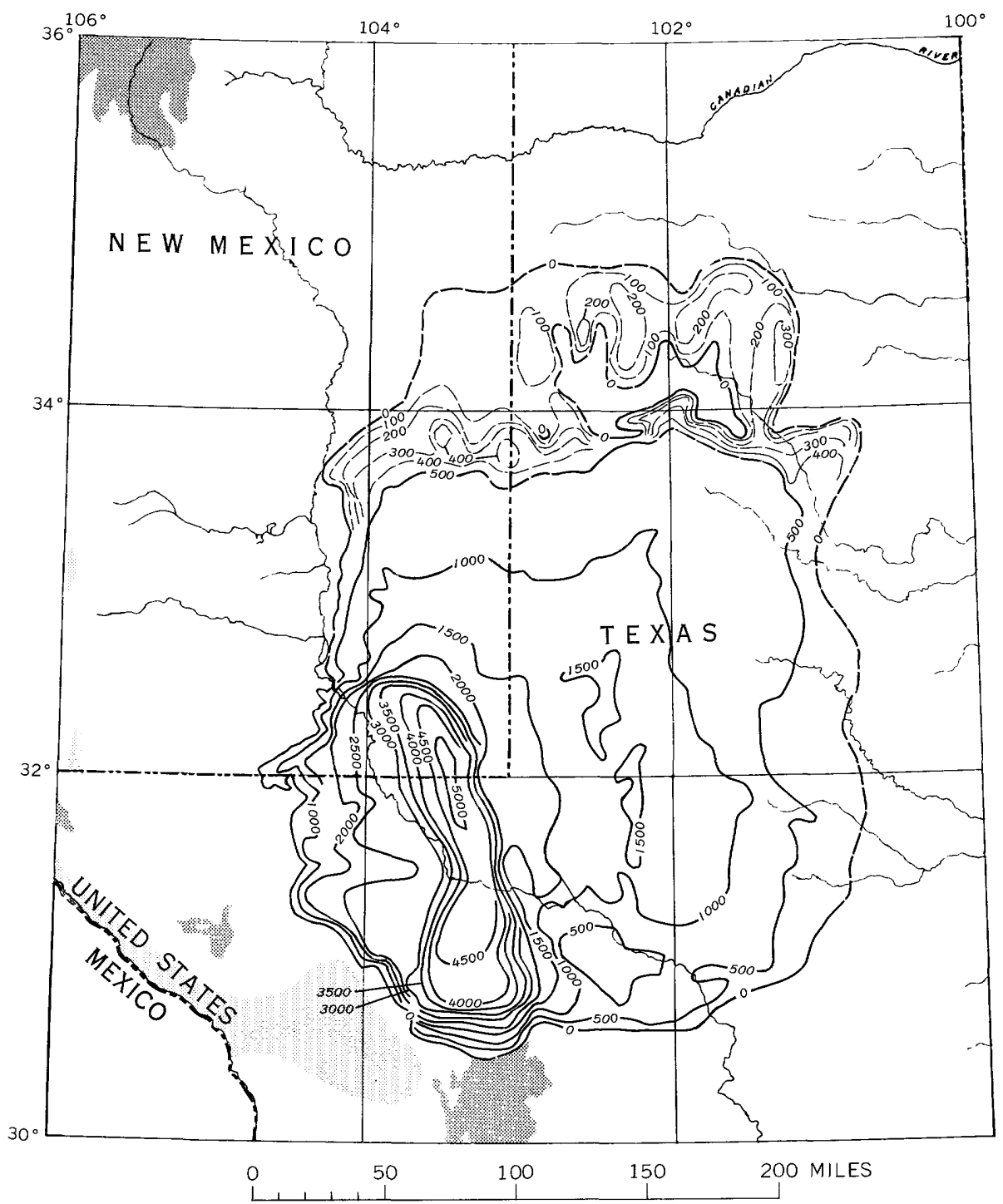

Figure 16.-Thicknesss of interval $D$ in west Texas and southeastern New Mexico. Isopach intervals 100 and 500 feet. Isopachs dashed where control is poor. Dark pattern, areas where rocks older than Permian are exposed; light pattern, areas where rocks younger than interval $\mathbf{D}$ have not been penetrated.

(Adams, 1944, p. 1617), or bank deposits. The sill probably restricted but did not stop circulation.

The interpretation of a reef sill is favored by rock types in the Tessey Limestone. These rocks have been compared with back-reef dolomite of the northern Guadalupe Mountains (King, P. B., 1942, p. 662) and may have been transitional between known evaporites to the north and a possible reef to the south. The inferred reef may have closed the Hovey channel, through which normal marine waters flowed earlier in Permian time. Absence of remnants of the inferred reef is attributed to post-Permian erosion.

Evaporation in the restricted basin may have resulted in density stratification, with dense, saline water within the basin and a lighter, less saline surface layer that was replenished by influx of sea water over the sill. The salinity of the surface layer, however, was probably greater in distal parts of the restricted basin than near the area of inflow (Scruton, 1953).

Both calcite and anhydrite laminae occur in the Castile Formation. Calcite precipitates from sea water of nearly normal salinity, but calcium surfate is not formed until salinity has increased to 3.35 times the normal content (Mason, 1958, p. 175).

Laminated deposits in the Castile have been regarded as varved (Udden, 1924) and have been attributed to intermittent inflow. At each seasonally controlled influx of a surface layer of sea water, progressive evaporation precipitated first calcite and then calcium sulfate in the form of gypsum (Adams, 1944, 
p. 1617-1619). Incomplete precipitation of marine salts, or the relatively low proportion of salt deposited in the formation, may have been caused by seepage of the denser layer through the inferred permeable sill.

The laminae have also been attributed to seasonal variations in temperature and accompanying variations in relative solubility of anhydrite and calcite, rather than to cyclic interruptions in deposition; excessive salinities in the basin might have been forestalled by nearly continuous reflux or outflow over the sill, but below the layer of influx of the lower, denser layer (King, R. H., 1947b, p. 477). The ratio of influx to reflux, based on dominance of anhydrite in the Castile and on the total content and relative solubilities of salts in sea water, has been estimated at about 10:1. Gypsum may have been deposited initially, but very early in Castile time salinity may have increased to 4.8 times that of sea water and specific gravity to 1.11 , at a temperature of about $30^{\circ} \mathrm{C}$., so that virtually all the calcium sulfate was precipitated as anhydrite. The volume of water estimated to have evaporated during deposition of the Castile Formation is $928.5 \times$ $10^{15}$ cubic feet, equivalent to a vertical column of $3,280,000$ feet or about 114 inches per year (King, $\mathbf{R}$. H., $1947 \mathrm{~b}$, p. 475$)$. At present, evaporation in the Delaware basin area ranges from 70 to 110 inches per year (Adams, 1944, p. 1619).

Modern oceanographic data support this inferred pattern of circulation in the basin (Scruton, 1953, p. 2502). Possible factors that may have affected salinity within the basin, or changes in the geographic position of salinity gradients, are seasonal variations in temperature, evaporation, precipitation, sea level, or wind. The intertonguing of the Castile Formation with halite in the northeastern or distal part of the Delaware basin supports the inferred source of sea water in the southwest or south.

The area of evaporation was restricted to the Delaware basin during all, or nearly all, of Castile time. Subsidence did not keep pace with the accumulation of the precipitates; the basin filled, and the depth of water decreased.

A change in the nature of the marine channelway, caused possibly by slight upwarping of or sedimentation on the sill, increased the ratio of influx to reflux and increased salinity; this resulted in deposition of the Salado Formation. A much greater area is covered by brine deposits of the Salado Formation than by those of the Castile.

That a tremendous volume of water evaporated during deposition of the Salado Formation is indicated by the presence of such salts as kieserite and carnallite, end members of the evaporative sequence (Phillips,
1947, p. 100), and sylvite. Potassium and magnesium salts do not begin to crystallize until sea water has been reduced to 1.54 percent of its volume. The total volume of water removed is unknown.

Silt and sand in the Salado Formation may have been carried into the evaporative basin by wind or by ephemeral desert streams during interludes of desiccation (Adams, 1944, p. 1621). The presence of many layers of mixed halite and detritus in cyclic sequences may indicate many times of desiccation (Jones, C.L., 1954, p. 110).

The salinity of brines in the Permian basin was much reduced by the time the Rustler Formation was deposited. The formation has been considered as reflecting the final incursion of the Permian sea in west Texas (Adams, 1944, p. 1615). Evidence in support of this interpretation is the marine fauna reported from the Rustler in Culberson County, Tex. (Walter, 1953). This fauna, composed of brachiopods, pelecypods, and gastropods, suggests nearly normal marine waters for at least part of Rustler time. The upper part of the Rustler contains, however, an aberrant pelecypod and gastropod fauna, suggestive of development in hypersaline water. Restricted circulation and evaporation of sea water are indicated by the presence of anhydrite beds, especially in the upper part of this formation.

The Dewey Lake Redbeds differ mineralogically from siltstones and sandstones in underlying units of the Permian basin principally in the abundance of fresh feldspar and thepresence of hollow sanidine grains (Miller, D. N., Jr., 1955). The detritus may have been derived from a granitic source in Coahuila, Mexico, transported by wind in an arid climate, and deposited in shallow saline water (Miller, D. N., Jr., 1955 , p. $60-63,104-106)$ in the basin remaining after deposition of the Rustler Formation.

Although more than 5,000 feet of interval D occurs in parts of the Delaware basin, this probably represents a relatively brief span of geologic time. If laminae in the Castile Formation are varves, then the duration of Castile time may have been 306,000 years (Udden, 1924, p. 353). Halite, the most abundant component of the thick Salado Formation, can accumulate at the rate of two-thirds foot or more per year under optimum conditions (Briggs, 1958, p. 55); thus, the salts in the Salado Formation may have formed in a few hundred thousand years or less (J. E. Adams, oral commun., 1958).

\section{PALEOTECTONIC IMPLICATIONS}

The west Texas Permian basin during latest Permian time was very stable. Although the upper part 
of interval D probably formed at the close of the Paleozoic Era, evidence of orogeny is absent. Marked stability permitted the maintenance of an evaporite pan in which the sequence of precipitation proceeded to the formation of bittern salts. Hydrographic features evolved from those which existed in the basin earlier would have been markedly affected by tectonism, but neither normal marine sediments nor coarse detritus invaded the basin until latest Permian time.

Tectonic stability is also implied by the near conformity of Permian and Upped Triassic rocks over much of west Texas and southeastern New Mexico and the apparently limited extent of more marked discordances such as that between Permian and Triassic rocks in the Glass Mountains.
Deposition of the Dewey Lake Redbeds may imply slight to moderate uplift of bordering land areas, possibly to the south in Mexico very late in Permian or early in Triassic time.

\section{TOTAL THICKNESS OF PERMIAN ROCKS}

\section{THICKNESS AND TRENDS}

Maximum thickness of Permian rocks exceeds 17,000 feet in the Val Verde area, where, however, basal strata of pre-Permian age may have been included. Permian rocks are more than 15,000 feet thick in the central part of the Delaware basin and exceed 10,000 feet in other parts of this basin. Thickness in other parts of the region is less, as shown in figure 17.

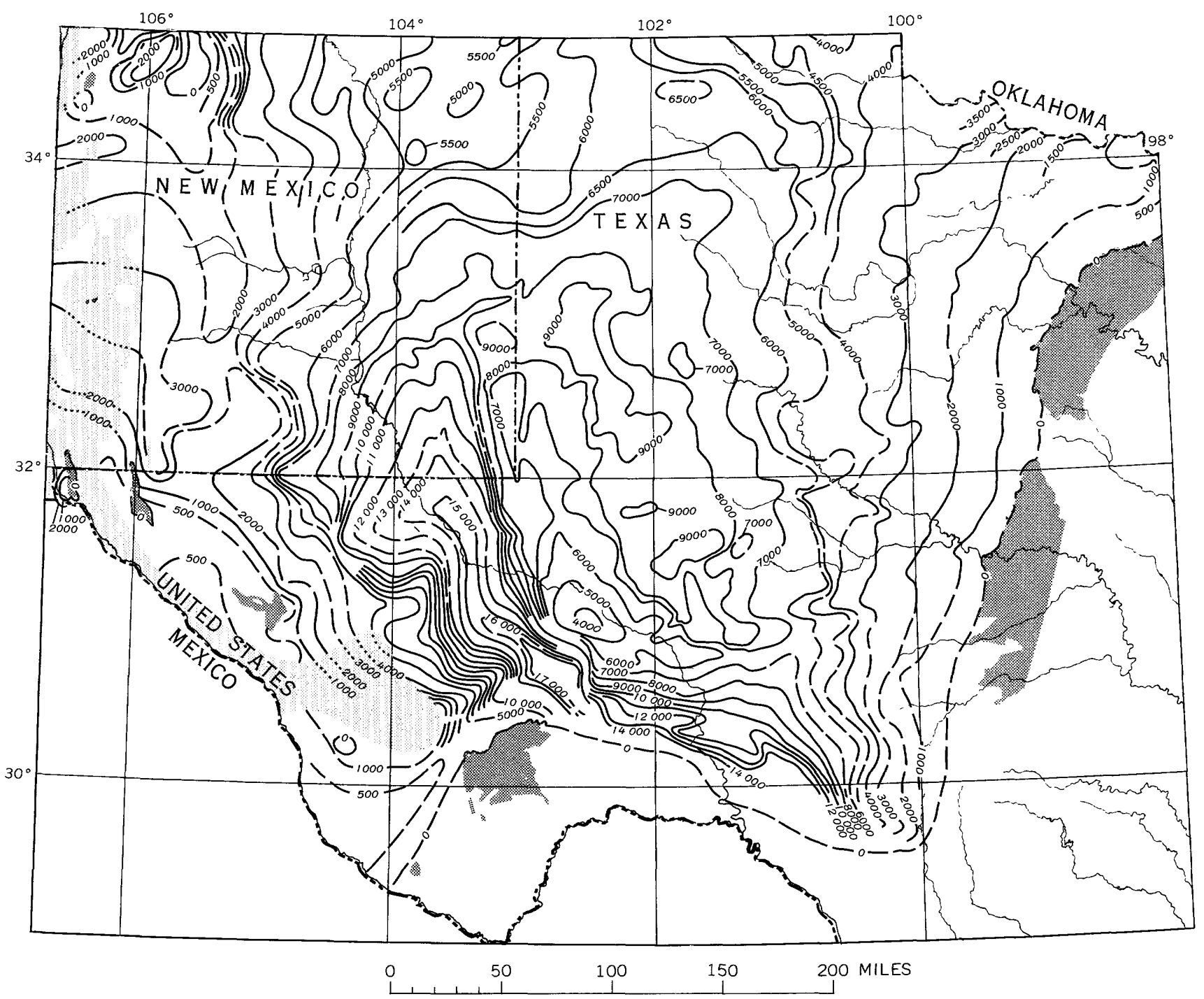

Figure 17.-Total thickness of Permian rocks in west Texas and southeastern New Mexico. Isopach intervals 500 and 1,000 feet. Isopachs dashed where control is poor, dotted where Permian rocks have not been penetrated by drill. Dark pattern, areas where rocks older than Permian are exposed; light pattern, areas where rocks younger than Permian have not been penetrated. 
The great thickness of the Permian System in basins of west Texas diminishes eastward to a beveled edge and northward to considerably thinner but not notably incomplete stratigraphic sequences. The rocks undoubtedly thin rather abruptly southward from the belt of maximum thickness in the Val Verde area, but available data are insufficient to define this belt of thinning.

Thicknesses of Permian strata have been affected by later events not only where exposed to weathering and erosion, but also in the subsurface. The large proportion of relatively soluble minerals in the system have made it especially susceptible to leaching and thinning by ground water. The Carlsbad Caverns in the carbonate facies of the Artesia and Capitan Limestones (Bretz, 1949; Horberg, 1949; Hayes, 1957) are a spectacular example. Hydration of anhydrite to form gypsum and also leaching of halite and the sulfates have taken place on a much more extensive scale than solution of limestone. In general, times of solution are believed to have coincided with times of erosion (Adams, 1944, p. 1622-1625).

\section{PALEOTECTONIC IMPLICATIONS}

Major tectonic elements that influenced sedimentation throughout Permian time are evident in figure 17. The Val Verde trough, site of extremely great sedimentation in earliest Permian time (fig. 12), is also the area of maximum thickness for the total Permian System in this region. The Delaware and Midland basins contain thicker sequences than do the Diablo and Central Basin platforms and the Northwestern and Eastern shelves. Also evident are such smaller features as the Hobbs channel, on the north end of the Central Basin platform, and the Hovey channel, in northern Brewster County.

The combination of thicknesses of all intervals of the Permian System on a single map, however, does mask some major features and events. The margins of the basins, for example, and such smaller features as the Sheffield channel are not sharply defined in figure 17.

Places of maximum thickness do not necessarily represent persistent or recurrent areas of maximum depression during all of Permian time. In the Val Verde trough area, for example, more than 10,000 feet of detrital rocks accumulated very early in Permian time. This amount was far greater than that deposited later. Maximum sinking in later Permian time occurred in the northwest segment of the Val Verde trough; but even there, deepening of the trough in Early Permian time provided for an accumulation of $1 / 2^{-2 / 3}$ of the total thickness of Permian rocks.
In the central part of the Delaware basin, on the other hand, the total thickness includes unusually great thicknesses of intervals A and D but only moderately great thicknesses of intervals B and C. The basin was a topographic depression throughout Permian time. Sedimentation did not keep pace with sinking, and the basin wasn't filled until late in the period.

Total thickness of Permian rocks within the Permian basin region reflects, in a general way, strongly negative movements of late Paleozoic age. Great thicknesses in the Delaware and Midland basins are the result of Late Pennsylvanian and Early Permian downbuckling. Lesser thickness on the Central Basin platform is the result of uplift in earliest Permian time and subsequent regional subsidence; the platform, however, sank less than the adjoining basins. Farther north, however, moderate thickness on the Northwest shelf probably reflects a gradually subsiding belt. Total thickness of Permian rocks along the east and west margins of the Permian basin region, on the other hand, has at several times been reduced by post-Permian erosion.

\section{GEOLOGIC UNITS DIRECTLY ABOVE PERMIAN SYSTEM UNITS OVERLYING PERMIAN}

The Permian System is unconformably overlain (fig. 18 ), in most parts of the west Texas Permian basin region, by alluvial sandstone, red mudstone, and some conglomerate and fresh-water limestone assigned to the Dockum Group (McKee and others, 1959, p. 13-14, 21-22) of Late Triassic age. Upper Jurassic rocks, of the Malone Formation, are preserved in a single small area in the Quitman and Malone Mountains in the south-central part of Hudspeth County, Tex.

Permian rocks in parts of trans-Pecos Texas, in the southeastern part of the Permian basin region, and in local areas along the Eastern shelf are unconformably overlain by various rock units assigned to the Lower Cretaceous and locally to the Comanche Series. Cretaceous rocks are much more extensive than shown (fig. 18), because they extend over the Dockum Group in much of the southern part of the west Texas Permian basin region. They formed during a very extensive transgression of the sea from the Gulf region.

Cenozoic rocks and sediments directly overlie Permian and younger rocks in topographically low areas in the southwestern part of the region. In addition to areas shown in figure 18, Cenozoic rocks and unconsolidated sediments also fill the Rio Grande trench and the Tularosa basin.

Tertiary volcanic rocks, overlapping the Cretaceous, lie on Permian rocks in small areas in the Chinati Mountains. 


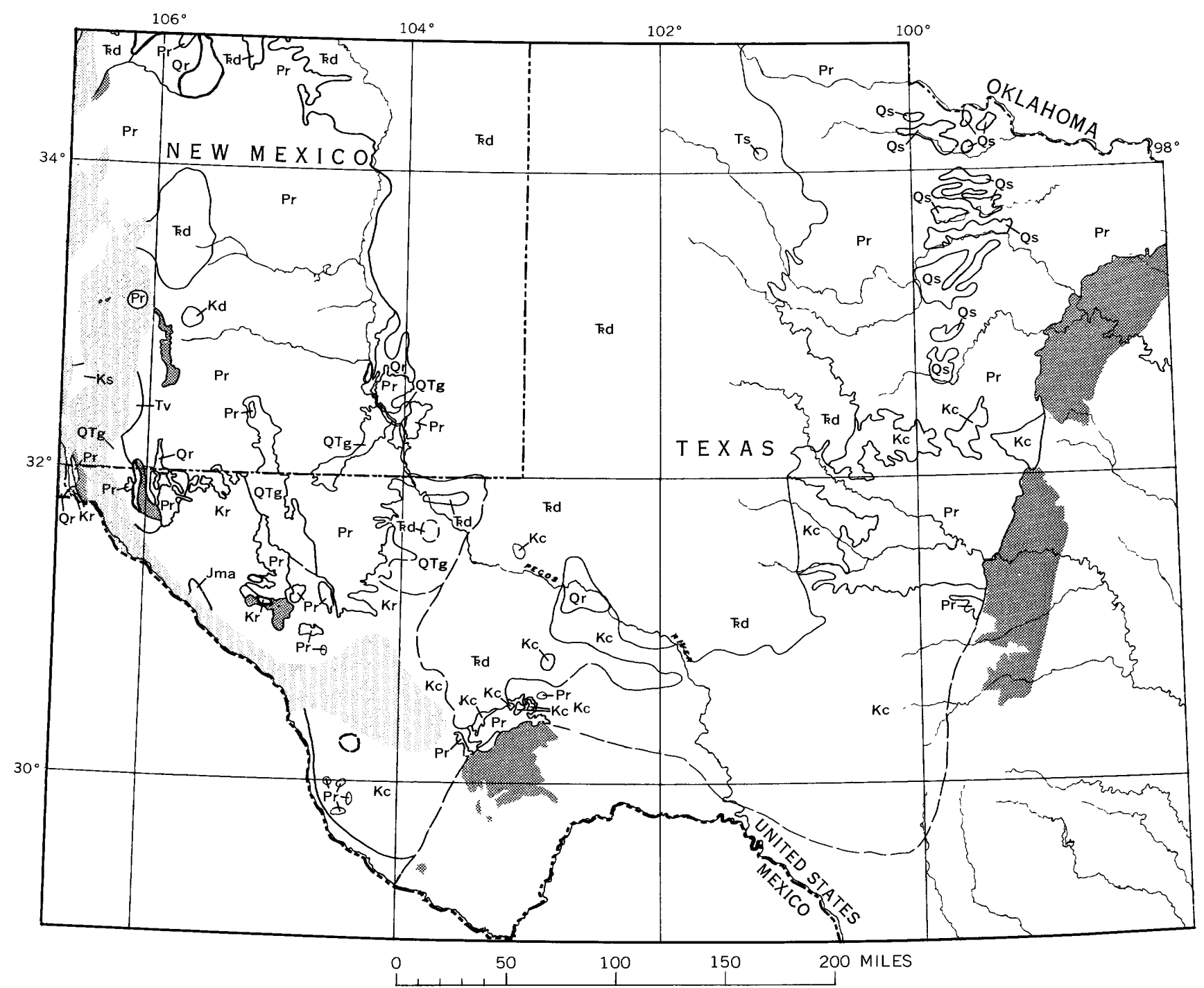

Figure 18.-Geologic units directly above Permian System in west Texas and southeastern New Mexico. Qs, Quaternary Seymour Formation. QTg, Quaternary and, locally, Tertiary gravel, sand, and clay. Tertiary rocks: Ts, undivided sedimentary rocks; To, Ogallala Formation; Tv, volcanic rocks. Cretaceous rocks: Kr, undivided; Kc, rocks of Comanche age; Kd, Dakota Sandstone; Ks, Sarten Sandstone. J ma, Jurassic (interval D) Malone Formation. Kd, Triassic (interval C) Dockum Group. Pr, area where Permian rocks are exposed. Dark pattern, areas where rocks older than Permian are exposed; light pattern, areas where rocks younger than Permian have not been penetrated. Contacts between stratigraphic units dashed where uncertain. Limit of Permian rocks shown by heavy line; dashed where uncertain.

Quaternary deposits rest directly on Permian and Triassic rocks above part of the south end of the Central Basin platform. In the area of the Eastern shelf numerous remnants of probable flood-plain deposits on the eroded surface of the Permian are assigned to the Seymour Formation of Quaternary (Pleistocene) age. In the western part of the region, Permian rocks are overlain by lake deposits of inferred late Pleistocene age, as in the Salt Basin (King, P. B., 1948, p. 157), and by alluvial gravel deposits, as in central and southcentral Eddy County (Hayes, 1957).
Permian rocks are now exposed in much of the Eastern shelf area, in part of the Midland basin, and along the west margin of the region, in southeastern New Mexico.

Permian rocks are also exposed in parts of the Glass Mountains, the Chinati Mountains, and in a few isolated areas too small to show on the maps of this paper. These small areas lie along the Pecos River north of the common point of Terrell, Crockett, and Val Verde Counties (King, P. B., 1942, pl. 1; West Texas Geol. Soc., 1959, p. 52-53) and near the east 
edge of Permian rocks in Sutton, Menard, and Kimble Counties (Darton and others, 1937).

\section{PALEOTECTONIC IMPLICATIONS}

The post-Permian record in west Texas and southeastern New Mexico is fragmentary and largely one of erosion. Conspicuous unconformities mark the bases of Upper Triassic, Cretaceous, and poorly dated but probably mainly upper Cenozoic strata (McKee and others, 1959, p. 2, 20; Adams, 1929, p. 1047).

Topographic relief after deposition of the uppermost Permian rocks continued to be low or subdued. Broad regional warping, however, probably took place along the northern and western periphery of the west Texas Permian basin region, as indicated by beveling of the successively older Permian units that directly underlie the Dockum Group northwestward (McKee and others, 1959, pl. 2). Detritus from the southeastern New Mexico area seems to have been a major component of the Moenkopi Formation; therefore, warping and erosion took place in Early Triassic time.

In the central part of the west Texas Permian basin region, however, relatively nonresistant uppermost Permian rocks are preserved beneath the Dockum Group at most places. Although the land was emergent by Late Triassic time, erosion was mainly by small streams. The Dockum Group was later deposited in the channels and flood plains of these streams.

In the Midland basin, Upper Triassic rocks were not deposited much farther east than the present zero isopach of the Triassic System (McKee and others, 1959). The area east of Triassic deposition probably remained positive until Early Cretaceous time, when marine sediments overlapped the Dockum Group.

In the southeastern part of the west Texas Permian basin region, Permian rocks were warped, possibly in
Early Triassic time, and beveled by erosion in an area at least $80-100$ miles wide. To the west, in the Glass Mountains area, however, there seems to have been no comparable widespread erosion before deposition of the Upper(?) Triassic Bissett Conglomerate, which was derived from rocks immediately to the south and laid down on slightly tilted Upper Permian rocks.

The west Texas region was probably emergent but low during the Jurassic Period. By Late Jurassic time, areas in the northern part of, or north of, the Permian basin region probably supplied some of the coarse detritus in the Morrison Formation in the Oklahoma Panhandle. In the southwesternmost part of the region, however, downbuckling permitted encroachment of a seaway from Mexico, in which the Jurassic Malone Formation was deposited.

By Early Cretaceous time, the once-prominent highlands along the Ouachita-Marathon structural belt were submerged by transgression of the sea from the south. North of the structural belt, Cretaceous deposition advanced across an irregular surface of warped, eroded, and partly leached Permian and Triassic rocks.

Prominent block faulting and buckling of basinrange type in the western part of the Permian basin region are probably late Cenozoic (King, P. B., 1948, p. 106-108). Many of these features cut across earlier structures and larger tectonic elements, but some renewal of movement occurred along early belts of weakness. Major movement was on northwest-trending faults along the northeast margin of the Diablo platform of Permian time.

Late Cenozoic regional uplift exposed many of the Permian strata in the west Texas Permian basin to erosion. 


\section{Paleotectonic Investigations}

of the Permian System

in the United States

Chapter D. Northeastern New Mexico and Texas-Oklahoma Panhandles

By GEORGE H. DIXON

GEOLOGICAL SURVEY PROFESIONAL PAPER 515-D

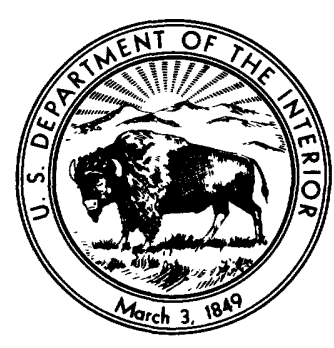





\section{CONTENTS}

Abstract

Region defined.

Paleogeology

Lower boundary of Permian

Northeastern New Mexico ... . . . . . . . . . . . .

Texas-Oklahoma Panhandles.

Paleotectonic implications . . . . . . . . . . . . . .

Interval A . . . . . . . .

Formations included . . . . . . . . . . . . . . .

Northeastern New Mexico.................

Texas-Oklahoma Panhandles. . . . . . . . . . .

Upper boundary of interval A...............

Central and southeastern New Mexico.........

Texas-Oklahoma Panhandles.

Thickness trends...........

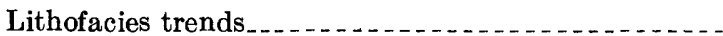

Sources and environments of deposition..........

Paleotectonic implications. . . . . . . . . . .

Interval B

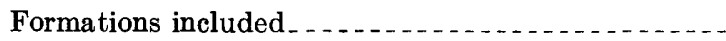

Northeastern New Mexico

Southwestern part of Texas Panhandle .......

Oklahoma Panhandle and northeastern part of

Texas Panhandle.

Upper boundary of interval $\mathrm{B}$

Northeastern New Mexico.................

Texas-Oklahoma Panhandles.

\begin{tabular}{|c|c|c|}
\hline Page & & Pag \\
\hline 65 & Interval B-Continued & \\
\hline 65 & Thickness trends & \\
\hline 65 & Lithofacies trends. & \\
\hline 65 & Sources and environments & \\
\hline 67 & Paleotectonic implications & \\
\hline 67 & Interval $\mathrm{C}_{2} \ldots$ & \\
\hline 67 & Formations included & \\
\hline 68 & Northeastern New Mexico & \\
\hline 68 & Texas-Oklahoma Panhandles & \\
\hline 68 & Upper boundary of interval $C_{1}$ & \\
\hline 68 & Northeastern New Mexico & \\
\hline 69 & Texas-Oklahoma Panhandles....... & \\
\hline 69 & Thickness trends. & \\
\hline 69 & Lithofacies trends. & \\
\hline 70 & Sources and environments & \\
\hline 70 & Paleotectonic implications & \\
\hline 70 & Interval D. & \\
\hline 71 & Formations included & \\
\hline 71 & Upper boundary of interval D. & \\
\hline 71 & Thickness trends. & \\
\hline 71 & Lithofacies trends_. & \\
\hline & Environments and sources & \\
\hline 72 & Total thickness of Permian rocks & \\
\hline 72 & Thickness and trends & \\
\hline 72 & Paleotectonic implications & \\
\hline 72 & Geologic units directly above Permian System & \\
\hline
\end{tabular}

\section{ILLUSTRATIONS}

Figure 19-27. Maps of northeastern New Mexico and Texas-Oklahoma Panhandles:

19. Tectonic elements in Late Pennsylvanian and Early Permian time

20. Counties, towns, and geographic features.

21. Thickness of interval A

22. Thickness of interval B (excluding "Blaine Formation" in northeastern part of Panhandle area)

23. Thickness of interval $B$.

24. Thickness of interval $\mathrm{C}$ (including "Blaine Formation" in northeastern part of Panhandle area)

25. Thickness of interval $\mathrm{C}$

26. Thickness of interval $D_{2}$

27. Total thickness of Permian rocks.

\section{TABLE}

TABLE 1. Generalized chart showing stratigraphic units in major Permian subdivisions 
. 


\title{
PALEOTECTONIC INVESTIGATIONS OF THE PERMIAN SYSTEM IN THE UNITED STATES
}

\section{NORTHEASTERN NEW MEXICO AND TEXAS-OKLAHOMA PANHANDLES}

\author{
By George H. Dixon
}

\begin{abstract}
Rocks of Permian age are present throughout the northeast quarter of New Mexico and the Panhandle of Texas and Oklahoma except in three places. Permian rocks are absent across a part of the buried Sierra Grande arch in eastern Colfax County, N. Mex., and they have apparently been eroded from the crest of the Pedernal positive element in central Torrance County, N. Mex. They are also absent west of a beveled edge along the south and east flanks of the present Sangre de Cristo Mountains.

Surface exposures of Permian rocks in northeastern New Mexico are limited to the area surrounding the Pedernal Hills and along the east flank of the Sangre de Cristo Mountains. In the Texas-Oklahoma Panhandles they occur in the southeast quarter of the Texas Panhandle and along the North Canadian River in Beaver County, Okla. Permian strata occur in the subsurface throughout the remainder of the region.

Major structural features that influenced Permian deposition were the Matador and Sierra Grande arches, the Pedernal positive element, and the Bravo dome, all in northeastern New Mexico, and the Matador arch, the Amarillo and Cimarron uplifts, and the Keyes dome in the Texas-Oklahoma Panhandles. These structures formed in pre-Permian time. The basins separating them received large amounts of detrital material from their erosion, but even larger amounts may have been derived from the ancestral Rocky Mountains to the northwest and west.

Early in Permian time the sea invaded this region from the south and transgressed northward with only minor or local regressions until late Permian time.
\end{abstract}

\section{REGION DEFINED}

The region described here includes the northeast quarter of New Mexico and the Texas-Oklahoma Panhandles.

Major features that influenced Permian deposition were formed earlier in the Paleozoic. The Palo Duro basin, in the central part of the region, was separated by the Matador arch from the west Texas Permian basin early in Permian time but was connected northward with the Dalhart basin. The Palo Duro was separated from the Rowe-Mora basin, in the northwestern part of the region, by the Pedernal positive element, the Sierra Grande arch, and the Bravo dome, which were active early in this period. It was separated from the Anadarko basin to the northeast and east by the Amarillo uplift, the Cimarron uplift, and the Keyes dome.

During Permian deposition, the sea entered this region from the south. Most of the detritus deposited in the basins was derived from the ancestral Rocky Mountains to the northwest and west.

\section{PALEOGEOLOGY UNITS UNDERIYING PERMIAN}

In northeastern New Mexico and the Texas-Oklahoma Panhandles, units directly underlying the Permian System range from Precambrian to Pennsylvanian (I-450, pl. 2). Middle Paleozoic rocks are assigned only to geologic systems, whereas upper Paleozoic rocks are assigned to provincial series in the subsurface and to groups or formations at the surface.

Rocks of Precambrian age lie directly under the Permian in structurally positive areas, such as the Pedernal positive element in central New Mexico, and under rocks of probable Permian age on the Sierra Grande arch and the Bravo dome of northeastern New Mexico (fig. 19). In the Texas-Oklahoma Panhandles many wells have penetrated Precambrian igneous rocks ranging from acidic (granitic) to basic, the acidic type is commonest (Totten, 1956, p. 1951). Small areas of Precambrian igneous rocks directly underlie the Permian in southern Roosevelt County, N. Mex., and eastward in Bailey, Cochran, and Lamb Counties, Tex. (fig. 20). These are local high areas along the eastward-trending Matador arch. Another area of Precambrian rocks is along the arc formed by the Amarillo uplift, which forms the southwestern limit of the Anadarko basin.

Rocks of Silurian or Devonian age directly underlie the Permian System in one borehole in central Roosevelt County, N. Mex.

Assignments of rocks to the Pennsylvanian System are based on paleontologic data in some places and on 


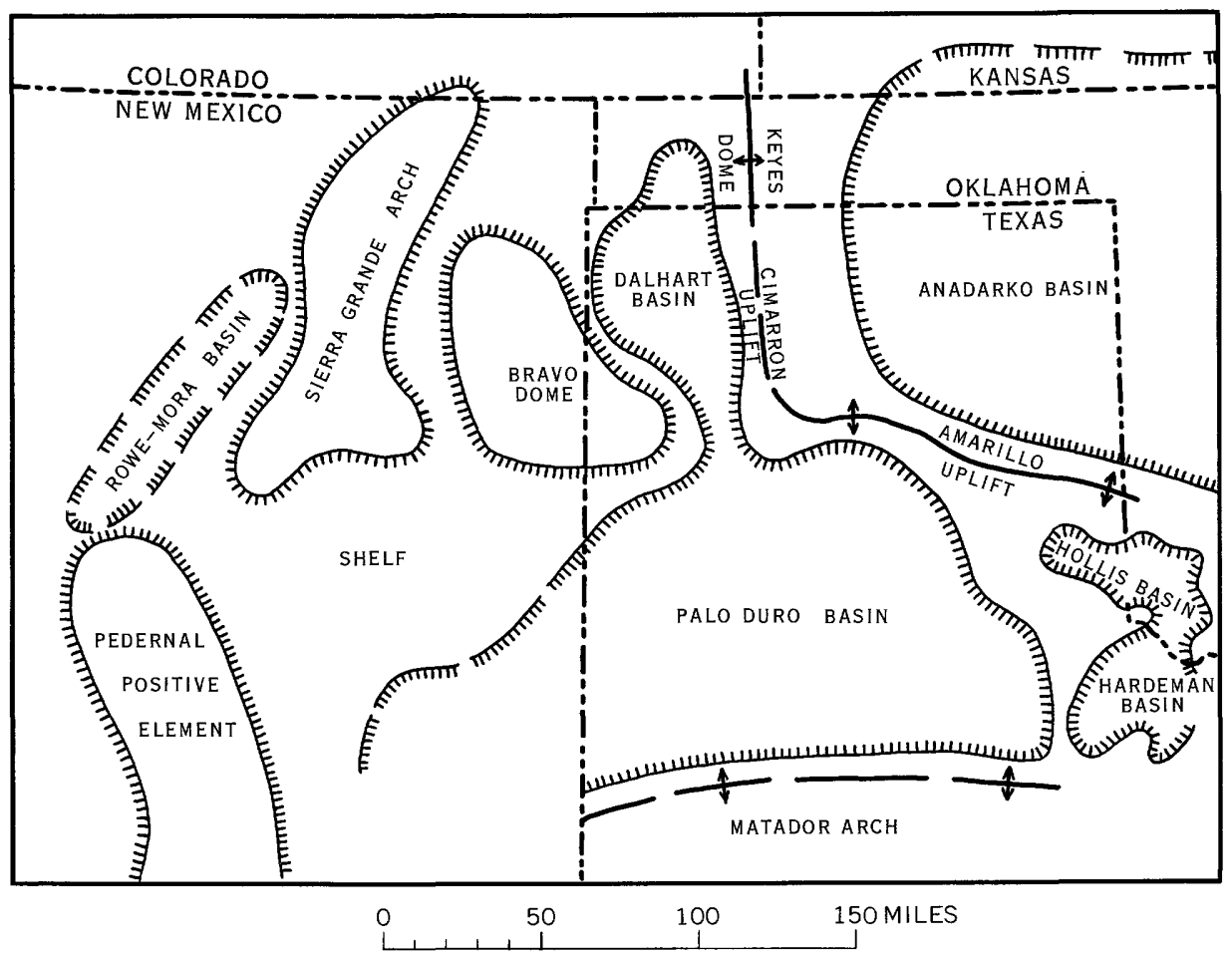

Frgure 19.-Tectonic elements of northeastern New Mexico and the Texas-Oklahoma

Panhandles in Late Pennsylvanian and Early Permian time. Based in part on Totten (1956).

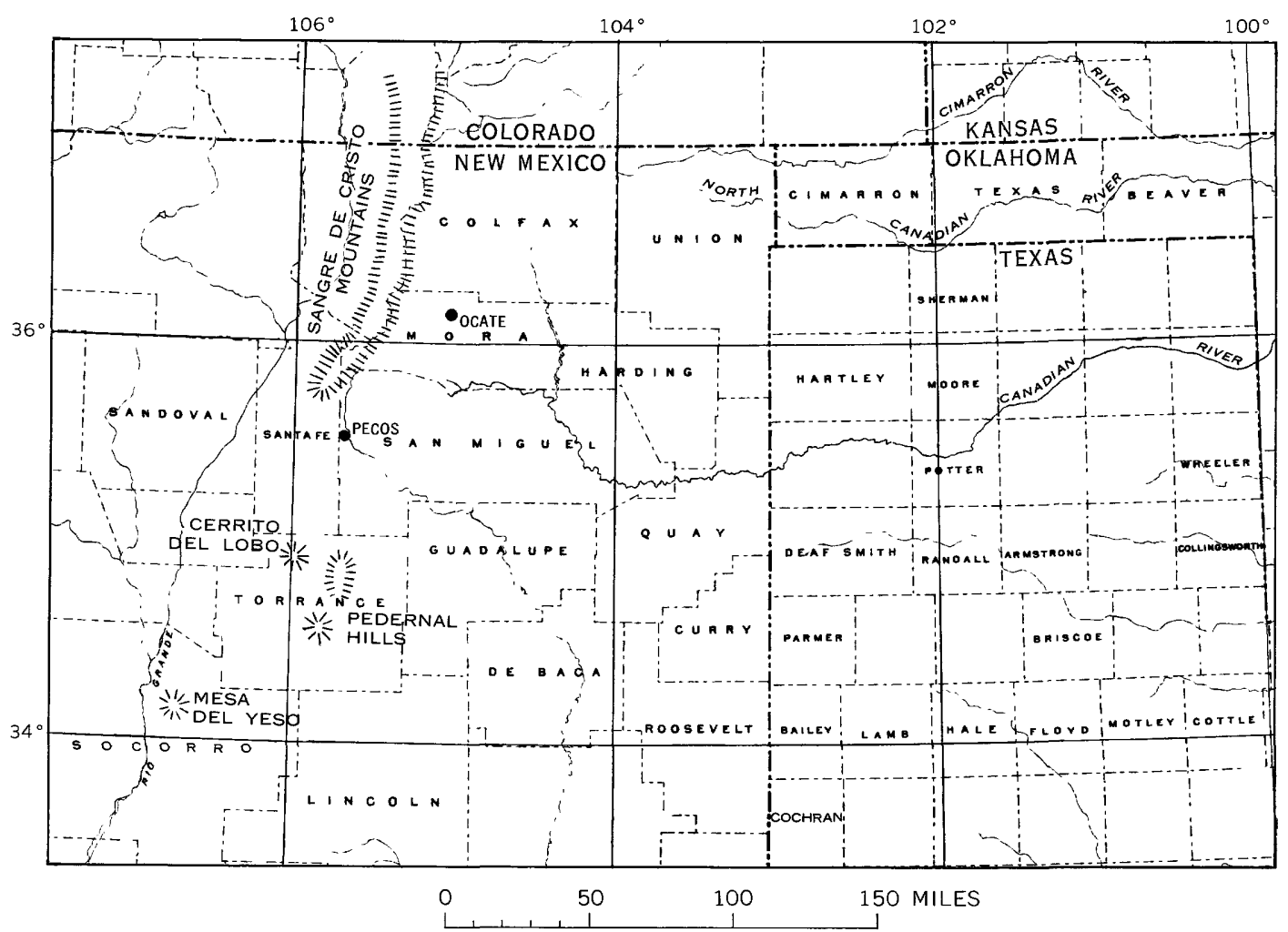

FIgURE 20.-Counties, towns, and geographic features of northeastern New Mexico and the TexasOklahoma Panhandles referred to in text. 
lithologic similarity in others. Fusulinid reports from the Paleontological Laboratory, Inc., Midland, Tex., have been used, insofar as possible, to separate the Permian and Pennsylvanian Systems and to differentiate the series within the Pennsylvanian System. Locally abrupt facies changes in Pennsylvanian rocks make recognition of series difficult.

According to many geologists, the Permian throughout most of this region is underlain by rocks of Virgil (latest Pennsylvanian) age, including the provincial Cisco Series; but Roth (1955, p. 437, fig. 12) believed that all rocks beneath the Permian in more than half of the region are older than Virgil. In a few parts of the region lithologically similar rocks of definite preVirgil age may occur but have not been differentiated in mapping. Throughout the Texas-Oklahoma Panhandles and in eastern New Mexico, the Cisco Series consists of red and gray siltstone and mudstone, coarse sandstone, limestone, and dolomite.

A few boreholes on the northeast and southwest flanks of the Amarillo uplift have entered siltstone and limestone of probable Missouri age below the Permian. Available data, however, are insufficient for locating the boundaries of rocks of Missouri age on the paleogeologic map. These rocks occur only in small isolated areas (I-450, pl. 2).

In much of northeastern New Mexico, Pennsylvanian rocks are assigned to the Madera Formation of the Magdalena Group of Middle and Late Pennsylvanian age and to the lower part of the Sangre de Cristo Formation of Pennsylvanian age.

In outcrops on the east and south flanks of the Sangre de Cristo Mountains in New Mexico, limestones of the Madera Formation underlie the Sangre de Cristo Formation, and fusulinids of the species of the genus Fusulina in the highest marine rocks of the sequence indicate a Des Moines age (Bachman, 1953); however, in other places the Madera may include strata of Missouri and Virgil age (G. O. Bachman, oral commun., 1960). In the Coyote district of northeastern Mora County the age has not been precisely determined, although fossils suggest an approximate Middle Pennsylvanian or a post-Morrow age. In several boreholes in De Baca County (Tschanz and others, 1958, p. 349350 ), limestone and silty mudstone of the Madera Formation directly underlie Permian strata and contain Triticites of probable Virgil age.

The upper arkosic member of the Madera Formation near the town of Pecos, in the area west of the Sierra Grande arch, has yielded species of Fusulina and Triticites characteristic of the Des Moines, Missouri, and Virgil Series (Brill, 1952, p. 819). Uppermost Pennsylvanian strata on the west side of the
Pedernal positive element may be of the same age. Northeast and east of this element Pennsylvanian rocks may be, in part, of Missouri age.

The Sangre de Cristo Formation contains few fossils, and its age is somewhat uncertain; however, it probably includes both Middle and Upper Pennsylvanian and Lower Permian beds. Sangre de Cristo strata underlying the Permian are considered to be of Virgil age (I-450, pl. 2).

\section{LOWER BOUNDARY OF PERMIAN}

\section{NORTHEASTERN NEW MEXICO}

The boundary between the Pennsylvanian and Permian Systems is difficult to recognize in this area. It occurs within the Sangre de Cristo Formation (Hills, 1900) which, near its sources in the Sierra Grande arch and the Bravo dome, is composed of red sandstone, siltstone, and coarse arkose. Southward this formation grades into arkosic silty mudstone containing thin units of interbedded marine limestone.

Sparse fossils in the Sangre de Cristo Formation on the south flank of the Sangre de Cristo Mountains indicate either a Permian or a Late Pennsylvanian and Permian age (Brill, 1952, p. 821). On the east flank of the mountains, in the Coyote district of west-central Mora County, brachiopods, pelecypods, crinoids, nautiloids, and gastropods from limestone and siltstone in the lower 950 feet of the formation all indicate a Pennsylvanian age (Tschanz and others, 1958, p. 354). In most other areas, however, the Sangre de Cristo contains few or no fossils, so Pennsylvanian and Permian components cannot be separated. The position of the Pennsylvanian-Permian boundary is also indefinite east of the Pedernal positive element, near which both systems consist of red silty mudstone grading laterally into limestone containing some red mudstone, siltstone, and dolomite. In east-central New Mexico, rocks in a few boreholes contain fusulinids for which identifications are available from the Paleontological Laboratory and from published reports by Needham and Bates (1943), Bates and others (1947), Wilpott and others (1946), and Dobrovolny, Summerson, and Bates (1946).

\section{TEXAS-OKLAHOMA PANHANDLES}

Paleontologic data for the Palo Duro or Plainview basin and for the Hollis (Harmon) and Hardeman basins of the Texas Panhandle are moderately abundant, and in most places within the area the base of the Permian is located near the bottom of a limestone overlying a mudstone and siltstone sequence. In places, however, the boundary is obscured by limestone reefs of late Virgil age (Roth, 1955; Totten, 1956), and in others the lithologic break does not coincide 
with the time line (Totten, 1956). The boundary is also obscure on both flanks of the Amarillo uplift, where arkosic siltstone and sandstone dominate both Upper Pennsylvanian and lowest Permian rocks.

In the western part of the Anadarko basin the Lower Permian and Upper Pennsylvanian rocks seem to be more nearly alike than in the Palo Duro basin, and lateral changes are not as abrupt. These rocks are largely gray mudstone; minor amounts of gray limestone and siltstone occur around the periphery of the basin. Fossils are available in places to determine the boundary.

The base of the Permian in the Dalhart basin, west of the Cimarron uplift, is obscure because of the similarity between Lower Permian and Upper Pennsylvanian rocks and because paleontologic control is poor.

A widespread unconformity is believed by some (Roth, 1949, p. 1672; 1955, p. 422; Totten, 1956, p. 1961) to be at the base of the Permian, but the information summarized above suggests that this is unlikely (Read and others, 1944).

\section{PALEOTECTONIC IMPLICATIONS}

Most, if not all, major tectonic elements that influenced sedimentation in northeastern. New Mexico and in the Texas-Oklahoma Panhandles early in Permian time probably either were fully formed or had begun to form by Middle to Late Pennsylvanian time. By Early Permian time, these tectonic elements apparently were fully formed or had passed their time of maximum influence and were beginning a gradual decline.

Major crustal instability before the end of Pennsylvanian time is indicated in parts of northeastern New Mexico on the paleogeologic map, but no extensive angular unconformity is apparant at the base of the Permian in the basins. On the other hand, local angular unconformities directly below the Permian occur on and near the Pedernal positive element, the Sierra Grande arch, the Bravo dome, the western extension of the Matador arch, and the Amarillo uplift.

The most active tectonic element in northeastern New Mexico, at least in Middle and Late Pennsylvanian and Early Permian time, seems to have been the Pedernal positive element, which extended from Torrance County southward through Lincoln and Otero Counties, N. Mex. (figs. 20, 75). It is the only positive element that was active in this region in late Paleozoic time in which the Precambrian core is now exposed at the surface. In Pennsylvanian and early in Permian time great volumes of mud and some silt were transported eastward from it into what may be a westward extension of the Palo Duro basin. Likewise much red mud, silt, and arkosic sand were deposited north of the Pedernal element, but this detritus may not have been derived solely from the Pedernal element. Part of it may have come from the southern extension of the Sierra Grande arch, which was also active from Middle Pennsylvanian through Early Permian time.

The Matador arch may have been active from Late Mississippian until well into the Permian Period (Totten, 1956), as indicated by small areas of Precambrian rock directly beneath Permian strata in southern Roosevelt County, N. Mex., and eastward into Bailey and Lamb Counties, Tex. In contrast, Lower Permian rocks in east-central New Mexico, which are mainly limestone and partly red mudstone, do not suggest the presence of any nearby positive areas of high relief.

Major tectonic elements in the Texas-Oklahoma Panhandles, other than those discussed, are the Amarillo uplift (fig. 19), which is a north-westward extension of the Wichita Mountains (Totten, 1956, p. 1963), and the Cimarron uplift, which is a "series of elongate anticlines, extending from the Keyes area of northeastern Cimarron County, Okla., southward through western Sherman County and possibly into southern Moore County, Texas." These began to rise in Late Mississippian time and were rejuvenated at different times during the Pennsylvanian; uplift persisted to some extent into Late Permian time (Totten, 1956, p. 1964).

\section{INTERVAL A FORMATIONS INCLUDED}

Rock units assigned to interval A ( $\mathrm{I}-450$, pl. 3) in northeastern New Mexico and in the Texas-Oklahoma Panhandles vary widely in composition and texture and represent many facies; therefore, a complex nomenclature has evolved.

Units included in interval $\mathbf{A}$ in northeastern New Mexico are the Bursum Formation, the Abo Formation, the Hueco Limestone, and upper part of the Sangre de Cristo Formation. Units in the Texas-Oklahoma Panhandles have been designated by various names but are here referred to as an unnamed limestone unit and the overlying "Herington dolomite."

\section{NORTHEASTPRN NEW MEXICO}

West of the Pedernal positive element toward central New Mexico (fig. 19), the basal unit is the Bursum Formation. Here it is defined as dark-purplish-red and green shale in beds as much as 40 feet thick separated by thinner beds of arkose, arkosic conglomerate, and gray limestone. A thin rubbly limestone consisting of reworked material from the underlying Madera Formation occurs locally at the base. Overlying lime- 
stone beds of the Bursum contain the fusulinids Schwagerina and Triticites ventricosus of Wolfcamp age (Wilpolt and others, 1946).

The Abo Formation of central New Mexico, west of the Pedernal positive element, consists largely of red mudstone but contains some sandstone, arkose, and conglomerate (Needham and Bates, 1943). The lower part of the Abo is of Wolfcamp age, but the upper part contains plants considered by C. B. Read (in Wilpolt and others, 1946) to be of Leonard age. The part of the Abo that is assigned a Leonard age is about 100 feet thick in most places (C. B. Read, oral commun., 1960).

The "Abo Formation" of middle eastern New Mexico, east of the Pedernal positive element, does not resemble the Abo to the west in age and lithology. It grades into the Hueco Limestone to the south (Needham and Bates, 1943, p. 1657; Bachman and Hayes, 1958 , p. 692-697) and apparently also to the southeast in De Baca and Roosevelt Counties. In the same counties a unit directly above the Hueco Limestone, locally referred to the Abo, contains large amounts of anhydrite and salt interbedded with red siltstone and mudstone resembling that of the type Abo to the west. This "Abo Formation," however, is probably equivalent to the lower part of the Yeso Formation, which overlies the Abo farther west.

The upper part of the Sangre de Cristo Formation of Early Permian age extends from northeastern New Mexico into the Dalhart basin of the northwest Texas Panhandle. Basinward the formation is mainly red mudstone. Near source areas, such as the Sierra Grande arch and the Bravo dome of northeastern New Mexico, the basal part of the unit consists of coarse red arkosic sandstone and conglomerate and some red mudstone. Higher in the section red arkosic detritus persists, but the sandstone and conglomerate are finer grained.

\section{TEXAS-OKLAHOMA PANHANDLES}

In the Palo Duro and Dalhart basins of the TexasOklahoma Panhandles, interval A was described by Totten $(1956$, p. 1961) as including, in ascending order, an unnamed basal unit, an overlying unit which he called the "Coleman Junction Limestone," another unnamed unit, and the Brown dolomite. The relation of his "Coleman Junction" of this area to the type Coleman Junction Limestone Member of the Putnam Formation farther south is uncertain. The Brown dolomite seems to be a southwestern continuation of the "Herington dolomite" and is so designated in this paper. Interval A below the "Herington" is here termed the unnamed limestone unit.
Lower Permian rocks in the western part of the Anadarko basin have been assigned to the Admire, Council Grove, and Chase Groups, in ascending order (Totten, 1956, p. 1961). This sequence, mainly of limestone and some red mudstone and siltstone, has been locally subdivided; however, units of regional extent are not recognized. Here, as in the Palo Duro and Dalhart basins, the rocks are designated unnamed limestone unit and the "Herington dolomite."

On the Amarillo uplift the basal rocks of interval A are mainly coarse red arkosic sandstone, overlain by the "Herington dolomite."

\section{UPPER BOUNDARY OF INTERVAL A}

Rocks of interval A are overlain by younger Permian rocks throughout the region except in small areas near the present Pedernal Hills of central New Mexico.

\section{CENTRAL AND SOUTHEASTERN NEW MEXICO}

In central New Mexico, near the Pedernal positive element, the top of the interval coincides with the contact between the Yeso Formation and the conformably underlying Abo Formation (Read and others, 1944). Here, dominantly red siltstone is overlain by pink and light-orange siltstone, the proportion of siltstone increases, that of mudstone decreases, and both anhy. drite and gypsum are more abundant upward.

In Lea and Eddy Counties, N. Mex., interval A consists mainly of limestone of the Hueco. The upper boundary is placed at the contact of limestone with overlying dolomite and evidence in support of this position is provided by paleontologic data. The conformably overlying unit in this area is the "Abo Formation," the basal part of which may be of Wolfcamp age but most of which is younger.

The upper part of the Sangre de Cristo Formation of northeastern New Mexico may include strata as young as Leonard, judging from its lateral gradation into the Abo and Yeso Formations (Baltz and Bachman, 1956, p. 101). The top of interval $A$ in this area is selected by projection of the contact between the Abo and Yeso Formations from east-central New Mexico and by projection of the "Herington dolomite""Wichita Group" contact from the Texas-Oklahoma Panhandles.

\section{TEXAS-OKLAFOMA PANHANDLES}

Interval $\mathbf{A}$ in the Palo Duro, Hollis (Harmon), and Hardeman basins of the southern part of the Texas Panhandle is easily recognized in most sections. The overlying unit is the "Wichita Group," which resembles in some respects the underlying "Herington dolomite" but includes distinctive green shaly mudstone. 
The "Wichita Group" of the Palo Duro basin grades northwestward into the Dalhart basin from dominant dolomite into unnamed arkosic red mudstone and siltstone partly equivalent to rocks assigned to the Sangre de Cristo Formation in New Mexico.

In northeastern Texas-Oklahoma Panhandles and across most of the Amarillo uplift, strata above interval A are the Panhandle lime, equivalent to the Wellington Formation in central Oklahoma.

\section{THICKNESS TRENDS}

Interval A (fig. 21) thins regionally from southeast to northwest. Its greatest thickness, which is approximately 3,500 feet, is near the Texas-Oklahoma boundary in the east-central Texas Panhandle.

In the southern part of the Texas Panhandle the interval attains a thickness of 2,000 feet in a small area near the east edge of the Palo Duro basin, from whence it thins toward the Amarillo uplift and the Bravo dome.

\section{LITHOFACIES TRENDS}

Interval $\mathbf{A}$ is mainly detrital in northeastern New Mexico, where it includes coarse- to fine-grained redbrown arkosic conglomerate and sandstone. A few thin limestone beds in the Sangre de Cristo Mountains extend eastward a short distance into this red-bed sequence but are not evident on the map. East of the present Pedernal Hills, red silty mudstone dominates, but southeast of this area limestone containing only minor amounts of red mudstone is present.

Interval A south of the Amarillo uplift in the Texas Panhandle grades southward from a narrow band of red muddy sandstone to limestone and dolomite containing various proportions of mudstone and silty mudstone north of the Matador arch.

\section{SOURCES AND ENVIRONMENTS OF DEPOSITION}

Large amounts of red feldspathic detritus, including gravel, were supplied to the areas around the Sierra Grande arch and the Bravo dome of northeastern New Mexico. This material was probably deposited in deltas (Northrop and others, 1946). The occurrence of thin limestone beds in the Sangre de Cristo Formation east of the present Sangre de Cristo Mountains, indicates brief incursions of the sea (Tschanz and others, 1958, p. 354). From the Pedernal positive element eastward to the Texas-New Mexico boundary,

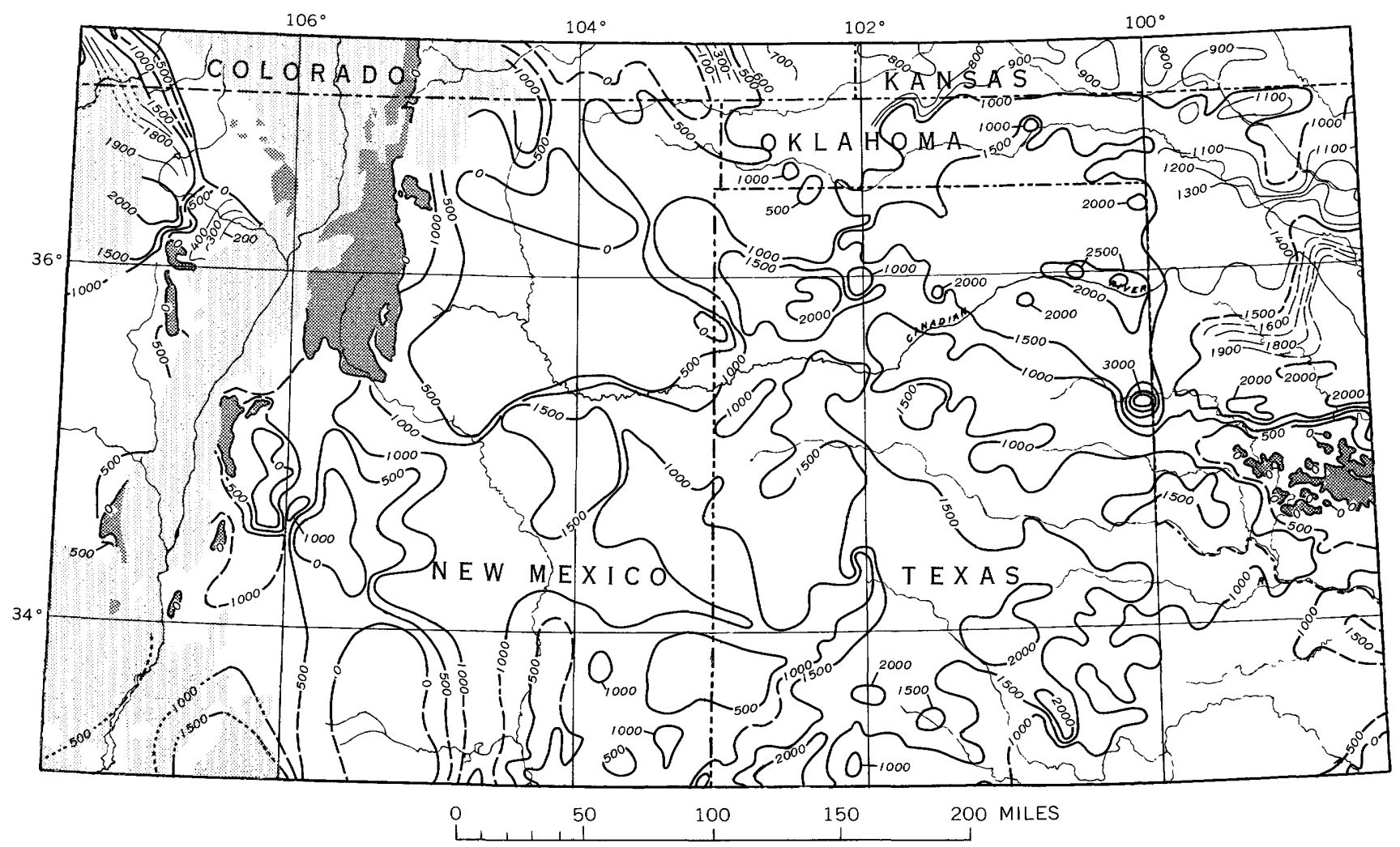

Frgure 21.-Thickness of interval A in northeastern New Mexico, Texas-Oklahoma Panhandles, and surrounding area. Isopach intervals 100 and 500 feet. Isopachs dashed where control is poor, dotted where Permian rocks have not been penetrated by drill. Dark pattern, areas where rocks older than Permian are exposed; light pattern, areas where rocks younger than interval A have not been penetrated. 
depositional environments were successively fluvial, including both river channel and flood plain, and marine.

Detritus shed by the Matador arch and the Amarillo uplift of the Texas Panhandle was probably deposited in a fluvial or deltaic environment.

The sources for detritus in the Dalhart basin, though problematical, may have been the Bravo dome on the west and the Cimarron uplift to the east. The ancestral Rocky Mountains, northwest of the region, may also have contributed significant volumes of detritus.

\section{PALEOTECTONIC IMPLICATIONS}

Positive elements tectonically active in Middle and Late Pennsylvanian time continued to influence sedimentation very early in Permian time but were lower in relief. Minor uplifts may have occurred in some places, but the positive elements were gradually leveled by erosion and buried by sediments. At the close of deposition of interval A, most, but not all, of the former positive elements were absent.

Positive elements that formed barriers between basins at the beginning of Permian time included the Pedernal positive element, the Sierra Grande arch and the Bravo dome in northeastern New Mexico, and the Cimarron and Amarillo uplifts and Matador arch in the Texas-Oklahoma Panhandles.

The trough between the Pedernal positive element and Cerrito del Lobo was probably the largest negative tectonic element in northeastern New Mexico. Although the boundary between the Permian and Pennsylvanian cannot be recognized with certainty in this area, some evidence that interval $\mathbf{A}$ probably exceeded 1,300 feet in thickness is available. The western extension of the Palo Duro basin in east-central New Mexico, and the Dalhart, Anadarko, Palo Duro, Hollis, and Hardeman basins, of the Texas-Oklahoma Panhandles, all received moderate amounts of sediment, and deposition probably was equal to or exceeded subsidence. Filling of the basins accompanied destruction of the positive elements, so that by the end of Wolfcamp time an extensive almost featureless southward-sloping shelf had formed.

\section{INTERVAL B}

\section{FORMATIONS INCLUDED}

Rock units assigned to interval B in northeastern New Mexico and in the Texas-Oklahoma Panhandles (table 1) have marked vertical and lateral facies changes, so that a varied nomenclature is used for them.

\section{NORTHEASTERN NEW MEXICO}

Interval B in northeastern New Mexico includes the Yeso Formation, Glorieta Sandstone, and, west of the Pedernal Hills, the San Andres Limestone. Also included are the northward continuation of the "Abo Formation" of southeastern New Mexico from Lea and Eddy Counties, and the upper part of the Sangre de Cristo Formation.

In central New Mexico, west of the Pedernal positive element (fig. 19), the basal unit of interval $B$ is the Yeso Formation. It consists of pink and varicolored mudstone, white to pink or orange siltstone, gysum, and a small amount of thin-bedded limestone.

In eastern New Mexico the basal unit of interval B is the "Abo Formation," most of which is probably younger than the type Abo Formation farther west. The conformably overlying Yeso Formation resembles the Yeso on the west side of the Pedernal Hills but is younger and intertongues with the upper part of the "Abo Formation."

The "Abo" of eastern New Mexico is mainly dolomite and partly red mudstone that decreases southward. Fusulinid identifications indicate that it is of Leonard age.

Traced northward, the Yeso Formation is progressively more arkosic and intertongues with the upper part of the Sangre de Cristo Formation (Dobrovolny and others, 1946; Bachman, 1953).

The Glorieta Sandstone, above the Yeso Formation, is easily recognized in both outcrop and subsurface. East and north of an arcuate line from western Curry and Quay Counties (Dobrovolny and others, 1946) northwestward to a point near Ocate, it is absent. Much sandstone in the upper part of the Yeso Formation resembles it, but the two units can readily be distinguished in most places. A sandstone unit in middle eastern New Mexico and in the Texas-Oklahoma Panhandles that is commonly referred to the Glorieta and whose position in the stratigraphic sequence is similar to that of the Glorieta is designated "Glorieta Sandstone" in this paper. This sandstone is light to dark red, poorly sorted, and friable and has angular grains, whereas the typical Glorieta is mainly white to gray, light yellow or light brown, moderately well to well sorted, and well cemented. Typical Glorieta contains medium- to well-rounded grains. The uppermost unit of interval B is the San Andres Limestone in the area west of the Pedernal Hills.

\section{SOUThWESTERN PART OF TEXAS PANHANDLE}

In the southwestern part of the Texas Panhandle, the basal unit of interval B is the "Wichita Group." In this area it consists of dolomite, anhydrite, and small amounts of green mudstone. Progressively more dolomite occurs to the southwest in the western part of the Palo Duro basin. The typical Wichita Group of 
northern Texas, in contrast, is dominantly sandstone with small amounts of siltstone and mudstone. The "Wichita," as referred to here, is equivalent to the upper part of the Wichita Group.

The Clear Fork Group, which is equivalent to the Yeso Formation, conformably overlies the "Wichita Group" in the Texas Panhandle. The Clear Fork Group is divided in ascending order into the Red Cave, the Tubb sand, the Cimarron Anhydrite, and an unnamed upper unit.

The Red Cave. consists mainly of red mudstone but contains some beds of anlydrite. Its contact with the $T u b b$ sand cannot be recognized everywhere, so, in places, all strata below the Cimarron Anhydrite are called lower part of the Clear Fork Group in this report.

The $T u b b$ sand (sometimes called $T u b b$ zone) is composed of anhydrite, salt, red mudstone, siltstone, and sandstone. The proportion of evaporite rock is progressively less from bottom to top. The Cimarron Anhydrite, above the $T u b b$ in most sections, contains some dolomite.

The unnamed upper unit of the Clear Fork Group consists of red mudstone, siltstone which contains some anhydrite and salt, and a few thin beds of dolomite. Locally, so much anhydrite and salt occur near the base that the unit merges into the Cimarron Anhydrite.

The Clear Fork Group is overlain by the "Glorieta Sandstone" of the southwestern part of the Texas Panhandle, which may be the same unit as that of southeastern New Mexico but not the type Glorieta Sandstone. In this area it is the uppermost unit of interval B.

\section{OKLAHOMA PANHANDLE AND NORTHEASTHRN PART OF TEXAS PANHANDLE}

The Panhandle lime is the basal unit in the Oklahoma Panhandle and the northeastern part of the Texas Panhandle, especially in the western Anadarko basin and the Hugoton embayment. It has been correlated with the "Wichita Group" (Totten, 1956, p. 1961) and is equivalent to the Wellington Formation of central Oklahoma. It consists mostly of anhydrite but includes dolomite and some red mudstone. The Panhandle lime is conformably overlain by the Clear Fork Group.

Divisions of the Clear Fork Group of this area resemble corresponding units farther southwest except for a slightly greater amount of salt. The "Glorieta Sandstone" conformably overlies the Clear Fork Group, and above it, in this area, is the "Blaine
Formation." The "Blaine" differs from the Blaine of the type section in that rocks equivalent to the Dog Creek Shale and Flowerpot Shale have not been separated from it. The "Blaine" is composed mostly of anhydrite, but it contains small amounts of dolomite and salt and local thin units of red mudstone. The age of the "Blaine" may be nearly equivalent to that of the lower part of the San Andres Limestone of southeastern New Mexico, but proof from fossils is lacking.

\section{UPPER BOUNDARY OF INTERVAL B}

Rocks of interval B are overlain by younger Permian rocks throughout the region except in small areas near the present Pedernal Hills of central New Mexico, where they are overlain by rocks of probable Quaternary age.

\section{NORTHEASTERN NEW MEXICO}

In Central New Mexico, west of the axis of the former Pedernal positive element, the boundary between intervals $\mathrm{B}$ and $\mathrm{C}$ is the conformable contact between the San Andres Limestone and the Artesia Formation (formerly called Bernal Formation in this area). The contact is marked by a contrast between the limestone, dominant in the San Andres, and the red siltstone and red fine-grained sandstone of the Artesia Formation.

In east-central and northeasternmost New Mexico, east of the Pedernal positive element, the upper boundary of interval B has been extrapolated from sections in Lea and Eddy Counties, N. Mex. Here the interval is overlain by the San Andres Limestone, whose base may include some beds of Leonard age but the major part of which is of Guadalupe age; therefore the entire unit is included in interval C. The San Andres conformably overlies the Glorieta Sandstone and, to the south and east, the "Glorieta Sandstone," and it consists mainly of dolomite, salt, and anhydrite as it does farther south.

\section{TEXAS-OKLAFOMA PANHANDLES}

Interval $B$ in the southwestern part of the Texas Panhandle is easily recognized and, as in middle eastern New Mexico, is conformably overlain by the San Andres limestone of interval $\mathrm{C}$. The criterion most commonly used in this area for distinguishing between the Clear Fork Group and the overlying San Andres Limestone, where the "Glorieta Sandstone" is absent, is the dolomite unit at the base of the San Andres. Where this dolomite is absent or not easily recognized, a decrease in proportion of salt and dolomite and an increase in proportion of red detrital material in the 
San Andres is helpful in choosing at least an approximate boundary.

In the Oklahoma Panhandle and northeastern part of the Texas Panhandle, interval $\mathrm{B}$ is conformably overlain by the "Whitehorse Group." The "Blaine" is mostly anhydrite and contains minor amounts of dolomite and salt, whereas the "Whitehorse" is dominantly red siltstone and mudstone and contains some red sandstone.

The "Blaine Formation" is the uppermost unit assigned here to interval B. The upper part of the "Blaine," however, may be of Guadalupe age, although no fossils have been reported that support this view. An alternative interpretation, excluding the "Blaine" from interval B in this area, is, therefore, shown in figure 22 .

\section{THICKNESS TRENDS}

Interval B (fig. 23) thins regionally from southeast to northwest. The greatest thickness of this interval in east-central New Mexico, approximately 3,100 feet, occurs in southern Roosevelt County, north of the

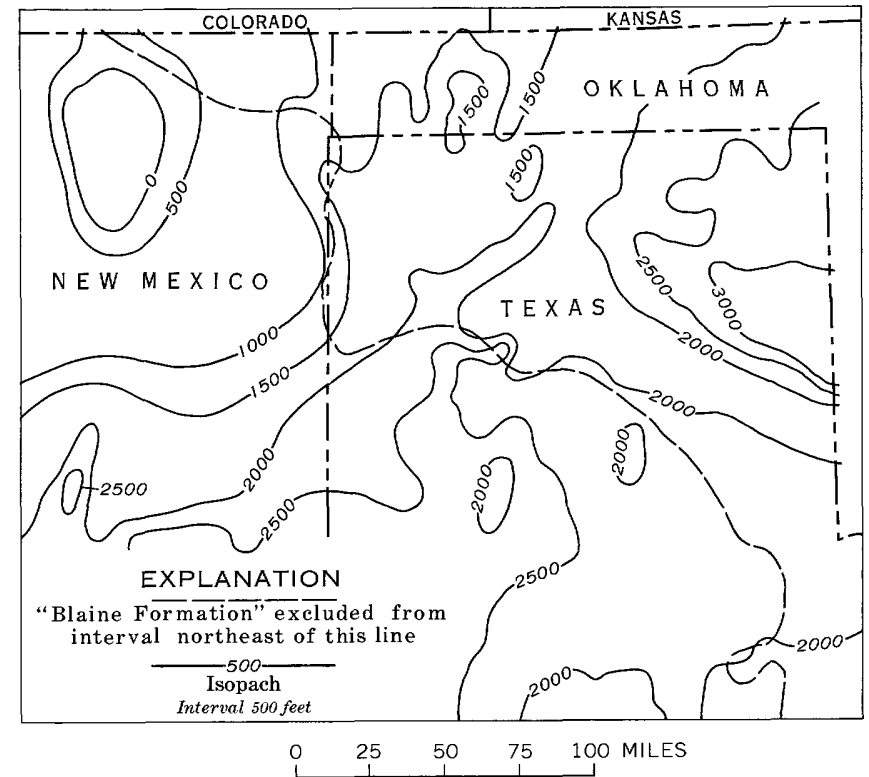

Figure 22.-Thickness of interval B in northeastern New Mexico and Texas-Oklahoma Panhandles. Isopach interval 500 fect.

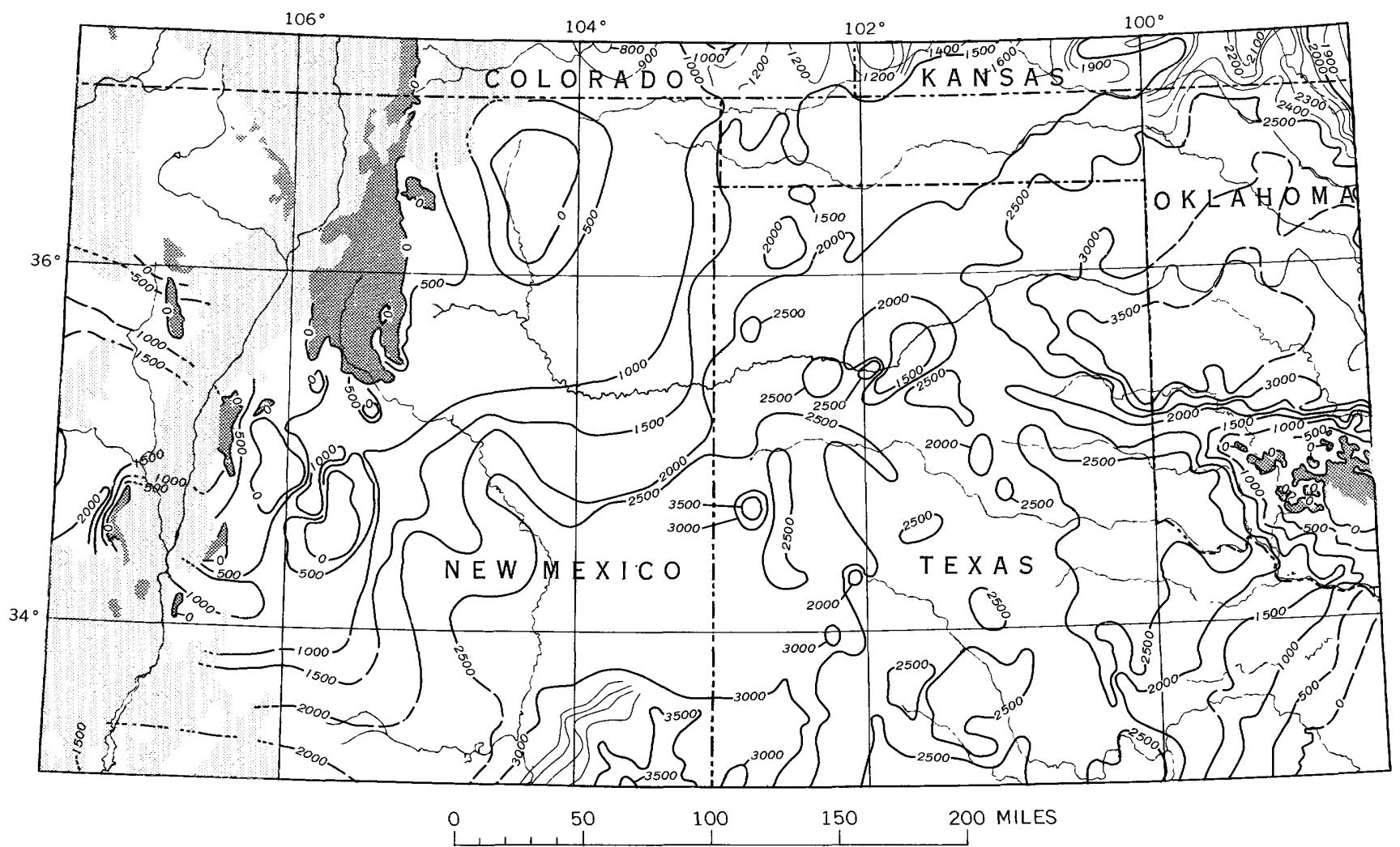

Figure 23.-Thickness of interval $\mathbf{B}$ in northeastern New Mexico, Texas-Oklahoma Panhandles, and surrounding area. Isopach intervals 100 and 500 feet. Isopachs dashed where control is poor, dotted where Permian rocks have not been penetrated by drill. Dark pattern, areas where rocks older than Permian are exposed; light pattern, areas where rocks younger than interval $\mathbf{B}$ have not been penetrated. 
Delaware basin. The interval thins westward, toward the Pedernal positive element, and northward, toward the Sierra Grande arch.

The greatest thickness of interval $B$ in the southwest part of the Texas Panhandle, approximately 2,700 feet, is near the middle of the Palo Duro basin. From here the interval thins greatly to the north and moderately to the east. In the Hollis and Hardeman basins the interval attains a similar maximum thickness.

In the northeastern part of the Texas Panhandle, interval $\mathrm{B}$ is about 3,600 feet thick, but it thins northward and northwestward to approximately 1,400 feet.

\section{LITHOFACIES TRENDS}

Interval B consists mainly of detrital rock in northeastern New Mexico, except in De Baca, Curry, and Roosevelt Counties, where carbonate rock and evaporite rock are dominant. The detrital rock north and east of the Pedernal positive element is mainly medium- to fine-grained, pink, orange, and red sandstone and siltstone.

Southeast and east of the Sierra Grande arch, detrital rock is progressively finer grained and consists mostly of arkosic red beds. The uppermost part of the intervai is light-colored nonfeldspathic siltstone that resembles some of the Yeso Formation in central New Mexico.

From northeastern New Mexico coarse detritus decreases southward and grades into red mudstone, evaporite rock, and dolomite. Likewise southward, from the Texas-Oklahoma boundary toward the southwestern part of the Texas Panhandle, interval B grades from red mudstone and evaporite rock to dolomite.

Along the Texas-Oklahoma boundary, red anhydritic mudstone is dominant from northern Cottle County eastward to northern Wheeler County. In the northeastern part of the panhandles the rocks consist of anhydrite and some red mudstone. In the northwestern part, interval $B$ consists largely of red mudstone but contains a small amount of anhydrite and siltstone.

\section{SOURCES AND ENVIRONMENTS}

In northeastern New Mexico the periphery of the northern part of the Pedernal positive element received red feldspathic detritus at the beginning of deposition of interval $B$ but in smaller quantity than during interval $\mathrm{A}$. Whether the Pedernal positive element continued to supply detritus until the end of Leonard time is unknown, but the Yeso Formation may have completely overlapped it. The history of the Sierra Grande arch is probably much the same as that of the Pedernal element, except that the Sierra Grande arch seems to have supplied detritus for a longer time. Detritus in the Sangre de Cristo Formation derived from the Sierra Grande arch interfingers with the Yeso Formation and possibly the Glorieta Sandstone (Bachman, 1953).

Detritus from the Pedernal and Sierra Grande areas was probably transported by streams of low gradient and deposited on deltas or flood plains.

Seas invaded the middle eastern part of New Mexico and the Texas-Oklahoma Panhandles during deposition of interval B. The evaporite beds and, along the south margin, the dolomite of the Texas-Oklahoma Panhandles were deposited in shallow water. Mudstone interbedded with the evaporite units likewise was deposited in a shallow sea. The detrital material in the northwest probably came partly from the Sierra Grande arch and partly from the ancestral Rocky Mountains; the detritus along the Texas-Oklahoma boundary probably came from the Wichita uplift in western Oklahoma. The Amarillo uplift, on the other hand, is overlapped by evaporites that were probably deposited in very shallow seas, which suggests that this positive element was not rising at the time of interval B.

\section{PALEOTECTONIC IMPLICATIONS}

The only positive elements in northeastern New Mexico that may have been active during Leonard time were the Pedernal positive element and the Sierra Grande arch. These were probably very low and may have been buried by uppermost strata of interval $B$. The Bravo dome and Matador arch, active earlier in Permian time, were probably not uplifted during Leonard time; nor were the Amarillo or Cimarron uplifts.

In the Texas-Oklahoma Panhandles only the Amarillo uplift apapears to have influenced deposition, and this only by slight thinning of interval $B$.

The major negative features are the Hollis, Hardeman, and Palo Duro basins, south of the buried Amarillo uplift, and the Anadarko basin to the north. These basins received more than moderate amounts of sediment, but subsidence seems to have kept pace with deposition.

After the destruction and burial of all the positive areas and the rapid filling of all the basins by the end of Leonard time, the surface of the south- to southeastward-sloping shelf was much more regular than at the end of Wolfcamp time. 
INTERVAL C FORMATIONS INCLUDED

Rock units assigned to interval $\mathrm{C}$ in northeastern New Mexico and in the Texas-Oklahoma Panhandles (table 1) do not vary as greatly in composition as 'those of intervals A and B. Vertical lithologic changes are perhaps as abrupt as those in the lower intervals, but less lateral variation results in fewer changes of nomenclature from one area to another.

\section{NORTHEASTERN NEW MEXICO}

Included in interval $\mathrm{C}$ in northeastern New Mexico are the San Andres Limestone and the Artesia Formation (or Artesia Group, where units within it are distinguishable).

In northeastern New Mexico, west of the Pedernal Hills, strata assigned here to interval $\mathrm{C}$ have until recently been called the Bernal Formation (Kelley, 1949, fig. 2 ; Bachman, 1953). This formation, as originally described, is not present much farther west than the west boundary of Torrance and Santa Fe Counties. East of this boundary strata assigned to it have recently been renamed the Artesia Group (Tait and others, 1962, p. 504-517). The Bernal Formation is at least partly equivalent to the abandoned Chalk Bluff Formation, as previously used in southeastern New Mexico.

Rocks in middle eastern New Mexico formerly included in the Chalk Bluff Formation but now assigned to the Artesia Group are divided into five units. They are, in ascending order, the Grayburg, Queen, Seven Rivers, Yates, and Tansill Formations.

The name Whitehorse Group, although still used in the Oklahoma Panhandle and the Texas Panhandle northeast of the Amarillo uplift, has been replaced in northeastern New Mexico and the Texas Panhandle southwest of the Amarillo uplift by Artesia Formation. Rocks of this unit form the upper part of interval $C$, except locally in northeasternmost New Mexico where the "Alibates Dolomite Lentil" of the "Quartermaster Formation," or a remnant of the "Quartermaster" above the "Alibates," overlies the Artesia Formation.

The basal unit of interval $\mathrm{C}$ in middle eastern and northeastern New Mexico, east of the Pedernal positive element, is the San Andres Limestone. It is composed of limestone, dolomite, anhydrite, minor amounts of salt, and, locally, some white to light-gray sandstone near the base. Limestone is less common and anhydrite and halite more common toward the northeast. Some of the sandstone near the base of the unit has been confused with the Glorieta Sandstone.
The Artesia Group in middle eastern and southeastern New Mexico consists of anhydrite, gypsum, sandstone, siltstone, dolomite, and limestone. The evaporite rock is generally dominant; detrital rock is less abundant and carbonate rock still less. In northeasternmost New Mexico, however, the Artesia Formation is composed of red mudstone and siltstone interspersed with anhydrite.

The "Quartermaster Formation," including the "Alibates Dolomite Lentil," is the topmost unit of interval $\mathrm{C}$ in northeasternmost New Mexico. In a few places the "Alibates" is directly and unconformably overlain by Triassic rock, but at other places $30-40$ feet of red mudstone overlies it and is included in the Permian.

TEXAS-OKLAHOMA PANHANDLES

Units assigned to interval $\mathrm{C}$ in the Texas-Oklahoma Panhandles are the San Andres Iimestone, the Artesia Group, the "Whitehorse Group," the "Quartermaster Formation," and the "Alibates Dolomite Lentil" of the "Quartermaster."

The San Andres Limestone in the southwestern part of the Texas Panhandle is chiefly salt, anhydrite, and dolomite and very minor amounts of red siltstone and mudstone. Dolomite is concentrated in the basal part, mostly in thin lentils, but some dolomite units are as much as 300 feet thick. Lying with apparent unconformity on the San Andres Limestone is the Artesia Group (Tait and others, 1962, p. 504-517). The unit consists of red siltstone and mudstone and minor sandstone, anhydrite, or gypsum. It forms the upper unit of interval $\mathrm{C}$.

The "Whitehorse Group" in the Oklahoma Panhandle and northeastern part of the Texas Panhandle cannot be divided easily. The lower contact is the base of interval C, and the upper contact is the top of the "Quartermaster Formation." For comparison of this area with areas to the south and west where the San Andres Limestone is included in interval C, see figure 24, which shows both interval $\mathrm{C}$ and the underlying "Blaine Formation."

Both the "Alibates" and the "Quartermaster" are regarded by Totten (1956, p. 1961) as part of the "Whitehorse Group," but a hiatus of some magnitude is considered by Roth (1955, p. 423) to separate the "Whitehorse" from the overlying "Alibates" and "Quartermaster." The "Alibates" and overlying red mudstone unit are missing in parts of the area.

The "Alibates" is correlated by some geologists with the Rustler Formation farther south. If this correlation is correct, then rocks of interval $\mathrm{D}$ and the Ochoa Series occur in the subsurface in much of northeastern New Mexico and the Texas-Oklahoma Panhandles. 


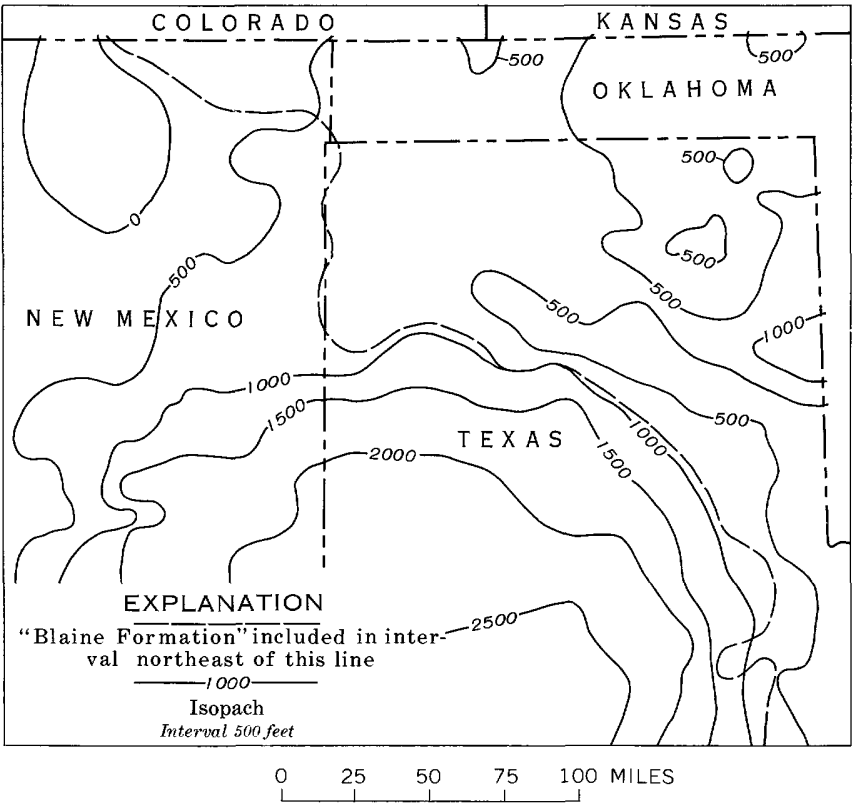

Figure 24.-Thickness of interval $\mathrm{C}$ in northeastern New Mexico and Texas-Oklahoma Panhandles.

According to other geologists, however, rocks of the Ochoa Series do not extend north of the central part of Roosevelt County (R. L. Bates, in Dobrovolny and others, 1946, fig. 4 ; Totten, 1956, p. 1962) and the "Alibates Dolomite Lentil" may correlate with parts of the Tansill or Seven Rivers Formations (E. D. Clements, oral commun., 1960).

North-south sections prepared during this study indicate the presence of three to four separate units, all of which have been called Alibates or Rustler Formation, between the southern panhandles area and the Colorado-New Mexico and Kansas-Oklahoma boundaries. As Upper Triassic strata of the Dockum Group lie on successively older Permian strata northward, each unit to which the name Alibates has been applied lies at the top of the Permian sequence at some locality, and it seems unlikely that the Alibates of the northern panhandles area is equivalent to the Rustler of the southern panhandles.

\section{UPPER BOUNDARY OF INTERVAL C}

As interpreted in the preceding paragraph, rocks of interval $\mathrm{C}$ are overlain by younger Permian rocks in this region only from Roosevelt County, N. Mex., on the west to the western part of Motley County, Tex., on the east. In other parts of the region rocks of interval $\mathrm{C}$ lie at the surface or are overlain by rocks of Late Triassic, Tertiary, or Quaternary age.

\section{NORTHEASTERN NEW MEXICO}

In southern Curry and Roosevelt Counties, N. Mex., the Tansill Formation of interval $\mathrm{C}$ is conformably overlain by the Salado Formation of the Ochoa Series. The Tansill and Salado are so similar in composition in this area that it is difficult to recognize the interval boundary, but a general key to recognition is the fact that more salt and less anhydrite occur in the Salado than in the Tansill.

Where Upper Triassic rocks overlie interval C, they include white to light-gray sandstone and brownishred or purple mudstone and siltstone, in contrast with the bright red or brick red of the Permian. Detrital components of the Triassic rocks directly above the Permian-Triassic contact are, in most sections, coarser grained than those in underlying strata and in places limestone-pebble conglomerate occurs.

\section{TEXAS-OKLAHOMA PANHANDLES}

In this area, interval $\mathrm{C}$ is overlain by younger Permian rocks only in the Palo Duro basin in the southwest corner of the Texas Panhandle, where the Rustler Formation and the Dewey Lake Redbeds rest directly on the Artesia Group.

\section{THICKNESS TRENDS}

Interval C (fig. 25) thins to the west, north, and east from a maximum of about 2,500 feet in the Texas Panhandle to an eroded edge along the east boundary of Torrance County, and within central and eastern Colfax County, N. Mex. In Cimarron and Texas Counties, Okla., the interval thins to approximately 400 feet and in Beaver County, Okla., to about 200 feet. An eroded edge occurs west of the Texas-Oklahoma boundary, south of the Amarillo uplift.

\section{IITHOFACIES TRENDS}

In middle eastern New Mexico interval C consists mainly of evaporite rock with some red mudstone, red siltstone, and dolomite. Detrital rocks are dominant only along the south and southeast flanks of the present Sangre de Cristo Mountains.

In the southwestern part of the panhandles area, south of the Amarillo uplift, interval $\mathrm{C}$ is composed almost entirely of evaporite and red detrital rock. The proportion of dolomite varies considerably from one area to another; mudstone in the south grades northward into siltstone. The map of facies in the area from Collingsworth County to Cottle County, Tex. $(\mathrm{I}-450, \mathrm{pl} .5)$ is possibly misleading because only erosional remnants of interval $\mathrm{C}$ are represented. North of the Amarillo uplift interval $\mathrm{C}$ is almost entirely red mudstone and siltstone.

\section{SOURCES AND ENVIRONMENTS}

Possible sources of detritus for interval $\mathrm{C}$ in northeastern New Mexico are the Pedernal positive element, the Sierra Grande arch and adjacent low-lying areas, 


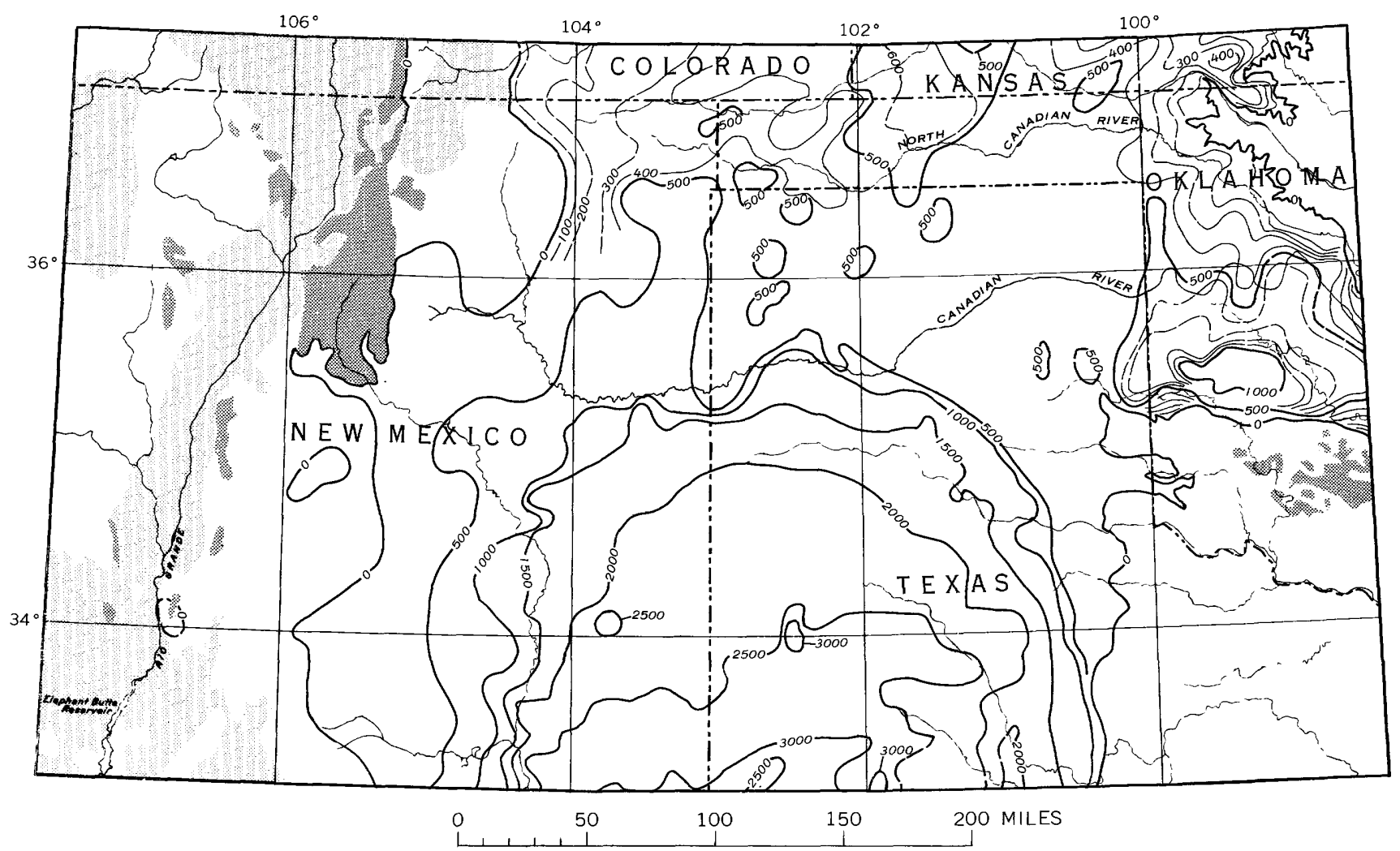

Figure 25.-Thickness of interval $\mathrm{C}$ in northeastern New Mexico, Texas-Oklahoma Panhandles, and surrounding area. Isopach intervals 100 and 500 feet. Isopachs dashed where control is poor. Dark pattern, areas where rocks older than Permian are exposed; light pattern, areas where rocks younger than interval $\mathrm{C}$ have not been penetrated.

and the ancestral Rocky Mountains to the northwest. Sediments were probably deposited as deltas or possibly on mudflats by very low gradient streams.

Evaporite rocks in middle eastern New Mexico were probably deposited on the margins of seas that transgressed from the south. Inferred depositional environments, from south to north, include a marine shelf, tidal flats, deltas, and flood plains.

\section{PALEOTECTONIC IMPLICATIONS}

Whether the Pedernal positive element and the Sierre Grande arch were tectonically active in Guadalupe time is not certain, but remnants of these elements were probably low landmasses that shed some detritus. In general, the panhandles area was relatively stable during Guadalupe time, as indicated by paucity of coarse detrital rock and by widespread distribution of evaporite rock.

INTERVAL D

\section{FORMATIONS INCLUDED}

Rock units assigned to interval D occur only in the southern part of the region-northeastern New Mexico and the Texas Panhandle. They include the Salado and the Rustler Formations and the Dewey Lake Red- beds (formerly the Pierce Canyon Redbeds). The Dewey Lake Redbeds are Permian in age, and they are assigned to interval $\mathrm{D}$ in this paper.

The Salado Formation is the basal unit of interval $D$ in east-central New Mexico, but because of its susceptibility to leaching it is very thin in many places. The formation is dominantly salt, but farther south in Texas and New Mexico it contains anhydrite, mudstone, and sandstone.

The Rustler Formation consists mainly of dolomite but in places contains much anhydrite.

The Dewey Lake Redbeds are composed dominantly of siltstone and mudstone but contain small amounts of gypsum.

\section{UPPER BOUNDARY OF INTERVAL D}

The upper boundary of interval $\mathrm{D}$ as used in this paper is the contact between the Dewey Lake Redbeds and the unconformably overlying Dockum Group of Late Triassic age. This contact is difficult to recognize along the south boundary of the area, but it is easy to identify farther north where the basal part of the Dockum Group contains relatively coarse material and is various hues of brown and purple. 


\section{THICKNESS TRENDS}

Interval D (fig. 26) thins northward from the Permian basin to a northern limit in central Curry County, N. Mex., and along the south boundaries of Deaf Smith, Randall, and Armstrong Counties, Tex. The east edge is in central Briscoe and Floyd Counties, Tex.

An irregularly shaped area in eastern Bailey, Lamb, and Hale Counties, Tex., contains no strata of interval D. This may be the result of leaching of the Salado Formation, in addition to erosion of the Rustler Formation and the Dewey Lake Redbeds before deposition of Upper Triassic strata.

\section{LITHOFACIES TRENDS}

Description of borehole samples adequate for the preparation of reliable lithofacies interpretations in this region are few, so lithofacies have been interpolated locally. In general, interval D grades northeastward from evaporite rock and red fine-grained detrital rock to mainly detrital rock.

A dominance of carbonate rock in Curry and Roosevelt Counties, N. Mex., and Parmer and Bailey Counties, Tex., probably reflects leaching of evaporite rock.

\section{ENVIRONMENTS AND SOURCES}

Because the area in which interval $\mathrm{D}$ is now present has been subjected to leaching and erosion, lithology of the remaining rocks may not indicate the environ- ment of deposition or the source of the detritus. Deposition may have been in lagoons, embayments, and flats bordering the north margin of a large basin; detritus was probably transported from the north.

Inferences drawn for the Permian basin region probably apply to remnants of interval D preserved along the southern part of the Texas Panhandle.

\section{TOTAL THICKNESS OF PERMIAN ROCKS THICKNESS AND TRENDS}

Figure 27 shows the thickness of Permian rocks in northeastern New Mexico, where a maximum of approximately 7,000 feet occurs in southern Roosevelt County, north of the Delaware basin. In the Texas Panhandle a maximum thickness of 7,500 feet occurs in southern Hale County, north of the Midland basin, and along the south limb of the Palo Duro or Plainview basin. In the Anadarko basin, in northeastern Wheeler County, Tex., the Permian System exceeds 6,000 feet in thickness.

In eastern New Mexico Permian rocks thin northwestward to a beveled edge near the present Pedernal Hills. Other beveled edges lie along the south and east flanks of the present Sangre de Cristo Mountains and around the Sierra Grande arch.

Permian rocks are moderately thick on each flank of a belt of thinning over the Amarillo uplift. Effects of the uplift diminish northwestward so that the two areas merge into a single basin. Rocks thin generally

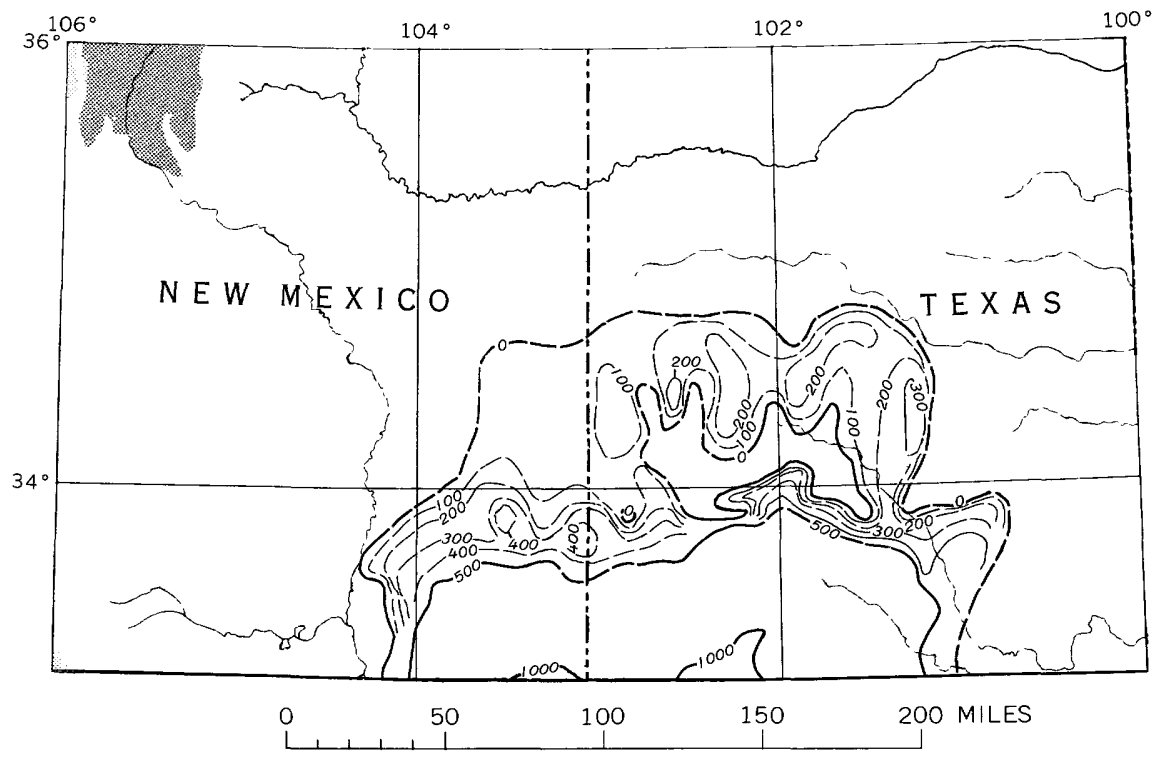

Figure 26.-Thickness of interval $\mathrm{D}$ in northeastern New Mexico and Texas Panhandle. Isopach intervals 100 and 500 feet. Isopachs dashed where control is poor. Dark pattern, areas where rocks older than Permian are exposed; light pattern, areas where rocks younger than interval $D$ have not been penetrated. 


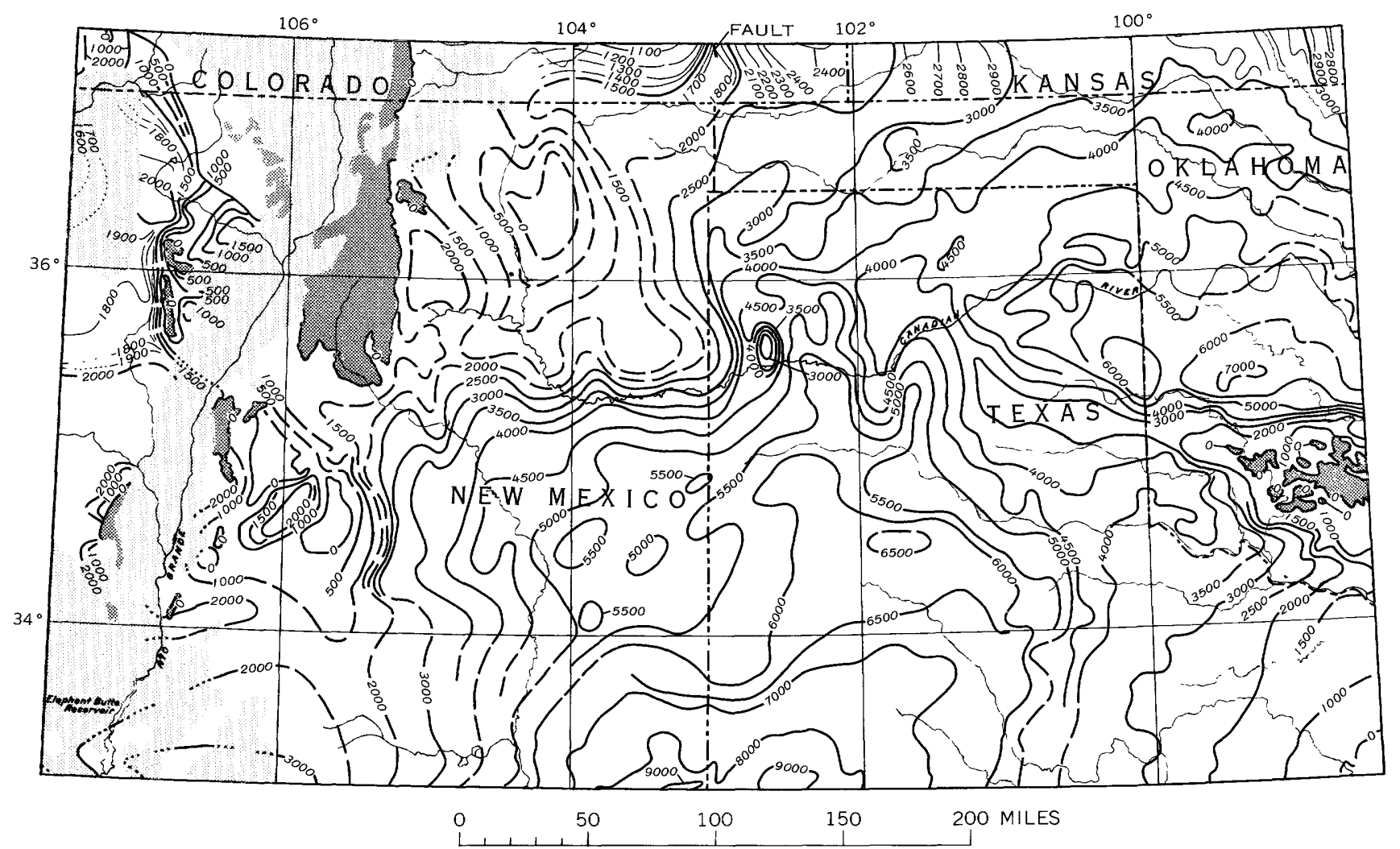

Figure 27.-Total thickness of Permian rocks in northeastern New Mexico, Texas-Oklahoma Panhandles, and surrounding area. Isopach intervals 100,500, and 1,000 feet. Isopachs dashed where control is poor, dotted where Permian rocks have not been penetrated by drill. Dark pattern, areas where rocks older than Permian are exposed; light pattern, areas where rocks younger than Permian have not been penetrated.

northward to approximately 2,500 feet in southeastern Colorado and southwestern Kansas. Permian rocks on the Amarillo uplift are 3,000-4,000 feet thick.

\section{PALEOTECTONIC IMPLICATIONS}

Major positive tectonic elements that influenced sedimentation throughout most of Permian time are the Pedernal positive element and the Sierra Grande arch in northeastern New Mexico and to a lesser degree the Amarillo uplift in the Texas Panhandle. Major negative elements included a belt in middle eastern New Mexico north of the Delaware basin, the Palo Duro or Plainview basin in the southwestern part of the Texas Panhandle, and the Anadarko basin in the northeastern part of the panhandle.

Comparison of the total isopach map with maps of each of the intervals indicates that the rate of movement of the tectonic elements was by no means constant through Permian time. The fact that detrital rocks near the Sierra Grande arch and the Pedernal positive element, for example, are coarser in interval A than in overlying intervals indicates greatest movement very early in Permian time. Moreover, although the thickness of interval $\mathbf{A}$ in the Anadarko basin is comparable with that of the same unit in the Palo Duro basin, interval B is thicker in the Anadarko. A greater thickness of interval $\mathrm{C}$ in the Palo Duro basin may indicate greater sinking there than in the Anadarko basin during the same time, but greater subsequent erosion and leaching toward the north might also explain this difference.

\section{GEOLOGIC UNITS DIRECTLY ABOVE PERMIAN SYSTEM}

The Permian System is unconformably overlain, in much of northeastern New Mexico and the Texas-Oklahoma Panhandles, by the Dockum Group (McKee and others, 1959 , p. 13-14, 21-22) of Late Triassic age. In the northeastern part of the panhandles, however, Tertiary rocks overlie the Permian. They are predominantly composed of white to pink medium to coarse free quartz sand and scattered quartz pebbles, yellowish-brown to reddish-brown mudstone, and white to pink caliche. They appear to be reworked from Upper Triassic rocks, which lie immediately to the west.

Quaternary strata unconformably overlie rocks of Permian age in a small area in western Torrance and southern Santa Fe Counties, N. Mex., west of the Ped- 
ernal Hills. These Quaternary deposits are mainly reworked medium to coarse unconsolidated red sand, silt, and mud with scattered pebbles of varying composition that were derived from Triassic, Permian, Pennsylvanian, and Precambrian rocks exposed to the north, south, east, and west.
Permian rocks are exposed in central New Mexico, south, east, and north of the Pedernal Hills, and in narrow bands along the east flank of the Sangre de Cristo Mountains. They are also exposed in the southeast quarter of the Texas Panhandle and along the North Canadian River in Beaver County, Okla. 


\section{Paleotectonic Investigations}

of the Permian System

in the United States

Chapter E. Oklahoma

By MARJORIE E. MACLACHLAN

GEOLOGICAL SURVEY PROFESSIONAL PAPER 515-E

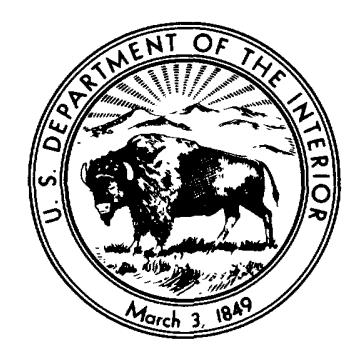


. 


\section{CONTENTS}

Abstract

Region defined

aleogeology _ _ _

Units underlying Permian

Lower boundary of Permian.

Paleotectonic implications _......

Interval A

Formations included ................................

Upper boundary of interval $A_{\ldots}$

Thickness trends.

Lithofacies trends_._._._.

Sources and environments of deposition.

Paleotectonic implications.

Interval B

Formations included.

Upper boundary of interval $B$

Thickness trends.

\begin{tabular}{r|} 
Page \\
85 \\
85 \\
86 \\
86 \\
86 \\
86 \\
86 \\
86 \\
87 \\
87 \\
87 \\
88 \\
88 \\
88 \\
88 \\
89 \\
89
\end{tabular}

Page

Interval B-Continued

Lithofacies trends_...

Sources and environments of deposition _..._. . . . 90

Paleotectonic implications. . . . . .

Interval C-D . . . .

Formations included $\ldots$

Upper boundary of interval C-D . . .

Thickness trends....... 90

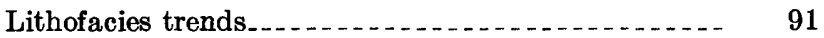

Sources and environments . . . .

Paleotectonic implications

Total thickness of Permian rocks.

Thickness trends............. 92

Paleotectonic implications _.................. 92

Geologic units directly above Permian System ........ 92

Units overlying Permian................... 92

Paleotectonic implications . . . . . .

\section{ILLUSTRATIONS}

Page

3. Cross section through Anadarko and Hollis basins

In pocket

Figure 28-33. Maps of Oklahoma:

28. Counties, towns, and geographic features

29. Tectonic elements in Late Pennsylvanian and Early Permian time.

30. Thickness of interval $A_{\ldots}$

31. Limit of arkose in interval A

32. Thickness of interval $B$

33. Thickness of interval C-D

\section{TABLE}

TABLE 1. Generalized chart showing stratigraphic units in major Permian subdivisions 



\title{
PALEOTECTONIC INVESTIGATIONS OF THE PERMIAN SYSTEM IN THE UNITED STATES
}

\section{OKLAHOMA}

\author{
By Marjorie E. MacLachlan
}

\section{ABSTRACT}

Within its borders, Oklahoma (east of the panhandle counties of Cimarron, Texas, and Beaver) contains the major parts of the Anadarko and Hollis basins, their eastern shelves, and an intervening positive belt. These tectonic features, inherited from the Pennsylvanian Period, persisted into the Early Permian.

The Permian System is represented by rocks more than 6,000 feet thick in the Anadarko basin and more than 4,000 feet thick in the Hollis basin. The Permian overlies rocks of Virgil age everywhere except locally on the positive belt where a thin section overlies the Precambrian. Permian rocks record environmental changes from normal marine (interval $A)$, to restricted marine (interval $B$ ), to marine mudflat (interval C-D) conditions. Rocks of Permian age are exposed in parts of central and western Oklahoma. Rocks of Pliocene and Quaternary age overlie the Permian near the Texas State line.

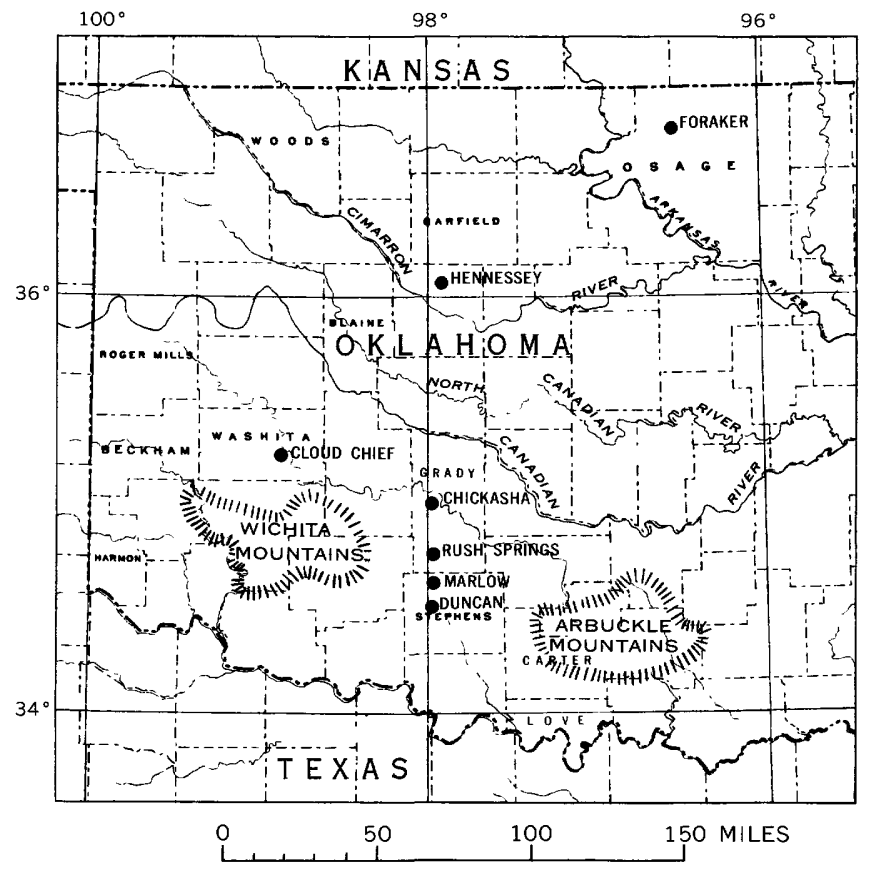

Figure 28.-Counties, towns, and geographic features of Oklahoma referred to in text.

\section{REGION DEFINED}

The part of Oklahoma discussed in this chapter extends from the central part of the State at the Pennsylvanian-Permian contact in outcrop (Miser, 1954) to the east border of the Texas Panhandle (fig. 28). The three counties of the Oklahoma Panhandle-Texas, Cimarron, and Beaver-are not included.

This region (fig. 29) contains the eastern part of the Anadarko basin and its eastern shelf, the Arbuckle Mountains to the southeast, and the Wichita Mountains to the south; it also includes the east half of the Hollis basin south of the Wichita Mountains. Beyond the limits of the region the Anadarko basin, which was a major negative element of the Permian, extended into the Oklahoma and Texas Panhandles, where it was bordered by the Amarillo uplift to the south and the

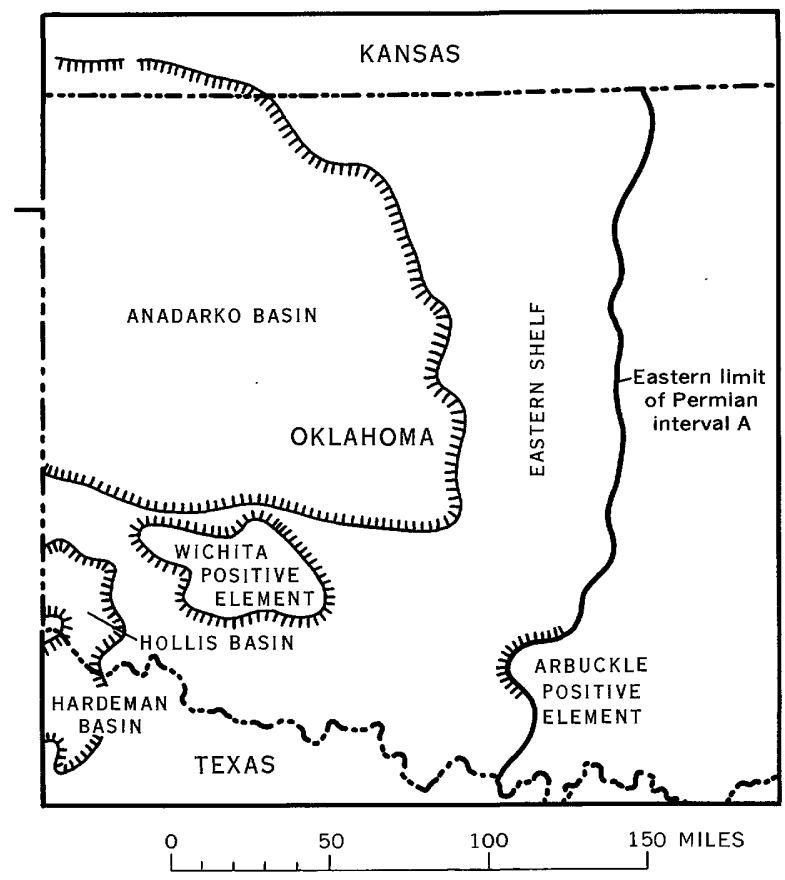

Figure 29.-Tectonic elements of Oklahoma in Late Pennsylvanian and Early Permian time. 
Cimarron uplift and Keyes dome to the west; to the north it merged into the shelf or embayment of southwestern Kansas and Colorado.

\section{PALEOGEOLOGY UNITS UNDERLYING PERMTAN}

Lower Permian rock in the Hollis basin and adjoining shelf in southern Oklahoma is underlain by rocks of the Cisco Group of Late Pennsylvanian age. To the north the Wichita Mountains stood above the surface of deposition.

West of the Wichita Mountains, in the subsurface, Permian strata locally rest on Precambrian. To the north and east of the Wichita Mountains, the upper part of the Pontotoc Group of Permian age rests on Pennsylvanian rock of the lower part of the Pontotoc. Farther north in the Anadarko basin, Permian rock is underlain by that of Virgil age.

\section{LOWER BOUNDARY OF PERMIAN}

In much of Oklahoma the lower boundary of the Permian System is not clearly defined. Continuous deposition is recorded, as like lithologies are present at the boundary between Pennsylvanian and Permian Systems. In the northern area the Brownville Limestone Member of the Wood Siding Formation, as recognized in Kansas, is considered the youngest Pennsylvanian unit. However, this member is difficult to trace as it is both underlain and overlain by thin-bedded limestone and mudstone of similar character. Southward, Upper Pennsylvanian and Lower Permian rocks become clastic, and at the south edge of the Anadarko basin coarse arkose obscures the systemic boundary. In the eastern part of the Hollis basin, southwest of the Wichita Mountains (fig. 28), uppermost strata of Virgil age consist of limestone and mudstone, but farther east they grade into predominantly detrital rock and the contact is obscure.

\section{PALEOTECTONIC IMPLICATIONS}

Three types of tectonic features (fig. 29) were prominent at the close of Pennsylvanian time. The Wichita and Arbuckle positive elements, probably expressed topographically as an archipelago, were a major source of sediment before Permian time. Limestone of Paleozoic age and granite of Precambrian age were probably extensively exposed at the end of Pennsylvanian time, as Lower Permian deposits contain fragments of such rocks. Deformation of the north front of the Wichita Mountains, begun in Pennsylvanian time, probably continued into Early Permian time.

The Anadarko and Hollis basins received much sediment during both the Pennsylvanian and Permian
Periods. East of these basins is a shelf that extends from Nebraska to Texas, where Upper Pennsylvanian strata are similar to those of Early Permian age.

\section{INTERVAL A}

\section{FORMATIONS INCLUDED}

The names given to rocks of interval $A$ in Kansas have been applied to rocks in northern Oklahoma and as far south as the Wichita Mountains. In most of southern Oklahoma, however, the nomenclature of northern Texas is used (table 1). Another exception is the type area of the Pontotoc Group next to the Arbuckle Mountains.

In northern Oklahoma the lowest part of the Permian is divided into the Admire, Council Grove, and Chase Groups (pl. 3). Individual formations within each group are shown in table 2 of chapter F (p. 99); the type sections of all but three are in Kansas. Several of the limestone units are distinguishable in the subsurface of northern Oklahoma, but farther south group names are more applicable because of the increased thickness of rocks and the presence of detrital materials.

Directly north of the Wichita Mountains marine limestone is thin, and the sequence consists largely of arkose and other detrital rocks. The southern limit of rocks to which the name Admire Group can be applied is, therefore, difficult to determine. On the shelf to the east thin limestone beds in Kansas grade southward into sandstone in Oklahoma.

In the eastern part of the Hollis basin of southwestern Oklahoma, rocks in the upper part of interval A consist largely of limestone and are similar to those of the Chase Group of the Anadarko basin. Detrital rocks of the Wichita Formation are present east of the Hollis basin.

In southern Oklahoma interval $\mathbf{A}$ is represented by the Wichita Formation, which is composed largely of sandstone and mudstone. The " $t$ " bed of Miser (1954) marks the top of the interval and is probably correlative with the Coleman Junction Limestone Member of the Putnam Formation of northern Texas. The lower part of the Post Oak Conglomerate Member of the Wichita Formation, adjacent to the Wichita Mountains, may be of Wolfcamp age. This conglomerate is composed of granite, limestone, and rhyolite porphyry boulders, derived from nearby Paleozoic and Precambrian rocks. The boulders are probably products of an intensive orogenic movement of the Wichita Mountains, in which activity that had begun earlier in the Paleozoic ended at about the time of deposition of the lowermost part of interval $B$. 
The upper part of the Pontotoc Group of Permian age lies northeast of the Arbuckle Mountains. It is composed of red-brown mudstone and arkosic sandstone and contains the Hart Limestone Member of the Stratford Formation. The Hart is considered to be the basal unit of interval A.

\section{UPPER BOUNDARY OF INTERVAL A}

The contact of the Herington Limestone Member of the Nolans Limestone and its correlatives with the overlying Wellington Formation is designated as the upper boundary of interval A. On the State geologic map (Miser, 1954) it extends as far south as Noble County. In western Oklahoma this contact represents a transition from normal marine limestone below to dolomite, anhydrite, and mudstone of the Wellington Formation above.

The contact is also transitional in central Oklahoma, along the eastern shelf. Limestone beds of interval A are progressively sandier southward from the Kansas border toward source areas in the Wichita and Arbuckle Mountains; thus, near the Arbuckle Mountains the upper part of the Pontotoc Group and the overlying Wellington Formation are mainly detrital. North of the Wichita Mountains the top of interval A is in the Post Oak Conglomerate Member of the Wichita Formation. The Post Oak is thought to be equivalent to the upper part of interval $A$ and to the lower part of the Wellington Formation of interval B. The interval boundary is projected from surrounding areas.

\section{THICKNESS TRENDS}

The rocks of interval A thicken irregularly westward from a beveled edge in central Oklahoma (fig. 30). This trend is modified near the Wichita Mountains in the south-central part of the State. North of the mountains the 1,500-foot isopach encloses a roughly square basin where the rocks thicken abruptly from a faulted south margin to as much as 2,225 feet. Beyond, the rocks thin toward Kansas and are less than 900 feet thick near the State border.

Southwest of the Wichita Mountains in the Hollis basin, interval $\mathrm{A}$ is more than 1,500 feet thick. The interval thins in southern Beckham County, across a subsurface extension of the Wichita Mountain trend that separates the Hollis from the Anadarko basin. Directly north of the mountains thickness is $165-500$ feet.

\section{IITHOFACIES TRENDS}

Interval $\mathbf{A}$ is composed of generally fine grained sandstone, mudstone, and limestone., Small areas near the eastern outcrop contain much sandstone. The area north of the Wichita Mountains, where the thickest deposits lie, also contains the coarsest material, because arkosic sediment derived from the mountains was spread northward (fig. 31).

In Oklahoma the proportion of limestone increases northwestward, although the Hollis basin to the south also contains a moderate amount ( $\mathrm{pl} .3$ ). A sequence of alternating mudstone and limestone occurs between

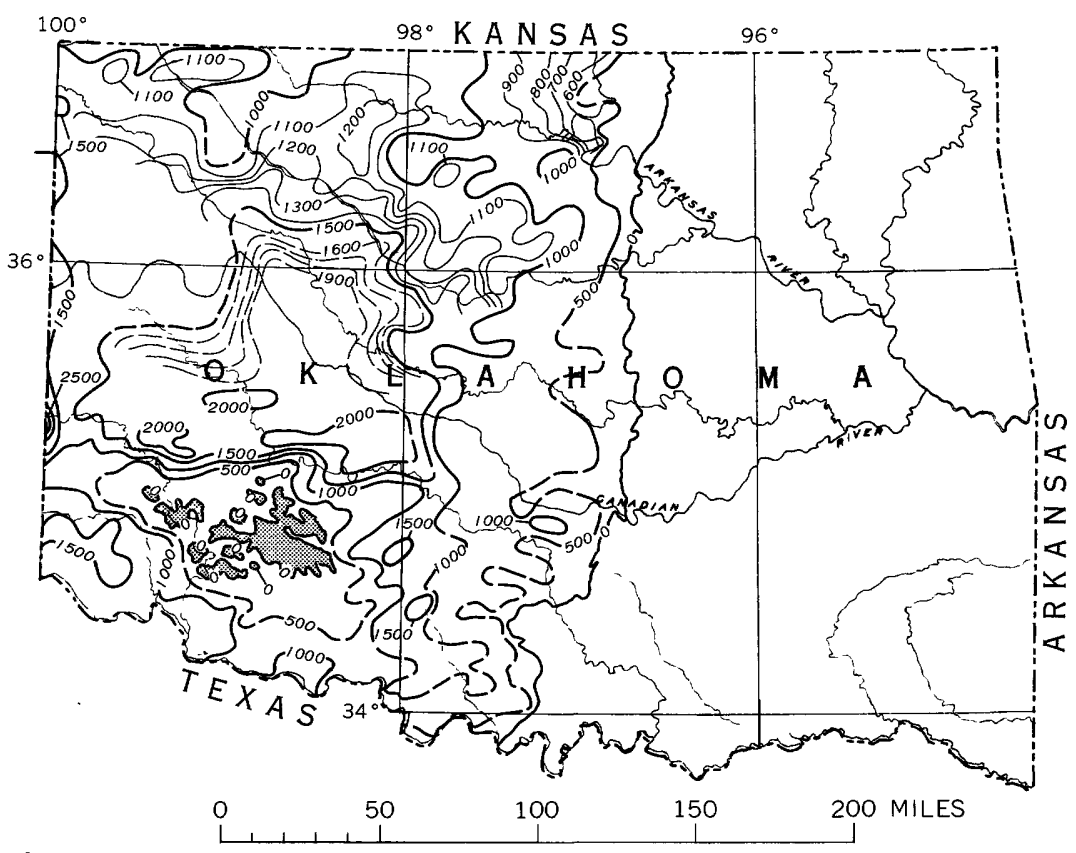

FIgURE 30.-Thickness of interval A in Oklahoma. Isopach intervals 100 and 500 feet. Isopachs dashed where control is poor. Pattern indicates areas where rocks older than Permian are exposed. 


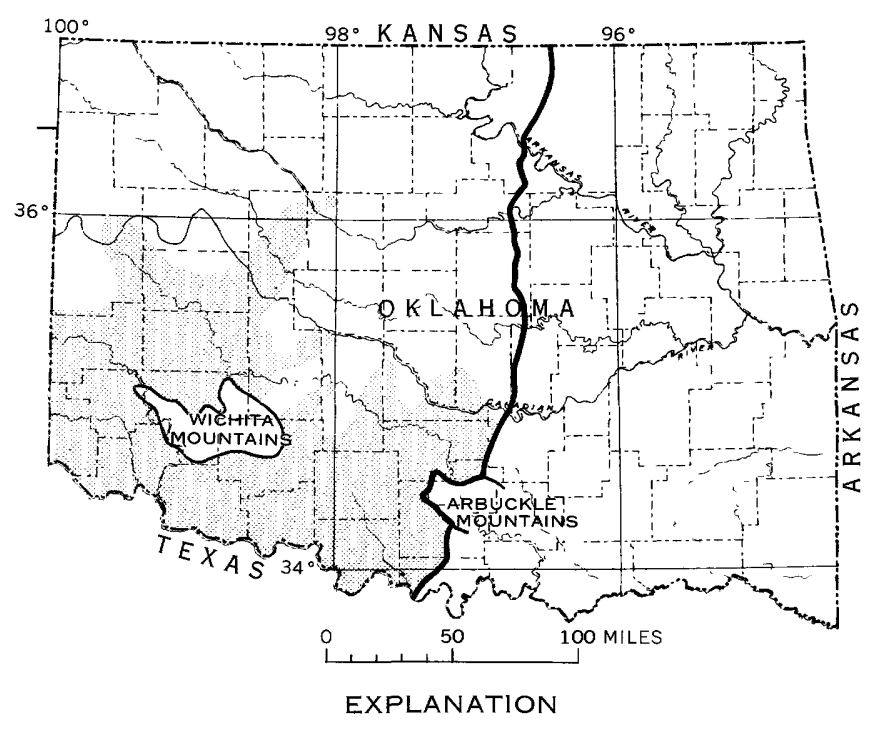

Eastern limit of interval A

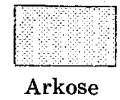

Frgure 31.-Limit of arkose in interval $\mathbf{A}$ in Oklahoma. Major source areas of arkose were Arbuckle and Wichita Mountains.

the east margin of deposition and the sites of limestone accumulation.

\section{SOURCES AND ENVIRONMENTS OF DEPOSITION}

In the Anadarko and Hollis basins, where the rocks of interval A consist of limestone, mudstone, and some dolomite, deposition was in a marine environment. Eastward, on the Oklahoma shelf, the mainly fine detrital material was probably deposited along the margin of a fluctuating sea; the sequence consists, therefore, of alternating offshore and nearshore deposits. In south-central Oklahoma the Wichita positive element that acted as a barrier between the basins was probably part of an archipelago that furnished detritus to adjoining areas.

\section{PALEOTECTONIC IMPLICATIONS}

The Anadarko basin (fig. 29), site of greatest accumulation of sediments of interval $\mathbf{A}$ in Oklahoma, subsided slowly. The basin had an approximately square outline, from which minor lobes extended both west and east. It became shallow northward toward the Kansas embayment and eastward toward the shelf. Three small relatively deep eastward-trending parts of the Anadarko basin are evident near the south edge. South of the basin was the Wichita positive element; this was separated from the basin by faults.

In the eastern part of the Hollis basin, deposits thin eastward toward the shelf and northward over the subsurface extensions of the Wichita Mountains. This positive belt was the source of a large volume of detritus during Early Permian time.

\section{INTERVAL B FORMATIONS INCLUDED}

Formations between northern Oklahoma and the Wichita Mountains assigned to interval B (table 1) are, from oldest to youngest, the Wellington Formation, Hennessey Shale, Stone Corral Formation, Duncan Sandstone, Flowerpot Shale, Blaine Gypsum, and Dog Creek Shale. The Wellington Formation, at the base, includes all beds between the top of the Herington Limestone Member of the Nolans Limestone and the base of the Hennessey Shale. The lower part is a thick evaporite sequence, mostly anhydrite but including some salt; the upper part is red mudstone containing small amounts of evaporite (fig. 32; I-450, pl. 19). A few thin brown dolomite beds occur near the base (pl. 3). The Wellington is more than 1,000 feet thick in parts of the Anadarko basin.

The Hennessey Shale consists of 300-600 feet of red mudstone, with tongues and lenses of sandstone, and a few beds of gypsum. The Cedar Hills Sandstone Member, at the top, is crossbedded, red, and lenticular. Some of the sandstone is coarse arkose, and some, north of the Wichita Mountains, is conglomeratic.

The Stone Corral Formation of Kansas extends for a few miles into northern Oklahoma. It is a graywhite anhydrite unit which contains some red mudstone and dolomite beds. The position of the Stone Corral and the correlation of the Hennessey with the Ninnescah Shale of Kansas suggests that the Cedar Hills of Oklahoma is not the same unit as the Cedar Hills of Kansas.

The Duncan Sandstone is white to buff, contains a few dolomitic lenses separated by mudstone, and is more than 100 feet thick. In many places it is coarse grained and crossbedded.

The Flowerpot Shale, locally more than 400 feet thick, is a red-brown mudstone with gray-green spots. It includes interbedded gypsum, especially toward the top. The Flowerpot also contains some thin bands of gray shaly mudstone and some very fine grained sandstone.

The Blaine Gypsum is more than 200 feet thick in parts of western Beckham County and includes four named gypsum members, interbedded with minor dolomite, and red mudstone, some of which is gypsiferous (Scott, G. L., Jr., and Ham, 1957, fig. 17). The Blaine is thickest and most gypsiferous westward; it is thinner and is predominantly mudstone eastward. The conformable contact with the underlying Flowerpot Shale is at the base of the Haystack Gypsum Member (Ham and others, 1957, fig. 2). 


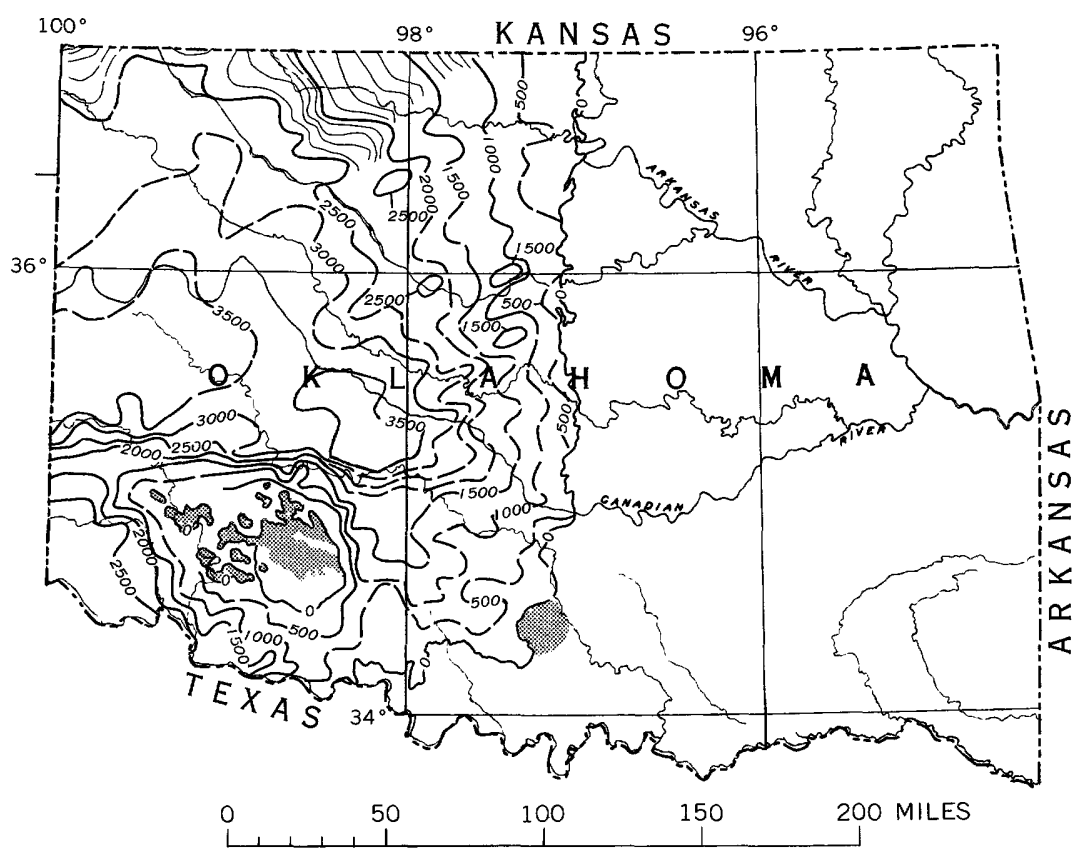

Frgure 32.-Thickness of interval B in Oklahoma. Isopach intervals 100 and 500 feet. Isopachs dashed where control is poor. Pattern indicates areas where rocks older than Permian are exposed.

The Dog Creek Shale, youngest formation of interval $\mathrm{B}$ in Oklahoma, is a red-brown mudstone containing thin dolomite and gypsum beds. The Dog Creek thickens from 10 feet near the Kansas line to 400 feet in Blaine County, Okla. (Norris, 1951, p. 8). Its contact with the underlying Blaine Gypsum is gradational (Scott, G. L., Jr., and Ham, 1957, fig. 4).

East of the Anadarko basin and south of the Wichita Mountains, interval B contains more sandstone and less evaporite than to the west and north. Here the sequence, from oldest to youngest, consists of the Wellington Formation, Garber Sandstone, Hennessey Shale, and El Reno Group. The El Reno Group includes the Flowerpot Shale (oldest), Blaine Gypsum, and Dog Creek Shale (youngest).

The Garber Sandstone is a coarse-grained red sandstone and sandy mudstone; the sandstone coarsens eastward. The formation is 400 feet thick.

North and west of the Arbuckle Mountains, formations in the El Reno Group are the Duncan Sandstone and Chickasha Formation. The Chickasha consists of 300 feet of sandstone and mudstone. It resembles the underlying Duncan Sandstone.

In southern Oklahoma, between the Wichita and Arbuckle Mountains, the part of the Wichita Formation above the " $t$ " bed of Miser (1954) is included in interval $\mathrm{B}$.
UPPER BOUNDARY OF INTERVAL B

The upper boundary of interval $B$ is at the base of the Marlow Formation of the Whitehorse Group. In northern Oklahoma Marlow sandstone is underlain by bedded anhydrite and red mudstone of the Dog Creek Shale. In southeastern Oklahoma the contact is between orange-red sandstone and sandy mudstone of the Whitehorse above, and sandstone and dark-réd mudstone of the Chickasha Formation below.

\section{THICKNESS TRENDS}

Interval B thickens westward across Oklahoma from an east edge that extends almost due south from central Kansas to the Arbuckle Mountains, then west to the Red River (fig. 32). In the Anadarko basin, where the greatest thickness of the interval occurs, more than 3,700 feet is present. In the Hollis basin to the southwest more than 2,800 feet is present. The interval thins eastward from these basins, and also over the buried Wichita ridge. It is missing locally around the Wichita Mountains. The interval's thickness between the Wichita and Arbuckle Mountains is not known with certainty.

\section{LITHOFACIES TRENDS}

Fine-grained detrital rock dominates interval B, except in parts of northern Oklahoma where it is interbedded with evaporite rock. Elsewhere in Oklahoma evaporite rock forms less than 20 percent of the in- 
terval. The vertical distribution of this rock is shown on plate 3 .

Coarse-grained detrital components are most abundant along the Eastern shelf and near the Wichita Mountains. North of the Wichita Mountains and south of the Canadian River (fig. 28) sandstone is masked by mudstone.

\section{SOURCES AND ENVIRONMENTS OF DEPOSITION}

Widespread thick anhydrite deposits (pl. 3) and associated red beds of the Wellington Formation make up the basal part of interval B in the Anadarko basin. Eastward, on the shelf, red beds containing small amounts of sandstone are predominant in interval B, whereas normal marine limestone characterizes interval $\mathrm{A}$ in the same areas. During deposition the change in sediment type was gradual; as a result brown dolomite now separates normal marine limestone of interval $\mathbf{A}$ from the evaporite rock that makes up the lower part of the Wellington. Circulation of water within the Anadarko and Hollis basins apparently become more restricted than before, and the water shallower.

The Hennessey Shale above the Wellington contains mudstone and some evaporite rock. The Hennessey was probably formed as a nearshore deposit. Its basal part contains tongues of coarse conglomerate made up of granite pebbles derived from the Wichita Mountains.

The Duncan Sandstone and the overlying Chickasha Formation to the east formed in a deltaic environment (Tussy delta) at the mouth of westward- and northwestward-flowing streams, which drained source areas to the east. Basinward equivalents (Duncan Sandstone, Flowerpot Shale, Blaine Gypsum, and Dog Creek Shale of western Oklahoma) contain evaporite rock, evaporitic mudstone, and small amounts of dolomite, apparently deposited in a shallow, restricted marine environment.

The Blaine Gypsum includes thin dolomite beds, ripple marked in part, which contain pelecypods, brachiopods, and gastropods. The Blaine was probably deposited in shallow water, where salinity varied with depth fluctuations.

\section{PALEOTECTONIC IMPLICATIONS}

Majol tectonic features of interval A persisted through interval B. Greatest downwarping was in the Anadarko basin, which continued to be asymmetrical and to trend northwestward. The Hollis basin continued to subside during interval $B$. The Wichita and Arbuckle Mountains, prominent source areas during the interval, contributed detritus from older Permian and older Palezoic rocks.
More sediments were deposited on the shelf and in the basins during this interval than during interval $\mathbf{A}$. Interval $\mathrm{B}$ has been reduced in extent on the eastern shelf because of beveling.

\section{INTERVAL C-D FORMATIONS INCLUDED}

Rock units in Oklahoma included in interval C-D (table 1) are, from oldest to youngest, the Marlow Formation and Rush Springs Sandstone, both of the Whitehorse Group, the Cloud Chief and the Quartermaster Formations. The oldest formation of the Whitehorse Group is the Marlow Formation, an orange-red friable sandstone containing thin beds of gypsum and dolomite, about 100 feet thick (Stevenson, R. H., 1958, p. 41). In Stephens County this formation contains the Verden Sandstone Member, which is 15 feet or more thick and contains rounded medium to coarse quartz sand. The youngest formation in the Whitehorse Group, the Rush Springs Sandstone, is even-bedded cross-laminated pink to orangered, fine-grained sandstone containing some feldspar grains. It is $160-300$ feet thick.

The Cloud Chief Formation consists of red mudstone and lenses-of gypsum and dolomite, some of which are as much as 50-80 feet thick.

The Quartermaster Formation includes the Doxey Shale Member, about 160 feet thick, and the Elk City Member, 170 feet (Green, 1936, p. 1474). The formation is made up of red or maroon mudstone and red to white sandstone. Its thickness has been locally modified by slumping and leaching of the underlying Cloud Chief Formation and Blaine Gypsum.

Clay-pellet conglomerate, locally present at the base of the Whitehorse, and a sharp contrast in lithology are both indications of unconformity between the Dog Creek Shale and the Whitehorse Group.

\section{UPPER BOUNDARY OF INTERVAL C-D}

Rocks of interval C-D crop out across most of western Oklahoma, except toward the west where they are overlain by rocks of Tertiary and Quaternary age $(\mathrm{I}-450$, pl. 8). The Marlow Formation is exposed at the east edge of interval C-D and the Elk City Member of the Quartermaster Formation at the west margin.

\section{THICKNESS TRENDS}

Interval $\mathrm{C}-\mathrm{D}$ thickens from less than 20 to more than 1,400 feet toward the south edge of the Anadarko basin (fig. 33). Thickness trends in Oklahoma are difficult to evaluate because this interval has been extensively eroded. In many parts of the State only remnants of lowest parts of the interval are preserved. 


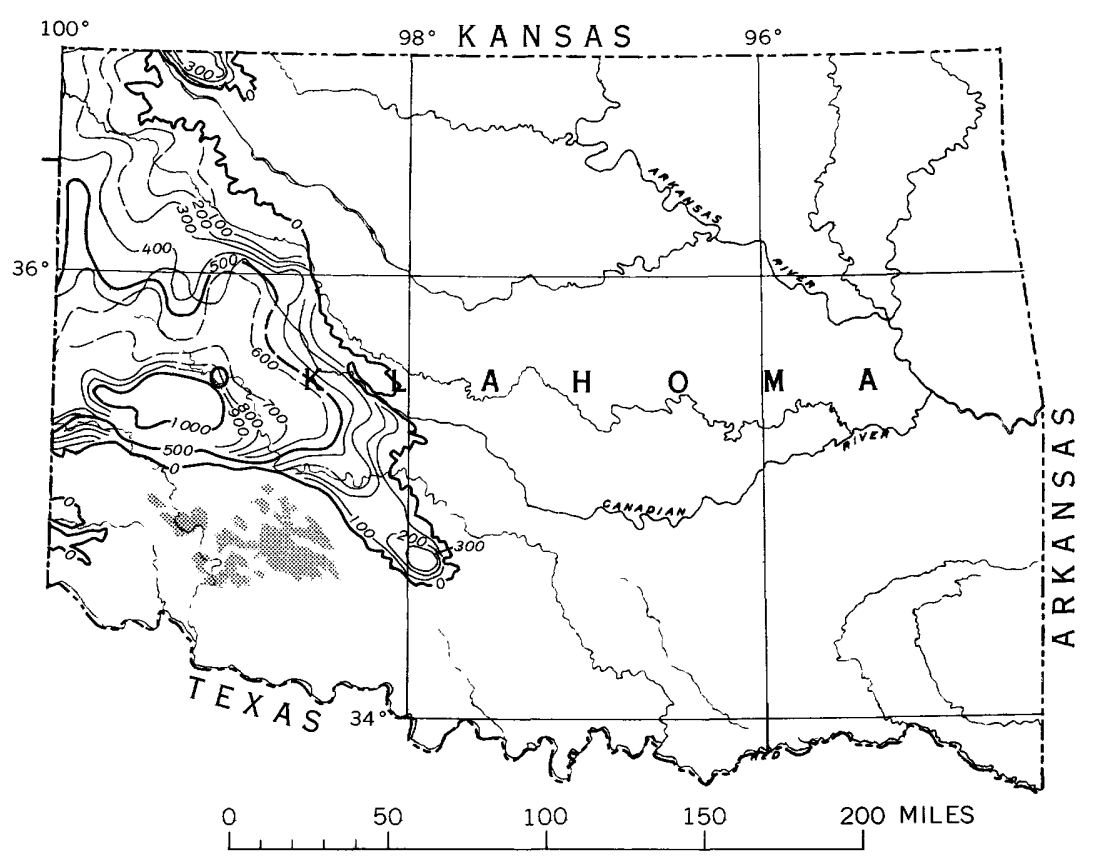

Figure 33.-Thickness of interval C-D in Oklahoma. Isopach intervals 100 and 500 feet. Isopachs dashed where control is poor. Pattern indicates areas where rocks older than Permian are exposed.

\section{LITHOFACIES TRENDS}

Coarse-grained detrital rock near the exposed edges of interval C-D grades into finer grained ruck toward the center. Locally, anhydrite and gypsum form more than 20 percent of the interval.

\section{SOURCES AND ENVIRONMENTS}

Orange-red friable sandstone, mudstone, and anhydrite of interval C-D contrast with red mudstone and evaporite rock of interval B. During deposition of interval C-D, Oklahoma was probably part of a vast mudflat containing local evaporite basins and intersected by channels. The Arbuckle Mountains to the southeast (fig. 29) apparently provided most of the detritus, although some was derived from the west, even as far away as Colorado, and some may have been derived from older Permian sedimentary rocks.

Fine-grained sandstone and mudstone of the Marlow Formation may have been deposited on a mudflat bordering the sea, and the Verden Sandstone Member may have filled a channel in the mudflat. Marine fossils (pelecypods and gastropods) incorporated in the Verden are worn. The presence of fossils and the shape of the unit are interpreted (Bass, 1939) as evidence of sandbar origin. On the other hand, the character of crossbeds and ripple marks, a decrease in grain size to the north, and presence of interstratified mudstone led some geologists (Evans, O. F., 1949, p. 94) to regard stream-channel origin as more likely. The Relay Creek Dolomite Beds at the top of the Marlow is a widespread deposit which contains pink mudstone possibly derived from volcanic ash falls.

The Rush Springs Sandstone is a crossbedded unit which may have been deposited as dunes. However, it contains a large percentage of authigenic feldspar overgrowths, which suggests accumulation in a marine environment. The Rush Springs may have formed as dunes near a beach which was inundated periodically (Ham and others, 1957, p. 54-55).

The Cloud Chief Formation contains as much as 90 feet of evaporite rock. This evaporite may have formed in a more stable environment, extending across a wider area, than did the relatively thin-bedded and localized gypsum beds lower in the section. The overlying sandstone and mudstone of the Quartermaster were deposited in an environment similar to that of the Marlow.

\section{PALEOTECTONIC IMPLICATIONS}

Interval C-D in Oklahoma has been eroded to such an extent that the history of tectonic activity during its deposition can only be inferred in a very general way. The interval is now thickest just north of the Wichita Mountains and thins progressively northward and eastward. These trends probably represent a final stage of filling of the Anadarko basin in a tectonically stable region. The presence of a small outlier of interval C-D in Harmon County indicates that rocks of this interval once extended at least that far south. 


\section{TOTAL THICKNESS OF PERMIAN ROCKS THICKNESS TRENDS}

The zero isopach in Oklahoma is the exposed contact between the Permian and older Paleozoic systems, except in Carter and Love Counties (fig. 28), where the contact is concealed by Lower Cretaceous rocks. Westward thickening of Permian rocks results partly from erosional beveling.

Isopachs near the east edge of the Permian are sinuous and trend generally north-south. West of the east margin they trend west, outlining the Anadarko basin to the northwest and the east margin of the Hollis basin to the southwest (fig. 29). These two basins are separated by the Wichita Mountains.

The south edge of the Anadarko basin is delimited by closely spaced westward-trending isopachs directly north of the Wichita Mountains, where locally. more than 6,500 feet of Permian rocks remains. In the Hollis basin to the southwest, the Permian System is locally more than 4,400 feet thick. Near the mountains the thickness varies greatly. West from the Wichita Mountains, Permian rocks thin across a subsurface extension of this positive element.

\section{PALEOTECTONIC IMPLICATIONS}

The Anadarko and Hollis basins actively subsided during Permian time and received mainly marine deposits. The larger Anadarko basin did not have any apparent hinge line. Sediments within it attained a great thickness directly north of the Wichita Mountain front and thinned progressively northward without abrupt change toward Kansas and eastward toward the shelf in central Oklahoma.

Between these two basins are the Wichita Mountains, part of the larger Amarillo, Wichita, and Arbuckle positive belt. These mountains were probably part of the archipelagic chain that supplied most of the Permian sediment to Oklahoma. They therefore were both barrier and source.
A gradual westward migration of the shoreline is postulated because Permian rocks record a change in the dominant lithologies of each interval. In western Oklahoma a normal marine basin which received carbonate deposits during the time of interval $A$ later became an evaporitic basin. During the time of interval B thick gypsum beds and interbedded mudstone accumulated there. Interval $\mathrm{C}-\mathrm{D}$ includes the youngest Permian strata in Oklahoma, deposited in the most restricted basin. This interval comprises evaporite rock, sandstone, and mudstone.

\section{GEOLOGIC UNITS DIRECTLY ABOVE PERMIAN SYSTEM UNITS OVERLYING PERMIAN}

Permian rock is exposed across much of central and western Oklahoma, except in a relatively small area near the Texas and Oklahoma Panhandles where Cenozoic strata (dune sand, Ogallala and Laverne Formations) overlie it. Recent alluvium covers the Permian along major stream courses.

Lower Cretaceous rock of the Kiowa Shale Member of the Purgatoire Formation crops out locally in western Oklahoma. The extent of these exposures is exaggerated on plate 8 of $\mathrm{I}-450$ to show them at the published map scale. Lower Cretaceous rock of the Trinity Group is present south of the Arbuckle Mountains, where it oyerlaps Lower Permian rock.

\section{PALEOTECTONIC IMPLICATIONS}

Successively younger strata are exposed westward across Oklahoma. Tertiary rocks are still present in western Oklahoma, though they have been removed along major drainages.

The region. was probably tilted down toward the west after Permian time. The lack of Triassic rocks in this area may be the result of a shift westward in the position of basin subsidence during post-Permian time (Tomlinson and McBee, 1959, p. 51). Erosion during Triassic and Jurassic time is suggested by Eardley (1951, pl. 11-1). A thick Cretaceous cover is thought to have been eroded during Cenozoic time. 


\section{Paleotectonic Investigations}

of the Permian System

in the United States

Chapter F. Central Midcontinent Region

By MELVILLE R. MUDGE

GEOLOGICAL SURVEY PROFESSIONAL PAPER 515-F

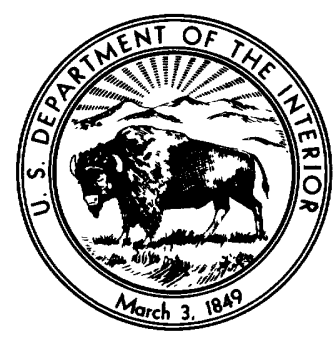





\section{CONTENTS}

Abstract.

Region defined

Paleogeology

Units underlying Permian.........................

Lower boundary of Permian....................

Paleotectonic implications . . . . . .

Interval A.

Formations included.

Upper boundary of interval A . . . . .

Thickness trends.

Lithofacies trends

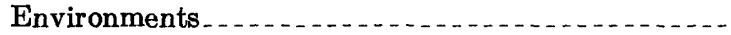

Sources of detritus

Paleotectonic implications

Interval B.

Formations included.

Page
97
97
97
97
98
98
99
99
101
101
101
104
105
106
109
109

Page

Interval B-Continued

Upper boundary of interval B. . .

Thickness trends. .......................... 113

Lithofacies trends. . . .

Sources and environments . . . . . . . . . . . . . 113

Paleotectonic implications . . . . . .

Interval C-D . . . . .

Formations included .

Upper boundary of interval C-D _. . . . . . . 116

Thickness trends............................ 116

Sources and environments . . . . . .

Total thickness of Permian rocks. .

Thickness trends. ............... 117

Paleotectonic implications _. _...

Geologic units directly above Permian System ......... 120

Units overlying Permian..................... 120

Paleotectonic implications

\section{ILLUSTRATIONS}

Page

Plate 4. Maps showing facies relations of interval $A$ in Kansas

Figure 34-43. Maps of the central Midcontinent region:

34. Thickness of interval $A$

35. Thickness of interval $\mathrm{B}$

36. Thickness of interval C-D

37. Distribution of salt of Wellington age

38. Distribution of salt of Ninnescah age

39. Distribution of salt of Nippewalla age

40. Total thickness of Permian rocks.

41. Present and Permian structures. 119

42. Geologic units directly above Permian rocks

43. Inferred Mesozoic and Cenozoic drainage that eroded part of the Permian rocks

\section{TABLES}

1. Generalized chart showing stratigraphic units in major Permian subdivisions....

2. Stratigraphic units of Kansas assigned to interval $\mathbf{A}$ 



\title{
PALEOTECTONIC INVESTIGATIONS OF THE PERMIAN SYSTEM IN THE UNITED STATES
}

\section{GENTRAL MIDGONTINENT REGION}

\author{
By Melville R. Mudge
}

\begin{abstract}
The Midcontinent region underwent nearly continuous deposition throughout the Permian, which resulted in an accumulation of as much as 3,400 feet of sediment in places. In most areas Permian strata rest conformably on those of Pennsylvanian age; locally they rest disconformably on rocks as old as the Precambrian. Structural features that controlled the kind and thickness of sediment that was deposited were the central Kansas Permian basin, Hugoton embayment, Las Animas arch, Apishapa arch, northeastern Colorado basin, and the western Nebraska Permian basin. Most of this sediment was derived from the ancestral Rocky Mountains, Wet Mountains, and the Siouxia uplift. The Apishapa and Sierra Grande uplifts were positive areas only during the early part of the Permian.

Strata of the Midcontinent Permian were formed in epicontinental marine, marginal, and continental environments. During the early part of the period, neritic deposits of the eastern part intertongued with and overlapped deltaic and alluvial deposits to the west. Later, alternating normal marine, brackish-water, and continental environments persisted, but still later the environment was dominantly nonmarine or brackish water and, for brief periods, restricted marine. During Late Permian time environments of deposition in eastern Colorado included deltaic, alluvial, beach, eolian, and restricted marine.

Three dominant structural trends of the Permian áre conspicuous in the region: a northeast trend, represented by the Las Animas arch; a northwest trend, in Kansas and southeastern Colorado; and an east trend, in northeastern Colorado and western Nebraska. These trends and their associated folds may be explained by a horizontal couple in which principal force was transmitted northeastward on the Las Animas arch.

Rocks directly above the Permian are of eight different ages and include strata of both marine and nonmarine origin. Across the region eastward from the Front Range in Colorado successively younger beds overlap the Permian.
\end{abstract}

\section{REGION DEFINED}

The central Midcontinent region includes Kansas, Nebraska, and eastern Colorado. Permian intervals $\mathrm{A}, \mathrm{B}$, and $\mathrm{C}-\mathrm{D}$ are exposed in eastern and central Kansas, along the east side of the Rocky Mountains in Colorado, and in southeastern Nebraska. In Kansas thousands of oil and gas exploration wells penetrate the Permian; therefore, a large amount of data is available. In eastern Colorado and Nebraska, exploratory wells are more widespread; they are only locally concentrated $(I-450$, pl. 1). For the Midcontinent region the nomenclature and data given here are as of June 1957.

\section{PALEOGEOLOGY \\ UNITS UNDERLYING PERMIAN}

In the central Midcontinent region, Permian rocks overlie Pennsylvanian rocks except in a few places where they are disconformable on considerably older rocks. As units underlying the Permian were not studied in detail during this investigation, they are differentiated only by systems on the paleogeologic map (I-450, pl. 2).

In most of Kansas and adjoining areas, Pennsylvanian rocks beneath the Permian belong to the Virgil Series. An exception is in northwesternmost $\mathrm{Ne}$ braska, where Mitchell (1953, fig. 3) showed Permian rocks disconformable on Pennsylvanian rocks of the Missouri Series. Locally within this area Permian rocks may overlie still older Pennsylvanian strata.

At two places in Cherry County, Nebr., Permian rocks may rest directly on Precambrian rocks. Elsewhere in this county they overlie undifferentiated Pennsylvanian rocks which form a thin veneer on the Precambrian ( $\mathrm{I}-450, \mathrm{pl} .2)$.

In eastern Las Animas County in southeastern Colorado, Permian rocks rest disconformably on undifferentiated Ordovician and Silurian rocks (Maher and Collins, 1952). Farther south, near the New Mexico border, they overlie rocks possibly of Mississippian age (I-450, pl. 2).

In the Apishapa uplift of southern Colorado, Permian rocks rest directly on Precambrian igneous and metamorphic rocks (Maher and Collins, 1952; Maher, 1958 , p. 63, figs. 14, 15). Elsewhere along the Front Range the Fountain Formation includes beds of both Permian and Pennsylvanian age in conformable sequence (Maher, 1958; Maher and Collins, 1952; Mitchell, 1953, fig. 1). 


\section{LOWER BOUNDARY OF PERMIAN}

In the outcrop belt of eastern Kansas, the top of the Brownville Limestone Member of the Wood Siding Formation is considered to be the boundary between the Pennsylvanian and Permian Systems (Moore, R. C., Frye, and others, 1958, p. 58; Moore, R. C., and Mudge, 1956, ilg. 1; Mudge and Yochelson, 1962). "The lowest known occurrence of the Pseudofusulina (Pseudoschwagerina) zone in Kansas is in the Five Point limestone member of the Janesville shale" (R. C. Douglass, written commun., 1956), about 85 feet above the Brownville Limestone Member (Mudge, 1957, p. 115-116). The top of the Brownville, an arbitrary boundary, is used in outcrops because of its fauna and ease of recognition.

This limestone member cannot be recognized in many subsurface sections in central Kansas, but the Pennsylvanian-Permian boundary can generally be placed at the contact between the Admire Group, identified by lithology, and an underlying thick sequence of Pennsylvanian limestone and interbedded gray mudstone. The Admire Group is red and gray mudstone containing interbeds of sandstone, sandy shale, mudstone, and thin-bedded limestone. Identification of the Admire Group is facilitated by recognition of the overlying Foraker Limestone, which in most places contains chert nodules and abundant Early Permian fusulinids.

In westernmost Kansas, in southeastern and northeastern Colorado, and in Nebraska the PennsylvanianPermian boundary has been selected mainly on the basis of lithologic correlation with the sequence in central Kansas. The choice of boundary in northeastern Colorado and western Nebraska agrees with fusulinid evidence supplied by the American Stratigraphic Co. and by the Gulf Oil Co. The boundary in subsurface sections in southeastern Nebraska can be correlated with that in the outcrop belt as well as with that in the subsurface in Kansas.

In a few places in the northern Front Range of Colorado, selection of the systemic boundary by correlation with the Kansas sequence has been supplemented by fusulinid data. Fusulinids throughout the Ingleside Formation as defined by Butters (1913, p. 68) have been collected by Maughan and Wilson (1960, p. +1-42) and identified by Lloyd Henbest as Early Permian. At one northern Colorado locality, Willhour $(1958$, p. 19) found fusulinids of possible Virgil (Late Pennsylvanian) age about 56 feet below fusulinids of probable Wolfcamp age. In that area the boundary between the two systems is placed at the base of the lowest limestone containing Early Permian fusulinids.
In parts of southeastern Colorado the base of the Permian is inferred to coincide with the base of a sandstone and mudstone sequence that rests on massive limestone beds containing fusulinids of Pennsylvanian (early Virgil) age. In a few places this contact is at the base of a fine- to coarse-grained sandstone 50150 feet below the thin chert-bearing limestone beds believed to be equivalent to the Foraker Limestone. Correlations in this area are substantiated by fusulinid data furnished by the American Stratigraphic Co. and the U.S. Geological Survey for part of the stratigraphic section at localities $293,148,157,44,192,255$, $65,310,364,181,267,58,381$, and 382 (I-450, pl. 1).

The sandstone discussed above may lie unconformably on the Pennsylvanian System (Maher and Collins, 1952; Fentress and others, 1958), but it seems to be restricted to the Apishapa and Sierra Grande uplifts and the southern part of the Las Animas arch (I-450, pl. 16) and does not extend into western Kansas and northeastern Colorado.

Along the southern Front Range and the Wet Mountains of Colorado, an arbitrary boundary for the base of the Permian has been selected on the basis of correlation of dominant arkosic units with similar units farther east ( $I-450, \mathrm{pl}, 16)$. This boundary is very similar to that chosen by Maher (1958, figs. 13-15) and is supported by additional, unpublished data compiled by W. W. Mallory in 1959 .

\section{PALEOTECTONIC IMPLICATIONS}

Many of the structural features that originated during Pennsylvanian time remained prominent during Early Permian time. Major features such as the $\mathrm{Ne}$ maha anticline, the Salina basin, the central Kansas uplift (Lee and others, 1948, p. 138-139), the Las Animas arch (Maher, 1945, p. 1663), and the Hugoton embayment were in existence at the beginning of Permian deposition.

The boundary between the Permian and Pennsylvanian Systems in Kansas and central Nebraska has been considered by some geologists to be a widespread disconformity, but no evidence is available to support this contention. The existence of such a disconformity would imply tectonic activity, but the facies of uppermost Pennsylvanian rocks seem to be very similar to, if not identical with, those of the lowermost Permian, and there is no evidence of pronounced beveling or truncation of the uppermost Pennsylvanian beds. Apparently the boundary between the Pennsylvanian and Permian Systems in Kansas and the east half of Nebraska is a conformable contact.

Disconformities between the Permian and Pennsylvanian Systems have been recognized in areas of local 
uplift in the westernmost part of the central Midcontinent region, but these disconformities can be traced, with reasonable accuracy, only short distances away from such uplifts. The most apparent disconformity is in northwestern Nebraska, where Permian strata rest on rocks of Missouri age (Mitchell, 1953, p. 89). Similar relations have been noted in southeastern Colorado, where beds of late Virgil age are absent as a result of pre-Permian erosion (Fentress and others, 1958).

Along the Front Range and in southeastern Colorado, deposition of coarse arkosic sediment began during Early Pennsylvanian time and continued through the time represented by intervals $A$ and $B$ of the Permian (I-450, pls. 3, 4, 16). This sediment was derived from the actively uplifted ancestral Rocky Mountains, the Wet Mountains, and the Apishapa and Sierra Grande uplifts (I-450, pl. 16). The amount of detritus contributed by the two small uplifts was minor compared with that contributed by the two elevated ranges. In addition, the Siouxia uplift continued during Late Pennsylvanian time but seemingly contributed very little, if any, first-cycle detritus during Early Permian time.

\section{INTERVAL A}

\section{FORMATIONS INCLUDED}

In the central Midcontinent region, formations included in interval A form three principal sequences. Names of rocks in Kansas and eastem Nebraska (tables 1,2) follow the classification of Moore, Frye, and others.(1951, p. 37-52), except those in the lower part of the interval, which follow that of Moore and Mudge (1956). In Colorado the nomenclature used for rocks of interval A follows that of LeRoy (1946) and of Maher (1954, p. 2234; 1958, p. 72, 73, figs. 1315). In northwestern Nebraska it is according to Butters (1913) and Condra, Reed, and Scherer (1940). Correlation between sequences within the region is shown on table 1. It represents the interpretation of the author but follows, in part, Reed (1955, unpub. rpt.) and Maher (1954, p. 2234; 1958, table 1). The problem of correlation of the Fountain Formation in Colorado is discussed on page 98.

In Kansas and eastern Nebraska, formations of the Admire Group and some of the formations of the Council Grove and Chase Groups that are easily identified in the outcrop (table 2) are not recognizable in well cuttings or on electric logs. The more easily identified subsurface units of interval $\mathrm{A}$ are restricted to the eastern two-thirds of Kansas and eastern onethird of Nebraska. These are, in ascending order: the Foraker Limestone, Red Eagle Limestone, Neva
TABLE 2.-Stratigraphic units of Kansas assigned to interval $A$

\begin{tabular}{|c|c|c|}
\hline Group & Formation & Member \\
\hline \multirow{7}{*}{ 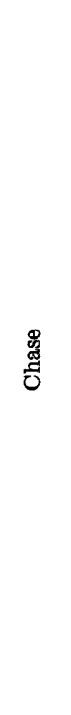 } & Nolans Limestone & $\begin{array}{l}\text { Herington Limestone } \\
\text { Paddock Shale } \\
\text { Krider Limestone }\end{array}$ \\
\hline & Odell Shale & \\
\hline & Winfield Limestone & $\begin{array}{c}\text { Cresswell Limestone } \\
\text { Grant Shale } \\
\text { Stovall Limestone }\end{array}$ \\
\hline & Doyle Shale & $\begin{array}{c}\text { Gage Shale } \\
\text { Towanda Limestone } \\
\text { Holmesville Shale }\end{array}$ \\
\hline & Barneston Limestone & $\begin{array}{l}\text { Fort Riley Limestone } \\
\text { Oketo Shale } \\
\text { Florence Limestone }\end{array}$ \\
\hline & Matfield Shale & $\begin{array}{c}\text { Blue Springs Shale } \\
\text { Kinney Limestone } \\
\text { W ymore Shale }\end{array}$ \\
\hline & Wreford Limestone & $\begin{array}{l}\text { Schroyer Limestone } \\
\text { Havensville Shale } \\
\text { Threemile Limestone }\end{array}$ \\
\hline \multirow{14}{*}{ 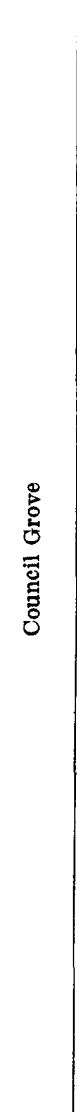 } & Speiser Shale & \\
\hline & Funston Limestone & \\
\hline & Blue Rapids Shale & \\
\hline & Crouse Limestone & \\
\hline & Easly Creek Shale & \\
\hline & Bader Limestone & $\begin{array}{l}\text { Middleburg Limestone } \\
\text { Houser Shale } \\
\text { Eiss Limestone }\end{array}$ \\
\hline & Stearns Shale & \\
\hline & Beattie Limestone & $\begin{array}{l}\text { Morrill Limestone } \\
\text { Florena Shale } \\
\text { Cottonwood Limestone }\end{array}$ \\
\hline & Eskridge Shale & \\
\hline & Grenola Limestone & $\begin{array}{l}\text { Neva Limestone } \\
\text { Salem Point Shale } \\
\text { Burr Limestone } \\
\text { Legion Shale } \\
\text { Sallyards Limestone }\end{array}$ \\
\hline & Roca Shale & \\
\hline & Red Eagle Limestone & $\begin{array}{l}\text { Howe Limestone } \\
\text { Bennett Shale } \\
\text { Glenrock Limestone }\end{array}$ \\
\hline & Johnson Shale & \\
\hline & Foraker Limestone & $\begin{array}{l}\text { Long Creek Limestone } \\
\text { Hughes Creek Shale } \\
\text { Americus Limestone }\end{array}$ \\
\hline \multirow{3}{*}{ 总 } & Janesville Shale & $\begin{array}{c}\text { Hamlin Shale } \\
\text { Five Point Limestone } \\
\text { West Branch Shale }\end{array}$ \\
\hline & Falls City Limestone & \\
\hline & Onaga Shale & $\begin{array}{c}\text { Hawxby Shale } \\
\text { Aspinwall Limestone } \\
\text { Towle Shale }\end{array}$ \\
\hline
\end{tabular}


Limestone Member of the Grenola Limestone, Eskridge Shale, and Beattie Limestone in the Council Grove Group, and the Wreford, Barneston, and Nolans Limestones in the Chase Group.

The Foraker is mostly massive gray chert-bearing limestone with thin interbeds of gray mudstone; all beds are very fossiliferous, and fusulinids are especially abundant. It is 50-100 feet thick.

The Red Eagle, like the Foraker, is a massive limestone that locally contains chert, but it contains little mudstone and few fossils. It is $20-100$ feet thick.

The Neva Limestone Member of the Grenola Limestone is a gray aphanitic limestone, ranging from dolomitic to calcitic, that is about 20 feet thick. It is most readily identified by its position beneath the Eskridge Shale.

The Eskridge Shale is a mudstone unit $300-350$ feet above the base of the Wolfcamp equivalent; it is partly red and partly red and gray. Its red rocks are generally the only ones in the Council Grove Group in central and eastern Kansas. The Eskridge is 20-50 feet thick.

The Beattie Limestone is recognized in the subsurface by the Kansas Sample Log Service on the basis of "weathered fusulinids in gray thin-bedded fossiliferous limestone." Locally it is a cream-gray dolomitic limestone. The Beattie is 3-24 feet thick (Imbrie and others, 1959 , p. 69).

The Wreford Limestone is composed of limestone beds separated by mudstone. At the type section it - is mainly gray to gray buff, finely crystalline, fossiliferous, and chert bearing, but in western Kansas it is dolomitic and noncherty. The unit is $20-50$ feet thick.

The Barneston Limestone consists of the Florence and Fort Riley Limestone Members, separated by the Oketo Shale Member. The Florence Member at the base, 30-70 feet thick, is the highest and thickest of the widespread chert-bearing gray finely crystalline limestones in the sequence. On the outcrop, and presumably also in subsurface, it is the youngest unit of the interval to contain fusulinids. The Fort Riley Limestone Member is mostly gray finely crystalline dolomitic limestone or dolomite that is $50-100$ feet thick.

The Nolans Limestone is the uppermost unit of interval $\mathrm{A}$; it is divided on the outcrop into three members. Only the uppermost unit, the Herington Limestone Member, is identified in subsurface. The Nolans is generally a tan to gray, dolomitic limestone on the outcrop but is a finely sucrose chert-rich dolomite in subsurface. It is $20-30$ feet thick.

In westernmost Kansas and southeastern Colorado, rock of interval $\mathbf{A}$ is dominantly a detrital sequence, whereas farther east. it is dominantly carbonate rock. Subdivisions of internal A that are traceable in Kansas cannot be recognized in most of southeastern Colorado (Mitchell, 1953, p. 89; Maher and Collins, 1952), although in Baca, Powers, aand Kiowa Counties the Foraker Limestone is identifiable.

The group divisions used in Kansas outcrop areas are applied to the subsurface rock of interval $\mathbf{A}$ in western Kansas and eastern Colorado even though the boundaries within the groups are not easily determined.

Near the Front Range and the Wet Mountains, rock of interval A includes the upper part of the Fountain Formation as defined by Maher and Collins (1952) and Maher (1958, figs. 13-15). Northward along the Front Range the Fountain Formation grades into or interfingers with the Ingleside Formation (Thompson, W. O., and Kirby, 1940, p. 143; Maughan and Wilson, $1960)$; the entire Ingleside is regarded as being Early Permian in age (Maughan and Wilson, 1960, p. 42).

In north-central Colorado, subsurface strata of interval A consist mainly of carbonate rock, dominantly dolomite $(\mathrm{I}-450, \mathrm{pl} .3)$; however, thin beds of anhydrite are locally interbedded in the lower and middle parts of the interval, and one or more evaporite beds occur near the top. Locally this higher evaporite rock is interbedded with dolomite or with red-brown mudstone. Thin beds of sandstone and red-brown mudstone are interbedded with carbonate rock at various levels in interval A. Chert occurs as thin nodules or lentils in two units. One cherty unit is a massive dolomite bed about 100 feet above the base of the interval which may be correlative with the Foraker Limestone; the other is dolomite and limestone, low in the upper third of the interval, which may be correlative with the Florence Limestone Member of the Barneston Limestone of Kansas.

Kansas nomenclature is used, where possible, in northeastern Colorado and west-central Nebraska. In places the Admire Group is represented by 50-100 feet of dolomite with interbedded mudstone and sandstone; locally, mudstone is predominant. The overlying Foraker Limestone is a chert-bearing carbonate rock (mainly dolomite) with some interbedded evaporite. The interval from the Foraker up to and including the Wreford Limestone consists mostly of dolomite and interbedded mudstone; chert is locally present in the upper part. The Barneston Limestone is a chert-bearing dolomite, limestone, and dolomitic limestone unit. The rest of the interval up to the top is composed of dolomite and interbedded evaporite rock, mudstone, and sandstone; the top dolomite is correlated with the Nolans Limestone. 
In northwestern Nebraska interval $A$ is divisible into four lithologic units which can be tentatively correlated with the Kansas section, as follows:

\begin{tabular}{|c|c|c|}
\hline Unit & Nebraska Panhandle & Kansas \\
\hline $4 \ldots \ldots$ & $\begin{array}{l}\text { Anhydrite with some } \\
\text { dolomite. }\end{array}$ & $\begin{array}{l}\text { Upper part of Chase } \\
\text { Group. }\end{array}$ \\
\hline $3 \ldots$ & $\begin{array}{l}\text { Dolomite with some mud- } \\
\text { stone. }\end{array}$ & $\begin{array}{l}\text { Lower part of Chase } \\
\text { Group. }\end{array}$ \\
\hline $2 \ldots \ldots$ & $\begin{array}{l}\text { Anhydrite and dolomite with } \\
\text { much anhydrite toward } \\
\text { north. }\end{array}$ & $\begin{array}{l}\text { Council Grove } \\
\text { Group. }\end{array}$ \\
\hline $1 \ldots$ & $\begin{array}{l}\text { Dolomite and mudstone, } \\
\text { with local thin beds of } \\
\text { anhydrite, sandy mudstone, } \\
\text { and sandstone. }\end{array}$ & Admire Group. \\
\hline
\end{tabular}

In the Nebraska Panhandle the units included in interval A are assigned to the Broom Creek Group of the Black Hills (Condra and others, 1940, figs. 13, 14).

UPPER BOUNDARY OF INTERVAL A

The top of interval $A$ is widely traceable in all parts of the central Midcontinent region, except in northwestern Kansas and southeastern Colorado. Strata in interval $\mathbf{A}$ are mainly thick beds of carbonate rock with some interbedded detrital rock. In contrast, strata forming the lower part of interval B are largely detrital with interbedded evaporite rock, but locally in the lower part they contain one or more thin dolomite beds. Bedded evaporitic rock occurs mostly, but not entirely, above the boundary. In most places in southcentral Kansas the uppermost unit of interval A (the Nolans Limestone) is a carbonate rock with nodules of chert. Where chert is absent this bed is recognized as the highest dolomite-20-30 feet thick-that overlies a gray mudstone. This dolomite is generally about 250-300 feet above the base of the easily identified Barneston Limestone.

In northeastern Colorado and western Nebraska the top of interval $A$ is above a dolomite or anhydrite bed $(\mathrm{I}-450, \mathrm{pl} .14 E)$ in the fourfold sequence mentioned previously. This boundary underlies red mudstone that in places is sandy or contains some thin interbedded anhydrite and small amounts of salt.

In the northwesternmost part of Nebraska, the top of interval $A$ is beneath beds of coarse-grained sandstone of interval B. In central and eastern Nebraska it is on top of the first dolomite below the Stone Corral Formation and beneath anhydritic mudstone with interbedded anhydrite that constitutes the Wellington Formation equivalent.

In western Kansas and southeastern Colorado, the contact between intervals A and B is difficult to determine (Maher and Collins, 1952; Mitchell, 1953; Fentress and others, 1958) and has been established arbitrarily by projection on sample and electric logs from central Kansas and northeastern Colorado-areas where it is more clearly defined. In much of the western area, the Stone Corral Dolomite and equivalents (I-450, pl. 14F) in interval B and the Foraker Limestone and equivalents in the lower part of interval $\mathbf{A}$ are extensive. Dolomite beds are more numerous and persistent in interval $\mathbf{A}$ than in interval $\mathbf{B}$ or in Pennsylvanian rock.

On the Apishapa uplift and the southern part of the Las Animas arch, the upper boundary of interval $\mathbf{A}$ is placed at the base of a coarse-grained sandstone unit which may mark a disconformity. In Las Animas and Huerfano Counties (I-450, pl. 16), an angular unconformity at this horizon has been inferred, and above it is a coarse-grained arkosic orange sandstone.

In southeastern Colorado, in counties west of the eastern tier of counties and east of the outcrop along the mountain front, interval A contains a higher percentage of mudstone than interval $B$, which is dominantly sandstone (I-450, pl. 16).

\section{THICKNESS TRENDS}

The isopach map of interval A (fig. 34) shows many significant trends, which are obscured in part by Cenozoic erosion.

In Kansas, rock of interval $\mathbf{A}$ is 435 feet thick in the northwest and as much as 1,000 feet in the southcentral part.

In northeastern Kansas, east of the Nemaha anticline, Permian rock has been reduced to an outlier by Cenozoic erosion (fig. 34). The northeast trend of its structure is reflected by the outcrop pattern of Pennsylvanian rock in Nemaha and Pottawatomie Counties, Kans., and in Pawnee and Johnson Counties, Nebr.

In southeastern Colorado there is a northeastward thinning of interval A across central Kiowa and Cheyenne Counties and, farther east, a southward thickening. Faulting may have been a cause of the abrupt change in the thickness of interval $A$ near the positive area in northern Las Animas County (fig. 34).

In Dundy and Chase Counties, southwestern Nebraska, and in northwestern Kansas, thinning is expressed by isopachs in the form of a south-trending reentrant. An especially noticeable reentrant is present in the central part of Nebraska. Here, rock of interval A thins southwestward, whereas in the northern part of the Nebraska Panhandle it thins northward. The configuration of the east margin of interval A in Nebraska is the result of pre-Cretaceous erosion (fig. 42).

\section{LITHOFACIES TRENDS}

In Kansas, carbonate rock dominates interval A; some mudstone (I-450, pl. 3) roughly outlines the 


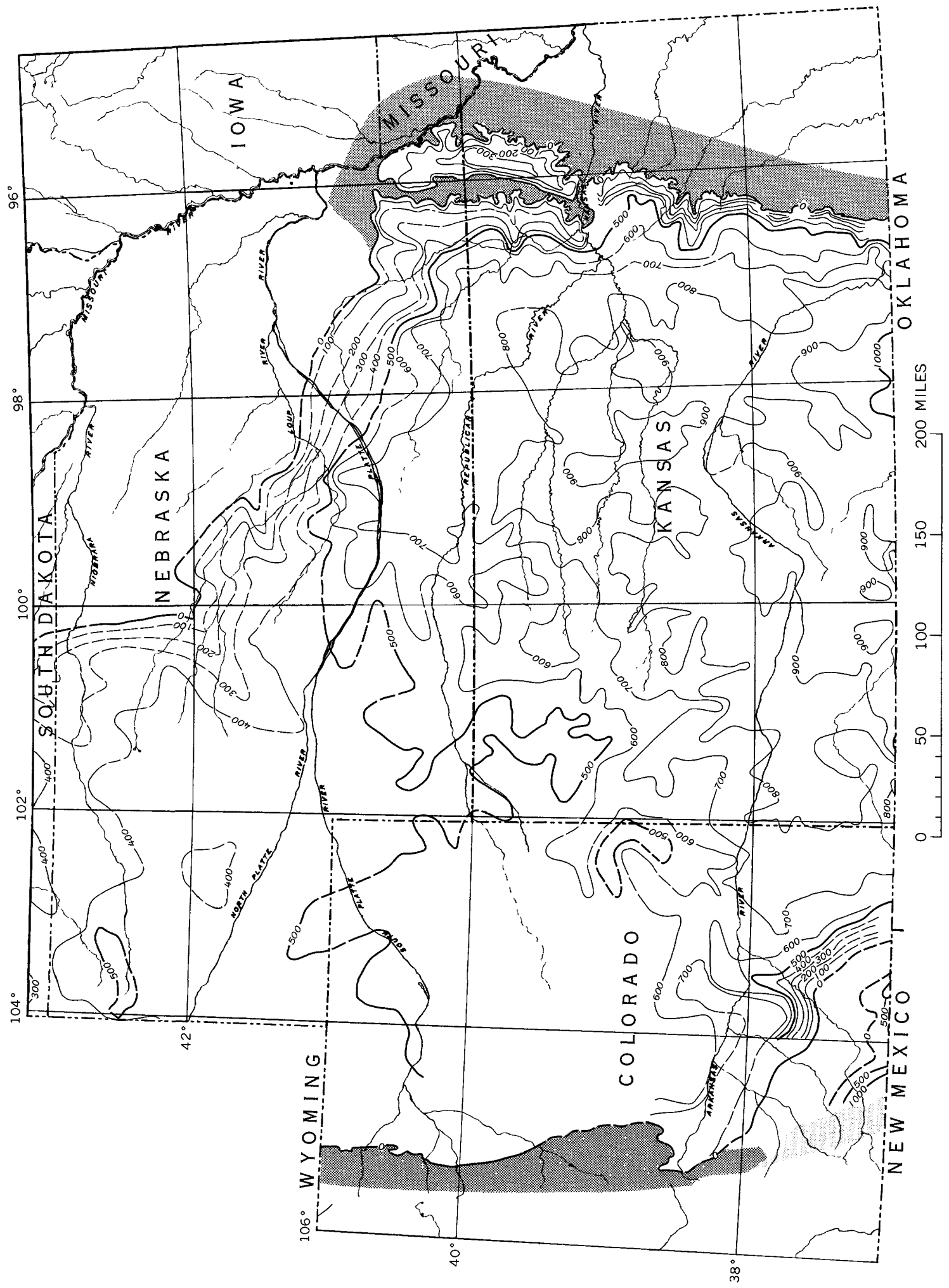


deeper part of the Permian depositional basin. A significant reentrant in this facies, which trends northwest, is in the west-central part of the State. During deposition of the lower part of interval $A$ this reentrant formed a small southeast-trending prong in eastcentral Colorado. On the lithofacies map this connection is partly masked by dominantly detrital rock in the upper part of the interval. A lithofacies map of the lower part would only show a narrow band of dominantly carbonate rock across this area, connecting the facies of basins on each side. This feature is interpreted as a low swale connecting the two basins. It trends southeast and was formed at the northeast margin of a large delta that formed over the Las Animas arch and across much of southeastern Colorado.

Near the large area of carbonate rock and gradational with it is a narrow band containing mainly mudstone with some limestone. This facies dominates most of the eastern outcrop area in Kansas, except in the southernmost part, where the edge of the carbonate rock trends southeastward.

In the region of eastern Colorado, western Kansas, and southwesternmost Nebraska, lithofacies patterns differ from place to place along the Las Animas arch. Near the Wet Mountain area dominantly arkosic sandstone grades eastward into mudstone with some sandstone, and, farther east, into mudstone. Elsewhere along the arch and also in southeastern Colorado, lithofacies include dominant sandstone and dominant mudstone. In most of western Kansas and southwestern Nebraska, mudstone is the main rock, but some sandstone and limestone occur near the margins of the basin (I-450, pl. 3).

In the basin of northeastern Colorado and adjacent parts of Nebraska, interval A has not been penetrated in many places, but most of it is apparently carbonate rock. This rock forms a band around a central area of combined evaporite and carbonate rock.

Lithologic variations in interval A result from differences in environments of deposition, as is well illustrated in Kansas by rocks from the top of the Wreford Limestone, (the basal formation of the Chase Group) to the top of interval A. They are analyzed by means of carbonate ratios, relative abundance of chert, mudstone ratios, relative abundance of sandstone, and variation in lithofacies on special maps (pl. 4).

The proportion of carbonate rock to other lithologic types varies greatly from one part of Kansas to another. In south-central Kansas, carbonate rock forms as much as 80 percent of interval $\mathbf{A}$; but in parts of western Kansas, less than 20 percent. Where it exceeds 50 percent the rock is fossiliferous and cherty and is largely of marine origin. This carbonate rock contains dolomite beds in almost all sections, as shown by analyses that involve plotting the dolomite-limestone ratio and the lowest occurrence of dolomite in each section (pl. $4 D, E, H$ ).

Dolomite-limestone ratios for rock of interval A indicate more than 50 percent dolomite in parts of northwestern and north-central Kansas (pl. $4 D$ ) ; more than 25 percent in the west-central and central parts of the State adjacent to the platform; and less than 25 percent elsewhere, with none in southwestern and eastern Kansas. The nondolomitic carbonate rock of the outcrop changes to dolomitic limestone in the subsurface.

A fairly consistent trend from northwest to southeast is shown in the position of dolomite above the base of the Permian (pl. 4H). In parts of northwestern Kansas, dolomite beds occur as low as the Upper Pennsylvanian, but in most places not below the Foraker Limestone. From northwestern Kansas (platform area) toward the southeast (basin area) the lowest dolomite beds are progressively younger, and in the central parts of the basin they are generally not below the Florence Limestone Member of the Barneston Limestone.

An analysis of the presence and quantity of chert nodules and lenses in many of the beds of limestone in interval A shows that the distribution of chert coincides with the general configuration of the Kansas Permian basin and is probably directly related to the environment of deposition (pl. $4 B$ ). The chert, therefore, is assumed to have formed penecontemporaneously with the enclosing rock. In the central parts of the basin, chert is common to abundant in many limestone beds. Toward the northeast margin of the basin, it occurs only in some beds, the Beattie, Wreford, and Barneston Limestones. At the edge of the platform, in western Kansas, chert is sparse, and on the platform it is absent. Locally on the platform the Foraker Limestone contains chert, but, in places, it too is barren.

Mudstone ranging from dark gray to red brown occurs at many levels. The ratio of red-brown to gray units is related to the environment of deposition. Dominantly red-brown mudstone (red brown: gray > $2: 1)$ occurs only in the western part of Kansas. Mudstone in which the ratio of red to gray is $1: 1 \mathrm{ex}$ tends over much of the central and eastern parts of the area. Gray mudstone (gray:red brown $=2: 1$ ) is dominant in the central and southeastern parts of the Kansas Permian basin (pl. $4 F$ ).

The area of dominant red-brown mudstone, for rock forming the sequence from the top of the Wreford Limestone to the top of interval A, is generally similar 
to that illustrated for interval A (pl. $4 F, G)$. In the southern and southeastern parts of the basin small isolated areas contain mudstone in which the gray to red brown ratio is $2: 1$.

In the basin area of Kansas, gray mudstone beds occur mostly between the base of the Council Grove Group and the base of the Eskridge Shale. The thickest sequence of variegated mudstone is in the Chase Group.

Thin coal beds are reported locally in the Eskridge Shale and Stearns Shale of the Council Grove Group in Lyon County (O'Connor, 1953, p. 10) and in Wabaunsee County (Mudge and Burton, 1959, p. 70). There is also a thin lens of coal in the Eskridge Shale in Morris County (Mudge and others, 1958, p. 10), and thin widespread coal beds are common in the Admire Group (Mudge and Yochelson, 1962).

In sandstone and in sandy mudstone of interval A in Kansas almost all the quartz grains are fine to very fine. Coarse-grained sandstone, some of which is arkosic, occurs in the upper part of interval $\mathbf{A}$ in Thomas County and in the lower part of the interval in Hamilton County. Most sandstone forms lenticular beds, and some fills small channels. The occurrence of sandstone in interval $\mathrm{A}$ is shown on plate $4 I$. In the Admire Group in Kansas, sandstone and sandy mudstone are widespread. In the Council Grove Group they occur only in small areas in the western part of the State. In the Chase Group they are widespread and make up as much as 50 percent of the group in western Kansas.

Arkosic sandstone is dominant near the Front Range, where it makes up the upper part of the Fountain Formation. Northward along the outcrop the upper part of the Fountain grades into the Ingleside Formation (p. 98).

\section{ENVIRONMENTS}

Strata of interval $\Lambda$ were deposited in epicontinental marine, narginal, and continental environments. Neritic deposits to the east intertongued with and overlapped deltaic and alluvial deposits to the west. Shifting environments resulted in accumulation of thick cyclical deposits, including both marine and nonmarine types in the Kansas Permian basin, extending across much of Kansas and eastern Nebraska. This basin contained many structural elements that controlled the configuration of the depositional floor ( $p$. 106). A platform area extended across parts of western Kansas, eastern Colorado, and western $\mathrm{Ne}$ braska. Other structural elements that directly influenced deposition of the facies of interval $\mathrm{A}$ in the platform and basin-margin areas are the Las Animas arch, the Apishapa-Sierra Grande uplift, the northeast Colorado Permian basin, and the Siouxana arch.

The Kansas Permian basin subsided periodically, as the cyclical deposition of carbonate and clastic rocks indicates. Predominantly detrital rock in the northern part of the outcrop area represents deposition in the shallower part of the basin, whereas carbonate rock and gray mudstone in the southern outcrop area represent deposition in somewhat deeper water. The amount of agitation on the sea floor, inferred from the character of the exposed strata, was greatest in the northern area, as is shown by abundant intraformational breccia, conglomerate, ripple-marked and crossbedded sandstone and sandy mudstone, coquinas, detrital material associated with algal structures, and biostromes (pl. $4 J$ ). The irregularity of the sea floor is emphasized by the association of coarser clastic beds with Precambrian highs and by the presence of thicker mudstone units in intervening lows across the Nemaha ridge.

Evidence of a shallow-water environment in the vicinity of three biostromes among rocks of interval A has been presented by Mudge and Yochelson (1962). A biostrome in the Funston Limestone is composed of oolites believed to be of algal origin. It is locally encrusted with algal deposits. Detrital sediments, possibly produced by wave action, were deposited locally on the flanks of the biostrome (Mudge and Burton, 1959 , p. 85-86).

The possibility of a relation between biostromes and the occurrence of oil and gas in this area has not been studied in detail. However, the principal accumulations of oil and gas are in the same area as biostromes of the Funston Limestone and the Threemile Lime. stone Member of the Wreford Limestone (pl. $4 J)$.

Fossil plants collected from the upper part of a biostrome of the Wreford Limestone in Riley County were identified by S. H. Mamay (written commun., 1959) as being typical representatives of the Late Pennsylvanian and Early Permian swamp flora. He stated that the flora "consists of forms indicative of environmental conditions closely similar to those in which the Pennsylvanian coal flora flourished.*** a mild, humid climate with little or no seasonal fluctuation." He further stated that "they show no evidence of extensive transportation" and that "they were probably transported only a short distance, from their site of growth in a coastal lowland environment into an estuarine or lagoonal situation a short distance offshore."

The fauna of interval A consists mainly of fusulinids, but it also includes a variety of pelecypods and brachiopods in the lower part. The most fossiliferous 
unit in outcrops is the Foraker Limestone. Little agitation by waves and currents occurred during the early stages of deposition of interval A (Mudge and Yochelson, 1962), and the environment must have been one of relatively shallow warm clear marine water of about normal salinity.

The environment of deposition of the variegated mudstone in the Kansas basin is uncertain. In the central part of the western Kansas basin some of the red-brown rocks of the Lower Permian may be marine (Moore, R. C., 1950, p. 9-10). Elsewhere the red beds of this interval in Kansas were probably deposited on a coastal flood plain and were the lateral equivalents of gray mudstone and limestone in the basin. The absence of fossils and the local occurrence of a few thin beds of coal with the red beds support this concept.

The upper units of interval A grade from lower beds formed under dominantly neritic conditions to upper beds deposited mainly in brackish and restrictedmarine waters. Toward the end of accumulation of interval $A$, the Kansas basin was shrinking, and shallow waters probably prevailed. The high proportion of red-brown mudstone in the upper part of the interval indicates that much of the area tributary to the basin was exposed to oxidizing processes. The climate was probably arid during deposition of this mudstone.

The platform area of eastern Colorado, western Nebraska, and southeastern Wyoming contains the Las Animas arch on its east border, the northeastern Colorado ancestral Denver basin on its northwest border, and the Apishapa-Sierra Grande uplift on its south border. Environmental conditions that controlled deposition of interval $\mathrm{A}$ differed along each of these structural elements. The east edge of the platform included a shoal area that received detritus mainly from the positive Wet Mountains-Apishapa-Sierra Grande area. Adjacent to this high area detrital sediment was deposited on deltas and flood plains, apparently in one or more small basins that were periodically separated from the Kansas basin.

In northwestern Kansas and adjacent parts of Colorado carbonate rock accumulated in relatively larger proportions than to the northeast and southwest. This carbonate rock possibly formed in a local swale that at first periodically linked the Colorado Permian basin with the Kansas basin. The swale was later obliterated by an influx of detrital sediment across the arch from the southwest, so that the whole arch area became a shoal which may have been periodically exposed to erosion.

The shallow Colorado basin is filled mostly with normal marine deposits. Its east, south, and west margins are largely made up of argillaceous limestone, whereas in the interior of the basin a higher proportion of evaporite rock occurs. The two units of interval A that contain evaporite rock are in the middle and upper parts. They are interpreted as groups of strata formed at times when the ancestral Denver basin was a restricted sea. The barrier between this basin and the Kansas basin may have resulted from structural uplift of the Las Animas arch or from sedimentation not necessarily related to uplift. In northwestern Kansas and adjacent parts of eastern Colorado, strata in the stratigraphic position of the evaporite rock of the ancestral Denver basin consist mostly of sandstone and sandy mudstone. These were derived from the southwest and very likely filled or dammed the channel between the two basins.

In north-central and southeastern Nebraska, the rocks of interval $A$ have been penetrated by few wells. Along the outcrop in southeastern Nebraska, these rocks resemble those exposed in northern Kansas. Their composition suggests that they were nearer shore than those in Kansas, but how close the original shoreline may have been is uncertain.

\section{SOURCES OF DETRITUS}

Many sources contributed detritus to the Kansas basin during accumulation of interval $A$. The principal sources for first-order sediments (derived from crystalline rocks) were to the west, southwest, and southeast. Those furnishing second-order sediments (derived from older sedimentary rock) were to the north, east, and southeast. The type of detritus and the amount contributed from any one source area apparently varied for different parts of the interval. This is partly inferred from plate $4 I$. Interval A comprises three groups of rock. In the lower group (Admire) detrital rock is widespread; in the middle group (Council Grove) it is of very limited extent; and in the upper group (Chase) it is widespread only in western Kansas.

Sandstone and sandy mudstone in the Admire Group are extensive because detritus was transported from several directions. The proportion of sandstone to mudstone and carbonate rock along the outcrop increases northward, implying a northern source for rock of the northeastern part of the basin. The fact that the percentage of sandstone is relatively small, however, indicates that either the landmass of Siouxia had low relief or streams eroding the landmass were deriving detritus from fine-grained sedimentary rock, possibly of Pennsylvanian age. A fine-grained-rock source would account for the fine size of detritus in interval $\mathrm{A}$ and for the similarity in composition of 
sandstone and sandy mudstone in this interval to that of Pennsylvanian rocks (Mudge, 1956, p. 659).

Much of the sediment in southeastern Kansas was probably derived from the south and southwest, as suggested by R. C. Moore (1931, p. 255) and substantiated by data compiled in this paper for Oklahoma (p. 88). Sources of sediment deposited in the western part of the Kansas Permian basin lay to the southwest, west, and northwest; these source areas included the Wet Mountains, ancestral Rocky Mountains, and the Apishapa-Sierra Grande uplift area of southeastern Colorado. The presence of coarse-grained arkose in southwestern Kansas and eastern Colorado suggests that at least part, if not all, of the Apishapa-Wet Mountains positive area was fairly high.

Sandstone and sandy mudstone are of small extent in the Council Grove Group. In contrast, chert-bearing limestone (Foraker), noncherty marine limestone, and gray mudstone are more widespread than they are in the groups above and below. Sources of the detritus in this group were therefore low-lying areas. The only sand deposited was near the source, which was to the southwest.

The Chase Group contains thick widespread sandstone in western Kansas. This group is dominantly mudstone in northern and eastern Kansas (pl. 4C). A western and southwestern source area is suggested by an increase in the proportion of detrital rock, some of which in western Kansas is coarse grained.

Sandstone in the upper half of the Council Grove Group and in the Chase Group along the Las Animas arch was probably derived from the southwest. In the area of the present Raton basin in south-central Colorado, nonmarine red arkosic sandstone and interbedded mudstone were supplied from the Apishapa uplift to the north and from the Sangre de Cristo Range and Wet Mountains to the west.

\section{PALEOTECTONIC IMPLICATIONS}

Structural elements in Kansas that affected deposition of interval A are summarized by Wallace Lee $(1956$, p. 12$)$ as follows:

A third period of deformation began early in Mississippian time, culminated at the end of Mississippian time, and continued with decreasing emphasis until middle Permian time. The most conspicuous structural feature of this period was the Nemaha anticline, which divided the older North Kansas basin, giving rise to the Forest City basin on the east and the Salina basin on the west. The Central Kansas uplift and the Hugoton embayment attained their maximum development during this period. Arching of the central Kansas uplift ceased with the downwarping of the salt basin in Wellington time.

The position of the Nemaha anticline is apparent on the isopach and lithofacies maps of northeastern
Kansas where a narrow band of exposed Pennsylvanian rock lies between a Permian outlier and the main area of Permian rock (fig. 34). This pattern is a result of post-Cretaceous erosion.

In southeastern Kansas local thickening of interval A reflects an early origin of part of the Sedgwick basin.

In northern and central Kansas general thinning of the interval indicates that the southern part of the Cambridge arch and the central Kansas uplift existed early in Permian time. An irregular area of small highs and lows is inferred from thicknesses determined along the central Kansas uplift. This agrees in part with the structural interpretation in reports by Wallace Lee (1956, p. 12) and by Lee and Merriam (1954). In Saline and eastern Ellsworth Counties a local area of thickening may represent an initial stage in growth of the Salina basin (Lee, 1956, pl. 9, p. 151-152).

The Kansas basin (fig. 34) seems to have intermittently subsided during interval A time. The largest volumes of sediment accumulated in the south-central part of the State.

In southwestern Kansas subsidence of the ancestral Hugoton embayment is indicated by thickening of interval $\mathrm{A}$.

In eastern Colorado the ancestral Las Animas arch was active and influenced sedimentation during much of Permian time (Rich, J. L., 1921). This arch "appears to have been accentuated by minor structural adjustments throughout late Pennsylvanian and most of Permian time" (Maher, 1945, p. 1665). Interval A thins only along the southern part of the Las Animas arch, from southwestern Nebraska into southeastern Colorado. A lithofacies belt, on the other hand, occurs along the entire arch and shows that the element influenced deposition throughout its extent.

The Apishapa-Sierra Grande uplift in southeastern Colorado was probably a nearly stable low area which shed only moderate amounts of arkosic sand during the early part of interval $\mathrm{A}$. The Wet Mountains area, in contrast, was high, as it contributed much coarse arkosic sediment. An abrupt lateral change in the thickness of interval A in the southeastern part of the State (fig. 34) may reflect rapid uplift of the ApishapaSierra Grande area during accumulation of the upper part of the interval.

Deep erosion of the Apishapa-Sierra Grande positive area is indicated by removal of part of the older Paleozoic rocks there (I-450, pl. 2; Maher and Collins, 1952, secs. $\mathrm{A}-\mathrm{C}$ ), but the north and northeast side may have been downfaulted (Buehler, 1947). If there was faulting, the last displacement was presumably before the end of deposition of the interval, as the uppermost 


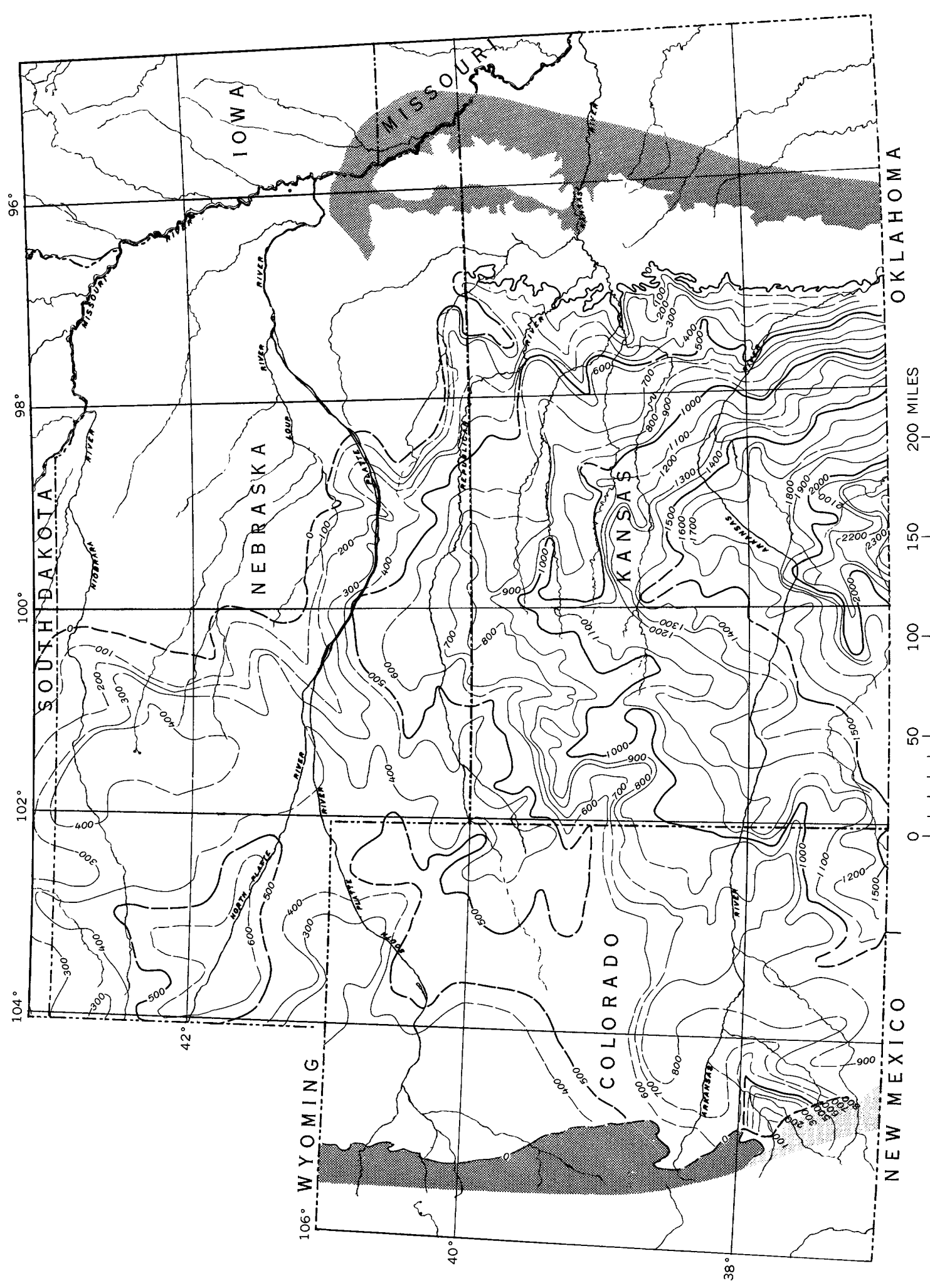




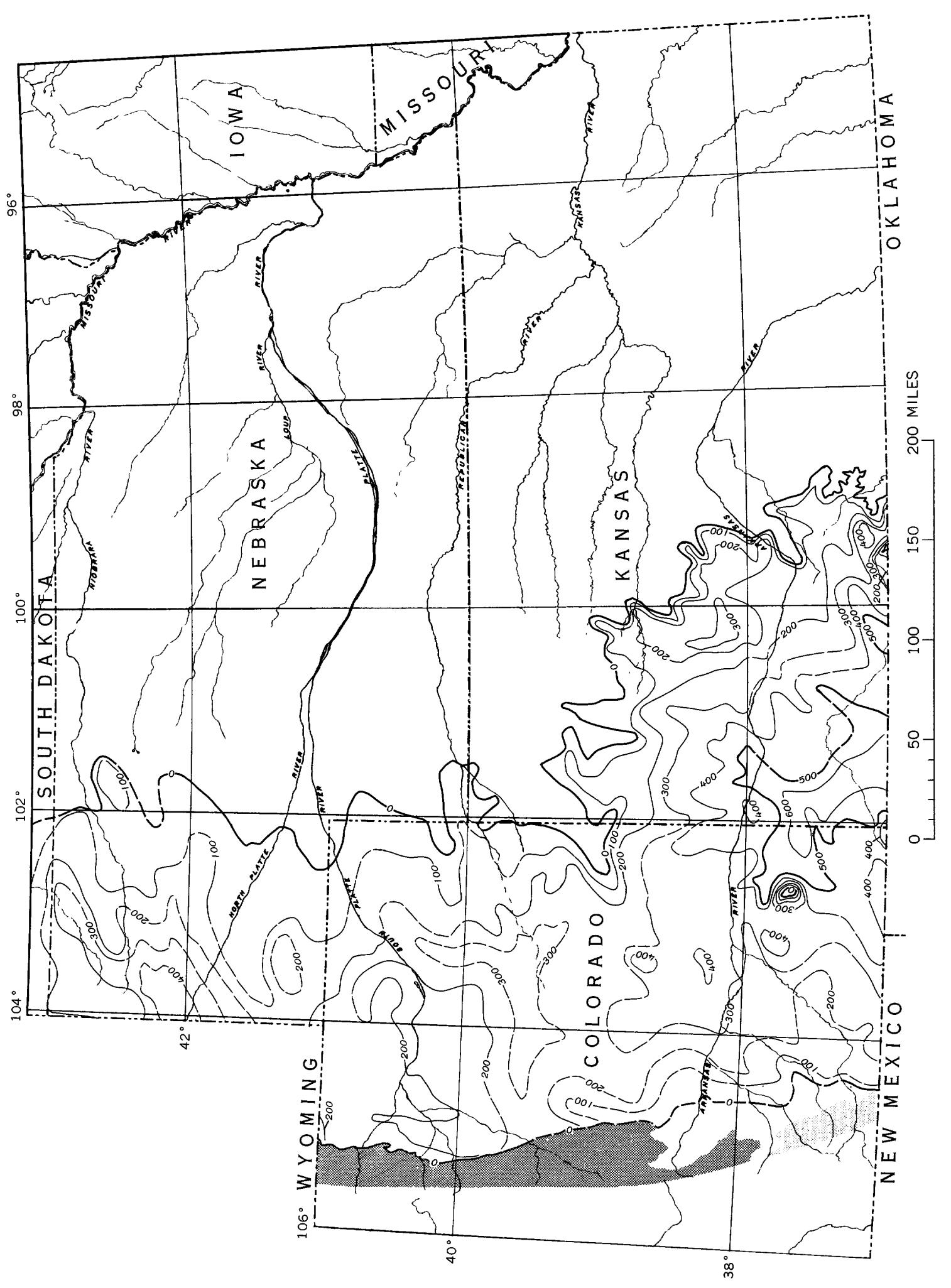

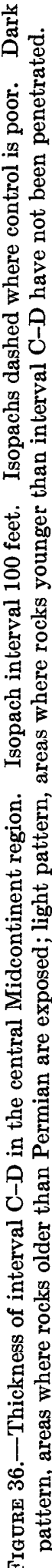


rock of interval $A$ and also that of intervals $B$ and C-D overlap the uplift, without any displacement (Maher and Collins, 1952, secs. A-C; figs. 34-36, this paper).

In northeastern Colorado and western Nebraska isopach trends do not indicate the ancestral DenverJulesburg basin, whose presence is suggested by facies in that area. Apparently the basin was relatively broad, shallow, and stable during much of the interval.

\section{INTERVAL B}

\section{FORMATIONS INCLUDED}

Three sequences of formations are represented in interval $\mathrm{B}$ in the central Midcontinent region. In Kansas, easternmost Colorado, and most of Nebraska, the formations are those listed for the Leonard Series by Moore, R. C., Frye, and others (1951, p. 38-41). Interval $\mathrm{B}$ in east-central Colorado, east of the Front Range and south toward the New Mexico line, is composed of the Lyons Sandstone and the basal part of the Lykins Formation as defined by LeRoy (1946). The interval in north-central Colorado and western Nebraska consists of the Owl Canyon Formation of the Cassa Group as described by Condra, Reed, and Scherer (1940) or the lower part of the Satanka Shale of Maughan and Wilson (1960).

In Kansas the subdivisions of interval $B$ recognized in most subsurface sections are, in ascending order, the Wellington Formation, Ninnescah Shale, Stone Corral Formation, undifferentiated units between Stone Corral and Blaine Formations, and Blaine Formation and Dog Creek Shale undifferentiated.

In much of Kansas the lower part of the Wellington Formation is largely red anhydritic mudstone interbedded with anhydrite. The middle part of this unit is mostly red mudstone, anhydrite, and salt, termed the "salt section," and is the thickest and most widespread salt-bearing unit in Kansas. The distribution of salt-bearing strata of the Wellington Formation (fig. 37) suggests the shape but does not indicate the full extent of the Kansas Permian depositional basin. The east edge of the salt originally extended farther eastward but has been removed by erosion. The upper part of the Wellington is mostly gray anhydritic mudstone interbedded with red mudstone.

The Ninnescah Shale is mainly red anhydritic mudstone which, in part of northwestern Kansas, contains sandstone and sandy mudstone. Locally, as in southcentral and western Kansas, salt-bearing units are interbedded with anhydrite and mudstone in the upper part of the formation (fig. 38). The Ninnescah is as much as 270 feet thick.

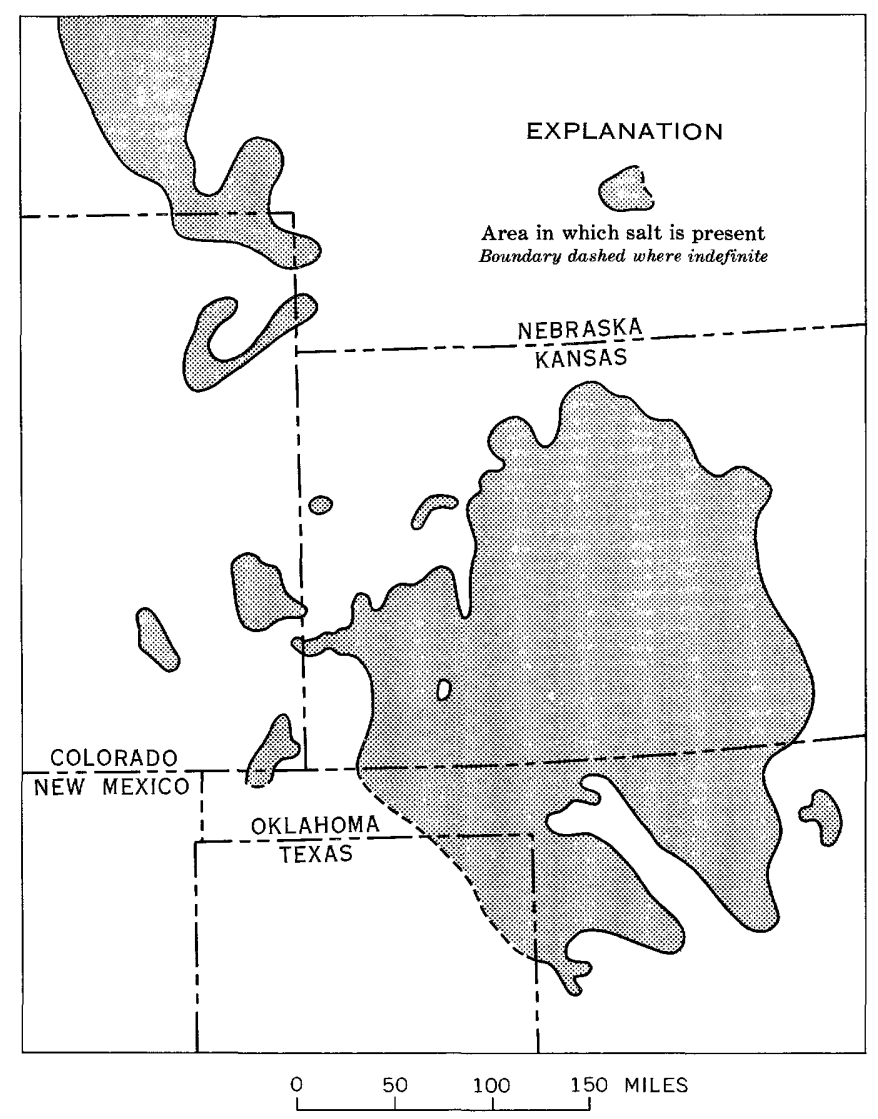

Figure 37.-Distribution of salt of Wellington age in Kansas and adjacent areas.

The Stone Corral Formation is the most conspicuous layer in the subsurface Permian of Kansas. Along the outcrop it is dolomite with dolomitic mudstone (Merriam, 1957, p. 268, 269; Swineford, 1955, p. 47), but a short distance downdip in the subsurface it is almost entirely anhydrite. In southern Kansas it is largely anhydritic or dolomitic mudstone; farther west it is dolomitic mudstone to pure anhydrite but locally includes a dolomite bed; in the southwest it consists of two beds of anhydrite separated by red mudstone (Merriam, 1957, p. 268, 269). This formation is 6100 feet thick (Merriam, 1957, p. 274).

A minor disconformity has been recorded at the top of the Stone Corral (Norton, 1939, p. 1774; Maher, 1946, 1947, 1948; Collins, 1947). The base of the Stone Corral was also interpreted as a disconformity by Norton, but not by Maher (1946), Collins (1947), and Wallace Lee (1949).

In subsurface, rocks between the Stone Corral and the Blaine differ lithologically. The lower strata (possibly the Harper Siltstone and Salt Plain Formation) consist mainly of red mudstone, in part sandy. The upper strata (possibly the Cedar Hills Sandstone and Flowerpot Shale) generally consist of red mudstone 


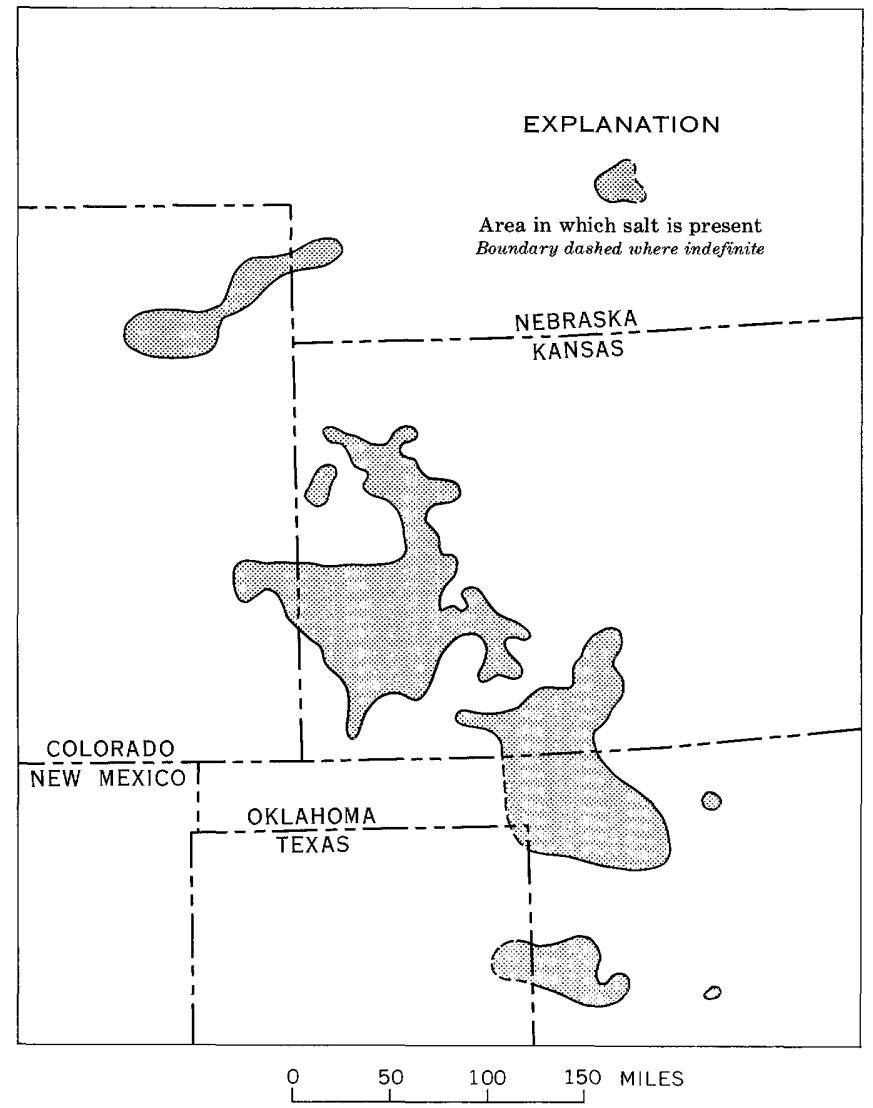

Figure 38.-Distribution of salt of Ninnescah age in Kansas and adjacent areas.

and many beds of sandstone and sandy mudstone. In the north-central part of the State most of the upper strata consist of sandstone and sandy mudstone; some of the sandstone is very coarse. The sandstone seems to lie disconformably on the mudstone, and it may be a channel fill; elsewhere it is probably conformable.

Locally in western and southwestern Kansas as much as 300 feet of strata beneath the Blaine Formation (fig. 39) consists of salt interbedded with anhydrite and mudstone.

The Blaine Formation is easily recognized throughout the subsurface of Kansas, easternmost Colorado, and parts of western Nebraska. The overlying Dog Creek Shale is combined here with the Blaine Formation, as the two units are not easily distinguished in subsurface sections. In northern Kansas and central Nebraska these units are absent, possibly because of pre-.Jurassic erosion.

In Kansas the Blaine Formation is composed mostly of gypsum and anhydrite (Kulstad and others, 1956, p. 23). The outcropping Blaine also contains beds of dolomite and red mudstone, and it is overlain by maroon silty mudstone, dolomite, and dolomitic siltstone of the Dog Creek Shale (Swineford, 1955, p. 91).
In subsurface the Blaine is dominantly evaporite rock with some thin interbedded red mudstone (Collins, 1947; Maher, 1947; Lee, Wallace, 1953; and Edson, 1947).

The names applied to Permian rocks in easternmost Colorado are the same as those applied in Kansas, but many of the formations cannot be differentiated. Rocks correlated with the Wellington and Ninnescah consist mainly of red mudstone, in places interbedded with sandy mudstone and sandstone. Locally in the northeastern and southeastern parts of the State the upper and lower parts of this unit contain salt beds and mudstone with salt casts, interstratified with thick beds of red mudstone and thin beds of anhydrite. These rocks are assigned to the Sumner Group in the southeast.

Near the Front Range in east-central Colorado, sandstone equivalent to the Wellington and Ninnescah Formations is included in the upper part of the Fountain Formation. It is arkosic, and much is very coarse, even conglomeratic. The coarse beds seem to grade eastward, first into fine-grained sandstone, and then into sandy mudstone and mudstone of easternmost Colorado (I-450, pl. 4).

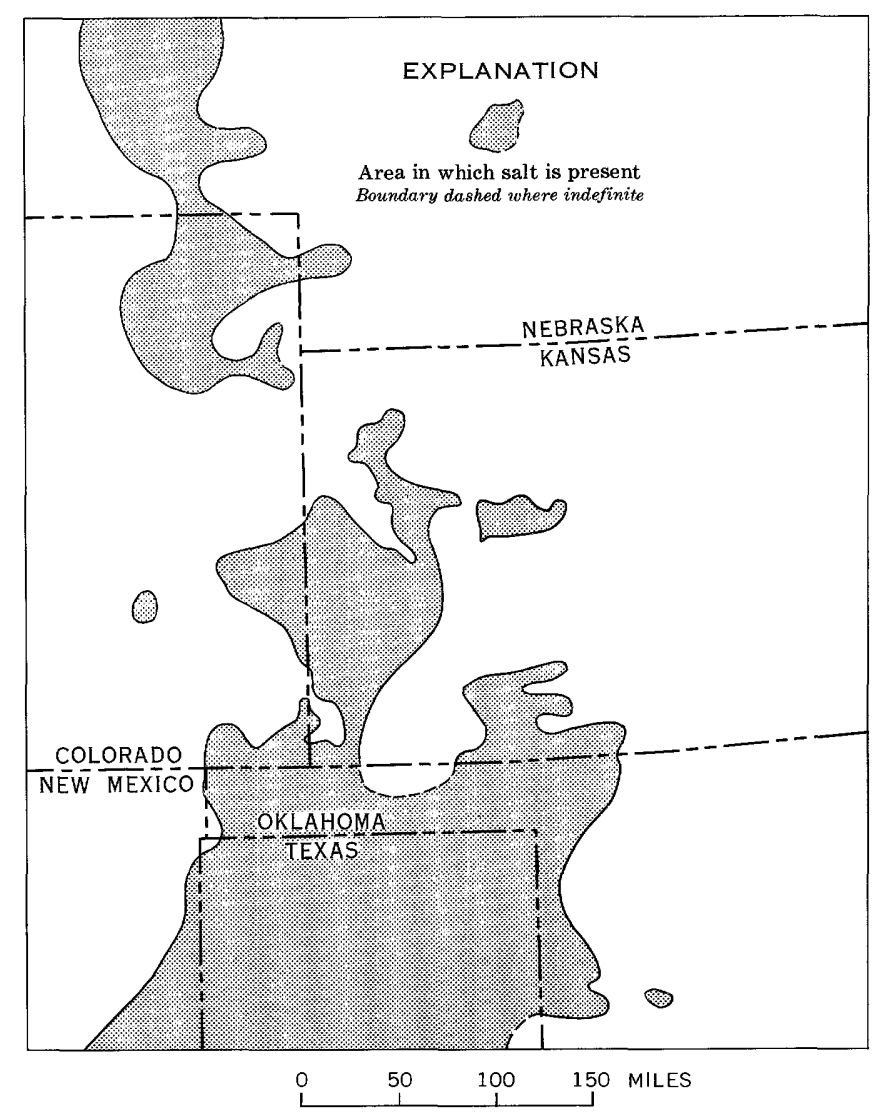

Figure 39.-Distribution of salt of Nippewalla age in Kansas and adjacent areas. 
The maximum western extent of the Stone Corral Formation follows a line extending from east-central Las Animas County northward through western Otero and western Kiowa Counties, western Kit Carson and eastern Washington Counties, and northeastward through the central parts of Phillips and Sedgwick Counties. West of this line a few subsurface sections contain beds of anhydrite or dolomite that may be equivalent to the Stone Corral. This dolomite has been correlated with the contact limestone at or near the top of the Fountain Formation along the Front Range (Maher, 1953, p. 921; 1958, p. 72). In most sample logs from eastern Colorado it is recorded as mostly anhydrite, but it contains thin beds of dolomite and locally consists entirely of dolomite.

Where the Stone Corral is absent in the southeastern part of Colorado, its stratigraphic position is tentatively placed below an arkosic sandstone that in many places is conglomeratic (I-450, pl. 16). This sandstone underlies fine- to medium-grained orange sandstone called the Lyons Sandstone in reports by Maher and Collins (1952) and Maher (1958, p. 72, figs. 13, 14).

In easternmost Colorado the interval from the top of the Stone Corral to the top of the Blaine is in the Nippewalla Group (Maher and Collins, 1952; Maher, 1958 , p. 72-73; Collins, 1947). It is mostly red mudstone interbedded with sandstone, sandy mudstone, and anhydrite. Locally in northeastern and southeastern Colorado the upper part of this group contains interbedded salt and anhydrite (I-450, pl. 4; fig. 39, this paper).

In most of Kiowa and Crowley Counties and much of northeastern Colorado a major anhydrite unit lies near the middle of the Nippewalla Group. On electric logs this "stray" anhydrite leaves a record similar to that of the Blaine. In Hamilton County, Kans., and part of Kiowa County, Colo., a "salt section" between the "stray" anhydrite and the Blaine forms a distinctive electric-log unit (A. E. Dufford, oral commun., 1956).

In east-central Colorado, sandstone and sandy mudstone constitute much of interval $B$ below the Minnekahta Limestone or the Lykins Formation. Along part of the Front Range, sandstone beds between the base of the Lykins and the top of the Fountain Formation are called the Lyons Sandstone (Fenneman, 1905, p. 58-59). The Lyons Sandstone at its type locality is about 370 feet thick (Thompson, W. O., 1949, p. 54), consists almost entirely of well-sorted subangular quartz grains, and is distinctively crossbedded; it contains some channels, minute swash marks, rhomboid ripple marks, and possible bubble impressions or rain prints (Thompson, W. O., 1949, p. 59-63).

The contact of the Lyons Formation with the underlying Fountain Formation is sharp and is probably an unconformity (Van Horn, 1957). Crossbedding in both formations makes it difficult to determine whether a widespread disconformity exists (Van Horn, oral commun., 1959).

The Lyons crops out northward from just south of Colorado Springs; it thins and wedges out near the Wyoming line (Thompson, W. O., and Kirby, 1940, p. 143; Maughan and Wilson, 1960, p. 37-38). Similarly it wedges out in the subsurface eastward from the outcrop to a point in eastern Morgan County. It has been correlated with the "creamy sandstone" a few miles south of Colorado Springs (Thompson, W. O., 1949 , p. 53-54).

Two distinct sandstone units in the subsurface in southeastern Colorado have been considered stratigraphically equivalent to the Lyons (I-450, pl. 14; Maher and Collins, 1952; Maher, 1958, p. 73, figs. 13-15). The lower is orange to orange-red fine- to medium-grained sandstone that locally contains interbedded red mudstone and some arkose. The upper unit is pink to white, light-yellow, or light-orange, fine- to medium-grained sandstone that contains some coarse grains and locally near its base, conglomerate, but no arkose. Only the upper sandstone unit is correlated with the Lyons Sandstone in this paper. A north-trending geologic cross section from Las Animas through Otero, Crowley, Lincoln, Elbert, Adams, and Weld Counties indicates that the upper sandstone may be continuous with the Lyons, and the lower sandstone with the sandy mudstone and sandstone beds beneath the Lyons. The generally northwest trend of the lower sandstone unit suggests that it, rather than the upper sandstone unit, may be equivalent to the "creamy sandstone" of the Colorado Springs area.

In much of northeastern Colorado where the Lyons Sandstone is thin or absent the section from the top of interval A to the base of the Minnekahta constitutes the lower part of the Satanka Formation (Maughan and Wilson, 1960), or Owl Canyon Formation (Condra and others, 1940, p. 6). Its rocks generally consist of red mudstone in the lower part, and sandy mudstone and sandstone, interbedded with red mudstone, in the upper part. Along the Front Range the Satanka, or Owl Canyon, contains much sandstone (Condra and others, 1940, p. 6).

In southeastern Colorado a relatively widespread unconformity occurs at the base of the lower sandstone unit of the Lyons Sandstone (Maher and Collins, 1952). At and near the Apishapa uplift this uncon- 
formity appears to truncate the underlying units at a low angle, cutting to and even through the Stone Corral Formation. Other small disconformities probably occur between the lower sandstone unit and the Stone Corral (I-450, pl. 16), but they can be recognized only near positive areas, and their areal extent is not known ( $\mathrm{I}-450$, pl. 16).

The Dog Creek Shale and Blaine Formation or equivalent rock (uppermost units of interval B) are recognized in most boreholes in eastern Colorado but are absent near the Wet Mountain and Apishapa uplifts. The formation includes one or more beds of anhydrite, generally with interbedded red mudstone, and locally it contains thin dolomite at either the top or base, or it consists entirely of dolomite.

In the subsurface east of the Front Range the lowest anhydrite in the Lykins Formation, the lower limestone of the Harriman Shale Member of LeRoy (1946, p. 32), is correlated with the Blaine Formation to the east. This unit extends northward to northeastern Colorado and southern and eastern Wyoming, where it is correlated with outcropping Minnekahta Limestone (p. 140). This correlation places the Blaine slightly lower in the section than does that of Fentress and others $(1958, \operatorname{logs} 4-6)$.

In westernmost Nebraska, rocks equivalent to the Wellington Formation of Kansas are thin or absent (Reed, 1955; Juilfs, 1953). Here strata correlative with the Ninnescah are part of the Cassa Group of Condra, Reed, and Scherer (1940, p. 45). These strata are red sandy mudstone containing some interbedded sandstone. The proportion of sand increases toward the Black Hills. In the northernmost part of Nebraska and in adjacent parts of South Dakota the basal unit of this formation contains very coarse grained conglomeratic sandstone.

The Stone Corral Formation is everywhere recognized in the subsurface except in the westernmost part of Nebraska and in northeastern Colorado, near where it has apparently wedged out. It consists mainly of beds of anhydrite a few feet to 50 feet thick.

Mudstone between the Stone Corral and the Minnekahta Formations is called the Opeche Shale in western Nebraska (Condra and others, 1940, p. 40; Reed, $1955)$. It is dominantly a red mudstone that is locally sandy and contains many beds of sandstone. Where the Stone Corral is absent, rocks of the Opeche cannot easily be separated from those of the Cassa Group. In the central part of westernmost Nebraska the upper part of the section is composed of the Opeche Shale and the Cassa Group and contains as much as 75 feet of salt and anhydrite.
The Minnekahta Limestone is the uppermost unit of interval B in westernmost Nebraska. In sample logs this formation is recorded as all limestone, or all dolomite, or limestone with interbedded dolomite. The Minnekahta may correlate southward and southeastward with the upper part of the Blaine Formation, and part of the Minnekahta may correlate with the anhydrite beds of the Dog Creek Shale which overlie the Blaine.

In northwestern Nebraska and near the South Dakota line the Minnekahta Limestone is 50-100 feet thick. It grades southward from limestone into a sequence of thin dolomite beds separated by thicker red mudstone beds. The proportion of anhydrite also increases southward.

\section{UPPER BOUNDARY OF INTERVAL B}

The upper boundary of interval $B$ in the central Midcontinent region is the top of the Dog Creek Shale, which generally cannot be distinguished from the Blaine Formation in sample and electric logs.

The contact of interval $B$ with interval $C-D$ is regarded by many as conformable (Lee, Wallace, 1953; Collins, 1947; Maher, 1946, 1947), but others believe that it represents a major unconformity (Norton, 1939, p. 1802-1803). In two small areas in Kansas-in southern Lane County (loc. 898, I-450, pl. 1) and in northeastern Finney County (loc. 893) the evaporite units of the Blaine Formation are missing, probably because of wedging out rather than erosion, as no unconformity is apparent. Correlation with nearby wells indicates thinning of the Blaine in adjacent areas. A red and gray fine- to coarse-grained angular to subrounded sandstone at localities 893 and 898 (I-450, pl. 1) occupies the stratigraphic position of the Blaine, but this sandstone is equivalent to the Nippewalla at localities 449 and 487.

In eastern Colorado no unconformity is known between intervals $\mathrm{B}$ and $\mathrm{C}-\mathrm{D}$ (Maher and Collins, 1952; Fentress and others, 1958), but the author believes that there may be a local disconformity near the Wet Mountain and Apishapa areas. In Las Animas and Huerfano Counties and part of Pueblo County, the Blaine Formation and some of the underlying beds seem to have been truncated. Across the Apishapa uplift most of the Permian beneath the base of the interval $\mathrm{C}-\mathrm{D}$ is absent.

The contact between intervals $\mathrm{C}-\mathrm{D}$ and $\mathrm{B}$ in $\mathrm{Ne}$ braska coincides with the top of the Minnekahta Limestone and is probably conformable (E. C. Reed and J. D. Juilfs, Nebraska Geol. Survey unpub. repts., 1955, 1953). 


\section{THICKNESS TRENDS}

In eastern and northern Kansas and much of Nebraska, interval $\mathrm{B}$ isopach trends (fig. 35) are partly controlled by the effects of post-Permian erosion $(\mathrm{I}-450$, pls. 5,10$)$. In eastern Colorado, central and southwestern Kansas and westernmost Nebraska, interval $B$ has not been subject to erosion and isopachs indicate the original thickness.

Interval B thickens from 350 to 2,400 feet from northwestern to south-central Kansas, a greater variation than in interval A (p. 101). A northwesttrending belt of thickening in the south-central part of the State parallels the west side of the central Kansas uplift and may be the axial trend of a basin that existed during interval B. In the central part of western Kansas, a south-trending belt of thinning nearly coincides with the present axis of the Selden anticline. Farther west interval $B$ thickens into the Hugoton embayment.

In northeastern Colorado interval B is of relatively uniform thickness. Farther south the interval thickens southeastward from 250 to 1,265 feet (fig. 35). As in Kansas, the variation is greater than in interval A. In this part of Colorado and nearby Kansas and Nebraska, the interval thins near the axis of the Las Animas arch, which in Permian time may have been a hinge line where strata began to thicken eastward.

In Nebraska, rocks of interval B thin from 750 feet along the Kansas border to an edge beveled by by Post-Permian erosion in the east-central part.

In southwestern Nebraska, adjacent to Colorado and Kansas, the rocks thin northeastward near the present axis of the Las Animas arch.

\section{IITHOFACIES TRENDS}

The apparent lithofacies pattern of interval $B$ shown on plate 4 of $I-450$ in central and northwestern Kansas and all Nebraska except the Panhandle results from post-Permian erosion at various times during the Mesozoic and Cenozoic.

In Kansas interval B consists of mudstone and some salt and anhydrite; the greatest proportion of evaporite rocks is in the Wellington Formation. This facies pattern closely coincides with the distribution of salt of the Wellington and Ninnescah Formations and is seemingly inherited from the dominant carbonate facies of interval A. Adjoining the salt basin, interval $\mathrm{B}$ comprises mudstone and some bedded evaporites.

Areas in which mudstone and some sandstone and anhydrite are present are scattered through western and central Kansas. This distribution reflects an abundance of sandstone between the Stone Corral and the Blaine Formations. Along the eastern outcrop area in Kansas the facies is dominantly mudstone. According to Wallace Lee $(1956$, p. 116$)$ the evaporite beds "normally crop out in a belt trending south from Osage and Saline Counties, but *** have been dissolved by surface waters for a distance of 20 to 30 miles down dip."

In northwestern Kansas and nearby Colorado, lithofacies range from dominant sandstone, which increases westward, to dominant anhydritic mudstone.

In Nebraska interval B consists mostly of detrital rock ranging from sandstone to mudstone ( $\mathrm{I}-450$, pl. 4); westward, however, anhydrite with included salt in the upper part alters the lithofacies pattern. In northwestern Cherry County sandstone is abundant, and the lower part of the interval is conglomerate.

\section{SOURCES AND ENVIRONMENTS}

The sediment of interval $B$ came from several sources but mainly from two (I-450, pls. 4, 10A). One was on the west near the present Front Range and included the Wet Mountains, which supplied most of the feldspathic debris (Swineford, 1955, p. 164). The Wet Mountains probably contributed a major part of the detritus. Parts of the Apishapa and Sierra Grande uplifts and of the ancestral Front Range were positive areas during much of interval $\mathrm{B}$ time and also contributed some sediment. A second source was the Siouxia landmass, north and northeast of the Kansas basin, which contributed finer material than the Colorado sources.

Some of the feldspathic detritus in interval B may have come from the south. Large rounded quartz and chert grains scattered in finer sediments in the upper part of the interval were derived from isolated mountain uplifts to the south within the basin according to Swineford (1955, p. 164-166). She further stated that the coarseness of these sandstones increases markedly into Oklahoma, that the large quartz and chert grains are typical of second-cycle orthoquartzites, and that the silicic detritus seems to have been the product of erosion of Cambro-Ordovician rocks.

The several depositional environments recorded by rocks of interval $B$ in the central Midcontinent region were controlled by structural features.

In the Kansas depositional basin alternating openmarine, brackish-water, and continental environments of the latest interval $A$ persisted into early interval B (Wellington Formation and Ninnescah Shale). The environment later changed to dominantly nonmarine or brackish-water; during many brief intervals restricted-marine conditions prevailed. 
The basin was only periodically connected with the open sea. During deposition of the Stone Corral Formation (mainly evaporite), marine waters covered Kansas, much of eastern Colorado, and southern $\mathrm{Ne}$ braska.

Following accumulation of the Stone Corral Formation much of the region was a broad alluvial flat, but brackish-water conditions may have prevailed in the Kansas Permian basin; waters from a southern encroaching sea may have locally affected the sediments (Harper Siltstone, Salt Plain Formation, and $\mathrm{Cedar} \mathrm{Hill}_{s}$ Formation). Conditions apparently fluctuated many times between continental and coastal. Abundant sandstone in north-central Kansas may be marine coastal, stream, or wind deposits. With only subsurface data to draw on, primary structures in these rocks are not recognizable.

In the latter part of interval B time (Blaine), restricted-marine conditions developed locally and possibly alternated with brackish-water and alluvialflat environments that gradually became widespread. Interval B thus records two major cycles of deposition and many small cycles. One major cycle is recorded by rocks that extend from the top of interval $A$ to the top of the Stone Corral Formation; the second, by rocks that extend from the top of the Stone Corral through the Blaine and Dog Creek Formations. Each cycle closed with prolonged and widespread deposition under restricted-marine conditions.

Interval $B$ environments in the platform area of easternmost Colorado and westernmost Kansas are relatively unknown. Along the Las Animas arch, sediments were probably deposited under deltaic conditions, which were periodically replaced by openmarine, closed-marine, or alluvial-flat enviroments. Part of the sandstone may have been deposited by wind. Restricted-marine conditions existed during accumulation of the Stone Corral and Blaine Formations. Between the times represented by these formations, many small areas received restricted-marine deposits.

Extensive deltas formed in east-central and northeastern Colorado during interval B time. Alluvialflats and small restricted marine basins, however, were probably also formed during the early part of the interval.

The lower part of the Lyons Sandstone near the type section along the Front Range may have been deposited on a beach; the upper part was probably formed by the wind (R. F. Wilson, oral commun., 1959). The presence farther south of coarse arkosic sandstone lenses indicates periodic stream deposition that alternated with dune accumulations. The dunes are inferred to have trended southeastward from the type area, parallel to the seashore. After deposition of the Lyons Sandstone, nonmarine and restrictedmarine environments, like those represented by the Blaine and Dog Creek in Kansas, alternately prevailed.

Environmental conditions were uniform over large areas of Nebraska. A large delta covered much of the area and was succeeded in the north by a flood plain. In the western part of the State, deposition in the ancestral Julesburg basin (Osterwald and Dean, 1958) was mainly under restricted-marine conditions alternating with brackish-water and floodplain environments. The upper part of interval $B$, the Minnekahta Limestone, was deposited in normal marine waters.

Environments of interval B in southern Nebraska, as in northern Kansas, were alternating nonmarine, brackish water, and restricted marine, followed by normal marine, and possible beach, eolian, and stream.

\section{PALEOTECTONIC IMPLICATIONS}

Many of the tectonic elements that controlled deposition of interval A persisted through the time of interval $\mathrm{B}$, and some new structural features also formed during interval $\mathrm{B}$ (figs. 35, 41).

In Kansas a major depositional basin formed. The volume of sediment it received was considerably greater than that of interval $\mathbf{A}$. The area actively subsided during the interval, and a restricted-marine embayment was formed. Rocks of interval $B$ are thick over the central Kansas uplift; this indicates that at that time the entire region was part of the Kansas basin. The Selden anticline, west of the Kansas basin, is marked by thinning of interval B rocks toward the south; the anticline originally extended farther into southern Kansas (Merriam, 1958, fig. 1). West of the anticline the north-trending Hugoton embayment originally extended considerably farther north.

In southwestern Nebraska and adjacent Kansas and Colorado the Las Animas arch persisted as a major structural feature, but farther south in eastcentral Colorado it was not pronounced, although its position is indicated by a break from the relatively uniform platform into the basin on the east.

The low swale between the Kansas and Colorado basins of interval A persisted into interval B (fig. 35). It is shown by a southeast-trending belt of thinning that bends southward in Kansas into an ancient anticline west of the Hugoton embayment. 
In southeastern Colorado the Apishapa uplift was overlapped by progressively younger units of interval $\mathrm{B}$, and toward the end of the interval it was completely covered. Across the Apishapa-Sierra Grande area, from Prowers County to the present mountain front, six folds formed during interval B. The westernmost syncline today forms the Raton basin. Here, isopach trends may reflect erosion that occurred at many times during the interval.

\section{INTERVAL C-D FORMATIONS INCLUDED}

Rocks of interval C-D in Kansas, Nebraska, and eastern. Colorado have been given different sets of names according to area. The classification that has been established in Kansas (Moore, R. C., Frye, and others, 1951, p 37-38) has been extended into eastern Colorado (Maher and Collins, 1952; Maher, 1946, 1947, 1948; Collins, 1947; Fentress and others, 1958). Another set of names is used along the Front Range in northern Colorado, near Denver and Boulder (LeRoy, 1946, p. 30-42). A classification used farther north along the Front Range combines terminology from Colorado, Wyoming, and the Black Hills (Lee, W. T., 1927, p. 10-12 ; Condra and others, 1940, p. 6; Maughan and Wilson, 1960). Still another classification is used in western Nebraska (Condra and others, 1940).

Formations of interval C-D in Kansas and easternmost Colorado are, in ascending order, the Whitehorse Sandstone, Day Creek Dolomite, and Taloga Formation. On the outcrop the Whitehorse Sandstone consists of about 270 feet of very fine grained red sandstone and siltstone, and includes some mudstone and dolomite (Swineford, 1955, p. 92.) In subsurface it is mostly red mudstone, red sandy mudstone, and red sandstone, with a few thin beds of buff dolomite (Maher, 1947, p. 3; 1946, p. 2; Maher and Collins, 1952), and, in southeastern Colorado, of evaporite (Maher and Collins, 1952; I-450, pl. 5).

The Day Creek Dolomite is equivalent to the Forelle Limestone (Maher, 1954, p. 2234) and the Glennon Limestone Member (LeRoy, 1946) of the Lykins Formation. It occur's everywhere along the Front Range in eastern Colorado except in the Raton basin, near the Apishapa uplift and Wet Mountains, and in the Canon City embayment. Like the Blaine and the Stone Corral Formations of interval B, the Day Creek is a widely traceable subsurface marker.

The Day Creek Dolomite in Kansas is uniformly thin in outcrop but thickens in the subsurface to as much as 120 feet (Swineford, 1955, p. 92). It is entirely composed of anhydrite in some wells but com- prises two brown or pink dolomite beds separated by red mudstone or anhydrite in others; in places it consists of thin-bedded anhydrite and red mudstone (Maher, 1947, p. 3). Where thickest, in northeastern Morton County, it is mostly made up of anhydrite (Maher and Collins, 1952, sheet 3).

The Taloga Formation is red sandy mudstone, fine red silty sandstone, and thin beds of anhydrite and dolomite (Maher, 1946, p. 3; 1947, p. 3).

Farther west, in eastern and southeastern Colorado, the Whitehorse Sandstone is principally red mudstone, siltstone, and sandstone (Maher and Collins, 1952) but includes thin beds of dolomite and evaporite rocks. The Day Creek Dolomite is mainly dolomite but in places is partly or wholly anhydrite. The Taloga Formation in the subsurface is primarily red mudstone, siltstone, and fine-grained sandstone (Maher and Collins, 1952). Where exposed in a few places in Baca County it is red to yellowish-brown or buff mudstone, siltstone, sandy mudstone, and a few thin beds of hard sandstone (McLaughlin, 1954, p. 81 ).

Along the Front Range and in the subsurface in northeastern Colorado interval C-D forms approximately the lower half of the Lykins Formation and includes all the Harriman Shale Member except the lower limestone and mudstone beds, which are placed in interval B. It also includes the Falcon Limestone Nember, the Bergen Shale Member, the Glennon Limestone Member, and the lower part of the Strain Shale Member. The upper contact of the interval which is the top of the Permian of this area, is within the Strain Shale Member.

In outcrops along the Front Range, rocks of interval C-D are mostly red mudstone with two or more widespread thin beds of limestone in the lower part and locally thin beds of very fine grained sandstone and lentils of dolomite, limestone, and anhydrite higher up. Many of the limestone beds contain conspicuously distorted wavy laminae (LeRoy, 1946, p. 30-42; Van Horn, 1957).

In the subsurface just east of the Front Range the interval is much like that on the outcrop but includes more beds of dolomite and anhydrite. Many of the anhydrite beds are associated with or underlie dolomite beds that are laterally equivalent to limestone beds of the outcrop. The absence of anhydrite and other evaporites along the Front Range may result from leaching or from flowage shortly after deposition. These processes may have caused distortion of the laminae in many of the limestone beds, thinning of outcrop sections compared with nearby thicker 
subsurface sections, and local presence of breccia in some limestone outcrops.

In most of Nebraska, interval $\mathrm{C}-\mathrm{D}$ has been removed by post-Permian erosion. It wedges westward, and its original sequence is preserved in only a few places. Where complete, the interval consists of rocks equivalent to the lower part of the Spearfish Formation: the Glendo Shale, the Forelle Limestone, and the lower part of the Freezeout Shale. These units are mainly red mudstone and evaporite rock with some thin beds of dolomite and, locally, thin beds of very fine grained sandstone. In the southern parts of Sioux and Dawes Counties, salt and other evaporite rock make up as much as 90 percent of the interval.

Eastward toward its beveled edge (fig. 36), interval C-D is 200 feet thick, or less, and is mostly red mudstone with some anyhydrite, sandstone, sandy mudstone, and dolomite. It is traceable into part of the Whitehorse Sandstone in Kansas.

\section{UPPER BOUNDARY OF INTERVAL C-D}

The upper boundary of interval C-D and of the Permian System can be determined with reasonable accuracy in the central Midcontinent region. Only in north-central Colorado and locally in westernmost $\mathrm{Ne}$ braska, where rocks of Early Triassic age rest with apparent conformity on the Permian, is the contact difficult to place. There it is arbitrarily placed at the top of a thin dolomite bed that lies about 90 feet above the upper crinkled limestone of Colorado and the Day Creek limestone of Nebraska. Reasons for selection of this boundary are discussed elsewhere (Mudge, in McKee and others, 1959, p. 10).

A thin dolomite bed that crops out on the east side of the Front Range is used to mark the upper contact of interval C-D. It does not extend as far south as Denver (Broin, 1957, fig. 5, p. 18-19). In that area and southward, the contact is arbitrarily placed in a mudstone sequence about 100 feet abore the Glennon Limestone Member of the Lykins Formation. This boundary is correlated with that in well $\operatorname{logs}$ of the nearby subsurface, where mudstone units similar to those above and below the thin dolomite unit to the north are recognized. South of the south edge of the thin dolomite unit, the underlying mudstone beds are recorded in sample logs as orange and orange-red siltstone and some mudstone. In places this lower unit contains very fine grained orange sandstone, with interbedded mudstone. The unit above the horizon of the thin dolomite is described as orange-red and red mudstone with traces of sandstone. This distinction has not been made in the outcrop.
In southeastern Colorado sandstone of the Dockum Group (Upper 'Triassic) rests disconformably on rocks of interval $\mathrm{C}-\mathrm{D}$. In some places the Triassic sandstone rests on sandstone of the Permian; therefore it is difficult to distinguish between rocks of these two systems (McLaughlin, 1954, p. 85-96; Oriel and Mudge, 1956, p. 20-21; Mudge, in McKee and others, 1959 , p. 14). Grain size of the Dockum ranges from fine to coarse; however, in the Permian of this area the size of the grains rarely exceeds fine. Other criteria used in distinguishing between Triassic and Permian rocks are listed by Mudge (in McKee and others, 1959 , p. 3 ).

\section{THICKNESS TRENDS}

The thickness of interval C-D across most of the central Midcontinent region is the result of postPermian erosion rather than original deposition (figs. $36,42)$. In western Nebraska the original thickness of all units of interval C-D is present; nevertheless, the sequence in Colorado and Kansas, although incomplete as the result of erosion, contains the greatest thickness of rocks of this interval in the Midcontinent region. In parts of northeastern Colorado and westernmost Nebraska some of the thickness trends have tectonic significance.

\section{SOURCES AND ENVIRONMENTS}

Deductions as to the origin, environment, and source of rocks of interval C-D in the Midcontinent region are difficult to make because of subsequent erosion, but a few inferences are possible, as follows.

Rock of interval C-D is somewhat like rock of interval $\mathrm{B}$; it probably had a similar origin and environinent of deposition and was deposited in partlv enclosed basins that persisted from earlier Permian time.

Much evaporite was deposited in basins in the central Midcontinent region as a result of the highsalinity of the waters. The associated dolomite was also deposited in a concentrated-marine environment.

In most of the central Midcontinent region, red mudstone dominates interval $\mathrm{C}-\mathrm{D}$. The origin and depositional environment of this rock remain controversial because criteria normally used for environmental interpretation, including fossils, are generally alsent. Some interbedded sandstone in the lower part contains structural evidence of deposition in a beach environment, and some in the upper part may represent an eolian environment (E. K. Maughan, oral commun., 1959).

The red beds of interval C-D in Kansas are probably primary deposits, according to Swineford (1955, 
p. 155). In describing the processes that formed these rocks, she stated (p. 166) :

an influx of fine feldspathic sand, perhaps both from the west and south, produced the Whitehorse Formation. The supply of medium-grained clastic material gradually diminished during Whitehorse time, and montmorillonitic (bentonitic?) clays were deposited, as was also a thin persistent dolomite (Day Creek). The poorly sorted sands and silts of the Taloga formation suggest that incidence of slight instability and perhaps the deposition of poorly reworked flood-plain materials before the Permian seas withdrew ***.

Along the Front Range, beds of Permian limestone, as interpreted from their meager fauna, were deposited in a shallow sea that had freer circulation than the areas in which dolomite was deposited to the south and east.

The Lykins Formation may have been rapidly deposited under a uniform aqueous environment. Uniform bedding and lithology and continuity of the limestone beds in the lower part of the formation indicate deposition in a sea but not under normal marine conditions according to LeRoy $(1946$, p. 47).

Deposition by sluggish streams and in short-lived lakes on a broad nearly flat alluvial plain under unstable shelf conditions is postulated for some strata of interval C-D over much of the central Midcontinent region. Criteria for recognizing this type of environment are summarized by Krumbein and Sloss $(1951$, p. 372). Fluctuation between marine and nonmarine environments is indicated by the numerous alternations of carbonate rock, evaporites, and nonmarine mudstone, and this suggests many episodes either of epeirogeny or of eustatic change in sea level.

\section{TOTAL THICKNESS OF PERMIAN ROCKS THICKNESS TRENDS}

Permian rock in the central Midcontinent region ranges from a few feet to slightly more than 3,500 feet in thickness (fig. 40). The maximum is in south-central Kansas. Variations in thickness are partly caused by post-Permian erosion and partly by differences in amount of deposition. Where they are the result of deposition the thickness trends are interpreted as structural highs or lows. The positions of structural elements that affected deposition of strata representing various intervals of the Permian (fig. 41) can be determined from the isopach maps of each interval and from lithofacies data.

Major structural elements that influenced sedimentation are the central Kansas Permian basin, ancestral Hugoton embayment of Anadarko basin, ancestral Las Animas arch, ancestral Apishapa uplift, and the ancestral Denver-.Julesburg basin of northeastern Colorado and western Nebraska (fig. 41).

\section{PALEOTECTONIC IMPLICATIONS}

Three dominant structural trends are conspicuous on the map of present and Permian structures in the central Midcontinent region (fig. 41). One of these trends, along the Las Animas arch, is northeast; a second, in Kansas and southeastern Colorado, is northwest; and a third, in northeastern Colorado and western Nebraska, is east.

The pattern of structural trends of pre-Permian origin shown in figure 41 is recognized in trends of interval. A. Two principal elements-the ancestral Nemaha anticline and ancestral Las Animas archtrend northeast. The Nemaha anticline is the most striking structural feature of post-Mississippian folding (Lee, Wallace, 1956, p. 144, 149) and was active intermittently during Pennsylvanian and Permian time.

Major folds in Kansas that trend northeast, parallel to the Nemaha anticline, intersect at nearly right angles other folds that trend northwest, parallel to the central Kansas uplift. This right-angle change in trend of folds seems to have been caused by contemporaneous movements. The break in the Nemaha anticline, which results from intersection by the Salina basin syncline in Chase and Marion Counties, persisted into Early Pennsylvanian time (Lee, Wallace, 1956, p. 146). The Salina basin, a major northwest-trending fold, is nearly parallel to the northeast flank of the central Kansas uplift, except for its northeastern limb, which swings north around the broad north end of the Nemaha anticline (Lee, Wallace, 1956 , p. 145).

The orientation of folds in two directions may be explained as resulting from forces exerted in a horizontal couple. During Pennsylvanian and Early Permian time, uplift of the Wet Mountains area may have exerted horizontal compression northeastward on the Las Animas arch, moving rocks of the arch to the northeast. During Early Permian time the Nemaha anticline was apparently structurally high in its northern extremity and moderately low on its southern part. It apparently remained stationary but acted as a basement barrier to the transmitted forces. Movement of the Las Animas arch toward the northeast then created the northwest-trending folds and continued to downwarp the central Kansas Permian basin contemporaneously with uplift of the Apishapa-Wet Mountain area.

This interpretation is supported by evidence (I-450, pl. 3; figs. 34-36, this report) that (1) the Wet Mountains uplift area was an active positive element throughout Pennsylvanian, Permian, Triassic, and Jurassic time; (2) the northeastward move- 


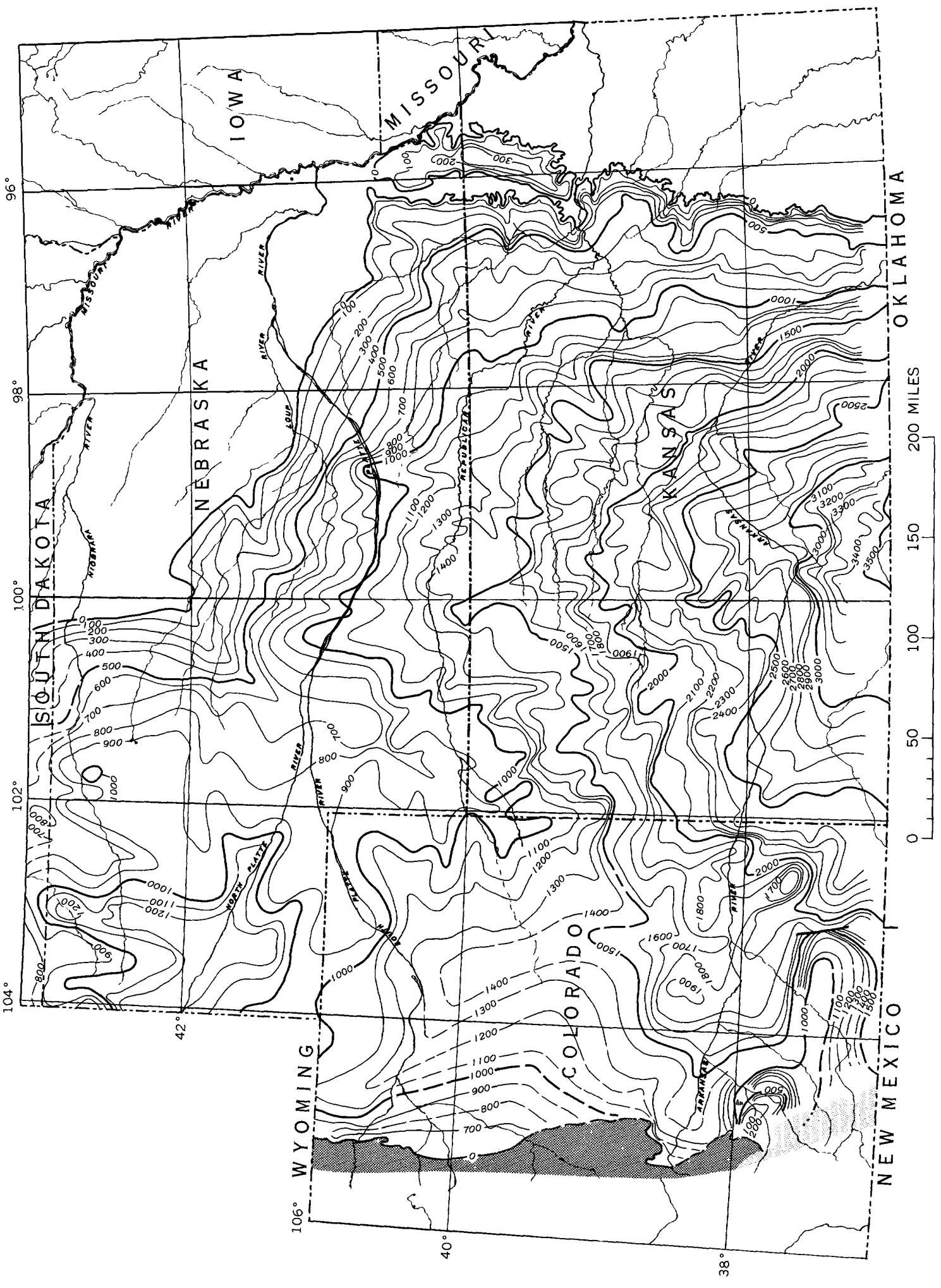




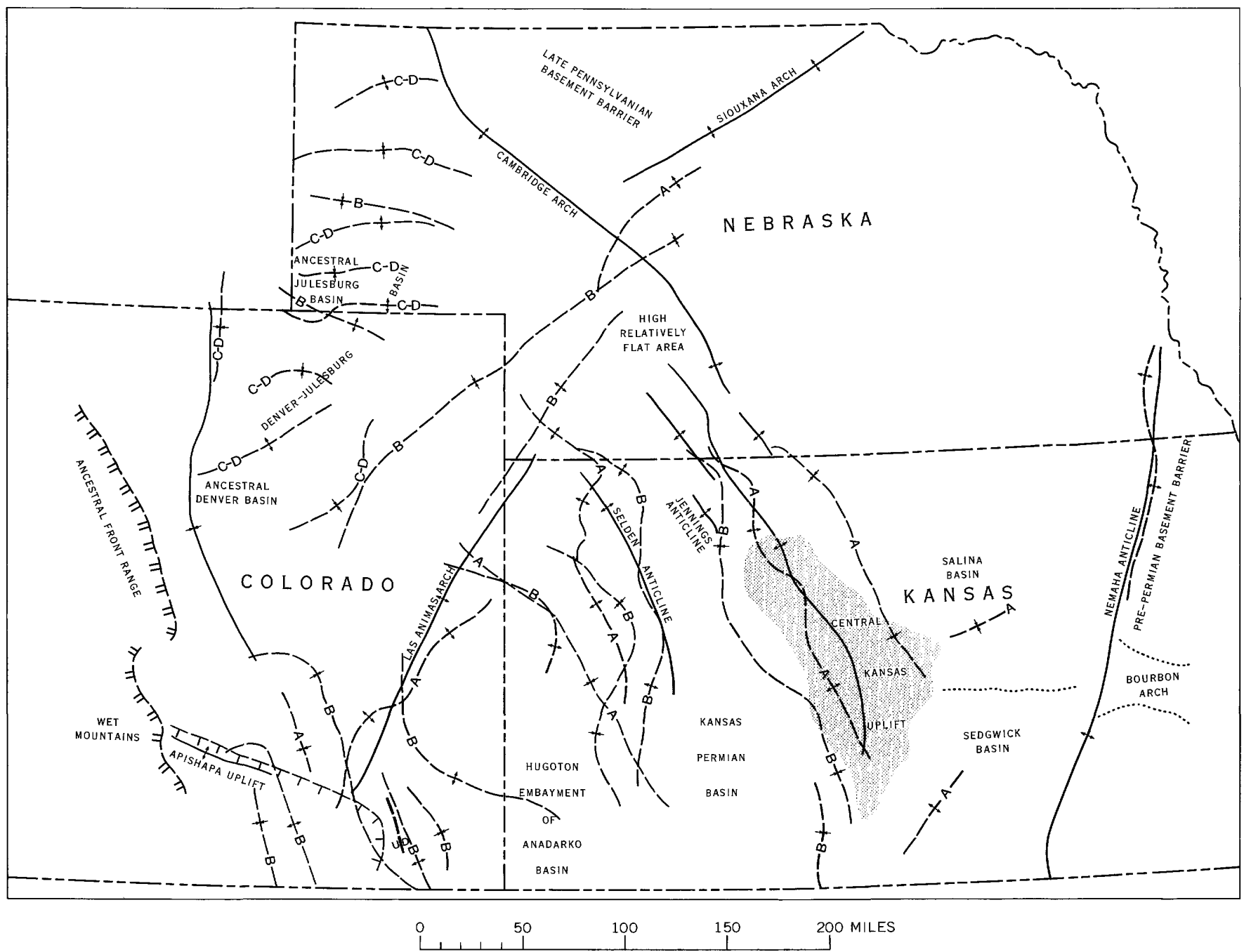

EXPLANATION

PRESENT STRUCTURES

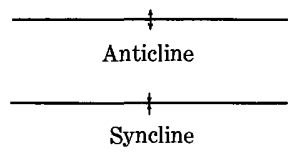

Area of uplift
PERMIAN STRUCTURES Interpreted mainly from isopach maps

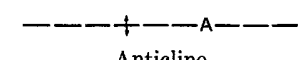

Letters indicate Permian interval in which structure formed

Syncline

Letters indicate Permian interval in which structure formed $\pi \pi \pi \pi \pi \pi \pi \pi$

Edge of positive area during deposition of all intervals of Permian System

TTTTTTTTT

Edge of positive area during deposition of lower and middle parts of interval A only

$$
-\frac{D}{U}-
$$

Fault active during deposition of interval A $\mathrm{U}$, upthrown side; $\mathrm{D}$, downthrown side

Boundary of structural element

Figure 41.-Present and Permian structures in the central Midcontinent region. 
ment of the Las Animas arch is reflected by the northward deflection of many of the northwest-trending Permian folds in nearby Kansas; and (3) a continual downwarping of the central Kansas basin in conjunction with uplift of the Wet Mountains area is illustrated by lithofacies and isopach maps of intervals $\mathrm{A}, \mathrm{B}$, and $\mathrm{C}-\mathrm{D}$.

Structural elements that persisted during deposition of interval $\mathrm{C}$ and were not affected by postPermian erosion are present in northeastern Colorado and western Nebraska. Only one of these elements trends northward, and its trace is faint on the isopach and lithofacies map. This trend, however, nearly coincides with that of the present Denver basin and may represent the initial downwarp in Late Permian time that formed a major basin in Early Triassic time (Mudge, in McKee and others, 1959, p. 10).

Structural trends of interval C-D with an eastwest orientation in northeastern Colorado and Nebraska may be explained in at least two ways. One of these is the couple used to explain the corresponding structures in Kansas and southeastern Colorado. Horizontal pressure on the Las Animas arch would have created folds recorded in interval C-D time if the Black Hills-Siouxia basement rock had acted as a barrier. Structures recorded in rocks of interval B are parallel to those of interval C-D. The resultant forces that created the structures of interval $C-D$ may therefore, have been present during deposition of interval B. Another possiblity is that the folds are a result of uplift in the Black Hills area. This seems less likely, for there is no evidence that the Black Hills uplift was active then.

The termination of the Las Animas arch at a crossfold or swale during interval A time is illustrated by isopachs (fig. 34). Northward a high relatively flat area seems to have included a small fold on the Nebraska-Kansas line. This northwest-trending downwarp, mainly apparent in rocks in the lower part of interval A, may represent an early stage of folding; an alternate interpretation is that it is the result of faulting in the basement.

While strata of interval B were forming, the Las Animas arch did not extend very far to the southwest (fig. 35). The axis of the arch, however, had shifted northwest a short distance. This shift may be the result of a cross fault or of a shifting of compressive forces exerted from the positive area. The latter explanation seems more probable because the Sierra Grande-lower Apishapa arch area was not active when the youngest strata of interval $A$ and most of those of interval B were deposited. The Wet
Mountains, however, apparently remained active, and the horizontal component of this uplift may account for the slight change in direction of the arch, as hinted by the westward bending of some of the folds in southeastern Colorado.

Bending of fold axes in northwestern Kansas conforms not only to the inferred southwestward direction of stresses but also to a regional pattern. In northwestern Kansas folds that are bent toward the west resemble virgation folds, as defined and described by Collet (1935). All appear to hinge on an area in southwestern Nebraska. During deposition of interval $\mathrm{A}$ this area was relatively high, broad, and flat. During deposition of interval B, however, the fold of the Las Animas arch originated.

\section{GEOLOGIC UNITS DIRECTLY ABOVE PERMIAN SYSTEM UNITS OVERLYING PERMIAN}

In the central Midcontinent region, units overlying the Permian System range from Triassic to Recent in age (fig. 42). Permian rock is exposed in a narrow belt along the east side of the Front Range, in a few isolated places in southeastern Colorado, and across a wide belt in eastern Kansas and southeastern Nebraska (fig. 42).

Rock directly above the Permian is of eight different ages, is both marine and nonmarine in origin, and contains many disconformities. Eastward from the Front Range, successively younger rock oversteps the Permian across the region. Upper Triassic rock overlies the Permian only in southeastern Colorado and southwesternmost Kansas. Tertiary rock covers the Permian in large areas of southewestern Kansas.

Because of successive eastward overstep of rock on the Permian, the upper surface of the Permian had different histories in different areas.

In western and northwestern Kansas the Ralston Creek and Morrison Formations of Late Jurassic age rest on a truncated surface of the Permian (Merriam, 1955 , p. 37; McKee and others, 1956, pl. 2).

From southwestern to north-central Kansas, Cretaceous rocks unconformably overlie successively older Permian strata. In the southwestern part of the State, for instance, interval C-D is overlain by Cretaceous rocks (Kansas Geol. Soc., 1955), whereas in the northeastern part of the State the Wellington Formation of interval B underlies the Cretaceous (Jewett, 1939, p. 93). The Cretaceous rock that rests on Permian in Kansas is mainly the Dakota Formation (Kansas Geol. Survey, 1937), except in southcentral and southwestern parts of the State where the older Cheyenne and Kiowa Formations occur. (Kansas Geol. Soc., 1955; Latta, 1948, p. 75-91). 

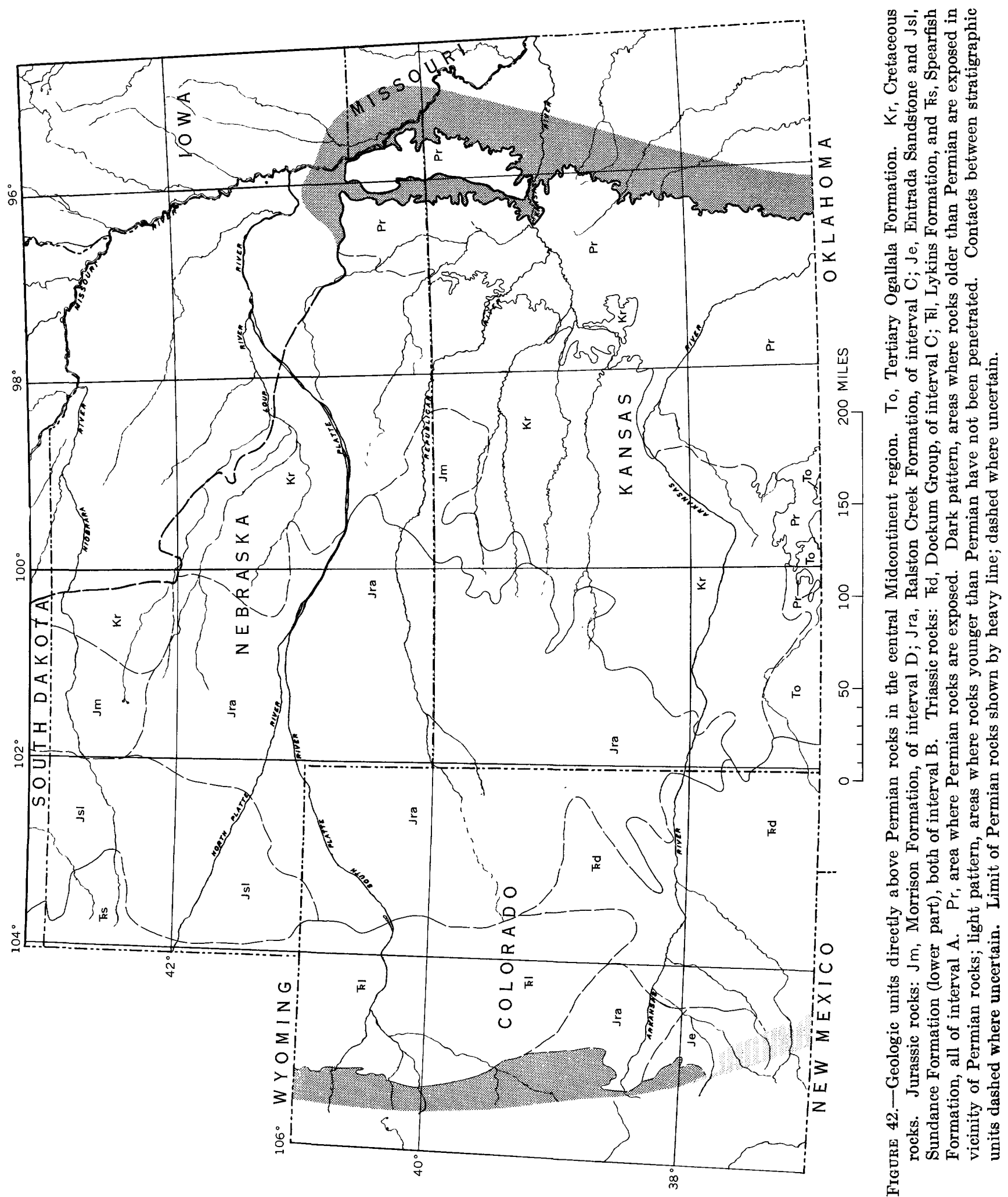
In southwestern and eastern Kansas unconformable strata of Tertiary and Quaternary age veneer the Permian. Tertiary rock in western Kansas is of the Ogallala Formation. Quaternary rock ranges in age from Nebraskan to Recent. In northeastern Kansas, glacial deposits of Kansan and possibly also of $\mathrm{Ne}$ braskan age mantle much of the Permian.

East of the northern Front Range, in Colorado, Lower Triassic rock (upper part of the Lykins Formation) apparently rests conformably on Permian rock, whereas in southeastern Colorado, Upper Triassic rock (Dockum Group) overlies Permian strata unconformably. Just west of this area, near the Wet Mountains, rock of Late Jurassic age (Entrada and Ralston Creek Formations) overlies the Permian disconformably. In northeastern Colorado the Ralston Creek Formation is disconformable on the Permian (fig. 42).

In Nebraska, rock ranging in age from Triassic to Quaternary overlies Permian rock. In the westernmost part of the State, rock of Early Triassic age (Spearfish Formation) is conformable on the Permian. East of this area, in central Nebraska, rock of Jurassic age (lower part of the Sundance and Morrison Formations) rests unconformably on the Permian. Farther east in central Nebraska, Cretaceous rock (Dakota Formation) overlies the Permian strata, but in the southeastern part of the State, glacial deposits of Kansan and possibly also of Nebraskan age overlie them.

\section{PALEOTECTONIC IMPLICATIONS}

Soon after the Permian rocks were deposited, deformation of the area was accelerated. The Denver basin was formed and received Triassic sediment. It began to subside in Late Permian time but acquired its basin shape in Early Triassic time (Mudge, in $\mathrm{McKee}$ and others, 1959 , p. 10).

Strata in southeastern and eastern Colorado were tilted westward, and the youngest Permian beds were truncated prior to deposition of Mesozoic sediment (Maher, 1945, p. 1665). This deformation began in Early Triassic time and was renewed in Early Jurassic time, as indicated by the fact that the Ralston Creek Formation lies unconformably on a truncated surface. The attitude of Cretaceous and older rock indicates considerable movement at times after the beginning of Mesozoic sedimentation (Maher, 1945, p. 1665).

Channels that have been cut into Permian rock are shown in figure 43. These are inferred from the isopach maps and from the data obtained on the geologic units overlying the Permian. The channels designated as Triassic or pre-Triassic in age show westward and southwestward drainage. The source of much of the Triassic sediment in rock of northeastern Colorado and also, to some extent, of southeastern Colorado was the Permian rocks farther east (Mudge, in McKee and others, 1959). Erosion after Triassic and before Jurassic deposition is recorded mainly in southeastern Colorado, where channels are incised in Triassic and Upper Permian rock. Pre-Jurassic erosion also beveled much of the Permian rock in northwestern and western Kansas and much of western Nebraska (Merriam, 1955, p. 37; McKee and others, 1956).

Cretaceous, Tertiary, and Recent erosion in Nebraska truncated Permian rock and created channels that are alined toward the east and northeast. The Early Cretaceous streams apparently flowed northwestward (Merriam, 1955, p. 41).

In southeastern Colorado some rock of interval C-D was eroded in Early or Middle Triassic time. Later the area subsided, and Upper Triassic strata (Dockum Group) were deposited (Mudge, in McKee and others, 1959). The area was again uplifted and beveled prior to deposition of Jurassic rock (McKee and others, 1956). 


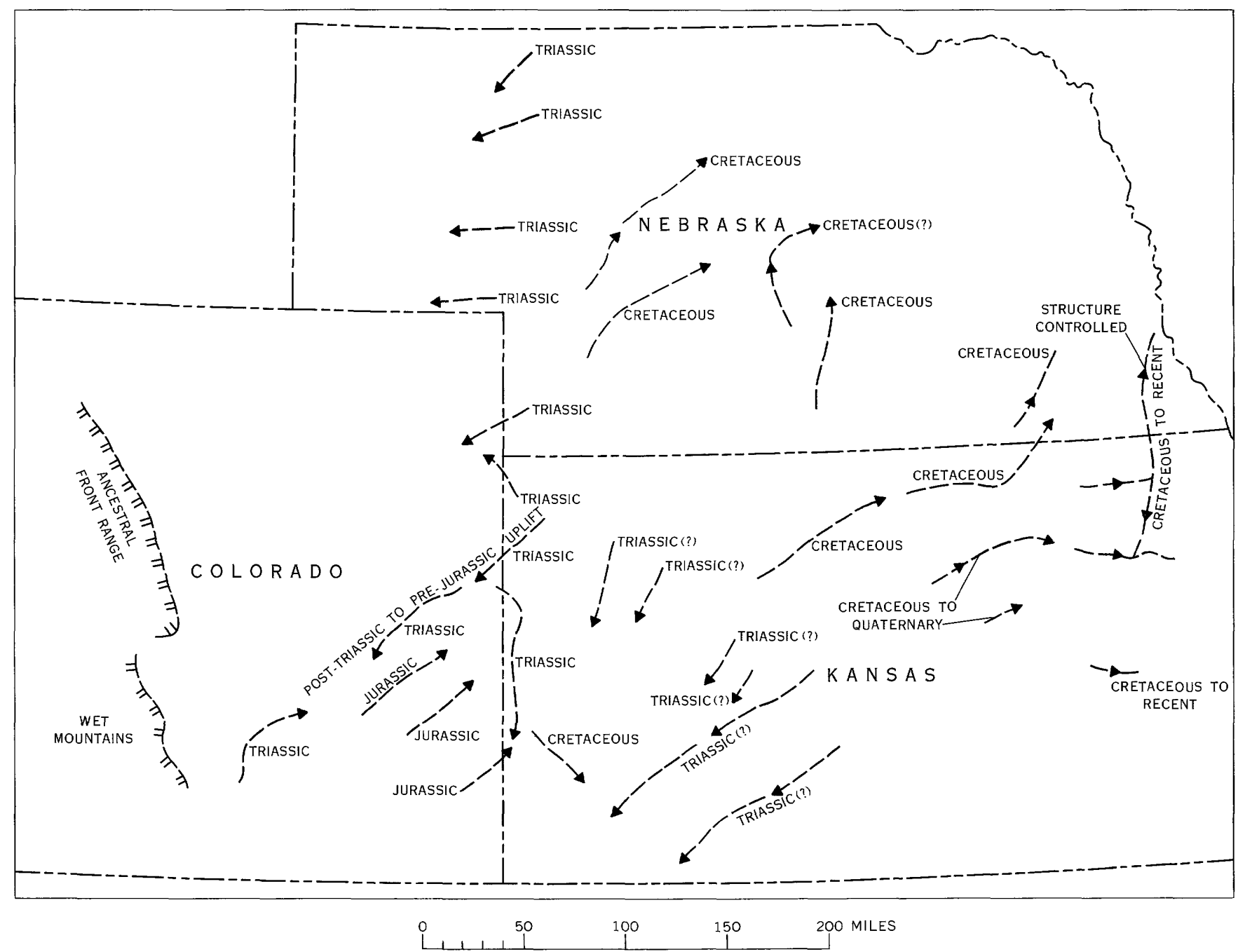

Figure 43.- Inferred Mesozoic and Cenozoic drainage that eroded part of the Permian rocks in the central Midcontinent region. 
, 


\section{Paleotectonic Investigations}

of the Permian System

in the United States

Chapter G. Eastern Wyoming, Eastern Montana, and the Dakotas

By EDWIN K. MAUGHAN

GEOLOGICAL SURVEY PROFESSIONAL PAPER $515-\mathrm{G}$

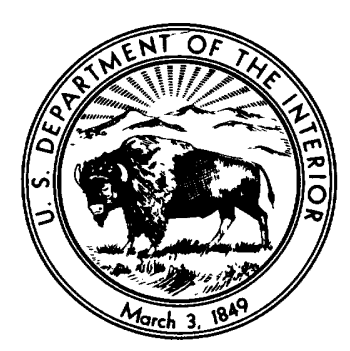


. 


\section{CONTENTS}

Abstract

Region defined

Paleogeology $\ldots \ldots$

Units underlying Permian . . . . . . . . . . .

Lower boundary of the Permian.

Paleotectonic implications. . . . . . . . . . . . .

Interval A. . . . . . .

Formations included.

Stratigraphic relations..........................

Upper boundary of interval A...

Thickness trends.............

Lithofacies trends...... . . .

Sources and environments. . . . . . . . . . . . . .

Paleotectonic implications. . . . . . . . . . . . . . .

Interval B.

Formations included.

Stratigraphic relations.

Upper boundary of interval $\mathrm{B}_{\ldots} \ldots$

Thickness trends

\begin{tabular}{r|} 
Page \\
129 \\
129 \\
129 \\
129 \\
132 \\
132 \\
133 \\
133 \\
133 \\
134 \\
136 \\
137 \\
137 \\
138 \\
140 \\
140 \\
140 \\
140 \\
141
\end{tabular}

Interval B-Continued

Lithofacies trends.............................. 141

Sources and environments..................... 143

Paleotectonic implications . . . . .

Interval C-D . . . . .

Formations included . . . . . . . . . . . . . . 144

Stratigraphic relations._.

Upper boundary of interval C-D . . . . . . . . 145

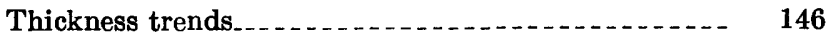

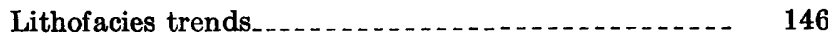

Sources and environments _. _.

Paleotectonic implications. . . . . . . . . . . . . . . 148

Total thickness of Permian rocks. . . . . .

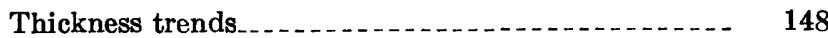

Paleotectonic implications. _. . . . . . . . . . . . . . . 148

Geologic units directly above Permian System ......... 150

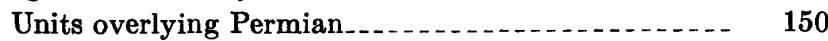

Paleotectonic implications. . . .

\section{ILLUSTRATIONS}

Plate 5. Correlated columnar section of upper part of Permian System and overlying rocks, from Goose Egg, Wyoming, to Pine unit, Montana

Figdre 44-47. Maps of Wyoming, Montana, the Dakotas, and parts of adjacent States:

44. Localities and geographic areas

45. Geologic units directly beneath Permian System

46. Thickness of interval A

47. Western limit of interval $\mathrm{A}$ in central Wyoming

48. Section showing generalized stratigraphic relations and nomenclature of Upper Pennsylvanian and Lower

Permian rocks in Wyoming

49-52. Maps of Wyoming, Montana, the Dakotas, and parts of adjacent States:

49. Thíckness of interval $B$

50. Thickness of interval C-D

51. Total thickness of Permian rocks...

52. Geologic units directly above Permian System

53. Correlation of Jurassic, Triassic, and Permian rocks in the Black Hills of South Dakota and the Williston basin of North Dakota.

\section{TABLES}

1. Generalized chart showing stratigraphic units in major Permian subdivisions

2. Subdivisions of the Hartville Formation proposed by Condra, Reed, and Scherer (1940) and their approximate 



\title{
PALEOTECTONIC INVESTIGATIONS OF THE PERMIAN SYSTEM IN THE UNITED STATES
}

\section{EASTERN WYOMING, EASTERN MONTANA, AND THE DAKOTAS}

\author{
By Edwin K. Madghan
}

\begin{abstract}
Rocks of Permian age rest unconformably on those of Pennsylvanian age throughout most of the northern Midcontinent region. These rocks record a general transgression of the sea accompanied by the lowering of adjacent positive elements and the filling of basins. Positive elements were partly inherited from Pennsylvanian time, but some were newly formed.

During deposition of interval A the sea transgressed from the southeast into a basin centered near the present Black Hills and lying east of a low land barrier that extended through central Wyoming from the ancestral Front Range on the south to a positive element in Montana. During the early stages of interval $\mathbf{B}$ deposition, general transgression was interrupted in the northern part of the region by uplift and erosion. Deposition only occurred south of the Wyoming lineament. During the later stages of interval $B$ deposition, sediments of the Midcontinent region coalesced with those of the Cordilleran region across a barrier in central Wyoming, and during the remainder of Permian time deposition was widespread in this region.

In Wyoming and parts of adjacent States, Permian rocks are overlain by seemingly conformable Lower Triassic strata. In eastern Montana and the Dakotas, however, Permian rocks are truncated by an unconformity and are overlain by Jurassic rocks.
\end{abstract}

\section{REGION DEFINED}

Permian rocks described in this chapter are in the northern Midcontinent region and adjacent parts of the central Rocky Mountains. The region includes Wyoming east of the 108th meridian as well as the Bighorn Basin in the northern part of the State, adjacent parts of eastern Montana, and the Dakotas. Exposures of Permian rocks in this region occur on the flanks of the Black Hills (fig. 44), Hartville uplift, Laramie Range, Medicine Bow Range, Sierra Madre, the central Wyoming ranges, Owl Creek Mountains, 13ighorn Mountains, and the Absaroka Range. Elsewhere in the intervening basins and the adjacent plains, information on Permian rocks is from subsurface drill-hole logs.

\section{PALEOGEOLOGY UNITS UNDERLYING PERMIAN}

Rocks of Pennsylvanian age underlie Permian strata throughout the northern Midcontinent region of eastern Wyoming, eastern Montana, North Dakota, and South Dakota, except possibly in the vicinity of the Sierra Madre (fig. 44) in the extreme southwest corner of this region, where strata believed to be of Mississippian age underlie the Permian (fig. 45).

Pennsylvanian rocks in North Dakota and eastern Montana belong to the Amsden and Tensleep Formations; in South Dakota and in northeastern and southeastern Wyoming, to the lower part of the Minnelusa Formation; and in central Wyoming, to the Tensleep Sandstone. Pennsylvanian rocks in the Hartville uplift (fig. 44) in middle eastern Wyoming are assigned to the lower part of the Hartville Formation; in the Laramie Range and Laramie Basins, to the lower part of the Casper Formation; and near the Colorado State line, to the Fountain Formation. These formations directly underlying the Permian are mainly stratigraphic equivalents of each other. The Tensleep and the Fountain are dominantly sandstone and arkose, respectively, and the other stratigraphic umits of Pennsylvanian age are dominantly carbonates with minor detrital layers.

In most of eastern Wyoming the Pennsylvanian formations may be subdivided, lithologically and paleontologically (primarily on the basis of fusulinids), into units which seem to correspond, at least in part, to series as used in the central Midcontinent (Agatston, 1954; 'Thomas, H. D., and others, 1953; Foster, D. I., 1958; Maughan and Wilson, 1960).

In southeastern Wyoming, Permian rocks overlie strata believed to be of Virgil age, except in an eastwest band traversing the southern Laramie Range and the Laramie Basin (Maughan and Wilson, 1960; Agatston, 1954). Within this band, rocks of Mis- 


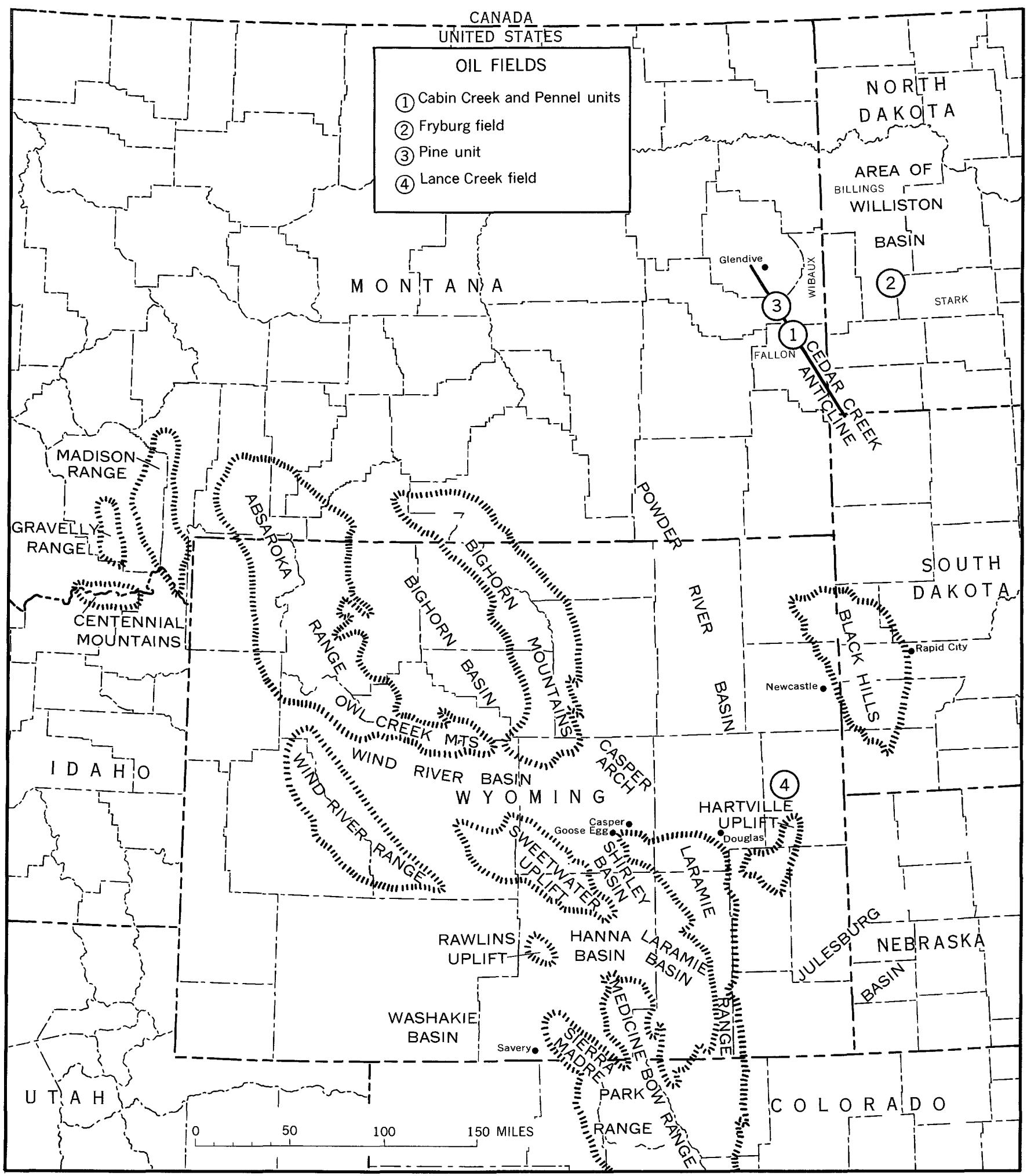

FIgure 44.- Localities and geographic areas in Wyoming, Montana, and the Dakotas referred to in text. 


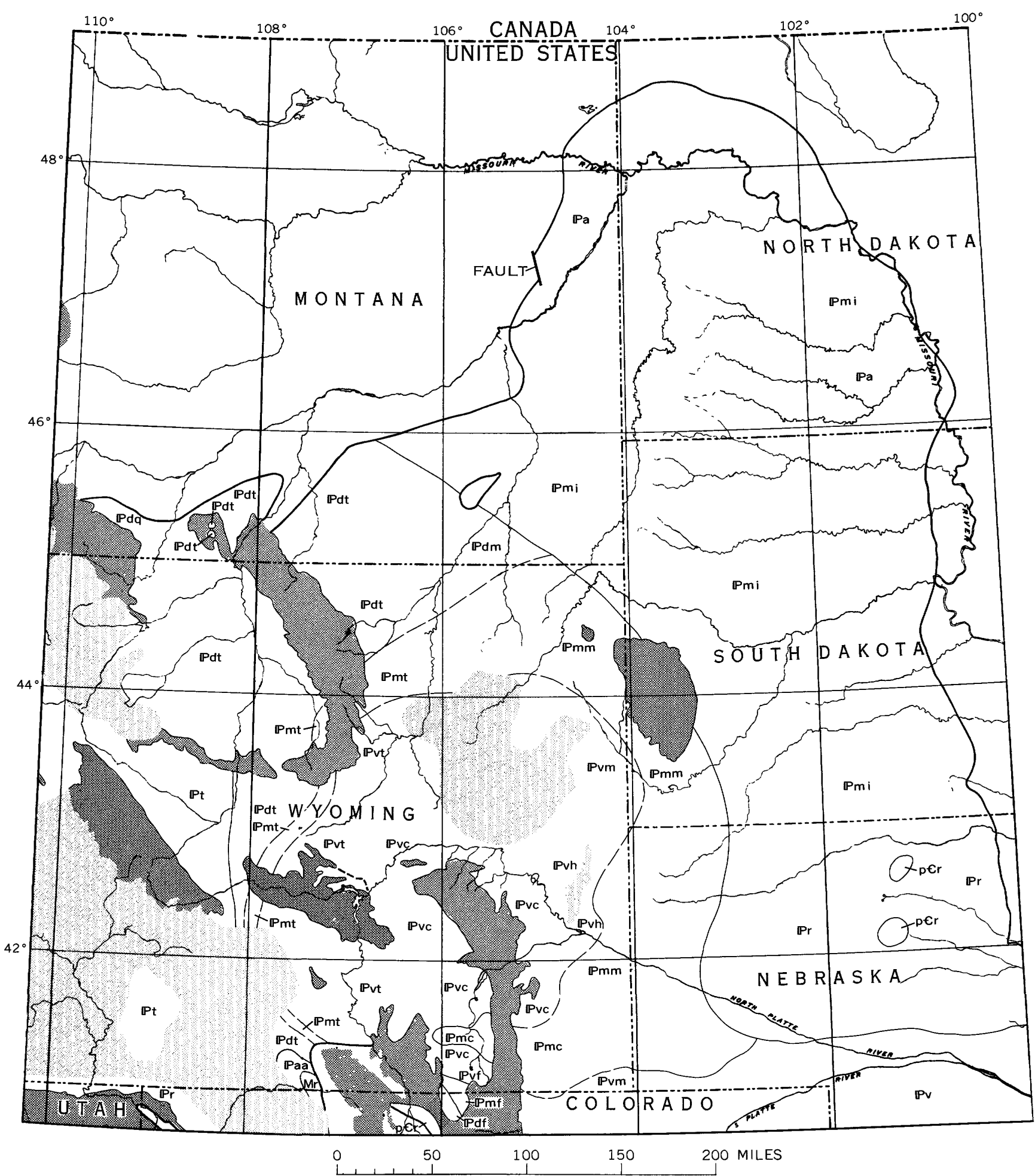

Figure 45.--Geologic units directly beneath Permian System in parts of Wyoming, Montana, the Dakotas and adjacent States. Pennsylvanian rocks: $\mathbb{P r}$, undivided; $\mathbb{P a}$, Amsden Formation (part); $\mathbb{P}$ mi, Minnelusa Formation (part); $\mathbb{P t}$, Tensleep Formation; $\mathbb{P} v c$, Casper Formation (part), Pvf, Fountain Formation (part), Pvh, Hartville Formation (part), $\mathbb{P} v t$, Tensleep Formation (part), and $\mathbb{P} v$, undivided, all of Virgil age; $\mathbb{P} \vee m$, undivided, of Virgil and Missouri age; $\mathbb{P}$ mc, Casper Formation (part), $\mathbb{P} m f$, Fountain Formation (part), $\mathbb{P} m m$, Minnelusa Formation (part), and $\mathbb{P} m t$, Tensleep Sandstone (part), all of Missouri age; $\mathbb{P d f}$, Fountain Formation (part), $\mathbb{P d m}$, Minnelusa Formation (part), $\mathbb{P d q}$, Quadrant Formation, $\mathbb{P d t}$, Tensleep Sandstone (part), all of Des Moines age; $\mathbb{P a a}$, Amsden Formation, of Atoka age. $\mathrm{Mr}$, Mississippian rocks, undivided. p $\mathrm{r}$, Precambrian rocks, undivided. Dark pattern, areas where rocks older than Permian are exposed; light pattern, areas where rocks older than Permian have not been penetrated. Contacts between stratigraphic units dashed where uncertain. Limit of Permian rocks shown by heavy line; dashed where uncertain. 
souri age underlie the Permian except in exposures along the west margin of the Laramie Basin, where younger Pennsylvanian rocks are missing and the Permian rests on strata of Des Moines age or older. Permian rocks are assumed to rest on rocks of Missouri age along a narrow band farther west in central Wyoming. Northward this band curves eastward and broadens through northeastern Wyoming. Beyond this band, in central Wyoming, Montana, and possibly in North Dakota, highest Pennsylvanian strata are of Des Moines age. In northeastern Wyoming and South Dakota, east of the Black Hills, the age of the Pennsylvanian is not established, but is possibly Des Moines in most places, although rocks of Missouri and even of Virgil age may occur locally.

Carbonate rocks beneath interstratified red beds and carbonates of undoubted Permian age in a well near Savery, Wyo., have been interpreted solely on the basis of lithology (Gudim, 1956; D. I. Foster, oral commun., 1960) as Madison Limestone of Mississippian age. This interpretation is supported by observations of Ritzma (1951) that Permian strata thin southward along the west side of the Sierra Madre to a place beyond which thin strata, probably of Mississippian age, are overlain by red beds believed to be of Triassic age. Some of these red beds may be of Permian age, however, and the strata thought to be Mississippian in the well near Savery may actually be an eastern extension of the Park City Formation of Permian age.

\section{LOWER BOUNDARY OF THE PERMIAN}

The base of the Permian is believed to be an unconformity throughout the region, except possibly in southeasternmost Wyoming. Northward and westward from southeastern Wyoming the hiatus increases between the Pennsylvanian and Permian Systems. In the northern Bighorn Basin (fig. 44), in southcentral Montana, equivalents of the youngest known Permian strata in Wyoming thin and disappear through overlap against Middle or possibly Lower Pennsylvanian strata (I-450, pl. 14c).

The base of the Permian System in Wyoming is placed at the lower contact of a mudstone known as the red marker, originally recognized in the subsurface of the Lance Creek field in central eastern $\mathrm{Wy}$ oming but now known in most of southeastern Wyoming and southwestern South Dakota. This very distinctive unit, composed of red mudstone with minor dolomite and sulfates, is recognized in the subsurface over a very large area. It is also exposed in the Hartville Formation in the Hartville uplift (J. W. Strickland, oral commun., 1958), the Minne- lusa Formation of the southern Black Hills (C. G. Bowles, oral commun., 1959), and somewhat less certainly, in the Casper Formation of the Laramie Range. The red marker does not extend westward into central Wyoming beyond Casper nor northward into northeastern Wyoming, northwestern South Dakota, or beyond. Strata approximately equivalent to the red marker can be recognized, however, in those areas (Foster, D. I., 1958; McCauley, 1956; Agatson, 1954) and serve to mark the base of the Permian.

The red marker is useful as a systemic boundary because (1) it is readily recognized in both surface and subsurface, (2) it overlies an unconformity (Foster, D. I., 1958, p. 39), (3) it separates rocks which, though generally included within a single formation, are nevertheless of distinctly different composition, and (4) fusulinids from below the red marker are of Virgil or older age (Love and others, 1953; Agatston, 1954; Thomas, H. D., and others, 1953), whereas fusulinids of only Early Permian age are known from above it or its equivalent (Agatston, 1954; Thomas, H. D., and others, 1953; McCauley, 1956; Maughan and Wilson, 1960).

The base of the Permian System in central Wyoming, eastern Montana, and North Dakota, beyond the line of overlap of Lower Permian strata, consists of progressively younger units northwestward as far as the limits of known Permian rock. In most of this region the basal unit is the Opeche Shale or its equivalents, but in the northern Bighorn and Powder River Basins, the Glendo Shale, the Forelle Limestone, the lower part of the Freezeout Shale, and, lastly, the Ervay Tongue successively mark the lowest Permian.

\section{PALEOTECTONIC IMPLICATIONS}

The unconformity that separates Permian and Pennsylvanian strata in central Wyoming seems to have resulted from slight regional uplift either in Late Pennsylvanian or earliest Permian time. The uplift was probably greatest in south-central Wyoming, where it coincided with the late stages of uplift of the ancestral Front Range. Northward, this uplift decreased to only moderate arching. Northeastern Montana and North Dakota were also uplifted and tilted southward. A probable southeast continuation of this uplift joined the Siouxia land area in eastern South Dakota and adjacent areas. These uplifts encircled a broad synclinorium that plunged gently southeastward and in which Lower Permian sediments were deposited.

Probably few or no strata were deposited in central Wyoming from the close of Des Moines time 
until well into Permian time (Thomas, 1948, p. 89), as rocks of this time interval are missing and Upper Pennsylvanian and Lower Permian strata in adjoining areas indicate a general period of regression. On the other hand, arching from central Wyoming northward may postdate the deposition of most Upper Pennsylvanian strata and may not have occurred until at least the end of the Pennsylvanian Period. Rocks of Missouri age are less clastic than the underlying rocks of Des Moines age, which may indicate a marine environment that was more widespread than during Des Moines time. Absence of Upper Pennsylvanian and Lower Permian rocks in central and northern Wyoming may therefore result from erosion rather than nondeposition.

Regional uplift of the northern Midcontinent region is interred in latest Pennsylvanian or earliest Permian time, when the sea withdrew from all but the southeasternmost part. The red marker is probably a lateritic soil or reworked laterite (J. S. Strickland, oral commun., 1958; Foster, D. L., 1958, p. 39; Richard Norman, oral commun., 1958) that locally formed in place, but in some areas was transported and redeposited.

Uplifted Pennsylvanian rock in central and northeastern Wyoming, eastern Montana, and the Dakotas probably supplied much of the detritus in strata formed during marine transgression in Permian time. In Pennsylvanian time most of the detritus came from older Paleozoic and Precambrian rocks exposed in positive areas that were remnants of the ancestral Front Range, but with the advent of the Permian these areas did not furnish much arkosic material to Wyoming because they were either too far to the southwest or too low.

INTERVAL A

\section{FORMATIONS INCLUDED}

Interval $\mathbf{A}$ in this region includes the upper parts of several formations long regarded as entirely of Pennsylvanian age but now known to be partly of Early Permian age. These are the Minnelusa Formation of the Black Hills and adjacent areas in western South Dakota, eastern Wyoming, southeastern Montana, and southwestern North Dakota; the Hartville Formation of the Hartville uplift in eastcentral Wyoming; the Casper Formation of the Laramie Range in southeastern Wyoming; and the Tensleep Sandstone in central Wyoming (table 1). The upper, or Permian, part of these formations is separated from the lower, or Pennsylvanian, part by a rock unit locally called the red marker or by strata considered to be approximately equivalent.
The Permian parts of the formations differ from the Pennsylvanian as follows:

1. Permian detrital strata are generally orange red to brownish red, whereas the Pennsylvanian beds are gray above and purplish red below.

2. Evaporites in thick beds are common in Permian strata, but they are thin bedded or sparse to absent in the. Pennsylvanian. Evaporites have mostly been leached from surface exposures, but their former positions are indicated by sandstone and limestone breccia, which are common in the upper parts of the Minnelusa and Hartville Formations (Bowles and Brảddock, 1960; Condra and others, 1940).

3. Radioactive black shaly mudstone occurs at several horizons in the Pennsylvanian but is unknown in the Permian.

4. Sandstone units within the Permian part of each formation commonly include scattered larger quartz grains, whereas sandstone in the Pennsylvanian part is of nearly uniform grain size.

5. Limestone is common in Pennsylvanian strata but rare in Permian strata, although dolomite is common in both.

6. The Permian parts of each formation and the lower parts of the Pennsylvanian are generally uniform in thickness and lithology, and their composition and position are predictable from place to place. The Upper Pennsylvanian strata differ widely in thickness because of an unconformity at their top.

\section{STRATIGRAPHIC RELATIONS}

The Hartville Formation was subdivided into six units (Condra and Reed, 1935) which were later classified as groups and named (Condra, and others, 1940) as shown in table 2. These units were tentatively correlated with similar divisions of the Casper and Minnelusa Formations.

Recent correlations of these strata in areas yielding paleontologic evidence have shown that the lower part of Division I, or the Broom Creek Group of Condra, Reed, and Scherer, is of Permian age (Love and others, 1953; Thomas, H. D., and others, 1953; Agatston, 1954; Verville, 1957; McCauley, 1956; Maughan and Wilson, 1960). These units are hard to recognize away from the Hartville area (Agatston, 1954; McCauley, 1956; Foster, D. I., 1958; Bates, 1955). The Pennsylvanian-Permian contact, however, has consistently been placed at the red marker and the base of the Broom Creek Group.

Correlations established during the present study confirm an Early Permian age for the Broom Creek 
TABLE 2.-Subdivisons of the Hartville Formation proposed by Condra, Reed, and Scherer (1940) and their approximate ages (Love. and others, 1953; Agatston, 1954; Foster, D. I., 1958)

\begin{tabular}{|c|c|c|c|}
\hline Division & Group & Approximate age & System \\
\hline I & $\begin{array}{c}\text { Cassa } \\
\text { Broom Creek }\end{array}$ & $\begin{array}{l}\text { Leonard } \\
\text { Wolfcamp }\end{array}$ & $\begin{array}{l}\text { 泀 } \\
\text { 总 }\end{array}$ \\
\hline II & $\begin{array}{l}\text { Wendover } \\
\text { Meek }\end{array}$ & $\begin{array}{c}\text { Virgil } \\
\text { Missouri }\end{array}$ & \multirow{5}{*}{ 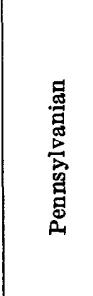 } \\
\hline III & Hayden & \multirow{2}{*}{ Des Moines } & \\
\hline IV & Round Top & & \\
\hline $\mathrm{v}$ & Reclamation & Atoka & \\
\hline VI & Fairbank & Morrow(?) & \\
\hline
\end{tabular}

Group and extend the known range of Lower Permian strata westward into rocks generally included in the Tensleep Sandstone of south-central and central Wyoming. The upper part of Division I, which is the equivalent of the Owl Canyon Formation is correlated into strata in western Nebraska that are generally regarded as younger than Wolfcamp, or of Leonard age.

The upper part of Division I, which was called the Cassa Group, by Condra, Reed, and Scherer (1940), is here divided between intervals A and B. The thin strata below the Ovl Canyon Formation in southeastern Wyoming, which those geologists included with the Owl Canyon to form their Cassa Group, resemble the underlying rocks more than the overlying ones. These lower strata are included in this study with the Broom Creek Group in interval $A$, and the Owl Canyon Formation is placed in interval $B$.

White to yellowish crossbedded sandstone, which is a facies of the Owl Canyon Formation, is included as part of the Casper Formation in a few places in the northern Laramie Range. In this area the Casper Formation, which is dominantly sandstone, is arbitrarily divided between interval $\mathrm{A}$ and interval B. In the Hartville uplift, the Lance Creek field, and the southern Black Hills a similar sandstone facies of the Owl Canyon, the Converse sands, is placed in the Hartville and Minnelusa Formations and included in interval $B$.

In central and south-central Wyoming, rocks of Permian interval A are difficult to separate from underlying Pennsylvanian rocks. The name Tensleep Sandstone has been applied in the vicinity of the type section in north-central Wyoming to rocks that are no younger than Des Moines (Pierce, 1947). This name has been applied to rocks as far southward as south-central Wyoming and to rocks of similar lithology but mostly of Early Permian age. Similarly, the Tensleep has been correlated southeastward with the Pennsylvanian and Permian Casper Formation of the Laramie Range. The generalized stratigraphic relationships of these units are illustrated in figure 48. More satisfactory stratigraphic, areal, and temporal interpretations could be made if these two formations were carefully differentiated.

In south-central Wyoming, sandstone of the Permian parts of the Casper Formation and Tensleep Sandstone is difficult to separate from sandstone of the underlying Pennsylvanian parts.

Paleontological or physical evidence for the Pennsylvanian-Permian boundary in the Laramie Range has been presented by Thomas, Thompson, and Harrison (1953, p. 13, pl. 9) and by Agatston (1954, p. $545,567)$; in the Casper area by Love (1954); and farther southwest by Agatston (1957, p. 33). This boundary has been projected into surrounding areas in preparing the isopach and lithofacies map for interval A (I-450, pl. 3; fig. 46, this report). Minor differences between lithologic units similar to those described above suggest that a thin tongue of Lower Permian rocks may extend into the Wind River Basin (figs. 44, 47), farther northwest than shown in figure 46. This tongue may be the Nowood Member of the Park City Formation (McCue, 1953), which is included in interval $B$.

\section{UPPER BOUNDARY OF INTERVAL A}

The upper boundary of interval $A$ in the eastern part of this region is placed at the top of the uppermost carbonate or sulfate rock in the Casper, Hartville, and Minnelusa Formations. Westward, in Wyoming, Montana, and North Dakota, the rocks of interval $A$ and the carbonate-sulfate unit at the top intertongue with sandstone. The upper boundary of the interval in the western part of the region is placed at the top of the well-sorted fine- and mediumgrained white sandstone.

Interval $\mathbf{A}$ is overlain by distinctive red mudstone of interval $B$ throughout most of the region, except along the east margin in the Dakotas, where rocks of Jurassic age directly overlie interval A. The overlying red mudstone of interval $B$ in the Hartville uplift intertongues westward with sandstone similar to interval $A$, and the two units are arbitrarily separated in the northern Laramie Range. In the southeastern part of the region, overlying red-bed units are the Ovl Canyon Formation and its equivalent, the lower part of the Satanka Shale. Northward and westward, beyond the limits of these formations, the 


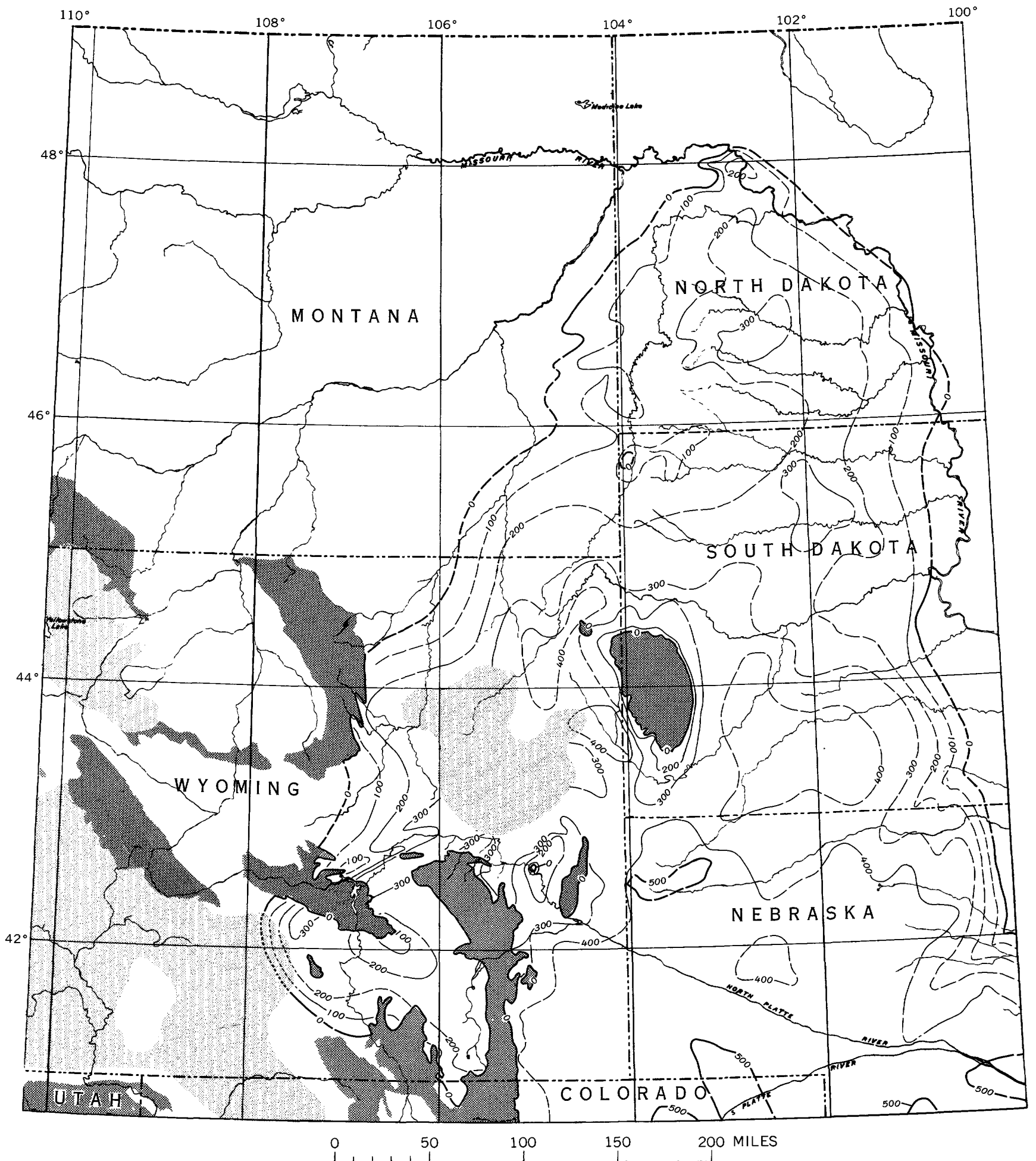

Figure 46.- Thickness of interval A in central Wyoming, eastern Montana, the Dakotas and parts of adjacent States discussed in this chapter. Isopach intervals 100 and 500 feet. Isopachs dashed where control is poor, dotted where Permian rocks have not been penetrated by drill. Dark pattern, areas where rocks older than Permian are exposed; light pattern, areas where rocks younger than interval A have not been penetrated. 


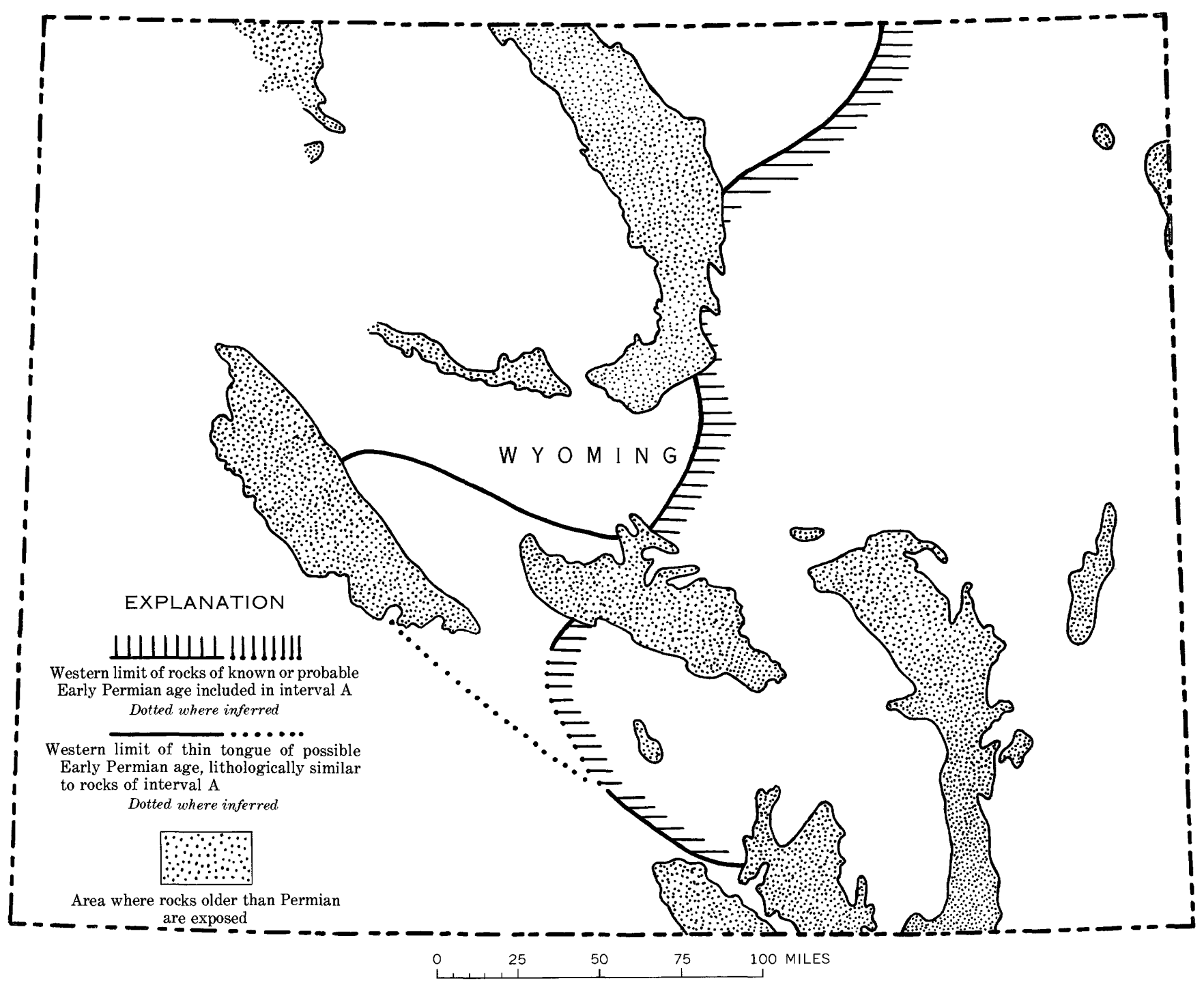

FIgURE 47.-Western limit of interval $\mathrm{A}$ in central Wyoming.

Opeche Shale and equivalent strata occupy a similar position. In the northeastern part of the region there is an overlying red-bed unit of Jurassic age, the Saude Formation.

In most places the Oiol Canyon or Satanka lies conformably on rocks of interval $A$. The Opeche Shale generally rests on rocks of interval A without angular discordance, although the Owl Canyon or lower part of the Satanka is absent. Evidence of unconformity at this contact in northeastern $\mathrm{Wy}$ oming has been presented by Barkley and Grosman (1958, pl. 4 between p. 178-179), F. H. Brady (1958, p. 46-47), Agatston (1954, p. 552), and D. I. Foster (oral commun., 1961).

A major angular unconformity separates rocks of interval A from overlying rocks of Jurassic age in central North Dakota and South Dakota.
THICKNESS TRENDS

Sediments of interval A were deposited in Early Permian time in in a large basin centered near the present Black Hills. The interval was originally thickest near the Black Hills, but near this uplift original thicknesses have been much reduced by leaching of anhydrite and gypsum (Bowles and Braddock, 1960). Interval A thickens southeastward into Nebraska but thins in other directions away from the Black Hills area.

Thinning of interval A west and north of the Black Hills is partly the result of transgression of the sea upon the flanks of the basin and partly due to differential sinking of the basin during Early Permian time. Some thinning in these directions probably also resulted from erosion, during a hiatus prior to deposition of the Opeche Shale when the Owl Canyon 
and lower part of the Satanka Formations were deposited in other areas.

Eastward thinning of interval A may be original in part but is mostly the result of erosion of the Minnelusa Formation before deposition of overlying strata of Middle Jurassic age.

In southeastern Wyoming, west of the Laramie Range, rocks of interval A extend further west than in northeastern Wyoming. In the southeastern area, rocks generally assigned to upper parts of the Casper Formation or the "Tensleep Sandstone" were probably formed of dune sand deposited on Pennsylvanian strata which had been arched in central Wyoming in latest Pennsylvanian or earliest Permian as a northward extension of the ancestral Front Range. These supposed dune deposits thin southwestward, westward, and northwestward, except for a belt of thick rocks, mostly of dune sand, which extends east-northeast across the center of the present Sweetwater uplift into the Casper area $(\mathrm{I}-450$, pl. 3 ; fig. 46 , this paper).

\section{ITTHOFACIES TRENDS}

Detritus in rocks of interval A was dominantly medium to fine sand in the southwest, fine sand and mud in the north, and mud in the southeast. Detrital rocks intertongue with carbonates and evaporites in all except the southwesternmost part of the region, where the rocks are entirely sandstone.

Cross-stratified sandstone of probable dune origin covers a large area in south-central Wyoming. Some sandstone, possibly of dune origin, lies near the west margin of interval A in northern Wyoming, eastern Montana, and North Dakota. This tongues eastward into carbonate rocks to form a north-trending belt which approximately coincides with the present Laramie Range. The sandstone in this belt contains low-angle rather than high-angle crossstrata, and was probably deposited in a beach environment. The ratio of carbonate to detrital rock increases eastward until the entire unit is marine. The facies of intertongued sandstone and carbonate rock extends northward from the Laramie Range into the Williston basin. In some parts of the basin, mudstone is a major constituent.

A dominantly carbonate and evaporite rock facies extends into the northern midcontinent region from western Nebraska and eastern Colorado. The outer margin of this facies, adjacent to the intertongued sandstone and carbonate rock, consists mostly of dolomite, but contains small amounts of sandstone, mudstone, and anhydrite. The dolomite grades eastward into anhydrite, so that east of the Hartville uplift of Wyoming and the Black Hills of South Dakota the unit is mostly interstratified anhydrite and dolomite.

An anomalous lithofacies pattern surrounds the Black Hills. The upper part of the Minnelusa Formation is interstratified sandstone and minor carbonate rock. In nearby subsurface sections, however, there is much anhydrite or gypsum. Either the deposits thinned against an ancestral Black Hills uplift (Gries, 1956, p. 113), or solution of the calcium sulfate left a detrital residue as the predominant constituent (Bates, 1955, p. 1999; Bowles and Braddock, 1960).

Solution of calcium carbonate seems the most plausible explanation, as an uplift near the center of a depositional basin is unlikely. Also, the upper part of the Minnelusa Formation was brecciated when strata collapsed owing to leaching. The apparent thinning and change of facies may be explained as the result of this leaching (C. G. Bowles, oral commun., 1959). However, brecciation in the northern Black Hills is less than that in the southern, so local uplift might have affected the Lower Permian strata in that area.

Collapse breccias, similar to those in the Black Hills, are known from the upper part of the Hartville Formation in the Hartville uplift (Love, and others, 1953) and from the upper part of the Casper Formation in the northern part of the Laramie Range near Douglas, Wyo. (Harrison, 1938; Agatston, 1954, p. 546). These breccias are evidence that solution of calcium sulfate also influenced the thickness and facies in those areas.

\section{SOURCES AND ENVIRONMENTS}

Rocks of interval A, in general, grade eastward from strata considered to be of fluvial origin into what are probably dune and beach deposits. The probable shore deposits, in turn, intertongue with marine strata. A principal source of detritus was the ancestral Front Range to the west, although an inferred land area east of the present east margin of interval A was probably also a source, as was the uplift in central Montana. The marine deposits extend between Early Permian land areas from western Nebraska and northeastern Colorado across southeastern Wyoming. They are thickest adjacent to the Black Hills.

Most of the detritus incorporated in this interval seems to have been derived from positive elements which largely enclosed the area of deposition. The Pennsylvanian part of the Tensleep Sandstone and related formations, exposed to erosion as parts of 
these positive elements, were the principal sources of sand. Sediment derived from the Tensleep Sandstone during Early Permian time was apparently redeposited in an environment similar to that of its earlier origin, as the sandstones of these two ages are much alike. The similarity of these units has led to confusion in names used for Pennsylvanian and Permian rocks in central and south-central Wyoming (fig. 48). Only rocks of Pennsylvanian age occur at the type section of the Tensleep in north-central Wyoming. In much of central Wyoming the upper part of the Casper Formation partly overlaps the Pennsylvanian Tensleep Sandstone, and the name Tensleep has been applied to Permian rocks equivalent to the upper part of the Casper. Nomenclature of Pennsylvanian and Permian rock- and time-stratigraphic units in central Wyoming is illustrated in figure 48.

The distribution of sandstone and mudstone in rocks along the west margin of interval A suggests that positive areas to the south were higher than those to the north and that the chief source for sediment was to the southwest. This distribution of sandstone and mudstone, however, may have also been influenced by the composition of source rocks in the two areas. This interpretation is based on the assumption that erosion of these Lower Permian rocks was relatively minor and that the rocks now preserved in the northern part of the region represent most of the strata originally deposited there.

Sandstone of interval A in south-central Wyoming was probably deposited mostly as dunes (as indicated by the abundant wedge-planar sets of high-angle cross-strata), although it has been interpreted as chiefly marine (Knight, S. H., 1929, p. 72-74; 1960, p. 228). Westward, the unit wedges out, the sandstone lacks high-angle cross-stratification, and stratification is nearly horizontal. In the western areas, deposition was probably in a fluvial environment. Eastward, the high-angle cross-stratified sandstone intertongues with sandstone that contains low-angle cross-stratification. The low-angle cross-strata probably resulted from deposition in a beach environment, and the rock in which they appear intertongues in southeastern Wyoming with beds of marine sandstone and carbonate rock.

The sandstone of supposed fluvial origin in the western part of the region has not yielded fossils and is inferred to be continental only because of its geographic position between eolian sandstone and the landward limit of deposition of rocks of interval $\mathrm{A}$.

In northeastern Wyoming, southeastern Montana, and southwestern North Dakota, rocks of interval A are probably entirely marine (Foster, D. I., 1958, p. 39), but depositional environments in this area may have paralleled those in south-central Wyoming, and along the west and north margins might include beach, dune, and flood-plain sand.

Climate during deposition of interval $\mathbf{A}$ was probably arid to semi-arid and warm. The abundant calcium sulfate toward the center of the depositional area, surrounded by a belt of dominant dolomite, the dearth of fossils, and the abundance of red iron hydroxides suggest a warm super-saline environment. The deposition of limestone and presence of marine fossils at the margins of this body of water suggest freshening near the shore by inflow of water from streams. On the other hand, the occurrence of dolomite and limestone around a central area of gypsum and anhydrite may indicate areas of lower salinity near the margins of a partly restricted evaporite basin (Scruton, 1953, p. 2505-2507).

\section{PALEOTECTONIC IMPLICATIONS}

The broad gentle synclinorium which formed near the end of Pennsylvanian or the beginning of Permian time in parts of Wyoming, Montana, and the Dakotas was a large basin which probably persisted with little change during deposition of interval $\mathbf{A}$. Initial deposits were restricted to southeasternmost Wyoming, but as the synclinorium broadened and deepened the Early Permian sea transgressed widely. Original margins of maximum marine transgression are preserved in southeastern Wyoming but elsewhere have been removed by erosion. The maximum transgression of this sea probably did not extend far beyond the present eroded margins of the interval except in central South Dakota. Here, rocks of interval $A$ are deeply eroded and may once have extended much farther east.

The positive elements which surrounded this basin except on the southeast were probably anticlinoria where Middle and Upper Pennsylvanian strata were exposed and eroded. Most of these positive elements were probably low, although in south-central Wyoming and north-central Colorado the ancestral Front Range may have been higher, so that strata older than Pennsylvania were exposed and eroded:

The basin had a north-northwest-trending axis nearly parallel to the northern part of the ancestral Front Range. A parallel structural trend approximately coincident with the Cedar Creek anticline (fig. 44) near the east side of the present Powder River Basin was also tectonically active during deposition of interval A. The apparently anomalous isopachs 


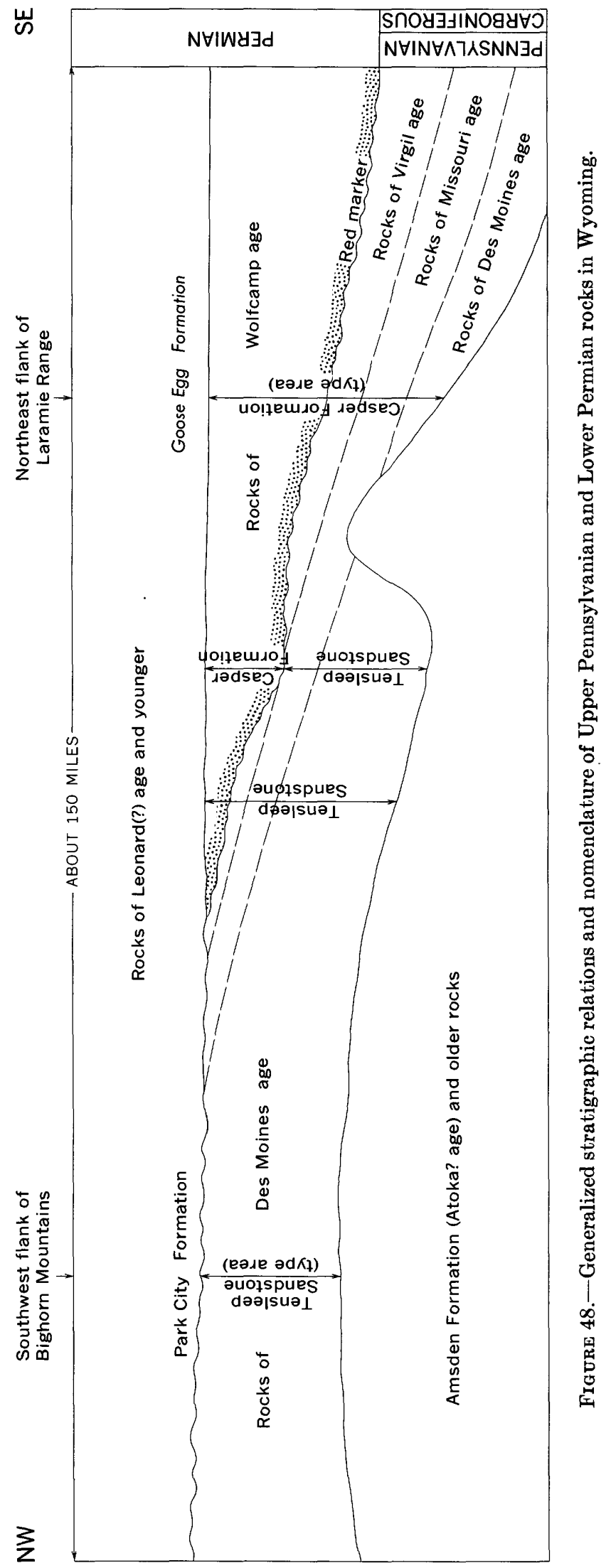


in this area (fig. 46) suggest general instability before the faulting, or monoclinal folding that was more sharply defined later in Permian time.

\section{INTERVAL B}

\section{FORMATIONS INCLUDED}

The Owl Canyon Formation, Opeche Shale, and Minnekahta Limestone and their equivalents compose this interval in eastern Wyoming and adjacent parts of South Dakota, North Dakota, and Montana (table 1). Equivalent units are the lower part of the Satanka Shale, Converse sands, Nowood Member of the Park City Formation, and the lower part of the Goose Egg Formation.

In the southern Bighorn and eastern Wind River Basins the Nowood Member (McCue, 1953) of the Park City Formation is probably also equivalent to part of the Owl Canyon Formation. In the southern Bighorn Mountains, the Nowood lies unconformably on the Tensleep Sandstone and, locally, unconformably below equivalents of the Phosphoria Formation; it may be equivalent westward to part of the Grandeur Member of the Park City Formation. Eastward it seems to be equivalent to a local argillaceous limestone or dolomite unit at the base of the Goose Egg Formation (Burk and Thomas, 1956, p. 9). This unit is thin at the type section but thickens in an adjacent well (Mississippi River Fuel 1 Government-Goose Egg; locs. 248, 249, pl. 5). Probably equivalent anhydrite or gypsum farther east and southeast are included at the top of the Owl Canyon Formation or the base of Opeche Shale.

In the Powder River Basin the Nowood Member either wedges out, forms a thin dolomite and anhydrite in the lower part of the Opeche Shale, or thickens into the Broom Creek Group where it is included in interval $A$. The dolomite-anhydrite unit in the lower part of the Opeche thickens northeastward into the Williston basin, where it forms interbedded detrital and evaporite strata, including halite.

\section{STRATIGRAPHIC RELATIONS}

The Owl Canyon Formation was named for Owl Canyon, Colo., where it lies between the Ingleside Formation and the Lyons Sandstone. In Wyoming it lies between the Casper or Hartville Formations and the Opeche Shale and is included in the Cassa Group of Condra, Reed, and Scherer (1940), with underlying thin limestone and thin sandstone units. As thin units in the lower part of the Cassa Group resemble the underlying strata more than the overlying Owl Canyon, they are included in interval A rather than interval $B$.
The Satanka Shale of the Laramie Basin includes equivalents of the Owl Canyon Formation, which is included in interval B. The Satanka also includes in its upper part 50-70 feet of strata equivalent to the Glendo Shale. These upper strata are included in interval C-D.

Some sandy strata, equivalent to the Owl Canyon, occur locally in the upper part of the Casper Formation in the northern Laramie Range (Agatston, 1954, p. 547). These also form the Converse sands of the upper part of the Hartville Formation in the Hartville uplift and of the upper part of the Minnelusa Formation in parts of the southern Black Hills. Elsewhere in the southern Black Hills these strata form the lower part of the Opeche shale.

The "Casper Sandstone" in the southwest part of Laramie Basin is a tongue in the Satanka Shale (Maughan and Wilson, 1960) which is separated from typical Casper Sandstone by a tongue of red beds which is the lower part of the Satanka. The Converse sands and the "Casper Sandstone" in the southwest part of the Laramie Basin intertongue similarly into the $O w l$ Canyon, or lower part of the Satanka, as does the Lyons Sandstone in northeastern Colorado with which they are correlated.

The Opeche Shale and Minnekahta Limestone were named for exposures in the Black Hills (Darton, 1901, p. 513-514) but extend westward into central Wyoming as members of the Goose Egg Formation (Burk and Thomas, 1956, p. 9). They also occur in subsurface north and east of the Black Hills, but southward the Minnekahta grades into anhydrite and gypsum, then merges with the Blaine Formation.

The Opeche and Minnekahta thin from the Black Hills into the Laramie Basin and Laramie Range of south-central Wyoming, where they are generally less than 20 feet thick. Here they are commonly sandy and apparently intertongue south ward with the upper part of the Lyons Sandstone.

The Opeche and Minnekahta also thin northwestward from the Black Hills, wedging out near the margin of interval $\mathrm{B}$ in north-central and northeastern Wyoming and southeastern Montana. Westward they merge into the lower part of the Franson Member of the Park City Formation across a narrow belt between the ancestral Front Range to the south and a positive element in northern Wyoming and central Montana to the north. Their northern and eastern limits are truncated.

UPPER BOUNDARY OF INTERVAL B

The tops of the Minnekahta Limestone and equivalent rocks serve as the upper boundary of interval B throughout this region. These probably form a 
nearly isochronous surface. In most of the eastern Wyoming-Montana region the Minnekahta is overlain by apparently conformable strata of interval C-D.

Near the north and east margins of Permian rocks in North and South Dakota the Minnekahta, because of erosion, gradually thins eastward to the margin of interval $B$ rocks and is overlain with regional unconformity by rocks of Middle Jurassic age. The more easily eroded claystone and siltstone of the underlying Opeche Shale and Owl Canyon Formation do not extend much beyond the limits of the resistant Minnekahta.

\section{THICKNESS TRENDS}

A broad belt in which interval B is relatively thin extends northeastward from central Wyoming into northwestern South Dakota and southwestern North Dakota. This belt lies between the modern Laramie Basin and Denver-Julesburg basin on the south and the modern Williston basin on the north. Interval B also thins depositionally west and northwest toward eastern Montana and by erosional truncation to the north and east in North and South Dakota (fig. 49).

The thickening of interval $B$ in southeastern Wyoming and southwestern South Dakota is largely in the lower part of the Satanka Shale or Owl Canyon Formation. These lower beds were only deposited southeast of a line through the Shirley basin and the northern part of the Laramie Range in Wyoming and the southern Black Hills south of Newcastle, Wyo., and Rapid City, S. Dak. (fig 44). On the west, this line curves southward, parallel to the ancestral Front Range highland and the present Medicine Bow Range.

The lower rocks of interval B thicken southeastward into the ancestral Julesburg basin in northwestern Nebraska. Another basin of deposition centered in the southern Laramie Range. These two basins were apparently separated by an area of thin deposits that extends from the southeast cormer of Wyoming north-northwest to the east flank of the northern Laramie Range, west of Douglas, Wyo.

The upper part of interval B, composed of the Opeche Shale and the Minnekahta Limestone, is rather uniformly 75-125 feet thick but thins southwestward into Colorado where it approaches a depositional boundary along the northeast flank of the ancestral Front Range.

The upper part of the interval extends into central and northern Wyoming, eastern Montana, western North Dakota, and northwestern South Dakota, overlapping far beyond the lower part. Here, as farther south, the thickness of interval B is fairly uniform; but the Opeche Shale thickens somewhat in western North Dakota, where it may include older strata equivalent to part of the Owl Canyon Formation and to the Nowood Member of the Park City Formation.

Interval $\mathrm{B}$ abruptly thickens eastward across the Cedar Creek anticline of eastern Montana toward the central part of the Williston basin (fig. 44). The Opeche also thickens northward in Montana and North Dakota across an east-northeast structural trend which crosses the Cedar Creek anticline in the vicinity of the Pennel and Cabin Creek units in Wibaux and Fallon Counties, Mont. (fig 44), and intersects the Fryburg field in Billings County, N. Dak.

In central Wyoming, interval B gradually thickens westward, mostly in the basal part of the Nowood Member. Some of this variation may be due to an unconformity between the Nowood and the overlying Opeche (Tourtelot, 1953; McCue, 1953).

\section{IITHOFACIES TRENDS}

Three contrasting lithofacies occur in interval B. Mudstone, anhydrite or gypsum, and halite are present in the central part of the Williston basin in North Dakota and Montana. Detrital and evaporite rocks are present in southeastern Wyoming and southwestern South Dakota. Normal and calcereous mudstone form a northeast-trending belt across the northern and the southern facies.

In the southern part of the region detrital and evaporitic rocks form the thick lower part of only interval B (the Owl Canyon Formation or lower part of the Satanka Shale). These rocks are predominantly sandstone near the northern limit of deposition from the northern Laramie Range to the southern Black Hills but grade southward into siltstone and evaporite rock. This evaporite rock, including halite, is most abundant in the ancestral Julesburg basin, in northwestern Nebraska.

The dominant facies of the central part of the region is determined by the Opeche Shale and the Minnekahta Limestone. Although these formations are present north and south of this area, they are masked by thick underlying sedimentary rocks of contrasting composition. In central Wyoming, interval B is mainly carbonate rock, but eastward it is mostly mudstone. Minor amounts of evaporite rock occur in many places. Carbonate rock dominates along a sinuous band trending north-south through the Powder River Basin in southeastern Montana and northeastern Wyoming (I-450, pl. 4). This carbonate rock is within the Opeche Shale. The south end of the carbonate rock band curves westward and may connect with similar carbonate rock in the lower part 


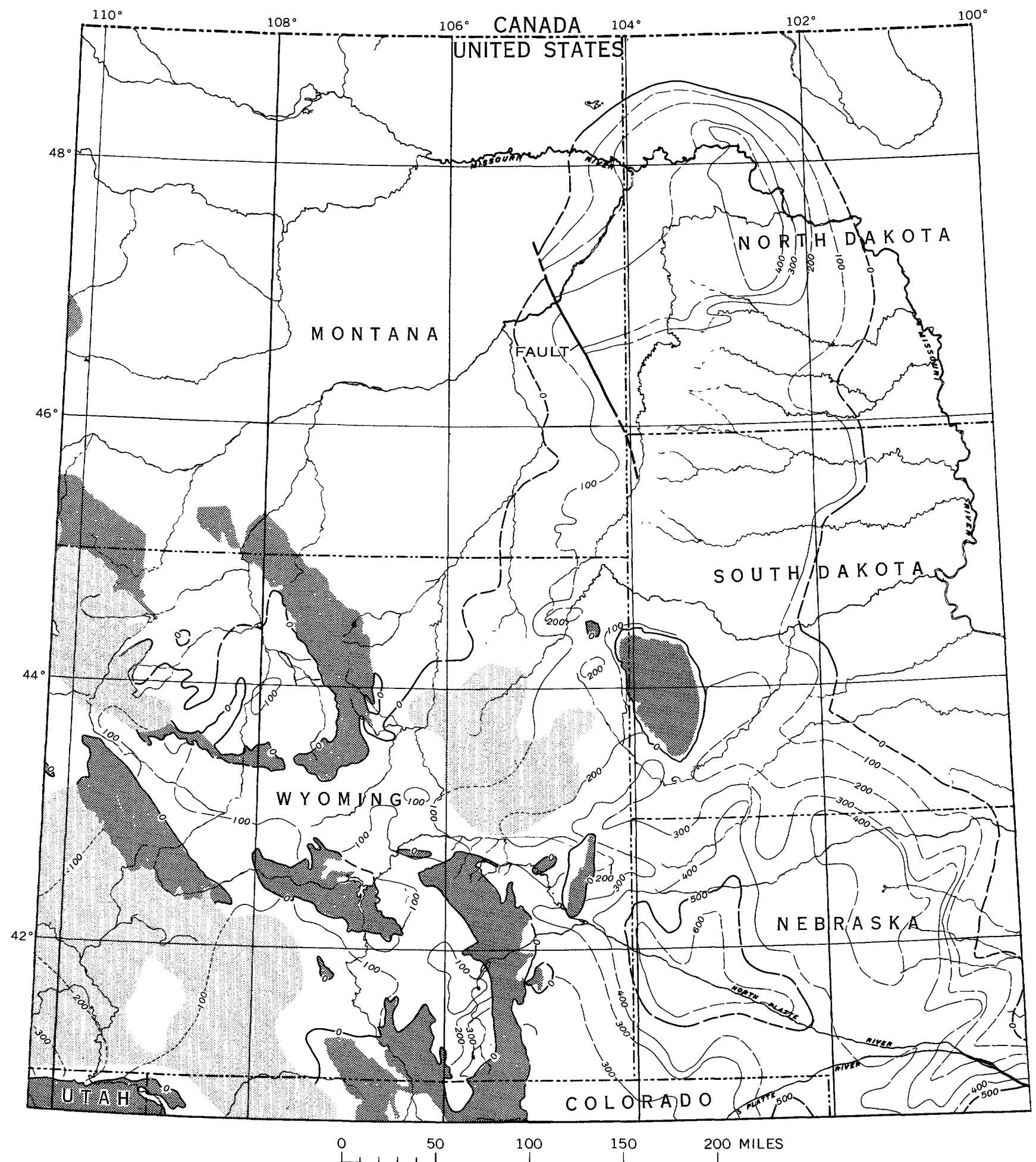

FIgURE 49.-Thickness of interval B in central and eastern Wyoming, Montana, the Dakotas, and parts of adjacent States. Isopach interval 100 feet. Isopachs dashed where control is poor, dotted where Permian rocks have not been penetrated by drill. Dark pattern, areas where rocks older than Permian are exposed; light pattern, areas where Permian rocks younger than interval $\mathrm{B}$ have not been penetrated. 
of the Park City Formation of central Wyoming. A branch of this band extends southward west of the Black Hills into a basin in northwestern Nebraska.

In central Wyoming, interval B grades westward from mudstone to carbonate rock. Detrital rock in this area is mainly red in the east and green in the west. Anhydrite grades westward into dolomitic limestone.

Lithofacies in the northern part of this region, near the Williston basin, resemble those in the central part, except for more gypsum, anhydrite, or halite in the Opeche Shale.

Near the east margin of interval B in North Dakota and South Dakota, the abundance of sandstone indicates an influx of relatively coarse detrital sediment from an eastern positive element.

\section{SOURCES AND ENVIRONMENTS}

The source of the Owl Canyon Formation in the lower part of interval B was probably chiefly to the northwest but partly to the west or possibly southwest. Much of the detritus must have come from Pennsylvanian and lower Permian rocks in the Tensleep, Casper, Hartville, and Minnelusa Formations. Another source which included rocks as old as Precambrian may have been to the west or southwest, beyond the Laramie Basin.

Rocks forming the lower part of interval B were probably dune, delta, littoral, and neritic deposits near the margin of a sea to the southeast. Sand near the northwest and southwest margins was probably deposited chiefly by wind, as indicated by many wedge-planar sets of high-angle cross-stratification. This probable eolian sandstone grades laterally into horizontally stratified red sandstone and mudstone that may have been deposited on deltas or tidal flats. Farther southeast, where evaporites intertongue, there was a very saline sea.

The Opeche and the Minnekahta, in the upper part of interval $\mathrm{B}$, seem to have been deposited in a partly restricted sea. This sea's advance into the region followed a time of regression and took place during deposition of the lower part of the interval. At first the sea was shallow and of greater than normal salinity. Later, the depth of water apparently increased, and salinity decreased to nearly normal concentrations, except in southeastern Wyoming and adjacent areas in Nebraska and Colorado, where salinity remained high.

The Opeche is probably transitional from continental into marine deposits, although the red color and lack of fossils suggest the possibility of continental origin. A transitional environment is sug- gested by stratigraphic position; widespread uniformly thick deposits; inclusion of dolomite, anhydrite, gypsum, and halite; gradation upward into marine Minnekahta Limestone; and uniformity of color.

The Minnekahta Limestone is largely of marine origin as indicated by carbonate lithology and marine fossils. The water in which it formed was probably of near normal salinity, but many factors, such as the dearth of fossils, widespread dolomitization of the limestone, and local patches of anhydrite or gypsum, suggest local abnormal conditions.

Carbonate sediment of the Minnekahta Formation was deposited contemporaneously with anhydrite and gypsum of the Blaine to the southeast, and a physical or hydrostatic barrier may have separated nearly normal sea water in one area from supersaline water in the other.

A low sill in central Wyoming connected the eastern Wyoming sea with the Phosphoria sea to the west. Because the sill was relatively shallow and narrow, it probably did not afford ample space for reflux circulation necessary for maintenance of normal marine salinity in the basin to the east. An alternative explanation for nearly normal marine conditions in eastern Wyoming is that circulation may have been established through a connection to the north with a sea in Canada, beyond the present truncated limits of the Minnekahta in North Dakota.

\section{PALEOTECTONIC IMPLICATIONS}

The sea in central Wyoming, southeastern Montana, and southwestern North Dakota in which strata of interval A were deposited during Early Permian (Wolfcamp) time, withdrew to the southeast because of slight uplift north of an east-northeast-trending hinge, approximately coinciding with the belt of the structural elements of the Wyoming lineament (Ransome, 1915, p. 294-295; Blackstone, 1956, p. 8, 18).

During interval $\mathrm{B}$ the sea transgressed into southeastern Wyoming and southwestern South Dakota but was slowed or halted along the hinge and did not cross it until later in interval $B$. This transgression from the south coincided with a transgression of the Phosphoria sea from the west, and when these joined they inundated eastern Wyoming, Montana, and the Dakotas.

Faulting or sharp folding along ancient structural elements affected rocks as young as those in the upper part of interval B. This faulting or folding was related to a general uplift of the northern part of the region. The most clearly defined structure is a probable fault in southeastern Montana and northwestern South Dakota along the present Cedar Creek anticline. Rocks similar to the Opeche Shale occur 
on both sides of this structure but are much thinner on the west. Whether deformation occurred shortly before or during deposition of the Opeche Shale is not certain, but thickness of the overlying Minnekahta Limestone and of the underlying upper part of the Minnelusa Formation were not significantly affected.

A fault or a fold near the west margin of the Powder River Basin closely parallels the Cedar Creek anticline and affected the thickness and distribution of both the Opeche and Minnekahta. West of it interval $\mathrm{B}$ extends much farther north in the Bighorn Basin than in the Powder River Basin. The western block was lowered relative to the eastern block, and movement probably occurred before deposition of the upper part of interval B, as the Opeche and Minnekahta wedge out similarly upon both blocks.

The apparent offset of rocks in the upper part of interval $B$ along the present trend of the Bighorn Mountains is alined with the Horn fault of Laramide age and with older structural elements-farther southeast along the northeast side of the Laramie Range and in the Julesburg basin. An ancient structural element may have extended southeastward along this alinement into the Julesburg basin, as rocks in the lower part of interval B thin over it (fig. 49). This element approximately coincides in central Wyoming with the northeast flank of the Casper arch (fig. 44), to which it may have been ancestral.

\section{INTERVAL C-D FORMATIONS INCLUDED}

Several overlapping sets of names have been used for interval C-D of the Permian System in this region of eastern Wyoming, eastern Montana, North Dakota, and South Dakota.

In outcrops in the Black Hills and in the subsurface northward into Montana and North Dakota, rocks of this interval include the lower part of the Spearfish Formation and, locally, the Pine salt.

In southeastern Wyoming, strata equivalent to the lower part of the Spearfish are the upper part of the Satanka Shale, the Glendo shale, the Forelle Limestone, and the lower part of the Chugwater Formation.

In central Wyoming, interval C-D is part of the Goose Egg Formation. which includes the Glendo Shale and Forelle Limestone also, as well as the lower part of the Freezeout Tongue of the Chugwater Formation (Thomas, H. D., 1934, p. 1670), and the Ervay Carbonate Rock Member of the Park City Formation. These units were incorporated as members in the Goose Egg at its type section (Burk and Thomas, 1956 , p. 9-10. This nomenclature has subsequently been extended to adjacent parts of northeastern Wyoming( Privrasky and others, 1958, p. 50, 52).

In the Bighorn Basin and adjacent areas of northcentral Wyoming and south-central Montana, this interval occurs in the Embar or Phosphoria Formations of early usage, now called the Park City Formation in this area (McKelvey and others, 1956). Here the upper part of the Franson and Ervay Carbonate Rock Members of the Park City as well as the eastward-extending Retort Phosphatic Shale and Tosi Chert Tongues of the Phosphoria Formation are included in the interval.

\section{STRATIGRAPHIC RELATIONS}

The lowest unit of interval $\mathrm{C}-\mathrm{D}$ is the Glendo Shale, about 60 feet of mudstone and siltstone lying between the Minnekahta and Forelle Limestones (Condra and others, 1940, p. 5). Strata equivalent to the Glendo can be recognized in the upper part of the Satanka Shale in the Laramie Basin in southcentral and southeastern Wyoming beyond the limits of the Minnkahta, and in northwestern South Dakota and nearby States at the base of the Spearfish Formation beyond the limits of the Forelle.

The Glendo Shale is probably equivalent to the "Whitehorse Sandstone" to the southeast in the central Midcontinent region, although its lower part may be equivalent to the Dog Creek Shale. Westward in central Wyoming a tongue of the Glendo apparently projects into the middle or lower part of the Franson Member of the Park City Formation. The Glendo Shale locally includes anhydrite and gypsum lenses in the Laramie Basin, the Cheyenne area, and farther south along the Front Range in north-central Colorado. These lenses grade into dolomite or limestone farther south and have been correlated with the Falcon Limestone Member of the Lykins Formation of the Golden, Colo., area (Broin, 1957).

Northward along the east side of the Laramie Range the Falcon correlates with the Minnekahta, according to Broin (1957); however, in the Laramie Basin and on the east side of the range where the gypsum facies of both the Falcon and the Minnekahta are present, about 45 feet of typical Glendo Shale separates these units. The Glendo Shale, therefore, probably correlates southward with the Harriman and Bergen shale Members of the Golden area and encloses the Falcon Limestone Member.

The Forelle Limestone is a widespread thin unit, generally about 30 feet thick, of "crinkly" algal limestone (Darton, 1908, p. 430). In central Wyoming the Forelle is a member of the Goose Egg Formation (Burk and Thomas, 1956, p. 9). The Forelle changes 
eastward into anhydrite and gypsum; but in the southern Black Hills, where it is mapped with the lower part of the Spearfish Formation, it is locally composed of dolomite and retains its crinkly lamination (D. E. Wolcott, oral commun., 1959).

The Forelle thins westward across Wyoming to an edge in central Wyoming; in north-central Wyoming it connects with the middle or upper part of the Franson Member of the Park City Formation. This concept of a westward connection was illustrated by H. D. Thomas (1934, fig. 3, p. 1664), who showed the Forelle as an eastward-extending tongue of the Phosphoria Formation.

The Forelle also thins northward against a positive element and is missing in subsurface in the northern Bighorn and Powder River Basins and in exposures in the northern Bighorn Mountains. The Forelle is absent north of the Black Hills also, although strata of equivalent age probably extend into the Williston basin, where they are either a basal part of the Pine Salt or part of the siltstone unit directly below the Pine.

Southward the Forelle Limestone crops out discontinuously along the east side of the Laramie and Front Ranges from southern Wyoming into northern Colorado and is equivalent to the crinkly sandstone, or Glennon Limestone Nember of the Lykins Formation, near Golden, Colo. (LeRoy, 1946, p. 44), as well as to the Day Creek Dolomite of Kansas and equivalents of the Day Creek in Nebraska.

Red mudstone above the Forelle and below the eastward-extending Ervay Tongue forms the lower part of the Freezeout Nember (Thomas, H. D., 1934, p. 1670; Burk and Thomas, 1956, p. 9-10). The Ervay and contemporaneous evaporitic rocks extend throughout this region and everywhere separate the Freezeout Member into an upper and a lower unit (Wyoming Geol. Assoc., 1956). The upper part of the Freezeout Nember is probably of Triassic age, as it seems to be stratigraphically equivalent to the lower part of the Early Triassic Dinwoody Formation farther west.

The lower part of the Freezeout Member averages 20-50 feet in thickness and wedges out northwestward against a positive element. In parts of eastern Montana and western North Dakota it intertongues with halite included in the Pine Salt.

In central Wyoming the lower part of the Freezeout Member intertongues with parts of the Ervay Carbonate Rock and Franson Members of the Park City Formation and with the Tosi Chert and Retort Phosphatic Shale Members of the Phosphoria Formation. In north-cent ral Colorado it is part of the Lykins Formation. The unit may be equivalent to some part of the Taloga Formation in Kansas and Quartermaster in adjacent areas, but strata of this age are eroded in most of the intervening area.

The Ervay Carbonate Rock Member of the Park City Formation intertongues eastward and is included in the Goose Egg Formation in central Wyoming (Burk and Thomas, 1956, p. 9). The member includes limestone and dolomite and father east grades into gypsum and anhydrite, and halite.

The gypsum and anhydrite facies of the Ervay occupies most of eastern Wyoming, western South Dakota, and adjacent areas. The halite facies or Pine Salt (Zieglar, 1955, p. 50) occurs principally in the Williston basin in eastern Montana and North Dakota, but it also extends into parts of northeastern Wyoming.

The Pine Salt was originally thought to be Jurassic but now is believed to be mainly Permian, with a small thickness of Early Triassic at the top (Zieglar, 1955, p. 55; oral commun., May 1959).

Plate 5 is a correlation of sample and electric logs from the type section of the Goose Egg Formation (Burk and Thomas, 1956 , p. 6) near Casper, Wyo., to an oil-test hole in the Pine field near Glendive, Mont. The Little Medicine Tongue of the Dinwoody Formation and the red mudstone of the upper part of the Freezeout Member, probably of Early Triassic age, can be traced northward from the Goose Egg Formation into halite in the upper part of the Pine Salt in the Pine field.

The Ervay and the red mudstone of the lower part of the Freezeout Member, of Permian age, can be traced similarly into the lower part of the Pine Salt. In most of the Williston basin to the north the upper part of the Pine Salt seems to be absent, so that the basal Jurassic red-bed unit (Saude Formation of Zieglar) overlies halite of Permian age.

Equivalents of the Ervay extend into southeastern Wyoming and perhaps into nearby Colorado and Nebraska. Outcrops are poor, but subsurface data from the Laramie Basin and the northern part of the Denrer-Julesburg basin indicate that these strata are mostly gypsum and anhydrite, with some red mudstone and dolomite. Surface exposures contain relatively little gypsum and anhydrite, for the reasons suggested by Mudge (chap. F); and equivalents of the Ervay and lower part of the Freezeout are generally included as part of the Chugwater Formation.

\section{UPPER BOUNDARY OF INTERVAL C-D}

The Ervay Carbonate Rock Member of the Park ('ity Formation and the probably equivalent parts of the Pine Salt are the youngest Permian rocks throughout the eastern Wyoming-Montana-Dakota region, and 
the youngest of interval C-D. In most of the region they are overlain with seeming conformity by correlatives of the Dinwoody Formation of Early Triassic age. Near the present limits of interval C-D in the Dakotas, the strata of Triassic age have been removed by erosion and the interval is overlain by Jurassic rocks.

The nature of the contact between strata assigned to the Permian and Triassic Systems in this region is uncertain. The several alternatives are discussed in greater detail by R. P. Sheldon (chap. H, p. 164-166); evidence in eastern Wyoming seems to favor nearly continuous deposition, and only a short hiatus, if any, seems possible between Permian and Triassic strata.

Regressive offlap in Permian time succeeded by local erosion and transgressive overlap in Early Triassic time is most likely in eastern Wyoming. Erosion had little effect on the uppermost Permian rocks and may have only occurred in a few places, such as the southern part of the Laramie Basin ( $\mathrm{I}-450$, pl. $14 C$ ) near the tectonically unstable Front Range highland. Continuous or nearly continuous deposition is suggested by conformity in most other places between uppermost Permian and basal Triassic strata, by similar distribution of facies, as well as by widespread distribution in uppermost Permian strata of readily soluble evaporitic rocks, which were probably not leached prior to deposition of the basal Triassic strata.

\section{THICKNESS TRENDS}

Interval C-D thickens southward and eastward from its depositional edge in southeastern and south-central Montana (fig. 50). Although differences in thickness are generally slight, the rocks abruptly thicken to about $450^{\circ}$ feet east of the Cedar Creek anticline. The interval wedges out not far west of the Cedar Creek anticline (I-450, pl. $14 D)$. The lower part of the interval has about the same thickness on both sides of the anticline, and the difference in thickness is in the upper part. These rocks also thin and wedge out near the Sierra Madre in south-central Wyoming.

Interval C-D is as much as 450 feet thick in northwestern South Dakota, in the present Powder River Basin in northeastern Wyoming, and in the northern part of the present Julesburg basin of western $\mathrm{Ne}$ braska. Elsewhere the interval is 150-250 feet thick. Local minor thickening suggests incipient basins near the present Bighorn and Laramie Basins.

In the Black Hills original thickness of interval C-D was probably somewhat less than in surrounding areas, but the present thickness to the north and east apparently also results from erosion before deposition of overlying Jurassic strata.

\section{LITHOFACIES TRENDS}

Interval $\mathrm{C}-\mathrm{D}$ throughout the region is mainly finegrained detrital rock, interstratified with small amounts of evaporitic rock. The detrital rock consists mainly of extensive blanket deposits of clay and silt. The evaporitic rock also forms blankets mostly of anhydrite and gypsum but locally of dolomite, limestone, or halite.

The dolomite and limestone are most abundant in the western part of the region, and halite occurs only in the eastern part (pl. 5; and I-450, pl. 5), as in the Williston basin area. These rocks are increasingly calcareous to the west, and most of the detrital rocks, as well as the evaporitic rocks, intertongue with carbonate rock deposited in the Phosphoria sea of central Wyoming.

\section{SOURCES AND ENVIRONMENTS}

Interval C-D seems to have been deposited in a shallow sea during a warm arid period. A "specialized marine environment" (Thomas, H. D., 1934, p. 16921693) is believed to be indicated because: (a) Individual beds of red mudstone only show slight variation in thickness or in texture over wide areas; (b) mud cracks or rain-drop impressions have never been noted in the red mudstone; (c) the shaly mudstone lacks certain features-such as lenticularity of beds or changes in texture within short distances, channeling, and cross-lamination-which are common characteristics of red beds of unquestionable continental origin; (d) red mudstone is intercalated and intergraded with limestone or sandstone of undoubted marine origin and with laminated chert of probable marine origin; (e) the absence of fossils in the red beds indicates nothing regarding environment of deposition.

Evidence of an arid climate (Richardson, G. B., 1903 , p. $389-390)$ at the time sediments of interval $\mathrm{C}-\mathrm{D}$ were deposited consists of beds of rock salt and gypsum and a paucity of organic matter. Absence of organic remains and of chemical reduction, which would have changed the red ferric oxides to drab ferrous compounds, testifies to relatively arid climate.

Detritus in interval C-D was apparently derived from adjacent positive elements which probably were low and deeply weathered in a warm arid climate. The uniformly fine size of detrital particles suggests residual red soil as a source (Richardson, G. B., 1903, p. 389-391). The ancestral Rocky Mountains were probably the chief contributor (Thomas, H. D., 1934, p. 1691-1692; Richardson, G. B., 1903, p. 388). An increase in abundance of detritus eastward suggests an eastern source also (Thomas, H. D., 1934, p. 1692), 


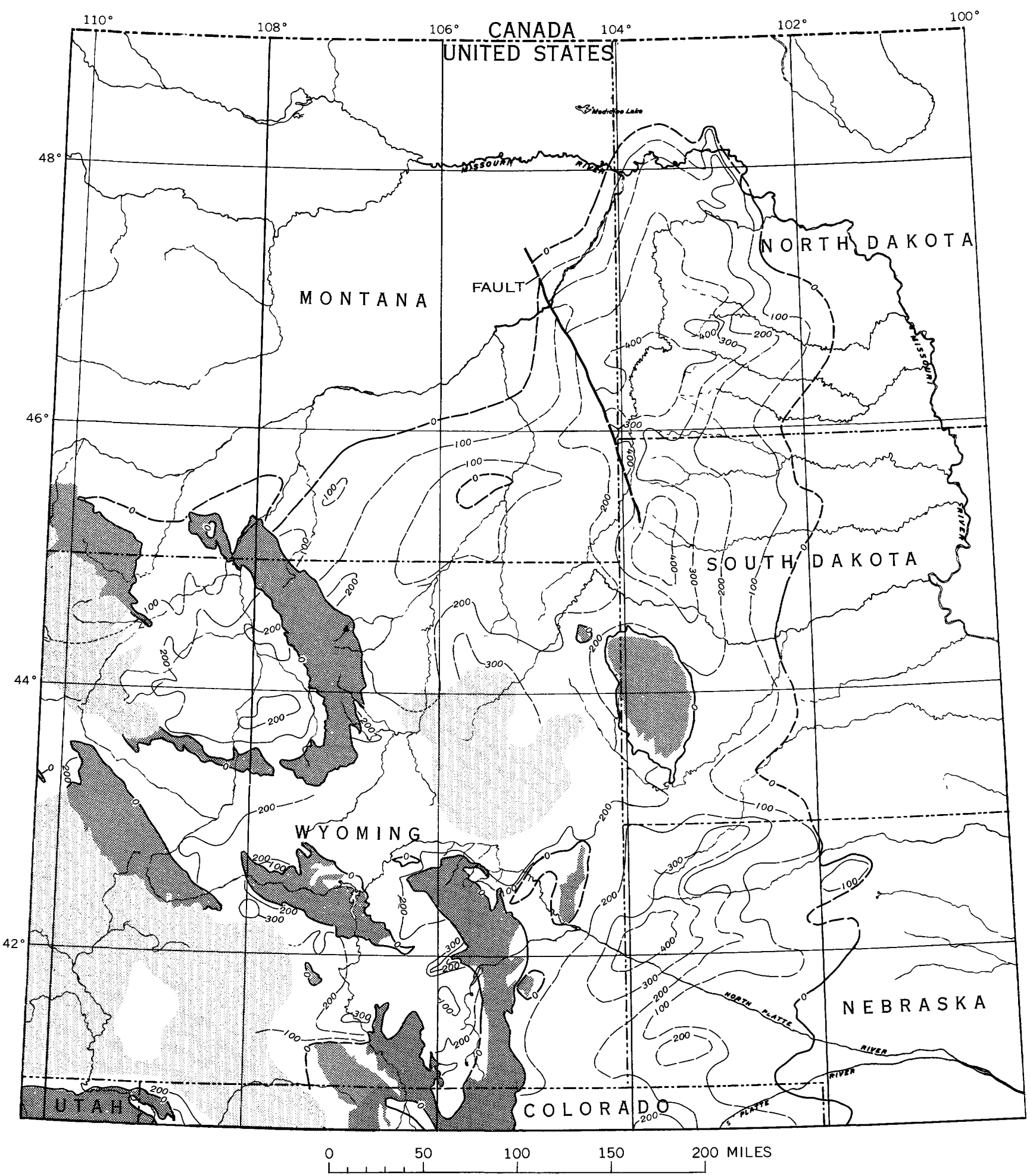

FiguRE 50.-Thickness of interval C-D in central and eastern Wyoming, Montana, the Dakotas, and parts of adjacent States. Isopach interval 100 feet. Isopachs dashed where control is poor, dotted where Permian rocks have not been penetrated by drill. Dark pattern, areas where rocks older than Permian are exposed; light pattern, areas where Permian rocks younger than interval $\mathrm{C}-\mathrm{D}$ have not been penetrated. 
and some material may have come from a positive element to the northwest in central Montana.

\section{PALEOTECTONIC IMPLICATIONS}

Strata of interval C-D in the northern Midcontinent region indicate only slight tectonic instability during the latter part of the Permian. The sediments were deposited in a wide shallow basin bordered on the north, east, and southwest by low positive elements. The basin had approximately the same extent as the basin in which the upper strata of interval B were deposited.

Epeirogeny seems to have affected the entire northern Midcontinent region during the time of interval C-D. Gradual marine transgression across the adjacent positive areas is indicated by overlapping of progressively younger Permian strata. Thus, the uppermost unit, the Ervay and equivalent strata, is the most widespread Permian unit.

Several small basins formed in areas approximately coincident with Mesozoic structural basins which strongly influenced the modern physiography. The most conspicuous of these was on the site of the present Williston basin of western North Dakota and eastern Montana.

Near the west margin of the Permian Williston basin, a fault or sharp fold formed near the axis of the present Cedar Creek anticline (fig. 50). Movement on this structure during interval C-D probably occurred after deposition of the Glendo Shale and Forelle Limestone, or their temporal equivalents, but before deposition of Lower Triassic strata. Thickness of the lower units is similar on both sides of the structure; on the other hand, thickness of the upper units, consisting of the Pine Salt and related strata, is greatly different on opposite sides of this fault or sharp monoclinal fold.

Thick accumulations of sediment approximately coincide in position with the Powder River Basin and the northern part of the Denver-Julesburg basin and possibly with the Bighorn and Laramie Basins. These thick deposits seemingly indicate tectonically unstable areas which were persistently or intermittently active through long periods. The thinning of interval $\mathrm{C}-\mathrm{D}$ in the Black Hills area indicates a positive tendency there for the first time in the Permian. A conspicuous structural feature was not formed in this area, however, until the Laramide orogeny.

\section{TOTAL THICKNESS OF PERMIAN ROCKS THICKNESS TRENDS}

Permian rocks of the northern Midcontinent region thicken westward and southward from an edge in western South Dakota and North Dakota and in eastern Montana (fig. 51). These rocks also thicken from an edge in the Sierra Madre area in south-central Wyoming, where they overlap older rocks. Their original thickness has been reduced in most parts of South Dakota and North Dakota and in extreme middle-eastern Montana by pre-Jurassic erosion. In other parts of eastern Montana and in south-central Montana, Permian rocks are thin because of overlap upon older rocks.

The maximum thickness of Permian rocks in this region is 1,275 feet in the Julesburg basin at the $\mathrm{Ne}$ braska-Wyoming State line. Another maximum of about 950 feet is in the Williston basin. Still another, of as much as 970 feet, is in the subsurface near the Black Hills. This maximum may originally have been $1,000-1,200$ feet, but it has been reduced by solution of gypsum and anhydrite in the lower part.

Several northwest and northeast trends seem to have been controlled by major regional structural elements. The most prominent structural element is a probable fault, coincident with the Cedar Creek anticline. This structure separates an area of relatively thick rocks on the east from one of relatively thin rocks on the west. The eroded northeast edge of the Permian near the Nesson anticline in North Dakota trends roughly parallel to the Cedar Creek element and is probably structurally controlled also.

The most prominent northeast trend is a narrow belt of anomalous thicknesses in southeastern Wyoming through the northern Laramie Range, approximately coincident with the present Wyoming lineament (Ransome, 1915, p. 294-295 ; Blackstone, 1956, p. 8, 18). Other less prominent trends parallel this belt, including one near Casper, Wyo., where interval $A$ is much thicker than in adjacent areas shown on plate 3 of I-450. The depositional limit of Permian rocks in south-central and southeastern Montana also has a northeast trend. In North Dakota and South Dakota, belts of thin Permian rocks parallel trends extending northeastward from near the north and south ends of the Black Hills uplift.

\section{PALEOTECTONIC IMPLICATIONS}

The distribution and composition of Permian rocks in this region indicate deposition in a slightly depressed area adjacent to the Cordilleran miogeosyncline. The embayment formed by this depressed area was filled by a sea encroaching from the southeast early in Permian time. This embayment did not at first connect westward with the Cordilleran geosyncline. Sediments were widely and rather uniformly deposited in the embayment as the Permian sea gradually extended onto adjacent positive areas and finally, 


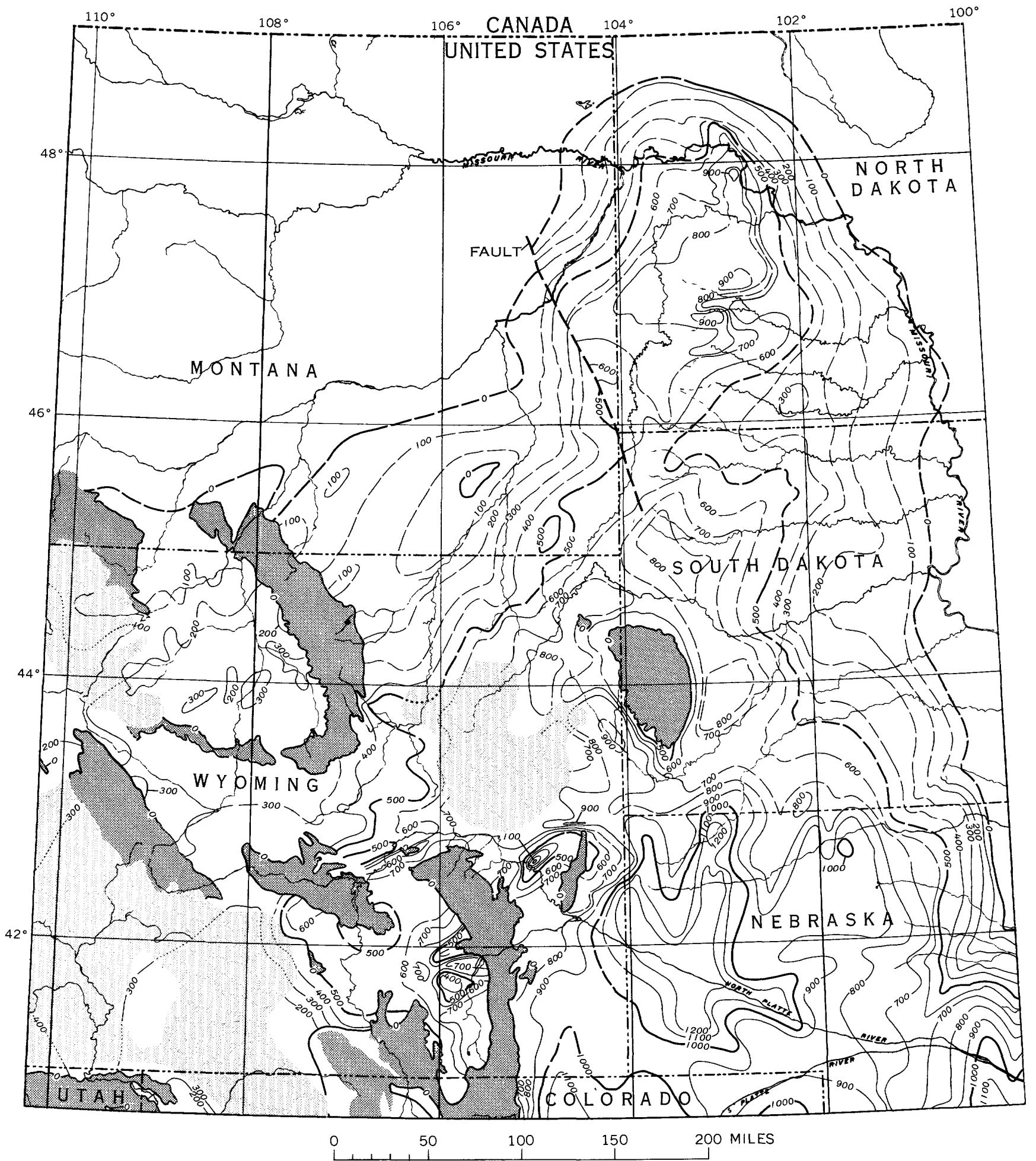

Figure 51.- Total thickness of Permian rocks in central and eastern Wyoming, Montana, the Dakotas, and parts of adjacent States. Isopach interval 100 feet. Isopachs dashed where control is poor, dotted where Permian rocks have not been penetrated by drill. Dark pattern, areas where rocks older than Permian are exposed; light pattern, areas where rocks younger than Permian have not been penetrated. 
after a regression and transgression in the time of interval B, connected with the Cordilleran sea through central Wyoming.

Positive elements adjacent to this northern Midcontinent basin seem to have grown in the late stages of the Pennsylvanian or early in Permian time. The northern extension in Wyoming of the ancentral Front Range highland, which influenced the distribution and lithology of the sediments of Pennsylvanian age, remained positive but low through Permian time. Early in Permian time, as in Pennsylvanian time, this positive area was reduced mainly by erosion; later in Permian time, epeirogeny or eustatic changes, or both, nearly obliterated it.

A northern positive element which extended southward from north-central Montana into northern Wyoming was reduced in size during Permian time either by downwarping or by a eustatic rise similar to that believed to have reduced the northern extension of the ancestral Front Range highland. This positive element, unlike the ancestral Front Range, however, does not seem to have existed before Permian time. Deposition in this area in Pennsylvanian time was apparently in a widespread marine basin, as no shore facies of the rocks involved have been recognized (J. W. Goldsmith, in McKee and others, 1959, p. 4).

The northern positive element persisted into Triassic time, as indicated by overlapping and wedging out of Triassic rocks beyond the depositional edge of Permian rocks. The rate of regional sinking and of deposition from Late Permian to Early Triassic time probably did not change significantly; therefore approximately the same area remained positive until Middle Jurassic time. By that time this northern positive element appears to have been nearly or entirely destroyed and to have become part of a basin in which Middle Jurassic strata were deposited unconformably on rocks of Paleozoic age (McKee and others, 1956, pl. 2). A large island in central Montana during Middle Jurassic time (McKee and others, 1956, pl. 5) is possibly a remnant of this positive element.

The Permian Black Hills basin, which is surrounded by relatively thin rocks of interval $A$, was destroyed, and a platform formed in its place during Late Permian time. This platform may indicate an incipient structural element which later became the modern Black Hills uplift.

In the Williston basin area, sinking, such as occurred in early Paleozoic time, was renewed. Much of the sinking along the west side of the basin coincided with the present Cedar Creek anticline. Similar structures probably bounded other parts of this basin in Permian time.
The Powder River Basin and possibly also the Bighorn and Laramie Basins apparently formed in Permian time, but these areas did not sink appreciably until late in the period. Whether the position of these subsiding areas coincided with that of earlier tectonic elements is not known. In any event the sinking in Late Permian time approximately corresponds in location to later structural features, which suggests incipient development of those basins that became important during the Laramide orogeny.

The Wyoming lineament, as defined by Ransome $(1915$, p. $294-295)$, seems to have been a hinge line during part of interval $\mathrm{B}$ time, for deposits then were chiefly limited to the area south of this structural element. Tectonic activity along the lineament did not affect other Permian rocks until after Permian time. These rocks were then completely removed in some places and appreciably thinned in other places along the lineament.

\section{GEOLOGIC UNITS DIRECTLY ABOVE PERMIAN SYSTEM UNITS OVERLYING PERMIAN}

Strata of Early Triassic age which lie with apparent conformity upon Permian rocks throughout most of this region are equivalent to the Dinwoody Formation of western Wyoming. Although the Dinwoody is dominantly composed of carbonate rock, its eastern equilavent is largely composed of red mudstone and evaporite rock.

These strata in central Wyoming form the upper part of the Goose Egg Formation (Burk and Thomas, 1956), which also extends into eastern Wyoming and adjacent areas in Montana, North Dakota, and South Dakota (Goldsmith, in McKee and others, 1959, p. 10), where they are a part of the Spearfish Formation. Counterparts of these strata are included at the top of the Pine Salt in the Williston Basin (fig. 52).

In the northern and eastern parts of the region, red beds overlying the Permian are called the Saude Formation (Zieglar, 1955, p. 52-53; 1956, p. 175-176) and are assigned a Jurassic age in this paper (fig. 53). These beds were questionably included in Triassic interval A (Goldsmith, in McKee and others, 1959, p. 11 , cols. 1, 2), but studies by the writer, which incorporate newly available data, confirm a possible Late Triassic or a probable Jurassic age. A series of columnar sections (pl. 5) and unpublished data confirm a probably conformable position of the "Spearfish" or Saude Formation below the Piper and Gypsum Spring Formations in the southern part of the present Williston basin and the northern part of the Powder River Basin. These red beds lie uncon- 


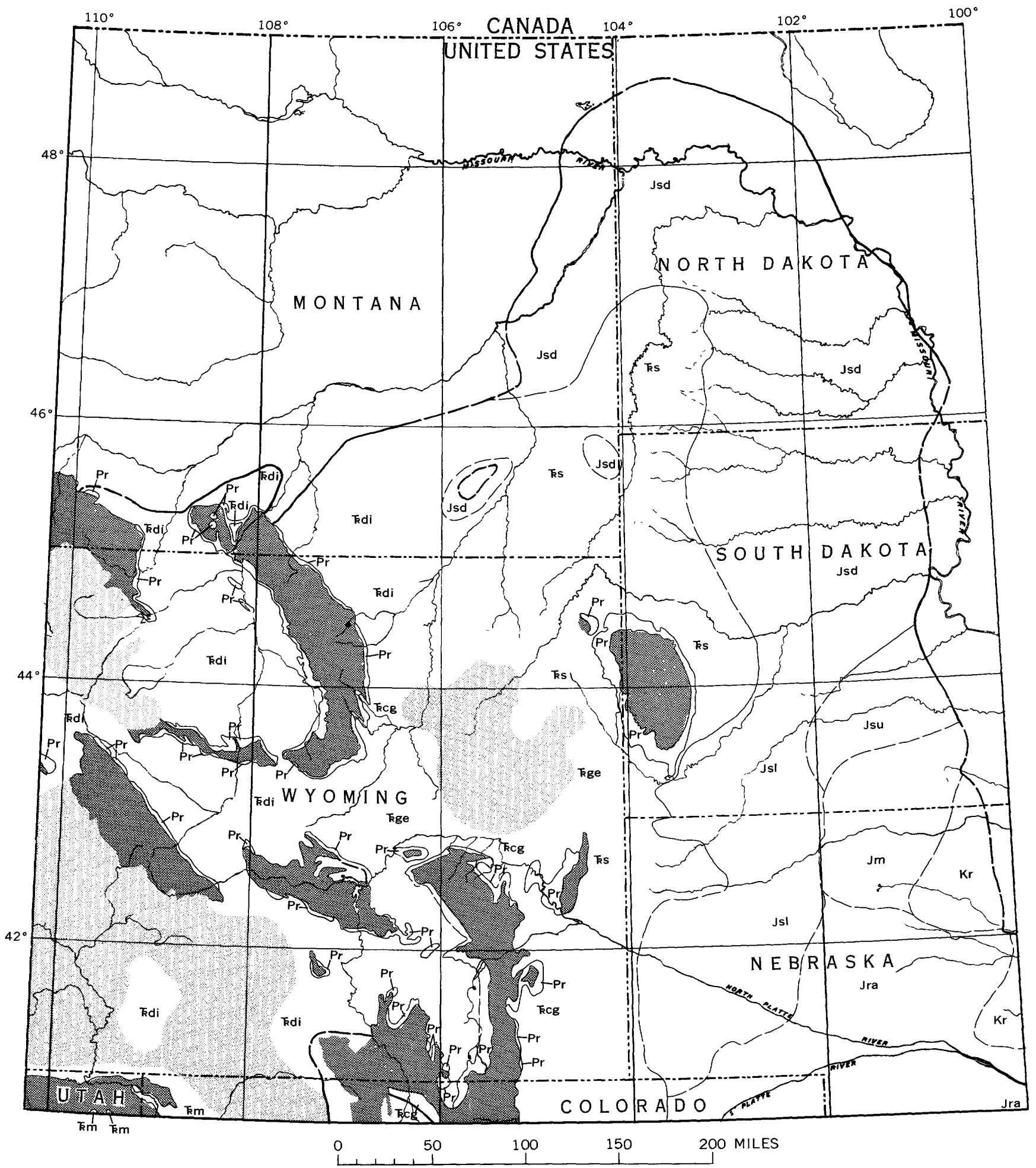

FIG URE 52.-Geologic units directly above Permian System in central and eastern Wyoming, Montana, the Dakotas, and parts of adjacent States. $\mathrm{Kr}$, Cretaceous rocks. Jurassic rocks: Jm, Morrison Formation, of interval D; Jra, Ralston Creek Formation and Jsu, Sundance Formation (upper part), both of interval C; Jsd, Saude Formation, and Jsl, Sundance Formation (lower part), all of interval B. Triassic rocks (interval A): Kcg, Chugwater Formation; Kdi, Dinwoody Formation; kge, Goose Egg Formation (upper part); km, Moenkopi Formation; ks, Spearfish Formation (upper part). Pr, Area where Permian rocks are exposed. Dark pattern, areas where rocks older than Permian are exposed; light pattern, areas where rocks younger than Permian have not been penetrated. Contacts between stratigraphic units dashed where uncertain. Limit of Permian rocks shown by heavy line; dashed where uncertain. 
GOLDSMITH

(TRIASSIC FOLIO, 1959)

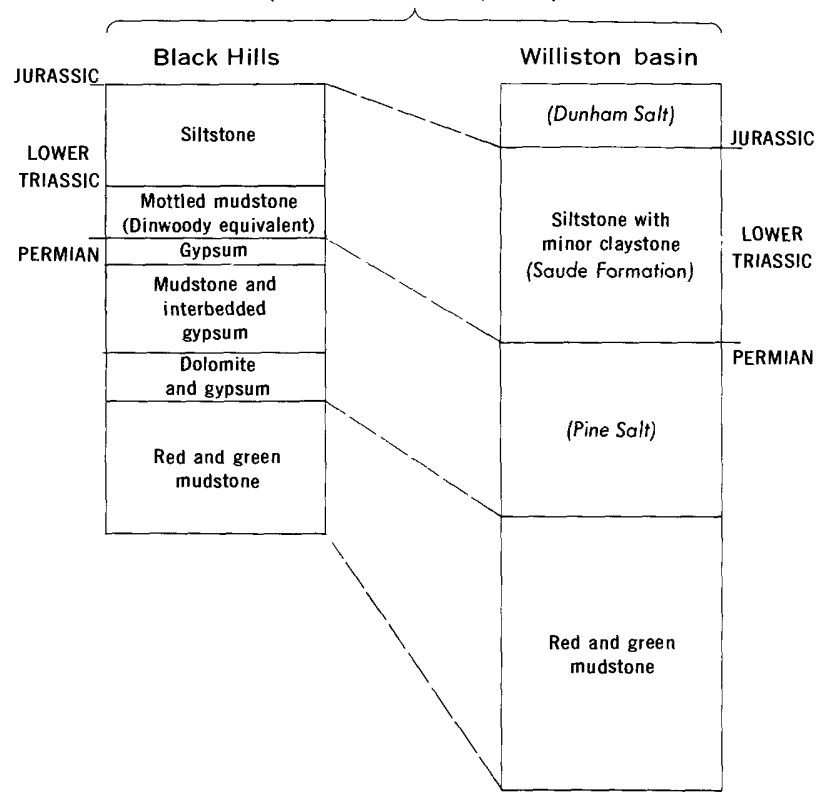

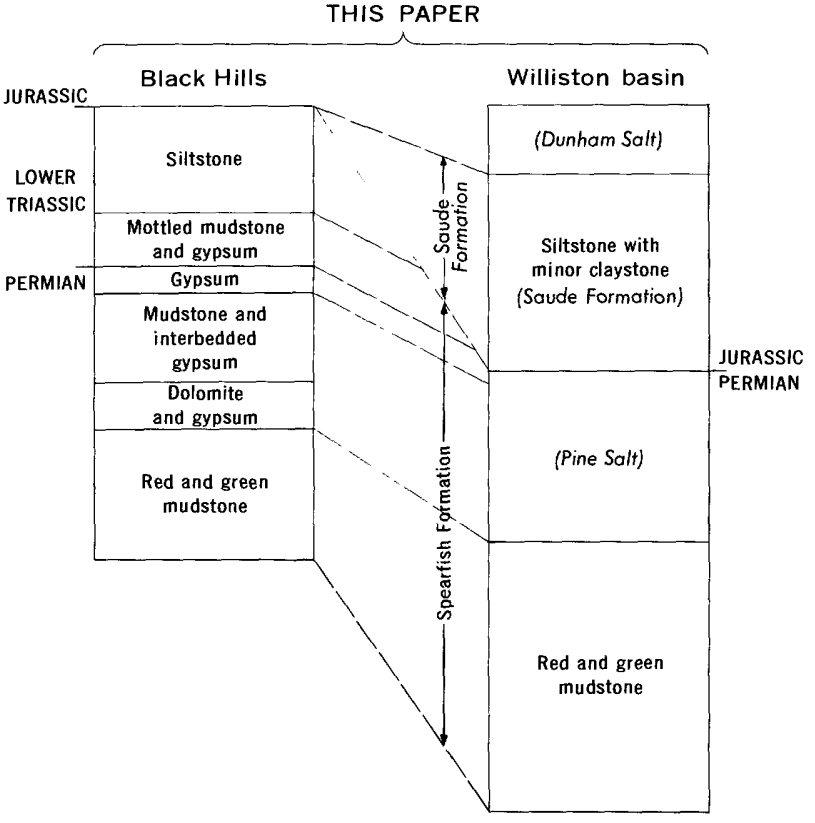

FIGURE 53.-Correlation of Jurassic, Triassic, and Permian rocks in the Black Hills of South Dakota and the Williston basin of North Dakota.

formably above Paleozoic strata as old as Devonian in the northeastern Williston basin (Zieglar, 1956, p. 175, 178, fig. 9) and form a wedge through onlap against strata of the Chugwater or Spearfish Formations of Early Triassic age in the subsurface of the Powder River and Williston basins north of the Black Hills (pl. 5).

The Saude Formation is believed to have formed chiefly through erosion of the Spearfish. Consequently, the red beds of this formation are very similar to those of the Spearfish, and the two units are difficult to separate where they are in contact. The Saude is unfossiliferous but seems to be related to the transgressive cycle of sedimentation which began in earlier Jurassic or Late Triassic time (Francis, D. R., 1956, p. 180-181) and produced the overlying Piper Formation of definite Middle Jurassic age.

\section{PALEOTECTONIC IMPLICATIONS}

The presence of apparently conformable Lower Triassic rocks indicates a continuation of relatively stable tectonic conditions from Permian into Triassic time (pl. 5). Depositional filling of basins, possibly related to epeirogenic sinking in Late Permian time, seems to have continued at a uniform rate into the Early Triassic and may have continued until about Middle Triassic time.

An inverse relation between thicknesses of Lower Triassic strata and uppermost Permian strata occurs in a few areas. In central and eastern Wyoming, relatively thick Permian rocks approximately coincide with areas where Triassic rocks are thin, as though the structural element behaved differently in Permian and in Triassic times, as well as in Triassic and later Mesozoic times (S. S. Oriel, in McKee and others, 1959 , p. 19). Another possibility is that uniformly thick Triassic sediments were originally deposited but were differentially compacted.

In contrast to the persistent stability of the region, renewal of relatively strong regional uplift followed deposition of Lower Triassic strata and preceded deposition of Middle Jurassic strata in northeastern Montana, nearby North Dakota, and South Dakota. This uplift probably coincided approximately with the positive elements that formed in these areas during Permian time and that persisted well into Mesozoic time.

The record in the northern part of this region during Triassic time, though largely destroyed, suggests that sediments which accumulated during Early Triassic time continued to spread over the positive element and may have finally buried it. In Late Triassic and Early Jurassic time, renewed uplift, centering in Montana, extended eastward into the Williston basin. Later this positive element was mostly destroyed, the area was tilted northward, and the Middle Jurassic sea transgressed from the north.

A more complex tectonic history would be required if the Saude Formation were of Triassic age, which is an additional reason for favoring the revised correlation proposed above. 


\section{Paleotectonic Investigations}

of the Permian System

in the United States

Chapter H. Middle Rocky Mountains and Northeastern Great Basin

By RICHARD P. SHELDON, EARL R. CRESSMAN, THOMAS M. CHENEY, and VINCENT E. McKELVEY

GEOLOGICAL SURVEY PROFESSIONAL PAPER $515-\mathrm{H}$

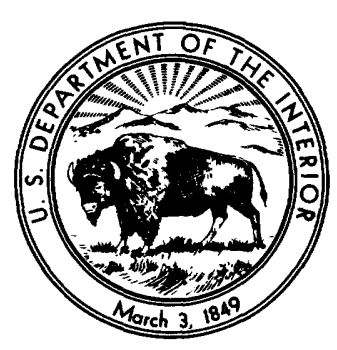




\section{CONTENTS}

Abstract

Region defined.

Paleogeology

undary of Permian

Paleotectonic implications. . . . . . . . . . .

Interval A. . . . . .

Formations included.

Upper boundary of interval A. . . . . .

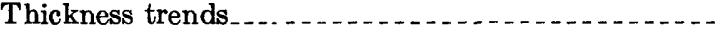

Lithofacies trends.... . . . . . . . . .

Paleotectonic implications. .

Interval B.

Formations included.

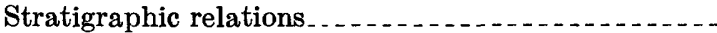

Upper boundary of interval $\mathrm{B}$.

Thickness trends
Page

157

157

157

157

157

157

158

158

158

158

158

158

160

160

160

160

162
Interval B Continued

Lithofacies trends...... 162

Sources and environments . .

Paleotectonic implications _. . _ .

Interval C-D . . . .

Formations included. . .

Upper boundary of interval C-D _ . . . . . .

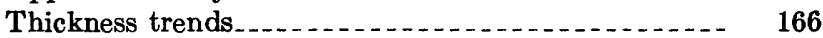

Lithofacies trends.......... 166

Sources and environments . . . . . . .

Paleotectonic implications . . . 168

Total thickness of Permian rocks _.

Thickness trends........... 168

Paleotectonic implications _. _.

Geologic units directly above Permian System......... 168

Units overlying Permian ..................... 168

Paleotectonic implications _.................. 170

\section{ILLUSTRATIONS}

Figure 54. Map showing thickness of interval A in Middle Rocky Mountains and northeastern Great Basin 55. Map showing facies of maximum regression at about the end of Leonard time in southwestern Montana, southeastern Idaho, western Wyoming, and northeastern Utah.

56. Map showing thickness of interval $B$ in the Middle Rocky Mountains and northeastern Great Basin.......

57. Diagrams showing possible stratigraphic relations between Permian and Triassic rocks in western Wyoming.-.-

58. Map showing thickness of interval C-D in the Middle Rocky Mountains and northeastern Great Basin.......

59. Map showing total thickness of Permian rocks in the Middle Rocky Mountains and northeastern Great Basin.-

Page

\section{TABLE}

TABLE 1. Generalized chart showing stratigraphic units in major Permian subdivisions 



\title{
PALEOTECTONIC INVESTIGATIONS OF THE PERMIAN SYSTEM IN THE UNITED STATES
}

\section{MIDDLE ROGKY MOUNTAINS AND NORTHEASTERN GREAT BASIN}

\author{
By Richard P. Sheldon, Eard R. Cressman, Thomas M. Cheney, and Vincent E. McKelvey
}

\begin{abstract}
The Middle Rocky Mountain and northeastern Great Basin region was the site of miogeosynclinal and cratonic sedimentation during the Permian Period. Facies in rocks of this region are related to the tectonic units, which indicates that the units were active in Permian time. Furthermore, several structural units of the next smaller magnitude-the Uinta Mountains, the Green River Basin, and the Wind River Range--seem to have exerted some control on Permian sedimentation.

Permian sediments were deposited across the entire region, probably disconformably, on Pennsylvanian rocks consisting mostly of sandstone of shallow-water origin. Thus the region was tectonically stable before Permian sedimentation began.

Interval A sediments consisted mostly of sand deposited in a geosyncline, with progressively more limy sediments westward. Intervals $B$ and $\mathbf{C}-D$ each consist of strata formed in a transgressive-regressive cycle. In each interval black mud, silica and phosphate, which make up the Phosphoria Formation, were deposited, mostly in the geosyncline. Carbonate sediment. of the Park City Formation, sand of the Shedhorn, and red beds of the Goose Egg and Moenkopi Formations were deposited on the craton.

At the end of Permian sedimentation, the cratonic area became slightly positive and the geosynclinal area remained slightly negative. The geosyncline may have received sediments continuously into Triassic time.
\end{abstract}

\section{REGION DEFINED}

The Middle Rocky Mountain and northeastern Great Basin region comprises Idaho, southwestern Montana, western Wyoming, northern Utah, and northeastern Nevada. Geologically this region includes the central Cordilleran foreland, whose structure is relatively simple, and the Cordilleran geanticline. The Cordilleran geanticline consists of folded and overthrust Paleozoic and Mesozoic rocks in eastern Idaho and the more intensely faulted Paleozoic and Mesozoic rocks in the eastern Great Basin. These major tectonic elements were active in Permian time, and facies of the Permian rocks show a close relationship to them. Across the whole area the Permian facies show a varied and complex pattern.

\section{PALEOGEOLOGY}

\section{UNITS UNDERLYING PERMIAN}

Beds of Pennsylvanian age underlie the Permian System over all the Middle Rocky Mountains and northeastern Great Basin. In southwestern Montana the underlying Pennsylvanian beds are the Quadrant Quartzite; in western Wyoming, the Tensleep Sandstone; in southeastern Idaho and immediately adjacent areas, the lower member of the Wells Formation; in northeastern Utah, the Weber Quartzite; in parts of north-central and northwestern Utah, the lower part of the Oquirrh Formation; and in northeastern Nevada, extreme northeastern Utah and south-central Idaho, an unnamed sandstone. The precise ages and stratigraphic relations of these formations are not fully established, but they represent a widespread body of sandstone, intertongued with limestone in the western part of the region.

\section{LOWER BOUNDARY OF PERMIAN}

Permian and Pennsylvanian rocks are concordant throughout the region. In several places they are disconformable, as in the Wind River and Gros Ventre Ranges of Wyoming (Sheldon, 1957, p. 124; Keefer, 1957. p. 174), where the contact is marked by a conglomerate or an erosion surface on top of the Pennsylvanian sandstone. In other places paleontologic evidence demonstrates an absence either of Lower Permian or of Upper Pennsylvanian rocks.

\section{PALEOTECTONIC IMPLICATIONS}

At the end of Pennsylvanian time the Middle Rocky Mountain region had been blanketed by Pennsylvanian sandstone of probable shallow-water shelf origin. Most of this region then underwent slight erosion but not enough to expose Mississippian or older rocks. The region was thus tectonically stable before Permian sedimentation began. 


\section{INTERVAL A FORMATIONS INCLUDED}

In southeastern Idaho interval A consists of the middle sandy facies of the Wells Formation, as described by Mansfield (1927, p. 72). The same unit has been recently mapped by the U.S. Geological Survey as the upper member of the Wells Formation. Diagnostic fossils have not been found in the upper half of the unit, but fusulinids indicate that most of the lower half is of Wolfcamp age (McKelvey and others, 1959, p. 36). Beds in the basal few feetlithologically like the rest of the unit but containing fusulinids of Middle Pennsylvanian age - are included for operational purposes in interval $A$, because it is not practical to separate them, and their thickness does not materially affect regional trends.

In southwestern Montana, interval $\mathbf{A}$ includes all but the uppermost part of the Grandeur Member of the Park City Formation. The Grandeur in this area is assigned to interval $\mathbf{A}$ because fusulinids of probable Wolfcamp age occur near the base near Three Forks (Frenzel and Mundorff, 1942; J. Steele Williams, in McKelvey and others, 1959. p. 36). Rocks of Wolfcamp age may be much more extensive in western Montana than shown in figure 54, but at present they cannot be traced by either faunal or lithologic correlation beyond the limits shown.

In northeastern Nevada and northwestern Utah an unnamed and poorly defined sequence of sandstone and limestone is included in interval A. This lies below rocks equivalent to the grandeur Member of the Park City Formation of northeastern Utah and the Plympton Formation of the Confusion Range in west-central Utah (Hose and Repenning, 1959) and overlies rocks of Pennsylvanian age.

In northeastern Utah, sandstone beds at the top of the Weber Sandstone contain Wolfcamp fusulinids (Bissell and Childs, 1958) and are included in interval $A$. In the northern Oquirrh Range of Utah, the upper part of the Oquirrh Formation contains Wolfcamp fossils and is included in interval A (E. W. Tooker and R. J. Roberts, oral commun., 1959). Interval $\mathbf{A}$ in the Charleston thrust plate in the Provo area includes the upper part of the Oquirrh Formation and the overlying Kirkman Limestone and Diamond Creek Sandstone.

\section{UPPER BOUNDARY OF INTERVAL A}

In southeastern Idaho the upper boundary of interval $\mathbf{A}$ is placed at the contact between the Wells Formation and the conformably overlying Grandeur Tongue of the Park City Formation.

In southern Beaverhead County, Mont., the upper third or quarter of the Grandeur is interbedded red and tan mudstone and tan sandstone; the lower part is dolomite with some interbedded sandstone. The upper boundary of interval $A$ has been placed at the top of the dolomite. The upper mudstone and sandstone unit, where present, is assigned to interval B, but it is missing in many parts of southwestern Montana, and therefore the dolomite directly and disconformably underlies either the Meade Peak Phosphatic Shale Tongue of the Phosphoria Formation or the lower member of the Shedhorn Sandstone.

\section{THICKNESS TRENDS}

Isopachs of interval A (fig. 54) in southeastern Idaho and westernmost Wyoming parallel arcuate trends of the present-day major structural features. The eastern limit of rocks assigned to this interval nearly coincides with the east edge of the Paleozoic miogeosyncline (as defined by the Wasatch line of Kay, 1951). The interval thickens westward to 7,000 feet in eastern Cassia County, Idaho, the westernmost area in Idaho for which information is available.

In southwestern Montana, thinning of interval A along a north-south structural axis in eastern Beaverhead County is superimposed upon a regional pattern of northward and eastward thinning

In northern Utah and northeastern Nevada, data are insufficient for accurate determination of thickness variations but suggest that autochthonous rocks of this interval thicken westward to a maximum of 7,500 feet in northwestern Utah. An even greater thickness of more than 12,000 feet occurs in the eastwardly displaced Charleston thrust sheet, south of Salt Lake City. In a small area in the eastern part of the Uinta Mountains an outlier of rocks of this interval is only 140 feet thick.

\section{IITHOFACIES TRENDS}

Dolomite interpreted as marine is the dominant rock type in interval A in southwestern Montana, but the axis of thinning in eastern Beaverhead County is reflected by more sandstone than is present to the east and west $(\mathrm{I}-450, \mathrm{pl} .3)$. Across the rest of the region the interval is dominantly sandstone. In northeastern Nevada and northwestern Utah, lithologic data are insufficient to show a lithofacies pattern.

The interval contains more sandstone in Wyoming than in Idaho; an eastern source for the sand is therefore indicated.

\section{PALEOTECTONIC IMPLICATIONS}

Dominant features in this region early in the Permian Period were a geosyncline in Idaho and adjacent areas to the north and south and a shelf in Wyoming 
and adjacent areas. Deposition was limited to the geosyncline, except for the small outlier in the eastern Uinta Mountains, Utah (fig. 62). Deposition in the geosyncline kept pace with subsidence so that the sandstone and limestone of interval A were laid down in relatively shallow water.

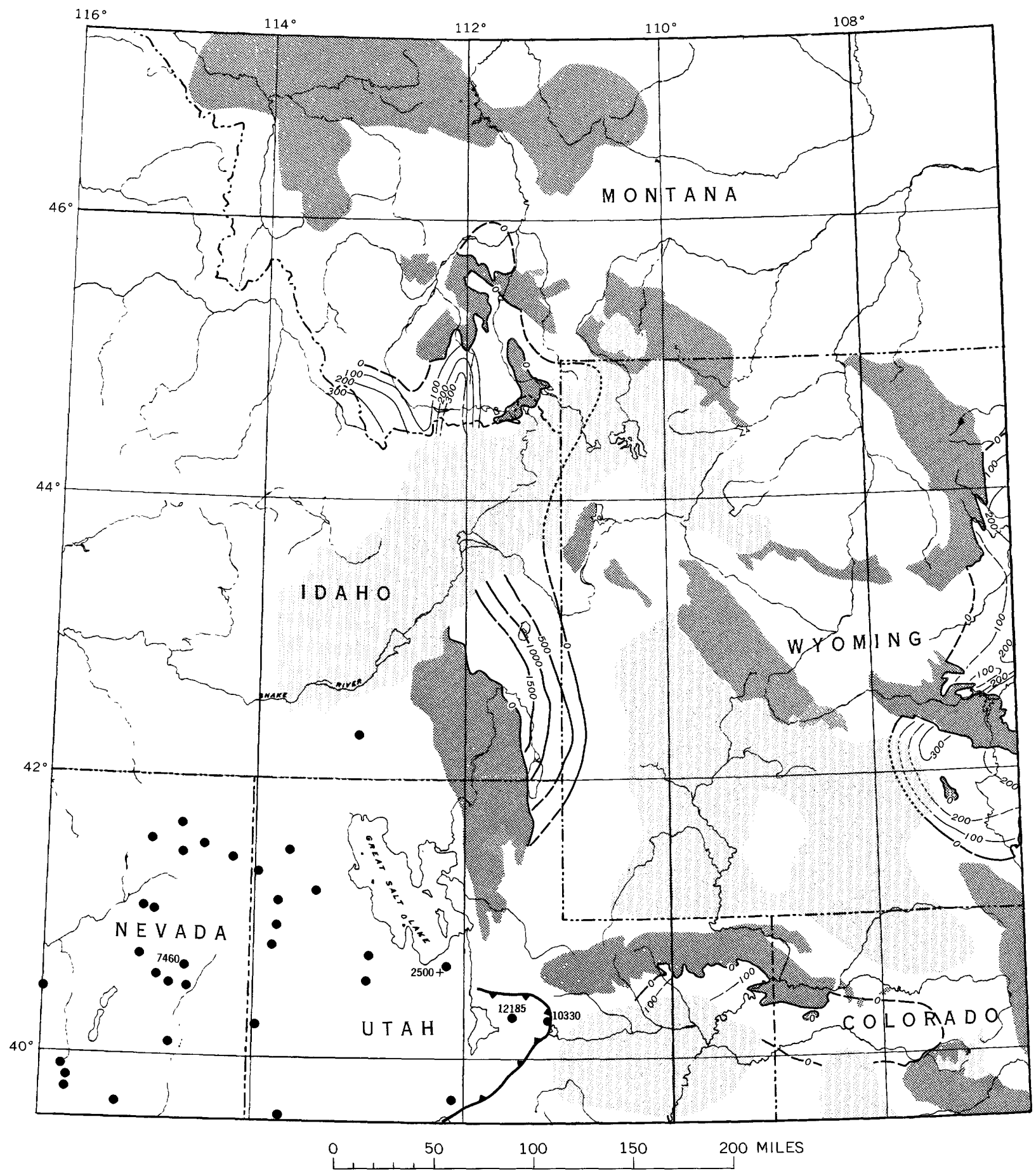

Figure 54.-Thickness of interval A in Middle Rocky Mountains and northeastern Great Basin. Isopach intervals 100 and 500 feet. Isopachs dashed where control is poor, dotted where Permian rocks have not been penetrated by drill. , indicates where Permian rocks have been identified, but control is inadequate for isopach construction; thicknesses in feet. Approximate trace of thrust fault shown by sawtooth line; sawteeth on upper plate. Dark pattern, areas where rocks older than Permian are exposed; light pattern, areas where Permian rocks younger than interval $\mathrm{A}$ have not been penetrated. 


\section{INTERVAL B}

\section{FORMATIONS INCLUDED}

Several contemporaneous intertonguing formations constitute interval $\mathrm{B}$ in the Middle Rocky Mountains and northeastern Great Basin (I-450, pl. 14A).

In western Montana, eastern Idaho, western Wyoming, and northeastern Utah, interval B comprises the Meade Peak Phosphatic Shale Member, the lower part of the Rex Chert Member, and the lower chert member of the Phosphoria Formation; the lower part of the Franson Member and the Grandeur Member of the Park City Formation (in Montana only the upper part of the Grandeur is included); and, in the Yellowstone Park area, the lower half of the lower member of the Shedhorn Sandstone (McKelvey and others, 1959).

In northwestern Utah and northeastern Nevada, interval B is an unnamed sequence of limestone, dolomite, chert, and phosphatic shale that is equivalent to the combined Grandeur Member and lower part of the Franson Member of the Park City Formation; in northeastern Utah this intertongues with the Phosphoria Formation. This unnamed sequence is equivalent also to the Kaibab Limestone and lower part of the Plympton Formation of the Confusion Range in west-central Utah (Hose and Repenning, 1959).

\section{STRATIGRAPHIC RELATIONS}

Interval $\mathrm{B}$ in the Middle Rocky Mountains and northeastern Great Basin forms one transgressiveregressive cycle. Ideally the cycle consists from base to top of red beds, light-colored mudstone and evaporite, light-colored dolomite and sandstone, light-colored bioclastic limestone and sandstone, chert, and dark interbedded phosphorite, dolomite, and mudstone, and finally dark mudstone alone, overlain by the same sequence in reverse order (Sheldon, 1957, p. 140; Cheney and Sheldon, 1959, p. 95).

All parts of the ideal cycle do not occur in any one place, but most parts of it are present at many localities; it is most complete in western Wyoming. The vertical sequence of red beds through dark mudstone also represents the ideal lateral sequence of facies at any one horizon from shallow water on the east, north, and south to relatively deep water on the west.

In terms of stratigraphic units, the Meade Peak Phosphatic Shale Member of the Phosphoria Formation, typically developed in southeastern Idaho, is the deepest water facies and grades northward, eastward, and southward through chert of the Phosphoria Formation into carbonate rock of the Park City Formation. It also grades northeastward into the Shedhorn Sandstone. In Wyoming the Park City Formation, in turn, grades eastward into the shallow-water red beds of the Goose Egg Formation.

\section{UPPER BOUNDARY OF INTERVAL B}

In western $\mathrm{Wyoming}$ a horizon of maximum regression forms the top of interval B and has been traced westward by lithologic correlation. This horizon is considered to be the top of the interval because:

1. Faunas from the Grandeur Member of the Park City Formation and from the Meade Peak Phosphatic Shale Member of the Phosphoria Formation are considered to be of Leonard age $(J$. Steele Williams, in McKelvey and others, 1959, p. $36-39$; Miller, A. K., and others, 1957) ; all beds above this boundary contain the Spiriferina pulchra fauna, considered to be of post-Leonard age (J. Steele Williams, in McKelvey and others, 1959 , p. 40).

2. Other logical correlations are possible on the basis of available data, but the horizon of maximum regression in western Wyoming can be traced over a larger area and with more confidence than any other horizon.

The top of interval B in westernmost Wyoming is the top of a bed of the lower tongue of the Shedhorn Sandstone (I-450, pl. 14A; fig. 55, this report). Farther east the contact is at the top of a green mudstone correlative with this sandstone bed. The green mudstone is probably correlative with the lower part of the Glendo Shale of eastern Wyoming.

In southwestern Montana the top of interval B is within the Franson Member of the Park City Formation. In north-central Utah it is below the base of the Mackentire Tongue of the Woodside Formation of H. D. Thomas (1939) and, where that tongue is absent, within the Franson at about the same stratigraphic position. The top of interval B in southeastern Idaho is in about the middle of the Rex Chert Member of the Phosphoria Formation, and in northwestern Utah and northeastern Nevada within beds equivalent to the Plympton Formation of west-central Utah.

In some parts of the region near the Cordilleran geosyncline the contact between intervals B and C-D is disconformable. In the Gros Ventre and the northwestern Wind River Ranges of northwestern Wyoming, conglomeratic sandstone lies at the top of interval $\mathrm{B}$, indicating erosion farther north (fig. 55). A similar conglomeratic sandstone in the southeastern Uinta Mountains of northeastern Utah indicates erosion in the southeastern part of the region.

In southeastern Idaho, west-central Wyoming, and northern Utah the contact between intervals $B$ and 


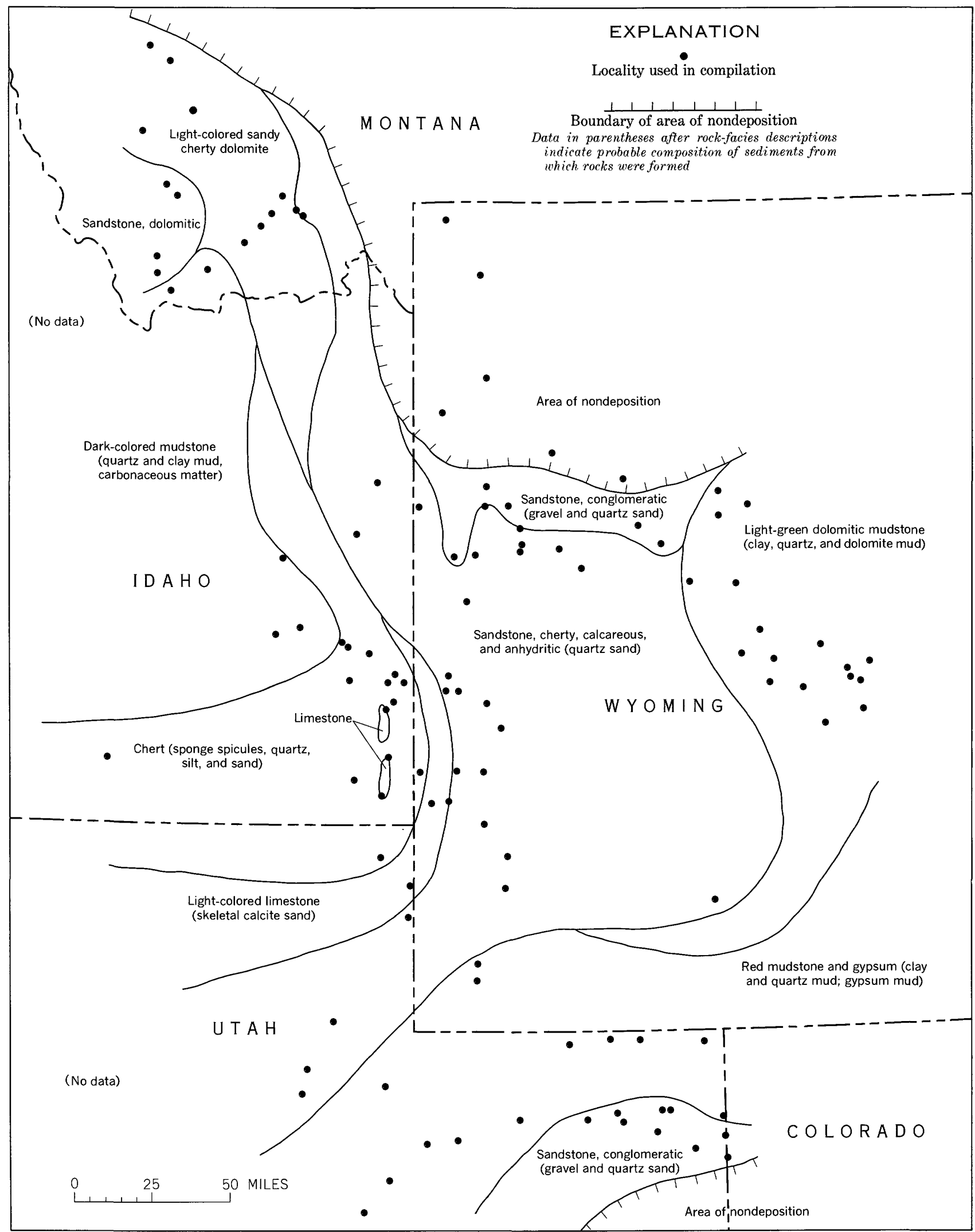

Figure 55.-Facies of maximum regression at about the end of Leonard time in southwestern Montana, southeastern Idaho, western Wyoming, and northeastern Utah. 
$\mathrm{C}-\mathrm{D}$ is conformable, and the rocks above and below are much alike. Here the contact is placed arbitrarily at horizons that are easily traceable, such as the tongue of the Shedhorn.

\section{THICKNESS TRENDS}

East of the orogenic thrust belt in western Wyoming and southwestern Montana, interval B is mostly less than 200 feet thick and thins northward and southward to a featheredge in southwestern Montana and northeastern Utah (fig. 56).

From the orogenic thrust belt westward interval B thickens regularly from several hundred feet to nearly 1,500 feet in northeastern Nevada. In westernmost Wyoming and eastern Idaho isopachs trend northnorthwestward (fig. 56), generally paralleling the strike of the thrusts in the orogenic belt, but in northeastern Utah the trend changes at the Uinta Mountains to west-southwest.

Several anomalies occur. In Beaverhead County, southwestern Montana, a northward salient of rocks thicker than 200 feet occurs (fig. 56). In western Wyoming there is an eastward salient of rocks thicker than 100 feet, nearly coinciding with the present-day Green River basin, that terminates near the Wind River Range. An abrupt change of direction of isopachs in northern Utah outlines a broad trough of thick rocks whose axis almost coincides with the axis of the Uinta Mountain anticline. Interval B is also about twice as thick on the allochthonous block of the Charleston thrust in northeastern Utah as it is on the autochthonous block.

\section{LITHOFACIES TRENDS}

The facies relations described above are apparent on maps of thin units but are obscured on the lithofacies map of the whole interval $(\mathrm{I}-450, \mathrm{pl} .4)$ because of widespread intertonguing and superposition of the previously described rock types. Moreover, darkcolored, light-colored, and red shales have different areal distributions but are not differentiated. Nevertheless, the lithofacies patterns on plate 4 of I-450 do suggest relative abundance of chert, phosphorite, and dark mudstone in southeastern Idaho, of shallower water carbonate and sandstone to the north, east, and south, and of light-colored and red mudstone beyond.

Thickness and lithfacies are related. The thickest deposits are chert, phosphorite, and dark mudstone, and the thinnest are carbonate rock, sandstone, lightcolored mudstone, and red mudstone. On plate 4 of I-450 the close relation between the sandstone facies and the 200-foot isopach is notable. Also, the salient of thick rock in southwestern Montana is also a salient of black mudstone, chert, and phosphorite.

\section{SOURCES AND ENVIRONMENTS}

In southeastern Idaho and nearby areas the sediments of interval B were deposited in an oceanic basin which passed into an oceanic shelf to the north, east, and south. Detrital sediments were washed onto the shelf from lowlands in westernmost Montana or eastcentral Idaho, and in central Montana, and from the ancestral Uncompahgre uplift in northwestern Colorado. The coarser detritus and the carbonates were deposited on the shelf, and the finer detritus, along with some carbonates, phosphorite, organic matter, and silica, was deposited in the oceanic basin.

Sheldon, Maughan, and Cressman $(\mathrm{I}-450)$ described in detail the sedimentation and paleogeography at the time of maximum transgression of the rocks of interval B. That study only concerns a moment of geologic time, but in general the same conditions persisted throughout interval B time; the main difference was that the various sedimentary environments were located farther to the west during the early stages of transgression and during the following regression. In one respect the sedimentation at the time of maximum transgression of the rocks of interval B was not representative of the sedimentation at other times during interval B. The chert facies, formed from sponge spicules, was not prominently represented. Had other approximate time horizons been chosen, large areas of siliceous spicule sedimentation would have appeared. The reason for this is not clear and awaits further research.

\section{PALEOTECTONIC IMPLICATIONS}

Source areas of detritus were low, as shown by the fine grain and small amount of the detritus. Both the source areas and the adjoining shelves were part of the craton, which was bordered on the west by the Cordilleran miogeosyncline, where sediments of interval $B$ were laid down in greater thickness and in deeper water. The Phosphoria Formation, composed of chert, phosphorite, and dark mudstone, is in general the geosynclinal facies; the carbonate rock of the Park City Formation, the Shedhorn Sandstone, and the red mudstone and anhydrite of the Goose Egg Formation (table 1, col. 33) are the shelf facies.

Sedimentation in the geosyncline seems to have been continuous from the time of interval $B$ into that of interval $\mathrm{C}-\mathrm{D}$, whereas on the craton it was interrupted by a slight withdrawal of the sea and an extensive regression of facies.

\section{INTERVAL C-D FORMATIONS INCLUDED}

Interval C-D in the Middle Rocky Mountains of western Montana, eastern Idaho, western Wyoming, 
and northeastern Utah comprises parts of four formations: the Phosphoria; the Woodside Formation, as used by H. D. Thomas (1939) (or Goose Egg in central Wyoming); the Park City Formation; and the
Shedhorn Sandstone (McKelvey and others, 1959, fig. $1 ; \mathrm{I}-450$, pl. $14 A$ ). The part of the Phosphoria Formation included in interval C-D consists of the Retort Phosphatic Shale Member, Tosi Chert Member, cherty

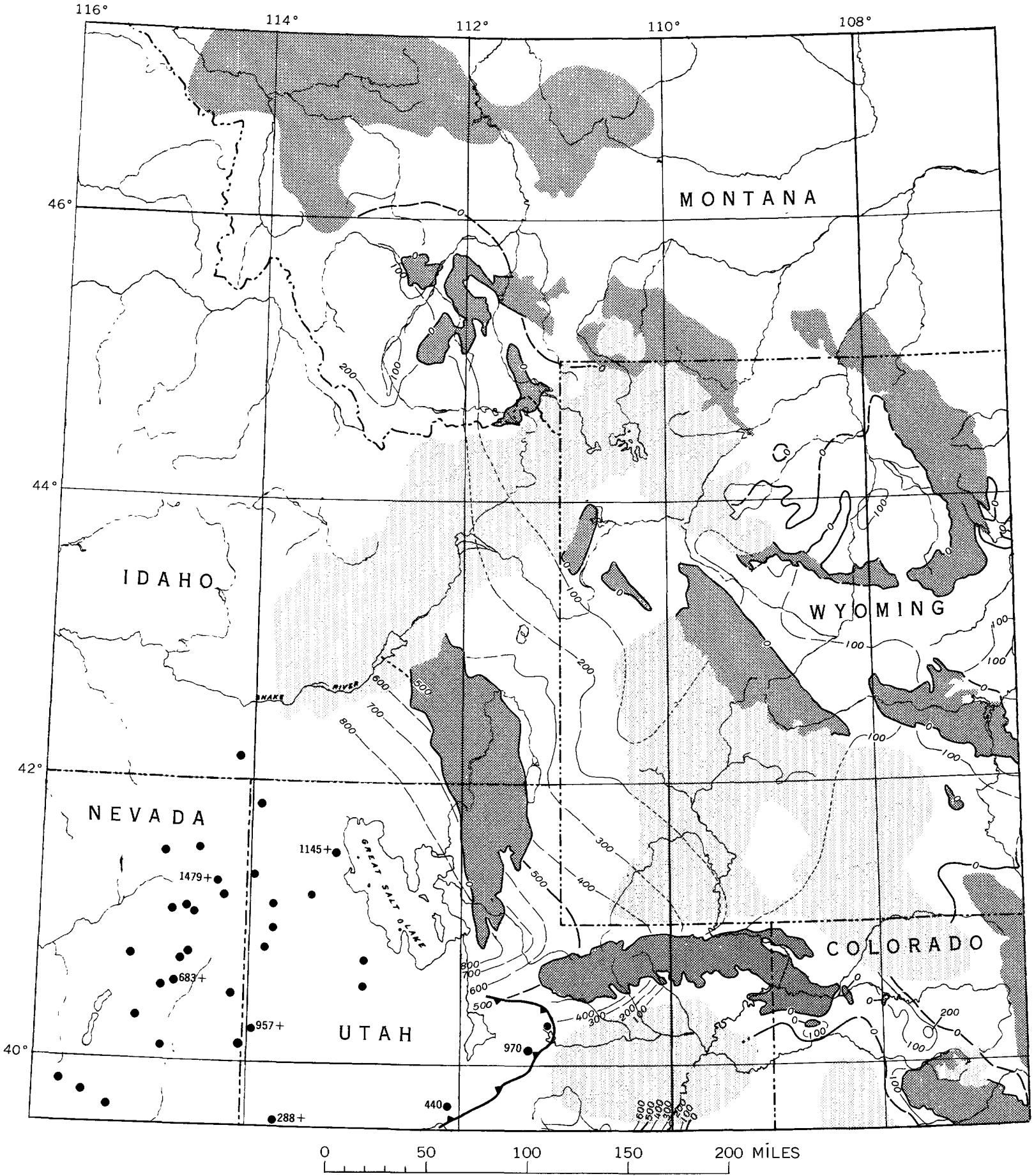

FIGURE 56.-Thickness of interval B in the Middle Rocky Mountains and northeastern Great Basin. Isopach interval 100 feet. Isopachs dashed where control is poor, dotted where Permian rocks have not been penetrated by drill. - indicates where Permian rocks have been identified, but control is inadequate for isopach construction; thicknesses in feet. Approximate trace of thrust fault shown by sawtooth line; sawteeth on upper plate. Dark pattern, areas where rocks older than Permian are exposed; light pattern, areas where rocks younger than interval $B$ have not been penetrated. 
shale member, and upper part of the Rex Chert Member. The part of the Park City Formation included in interval C-D consists of the Ervay Carbonate Rock Member and the upper part of the Franson Member. The upper member and the upper part of the lower member of the Shedhorn Sandstone are also in interval $\mathrm{C}-\mathrm{D}$.

In northwestern Utah and northeastern Nevada, interval C-D consists of an unnamed sequence of carbonate rock that is equivalent to the upper part of the Franson Member of the Park City Formation in northeastern Utah and to the upper part of the Plympton Formation, together with the Gerster Formation of the Confusion Range in west-central Utah (Hose and Repenning, 1959).

The parts of the four formations forming interval C-D are synchronous units and intertongue across the Middle Rocky Mountains. A tongue of the Phosphoria Formation extends from southeastern Idaho into the Shedhorn Sandstone of Montana and northwestern Wyoming, and into the Park City Formation of western Wyoming and the northeastern corner of Utah. This tongue of the Phosphoria splits the Shedhorn into an upper and lower member; interval C-D includes the upper member and the upper part of the lower member. Similarly the Park City is split into the Ervay and the Franson Members, and interval C-D includes the Ervay and upper beds of the Franson (table 1). In parts of northern Utah the upper tongue of the Phosphoria is absent, and interval C-D includes that part of the Franson Member of the Park City that lies above the Mackentire Tongue. In central Wyoming on the Glendo Shale Member of the Goose Egg Formation and, in northeastern Utah and northwestern Colorado, the Mackentire Tongue of the Woodside Formation tongue into the Park City to form the lower part and, in some places, all of interval $\mathrm{C}-\mathrm{D}$.

\section{UPPER BOUNDARY OF INTERVAL C-D}

The uppermost rocks of interval C-D are assigned to different formations in different parts of the region. In southeastern Idaho and nearby areas they constitute the cherty shale member or Retort Phosphatic Shale Member of the Phosphoria Formation. In Montana and northwestern Wyoming they form the upper member of the Shedhorn Sandstone or the Tosi Chert Member of the Phosphoria. To the east, in central and southwestern Wyoming and to the south in Utah, they are the Ervay Member or the Franson Member of the Park City Formation or unnamed Permian red beds.
Interval C-D is overlain by the Dinwoody Formation of Early Triassic age in all the Middle Rocky Mountain region except northeastern Utah, where it is overlain by the Woodside Formation of Early Triassic age and a facies of the Dinwoody Formation, and a part of southwestern Montana, where the interval is overlain by Jurassic rocks.

The contact between interval $\mathrm{C}-\mathrm{D}$ and the Lower Triassic formation is concordant in much of the region. Evidence of local erosion at the contact has been cited. In northern Utah, near Spanish Fork, the Woodside Formation bevels nearly 2,000 feet of tilted Permian strata in a horizontal distance of about 10 miles (Baker, A. A., and Williams, 1940, p. 624). In southwestern Montana in the Centennial and Gravelly Ranges part of the Permian rocks may have been eroded before deposition of the Triassic (Cressman, 1955 , p. 20-21), and in the Madison Range in southwestern Montana the Dinwoody rests disconformably on the Phosphoria (R. W. Swanson, written commun. to E. R. Cressman, 1954). Local erosion or leaching of Permian rocks before deposition of the Dinwoody in western Wyoming was reported by Newell and Kummel (1942, p. 938-939), although beds at the top of the Permian in that area can be traced for miles, which suggests that little or no pre-Triassic erosion occurred. In northeastern $\mathrm{Ne}$ vada and western Utah a gap in the paleontologic record between the Permian and the Triassic is indicated by the presence of Meekoceras (Middle Early Triassic in age) near the base of the Triassic rocks.

Regional stratigraphic studies provide additional data on the relation between the Permian and Triassic Systems. The stratigraphic relation between members of the Dinwoody Formation and the underlying Permian was interpreted by Newell and Kummel (1942, p. 938) as eastward onlap (fig. $57 B, C$ ). An alternative interpretation is that the several units are partial lateral equivalents resulting from regressive overlap (S. S. Oriel, in McKee and others, 1959, p. $3-4$; and fig. $57 A, D$, this report). The occurrence in Wyoming of different lithologic members of Permian formations at the top of the system (Sheldon, 1957, fig. 20) may be explained by regional beveling (fig. $57 B, D$ ). An alternative explanation is that these stratigraphic units, too, are partial lateral equivalents resulting from regressive offlap (Sheldon, 1957, p. $143-152$; and fig. $57 A, C$, this report). Four combinations of these differing interpretations are shown diagrammatically in figure 57.

Available data do not indicate which of the four alternatives is correct. Accurate dating of each of the units in both the Permian and Triassic rocks is 
West
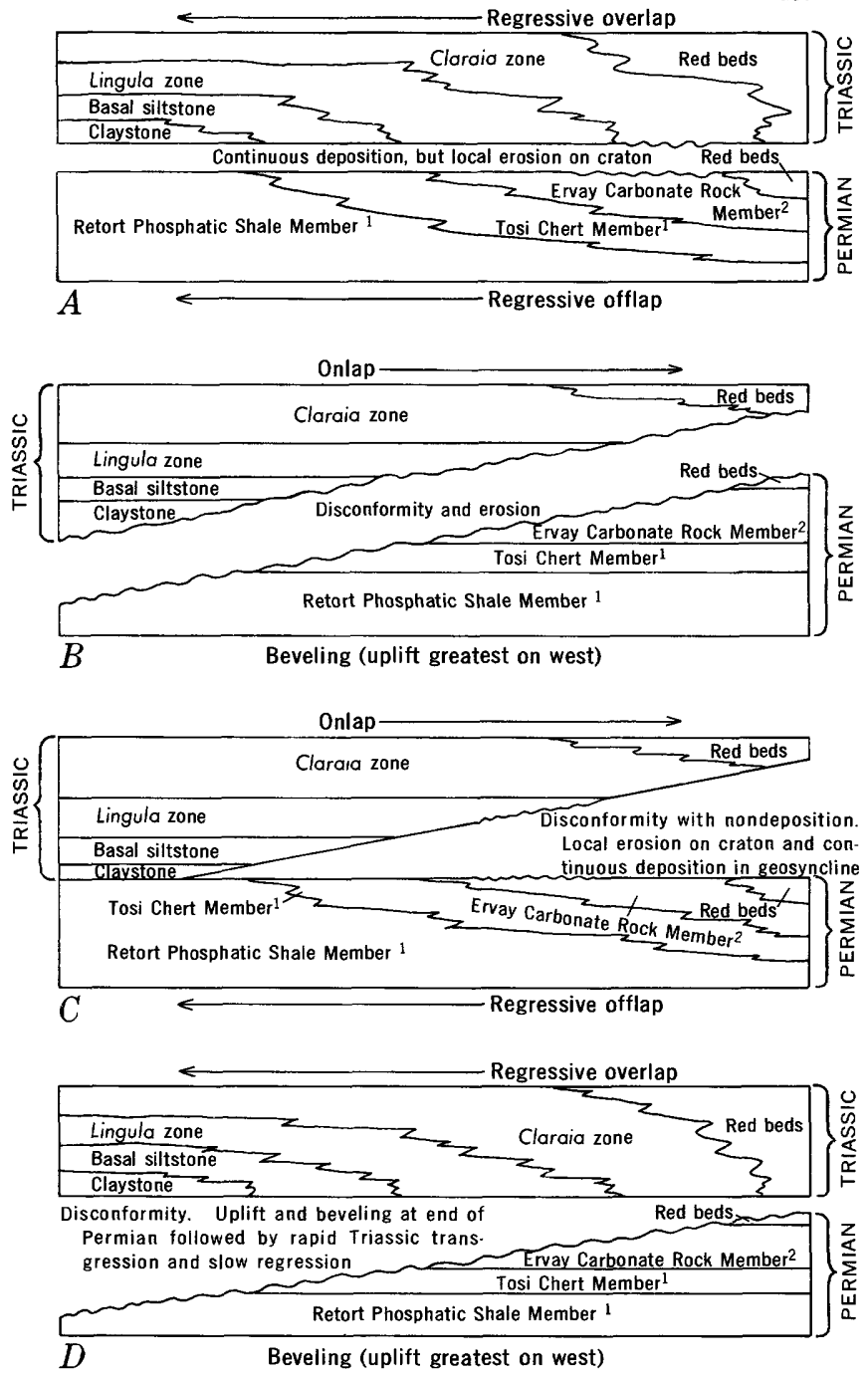

Frgure 57.-Possible stratigraphic relations between Permian and Triassic rocks in western Wyoming. 1 Phosphoria Formation; ${ }^{2}$ Park City Formation.

needed, but suitable faunas have not been found; probably some or all of these units cannot be dated precisely by paleontologic methods. Thus, the main evidence is physical, and it is suggestive rather than discriminating.

Regressive offlap of the Permian rocks, with consequent lateral facies changes at the top of the system, seems more likely than erosional beveling. The lateral relation between units is one of intertonguing, shown both by gradational contacts, by interbedding between units at any one locality, and by lateral gradation between units across a wide area (Sheldon, 1957). Also, in southeastern Idaho and adjacent areas, widespread distinctive key beds in the topmost few feet of the Phosphoria Formation are located in the same stratigraphic position relative to overlying Triassic beds. Thus, according to this interpretation, an oceanic basin in southeastern Idaho received deposits of phosphatic mud at the close of Permian time; an oceanic shelf adjoined the basin on the east. Silica was deposited on the outer edge of this shelf, and carbonate sediment accumulated in the inner part extending as far as the coastal or shoal area. Within the coastal belt, red and green mud was deposited in lagoons and on mud flats (Cheney and Sheldon, 1959, fig. 6).

Environmental relations described above were similar to those earlier in the Permian, as discussed by Sheldon, Maughan, and Cressman $(\mathrm{I}-450)$. Therefore, if the stratigraphic relations at the top of the Permian System were the result of regional beveling, this similarity between the pre-Triassic paleogeologic pattern and the facies patterns lower in the Permian would be fortuitous. Furthermore, such beveling would require more uplift and erosion in the geosynclinal area than in the cratonic area, a structural event which would be opposite to that demonstrated for structural history in other parts of Permian and Early Triassic time, when the geosyncline subsided more than the craton. For these reasons, interpretations $B$ and $D$ of figure 57 seem unlikely.

Of the remaining two interpretations, $A$ seems the more likely. If at the end of Permian time the geosyncline was the site of an oceanic basin and the craton formed an oceanic shelf, and if deposition from Permian into Triassic time were continuous, the facies within Permian and Triassic rocks should be related. Relatively deep-water sediments of the Permian (Cressman , 1955, p. 27-29; Sheldon, 1957, p. 146-152) should be overlain by deep-water sediments of the Triassic, and shallow-water sediments of both systems should be associated. That this occurred seems likely. Thus, the Retort Phosphatic Shale Member of the Phosphoria Formation is overlain by the olive buff shale unit of the Dinwoody in the geosyncline (Kummel, 1954, p. 169), the dark silty chert of the Tosi Chert Member of the Phosphoria is overlain by the basal siltstone on the outer edge of the craton and, to the east, the Ervay Carbonate Rock Member of the Park City Formation is overlain by the calcareous Claraia or Lingula beds. Still farther eastward in Wyoming and southward in Utah, red beds of Permian age are overlain by red beds of Triassic age.

These relations cannot be shown over all the Middle Rocky Mountains because of difficulties in correlation and lack of information on Triassic rocks. However, the facies and thickness changes of Triassic interval A rocks (McKee and others, 1959) and of 
the Permian interval $\mathrm{C}$ rocks are similar (compare pl. 5 of I-450 with pl. 3 of McKee and others, 1959), except that the Triassic rocks lack the abundant chert and phosphorite characteristic of the Permian. Furthermore, interpretation $A$ explains the apparent conformity between the two systems in the geosyncline and the local disconformities on the craton.

The paleontologic evidence does not help in the solution of the problem, as stated earlier. There are, furthermore, conflicts in the age dating of the Upper Permian rocks. The youngest Permian rocks in the area contain the Spiriferina pulchra fauna (E. L. Yochelson, oral commun., 1960) and are assigned a Word age, which is classed as Early Permian. If this age assignment is correct, Upper Permian rocks are absent in the area, owing to either erosion or nondeposition. On the other hand, the Spiriferina pulchra fauna is assigned a Capitan (Late Permian) age by other paleontologists (Dunbar and others, 1960, p. 1; Gordon and Merriam, 1961). If this age assignment is correct, Upper Permian rocks are present, and continuous deposition from Permian into Triassic remains a possibility.

Additional faunal evidence bearing on the PermianTriassic boundary is from the Triassic beds. Earliest Triassic fossils have not been found anywhere in the region. The earliest yet reported are from the lower part, but not the basal beds, of the Dinwoody Formation in southwestern Montana, southeastern Idaho, and western Wyoming. These are late Otoceratan or not quite earliest Triassic (Kummel, 1954, p. 183). If the inferred faunal gap represents a period of nondeposition rather than incomplete faunal migration, the physical conformity of the Permian and Triassic beds suggests that the gap was not caused or accompanied by emergence in most of the region.

In summary, available data do not permit a choice between the two most likely interpretations of the boundary between the Permian and Triassic Systems. Despite these uncertainties, however, the boundary here used as the top of interval $\mathrm{C}-\mathrm{D}$ is recognized with assurance throughout the region.

\section{THICKNESS TRENDS}

The rocks of interval C-D are thickest in southcentral Idaho, northwestern Utah, and northeastern Nevada (fig. 58). They thin to the north, east, and south, so that the east edge of the geosyncline is at about the 200 -foot isopach. On the adjoining shelf the interval ranges from 0 to about 200 feeet in thickness.

Three areas of anomalous thickness are evident in figure 58. The first is a lobate area of rock that is less than 100 feet thick extending southward from Montana along the Idaho-Wyoming boundary. The second, in part related to the first, is an area approximately coinciding with the present Green River basin where the interval is thicker than average (in most places greater than $100 \mathrm{ft}$ thick, and near the Wind River Range greater than $200 \mathrm{ft}$ thick). In the third area, interval C-D is $330-600$ feet thick in the allochthonous block of the Charleston thrust in Utah but is only 100-200 feet thick in the autochthonous block.

The thickness anomaly of interval B in Beaverhead County, Mont., discussed earlier and shown in figure 56 , is barely evident on the isopach map of interval C-D (fig. 58). A small salient of relatively thick rocks that trends northward into thinner rocks is shown by the 200- and 300-foot isopachs. The eastwest trough of interval $B$ just north of the Uinta Mountains is not present in interval C-D, but the 100 foot isopach swings westward at the Uinta Mountains, which accounts for a general similarity in the thickness variations of the two intervals.

\section{LITHOFACIES TRENDS}

Rocks of interval C-D form the uppermost cycle of deposition of Permian rocks in the region.

Intertonguing of interval C-D units creates the facies changes shown on plate 5 of $\mathrm{I}-450$. Thus, in southeastern Idaho and parts of northwestern Wyoming and southwestern Montana, black shale, chert, and phosphorite of the upper units of the Phosphoria Formation form most of the interval. To the northeast, in northwestern Wyoming and nearby Montana, the interval consists mainly of the Shedhorn Sandstone. To the east and south the black shale, chert, and phosphorite facies grades into carbonate of upper parts of the Park City Formation. East and south of this the carbonate of the Park City grades into red beds of the Goose Egg and Woodside (as used by H. D. Thomas, 1939) Formations.

In general, the lithofacies pattern of interval C-D corresponds to the thickness pattern, in a manner similar to that in interval B. Rocks of interval C-D are thickest in the geosyncline and are dominantly dark mudstone, chert, and phosporite. On the shelf the rocks are thinner and are mostly sandstone, carbonate rock, light-colored mudstone, and red beds. Furthermore, the lobate area of thin rock along the Idaho-Wyoming border shows a greater proportion of light-colored limestone than does the area to the west, where the geosynclinal rocks contain more mudstone, or to the east in the present Green River basin, where the rocks are thicker and contain more mud- 
stone. South of the Uinta Mountains, carbonate rocks grade into red beds at approximately the 100 foot isopach.

\section{SOURCES AND ENVIRONMENTS}

Statements concerning the sedimentation of interval $\mathrm{B}$ in this region also apply to interval $\mathrm{C}-\mathrm{D}$, and the

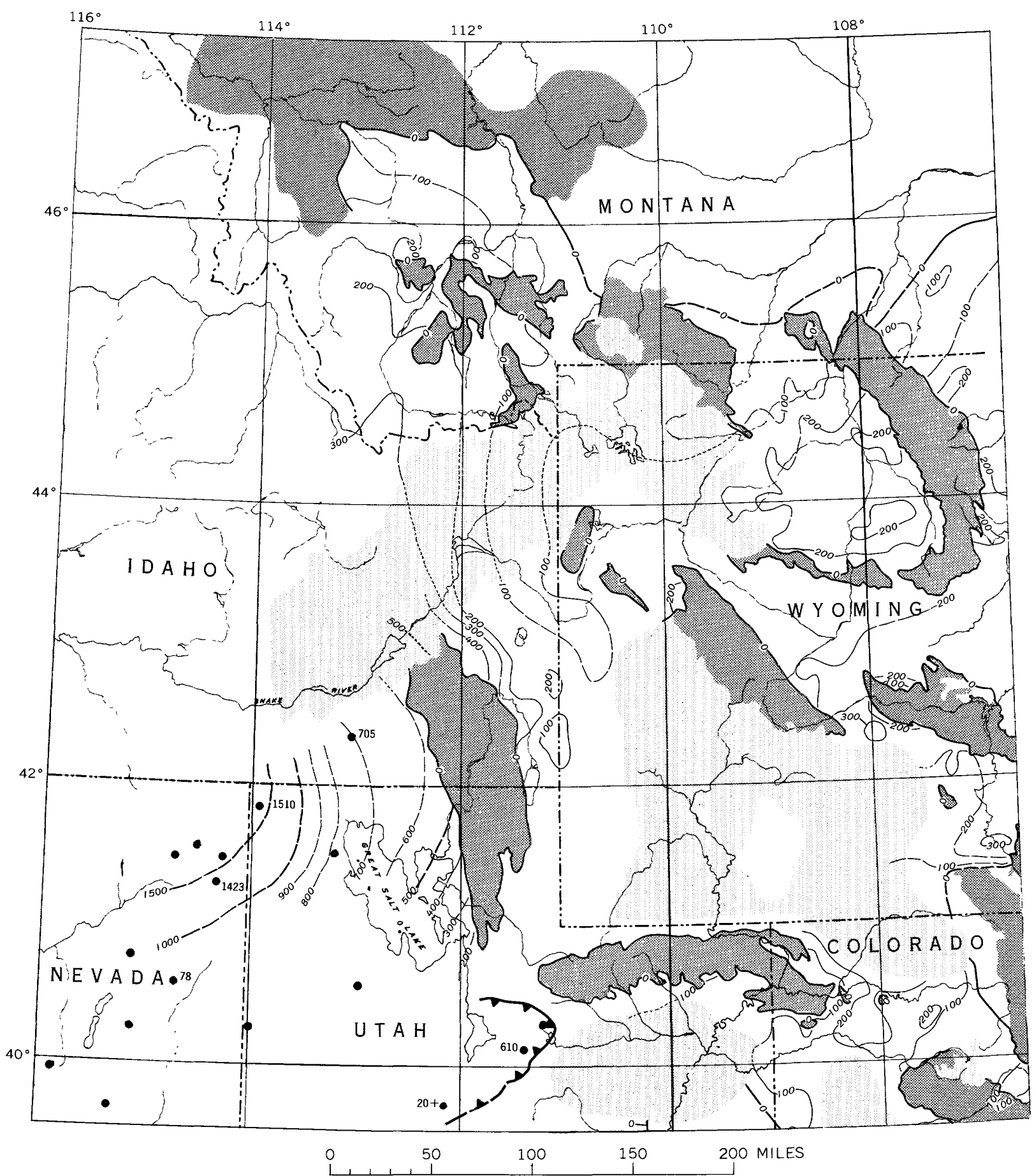

Figure 58.-Thickness of interval C-D in the Middle Rocky Mountains and northeastern Great Basin. Isopach intervals 100 and 500 feet. Isopachs dashed where control is poor, dotted where Permian rocks have not been penetrated by drill. $\quad$, indicates where Permian rocks have been identified, but control is inadequate for isopach construction; thicknesses in feet. Approximate trace of thrust fault shown by sawtooth line; sawteeth on upper plate. Dark pattern, areas where rocks older than Permian are exposed; light pattern, areas where rocks younger than interval $\mathrm{C}-\mathrm{D}$ have not been penetrated. 
environments of deposition inferred for the environmental maps (I-450, pl. $11 C$ ) apply equally well to interval $\mathrm{C}-\mathrm{D}$.

\section{PALEOTECTONIC IMPLICATIONS}

The major tectonic elements described for interval $B$ were active during the time of interval $\mathrm{C}-\mathrm{D}$. In addition, during interval C-D time a linear tectonic high formed on the east edge of the geosyncline. This high trended roughly north-south parallel to the present fold axes and strikes of thrust faults. On the crest of this structure, water was shallower and sedimentation less than before. The area was not emergent during deposition of interval C-D, but a shallow submarine ridge on the sea floor probably separated the open ocean on the west from a moderately deep basin on the east.

Whether these tectonic elements continued to influence sedimentation, without interruption, into Triassic time is uncertain. Possibly there was a period of nondeposition during much of Late Permian time, followed by Triassic sedimentation. More likely, the transition from Permian into Triassic time was marked by (a) withdrawal of the sea and some erosion near the positive areas, (b) continuous sedimentation and continued regression of lithofacies on the shelf adjoining these areas, and (c) continuous detrital sedimentation but a different type of chemical sedimentation in the geosyncline. The change in type of chemical facies possibly resulted from a cessation of major upwelling currents along the western margin of the shelf.

\section{TOTAL THICKNESS OF PERMIAN ROCKS THICKNESS TRENDS}

In the Cordilleran geosyncline the thickest sections of the Permian System lie in north-central Idaho and in northwestern Utah, where they exceed 9,000 feet (fig. 59). The section on the Charleston thrust block in Utah is 14,000 feet thick, but its original position was west of its present one. The system thins northward, eastward, and southward, so that at the edge of the geosyncline it is only about 200 feet thick. The orientation of the axis of the geosynclinal wedge of rock is difficult to fix but probably trends about northnortheast. On the shelf, adjoining the geosyncline on the east, the system ranges from zero to several hundred feet in thickness.

Thickness anomalies on the shelf, as shown for the various intervals, tend to reinforce each other so that they are clear on the total isopach map. The salient of thick rocks in southwestern Montana is conspicuous. The southward-trending lobate area of thin rocks along the Wyoming-Idaho border is clear, and the 300 foot isopach fairly well outlines the area of thickening that approximately corresponds to the present Green River basin. The east-west trending trough near the Uinta Mountains and the abnormally thick Permian section in the allochthonous block of the Charleston thrust fault in Utah are major features.

\section{PALEOTECTONIC IMPLICATIONS}

The pattern of variation in thickness of the Permian rocks roughly conforms to that of the Paleozoic and lower Mesozoic section as a whole (Kay, 1947); that is, Permian rocks in the Cordilleran miogeosyncline range from several hundred to several thousand feet in thickness, whereas those on the bordering shelf to the east are only a few tens to a few hundreds of feet thick. The transition zone between the Permian geosynclinal and shelf sections corresponds rather closely to the east edge of the Laramide thrust belt. In much of the area, the transition zone is only 10-20 miles wide, which is the result of original thinning and of east-west telescoping due to folding and thrusting.

Permian rocks of western Montana were partly or wholly removed by pre-Jurassic erosion in all but the southwestern part, but available data indicate that less than 200 feet of Permian rocks was deposited in most of this area. The Phosphoria and Shedhorn Formations in southwestern Montana were derived from the west, north, and east (Cressman, 1955, p. 23); this information, in addition to the data on thickness and distribution of Permian rocks, suggests that most of western Montana was moderately positive during Permian time.

The thickness of Permian rocks in southwestern and west-central Wyoming indicates the presence of a basin on that part of the shelf, separated from the main part of the geosyncline by a linear positive area. The intertonguing of relatively deep-water with shallow-water facies in western Wyoming implies that this was an unstable area (Sheldon, 1957, p. 154), as contrasted with the surrounding part of the shelf, where fairly uniform sediments indicate more or less continuous shallow-water deposition.

\section{GEOLOGIC UNITS DIRECTLY ABOVE PERMIAN SYSTEM UNITS OVERIYING PERMIAN}

The Permian rocks in most of the region are overlain by rocks of Triassic age. In parts of southwestern Montana, eastern Idaho, and western Wyoming, and in Rich County, Utah, the Dinwoody Formation of Early Triassic age overlies the Permian. In the Wasatch Range and western Uinta Mountains of Utah (fig. 62), the Woodside Formation, also of Early Tri- 
assic age, overlies the Permian, and in northwestern Utah and northeastern Nevada undifferentiated Triassic rocks occupy this position. In middle-western
Montana, north of the area where the Dinwoody Formation is truncated by pre-Jurassic erosion, Jurassic rocks unconformably overlie Permian rocks.

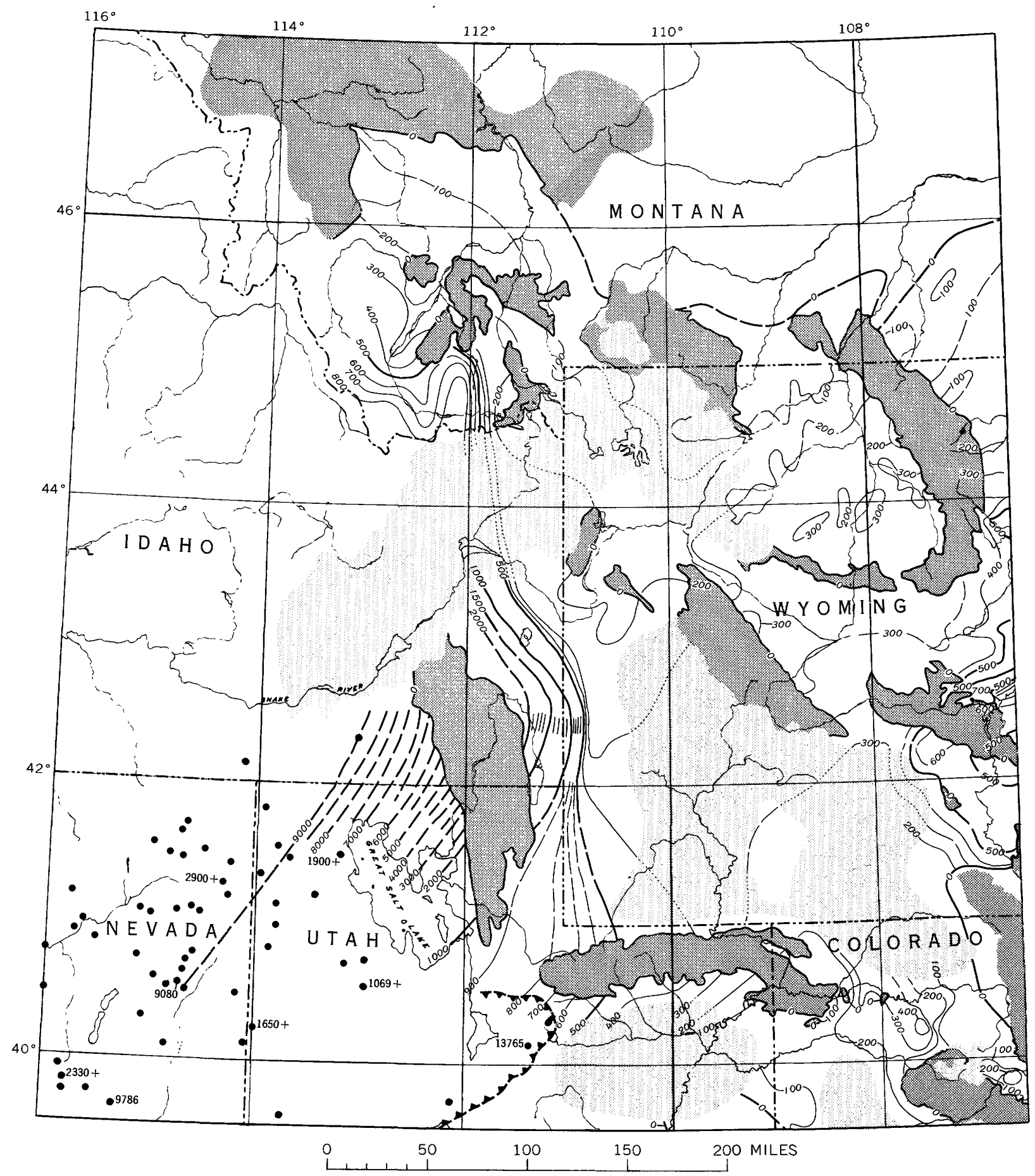

Figure 59.-Total thickness of Permian rocks in the Middle Rocky Mountains and northeastern Great Basin. Isopach intervals 100, 500, and 1000 feet. Isopachs dashed where control is poor, dotted where Permian rocks have not been penetrated by drill. - indicates where Permian rocks have been identified, but control is inadequate for isopach construction; thicknesses in feet. Approximate trace of thrust fault shown by sawtooth line; sawteeth on upper plate. Dark pattern, areas where rocks older than Permian are exposed; light pattern, areas where rocks younger than Permian have not been penetrated. 


\section{PALEOTECTONIC IMPLICATIONS}

The major paleotectonic event shown by rocks overlying the Permian System is pre-Middle Jurassic uplift and erosion in middle-western Montana. A low positive area formed in central Montana in Permian time and was the source of some sediment deposited in the Permian seas. This low positive area persisted into Triassic time (McKee and others, 1959, pl. 9). Then the area was uplifted more, so that Triassic and Permian rocks, as well as older rocks, were beveled before Middle Jurassic sediments were laid down.

Locally throughout the shelf area in Montana, Wyoming, and Utah, slight uplift occurred at the end of
Permian time, but nowhere was it prolonged or extensive enough to permit erosion of more than uppermost Permian rocks. In the vicinity of the geosyncline in Idaho and adjacent areas, no evidence of erosion after Permian time is apparent.

Thus, at the close of Permian time the shelf area of the Middle Rocky Mountains became slightly positive, and the geosynclinal area remained slightly negative and may have received sediments continuously into Triassic time. The transition from Permian to Triassic was not marked by a tectonic event having the significance of the pre-Permian regression or the Early Jurassic uplift and erosion. 


\section{Paleotectonic Investigations}

of the Permian System

in the United States

Chapter I. Western Colorado, Southern Utah, and Northwestern New Mexico By WALTER E. HALLGARTH

GEOLOGICAL SURVEY PROFESIONAL PAPER 515-I

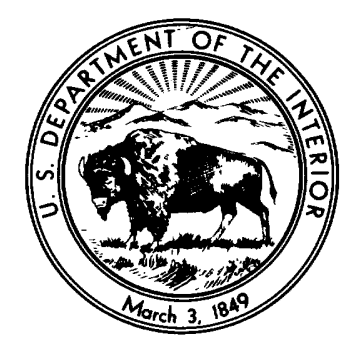





\section{CONTENTS}

Abstract

Region defined.

Paleogeology

Units underlying the Permian........

Rocks west and southwest of Uncompahgre

Plateau.

Rocks northeast of Uncompahgre Plateau.....-

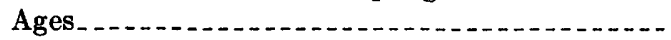

Lower boundary of the Permian.

Paleotectonic implications.........

Interval A . . .

Formations included.

Southwest of Uncompahgre Plateau.

East and northeast of Uncompahgre Platea

Upper boundary of interval A

Thickness trends

Lithobacies trends

Sources and environments

Paleotectonic implications

Interval $\mathrm{B}$.

Formations included

Stratigraphic relations.

Southwest of Uncompahgre Plateau.

\begin{tabular}{r}
\hline Page \\
175 \\
175 \\
175 \\
175 \\
175 \\
176 \\
177 \\
179 \\
179 \\
181 \\
181 \\
181 \\
183 \\
184 \\
184 \\
184 \\
185 \\
186 \\
186 \\
186 \\
186 \\
186
\end{tabular}

Interval B-Continued

Stratigraphic relations-Continued

Northeast of Uncompahgre Plateau _.. . . _. . 187

Upper boundary of interval B............. 187

Thickness trends.....

Lithofacies trends._._. . . .

Environments and sources............. 189

Paleotectonic implications _. . . . _ _.

Interval C-D _. . . . . .

Formations included .

Stratigraphic relations._._._._.

Upper boundary of interval C-D _... _. _._. . . 191

Thickness trends.

Lithofacies trends. . .

Environments. ... . . . . . .

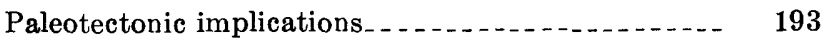

Total thickness of Permian rocks_._.

Rocks included....... 193

Thickness trends

Paleotectonic implications_._._._. 194

Geologic units directly above Permian System _._._. 196

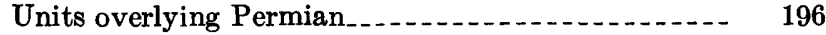

Upper boundary of Permian._._.

Paleotectonic implications.

\section{ILLUSTRATIONS}

PLATE 6. Columnar sections of Permian strata in Utah and Colorado showing thickness, lithology, and correlation Figure 60-63. Maps:

60. Geologic units directly beneath Permian System in western Colorado, southern Utah, and surrounding areas. . . . .

61. Structural features of Colorado, Utah, and parts of adjacent States at the time of deposition of interval A . .

62. Present structural elements in western Colorado and southern Utah

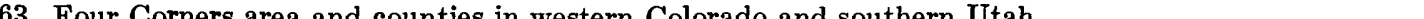

64-66. Diagrams:

64. Relations of lower part of State Bridge Formation to Schoolhouse(?) Sandstone and lower part of Maroon Formation along the east side of the White River Plateau, Colo . . . . . . . . . . .

65. Relation of Permian rocks to underlying Pennsylvanian rocks between the Uncompahgre Plateau (east) and western Juab County, Utah....

66. Present structural and stratigraphic relations of Maroon and Cutler Formations to the Uncompahgre highland, Colorado_.

67-71. Maps:

67. Thickness of interval A in western Colorado, southern Utah, and surrounding areas.

68. Thickness of interval $B$ in western Colorado, southern Utah, and surrounding areas

69. Distribution of thicknesses of Hoskinnini and Tenderfoot Members of Moenkopi Formation in part of Colorado Plateau.

70. Thickness of interval C-D in western Colorado, southern Utah, and surrounding areas...

71. Total thickness of Permian rocks in western Colorado, southern Utah, and surrounding areas.

\section{TABLE}

Table 1. Generalized chart showing stratigraphic units in major Permian subdivisions. 


\title{
PALEOTECTONIC INVESTIGATIONS OF THE PERMIAN SYSTEM IN THE UNITED STATES
}

\section{WESTERN COLORADO, SOUTHERN UTAH, AND NORTHWESTERN NEW MEXICO}

\author{
By Walter E. Hallgarth
}

\begin{abstract}
The Permian System of western Colorado, southern Utah, and northwestern New Mexico reflects uplift of ancestral highlands at the beginning of the period, followed by tectonic stability and a gradual wasting of the highlands. Permian structural elements of the region are the elongate Uncompahgre-San Luis highland, the ancestral Front Range, the elongate Colorado and Uncompahgre troughs, the Permian San Juan basin, the southern Utah basins, and the Oquirrh basin.

During deposition of interval A (lowest part of Permian), nonmarine coarse clastic materials, derived from the Front Range and Uncompahgre highlands, were accumulated in basins and troughs of central and western Colorado and eastern Utah. These continental sediments graded westward into marine clastic and carbonate materials in western Utah. During the early part of this interval, a restricted arm of the sea extended eastward into southeastern Utah. Adjoining highlands stood high or were rising throughout the interval.

During deposition of interval B (middle part of Permian), accumulation of marine beds was largely restricted to northwesternmost Colorado and western Utah. Areas of sandstone of eolian aspect, marginal to the areas of marine deposition, are interpreted as coastal dunes; and relatively fine grained red beds, adjacent to the highlands, are interpreted as continental fluvial and lacustrine deposits. Interval $B$ marks a time of stability in the basins and highlands.

Interval C-D (uppermost part of Permian) is dominantly limestone and dolomite in central and southern Utah but is dominantly mudstone elsewhere in the region. Thin fossiliferous beds indicate that marine conditions may have been relatively widespread for short periods. Interval $\mathbf{C}-\mathrm{D}$ marks a period of stability; areas of formed uplift had apparently been reduced to lowlands, and material supplied to the surrounding depositional areas was dominantly fine grained.
\end{abstract}

\section{REGION DEFINED}

The region discussed here includes that part of Colorado west of the east flank of the present Front Range, Utah south of the 40th parallel, and San Juan and Ria Arriba Counties in northwestern New Mexico.

Permian structural elements include: (1) The ancestral Front Range highland, trending northwest from central Colorado; (2) the Colorado trough; (3) the Uncompahgre and San Luis highlands extending from eastern Utah through southwestern Colorado; (4) the deep narrow Uncompahgre trough paralleling the Uncompahgre highland on the southwest; (5) the Permian San Juan ond the southern Utah basins, centered in northwestern New Mexico and southeastern Utah, respectively; and (6) a shelf or platform extending westward from eastern Utah to the Cordilleran geosyncline.

\section{PALEOGEOLOGY \\ UNITS UNDERLYING THE PERMIAN}

Rocks beneath the Permian in western Colorado, southern Utah, and northwestern New Mexico (fig. $60 ; \mathrm{I}-450$, pl. 2) are sedimentary and are of Pennsylvanian age, except in two small areas in Utah where they are probably of Mississippian age. In central Colorado on the edges of the ancestral Front Range (fig. 61), Permian rocks overlap Precambrian igneous rocks for a short distance.

\section{ROCKS WEST AND SOUTHWEST OF UNCOMPAHGRE} PLATEAU

The Hermosa Formation, which ranges from Des Moines through Virgil in age, underlies Permian rocks across a large area near and southwest of the Uncompahgre Plateau (fig. 62). In the eastern and northeastern parts of the western Colorado-Utah region, limestone in the upper part of the Hermosa is interbedded with arkosic conglomerate to form a transitional sequence with the overlying Cutler Formation of Permian age. In the San Juan Mountains (fig. 62 ) this sequence is named the Rico Formation (Cross, C. W., and Spencer, 1900).

Permian rocks rest on the Madera Limestone of Pennsylvanian age in southeastern San Juan County and southwestern Rio Arriba County, N. Mex. (Henbest and Read, 1944; Wood and Northrop, 1946). In west-central and southwestern Utah, Permian beds rest on rocks of Pennsylvanian age, including the lower parts of the Ely Limestone (Hose and Repenning, 1959; Steele, 1959), limestone strata with Pennsylvanian fossils in Beaver County, Utah (Steele, 1959), and 


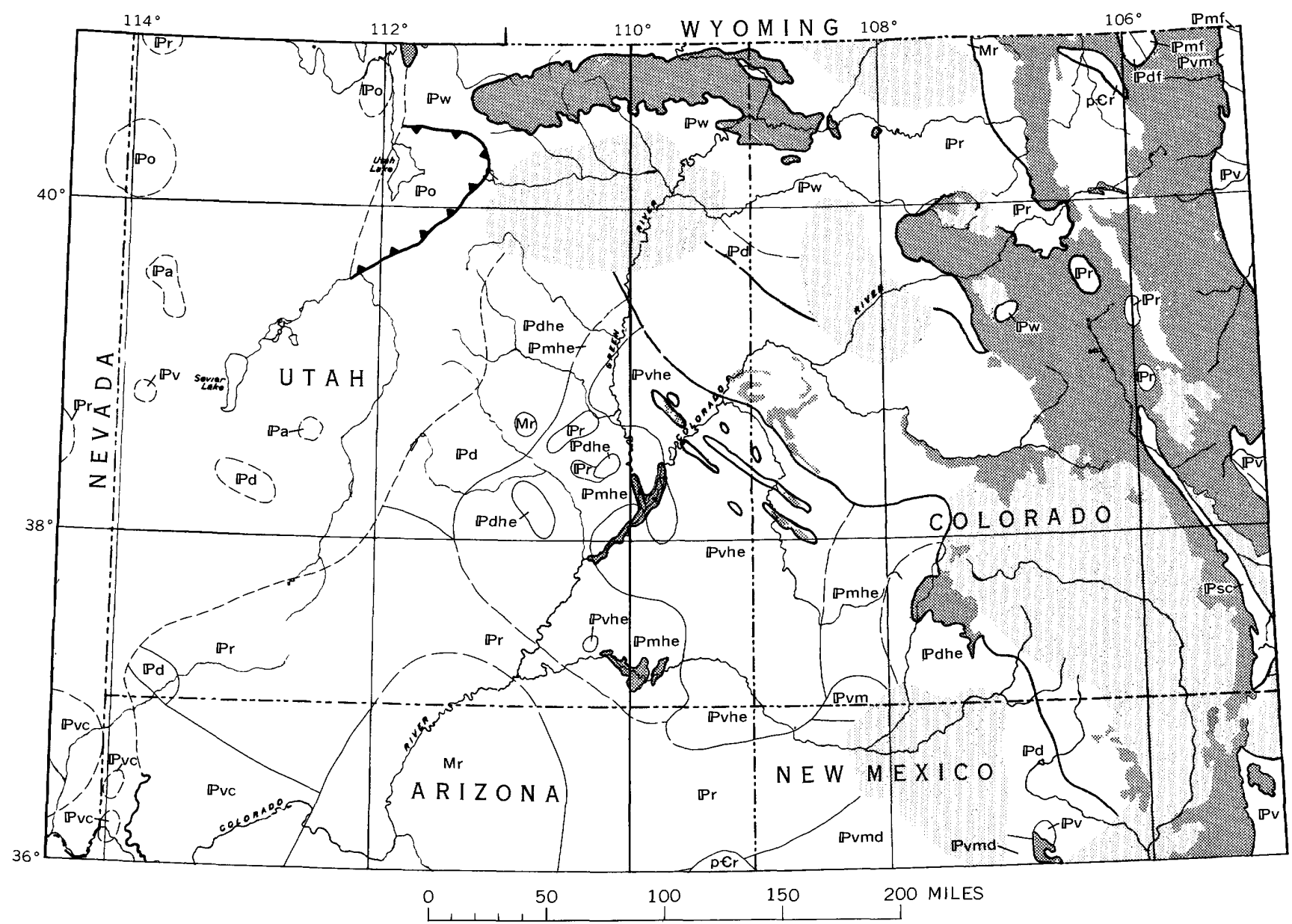

Frgure 60.-Geologic units directly beneath Permian System in western Colorado, southern Utah, and surrounding areas. Pennsylvanian rocks: $\mathbb{P r}$, undivided; $\mathbb{P o}$, Oquirrh Formation (part); Psc, Sangre de Cristo Formation (part); $\mathbb{P} w$, Weber Sandstone (part); Pvc, Callville Limestone, Pvhe, Hermosa Formation (part), Pvmd, Madera Limestone, and Pv, undivided, all of Virgil age; Pvm, undivided, of Virgil and Missouri age; $\mathbb{P} m f$, Fountain Formation (part) and Pmhe, Hermosa Formation (part), both of Missouri age; $\mathbb{P d f}$, Fountain Formation (part), $\mathbb{P}$ dhe, Hermosa Formation (part), and $\mathbb{P d}$, undivided, all of Des Moines age; $\mathbb{P a}$, undivided, of Atoka age. Mr, Mississippian rocks, undivided. $p €$, Precambrian rocks, undivided. Dark pattern, areas where rocks older than Permian are exposed; light pattern, areas where rocks older than Permian have not been penetrated. Approximate trace of thrust fault shown by sawtooth line; sawteeth on upper plate.

the Callville Limestone as restricted by McNair (1951, p. 520).

In the central part of southern Utah, rocks of Mississippian age underlie the Permian in an area projecting north from Arizona. Likewise in the San Rafael Swell area of Utah (fig. 62), rocks below the Permian at locality 646 have been assigned to the Mississippian System (Herman and Sharps, 1956).

\section{ROCKS NORTHEAST OF UNCOMPAHGRE PLATEAU}

Northeast and east of the Uncompahgre Plateau the youngest rocks directly beneath the Permian are included in the Weber Sandstone, the lower part of the Maroon Formation, the Paradox Formation, and the Sangre de Cristo Formation.

The Maroon Formation as redefined (Bass, 1958) incorporates all stratigraphic units between the top of the Paradox Formation of Pennsylvanian age and the base of the Chinle Formation of Late Triassic age. Where exposed in the White River Plateau (fig. 62), Eagle to Rio Blanco Counties (fig. 63), it consists of five lithologic units. Only the lowest unit, an arkose referred to in this publication as the lower arkosic part of the Maroon, is here considered to be in the Pennsylvanian System, but it is thicker than the rest of the formation and consists of three lateral subdivisions: the arkose facies along the ancestral Uncompahgre highland; the intermontane trough 
facies of arkose, mudstone, and limestone; and the arkose facies along the west flank of the ancestral Front Range. The upper part of the arkose facies along the Uncompahgre grades northeastward into fine-grained rocks of the intermontane facies in the White River Plateau area. Where the arkose facies is exposed around the western part of the Uncompahgre it underlies rock of interval B (Schoolhouse Sandstone). Farther east the equivalent intermontane facies underlies rocks assigned to interval B (Schoolhouse(?) Sandstone), and still farther east it underlies rock of interval $\mathrm{C}$ (lower part of State
Bridge Formation) (fig. 64). The arkose facies along the ancestral Front Range underlies rock of interval $\mathrm{C}$ in a small area along the Colorado River.

The Paradox Formation (Bass, 1958) underlies the Maroon where the latter is preserved, but north of the White River Plateau the Maroon has apparently been removed by erosion so that at localities 567 and 570 (pl. $6 D$ ) beds of the Paradox underlie the Permian.

The Sangre de Cristo includes strata of Pennsylvanian and of Permian ages (Wood and others, 1957, p. 14), but a systemic boundary has not been estab-

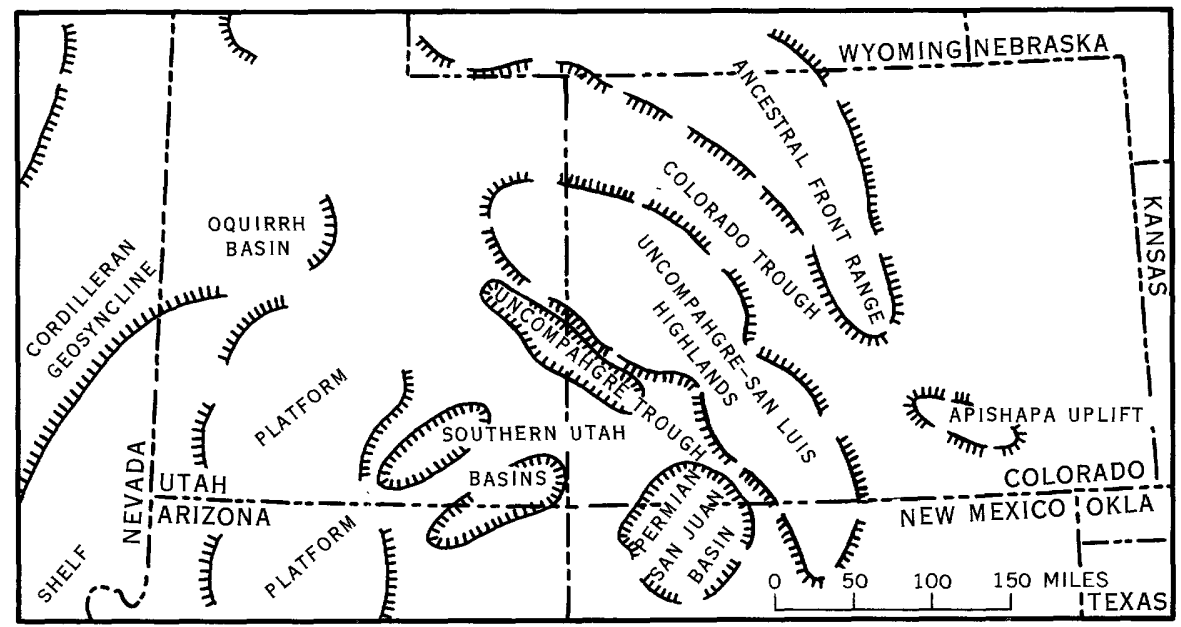

FIGURE 61.-Structural features of Colorado, Utah, and parts of adjacent States at the time of deposition of interval $\mathrm{A}$.

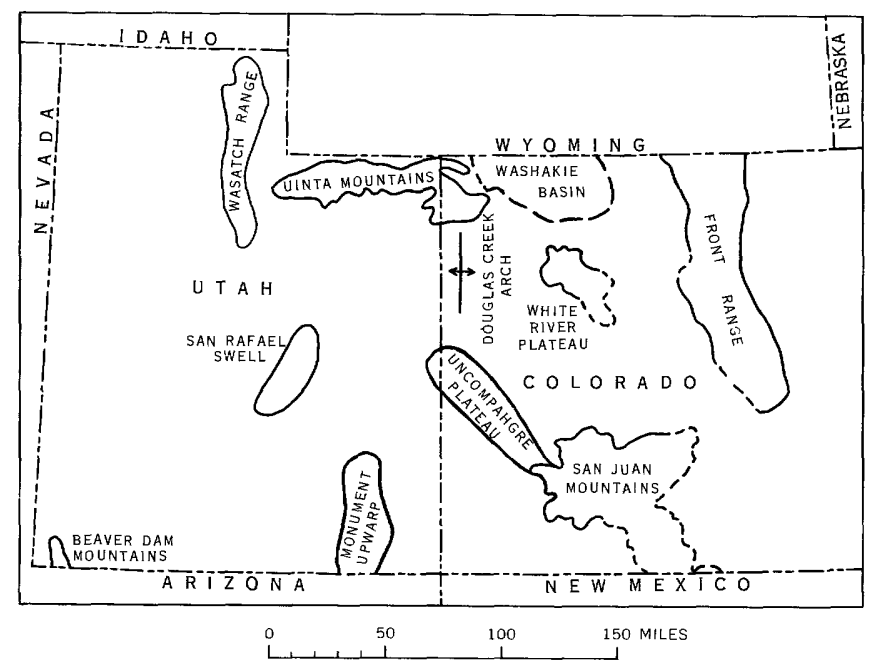

Figure 62.-Present structural elements in western Colorado and southern Utah referred to in text. lished because fossil data are inadequate.

AGES

The youngest definitely dated rocks of Pennsylvanian age (Virgil) beneath the Permian (fig. 65) are in the Madera Limestone of New Mexico (Henbest and Read, 1944) and in the Hermosa Formation of the Paradox basin (Chronic, 1960, p. 84-85), a Pennsylvanian basin which covered a large area in southeastern Utah and extended into southwestern Colorado and northwestern New Mexico. Rocks of Virgil age are also reported at one locality (714) in west-central Utah (Steele, 1959, fig. 3).

Fossils of Virgil age have not been reported from northwesternmost Colorado, northeast of the Uncompahgre highland. In south-central Colorado, sedimentation may have been continuous from Pennsylvanian into Permian time, although a break at the end of the Pennsylvanian has been suggested (Brill, 1952, p. 819). 
Rocks of Missouri age have been reported only in Paradox basin (fig. 60).

the Hermosa Formation (Chronic, 1960, p. 85). They probably directly underlie the Permian System in a band around the area of Virgil rocks in the

Rocks regarded as Pennsylvanian crop out near the New Mexico boundary in southwestern Colorado and in the northwestern part of the Paradox basin.

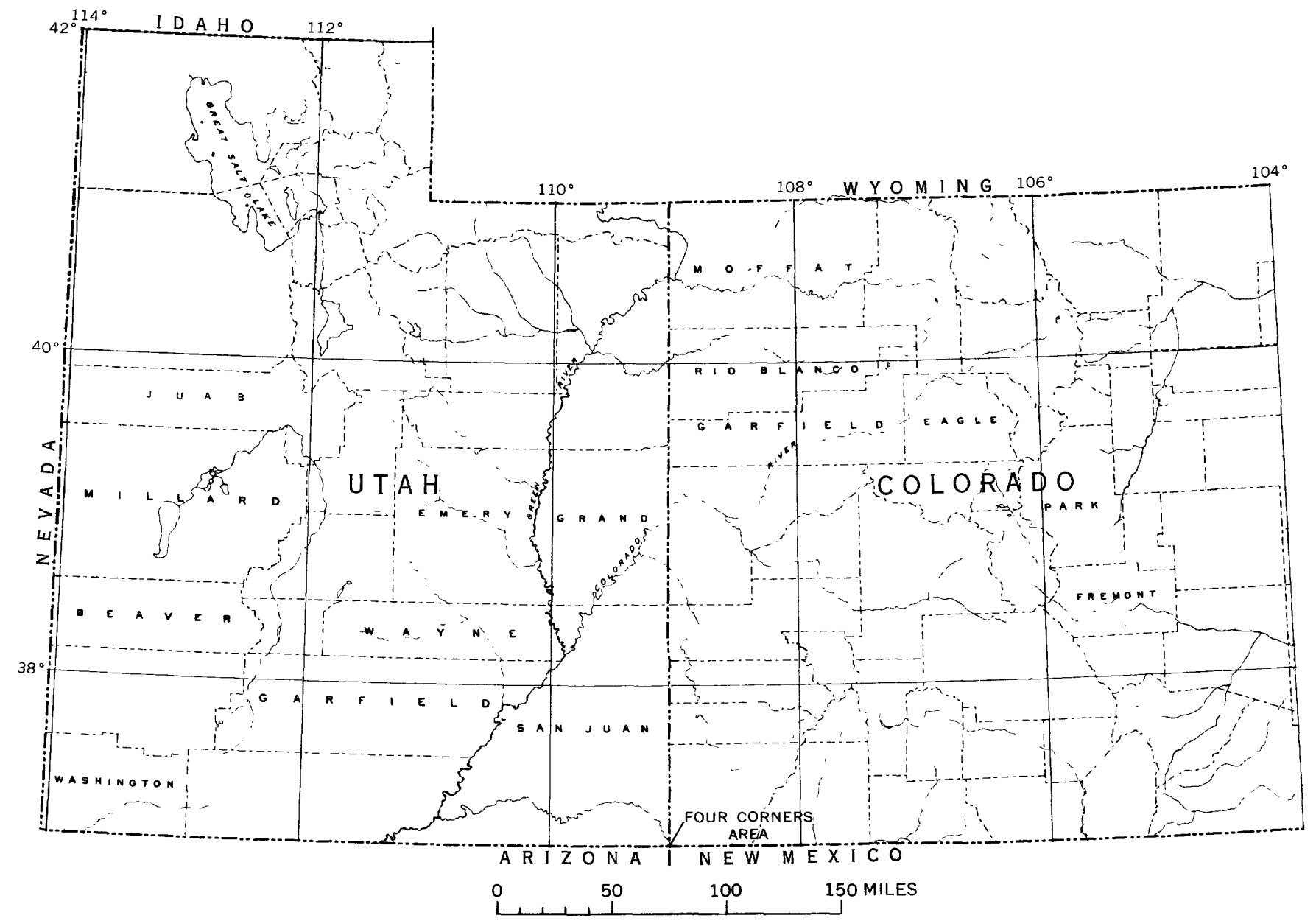

Figure 63.-Four Corners area and counties in western Colorado and southern Utah referred to in text.

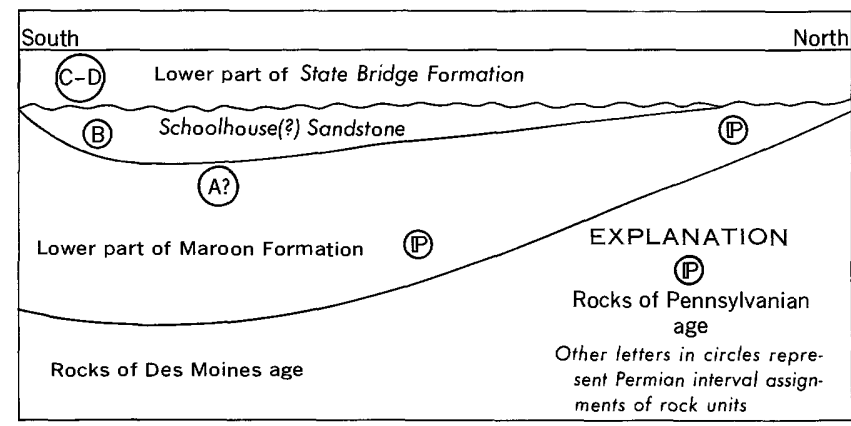

Figure 64.-Relations of lower part of State Bridge Formation to Schoolhouse(?) Sandstone and lower part of Maroon Formation for about 45 miles along the east side (locs. 661-677) of the White River Plateau, Colo. Not to scale.

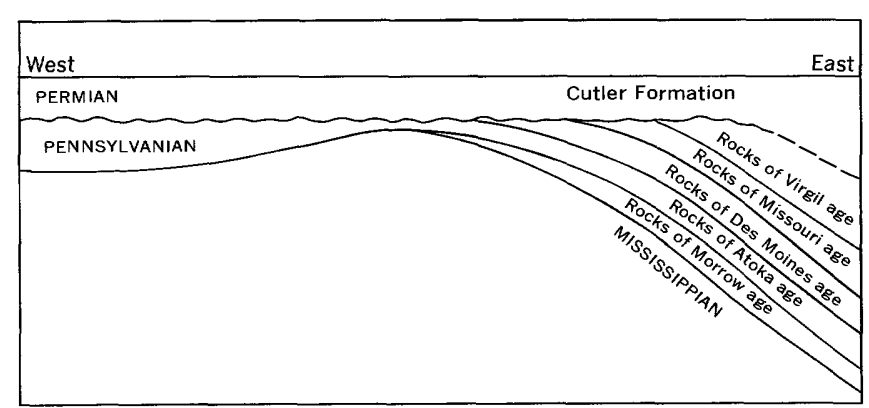

Figure 65.- Relation of Permian rocks to underlying Pennsylvanian rocks between the Uncompahgre Plateau (east) and western Juab County, Utah (west). Vertical scale and dips greatly exaggerated. 
These isolated occurrences may be either of Missouri or of Virgil age.

Strata probably of Des Moines age form the surface of the system in the San Rafael Swell area (Hallgarth, 1962, p. 1495-1496) and may form the surface in a large concentric area around the Paradox basin. These strata include rocks of the Hermosa Formation, the Rico Formation, and the Madera Limestone. The Callville Limestone underlies the Permian System in southwesternmost Utah and has been variously assigned a Des Moines or a Virgil age by Steele $(1959$, p. 42$)$ and by McNair (1951, p. 522).

In the intermontane area of northwestern Colorado the uppermost strata assigned to the Pennsylvanian (Weber Sandstone and lower part of the Maroon Formation) consist of unfossiliferous detrital rock, the exact age of which is unknown. They are shown in figure 60 as Pennsylvanian undivided, except for a strip along the northeast side of the Uncompahgre where the truncated Maroon Formation is comparatively thin and intertongues northward with rock of Des Moines age (Morgan Formation).

Rocks of Atoka age have not been reported in contact with the Permian except for two small areas in west-central Utah. However, rocks of Atoka age may possibly underlie the Permian adjacent to those areas where rock of Mississippian age lies directly below the Permian. These postulated areas of Atoka are not shown in figure 60 . In a large area in southwestern and south-central Utah the age of rocks directly beneath the Permian is uncertain and is shown as undifferentiated Pennsylvanian.

The oldest Paleozoic rock that directly underlies the Permian System in Utah is Mississippian, reported from the San Rafael Swell and probably along the south boundary of the State. Locally underlying the Permian on both sides of the ancestral Front Range landmass in north-central Colorado is Precambrian rock, which formed the core of the highland.

\section{LOWER BOUNDARY OF THE PERMIAN}

In parts of southern Utah and western Colorado the base of the Permian is an unconformity. Exceptions, where sedimentation was probably continuous, are in troughs along the west side of the ancestral Front Range, along the Uncompahgre highland, and in the deepest part of the Paradox basin.

A hiatus at the bottom of the Permian has been recognized on the basis of fossils in much of the region southwest of the Uncompahgre. An apparent unconformity has been described in parts of eastcentral Utah at the top of the Hermosa Formation (Herman and Sharps, 1956, p. 81), and an unconformity is reported from other parts of the Paradox basin (D. L. Baars, written commun., 1960).

In south-central Utah, evidence of unconformity at the base of Permian was cited by Heylmun (1958, p. 1790). In west-central Utah a hiatus of great magnitude, based on faunal evidence, may be present, as rock considered of Atoka age (Ely Limestone and equivalent beds) underlies Permian rock (Steele, 1959 , p. 52 and fig. 3). In southwesternmost Utah the Callville Limestone was considered to be of Des Moines age by Steele (1959) and of Virgil age by McNair (1951, p. 522), although their Callville underlies the Permian with no recognizable physical break.

In the San Rafael Swell area of Utah an irregular contact and a thin conglomerate at the base of the Permian suggest a disconformity (Hallgarth, 1962). Locally in northwestern Colorado similar evidence is known.

In northwestern Colorado, east of the White River Plateau, physical evidence of an unconformity is present between definite Permian beds and the lower arkosic part of the Maroon Formation (Murray, $\mathbf{H}$. F., 1958, fig. 3; p. 56-57). South and west of the White River Plateau uppermost strata of the lower arkosic part of the Maroon Formation are believed to be absent; therefore, in this area the entire arkosic unit is considered to be of Pennsylvanian age. Northwest of the plateau, near the Colorado-Utah line, the Permian-Pennsylvanian boundary may lie within the Weber Sandstone or in upper strata of the lower arkosic unit. Directly north of the plateau the systemic boundary is placed within strata assigned to the Maroon Formation undivided, possibly equivalent in part to the Schoolhouse Sandstone.

In south-central Colorado the base of the Permian System lies within the Sangre de Cristo Formation, and its position is uncertain.

\section{PALEOTECTONIC IMPLICATIONS}

Two prominent positive elements dominated the Utah-western Colorado region in the latter part of Pennsylvanian time. In southwestern Colorado and southeastern Utah, coarse conglomerate beds that intertongue with rock of Des Moines and younger Pennsylvanian age indicate that the Uncompahgre positive element (fig. 61) was elevated. Farther east the ancestral Front Range also rose during Pennsylvan- 
ian time and continued to be high at the end of this period, as shown by arkosic conglomerate in eastern Colorado (Maher and Collins, 1952); however, unfossiliferous arkosic rocks of the intermontane area add nothing to support this belief.

Troughs that formed in Pennsylvanian time flanked the southwest side of each of the major positive elements. Thick sections of detrital rock, accumulated in each trough during post-Atoka time, attest to subsidence in the troughs concurrent with elevation of the landmasses.

East of the White River Plateau, in the intermontane area of western Colorado, the Permian State Bridge Formation rests disconformably (Murray, 1958, p. 56-57) on the underlying mainly Pennsylvanian Maroon Formation, indicating elevation of an area that was formerly a trough; however, the age span of the disconformity is not definitely known. The exact age of erosional interludes at several other places in northwestern Colorado is also unknown, for relatively young Permian rock rests on the lower arkosic part of the Maroon Formation of Pennsylvanian and locally of Permian age. This part of the Maroon Formation thins within short distances southward along the Utah-Colorado boundary toward the Uncompahgre (fig. 66). Near the Uncompahgre, it tongues with limestone of the Morgan Formation of Des Moines age, a formation that underlies younger parts of the Maroon farther north. Erosion of postDes Moines Pennsylvanian rocks in the vicinity of the Uncompahgre may have occurred during any of several intervals during later Pennsylvanian and Early Permian time.

The Colorado trough formed in Early Pennsylvanian time, probably by faulting along the west side of the ancestral Front Range. It extended from Moffat County, Colo. (fig. 63), southeastward into New
Mexico, according to Brill (1952, p. 810). The trough was probably about 60 miles wide (Murray, 1958 , p. 47$)$, and its axis was apparently closer to the ancestral Front Range than to the Uncompahgre highland because the fine-grained clastic rocks that accumulated in the trough lie mostly east and northeast of the White River Plateau.

A similar northwest-trending trough, referred to as the Uncompahgre trough, formed in Late Pennsylvanian and Early Permian time along the southwest side of the Uncompahgre highland. It extends from the area of the present San Juan Mountains northwestward into east-central Utah, where it apparently terminates against an area of less subsidence separating the trough from the Oquirrh basin.

In latest Pennsylvanian and earliest Permian time the Paradox basin was segmented into three smaller basins by two folds that are reflected in lowest Permian (interval A) sediments (fig. 67). One of the segmenting features, trending northwest, formed as a hinge line to folding during initial subsidence in the Uncompahgre trough and later limited the southwest side of the subsiding trough (fig. 61) and separated it from the remainder of the former Paradox basin to the southwest. The hinge-line fold extended from near the San Juan Mountains northwestward into central Utah, where it apparently terminated against the Emery high discussed by Herman and Sharps (1956).

A second crossfold within the Paradox basin trended northeast and formed as a hinge line fold between the newly forming Permian San Juan basin of southwestern Colorado and northwestern New Mexico and the part of the basin to the west. It extends southwestward in the direction of the Four Corners area, where it is progressively less well defined.

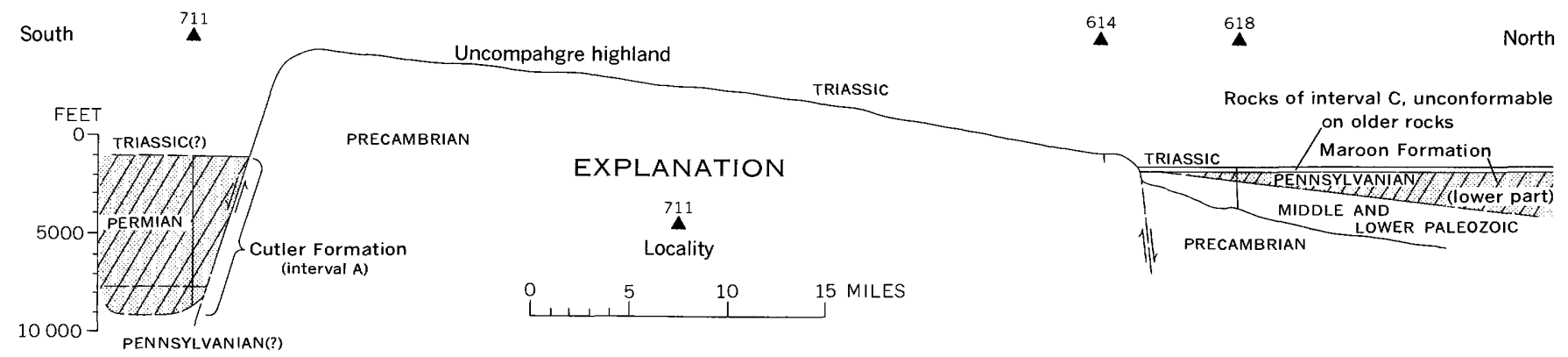

Figure 66.- Present structural and stratigraphic relations of Maroon and Cutler Formations to the Uncompahgre highland, Colorado. 
Broad regional upwarping took place on the west side of the Paradox basin. Rocks of Virgil, Missouri, and Des Moines age were eroded across the Emery high in the San Rafael Swell area (Herman and Sharps, 1956; fig. 62, this report) in central Utah, on the west flank of the basin, and Permian strata were deposited on rocks of Mississippian age (Herman and Sharps, 1956).

\section{INTERVAL A FORMATIONS INCLUDED}

Rock units included in interval $\mathbf{A}$ are widely distributed in western Colorado, Utah, and northwesternmost New Mexico (table 1) southwest of the Uncompahgre Plateau; but east of the plateau as far as the Front Range of Colorado, their extent has not been established.

Interval A includes the following: (a) In southwestern Colorado, northwestern New Mexico, and southeastern Utah, the lower part of the Cutler Formation; (b) in southwestern Utah, the Pakoon Limestone (McNair, 1951) and the lower part of the Supai Formation or Queantoweap Sandstone (McNair, 1951) ; (c) northward, in Beaver County, a sequence of limestone and overlying quartzite; (d) in west-central Utah, the upper part of the Ely Limestone and the lower part of the overlying Arcturus Formation; (e) in east-central Utah, rocks referred to as the Permian carbonate member of the Cutler Formation (Herman and Sharps, 1956)-more recently, as the Elephant Canyon Formation (Baars, 1962) - the overlying sandstone beds (Cedar Mesa Sandstone Member of the Cutler), and, in the subsurface of part of central Utah, beds equivalent to the Elephant Canyon and Permian carbonate member, here referred to as unnamed beds of Wolfcamp age; (f) in south-central Colorado, part of the Sangre de Cristo Formation. In northwestern Colorado the Maroon Formation and the Weber Sandstone are considered by some geologists (Brill, 1952; Bissel and Childs, 1958) to be partly of Permian age, but a systemic boundary has not been established, so the thickness of included units of earliest Permian age is not shown in figure 67 .

\section{SOUTHWEST OF UNCOMPAHGRE PLATHAU}

Rock units of interval A in southern Utah constitute an integrated assemblage ranging from continental arkosic conglomerate near the Uncompahgre Plateau in the east (fig. 62) to marine sandstone and limestone in the west. The stratigraphic relations between these units are graphically shown in a series of columnar sections (pl. $6 A, B$ ) modified after those prepared by the following authors: A. A. Baker and
Reeside (1929), McKee (1954a), Herman and Sharps (1956), Heylmun (1958), and Kunkel (1958).

In this area, interval A (Cutler Formation with De Chelly Sandstone Member excluded) is dominantly red conglomerate, sandstone, and. sandy mudstone, all probably of continental origin. Where subdivided in the Four Corners area, it includes the Halgaito Tongue, the Cedar Mesa Sandstone Member, and the Organ Rock Member (Baker, A. A., and Reeside, 1929).

The Halgaito Tongue is a sequence of red sandstone and sandy mudstone. To the north, it has been correlated (Baars, 1962) with the Elephant Canyon Formation, a carbonate rock unit with a Permian Wolfcamp fauna. Westward from the type locality the Halgaito sequence is difficult to recognize. Although the lack of fossils and of adequate stratigraphic data preclude direct correlation westward across southern Utah, the member is probably equivalent, at least in part, to the lower part of interval $A$ (pl. $6 A, B$ ).

Carbonate rock at the bottom of the Permian sequence in southwestern Utah has been referred ( $\mathbf{K}$. G. Brill, written commun., 1958) to the Pakoon Formation (McNair, 1951). Another unit in western Utah containing a Wolfcamp fauna, and therefore correlated with the Pakoon, is the upper $100-300$ feet of the Ely Limestone, which was renamed the Riepe Spring Limestone (Steele, 1960, p. 100) in west-central Utah.

The Cedar Mesa Sandstone Member of the Cutler Formation overlies the Halgaito Tongue in southeastern Utah and is a mappable unit containing much large-scale crossbedding. It forms a dominant part of interval $\mathrm{A}$ and is well formed along a southwest trending elongate area in south-central Utah ( $\mathrm{I}-450$, pl. 10B). The sandstone grades eastward into, or intertongues with, red beds of the undivided Cutler that are increasingly arkosic toward the east. A few dolomite beds near the eastern limit of the Cedar Mesa Member contain Wolfcamp fusulinids. Southward, toward the Arizona boundary, the Cedar Mesa passes into a red-bed facies (Baker, A. A., and Reeside, 1929, p. 1421) and is believed (Heylmun, 1958, p. 1793) to be equivalent in part to the Esplanade Sandstone Member of the Supai Formation in northcentral Arizona and probably the Queantoweap Sandstone in northwestern Arizona.

Buff Permian sandstone about 2,000 feet thick occurs in the Beaver Dam Mountains of southwestern Utah (fig. 62) and was referred to the Queantoweap Sandstone by K. G. Brill (written commun., 1958) and to the Supai Formation by Reeside and Bassler 


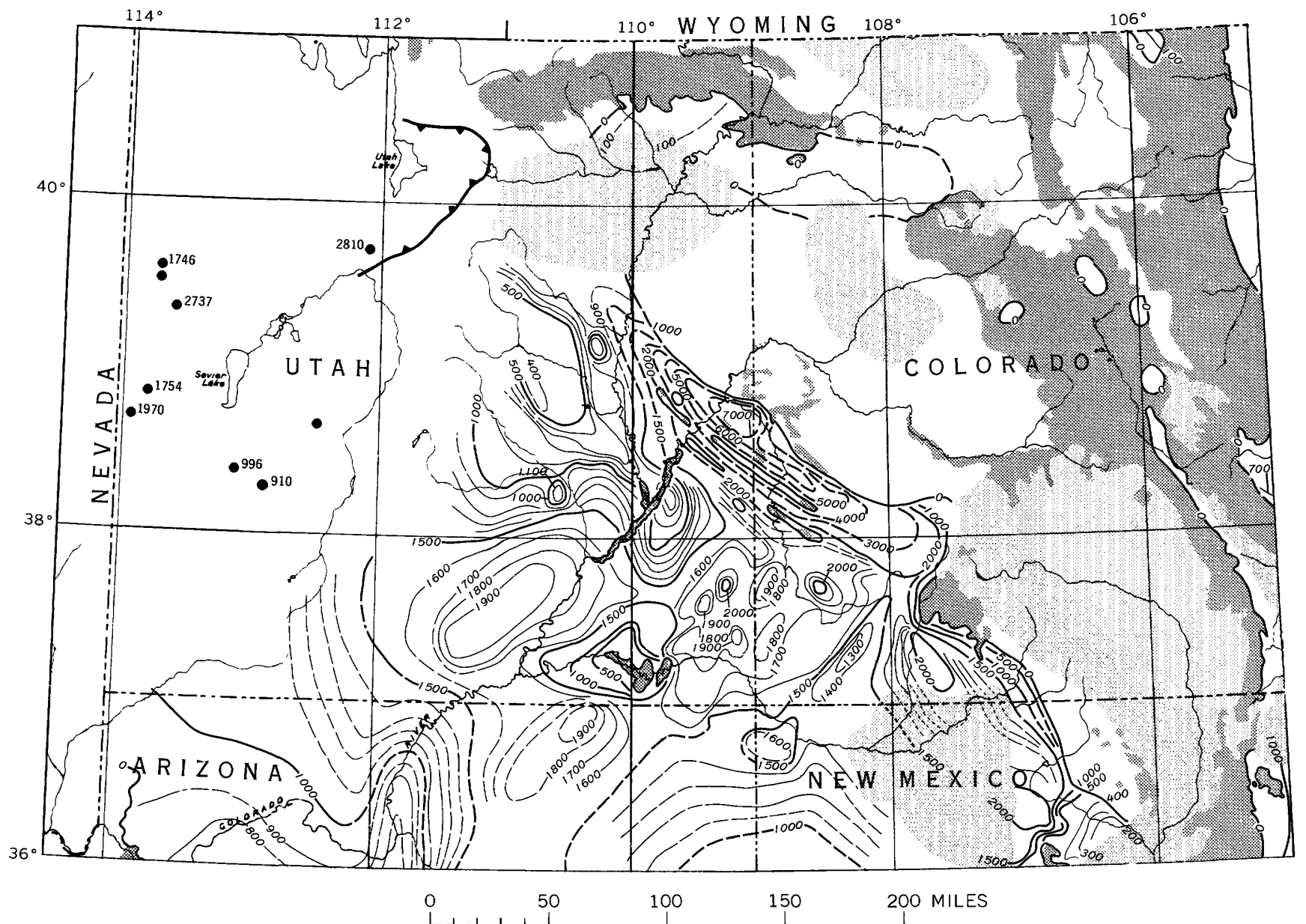

Figure 67.- Thickness of interval A in western Colorado, southern Utah, and surrounding areas. Isopach intervals 100 and 500 feet. Isopachs dashed where control is poor, dotted where Permian rocks have not been penetrated by drill. O, indicates where Permian rocks have been identified, but control is inadequate for isopach construction; thicknesses in feet. Approximate trace of thrust fault shown by sawtooth line; sawteeth on upper plate. Dark pattern, areas where rocks older than Permian are exposed; light pattern, areas where rocks younger than interval $\mathrm{A}$ have not been penetrated.

(1922). Toward the south in Arizona this sandstone unit is probably equivalent to both the Supai Formation and the Hermit Shale. The lower part of this sandstone grades southward into red strata that form the upper detrital part of the Supai Formation (Reeside and Bassler, 1922, p. 57), and the upper 800 feet is regarded (McKee, oral commun., 1959) as equivalent to the Hermit Shale, which overlies the Supai Formation in northwestern Arizona. As the Hermit is included in interval $B$ of this paper, the upper 800 feet of sandstone in southwestern Utah is placed in this interval. If these correlations are valid, the upper part of the sandstone in southwestern Utah may be younger than the Cedar Mesa farther east in Utah.

Northwestward from south-central Utah the Cedar Mesa Sandstone Member thins greatly and is apparently equivalent to a quartzitic sandstone unit in
Beaver County. Northwest of Beaver County the sandstone contains numerous interbeds of dolomite, and in west-central Utah this sequence constitutes the lower part of the Arcturus Formation (Hose and Repenning, 1959).

The Cedar Mesa thins regularly northward from its area of greatest thickness in southeastern Utah (pl. $6 \mathrm{~B}$ ). The underlying Elephant Canyon Formation, however, maintains a fairly uniform thickness, so intertonguing between these units seems unlikely.

The Cedar Mesa in much of southeastern Utah is overlain by a red sandy mudstone and red sandstone that is referred to as the Organ Rock Member. This member has been removed by recent erosion from parts of the Monument upwarp area (fig. 62). Westward, across southeastern Utah, the unit thins and the basal part seems to grade, between localities 
34 and 622 (pl. $6 \mathrm{~A}$ ), into the upper part of a sandstone considered to be the Cedar Mesa. North of locality $650($ pl. $6 \mathrm{~B})$, the Organ Rock also seems to grade into Cedar Mesa; however, along the line of section on plate $6 B$ the thickness of the Organ Rock Member is uniform, and the Cedar Mesa thins considerably toward the north. These conditions suggest a conformable boundary between the Organ Rock and the Cedar Mesa.

Westward from the interriver area, along the Wayne and Garfield County lines, westward-thinning red beds of the Organ Rock underlie the White Rim. Beyond the edge of these red beds, the White Rim rests on the Cedar Mesa, which also thins westward. Whether this contact is disconformable or not is uncertain, but in Straight Wash Canyon in southern Emery County, Utah, a stratigraphic break occurs in the massive "Coconino Sandstone" of Gilluly and Reeside (1928), about 150 feet above the base (Hallgarth, 1962). Here, the projected thickness of the Cedar Mesa Sandstone Member is about equivalent to this lower 150 feet of the Coconino.

\section{FAST AND NORTHEAST OF UNCOMPAHGRE PLATEAU}

The Sangre de Cristo Formation extends from New Mexico northward into south-central Colorado to the Fremont and Park County line (Brill, 1952, p. 822). North of that line, red beds of comparable stratigraphic position are assigned to the Maroon Formation. Only in the southern part of the Sangre de Cristo Mountains, where the beds of this formation dip sharply beneath younger strata of the high plains, is a fairly complete section preserved.

The Sangre de Cristo Formation includes beds of Pennsylvanian and Permian age, but fossils are rare and the systemic boundary is hard to place. Cotylosaurs and pelycosaurs, the fossil bones of which are found about 1,600 feet above the base in the Arkansas River area, also occur in Wolfcamp strata of Kansas, Oklahoma, Texas, and New Mexico. A Permian (Wolfcamp) age is therefore suggested for part of the Sangre de Cristo (Brill, 1952, p. 822). These fossils are apparently the most reliable indicators of age in the formation or in the arkose facies of the Maroon Formation along the ancestral Front Range. In the lower part of the Maroon in Park County, pelecypods, ostracodes, and plants that may be of either Pennsylvanian or Permian age have been reported (Brill, 1952, p. 822). The ostracodes are believed to indicate a post-Des Moines age.

In the intermontane facies of the Maroon Formation no fossils of Pennsylvanian age have been reported, but at one locality in eastern Rio Blanco
County, Colo., near the northwest margin of this formation, fossils were collected about 300 feet below the top of the red-bed sequence and are considered by oil-company geologists (confidential report) to be post-Pennsylvanian. They may have been collected from strata equivalent to the Schoolhouse Sandstone, as that unit grades southeastward into the Maroon Formation at about the top of the lower arkose member. Boulderlike colonies of corals of Pennsylvanian age are reported in a conglomerate in the arkose facies of the Maroon along the Uncompahgre; despite their appearance, evidence indicates that they grew in place (Brill, 1944, p. 630).

No fossils have been reported from the Weber Sandstone in northwestern Colorado. In Utah the Pennsylvanian and Permian age of this formation is determined by Pennsylvanian species of Triticites in the lower part, and the Permian genus Schwagerina within 100 feet of the top (Bissell and Childs, 1958). These strata may extend westward into the lower part of the Park City Formation (Kinney, 1955, p. 54).

The Weber Sandstone was originally correlated with the upper part of the Maroon Formation to the southeast (Brill, 1952, pl. 1). The Weber and Maroon have variously been correlated as follows: (1) They have been considered to be correlative, no older than Des Moines and no younger than middle Permian (Murray, H. F., 1958, p. 55) ; (2) the greater part of the Maroon has been considered as Pennsylvanian in age (Bissell and Childs, 1958); (3) the Maroon has been assigned a Pennsylvanian and Permian age (Bass, 1958); (4) the Weber has been referred to the Pennsylvanian on the basis of regional stratigraphic relations (Thomas, C. R., and others, 1945; Hallgarth, 1959) along the Colorado-Utah line. The relation between the Weber Sandstone and the Maroon Formation in the subsurface has been determined to a large extent by study of drill cores which show intertonguing southward.

Field relations between the Weber and the overlying Park City Formation in the eastern part of the Uinta Mountains suggest a disconformity between these units, as the upper surface of the Weber is undulatory and has 2-3 feet of relief. Limestone beds in about the middle of the Park City Formation overlie and fill in the depressions, thus reflecting an irregular contact.

In the Colorado trough of south-central and northwestern Colorado the boundary between the Pennsylvanian and Permian has not been defined because of inadequate fossil data. Furthermore, lithologic contacts, recognizable as interval boundaries, are lacking. The thickness of interval A in the Sangre de Cristo 
Formation, Maroon Formation, and Weber Sandstone is, therefore, not shown on the map (fig. 67).

\section{UPPER BOUNDARY OF INTERVAL A}

The upper boundary of interval $\mathbf{A}$ in southern Utah is a surface between rocks of contrasting facies, except in the southwesternmost part of the State. In that area (southwestern Washington County) the boundary is placed 800 feet below the top of rock assigned to the Supai Formation or the Queantoweap Sandstone, and the upper part is assigned to interval B. Elsewhere in western Utah the boundary marks a change from dominantly detrital rock (Supai and Arcturus Formations) below to dominantly carbonate rock (Toroweap and Kaibab Formations) above.

In south-central Utah both carbonate and evaporite rocks of interval B grade eastward into crossbedded sandstone of the White Rim and De Chelly Sandstone Members of the Cutler Formation (upper part). In southeastern Utah and northwestern New Mexico the boundary between intervals $\mathbf{A}$ and $\mathrm{B}$ is marked by a change from red beds of the Cutler to light sandstone of the White Rim and De Chelly. In eastcentral Utah, however, red beds of the Organ Rock Member are absent, and the White Rim Sandstone Member rests on white sandstone of the Cedar Mesa Member; together they form the "Coconino Sandstone" of Gilluly and Reeside (1928). In central Utah, the entire "Coconine" has been arbitrarily included on the maps of interval B because the equivalent of the Cedar Mesa Sandstone Member is relatively thin and difficult to recognize in well samples. Here, the boundary of interval $\mathrm{A}$ is at the top of the Elephant Canyon Formation.

In parts of eastern Utah, interval B is missing, and 'Triassic rock rests on interval A. In a few places in south western Colorado, near the zero isopach of interval A, the Entrada Sandstone of Late Jurassic age overlaps the Triassic and rests on Cutler of interval $\mathbf{A}$.

In northwestern Colorado the top of interval $\mathbf{A}$ is arbitrarily placed at the top of the Weber Sandstone beneath beds assigned to the Park City or Phosphoria Formation. Farther east the base of the Schoolhouse Sandstone is used as the boundary. East and southeast of the margin of this unit the top of the lower part of the Maroon Formation is regarded as the top of interval A.

In the Sangre de Cristo Formation of south-central Colorado neither upper nor lower boundary of interval $\mathbf{A}$ has been defined. Several thousand feet of this formation are Permian in age and are arbitrarily assigned to interval $\mathrm{A}$, but some strata may be of
Leonard or Guadalupe age. The top of the formation in this area is used as the top of interval A.

\section{THICKNESS TRENDS}

The thickness of interval $\mathbf{A}$ is shown by isopachs (fig. 67) everywhere in the region except northeast of the Uncompahgre landmass and in western Utah. In western Utah the thickness of individual outcrops is given, but data are too few to permit construction of a reliable isopach map.

A narrow belt of relatively thin rock trends northwest along the southwest side of the Uncompahgre trough (figs. 61, 67). This trend is clearly shown in east-central Utah but is obscured southeastward in Colorado because of inadequate control and structural complexities. From this belt of relatively thin rock, the interval thickens northeastward to a maximum of about 8,000 feet in the Uncompahgre trough, and westward to almost 2,000 feet in the middle part of southern Utah.

A prominent belt of thin rock extends from the southeast end of the Uncompahgre trough southwestward toward New Mexico. On the east it is bordered by a maximum thickness area, representing the Permian San Juan basin, and on the west by an area in which irregularities in thickness are common.

Another area of thin rock is located along the San Juan River in southeastern Utah. Thinness here is the result of post-Permian uplift and erosion.

\section{LITHOFACIES TRENDS}

An elongate belt of sandstone (Cedar Mesa and Supai) extends from east-central Utah southwestward toward Nevada (I-450, pl. 3). Northwest of this area of dominant sandstone, control is limited to central and east-central Utah, but data from scattered localities farther northwest indicate a facies of sandstone and interbedded carbonate rock. South and east of the sandstone belt, lithofacies patterns indicate increased proportions of mudstone in red beds of the Supai and Cutler Formations. In the Four Corners area (fig. 63), mudstone is the dominant component of interval $\mathbf{A}$.

Lithofacies patterns along the southwest front of the Uncompahgre highland reflect the large amount of coarse detrital material in the Cutler Formation. The proportion of mudstone increases from there southward in Colorado, southeastern Utah, and northwestern New Mexico. A belt of rocks composed mainly of mudstone forms a prominent salient trending northeastward toward the area between the Uncompahgre and San Luis highlands (fig. 61) and may indicate a low area between these highlands. 
Where the upper part of interval A (Organ Rock Member of Cutler) has been eroded over the Monument upwarp, southeastern Utah, lithofacies patterns show an increase in the relative amount of sandstone. In east-central Utah, detrital lithofacies patterns near the northwest end of the Uncompahgre trough represent material from the Uncompahgre highland.

\section{SOURCES AND ENVIRONMENTS}

A marine environment prevailed throughout most of western Utah during the time of interval $\mathbf{A}$, as indicated by the dominance of fossiliferous carbonate rock. This rock, interbedded with sandstone, forms a sequence that thins toward the southeast. In central and south-central Utah, rock above the lower carbonate unit (Elephant Canyon Formation) is entirely detrital.

The area of marine environment was bordered on the south and southeast by coastal and eolian environments in which a belt of sandstone formed; this belt trends southwest across southern Utah. Crossbedded sandstone along its southeast margin is believed to be largely of eolian origin (Baker, A. A., 1946, p. 40 ), but the type of crossbeds suggests that the northwestern margin was deposited under coastal waters (K. G. Brill, written commun., 1958; Steele, 1959, p. 117). The sand may have accumulated in bars along a shoreline and then been carried southeastward by prevailing winds, ultimately to be deposited as dunes. Marine conditions are indicated by the presence of small amounts of glauconite farther northward in south-central Utah.

Sand of near-shore and dune deposits probably accumulated on and directly northwest of the landmass in southern Utah. The sand was bordered on the northwest by open sea and on the north and northeast by a narrow seaway, at times reduced to a salt-, brackish-, or fresh-water lagoon. Fossils reported by the American Stratigraphic Co. provide evidence of a seaway that may have intermittently extended through southeastern Utah into New Mexico early in Permian time. In a narrow band along what is postulated as having been the east front of a dune area, the Cedar Mesa Sandstone Member contains a few beds of carbonate rock. These are also recorded by the American Stratigraphic Co. from localities in central Utah, where they contain marine fossils. West of the dune area the Cedar Mesa is entirely sandstone that may represent both marine and nonmarine conditions.

During deposition of part of the Cedar Mesa Member, the narrow passage in north-central Utah was apparently periodically cut off from the sea by sand and mud, for gypsum formed in an evaporite basin. The thickest gypsum bed, according to Sears (1956, p. 185-187), is about 80 feet thick. Thin beds of anhydrite are reported by the American Stratigraphic Co. in samples from eastern Wayne County in central Utah. Whether this anhydrite is primary or secondary is uncertain, but its location with respect to the seaway suggests that it is secondary; the anhydrite occurs in a stratigraphic unit that in other localities has yielded marine fossils. Normal marine and lagoonal environments probably alternated.

Near the end of Cedar Mesa accumulation, sand, possibly from encroaching dunes, and fine-grained detritus from both the Uncompahgre highland to the northeast and landmasses in northwestern New Mexico became intercalated with carbonate deposits, filling the relict sea.

In southeasternmost Utah a unit of lenticular sandstone and siltstone, 50-100 feet thick, is transitional between the Cedar Mesa Sandstone Member and the overlying Organ Rock Member (Mullens, 1960, p. 271-272). It contains lenticular sandstone, believed to be both fluviatile and eolian, and red-brown siltstone. At the bases of sandstone beds abundant scour marks filled with rounded to subrounded limestone pebbles, as much as 2 inches in diameter, form conglomerates less than 3 feet thick and about 100 feet long. These are probably cut-and-fill deposits in stream channels.

After the lagoons had become filled continental red beds advanced westward across the inferred dune area and the sea retreated. As during early Cedar Mesa deposition, eastern limits of the dunes were partly controlled by lagoons that impounded water from westward-flowing streams. Lenticular bodies of silt and sand apparently collected in the lagoons and, when the accumulation of dune sand failed to keep pace with lagoonal deposition, red-brown mud was transported across the dune area by westwardflowing streams. A similar set of environmental conditions may have existed farther west in southcentral Utah, where the Organ Rock Member grades westward into sandstone similar to the Cedar Mesa (loc. 34-622, pl.6A).

In much of southwestern Colorado, east-central Utah, and northwestern New Mexico, arkosic conglomerate, arkosic sandstone, and mudstone were formed from sediments derived from nearby highlands. In places along the Uncompahgre highland, coarse detrital material was deposited directly in the Uncompahgre trough. This trough may have been inundated by the sea in Early Permian time as sug- 
gested by faunal data (D. L. Baars, written commun., 1959). If inundation took place, alluvial fans and other fluviatile deposits extended outward from the landmass and forced an early retreat of the marine waters. Red mud and sand of the Organ Rock Member finally spread westward from the Four Corners area as far as central Garfield County in southcentral Utah and confined the postulated dune area to the west. In northwestern New Mexico the Cutler is believed to be of fluviatile origin (Wood and Northrop, 1946).

\section{PALEOTECTONIC IMPLICATIONS}

In this region tectonic activity very early in Permian time was mostly limited to western Colorado, where two highlands and two negative elements were formed (fig. 61). The highlands were the ancestral Front Range and the Uncompahgre-San Luis. The structural trend of both the ancestral Front Range and the Uncompahgre-San Luis highlands was northwestward. Each of these landmasses was bounded on the southwest by a trough. The Colorado trough (Brill, 1952) was adjacent to the ancestral Front Range, and the Uncompahgre trough was adjacent to the north end of the Uncompahgre-San Iuis highland.

The Colorado trough in south-central Colorado lay between the ancestral Front Range and the San Luis highland. Northwest of the Arkansas River evidence of the trough is sparse because of post-interval A erosion. Its configuration in that area is uncertain, but the trough apparently lay closer to the ancestral Front Range than to the Uncompahgre highland.

The ancestral Front Range, the easternmost of the positive elements, contributed sediments to the Colorado trough, for in central and south-central Colorado the trough contains coarse-grained arkosic sandstone and arkosic conglomerate. Sediment was also supplied to this trough from the west (Johnson, J. H., 1929, p. 15-17).

On the east flank of the San Luis highland, sediments deposited as alluvial fans became the Crestone Conglomerate Member in the upper part of the Sangre de Cristo Formation (Bolyard, 1959, p. 1937, fig. 15). This conglomerate grades, within short distances north, east, and south, into finer grained rocks whose components may have been derived in part from the east.

The Uncompahgre highland probably stood high at the beginning of Permian time as a result of major uplifts in Pennsylvanian time. The presence of coarse detrital rocks of known Pennsylvanian age on both sides of this highland indicates that it initially rose as a horst and shed debris toward both the northeast and the southwest.

Tectonic activity in the Uncompahgre highland area in Permian time consisted principally of continued uplift and faulting along the southwest front and accelerated subsidence in the Uncompahgre trough, which originated late in Pennsylvanian time. The highland may have been part of a high plateau much greater in extent than the Precambrian rock that forms the core of the modern Uncompahgre Plateau. Several thousand feet of coarse detritus (Cutler Formation) accumulated along its southwest front (fig. 66), and the Uncompahgre trough to the southwest was filled with both coarse- and fine-grained material.

Thin belts of interval $\mathbf{A}$ in southeastern Utah and southwestern Colorado record minor hinge-line folds between segments of the sinking Pennsylvanian Paradox basin. A stable shelf area apparently covered most of the remainder of southern Utah at this time.

\section{INTERVAL B}

\section{FORMATIONS INCLUDED}

Formations of interval B (table 1) are preserved in large areas in southern Utah, the southwest corner of Colorado, and in northwestern New Mexico. Rocks of this interval also extend across part of northwestern Colorado.

\section{STRATIGRAPHIC RELATIONS}

Rock assigned to this interval, like that of interval A, forms an integrated facies unit throughout most of southern Utah and adjoining areas in Colorado and New Mexico. In west-central Utah the interval consists principally of carbonate rock; in southwestern and south-central Utah, carbonate and evaporite rock; and in eastern Utah and the Four Corners area, sandstone grading eastward into red beds.

Various correlations have been suggested for rocks of interval B by A. A. Baker and J. B. Reeside, Jr. (1929), McKee (1954a), Heylmun (1958), Kunkel (1958), Read and Wanek (1961), and Baars (1962). The correlations shown on plate $6 A-C$ are derived in part from those geologists.

\section{SOUTHWEST OF UNCOMPAFGRE PLATEAU}

In westernmost Utah the oldest rock assigned to interval B is the upper 800 feet of the Supai Formation or the Queantoweap Sandstone in the south and the upper part of the Arcturus Formation farther north. The Toroweap Formation overlies the Supai (pl. $6 \mathrm{~A}$ ) and apparently grades eastward (Heylmun, 1958 , p. 1794) as well as northeastward (pl. 6C) across southern Utah into the lower part of the 
White Rim Sandstone Member. Rock of equivalent age may also be contained in the De Chelly Sandstone Member of the Cutler in southeastern Utah; however, a direct correlation between these units has not been made. Anomalies in thickness and lithology in southern Utah (locs. 368,369 , pl. $6 A$ ) make correlation between the Toroweap of southern Utah and that of northern Arizona difficult. A relatively positive area which contributed much of the sand in the Toroweap and was responsible for the formation of evaporite deposits at localities 158, 635, and 612 (pl. $6 A$ ) is postulated on the basis of these anomalies.

The Kaibab Limestone, above the Toroweap, was recognized in west-central Utah by Newell (1948) and by McKee (in Hose and Repenning, 1959, p. -2180). It was also recognized by Steele (1959, p. 107), who assigned a younger (Guadalupe) age to it in western Utah and Nevada. Lithologic units in the Kaibab are correlated eastward across southern Utah on plate $6 A$; they seem to grade into the upper part of the White Rim. For example, in south-central Utah (loc. 679, pl. $6 B$ ) the zone of Dictyoclostus (Productus) bassi is present (McKee, 1938, p. 212) in rock considered to be the upper part of the White Rim. This rock is overlain by carbonate rock that contains fossils younger than those of the Kaibab and correlates with the upper part of the Park City For. mation in northern Utah (McKee, 1954a). This cor. relation suggests that all the Kaibab in southwestern Utah grades eastward into the upper part of the White Rim Sandstone Member, and, to some extent, it also supports the correlation of the Toroweap with the lower part of the White Rim.

The White Rim Sandstone Member is exposed across southeastern Utah in a north-trending band of interval $B$. In its northern extent it passes westward in the subsurface to crop out in the San Rafael Swell. There it forms the upper part of the "Coconino Sandstone"; the Cedar Mesa Sandstone Member (interval A) forms the lower part. The thickness of the sandstone unit comprising the "Coconino" is unknown, but a stratigraphic break about 150 feet above its base may represent an unconformity (Hallgarth, 1962) equivalent to the top of the Cedar Mesa. Thinning of the underlying Organ Rock and Cedar Mesa Members northwestward toward the San Rafael Swell may be due to deposition or to erosion, but the fact that the Cedar Mesa continues to thin beyond the termination of the Organ Rock suggests that erosion was responsible.

The White Rim is correlated in this publication with the De Chelly Sandstone Member of the Cutler to the south. These sandstone units are believed to form a continuous body that extends from east-central Utah southward into northwestern New Mexico. North of the confluence of the San Juan and Colorado Rivers in southern Utah, the sandstone is referred to the White Rim; to the south and east it is referred to the De Chelly and is correlated with the upper part of the De Chelly Sandstone of Canyon De Chelly in Arizona (Read and Wanek, 1961, table 206.1). These sandstones seem to have a common genetic relationship to the Uncompahgre highland. They are both at the top of the Permian sequence, and both contain eolian crossbedding, in which foreset dips are generally in the same direction. In well samples there seems to be a gradual change from white sand of the White Rim to orange sand of the De Chelly. On the west side of the Monument upwarp and along the Colorado River the White Rim grades eastward into the upper part of the Organ Rock Member (Baker, A. A., 1946, p. 46; Stewart, 1959, fig. 4).

The age of the White Rim and De Chelly Sandstone Members apparently ranges from Leonard to at least Guadalupe. In the Circle Cliffs area, eastern Garfield County, Utah, Dictyoclostus bassi is present in the upper few feet of the White Rim. The same species is widespread in the Kaibab Limestone in Arizona and Utah (McKee, 1938), and in Nevada (Steele, 1959). In Arizona and Utah the Kaibab is considered to be of Leonard age. Eastward from Circle Cliffs the top part of the White Rim and the De Chelly may be younger because a thin part of these units is reported to grade (McKnight, 1940, p. 48; Mullens, 1960, p. 277) into the lower part of the Hoskinnini, which has recently been assigned a Triassic(?) age on the basis of its relation to the Moenkopi Formation (Stewart, 1959).

\section{NORTHEAST OF UNCOMPAHGRE PUATEAU}

Strata of interval $B$ occur in northwestern and north-central Colorado. Some sandstone and carbonate rock of the Park City Formation extend eastward from Utah a few miles into northwestern Colorado. The Schoolhouse Sandstone in the White River Plateau area (fig. 62) has been correlated with the Lyons Sandstone of eastern Colorado, tentatively assigned a Leonard age (Thompson, W. O., 1949, p. 72).

\section{UPPER BOUNDARY OF INTERVAI B}

Throughout east- and south-central Utah, interval $\mathrm{B}$ is overlain by interval C-D. In much of the area the boundary has arbitrarily been placed at the contact of the White Rim Sandstone Member and the overlying "Kaibab Limestone." Toward the east edge of the interval in Utah, however, the "Kaibab" 
is missing; its absence may be due to pre-Triassic erosion.

In southwestern Utah, interval B is unconformably overlain by the Triassic. Farther north it underlies the Permian Plympton Formation, and no clear lithologic or paleontologic break can be recognized. The contact is arbitrarily assigned at the top of the lower half.

In northwestern Colorado the upper boundary is marked by a change from carbonate rock or sandstone of interval $\mathrm{B}$ to mudstone of interval C-D.

\section{THICKNESS TRENDS}

Variations in thickness of interval B (fig. 68) result from both deposition and erosion. In south-central Utah a northwestward-trending belt of relatively thin rock is delineated by the 400 -foot isopach. Interval B thickens both southwestward and northeastward from this belt. Southwestward it thickens rather uniformly toward a maximum of 1,700 feet near the Arizona-Nevada-Utah corner. Northeastward the rock thickens irregularly to more than 600 feet. Thickness variations in this area seem to be due to both deposition and erosion of the White Rim Sandstone Member.

A major unconformity at the base of the Triassic affects the thickness of interval $B$ in southeastern Utah. In the White Canyon area of western San Juan County (fig. 63), for example, the White Rim seems to be truncated beneath the Moenkopi Formation of Early Triassic age. Along the Colorado River in eastern Wayne County it thins northeastward beneath the Moenkopi and grades laterally into the Cutler Formation (McKnight, 1940, p. 48).

In northwestern Colorado, interval B generally thickens northwestward toward the Uinta Mountains.

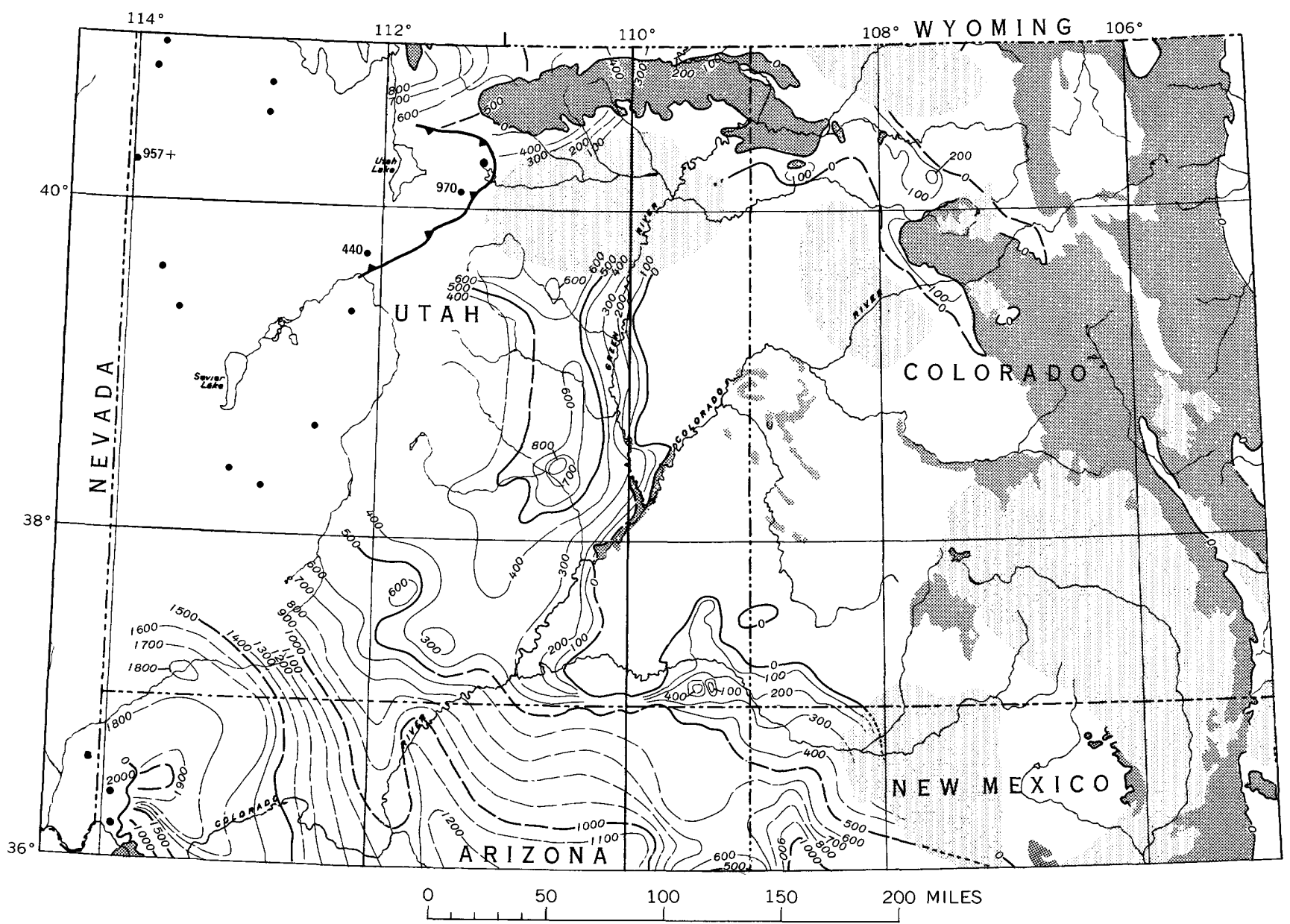

FIgure 68.-Thickness of interval B in western Colorado, southern Utah, and surrounding areas. Isopach interval 100 feet: Isopachs dashed where control is poor, dotted where Permian rocks have not been penetrated by drill. $\boldsymbol{O}$, indicates where Permian rocks have been identified, but control is inadequate for isopach construction; thicknesses in feet. Approximate trace of thrust fault shown by sawtooth line; sawteeth on upper plate. Dark pattern, areas where rocks older than Permian are exposed; light pattern, areas where rocks younger than interval $B$ have not been penetrated. 
An exception is the Schoolhouse Sandstone, which seems to be restricted to the White River Plateau area and whose limits are not well known because subsurface data are sparse.

\section{IITHOFACIES TRENDS}

Southwest of the Uncompahgre Plateau, sandstone units of interval B (I-450, pl. 4), including the Coconino, White Rim, and De Chelly, are prominent in a north-trending belt in eastern Utah. These sandstones grade westward into carbonate rock of the Kaibab Limestone, and in south-central Utal also into evaporite rock of the Toroweap Formation. The interval contains carbonate and evaporite rock in the middle part of western Utah also, but trends are not well known.

Northeast of the Uncompahgre Plateau in northwestern Colorado rock of the Park City Formation is principally calcium and magnesium carbonate. It grades southeastward into sandstone, which loses its identity within a few miles. This sandstone may grade into mudstone assigned to interval C-D; it may have been removed by erosion; or it may be continuous with the Schoolhouse Sandstone.

\section{ENVIRONMENTS AND SOURCES}

Southwest of the Uncompahgre Plateau rocks of interval $B$ were deposited in environments ranging from marine to continental. The White Rim Sandstone Members, which intertongues eastward with red mudstone (Baker, A. A., 1946, p. 48; McKnight, 1940, p. 48), is considered to be partly eolian but may include marine, coastal, lacustrine, or lagoonal deposits. The dip of the cross laminae, south and southeast, suggests a prevailing northwesterly wind (Pool, 1962). Red beds farther east were deposited by westward-flowing streams (Baker, A. A., 1946, p. 48) which probably dumped their loads in lagoons along the east front of the dune area. The main arteries of sediment transport, arising in the highland to the east, may have crossed the dune area and dumped their loads in the sea, where the material was reworked and distributed by waves and currents.

In the De Chelly Sandstone, crossbeds generally dip south and southeast in the western part of the Monument Valley area and south and southwest in the eastern part (Read and Wanek, 1961, fig. 206.1). In the western part this sandstone is principally eolian, on the basis of the character of its cross-stratification; but in the Four Corners area, to the east, where the De Chelly contains feldspathic sandstone and interbeds of mudstone, it may be partly fluviatile or lacustrine, and the sediment was apparently transported by streams arising on the ancient Uncompahgre highland to the northeast.

The Toroweap Formation and the Kaibab Limestone occur west of the White Rim and De Chelly. The Toroweap contains sandstone, carbonate, and evaporite rock-lithologies that suggest restricted marine deposition. The Kaibab, which overlies it, contains an invertebrate marine fauna. The high magnesian content of Kaibab rocks suggests that the sea in which the unit formed was somewhat restricted (McKee, 1954a, - p. 21). Similar marine conditions probably prevailed in west-central Utah during deposition of the upper part of the Arcturus and the lower part of the Plympton.

The detritus which formed rock of interval B was probably derived mainly from the ancestral Uncompahgre highland and Front Range. Mudstone beds in north-central Colorado and both mudstone and coarser clastic rocks around the Uncompahgre were probably deposited from streams draining the highland areas. The light-colored dominantly eolian sandstones of the White Rim and De Chelly are thought to have been formed by reworking of these stream-borne materials along the margin of a shallow sea bordering the west side of the dune area in eastern Utah.

The presence in northwestern Colorado of carbonate rock, sandstone, and mudstone suggests a diversity of environment. In the westernmost part of this area fossiliferous limestone, dolomite, and sandstone indicate marine conditions, but the seaway may have been restricted as indicated by the high magnesian content of some beds. The types of cross lamination in the Schoolhouse Sandstone farther east suggest nearshore and eolian deposition. In north-central Colorado a thin limestone overlies continental red beds; from this, marine invasion near the end of interval $B$ disposition is inferred.

\section{PALEOTECTONIC IMPLICATIONS}

Shelves and landmasses were evidently stable during interval B. The landmasses that were high earlier in Permian time were much reduced in height and shed only sand and mud into the areas of deposition.

A shallow sea covering the shelves at times invaded the low area between the greatly reduced ancestral Front Range and Uncompahgre highland, where probable coastal sands formed the Schoolhouse Sandstone. The landward extent of red beds which formed between coastal deposits and highlands is uncertain but the rate of thinning, the presence of coastal deposits, and associated facies of interval $B$ suggest that the 
landmasses were considerably broader than at any previous time during the Permian.

\section{INTERVAL C-D FORMATIONS INCLUDED}

Rock assigned to interval C-D (table 1) is distributed throughout parts of south-central and southwestern Utah. It includes the "Kaibab Limestones" described by Gilluly and Reeside (1928) in the San Rafael Swell and the upper part of the Plympton Formation (Hose and Repenning, 1959) and the Gerster Formation (Nolan, 1930) in west-central Utah.

In northwestern Colorado, interval C-D is formed of rock equivalent to the upper part of the Park City Formation of Utah. Farther southeast, in eastern Garfield County, Colo., it includes the upper part of the Maroon Formation (Bass and Northrop, 1950)that is, an unnamed siltstone member and the overlying South Canyon Creek Member. Equivalent rock of similar nature that is present northeast along the Colorado River was included by Donner (1936) with strata later assigned to the lower part of the State Bridge Formation (Brill, 1942). In northcentral Colorado, near the Wyoming line, the interval is formed of red mudstone and an overlying thin limestone unit that is correlated with the upper part of the Satanka Shale and the Forelle Limestone (Darton and others, 1910).

The Hoskinnini Member of the Moenkopi Formation in southeastern Utah, formerly included in the Cutler Formation, has been correlated with the lower or Tenderfoot Member of the Moenkopi (Stewart, 1959). Both may be either of Permian or of Triassic age, but they are currently classed as Triassic(?). They are not included on plates 5 and 8 of $\mathrm{I}-450$ but are shown in figure 69 of this publication. In part they may be equivalents of the White Rim Sandstone Member and possibly the "Kaibab Limestone" of the Circle Cliffs and San Rafael Swell areas.

\section{STRATIGRAPHIC RELATIONS}

Stratigraphic relations between formations and members assigned to interval C-D are shown on plate 6 ; they were determined on the basis of electric and radioactivity $\log$ correlation. The mechanical $\log$, rather than the lithologic $\log (\mathrm{pl} .6 D)$, was used in determining upper limits of the interval because of the difficulty in distinguishing Permian from Triassic on the basis of lithology.

The "Kaibab Limestone" and "Coconino Sandstone" of the San Rafael Swell in east-central Utah were originally correlated with the type Kaibab Limestone

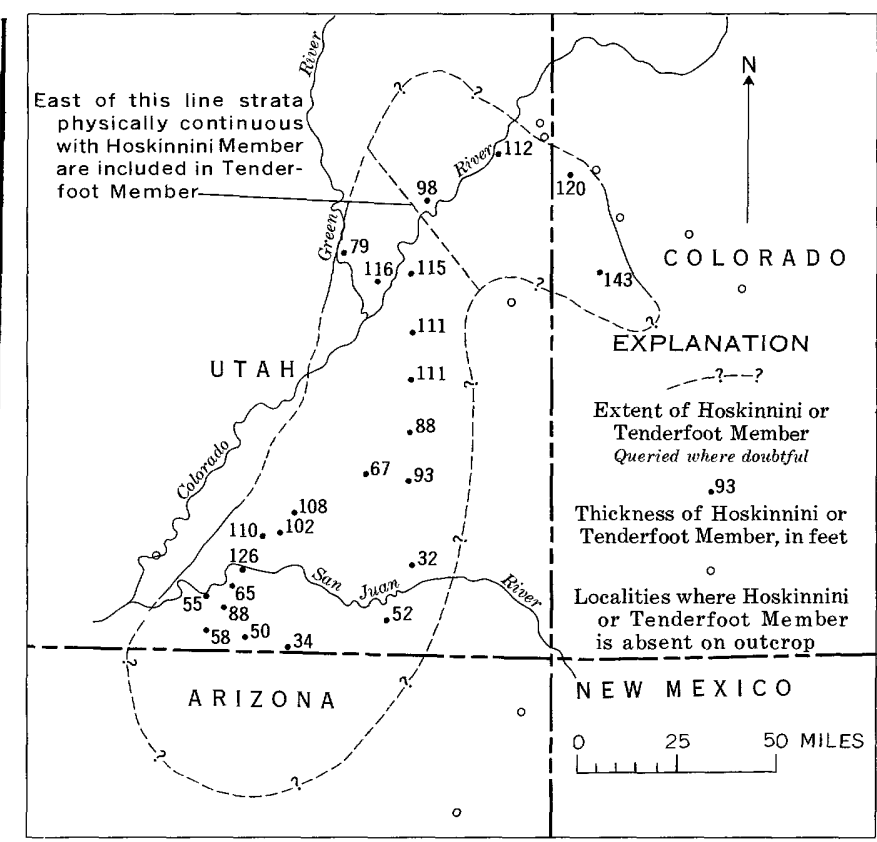

FIgURE 69.-Distribution and thicknesses of Hoskinnini and Tenderfoot Members of Moenkopi Formation in part of Colorado Plateau. Modified from Stewart (1959).

and Coconino Sandstone of Arizona (Gilluly and Reeside, 1928, p. 63). These units of the San Rafael Swell have been recognized in the subsurface and in scattered outcrops southward to the Circle Cliffs in eastern Garfield County, Utah, but control is sparse beyond that point. Units of intervals $\mathrm{B}$ and $\mathrm{C}$ may be continuous southward.

On the basis of fossils the "Kaibab Limestone" in central Utah is regarded by some geologists (McKee, $1954 a$, p. 23) as being younger than that in the type area and as being equivalent to the upper part of the Park City Formation of northeastern Utah and the Gerster Formation of west-central Utah (Hose and Repenning, 1959). A Neospirifer fauna occurs in the Kaibab as far south as the Circle Cliffs, in the upper part of the Park City and in the Gerster Formation, whereas the underlying beds in all these areas contain a Dictyoclostus bassi fauna similar to that in the type Kaibab of Arizona. The $D$. bassi fauna recognized by McKee (1938, p. 212 and fig. 13) at Circle Cliffs occurs in a thin carbonate unit in the upper part of the "Coconino" or White Rim and is separated from the overlying limestone unit by about $61 / 2$ feet of sandstone. This sandstone also contains a $D$. bassi fauna. Correlation of interval B strata in southern Utah suggests an intertonguing relation between the "Kaibab" and underlying sandstone; the Dictyoclostus-bearing limestone may be a tongue in this sequence. 
The precise stratigraphic relation of the Neospirifer-bearing limestone of central Utah to the type Kaibab Limestone has not been established because of relatively sparse boreholes between areas of outcrop. The Neospirifer-bearing beds may be continuous with and, therefore, indivisible from the Kaibab Limestone, forming a single lithogenetic unit, the upper part of which is younger northwestward, or the Neospiriferbearing beds may form a distinct separable rockstratigraphic unit. The second interpretation is adopted here, and the Neospirifer-bearing beds are assigned to interval C-D.

Beds of the Park City Formation are correlated on the basis of mechanical logs from northeastern Utah to northwestern Colorado (loc. 731) near the west end of the line of section on plate $6 D$. This correlation to a large extent provides the control for defining the limits of interval C-D throughout northwestern Colorado.

Between the Colorado and White Rivers, in eastern Rio Blanco and Garfield Counties, and farther east in Colorado, the interval consists of a widespread red mudstone unit overlain by the thin South Canyon Creek Member of the Maroon Formation (Bass and Northrop, 1950).

The South Canyon Creek Member has been correlated eastward with a carbonate rock unit in the lower part of the State Bridge Formation (Sharps, 1955). Farther east near the southwest corner of Grand County, the South Canyon Creek Member probably passes into siltstone (Sheridan, 1950), so the carbonate rock within it does not extend across the positive element of the ancestral Front Range.

At the type locality of the State Bridge Formation in northern Eagle County, Colo., the lower 141 feet is included in interval C-D. There the interval is composed principally of mudstone but is capped by a thin unit of fossiliferous limestone equivalent in age to the Phosphoria or Park City Formation (Brill, 1944, p. 636). Its fossils are stated to be of Middle or Late Pennsylvanian or Permian age (Newell, N. D., in Brill, 1942, p. 1393).

The South Canyon Creek Member of the Maroon occurs in a stratigraphic sequence similar to that of the State Bridge and near its type locality contains marine fossils which have been tentatively correlated with those in the Phosphoria Formation (Reeside, Williams, and Knight, in Thomas, C. R. and others, 1945; Northrop, in Bass and Northrop, 1950, p. 1549-1550). The fossils, however, are long-ranging forms and are of little value for accurate correlation. Some of the unfossiliferous red mudstone overlying the carbonate rock may also be of Permian age.
A sequence of mudstone, limestone, and sandstone about 5,500 feet thick forms an outlier of Permian rock in the southwest corner of Eagle County and has been correlated with the State Bridge farther north (Brill, 1944, p. 636). The upper 128 feet is a sequence similar to the South Canyon Creek Member and the underlying unnamed red siltstone unit of the Maroon Formation and is also similar to the lower 141 feet of the State Bridge. These sequences are probably equivalent. The remainder of the 5,500 feet in Eagle County is also correlated with the Maroon Formation (Brill, 1952, p. 822), and it may be partly of Permian age because immediately beneath rock assigned to interval $\mathrm{C}-\mathrm{D}$ it contains sandstone referred to the Schoolhouse Sandstone (interval B).

\section{UPPER BOUNDARY OF INTERVAL C-D}

In Utah the Permian is truncated eastward so that Triassic strata successively overlie rocks of intervals C-D, B, and A across the southern part of the State. The youngest rock of Permian age is in east-central and south-central Utah. In that area the top of the system is marked by an unconformity and by a change from carbonate rock to red mudstone. In west-central Utah, Permian rock is separated from similar carbonate rock of the Triassic by a hiatus (Hose and Repenning, 1959, fig. 6), but the boundary is difficult to recognize.

In western Garfield County (locs. 612, 635, 158, pl. $6 A$ ), south-central Utah, carbonate rock of the Sinbad Limestone Member of the Moenkopi Formation overlies the Kaibab and is difficult to distinguish from it. Some strata below the Sinbad in this area were previously referred to the Triassic but are here considered pre-Triassic because a fusulinid is reported from them at locality 635 (J. R. Clair, written commun., 1959). They are tentatively mapped with interval $\mathrm{C}-\mathrm{D}$ of the Permian.

In part of northwestern Colorado the upper boundary of interval C-D is placed, for ease of recognition, at the top of the South Canyon Creek Member of the Maroon Formation, although the systemic boundary is inferred to lie $\mathbf{1 0 0}$ feet or so higher (MacLachlan, M. E., in McKee and others, 1959, p. 3). Where this rock is missing, the boundary is located by electric logs (pl. $6 D$ ) within a thick mudstone unit.

\section{THICKNESS TRENDS}

Interval C-D thins eastward across south-central Utah (fig. 70), as a result of both less deposition in that direction and partial removal by pre-Triassic erosion. Furthermore, sections in northwestern Mil- 


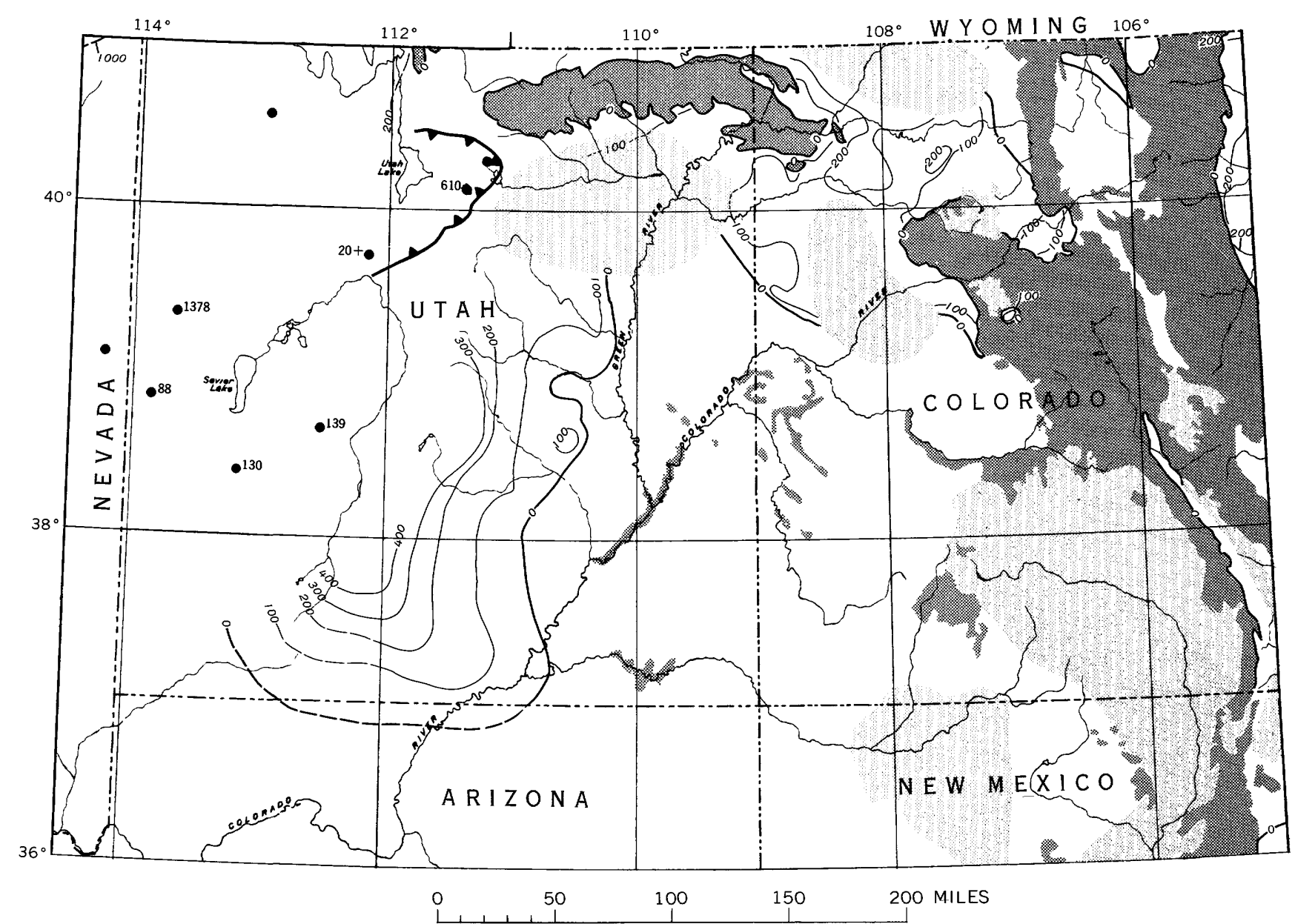

Figdre 70.- Thickness of interval C-D in western Colorado, southern Utah, and surrounding areas. Isopach interval 100 feet. Isopachs dashed where control is poor, dotted where Permian rocks have not been penetrated by drill. $\boldsymbol{O}$, indicates where Permian rocks are present but control is inadequate for isopach construction; thicknesses in feet. Approximate trace of thrust fault shown by sawtooth line; sawteeth on upper plate. Dark pattern, areas where rocks older than Permian are exposed; light pattern, areas where rocks younger than interval $\mathrm{C}-\mathrm{D}$ have not been penetrated.

lard County, Utah, may be thin because of pre-Triassic erosion. Farther south, in south-central Utah, a salient shown by isopachs may be the remnant of a trough that extended southeastward into Arizona.

In northwestern Colorado, interval C-D is thickest near the east end of the Uinta Mountains. The 200foot isopach of this interval swings eastward along the south side of the Axial Basin anticline, which apparently influenced the thickness of Permian rocks locally, both here and in eastern Moffat County. Toward the south and southeast the interval thins irregularly toward the ancegstral Uncompahgre and Front Range highlands. In north-central Colorado the Forelle Limestone and the upper part of the Satanka Shale form a wedge which terminates southwestward, against the flank of the ancestral Front Range highland.

\section{IITHOFACIES TRENDS}

Interval C-D in central and southern Utah is nearly all limestone and dolomite. In western Utah, control is inadequate for depicting lithofacies trends. Detrital rock forms a moderate proportion of the interval in several isolated localities, but its stratigraphic relation to the rock farther east is unknown.

Mudstone is the dominant rock of interval $\mathrm{C}-\mathrm{D}$ in northwestern Colorado. In places, the interval also contains thin beds of dolomite and evaporite, especially in its upper part. Carbonate cement is, in general, much more abundant than in beds of the overlying Moenkopi Formation. Near the Uncompahgre highland and near the southwest side of the ancestral Front Range highland, occurrences of conglomerate and sandstone indicate nearby sources. The mudstone of northwestern Colorado is believed 
to grade westward into carbonate beds of the Park City Formation in Utah (Kinney, 1955, p. 3-54).

\section{ENVIRONMENTS}

Carbonate rock that covers much of southern Utah was deposited in a shallow sea that extended as far east as the northwest corner of San Juan County, Utah (fig. 63). Near the west-central edge of San Juan County, marine fossils of Kaibab affinities (J. Steele Williams and J. B. Reeside, Jr., written commun., 1956) were found in a thin sandstone unit overlying the White Rim Sandstone Member of the Cutler Formation.

A sea invaded northwestern Colorado at least once during deposition of interval C-D, and the South Canyon Creek Member of the Maroon Formation was formed. In the State Bridge Formation, mudstone which forms most of the interval contains ripple marks and a bed of fossiliferous limestone, partly algal, both of which indicate a shallow-water origin (Brill, 1944, p. 635).

\section{PALEOTECTONIC IMPLICATIONS}

Stable shelf conditions prevailed throughout most of the western Colorado-Utah area during deposition of interval C-D, as indicated by the dominance of carbonate rock and mudstone. By this time the Uncompahgre and ancestral Front Range highlands were apparently reduced to low areas which were supplying little detrital sediment coarser than mud to the surrounding depositional areas.

Southern Utah was partly covered by a sea in which carbonate sediment accumulated, especially in the west. This sedimentation may have extended farther east into Colorado, but, if so, its record has been destroyed.

The latter part of Permian and the beginning of Triassic time are believed to have been marked by relative stability in northwestern Colorado (Crowley, 1955, p. 54). Some tectonic activity during the time of interval C-D is recorded in this area by coarsegrained arkosic conglomerate and sandstone along the west front of the ancestral Front Range highland and near the Uncompahgre highland. In both places this coarse detrital rock forms the lower part of the interval.

Thinning of interval C-D across the north end of the Douglas Creek arch (a Laramide structure which extends northward through Colorado from the Uncompahgre Plateau toward the Uinta Mountains (fig. 62) suggests that that area had positive tendencies during Late Permian time. Mudstone beneath the South Canyon Creek Member of the Maroon Formation thins toward the White River Plateau (fig. 62); hence, that area may have also had positive tendencies in Permian time.

\section{TOTAL THICKNESS OF PERMIAN ROCKS ROCKS INCLUDED}

Rock of Permian age in the northern part of the Colorado Plateau has been described in discussions of intervals $\mathrm{A}, \mathrm{B}$, and $\mathrm{C}-\mathrm{D}$. That assigned to interval $\mathrm{A}$ is probably also present in northwestern Colorado but is difficult to separate from underlying rocks of Pennsylvanian age. The Schoolhouse Sandstone of possible Leonard age is assigned to interval B. Rock equivalent to the Franson Member of the Park City Formation, assigned to interval B in northern Utah, is recognizable for only a short distance into adjacent northwestern Colorado. In western Utah, south of the 40 th parallel, rock of all three intervals is present and can be differentiated; however, east of the Green River and the confluent Colorado River in Utah, in southwestern Colorado to the edge of the Uncompahgre Plateau, and in northwestern New Mexico, rock of interval C-D and, in places, of interval $B$ is missing.

\section{THICKNESS TRENDS}

Permian rock of this region thins (fig. 71) from several thousand feet in western Utah to a few score feet in western Colorado. This eastward thinning is attributed to a combination of depositional differences and erosion. In western Utah, where carbonate rock is dominant, thinning toward the east is apparently initial, as it is in eastern Utah, where finegrained detrital rock is common. Farther east, where coarse-grained sandstone and arkose are dominant, post-Permian and recent erosion have probably removed some Permian beds.

In contrast with regional eastward thinning, the maximum thickness of Permian rocks is preserved in belts adjacent to the major positive elements.

One belt of maximum thickness extends northward from the New Mexico-Colorado border into central Colorado. It is poorly defined and, because of inadequate control, no isopachs delineate it on the map. Near the border the thickness of Permian rocks is believed to be about 9,500 feet. Farther north, in western Fremont County, Colo., a similar sequence is in this belt is approximately 8,100 feet thick. Midway between these localities, thickness of the upperpart of the Sangre de Cristo Formation, which includes both Permian and Pennsylvanian components, is reported to be about 21,000 feet (Asquith, 1958, p. 140).

A second belt of thickening is the northwestwardtrending area near the southwest flank of the Uncom- 


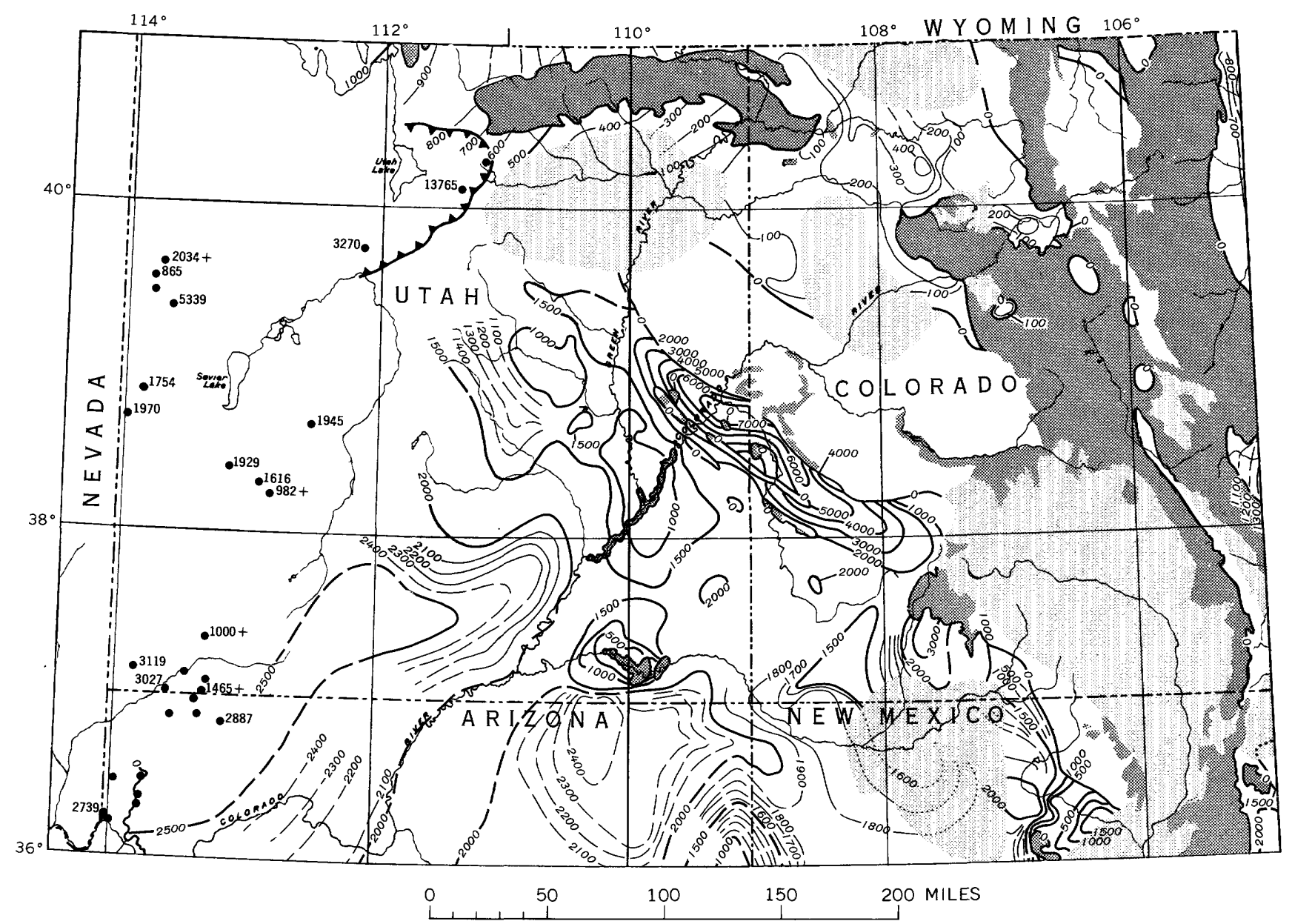

Figure 71.-Total thickness of Permian rocks in western Colorado, southern Utah, and surrounding areas. Isopach intervals 100,500 , and 1,000 feet. Isopachs dashed where control is poor, dotted where Permian rocks have not been penetrated by drill. , indicates where Permian rocks are present but control is inadequate for isopach construction; thicknesses in feet. Approximate trace of thrust fault shown by sawtooth line; sawteeth on upper plate. Dark pattern, areas where rocks older than Permian are exposed; light pattern, areas where rocks younger than Permian have not been penetrated.

pảhgre Plateau. It extends discontinuously from northwestern New Mexico through southwestern Colorado into eastern Utah, where a thickness of 7,800 feet has been drilled. This belt apparently terminates on the southeast against the San Juan Mountains; to the northwest an area of thin rock separates it from another area of maximum thickness in the Oquirrh basin of north-central Utah. Because of structural complexities and lack of reliable control, isopachs indicating the northern part of this belt outline the Uncompahgre trough but show only approximate thicknesses.

Permian rock thins rapidly toward the southwest from 7,800 feet in the Uncompahgre trough to less than 2,000 feet in southeastern Utah. Farther west the thickness gradually increases to more than 3,100 feet in southwestern Utah and 5,300 feet in west-cen- tral Utah. Between the two western Utah areas, in Beaver County, the rock is thinner.

\section{PALEOTECTONIC IMPLICATIONS}

The Permian summary map (fig. 71) shows the thickness of rock formed during two phases of tectonic activity. Early in Permian time the western part of the region was a stable shelf province, whereas the eastern part lay in the unstable ancestral Rocky Mountain province. Later in Permian time the entire region was comparatively stable; remnants of formerly high landmasses were low and shed mostly mud.

The progressive westward thickening of marine rock across southern Utah indicates stable shelf conditions throughout Permian time. The shelf was bordered by a geosyncline lying mainly west of Utah. 
Irregularities in thickness within the shelf area in parts of southern Utah are largely the result of erosion, but some depositional features were probably affected by local tectonic movements. The Monument upwarp in southeastern Utah and an unnamed post-Permian positive element, which separates two areas of maximum thickness along the Nevada State line, seem to have been eroded during the pre-Triassic hiatus. Thicker sections of Permian rock occur between these areas of minimum thickness, and these may have remained stable during the post-Permian movement.

The Monument upwarp area in southeastern Utah was a site of continental deposition during Permian time. During interval B inferred eolian and fluviatile deposits accumulated in the area. Thinning of these rocks on the flanks of the upwarp may result from both deposition and erosion. Following accumulation of probable eolian sand, which forms the lower unit of the White Rim Sandstone Member on the west and De Chelly Sandstone on the south, the upwarp area was eroded. Fluviatile rock of the De Chelly extends northeastward along the east side for several miles and wedges out beneath the Hoskinnini Member of the Moenkopi Formation. This indicates that the upwarp area was above depositional level during accumulation of the sands of the lower unit, or that it was slightly elevated following deposition and the sandstone over the upwarp was removed by erosion. The amount of pre-Triassic and Triassic erosion seems to have been greater eastward into southwestern Colorado, where Upper Triassic rocks rest on Permian. The upper sandstone unit of the White Rim and the De Chelly seem to thin depositionally eastward and northward into the upwarp area.

In southwestern Utah the belt of minimum Permian thickness represents an area of both depositional thinning and post-Permian erosion. Flanking this area on either side are much thicker sections of rock of Wolfcamp and Leonard age on the south and Wolfcamp, Leonard, and Guadalupe age on the north.

The east margin of the shelf in Utah is marked by thin Permian rock in a belt trending northwestward from southwestern Colorado into central Utah. In Early Permian time this belt separated the stable shelf in the west from the unstable area of the Rocky Mountain region to the east.

In the unstable area of eastern Utah and the west half of Colorado, three positive elements (fig. 61), known as the Uncompahgre highland, San Luis highland, and the ancestral Front Range, rose prominently in Pennsylvanian time and persisted as positive ele- ments during Permian time. The Uncompahgre highland, trending northwestward from Colorado into east-central Utah, contributed a large quantity of coarse detrital material to the Uncompahgre trough, which lay along its southwest flank (Kelley, 1958, p. 34).

The Uncompahgre trough originated in Pennsylvanian time and persisted through Early Permian time along the northeast margin of the site of the earlier Paradox basin. On its southwest side the trough is bounded by a belt of relatively thin rock which may delineate a hinge line. Lower Permian rock thickens more than 5,000 feet northeastward into the trough, whereas Upper Pennsylvanian (post-Paradox) rock thickens only $900-1,000$ feet across the same area. On the basis of these relative rates of thickening, the major part of the subsidence seems to have taken place in Early Permian time.

Subsidence of the trough, which occurred simultaneously with uplift of the adjoining Uncompahgre highland, was probably along faults. One fault northeast of Nucla, Colo., with displacement of several thousand feet, was identified in drill-hole tests and was further delimited by Joesting and Byerly $(1958$, p. 13), who used geophysical methods. Whether this fault extends northwestward along the front of the Uncompahgre is not known, but the steep irregular surface with slopes exceeding $30^{\circ}$ on which the Cutler rests near Gateway, Colo., suggests that faults are locally present. After the positive element had attained its maximum height and while the Cutler was being deposited, the old highland (at least the southwest flank) and the adjacent trough began to sink as a unit. By the beginning of Moenkopi (Early Triassic) time, subsidence in the Gateway area probably totaled not less than 8,000 feet. During this subsidence, possibly, the structural crest of the highland migrated eastward.

Rapid uplift of the Uncompahgre positive element was accompanied by rejuvenation of the deep-seated structures controlling the loci of the salt anticlines. These deep-seated structures passed upward through the Paradox salt beds into anticlines. Along the crests of these folds the Hermosa limestone, where present, was removed, and the Cutler was deposited directly on evaporite beds of the Paradox. During part of Permian time the coarse detritus from the highland was deposited so rapidly that the crests of growing salt cores in the anticlines were buried, but by the beginning of Moenkopi time the rising salt had pierced the overlying beds and broken through to the surface. 
The ancestral Front Range, trending northwest across middle Colorado, and the San Luis highland in south-central Colorado prevailed as positive elements during Permian time. Thick accumulations of detritus in the Colorado trough lay along the west side of the ancestral Front Range and along the east side of the San Luis highland, attesting to nearby sources. The youngest pre-Permian rocks in the trough that are dated with assurance are of Pennsylvanian (Des Moines) age. The overlying dominantly detrital sequence-the Sangre de Cristo Formation-attained a thickness of at least 10,000 feet.

From the Arkansas River the Sangre de Cristo Formation thins northward. In eastern Eagle County, equivalent strata in the Maroon Formation are about 2,000 feet thick and consist dominantly of conglomerate which grades north, west, and south into finer grained rock. The conglomerate of the Maroon is considered by Ogden Tweto (oral commun., 1961) to be a continuation of deposition by the same stream system that formed the Minturn Formation of Des Moines and younger (Pennsylvanian) age. The age of the Maroon in eastern Eagle County, as elsewhere, is unknown; but if the upper part is of Permian age, an eastern source area and a positive ancestral Front Range highland in Permian time are indicated.

\section{GEOLOGIC UNITS DIRECTLY ABOVE PERMIAN SYSTEM UNITS OVERLYING PERMTAN}

Rocks of Triassic age overlie the Permian throughout Utah and western Colorado. The Moenkopi Formation of Triassic(?) and Early and Middle(?) Triassic age rests unconformably on the Permian in southern Utah, except within a small area in eastern San Juan County, where the Chinle Formation of Late Triassic age overlaps the Moenkopi. Farther east in southwestern 'Colorado and in northwesternmost New Mexico the Chinle or equivalent Dolores Formation rests unconformably on Permian rock. In the middle part of eastern Utah the Moenkopi swings eastward into Colorado and overlies the Permian to the edge of the Uncompahgre uplift.

In southeastern Utah the Hoskinnini Member of the Cutler Formation has been reassigned to the Moenkopi Formation and correlated with the lower part (Tenderfoot Member) of the Moenkopi Formation of western Colorado (Stewart, 1959). These members may be either of Permian or Triassic age but are treated as Triassic in this report.

In northwestern Colorado the Permian is overlain by strata equivalent to the Moenkopi Formation, assigned to the upper part of the State Bridge Forma- tion, and to the Chugwater Formation. Here, the contact between the Permian and Triassic Systems seems to be conformable.

\section{UPPER BOUNDARY OF PERMIAN}

Southwest of the Uncompahgre Plateau the boundary between rocks of Permian and Triassic age is, in most places, marked by an unconformity and a change from carbonate rock and clean sandstone of Permian age to mudstone of Triassic age. Exceptions are in south-central and west-central Utah (Hose and Repenning, 1959, fig. 6, p. 2189), where, although a significant hiatus may exist, the boundary is diffcult to recognize because carbonate rock of Triassic age rests on limestone of Permian age.

Northeast of the Uncompahgre Plateau a precise boundary between Permian and Triassic rocks has not been established. Deposition may have been continuous, as the rock of both systems is dominantly mudstone and an unconformity has not been recognized in outcrops. On electric logs, however, the lower part of the Permian and Triassic sequence is distinguishable from the upper (pl. $6 D$ ).

\section{PALEOTECTONIC IMPLICATIONS}

Deposition of rocks assigned in this publication to the Permian System was followed by tectonic activity southwest of the Uncompahgre highland. General uplift and post-Cutler erosion is suggested for the area in Utah west of the thick sections and also across southern San Juan County and southwestern Colorado, where eastward onlap of Upper Triassic rock occurs.

In the Confusion Range of west-central Utah (Hose and Repenning, 1959, fig. 6) and in the San Rafael area farther east (Gilluly and Reeside, 1928, p. 82), pre-Triassic erosion was not pronounced. However, in southwestern Utah deep channeling has been noted at the base of the Triassic (Reeside and Bassler, 1922; McKee, 1945). In the Henry Mountain area of south-central Utah, pre-Triassic channels as much as 100 feet deep are cut into the Permian rock (Hunt, C. B., and others, 1953, p. 47). North of Circle Cliffs and west of the Henry Mountains, and near the San Rafael Swell, there is notable local channeling or scouring (McKee, 1938, p. 57). East of the confluence of the Green and Colorado Rivers in Utah, pre-Triassic channeling in the uppermost, Organ Rock Member of the Cutler is locally evident (Stewart, 1959 , p. 1862). Nearby, the contact between the Hoskinnini Member of the Moenkopi and underlying strata is discordant.

Parts of the ancestral Rocky Mountains persisted as low landmasses after Permian time and determined 
the position of the depositional edges of sediment. Accumulation of coarse detritus locally continued along the southwest side of the Uncompahgre highland in Early Triassic time, probably because of subsidence in the Uncompahgre trough and also because of a rejuvenation of the Uncompahgre highland. Subsidence in the trough is indicated by very thick sections of coarse detrital rock on the southwest flank of the Uncompahgre highland (Dane, 1935; Shoemaker and Newman, 1959).
The ancestral Front Range in north-central Colorado was apparently less positive than the Uncompahgre highland, and deposition may have been continuous across it after Permian time. Detrital rocks of Early Triassic age adjacent to this element are not appreciably coarser or thinner than corresponding strata farther away. Widespread distribution of mudstone in the transition zone from Permian to Triassic indicates that northwestern Colorado was comparatively stable at the close of the Permian. 



\section{Paleotectonic Investigations}

of the Permian System

in the United States

Chapter J. Arizona and Western New Mexico

By EDWIN D. McKEE

GEOLOGICAL SURVEY PROFESSIONAL PAPER 515-J

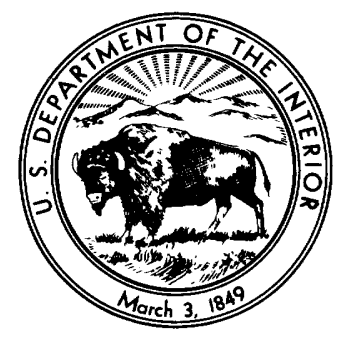





\section{CONTENTS}

Abstract

Region defined.

Paleogeology

Units underlying Permian

Lower boundary of Permian

Paleotectonic implications.

Interval A.

Formations included

Upper boundary of interval A.

Thickness trends

Structural framework

Sources and environments

Paleotectonic implications

\section{Page}

203

203

203

203

208

208

208

208

210

211

211

212

214
Interval B

Formations included.

Upper boundary of interval B................ 215

Thickness trends............................ 216

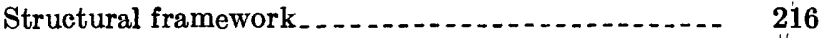

Sources and environments................... 216

Paleotectonic implications.

Interval C-D . . . . .

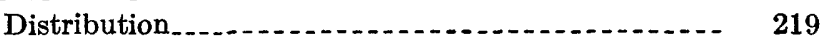

Total thickness of Permian rocks. . . . . . . . . . . 221

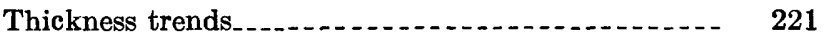

Paleotectonic implications.

Geologic units directly above Permian System ........ 221

Units overlying Permian ............ 221

Paleotectonic implications...

\section{ILLUSTRATIONS}

Figure 72-75. Maps of Arizona, New Mexico, and surrounding areas:

72. Structural features at the time of deposition of interval A

73. Geologic units directly beneath Permian System

74. Thickness of interval A. .

75. Geographic areas and localities..

76-79. Diagrammatic sections:

76. Correlation of units in interval A from the Sacramento Mountains, N. Mex., to the Hueco Mountains, Tex.

77. Alternative interpretations of intervals $A$ and $B$ in Fort Defiance area, Arizona and New Mexico.-

78. Subdivision of Permian at Fort Apache, east-central Arizona .

79. Generalized section of Supai, Bird Spring, and Callville Formations from southeastern Nevada to

80-84. Maps: northern Arizona.

80. Approximate distribution of salt in interval $\mathrm{A}$ in east-central Arizona.

81. Thickness of interval B in Arizona, part of New Mexico, and surrounding areas.

82. Transgressive deposits of intervals $\mathrm{B}$ and $\mathrm{C}-\mathrm{D}$ as shown by carbonate rocks in Utah, Arizona,

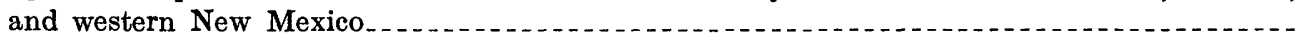

83. Thickness of interval C-D in parts of New Mexico and Arizona and surrounding areas.

84. Total thickness of Permian rocks in Arizona, part of New Mexico, and surrounding areas

\section{TABLE}

TABLE 1. Generalized chart showing stratigraphic units in major Permian subdivisions 



\title{
PALEOTECTONIC INVESTIGATIONS OF TPE PERMIAN SYSTEM IN THE UNITED STATES
}

\section{ARIZONA AND WESTERN NEW MEXICO}

\author{
By Edwin D. McKae
}

\begin{abstract}
History of the Permian System in Arizona and western New Mexico is analyzed on the basis of thickness, lithology, and other mappable features. At the beginning of the period the land surface in this region was of low relief but very irregular. There were six principal basins or negative areas and these were bordered by positive elements of older rocks, inherited from Pennsylvanian time.

During the time of interval A, representing the earliest part of the Permian (Wolfcamp time), negative elements continued to sink and to accumulate sediment, mostly continental but partly marine in the south and southeast. Although positive areas, largely composed of Precambrian rocks, formed barriers between these basins, no evidence is known of their renewed uplift during this time. The influxes of sediment, largely from the north, filled depressions between the positive areas with deposits of $1,000-3,000$ feet thick, thereby restricting marine invasion and progressively'burying topographic border features.

In contrast with the record of interval $A$, that of interval $B$ indicates deposition of uniform thicknesses of sediment on a fiat terrain that extended across wide areas in Arizona and New Mexico. The deposits ultimately formed great wedges of strata that thickened southeastward to 3,000 feet in the Delaware basin of New Mexico, southward to 2,500 feet in southeastern Arizona, and southwestward to what once were probably comparable thicknesses in southern Nevada and California. Extensive marine limestones in the thicker parts of the wedges indicate two major transgressions from the border areas toward the generally stable region of northeastern Arizona. Evaporite rocks in the thinner parts mark lagoonal areas of sedimentation bordering the fluctuating coastlines.

Interval $\mathbf{C}$ is unrepresented in most parts of Arizona and Western New Mexico. In the Delaware basin of southeastern New Mexico and in Sonora, Mexico, not far from the Arizona border, however, thick sequences of strata considered to belong to interval $\mathrm{C}$ are present. Doubtless these strata once lapped westward and northward to some extent, but evidence of an uplift responsible for minor channeling and subaerial erosion in northern Arizona during pre-Triassic time indicates that they probably never extended that far.
\end{abstract}

\section{REGION DEFINED}

The Arizona-western New Mexico region embraces the entire State of Arizona and adjoining western New Mexico, including most of the northwest quarter and two-thirds of the south half of the State. The north half of the region is a part of the Colorado Plateau, and the south half is in the Basin and Range province.

During Permian time this region included (fig. 72) a shelf bordering the Cordilleran miogeosyncline on the west, the north end of the Sonoran geosyncline on the south, and the Northwestern shelf of the Delaware basin on the southeast. Along the north margin lay the Southern Utah and Permian San Juan basins. Between these major limits were numerous small positive elements, separated early in Permian time by mildly negative areas and small basins, and later by broad shelves, platforms, and depressed land areas.

\section{PALEOGEOLOGY \\ UNITS UNDERLYING PERMTAN}

In the Arizona-New Mexico region, rocks underlying the Permian (fig. 73) conform to a pattern largely controlled by the distribution of late Paleozoic positive elements. These elements outline and, in some areas, partition off various basins in which sediments accumulated. The Permian tectonic elements in this region, as delineated by isopachs of interval A (fig. 74) and generalized in figure 72, differ somewhat in outline and position from those shown for the Pennsylvanian System by Kottlowski $(1960$, pl. 10). Some of these differences are probably the result of structural changes that carried over from Pennsylvanian into Permian time; others may be attributed to interpretation or to choice of control points.

Within most of the Arizona-New Mexico basins, strata underlying the Permian include youngest Pennsylvanian (Virgil) rocks and probably represent continuous deposition from Pennsylvanian into Permian time (fig. 73). Along the borders of the basins, most of the rocks beneath the Permian are of Precambrian age; other pre-Permian strata either underlie or project through the Permian sequence locally, in places with marked angular unconformity (Pray, $1949)$. 


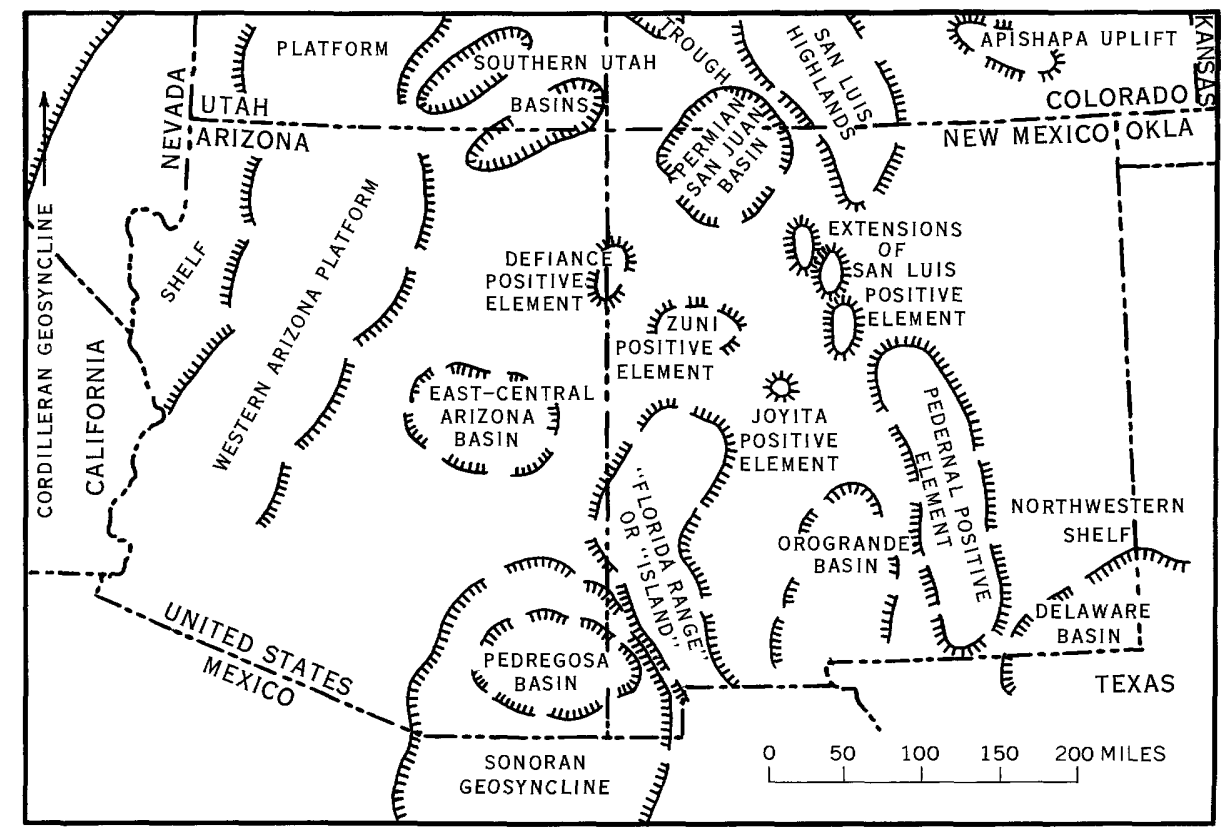

Frgure 72.-Structural features of Arizona, New Mexico, and surrounding areas at the time of deposition of interval A.

In the southeasternmost area a thick sequence of Pennsylvanian rocks, the youngest of which are of Virgil age, extends across a wide area of the Northwestern shelf adjacent to the Delaware basin (fig. 72). No formational name has been applied to these rocks, and they are separated from subjacent rocks largely on the basis of fusulinids.

The west margin of the Northwestern shelf was formed by the Pedernal positive element (fig. 72), which extends north-south across much of New Mexico as a broad linear belt of Precambrian and lower Paleozoic rocks (fig. 73). The boundaries of this positive element seem to have been highly irregular and to have varied with time (Foster, R. W., 1959, p. 137; Bachman, 1960, p. B239). At the beginning of Permian deposition, the element was roughly 50-70 miles wide in southern New Mexico and stood above the Pennsylvanian strata. Along its margins, Permian rocks rest on Precambrian for the most part and, as shown near the Texas border in the south, on lower Paleozoic strata that are progressively younger toward the neighboring basins.

In isolated ranges in south-central New Mexico, remnants of an elongate basin of Pennsylvanian and Early Permian (Wolfcamp) age, referred to as the Orogrande basin or trough (Kottlowski, 1958, p. 80; Pray, 1959, p. 93), are represented by a moderately thick sequence of strata. Pennsylvanian rocks are referred to by most geologists as the Madera Formation in the northern part of the basin; as the Magda- lena Group in the southwest; and as undifferentiated Pennsylvanian rocks in the southeast. Other names have been used locally, such as Gobbler Formation, Beeman Formation, Holder Formation (Pray, 1954, p. 93) in the Sacramento Mountains, and Panther Seep Formation (Kottlowski and others, 1956, p. 42) in the San Andres Mountains.

Margins of the former Orogrande basin in Grant and Luna Counties to the west and southwest and in Socorro, Sierra, and other counties to the north and northwest are preserved only as isolated remnants. They include the "late Pennsylvanian Florida Range" of Sidwell and Warn (1953, p. 988-990) and the Joyita positive element. In most of these remnants Permian rocks overlap onto Precambrian, but in some they rest on Ordovician (Kottlowski, 1958, p. 82) or other lower Paleozoic strata (Paige, 1916; Kelley and Bogart, 1952, p. 1645).

A large basin that extended from southwesternmost New Mexico across much of southern Arizona apparently received sediments continuously through most of Pennsylvanian and Permian time, for no evidence of unconformity between or within these systems is reported. On the basis of various types of invertebrate fossils examined by J. Steele Williams, the time boundary is placed near the base of the Earp Formation (Gilluly and others, 1954, p. 38). Thus, the lowest part of the Earp is of Late Pennsylvanian age and is underlain by the Horquilla Limestone of Middle and Late Pennsylvanian age. 


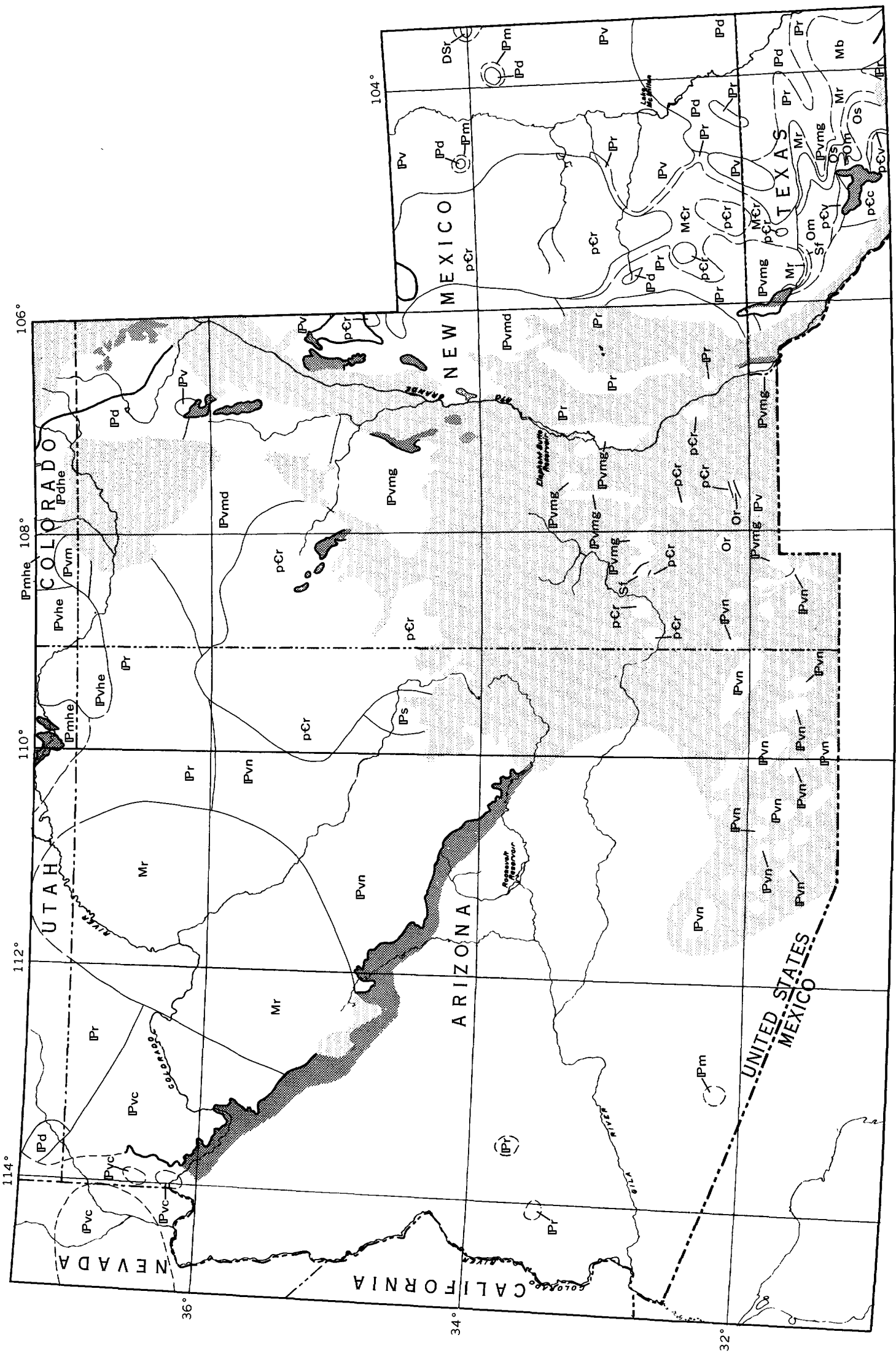

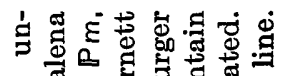

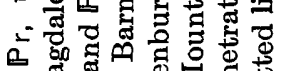

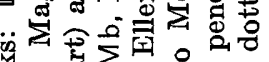

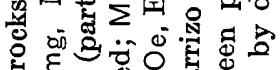

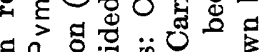

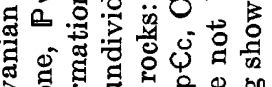
有家行

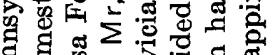

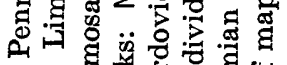
近 密要出

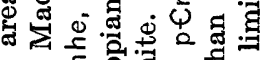

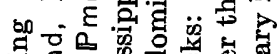

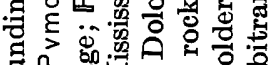

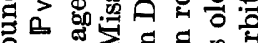
更

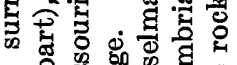

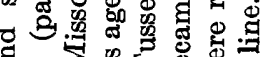

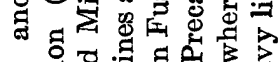

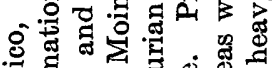

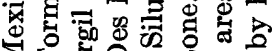

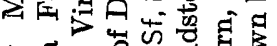

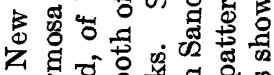
乙 द्:

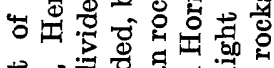

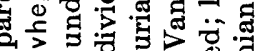
过

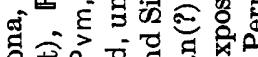

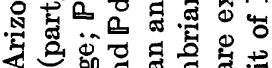
य ㅖㅕㅇ

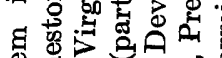
\& क它

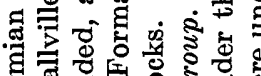

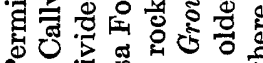
A . : क 워

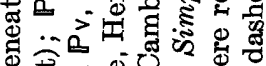

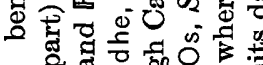

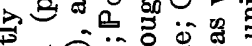

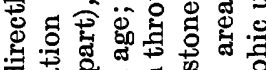

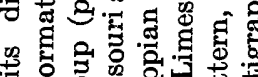

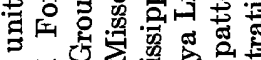

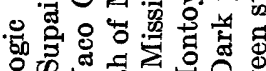

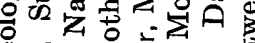
ऊँ 1 要 ๙

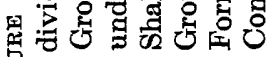
兽 


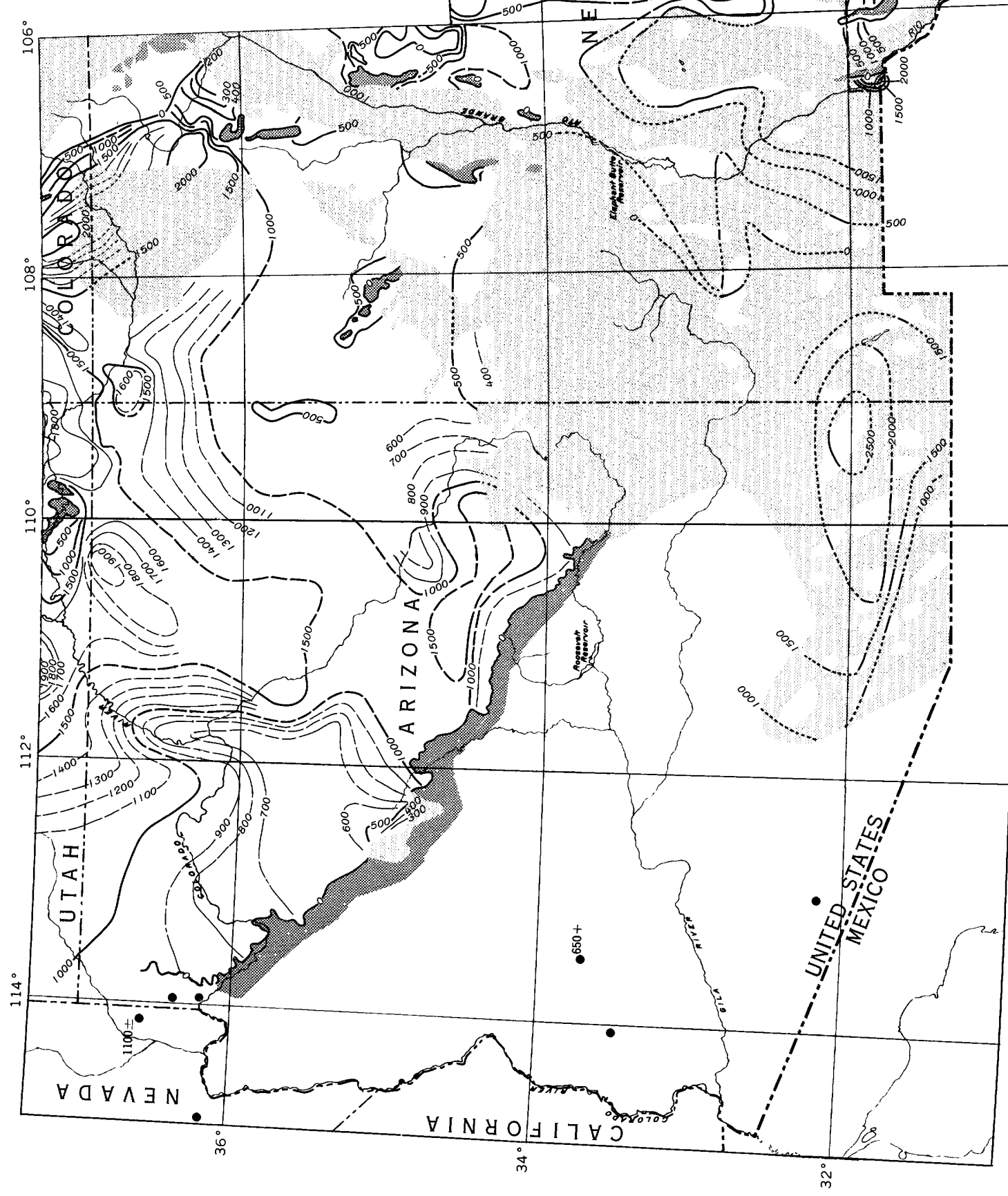

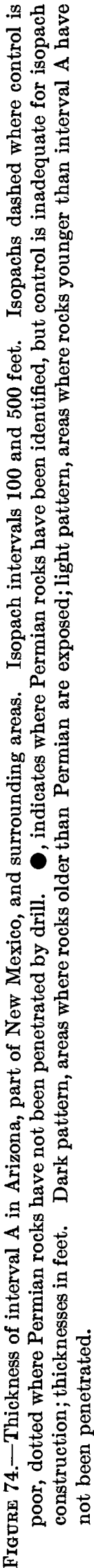


The western limit of the southern Arizona depositional basin is not known, for its record has been largely destroyed by erosion. Permian rocks have been recorded from only three isolated localities (fig. 73), each of which is underlain by strata of Pennsylvanian or Pennsylvanian(?) age. Little is known, however, of former thickness, age, or extent of these rocks.

In northwestern New Mexico a thick sequence of strata accumulated in Pennsylvanian and Permian basins that extended northward into Colorado. This area was rimmed on the east by the Uncompahgre positive element, on the south by the Zuni and Joyita, and on the west by the Defiance (fig. 72). Upper Pennsylvanian rocks underlying the Permian within this basin are commonly referred to the Madera Limestone in the south and the Hermosa Formation in the north.

Around the margins of the Permian basin in northwestern New Mexico, lowest Permian beds rest with onlap relations on various Precambrian rocks-especially granite and quartzite (Gregory, 1917, p. 17; Allen and Balk, 1954, p. 61; Darton, 1925, p. 18). North of the Defiance positive element in Arizona, near the south border of Utah (fig. 73), however, lowest Permian rocks rest on Pennsylvanian without apparent break, and the basin connects westward with the basin in northern Arizona.

In northeastern Arizona south of the Little Colorado River (fig. 75), Permian rocks rest conformably on Pennsylvanian strata of the Naco Group (Winters, 1963, p. 2) or the lower part of the Supai (Huddle and Dobrovolny, 1945); but farther north, near the Arizona-Utah boundary, they overlie rocks of the Pennsylvanian Hermosa Formation. Between these areas in northeastern Arizona, in undrilled sections of the present Black Mesa basin, Pennsylvanian rocks may or may not connect. Pennsylvanian strata may have extended across this area, as shown on the paleogeologic map (fig. 73), but it is equally plausible that a westward prong of the Defiance positive element separated basins to the north and south.

In northwestern Arizona, Permian rocks of the Supai Formation rest conformably on Pennsylvanian strata referred to the Callville Formation. The boundary is arbitrarily drawn between strata containing diagnostic fusulinids (McNair, 1951, p. 525). This area is believed to have been a shelf forming the east margin of the Cordilleran geosyncline of Nevada. Farther east, in the middle part of northern Arizona (eastern Grand Canyon area), the Supai Formation, considered to be of Permian and Pennsylvanian age, rests unconformably on Mississippian strata of the Redwall Limestone. The belt where

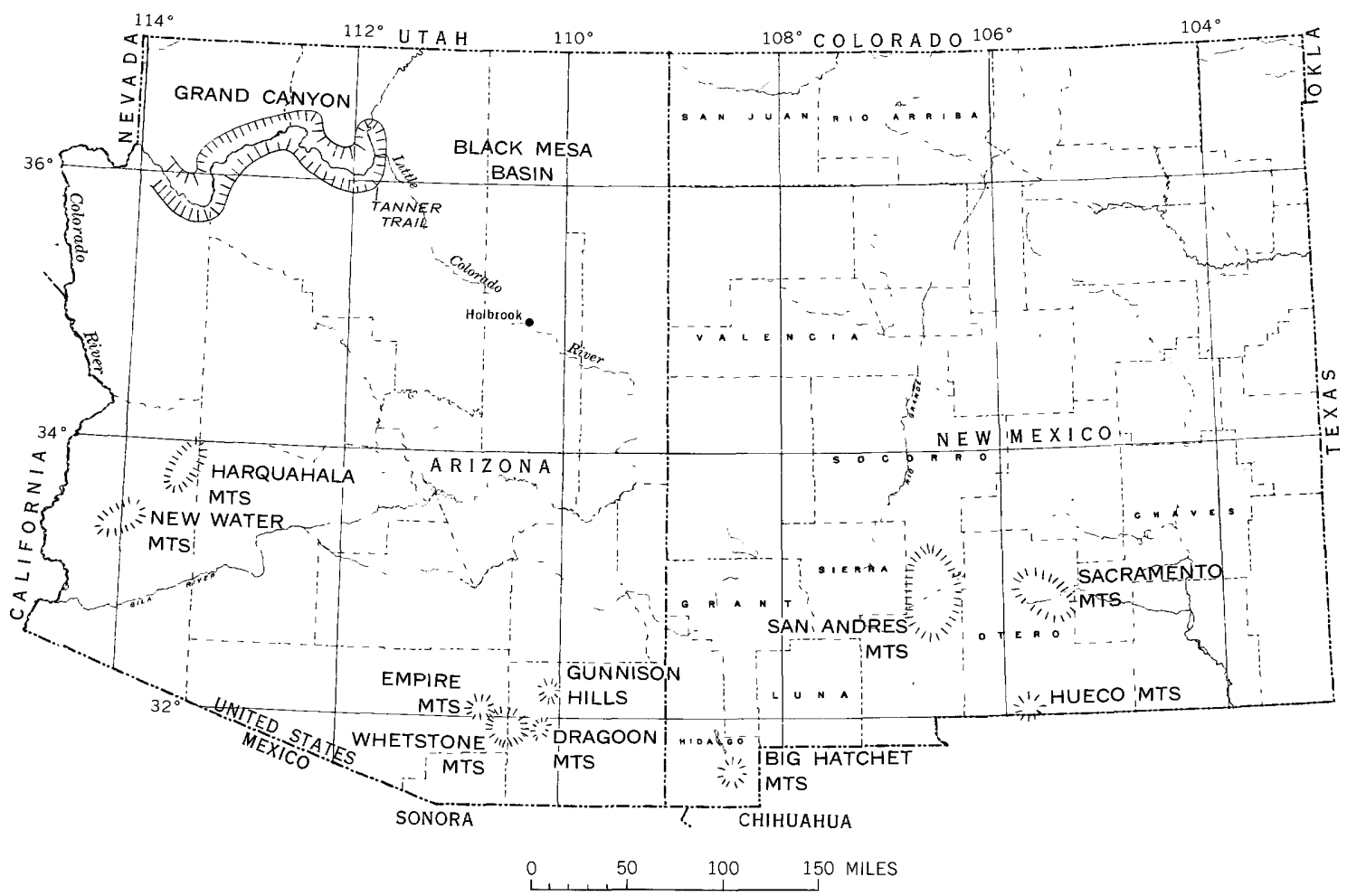

Figure 75.-Geographic areas and localities in Arizona and in western and southern New Mexico mentioned in text. 
Permian(?) rocks rest on Mississippian is at least 100 miles wide, from east to west, and indicates pronounced positive tendencies preceding Permian time. At one locality in eastern Grand Canyon an angular unconformity separates the Supai Formation and the Redwall.

\section{LOWER BOUNDARY OF PERMIAN}

In negative areas, currently recognized boundaries within gradational rock sequences have been arbitrarily chosen between the nearest dated beds of Pennsylvanian and Permian age. In contrast, Permian strata along the margins of these negative areas rest unconformably on older rocks. The hiatus represented is progressively greater toward the surrounding positive elements, where, for the most part, Permian rocks lap onto Precambrian.

Because of onlap relations, basal Permian strata in the basins are older than those on the borders of positive elements. Earliest Permian strata bank against the sides of the Pedernal, Zuni, Defiance, and other positive elements (fig. 72); and, in places, all the rocks of interval A lap out against Precambrian structural highs. By contrast, at least some units of interval B either now cover or probably once covered all the principal positive elements, as shown in reconstruction (I-450, pl. 9).

The relation between areas in which the Pennsylvanian-Permian boundary is a transition zone and areas in which it is a sharp contact is especially well exposed in the northwestern Sacramento Mountains, N. Mex., where a change from conformity in basin deposits to a major unconformity on the flanks of a positive area occurs within a few miles (Otte, 1959, p. 67; Oppel, 1959, p. 191; Pray, 1959, p. 126).

\section{PALEOTECTONIC IMPLICATIONS}

Sedimentation in Arizona and western New Mexico continued without appreciable change from latest Pennsylvanian into Early Permian time. It took place in a series of six principal basins or negative areas, each delineated by bordering positive elements composed of older rocks. Thus, the paleogeologic map (fig. 73) illustrating rocks underlying the Permian System shows tectonic elements very similar to those that existed early in the Permian: basins and shelves that gradually sank and positive elements that continuously stood above the level of deposition. Only gradually did the influence of this pre-Permian structural pattern change and allow Permian deposits to form a continuous sheet of sediment across most of the region.

\section{PERMIAN SYSTEM IN THE UNITED STATES}

\section{INTERVAL A \\ FORMATIONS INCLUDED}

Interval A in Arizona and western New Mexico is largely or entirely of Wolfcamp age. In the subsurface of the Northwestern shelf adjacent to the Delaware basin (fig. 72; table 1, col. 13), this interval is composed of the Hueco Limestone only; the overlying "Abo," which is younger than Abo of the type area to the west, is not included and is probably lithologically unrelated to it (I-450, pl. 9, sections $N-N^{\prime}$, $\left.O-O^{\prime}\right)$. The Hueco is dominantly limestone on the shelf and across much of the Delaware basin but passes into thick sections of red mudstone near the Pedernal positive element on the west.

The Bursum Formation of central New Mexico (north margin of Orogrande basin, table 1, col. 12) was named and described by Wilpolt and others (1946), and its stratigraphic relations were discussed by M. L. Thompson (1954, p. 18). It includes preAbo Wolfcamp rocks only. It is composed largely of marine limestone in the south but contains progressively more detrital rock toward its north edge. The overlying Abo Formation consists mainly of nonmarine red beds and locally contains a basal conglomerate that was correlated by M. L. Thompson (1954, fig. 6) with the Powwow Conglomerate Member of the Hueco. The validity of this correlation is doubtful.

Fusulinids indicate that most of the Abo is late Wolfcamp in age (Thompson, M. L., 1942, pl. 11). Stratigraphic relations with the Hueco, described above, tend to confirm this determination, but the uppermost part of the unit may be of Leonard age, as suggested by fossil plants examined by C. B. Read (King, P. B., 1942, p. 687-690). The discrepancy between the Leonard-Wolfcamp boundary and the formational contact was emphasized by Kuellmer (1954) ; however, in the present publication the entire Abo Formation is mapped as part of interval A.

In the Orogrande basin, west of the Pedernal element, interval A includes typical Abo underlain by the Bursum Formation in the north and by its partial equivalent, the Laborcita Formation (Otte, 1959, p. $25)$, in the south $\left(\mathrm{I}-450\right.$, pl. 3, section $\left.K-K^{\prime}\right)$. Farther south, near the Texas-New Mexico border, the stratigraphic position of the Abo is in part occupied by the Hueco, with a conglomerate member called the Powwow at its base. Probably little or no Bursum or lowest Permian occurs in the central and southern Sacramento Mountain area and in Otero Mesa (L. C. Pray, written commun., 1961), for these places are in an area that remained high; however, the Bursum is 
recognized south of the Sacramento Mountains (Thompson, M. L., 1954, p. 18-19, 25).

The Hueco of the southern border area was probably once connected with its counterpart in the Delaware basin by way of the south end of the Pedernal. Relations between the probably continental Abo in
In southwestern Arizona few Permian remnants are preserved, and formational names are not applied. In the New Water Mountains (fig. 75), Cretaceous strata include some large boulders lithologically like the Callville in southern Nevada, part of which is of Wolfcamp age (McKee, 1947, p. 286). In the Har-

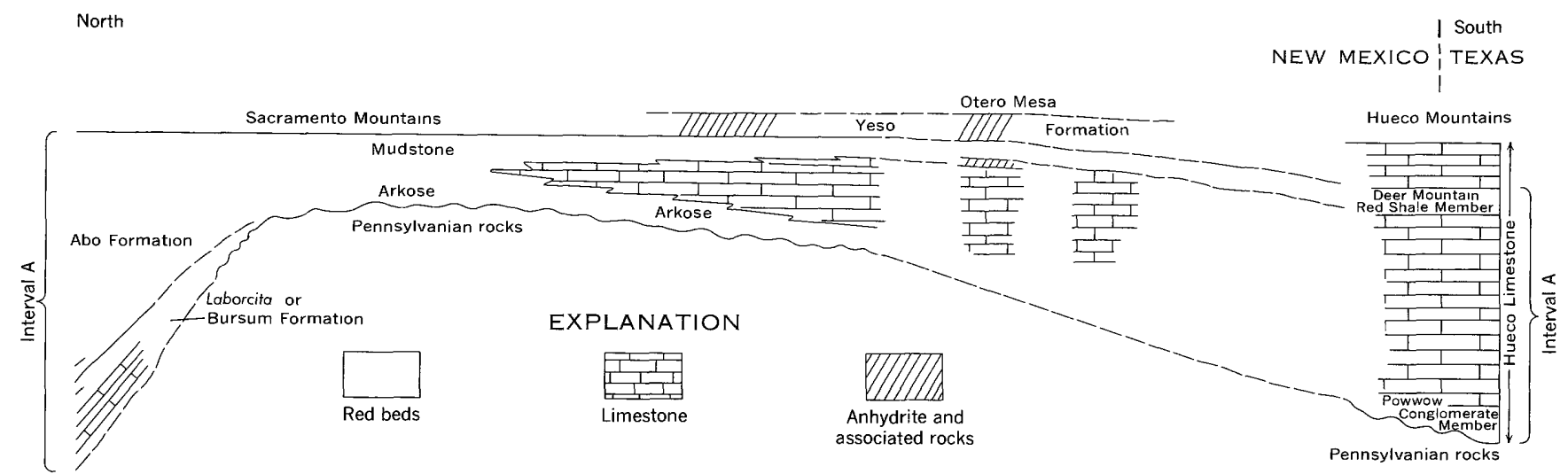

Figure 76.-Correlation of units in interval A from the Sacramento Mountains, N. Mex., to the Hueco Mountains, Tex. Data from L. C. Pray (written commun., 1960).

the Sacramento Mountains and the marine Hueco to the south were described by M. L. Thompson (1954, p. 18) and by Pray and Otte (1954); two major tongues of red beds of the Abo extend southward above and below a thick wedge of Hueco Limestone pointing northward (fig. 76).

West of the Orogrande basin and separated from it by a poorly defined positive element is a large Pennsylvanian and Permian basin, the Pedregosa. This basin, which was named by Kottlowski (1959, fig. $3 ; 1960$, pl. 10), extends westward across much of southeastern Arizona. Upper Paleozoic formations in this basin are parts of the Naco Group of Pennsylvanian and Permian age. Two of those formations-the Earp and the overlying Colina Limestone-are probably partly of Wolfcamp age. Although dating of these rocks is difficult on the basis of available fossils, time-stratigraphic boundaries clearly lie within the units, according to J. Steele Williams (in Gilluly, 1956, p. 49-50). Thus, the Earp is assigned a Late Pennsylvanian and Wolfcamp age and the Colina a Wolfcamp and Leonard(?) age. On paleotectonic maps of interval A only the upper member (Permian part) of the Earp Formation is included because subdivision seems reasonably practical in most sections. All the Colina Limestone has been included, however, for the amount considered to be of Leonard age is small and hard to separate. quahala Mountains (fig. 75) certain strata resemble parts of the Supai Formation in Grand Canyon, which is assigned to interval A (McKee, 1951, section 159).

In the vicinity of the Zuni positive element in northwestern New Mexico, the Abo Formation alone constitutes interval A. It consists mostly of red beds, including mudstone and some sandstone (Bates, 1942, p. 34), and contains a limestone unit whose fauna is referred to the Permian by G. P. Girty (in Darton, 1928, p. 21, 140). Farther north, near the ArizonaUtah border, similar rocks referred to the Cutler Formation (below the De Chelly Sandstone Member) are assigned to interval A (fig. 77, upper).

Immediately west of the Defiance positive element, interval A is represented by red beds of probable Wolfcamp age that underlie the De Chelly Sandstone (Coconino of some authors) and are assigned by some geologists to the Supai and by others to the Cutler Formation. The upper part of the red beds may be equal to the Yeso farther southeast (table 1,.col. 47) and to the Fort Apache Limestone Member and overlying parts of the Supai to the southwest (fig. 78), and is therefore of Leonard age; however, no clear method of dividing the red-bed sequence in this area is available at present.

In the central part of northern Arizona-the eastern Grand Canyon area-all the Supai Formation, but not the Hermit Shale above, is assigned to inter- 
South ABOUT 160 MILES
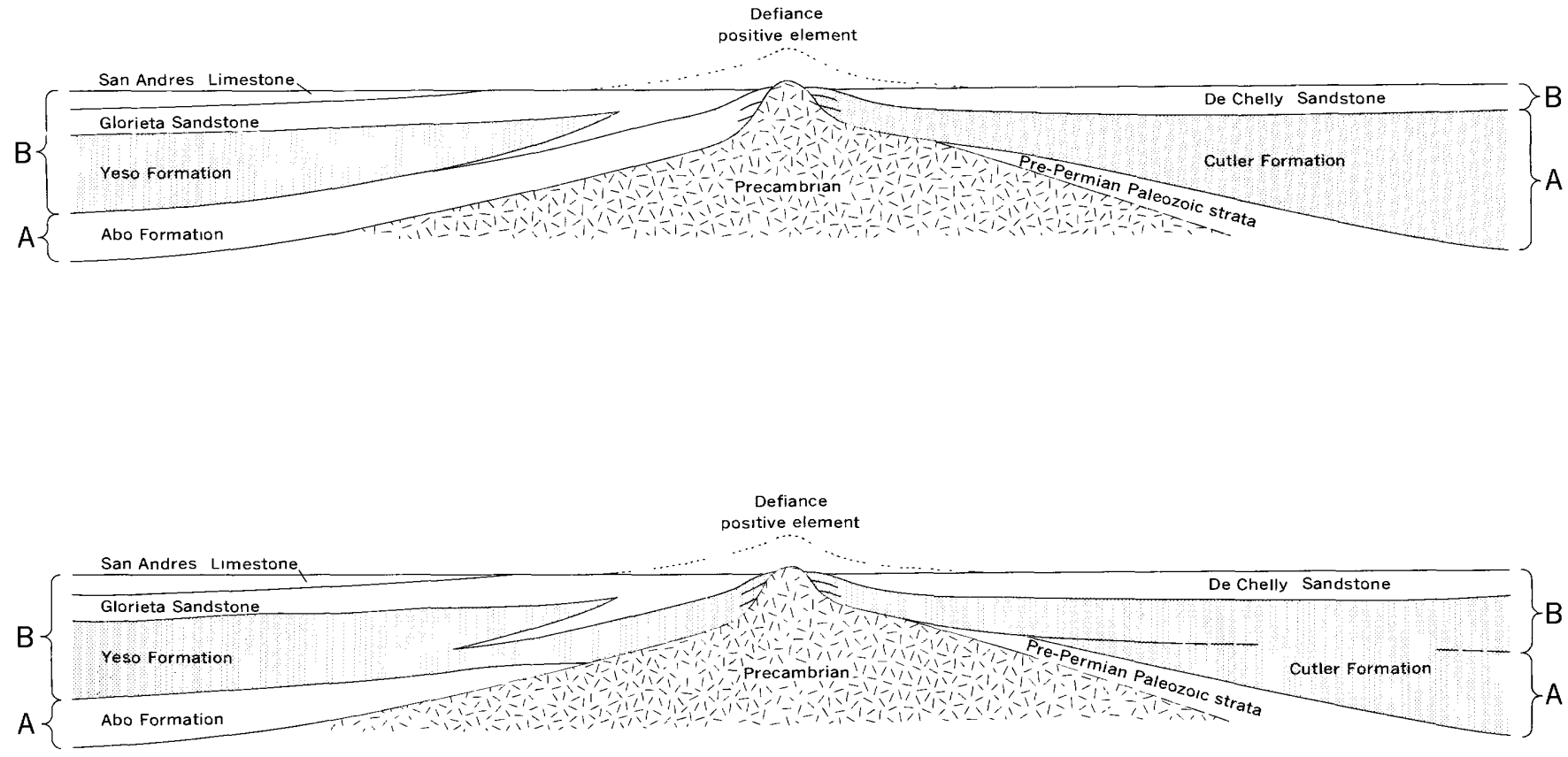

Figure 77.-Alternative interpretations of intervals A and B in Fort Defiance area, Arizona and New Mexico.

val A. ${ }^{1}$ Perhaps the lowest part of the Supai in part or all of this area is of latest Pennsylvanian age, but this has not been proved. Southwest of the Defiance positive element and south of the Little Colorado River, interval A (fig. 78) includes only the middle member of the Supai in the classification of Huddle and Dobrovolny (1945), or the Big "A" and Amos Wash Members in that of Jackson (1951, fig. 3).

In northwestern Arizona, toward the geosyncline of southern Nevada, rocks of probable Wolfcamp age and assigned to interval $\mathbf{A}$ include the Supai Formation and the upper part of the Callville Formation (Pakoon of McNair). Here red beds of the Supai Formation intertongue westward with limestone beds of the Callville (fig. 79), and the uppermost part of the Callville is of Permian age (McNair, 1951, p. 522). Farther west, in Nevada, rocks equivalent in age to these formations consist almost entirely of limestone and constitute the upper part of the Bird Spring Formation.

1 Since preparation of the maps and text for the Arizona part of this publication in 1962, new fossil and field evidence from western Grand Canyon has shown that much of the Supai Formation is of Pennsylvanian and not of Permian age. Thus, thickness figures for the total isopach and the interval $A$ maps in the northwest part of the state should be reduced by several hundred feet. The rocks involved in this reduction will be shown on maps of the Pennsy]vanian System now in preparation.

\section{UPPER BOUNDARY OF INTERVAL A}

The Leonard-Wolfcamp Series boundary is within but probably near the top of the Abo, Hueco, and Cutler Formations in New Mexico and within the Supai and Colina Formations in Arizona; its position cannot be determined precisely. Thus, in all these units (except that part of the Supai in central Arizona) the lithologic change that marks the formation boundary is chosen as the interval boundary. In the central Arizona area the boundary is placed at the base of the Fort Apache Limestone Member of the Supai on the basis of its fauna, which is of Leonard age (Winters, 1963, p. 15). In a few places in southwestern New Mexico (I-450, pl. 3, section $\left.N-N^{\prime}\right)$, rocks of Leonard age are missing, and Cretaceous strata unconformably overlie those of interval $\mathbf{A}$.

In some areas two formations or members in a sequence intertongue, as along the Abo-Yeso contact in northwestern New Mexico (Wood and Northrop, 1946), in south-central New Mexico (Kottlowski and others, 1956 , p. 53), at the top of the Hueco Limestone in southern New Mexico (Kottlowski and others, 1956 , p. 50), and among members of the Supai in east-central Arizona (Huddle and Dobrovolny, 1945). In these and some other places the arbitrarily selected formation boundary is assigned as the interval boundary. 


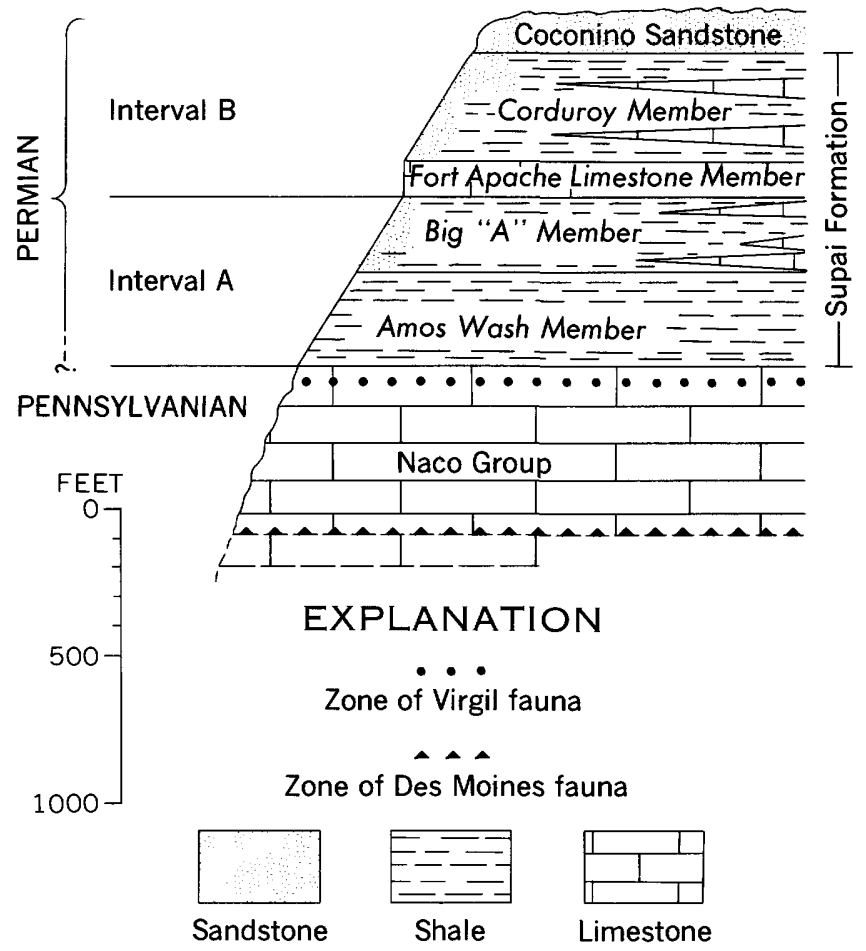

Figure 78.- Subdivision of Permian at Fort Apache, east-central Arizona (modified from S. S. Winters, in Jackson, 1951).

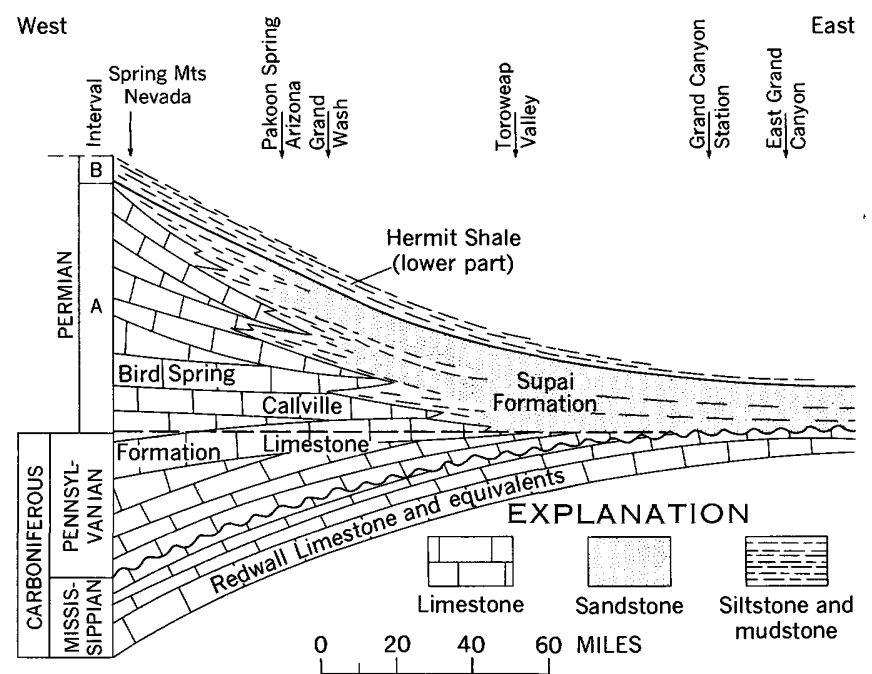

Figure 79.-Generalized section of Supai, Bird Spring, and Callville Formations from southeastern Nevada to northern Arizona.

\section{THICKNESS TRENDS}

Isopachs of interval $\mathbf{A}$ form a complex pattern (fig. 74 ) in which a number of separate centers of thickening each attaining a maximum of 1,000 feet or more occur. Structural elements responsible for this complexity constitute a framework discussed in the next section. In places, also, thickness of the interval has been greatly reduced by erosion, further complicating the overall pattern.

In most of northern Arizona and northwestern New Mexico present thickness of interval A (fig. 74) approximates the original thickness, for the rocks are conformably overlain by interval $\mathrm{B}$; likewise in most of southeastern New Mexico the thickness has probably been reduced only locally. In other parts of this region, however, interval $\mathbf{A}$ is either incomplete or missing as a result of widespread erosion. In southern Arizona and southwestern New Mexico its remnants are restricted to scattered mountain ranges, many of which contain only partial sections. Along the south margins of the plateau of northern Arizona and New Mexico, sections of this interval are progressively more incomplete toward the south.

\section{STRUCTURAL FRAMEWORK}

During the time of interval A, six well-defined negative areas in Arizona and western New Mexico accommodated masses of sediment 1,000-3,000 feet thick (fig. 74). Positive elements, mastly formed of Precambrian rocks, stood relatively high and formed barriers between the negative areas.

A relatively stable shelf adjoined the Delaware basin in the southeastern part of New Mexico (Chaves County), and strata deposited there were only 500800 feet thick. Directly west of this shelf, and separating it from the Pedernal positive element of northsouth trend, was a narrow trough in which sediments exceeding 1,500 feet in thickness ( $\mathrm{I}-450, \mathrm{pl}$. 3, section $N-N^{\prime}$ accumulated. The Pedernal positive element must have been a prominent topographic feature during this time. It extended above the base level of deposition to form a barrier across most of southern and part of northern New Mexico.

West of the Pedernal element the Orogrande basin extended northward across southern New Mexico and received more than 1,500 feet of sediment. This basin widens southward near the international boundary and terminates northward near the center of the State (fig. 74). Its northwest margin is uncertain, as much of west-central New Mexico is covered by Tertiary volcanic rocks; but southwest in Grant, Luna, and Hidalgo Counties, where pre-Permian rocks are now overlain by Cretaceous strata, a positive element may have formed the basin rim. This positive element apparently separated the Orogrande basin from negative areas farther west.

The rocks in many ranges of southeastern Arizona and southwesternmost New Mexico indicate that a large basin existed in that area during deposition of interval $\mathrm{A}$ and that this basin collected at least 2,500 
feet of sediment. Its general configuration shown in figure 74 by dotted isopachs is based on projections from isolated control points, many of which, unfortunately, represent sections that are incomplete as a result of structural complexities. Original limits of the basin may have been much farther north and west than indicated, but the record is largely obliterated by erosion.

In northwestern New Mexico the southern part of the San Juan basin of Permian time is outlined by the Uncompahgre and San Luis positive elements on the east, by the Zuni element on the south, and the Defiance on the west. Thicknesses of strata in this basin are in excess of 1,500 feet; the maximum is in southwestern Colorado.

West of the Defiance positive element the southwestern part of the Paradox basin extended into northern Arizona from Utah (fig. 74). More than 1,900 feet of strata of interval $\mathbf{A}$ was deposited in its deepest part, which was near the State boundary. The south margin was apparently in central Arizona, where the record is now partly obliterated by erosion and partly obscured by a thick covering of Tertiary volcanic rock. Somewhere in this part of the State the northward thickening of interval $\mathbf{A}$ changed to a southward thickening, toward the basin of southeastern Arizona.

A positive element existed in Early Permian time, centered near eastern Grand Canyon, in the middle part of northern Arizona. It was composed of Mississippian Redwall Limestone, rather than Precambrian rocks. This positive area was buried under 700-900 feet of earliest Permian deposits (interval A), and perhaps youngest Pennsylvanian, whereas other positive elements in the region generally persisted during interval A deposition.

In northwesternmost Arizona, interval A thickens across a shelf toward the Cordilleran geosyncline. This thickening was probably the result of normal increase in sedimentation.

\section{SOURCES AND ENVIRONMENTS}

The distribution of positive elements, basins, and other features of relief, now reflected in the lithofacies pattern of interval A, was notably complex. Most of the positive elements stood above the base level of deposition, forming barriers between basins (I450 , pl. 3, sections $\left.O-O^{\prime}, K-K^{\prime}, N-N^{\prime}\right)$, but apparently these barriers did not furnish appreciable amounts of coarse sediment to surrounding areas. Calcium carbonate deposits accumulated in marine waters that invaded the region from the south and southeast, and from the northwest. Evaporite sedi- ments, including salt deposits, formed locally in eastcentral Arizona (fig. 80).

Across the Northwestern shelf, east of the Pedernal positive element and north of the Delaware basin in southeastern New Mexico (fig. 72), relatively pure carbonate beds were laid down. Such deposits wore typical of many marginal platforms during Wolfcamp time (Galley, 1958, p. 423). Westward in a deep narrow trough between the Northwestern shelf and the Pedernal element, a thick sequence of red mud accumulated at the same time the carbonate beds formed (I-450, pl. 3, section $\left.N-N^{\prime}\right)$. At least part of this detritus was derived from the Pedernal element, for such material largely encircles its south half.

In the Orogrande basin, west of the Pedernal element, pure carbonate rock (Hueco Limestone) dominates the southern part; but northward, mudstone and limestone intertongue. Still farther north, mudstone (Abo Formation) with sandstone and arkose interbeds is dominant. Sedimentation in the Orogrande basin was probably in a marine environment to the south and in a continental one to the north.

Red beds of the Abo are probably of nonmarine origin for they contain such features as mud cracks, bones and tracks of land vertebrates, and land plants (Bates, 1942, p. 34; Tonking, 1957, pl. 13). Other features considered to be evidence of continental sedimentation (Wilpolt and others, 1946; Kelley and

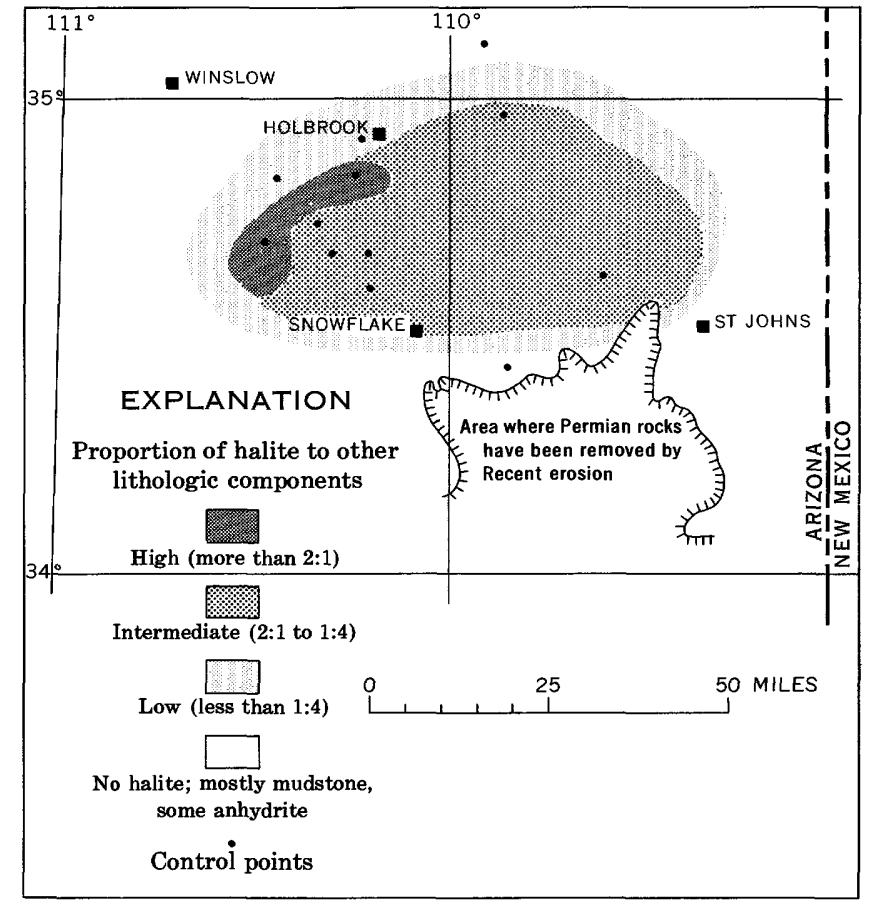

Figure 80.-Approximate distribution of salt in interval $A$ in east-central Arizona. 
Wood, 1946) are abundant channels and lenticular beds of coarse-grained detritus. The environment has been described (Read, 1950) as one of flood plains and deltas across a wide lowland area. In the northern Sacramento Mountains, however, conglomeratic beds of the Abo may represent alluvial fans of a piedmont surface (Otte, 1959, p. 65-66).

Most of the red siltstone and yellow sandstone tongues extending southward from the Abo are formed of sediment probably "derived chiefly from northern sources" (Kottlowski, 1958, p. 84). Some detrital sediment may have been derived from the "Florida Island" positive element west of the basin (Kottlowski, 1958, p. 84); some sediment was also locally derived from the Pedernal element on the east and northeast, as indicated by the lithofacies pattern of that area $(\mathrm{I}-450, \mathrm{pl} .3)$ and the presence of pebble conglomerates and nonstable rocks and minerals in Permian strata of the northern Sacramento Mountains (Otte, 1959, p. 62; Pray, 1959, p. 118).

In the southeastern Arizona basin, referred to as the Pedregosa trough (Kottlowski, 1958, p. 84), interval A consists of relatively pure carbonate rock near the center or deepest part but contains progressively more mudstone and siltstone toward the margins, especially westward. Some fine-grained detrital sedimentary rock near the east edge (Big Hatchet Mountains, fig. 75) may have been derived from the "Florida Island" positive element in New Mexico (Kottlowski, 1958, p. 83), but most of the detritus, as indicated by its present distribution, seems to have come from the west or northwest.

An uplift northwest of the Pedregosa basin may have been a source of local conglomerate cobbles in the Gunnison Hills area, Arizona (J. R. Cooper, in Gilluly and others, 1954, p. 21). Some of the finegrained detrital sediment might have come from highlands far to the northeast, such as the Uncompahgre and San Luis elements of Colorado, as suggested by Sabins (1957, p. 501); but this seems unlikely for interval A because (1) the intervening Defiance and Zuni positive elements were still partly above base level, (2) extensive areas of salt and gypsum accumulated in east-central Arizona (Little Colorado River area), and (3) the south margin of the basin in northeastern Arizona was apparently in central Arizona, far north of the Pedregosa basin (fig. 74).

Strata of interval A in the Pedregosa basin are largely marine. In the Dragoon Mountains (Gilluly, 1956, p. 42 ; fig. 75 , this report) and Whetstone Mountains (Tyrrell, 1957; fig. 75, this report), the lower beds (Earp Formation) contain many intraformational conglomerates and ripple marks, much crossbedding, and alternations of limestone and dolomite, all indicative of deposition in shallow water; the upper beds (Colina Limestone) are mostly dark-gray to black uniformly thick bedded limestone containing mollusks and echinoids. These deposits are apparently not normal marine. They accumulated in relatively quiet water under slightly reducing conditions (Tyrrell, 1957). Farther east, rocks of interval $\mathbf{A}$ contain less detrital material, less dolomite, but a more open-sea fauna. Westward, in the Empire Mountains (fig. 75), the rocks are largely detrital (Bryant, D. L., 1955), which suggests proximity to the west edge of the basin.

In northwestern New Mexico the southern part of the Permian San Juan basin contains red beds of the Abo (south) and Cutler (north) Formations, which are believed to have been deposited on flood plains (Wood and Northrop, 1946). These formations are very sandy near the Zuni and Defiance positive elements (fig. 72), which were probably local sources. Most of the fine-grained red detritus of this basin, however, must have been washed southwestward by streams from the Uncompahgre and San Luis positive elements in Colorado (Baker and Reeside, 1929).

In the basin of northeastern Arizona west of the Defiance positive element, red beds (Cutler, Supai), like those in New Mexico, extend southward from Utah. These red beds are largely mudstone in the east half and sandy mudstone to muddy sandstone farther west $(I-450, \mathrm{pl} .3)$. An increase in sand toward the northwest suggests transport from that direction, as do the mean dip directions of crossbedding in the Supai Formation of Grand Canyon (McKee, 1940 , p. $820-823$ ). The original source, however, may have been in the Uncompahgre positive element.

$A$ second source of detritus in interval $\mathbf{A}$ was probably to the southwest adjoining an area of high sand content near the south margin of the basin (I-450, pl. 3). Eastward, in the southeastern part of the basin, a mudstone sequence includes many evaporite beds, especially salt (fig. 80).

Red beds of interval A (Supai Formation) extend westward across the positive area of Mississippian rocks (eastern Grand Canyon) and intertongue with carbonate rocks (upper part of Callville Formation (Pakoon of McNair)). Here they form shelf deposits which thicken westward toward a geosyncline.

Cross-stratification is conspicuous in rocks of interval A in northwestern Arizona; dips are mainly to the south or southeast, as in Supai rocks farther east. 
This dominant dip direction is away from, rather than toward, a supposed seaway in southern Nevada. McNair $(1951$, p. 532) suggested that these crossbeds were formed in a marine mudflat environment marginal to the sea. The mudflats were repeatedly flooded by marine waters and periodically covered with sand introduced by marine currents. Much of the stratification, however, is of large-scale deltaforeset type, very different from that of tidal flats. Moreover, these rocks contain tracks of land animals and are associated with beds that contain land plants.

A notable exception to the uninterrupted sedimentation of Late Pennsylvanian and Wolfcamp time is in southernmost New Mexico (southern Sacramento Mountains and Hueco Mountains, fig. 75), where rocks of early Wolfcamp age are missing and both Abo and Hueco lie with angular unconformity on rocks of Pennsylvanian and earlier age (Pray, 1949, p. 1914; Pray, 1954, p. 101; Kottlowski and others, 1956$, p. 49,76$)$. In the northern Hueco Mountains for example, 1,200 feet of Pennsylvanian rocks is recorded (Hardie, 1958, p. 44) ; but in nearby areas, Ordovician strata underlie Permian (Kottlowski, 1958, p. 80). This unconformity indicates that uplift and erosion occurred here very late in Pennsylvanian or early Wolfcamp time.

Many areas in which strata of interval $\mathbf{A}$ lap onto long-established positive elements, such as the Pedernal (Willis, R., 1929, p. 1028), Zuni (Darton, 1928), and Defiance (Darton, 1925, p. 85), show no evidence of renewed uplift in the early part of Permian time, but rather a continuing degradation and burial throughout the time of interval A. The history of the Late Pennsylvanian "Florida Island" in southwestern New Mexico is less certain, however, as Pennsylvanian rocks are thin or absent nearby (Thompson, M. L., 1942, p. 16, 20). The rocks were perhaps removed by erosion during the early part of Permian or latest Pennsylvanian time (Kottlowski, 1958, p. 79, 83), presumably as a result of uplift. Here the Hueco lies unconformably on Mississippian strata (Bogart, 1953, p. 27).

\section{PALEOTECTONIC IMPICATIONS}

Throughout nearly all the Arizona-western New Mexico region, tectonic activity of interval A was a continuation of what had originated during the Pennsylvanian. All six principal negative areas continued to sink, as indicated by moderate thicknesses of Wolfcamp age strata; and bordering positive elements remained high enough to form barriers and furnish some sediment. Tectonism was probably more active in early than in late Wolfcamp time, for the Bursum and its equivalents are more locally distributed than the later units in the Sacramento and Hueco Mountain areas (L. C. Pray, written commun., 1961).

Regressions of the sea are recorded in the upper part of the Supai or Pakoon of northwestern Arizona (McNair, 1951, p. 524), in the Big "A" Member of the Supai in east-central Arizona (Winters, 1963), in the Earp of southern Arizona (Tyrrell, 1957), in the Abo and Hueco sequence of southern New Mexico (Thompson, M. L., 1954, p. 17), and in other rocks in other areas. They were caused by great influxes of continental sediment, so that although marine deposition was restricted in most places, areas of deposition were more extensive than before, and in many places the sediment lapped against positive elements.

In north-central Arizona (eastern Grand Canyon area), stratigraphic relations are distinctive. The Supai Formation rests with erosional unconformity and in one place-Tanner trail (McKee, in a paper in preparation on Redwall Limestone)-with angular unconformity on rocks of Early Mississippian age. Stratigraphic relations in this area suggest uplift before or early in Pennsylvanian time, rather than at its close. The absence of Pennsylvanian strata may therefore be the result of nondeposition rather than erosion.

\section{INTERVAL B FORMATIONS INCLUDED}

In Arizona and western New Mexico seven separate sequences of interval B are recognized, but they did not all form in separate depositional basins or shelves.

On the Northwestern shelf of the Delaware basin, in southeastern New Mexico, interval B includes, in ascending order, the "Abo" of the subsurface, the Yeso Formation, and the Glorieta Sandstone (table 1, col. 13). The "Abo," mixed dolomite and mudstone, contrasts with the relatively pure limestone in the thick sequence below. This formation is of Leonard age, on the basis of fusulinids examined by the Paleontological Laboratory, Inc., Midland, Tex. (commercially prepared reports by R. V. Hollingsworth) and is believed to have no direct relation to the Abo of the type section of interval $A$.

The thick San Andres Limestone of the Northwestern shelf is placed in interval $C$ rather than $B$ because fusulinids indicate that it is mostly, if not entirely, of Guadalupe age in this area. The presence of Perrinites in its lowest part suggests Leonard age (Boyd, 1956), but even this part may be younger. The entire sequence, therefore, is mapped as a unit.

In south-central New Mexico, north of the Diablo platform (fig. 7), interval B includes the Yeso For- 
mation, the Glorieta Sandstone (in the north only), and the San Andres Limestone. Because the Pedernal positive element had ceased to form a barrier by the time of interval $B$, these formations extend eastward onto the Northwestern shelf area with little change in lithology. The relatively thin San Andres in south-central New Mexico has been placed in interval $B$ rather than $C$ because its fossils indicate Leonard age (Bates, 1942, p. 37; Kottlowski and others, 1956 , p. 59).

On a wide shelf that covered much of northwestern New Mexico and northern Arizona, at least four different sets of formations of interval B are represented. In west-central New Mexico, where the Zuni positive area had been high during deposition of the underlying interval, the Yeso, Glorieta, and San Andres Formations are recognized. In the Defiance area of northeastern Arizona and northwestern New Mexico the interval comprises the De Chelly Sandstone and its lateral equivalent, the Coconino Sandstone. In east-central Arizona the interval is formed by the upper part of the Supai Formation, including the Fort Apache Limestone Member, the Coconino Sandstone, and the Kaibab Limestone. Finally, in the Grand Canyon region of northwestern Arizona, interval B consists of the Hermit Shale, Coconino Sandstone, Toroweap Formation, and Kaibab Limestone.

The age of rocks in various parts of this wide shelf is known with varying degrees of certainty. In the Defiance area, for example, the upper part of the De Chelly Sandstone is certainly of Leonard age, as shown by stratigraphic position and lateral equivalents; the lower part, separated from the upper by a tongue of Cutler (Read and Wanek, 1961), is placed in interval B, in the absence of faunal or other definitive evidence of age.

In east-central Arizona the lowest rock of interval B, the Fort Apache Limestone Member of the Supai, has been dated as Leonard on the basis of brachiopods (Winters, 1963), yet the underlying red beds included in interval A may also be at least partly of Leonard age.

In northwestern Arizona, near the Cordilleran geosyncline, Leonard age is indicated by fossils in the lowest and highest units-fossil plants in the Hermit Shale (White, C. D., 1929, p. 38-40) and brachiopods in the Kaibab Limestone (McKee, 1938, p. 170-171). Plants have been found in the Hermit Shale only in the relatively thin eastern sections, however.

Leonard age of the Hermit Shale is further suggested by a specimen of the Hermit species, Callipteris arizonae, that has been collected by Humble Oil Co. geologists from the Bone Spring Limestone of Leon- ard age in southeastern New Mexico (C. A. Arnold, written commun., 1959).

In southeastern Arizona and southwesternmost New Mexico, including the north end of the former Sonoran geosyncline and part of a shelf to the west, there is a sequence of formations very different from any other in the region. In this area, units of Leonard age are, from bottom to top, the Epitaph Dolomite, Scherrer Formation, Concha Limestone, and Rainvalley Formation. The uppermost part of the Colina Limestone, although probably also of Leonard age (J. Steele Williams, in Gilluly, 1956, p. 49), is included with rocks of interval A because it is thin and cannot be readily distinguished from the rest of the formation. The highest rocks included in interval B (Rainvalley Formation) may be of Guadalupe age as suggested by the presence of certain fusulinids (Bryant, 1955).

In southwestern Arizona, rocks assignable to interval $B$ have been recognized in only a few places. In the Harquahala Mountains, straw-colored crossbedded quartzitic sandstone, overlain by limestone containing a Dictyoclostus bassi fauna, suggests correlation with the Coconino and Kaibab sequence farther north (McKee, 1951, p. 487). In the New Water Mountains, Cretaceous conglomerate contains large boulders of fossiliferous limestone resembling Toroweap and Kaibab (McKee, 1947, p. 290-291). These occurrences suggest that the Permian sequence of the Grand Canyon probably once extended across much of western Arizona.

\section{UPPER BOUNDARY OF INTERVAL B}

Rocks of interval $B$ form the surface of the region throughout large parts of Arizona and western New Mexico, but in some areas they are covered unconformably by Triassic or Cretaceous strata (I-450, pl. 8).

On the Northwestern shelf of the Delaware basin to the southeast, the San Andres Limestone, mostly or entirely of Guadalupe age and assigned to interval $C$ in that area, rests conformably on rocks of interval B. At several isolated localities in central New Mexico, the Bernal Formation of post-San Andres age overlies rock of Leonard age (Smith, C. T., and Budding, 1959; G. A. Bachman, written commun., 1961) and is placed in interval C.

In southern Arizona, the uppermost rock of the Permian sequence, possibly of Guadalupe age, is not placed in interval $\mathrm{C}$ because the age assignment is very questionable (Tyrrell, 1957; Bryant, D. L., and McClymonds, 1961, p. 1333). This rock is covered unconformably by Cretaceous strata. 


\section{THICKNESS TRENDS}

Trends in thickness of interval B are relatively uniform. Strata deposited in shelf areas form wedges ranging in thickness from a thin edge to as much as 2,000 feet; in the bordering Sonoran and Cordilleran geosynclinal areas and Delaware basin, thicknesses of 2,500-3,000 feet are attained.

In large parts of the region, interval $\mathrm{B}$, like interval A, either is absent or its thickness is greatly reduced as a result of erosion. Only in the southeasternmost area, in New Mexico, is the original thickness preserved beneath a comformable cover of interval C. In northern Arizona and northwestern New Mexico, however, stratigraphic evidence indicates that very little of interval B was removed by pre-Lower Triassic erosion.

In addition to southward thinning through erosion along the south margin of the northern Arizona-New Mexico plateau, interval $B$ has been reduced in thickness and, in places, entirely removed across the summits of positive elements such as Defiance and Zuni. In southern Arizona and southwestern New Mexico, furthermore, it is restricted to outcrops of sections, mostly incomplete, in scattered mountain ranges.

\section{STRUCTURAL FRAMEWORK}

The pattern of interval $B$ isopachs differs greatly from that of interval A. Most of the positive elements that had previously partitioned the area into many small basins were no longer topographically prominent, so that large bodies of detrital sediment were spread across the former barriers and independent basins alike. Elsewhere seas advanced beyond their earlier margins across a flat terrain.

The shelf sloping eastward and southward from the center of New Mexico (I-450, pl. 4, sections $O-O^{\prime}$, $N-N^{\prime}$ ) passes over the site of the ancient Pedernal positive element but was apparently unaffected by it; rocks of interval $\mathrm{B}$ thicken across it at a constant rate from 1,000 to 3,000 feet. Its southeast margin bordering the Delaware basin, unlike that of other intervals, is not marked by a belt of abrupt thickening. Thinning of interval B rock (fig. 81) toward the south across the shelf is caused by late erosion that has cut progressively deeper in that direction.

On the wide shelf of northwestern New Mexico and northern Arizona, interval B forms a wedge that thickens southwestward. It is a few hundred feet thick along the Arizona-Utah boundary; southward in both New Mexico and Arizona it attains maximum thicknesses of more than 1,500 feet. The isopach pattern (fig. 81) is complex, however, for locally much rock of interval $B$ has been removed by late erosion. For example, on the Defiance and Zuni uplifts (fig. 72) interval $B$ is absent, and structurally high Precambrian rock is now exposed at the surface. Sections across these areas show that a considerable thickness of interval $\mathrm{B}$ originally covered the Precambrian rock.

In western New Mexico the position of the original south margin of the shelf is obscure because in the critical area most of the record is concealed by Tertiary volcanic rock. South of the volcanic field, Permian rock is absent, probably because of pre-Cretaceous erosion. In Socorro and Torrance Counties to the northeast, thickness trends suggest a tectonic high extending northeast-southwest. This belt of relatively thin interval $B$ separates the northwestern New Mexico shelf from that to the southeast adjoining the Delaware basin.

In eastern Arizona, shelf strata increase in thickness southward and southwestward to 1,800 feet in east-central Arizona. Beyond this maximum, thinning (fig. 81) results from recent erosion of interval B. Farther south for a distance of 100 miles all Permian rock has been stripped away; but in southernmost Arizona and in southwestern New Mexico scattered outcrops of interval $B$ are more than 1,700 and 2,500 feet thick, respectively. These thick remnants of geosynclinal strata were probably once continuous with shelf strata of northeastern Arizona.

In northwestern Arizona, thickness increases southwestward at a rather uniform rate toward the Cordilleran geosyncline. This region is indefinitely separated from the depositional shelf in northeastern Arizona by an arch or positive element in the eastern Grand Canyon area (fig. 81); this positive area had also been prominent during interval $\mathrm{A}$. It formed along a belt where Mississippian rock directly underlies Permian.

The north end of the Sonoran geosyncline, represented by a thick section of interval B in southeastem Arizona, extends southward across the State of Sonora, Mexico, where fusulinids indicate that a considerable thickness of Permian limestone is probably of Leonard age (Imlay, 1939, p. 1732; Dunbar, 1939, p. 1745). These rocks are exposed in three sections about 70 miles south of the international boundary at the Arizona-New Mexico line. At nine other localities, 160-260 miles south of the border, there are other rocks of probable Leonard age, which are locally fossiliferous (King, R. E., 1939, table 2).

\section{SOURCES AND ENVIRONMENTS}

On the south- and east-sloping shelf of southern New Mexico, sandstone is concentrated (I-450, pl. 4) 

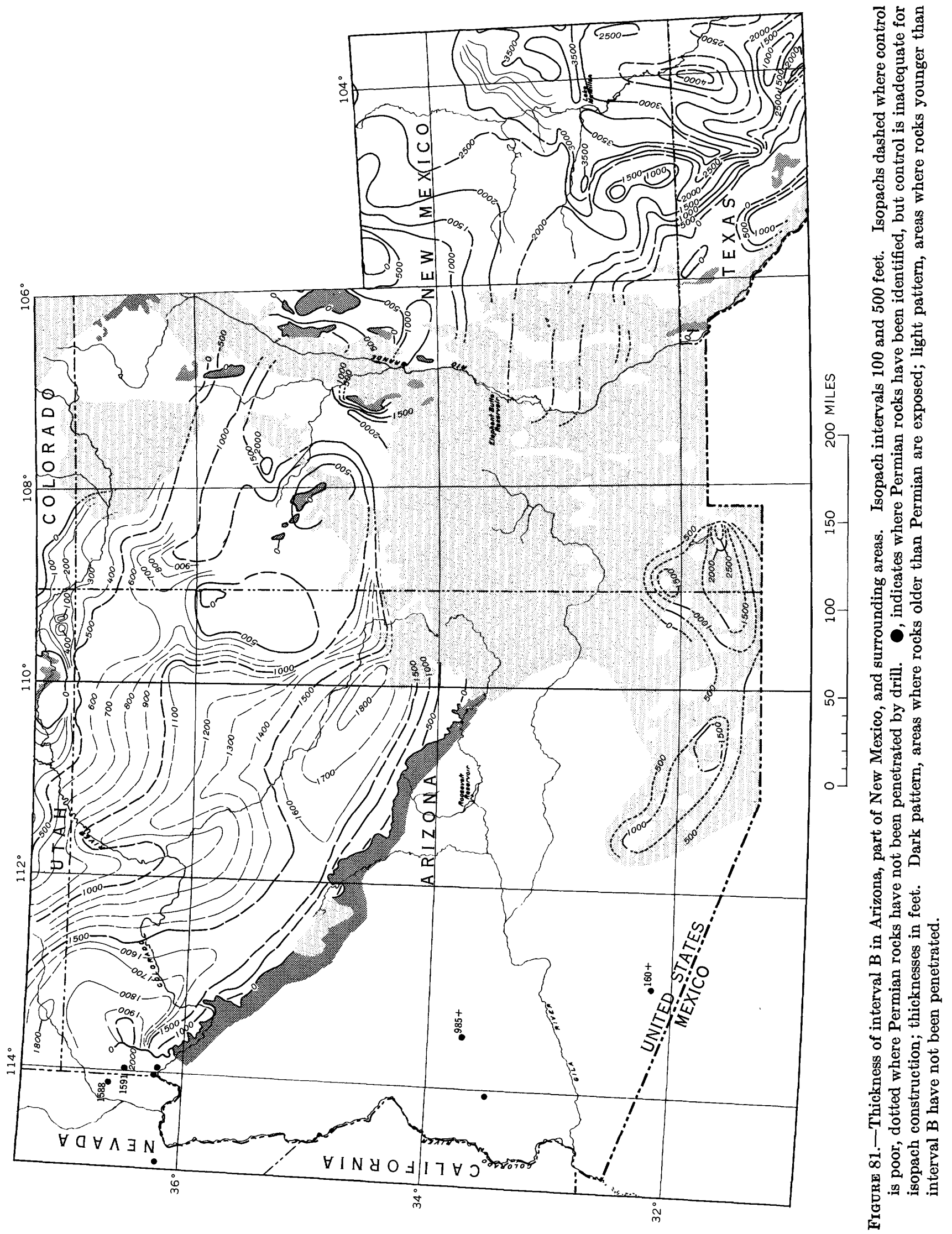
northwestward (central New Mexico). Along the southeast margin of the shelf, carbonate rock dominates. Detrital sediment seems to have been transported from northwest to southeast; the lithofacies pattern in northwestern New Mexico suggests that the principal source was in Utah or Colorado.

In central New Mexico, evaporite rocks are relatively abundant in the Yeso and overlying Permian formations (Kottlowski and others, 1956, p. 53; Tonking, 1957, p. 13 ; I-450, pl. 4). They probably formed in lagoons (Kottlowski and others, 1956, p. 76) adjoining normal marine waters to the south. During succeeding San Andres deposition, marine waters advanced northward and eventually covered the whole area.

The southeast margin of the northern New Mexico shelf is formed by a structural high in central New Mexico. This high separates the northern area from the Northwestern shelf of the Delaware basin. Formational units are continuous, but the total thickness of interval B rock is considerably greater in northwestern than in central New Mexico. This relationship is shown by a belt of thinning $(<1,000 \mathrm{ft})$ in northern Socorro County which separates the northern shelf $(>1,500 \mathrm{ft})$ from the southeastward-sloping shelf $(>2,000 \mathrm{ft})$.

In northeastern Arizona the great mass of sandstone that covers the northern part of the shelf extends south to the south margin of the former Defiance positive element, beyond which mudstone and siltstone, mostly in the lower part of the interval, are relatively more abundant. In the middle part of eastern Arizona, evaporite deposits (largely gypsum) occur near the place of maximum thickness $(1,800$ $\mathrm{ft})$. These deposits indicate that lagoons or other isolated water bodies existed in this area (Winters, 1963). South of the area the record is incomplete because of Tertiary and Recent erosion. Still farther south, all Permian rocks have been removed.

On the shelf in northwestern Arizona a westward decrease in sandstone, an increase in mudstone, and an increase in limestone correspond to a thickness increase from less than 1,000 to more than 2,000 feet. These changes reflect normal shallow-water deposition on a part of the shelf sloping westward toward the Cordilleran geosyncline in Nevada.

The inference of general southward transport across the shelf (fig. 81) is supported by measurements of mean dip directions of foreset slopes in all crossstratified units, regardless of origin. The probably eolian Coconino Sandstone of northern Arizona is formed from sand that was transported southward (Reiche, 1938, p. 916-918; McKee, 1945, p. 315) ; and the water-laid beds of De Chelly Sandstone along the Arizona-New Mexico border have a preferred orientation slightly west of south (Allen and Balk, 1954, p. 64). Cross-stratification in the Glorieta Sandstone, probably eolian, and the earlier water-laid Meseta Blanca Member of the Yeso Formation in the Zuni area, New Mexico, have mean dip directions of southwest and of east to southeast, respectively (Read and Wanek, 1961, pl. 1).

The De Chelly Sandstone has been regarded as a shifting beach and bar deposit (Read, 1951, p. 83), but such an interpretation seems unlikely in view of the steep dips (Thompson, W. O., 1937, p. 731-735) and of the average dip direction, which is opposite to that which would be expected in offshore bars (McKee and Sterrett, 1961, p. 26). This formation probably originated as deltaic deposits with steep foresets to seaward.

Carbonate rock constitutes a major part of the few preserved remnants of interval $B$ in southeastern Arizona $(\mathrm{I}-450, \mathrm{pl} .4)$, but sandstone is dominant in the western part of the area. These rocks, largely of marine origin, were probably originally continuous with the dominantly evaporite-mudstone sequence in central Arizona, but the rocks between have been removed by erosion.

Detrital sediment in southern Arizona may have come from the north or northeast (Sabins, 1957, p. 501). A western or northwestern source seems more probable, however, because of a higher proportion of sand in western than in eastern sections and because sand from the north would have had to cross a broad area of gypsum and mud deposits in central Arizona.

Seas progressively advanced from several directions to reach a maximum expansion during deposition of the upper part of interval B (I-450, pl. 4, sections $\left.L-L^{\prime}, N-N^{\prime}\right)$. The greatest marine advance is represented by the San Andres Limestone in northwestern New Mexico, the Concha Limestone in southern Arizona, and the Toroweap Formation and Kaibab Limestone in northwestern Arizona.

\section{PALEOTECTONIC IMPLICATIONS}

Strata of interval B (fig. 81) in Arizona and western New Mexico represent three principal areas of accumulation: (1) the western part of a shelf in south-central and southeastern New Mexico, sloping east and south, (2) a wide shelf extending across northern Arizona and northwestern New Mexico, sloping toward geosynclines to the south and west, and (3) the north end of the Sonoran geosyncline in southeastern Arizona and southwesternmost New Mexico. Parts of a shelf adjoining the Sonoran geo- 
syncline to the west are poorly represented in southwestern Arizona.

Rocks of interval B in Arizona and western New Mexico preserve the record of seaways that were generally transgressive from the southeast, south, and west, and that ultimately covered major parts of both States. Marine waters were excluded only from northwesternmost New Mexico and northeastern Arizona, where detrital sediments introduced from the north kept pace with regional sinking. . Both carhonate and evaporite deposits were prominent wherever terrigenous sediments were scarce.

Positive elements such as the Pedernal, Zuni, and Defiance, which during Pennsylvanian and earliest Permian time had strongly influenced local sedimentation, were nearly or entirely absent when interval $B$ began àccumulating. Throughout most of the region, two or more marine transgressions took place, interrupted by minor regressions (fig. 82). The last transgression was the most extensive (San Andres, Concha, and Kaibab Limestones).

The great transgression of interval B time was followed by a general withdrawal of seas from the entire region west of central New Mexico-the result of cessation in downwarping along the shelves between western New Mexico and southern Nevada. The youngest Permian deposits of the region, preserved beneath the pre-Triassic unconformity, consist of red beds, dolomite, and gypsum and are interpreted to be regressive sediments (McKee, 1938, p. 43; Tyrrell, 1957). No trace of post-Kaibab Permian rock is reported from northwestern New Mexico or northern Arizona. That strata of interval C-D might have been deposited in this area but later removed during pre-Moenkopi erosion seems doubtful. Even where deep channels were cut during this erosion (McKee, 1938 , p. 58), no rocks younger than Kaibab occur in the interchannel areas.

Tectonic activity in the Arizona-western New Mexico region during deposition of interval $B$ may be summarized as a gradual and widespread sinking of the surface, probably in a series of stages, but sufficiently rapid at times to permit major advances of the sea. Meanwhile land-derived sediments, both fluviatile and eolian, were constantly introduced from the north. They blocked the advance of the seas in that direction and largely covered the shelves. Deposition was apparently terminated near the close of Leonard time partly because the source areas ceased furnishing detrital material and partly because regional sinking had ended. Slight uplift of the region occurred either then or relatively soon after to permit a channeled surface to form between the upper-

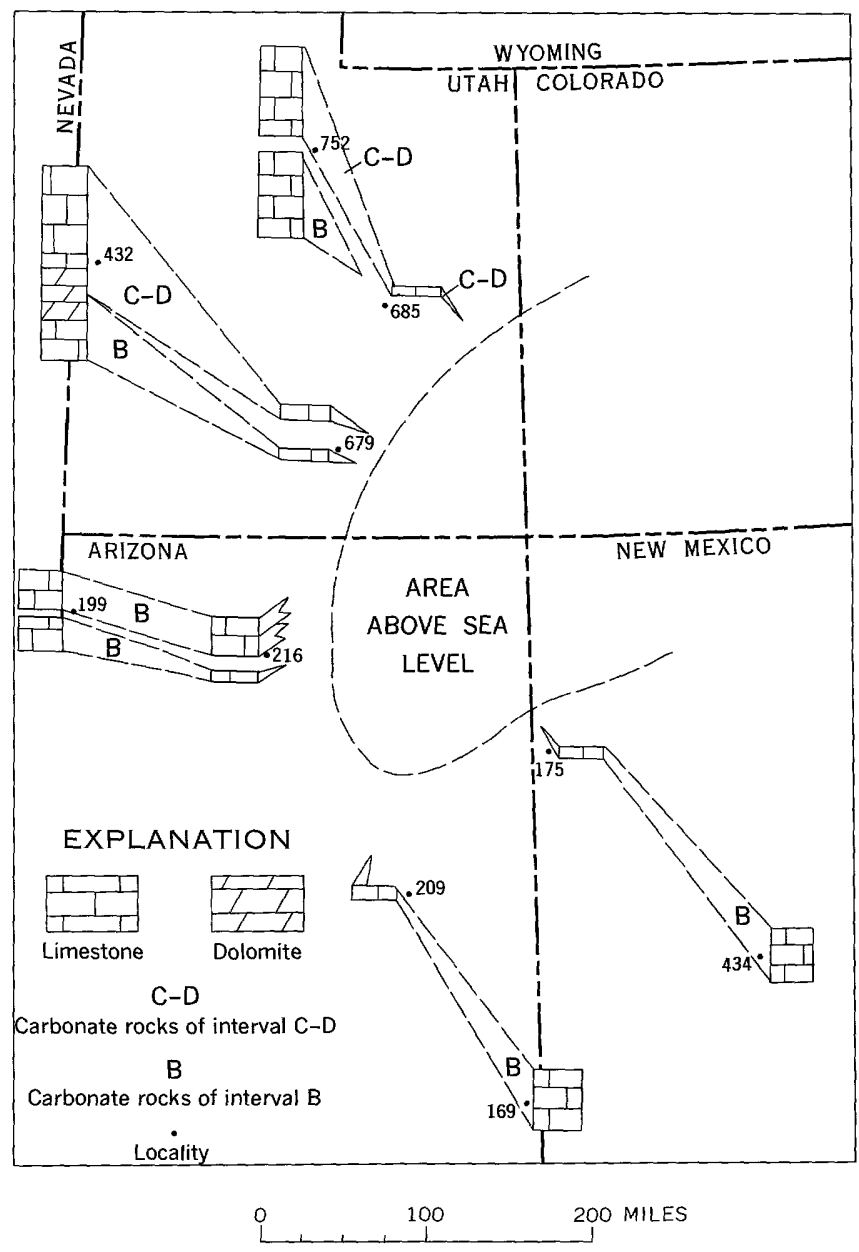

Figure 82.-Transgressive deposits of intervals $\mathrm{B}$ and $\mathrm{C}-\mathrm{D}$ as shown by carbonate rocks in Utah, Arizona, and western New Mexico.

most Permian and lowest Triassic rocks (McKee, 1954b, p. 33-36).

\section{INTERVAL C-D DISTRIBUTION}

Rocks of interval C-D, represented by a great thickness of strata in the Delaware basin of southeastern New Mexico and elsewhere to the south and east, are missing in western New Mexico (fig. 83). The San Andres Limestone, which attains a thickness in excess of 1,300 feet on the Northwestern shelf of the Delaware basin, is considered to be largely (Boyd, 1958, p. 65-67; Hayes, 1959 , p. 2197) or entirely (Jones, T. S., 1953, p. 38) of Guadalupe age in that area, whereas in western New Mexico the thin remnants of this formation are generally believed to be of Leonard age (Needham and Bates, 1943, p. 1666; Kottlowski and others, 1956, p. 60). Thus, although in southeastern New Mexico the San Andres is assigned to 


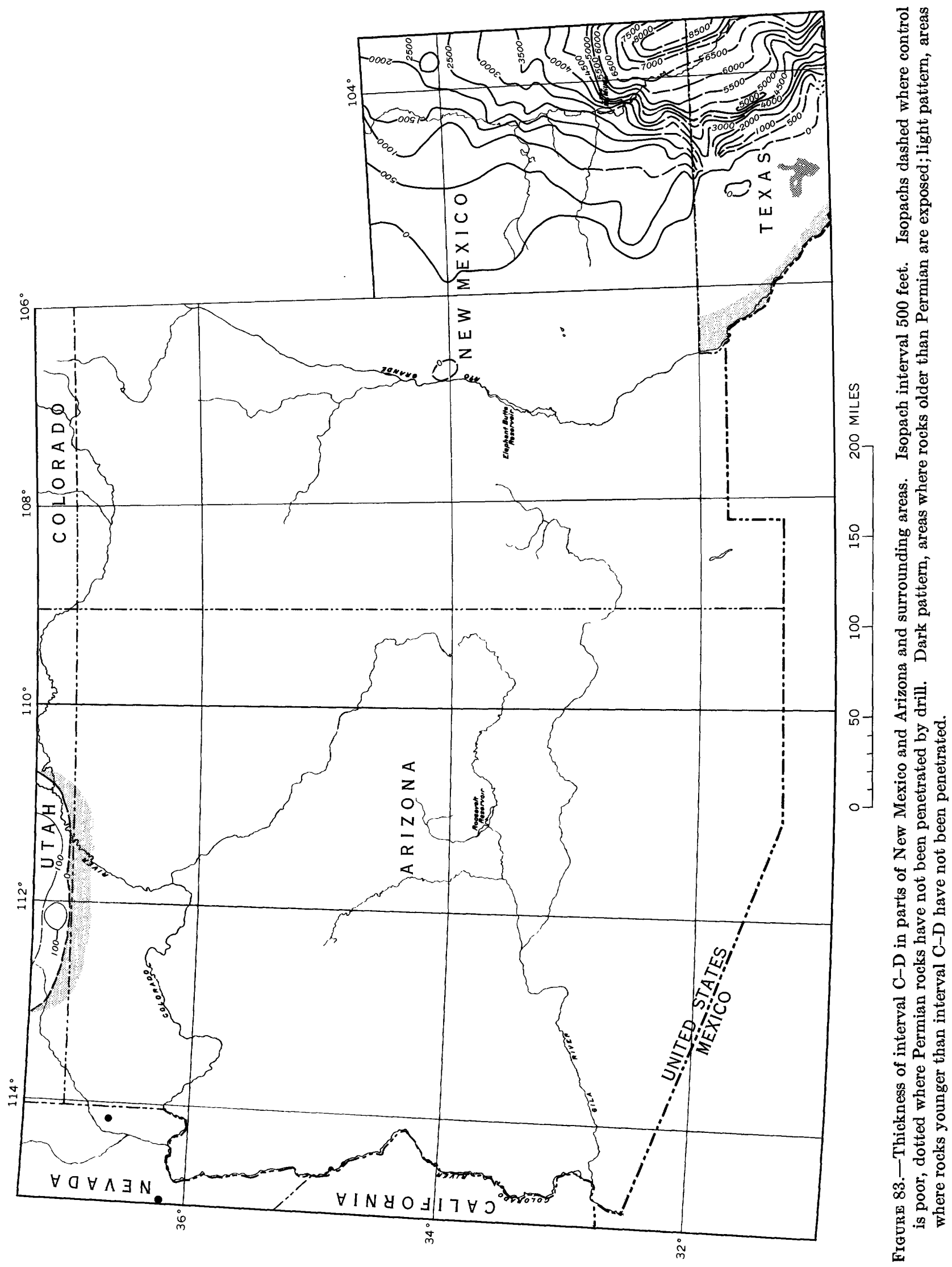


interval C-D, this formation is placed in interval B west of an arbitrary line near the middle of the State, where it is very thin.

In central New Mexico, as far west as the vicinity of Socorro, interval C-D is represented by the Bernal Formation, which overlies the San Andres. This formation is shown as " 200 to over 300 feet" thick in the Little Black Peak quadrangle (Smith, C. T., and Budding, 1959) and about 216 feet thick north of Bent, N. Mex. (G. O. Bachman, written commun., 1961). Rocks probably equivalent to the Bernal Formation in other parts of central New Mexico include the 5-36 feet of the upper member of the San Andres Limestone in the area east of Socorro (Wilpolt and Wanek, 1951, graphic sections) and 354 feet of strata east of the Capitan quadrangle, New Mexico, referred to as Bernal but listed as Triassic (W. C. Colbert, in Allen and others, 1951, strat. section).

In southeastern Arizona the thick Permian sequence near the top of the interval contains some fusulinidbearing strata that may be of early Guadalupe age (Bryant, 1955, p. 9; Bryant and McClymonds, 1961, p. 1333) but are more likely of late Leonard age (Tyrrell, 1957). Because of this uncertainty regarding age, none of the Permian rocks of this area are assigned to interval $\mathrm{C}-\mathrm{D}$.

Rocks of definite Guadalupe age occur near Caborca in northwestern Sonora, Mexico (Cooper, G. A., and Arellano, 1946, p. 610), and represent the closest recorded approach of this interval to southern Arizona. They are more than 1,500 feet thick; they contain Parafusulina near the base (C. O. Dunbar, in Cooper, G. A., and Arellano, 1946, p. 610) and Waagenoceras dieneri near the top (Miller, A. K., 1945). The northern limits of the seaway in which , this section formed are not known.

\section{TOTAL THICKNESS OF PERMIAN ROCKS THICKNESS TRENDS}

The map showing total thickness of Permian rocks (fig. 84) in Arizona and western New Mexico closely resembles that of interval A for the same region. The pattern consists of a group of elliptical areas, each containing a relatively thick sequence of rock and separated from other thick sequences by elongate belts of thin Permian rock or by areas in which Permian rock is absent. The summary map includes, in this region, only rocks of intervals $A$ and $B$; those of interval $B$ are not sufficiently irregular in thickness to obscure the pronounced extremes of interval A formed by strongly positive areas separating basins and shelves.
Maximum thickness of Permian rocks in each principal geographic unit is as follows:

\begin{tabular}{|c|c|}
\hline \\
\hline & \\
\hline \multicolumn{2}{|c|}{$\begin{array}{l}\text { Southeastern New Mexico } \ldots \ldots \ldots \\
\text { South-central New Mexico } \ldots \ldots \ldots\end{array}$} \\
\hline Northwestern New Mexico & 2,000 \\
\hline Southeastern Arizona & 4,500 \\
\hline Northeastern Arizona....... & 2,400 \\
\hline entral Arizona. & 2,700 \\
\hline western Arizona & \\
\hline
\end{tabular}

Permian rocks in intermediate areas are thinner than in those listed above primarily because positive elements persisted between basins during interval A. Furthermore, in some positive areas, thickness was greatly reduced by erosion following late uplift. Examples are the Zuni, Defiance, southern part of the Pedernal, and southwestern New Mexico ("Florida Island") areas. In all these localities the present thickness of Permian rocks is much less than the original thickness. Furthermore, in two broad areas-one in southwestern Arizona and the other near the Arizona-New Mexico boundary south of the midpoint-original Permian trends have been destroyed or obscured by recent erosion or by volcanic cover.

\section{PALEOTECTONIC IMPLICATIONS}

A record of paleotectonic activity in Arizona and New Mexico during Permian time can be deduced from the total isopach map. The sequence of events begins with deposition on an irregular regional surface interrupted by positive elements high enough to form barriers between, and to furnish some sediment to, adjoining shelves and basins. The influence of the local structural highs progressively diminished and finally disappeared as a result of erosion and burial by sediments, but downwarping on a regional scale continued until near the end of Leonard time, so that a thick blanket of sediment covered virtually the entire region. This deposition ended with a very moderate uplift that permitted minor channeling and subaerial erosion prior to Triassic time.

\section{GEOLOGIC UNITS DIRECTLY ABOVE PERMIAN SYSTEM UNITS OVERLYING PERIMIAN}

Permian rocks throughout most of northern Arizona, except where exposed by recent erosion, are overlain by the Moenkopi Formation of Early and Middle(?) Triassic age (I-450, pl. 8). In northeasternmost Arizona and in most of northwestern New Mexico, where the Moenkopi is absent through nondeposition (McKee and others, 1959, p. 7), rocks of the Chinle Formation of Late Triassic age rest directly on Permian. Thus, an unconformity representing a hiatus from late Leonard to a time ranging from mid- 


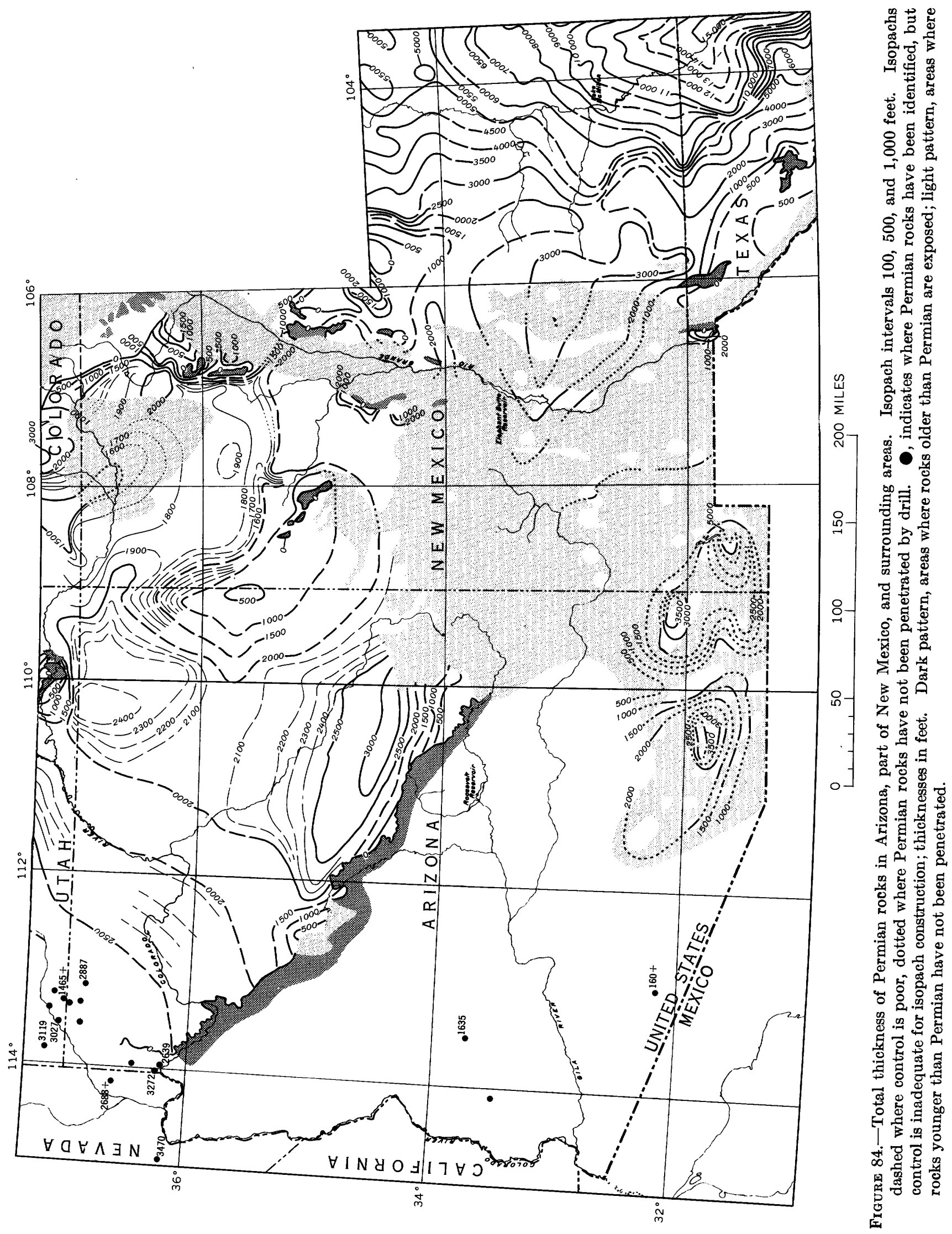


dle Early Triassic to early Late Triassic is recorded in these areas.

In southern Arizona, Permian rocks are covered by Lower Cretaceous strata of the Bisbee Group, especially the Glance Conglomerate; whereas farther east, in southwestern New Mexico, they are overlain by younger Cretaceous rocks (Harley, 1934, p. 28), including the Dakota Sandstone. Still farther east Permian strata are exposed at the surface across a wide area extending into southeastern New Mexico, where the Upper Triassic Dockum Group overlies them. The hiatus in most parts of southern Arizona and New Mexico, therefore, is much greater than to the north, and a pre-Late Cretaceous structural high is represented locally (Elston, W. E., 1958, p. 2514).

\section{PALEOTECTONIC IMPLICATIONS}

Intervals $\mathbf{A}$ and $\mathbf{B}$ record a series of widespread negative movements in the Arizona-western New Mexico region. At times, the introduction of detrital sediment did not keep pace with the sinking, however, and carbonate sediment covered successively larger parts of the region. Near the close of Leonard time the region was low, but widespread sinking apparently ceased and regression of the seas resulted.

Regression was probably accomplished by slight uplift rather than by filling of the basin. Its record consists of residual deposits-a thin sequence of red beds, dolomite, and gypsum in the uppermost part of the Kaibab of northern Arizona (McKee, 1938, p. 50) - and of a correspondingly small amount of detrital sediment and dolomite in the Rainvalley Formation of southern Arizona (Tyrrell, 1957). Regional upwarping probably ended sedimentation and initiated channel cutting and other erosion on the Permian surface prior to middle Early Triassic (Moenkopi) time. This record is preserved as an uncomformable surface (Dake, 1920, p. 66-74; Longwell, 1925 ; McKee, 1938, p. 54-56; McKee, 1954b, p. 33-36). In western New Mexico, karst topography formed on the San Andres Limestone before Late Triassic deposition (Tonking, 1957, p. 12). 



\section{Paleotectonic Investigations}

of the Permian System

in the United States

Chapter $K$. West Coast Region

By KEITH B. KETNER

GEOLOGICAL SURVEY PROFESSIONAL PAPER 515-K

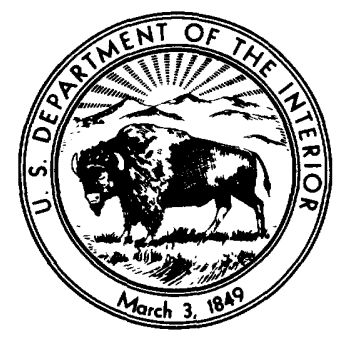





\section{CONTENTS}

Abstract

Region defined

Paleogeology

Units underlying Permian

Lower boundary of Permian.

Paleotectonic implications.

Interval A.

Formations included and upper boundary of interval A

Thickness and lithofacies trends

Paleotectonic implications _.

Interval B.

Formations included and upper boundary of interval B.
229

229

229

229

229

230

230
Interval B-Continued

Thickness and lithofacies trends_._.

Paleotectonic implications.

Interval C-D_.

Formations included and upper boundary of interval C-D_... 235

Thickness and lithofacies trends _...

Paleotectonic implications _... 237

Total thickness of Permian rocks

Geologic units directly above Permian System..... 237

Units above the Permian. 237

Paleotectonic implications. 238

\section{TABLES}

TABLE 1. Strata directly underlying the Permian

2. Formations and upper boundary of interval $A$

3. Formations and upper boundary of interval $\mathrm{B}$

4. Formations and upper boundary of interval C-D 



\title{
PALEOTECTONIC INVESTIGATIONS OF THE PERMIAN SYSTEM IN THE UNITED STATES
}

\section{WEST COAST REGION}

\author{
By KeIth B. Ketner
}

\begin{abstract}
In many places throughout the West Coast region, deposition in a marine environment continued with little or no break from Pennsylvanian into Permian time. In northeastern and southwestern Nevada and northern California, however, the Permian System lies unconformably on beds which range in age from Ordovician to Middle Pennsylvanian.

During Permian time the West Coast region was divided into three paleotectonic parts: an eastern miogeosyncline, a western eugeosyncline, and an intervening tectonic land (Antler orogenic belt) with bordering aprons of detrital material.

The tectonic behavior of a vast region extending from beyond northern Washington at least to southern California is little known. The character of the sparsely exposed Permian rocks in the region, however, suggests that this region was covered by a sea which received sediments derived from emergent lands and from either subaerial or submarine volcanoes. Local beds of limestone, some possibly of reef origin, suggest the existence of shoals. These rocks crop out at scattered localities along a curved belt that may define the configuration of the former eugeosyncline. They are part of a terrane that includes similar eugeosynclinal rocks of Carboniferous and Triassic ages.

Much of the West Coast region was uplifted near the end of Permian time. The general absence of angular unconformity or of deep erosion below Triassic beds suggests, however, that Permian strata may not have been raised much above sea level before deposition of Lower to Upper Triassic sediments.
\end{abstract}

\section{REGION DEFINED}

The West Coast region includes Nevada, California, Oregon, Washington, and part of Idaho. In Permian time it was the site of varied environments including eugeosyncline, miogeosyncline, tectonic lands, and volcanoes which may or may not have projected above the surface of the sea. Unfortunately the sparse stratigraphic data for this immense area permit only a sketchy outline of major paleotectonic events. A synthesis of these data is available in "Paleotectonic Maps of the Permian System" (I-450, pls. 2-8).

\section{PALEOGEOLOGY}

\section{UNITS UNDERLYING PERMIAN}

Table 1 shows the formations on which the Permian System lies in the West Coast region and the position of the base of the system.
TABLE 1.-Strata directly underlying the Permian in the West Coast region

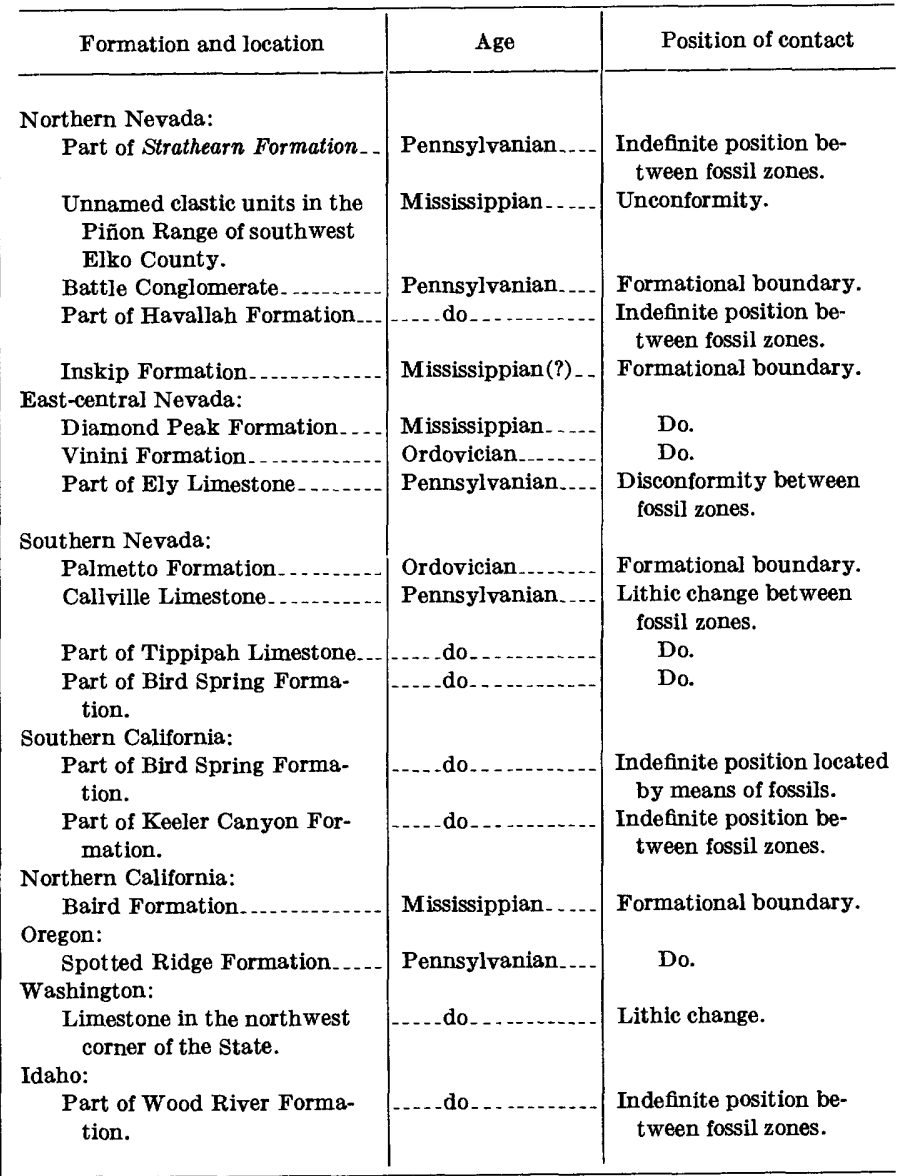

LOWER BOUNDARY OF PERMIAN

In western Elko County, Nev., the Strathearn Formation of Dott (1955, p. 2248) is partly of Pennsylvanian and partly of Permian age. The base of the Permian System lies between zones (below) of $T r i$ ticites cf. T. cullomensis Dunbar and Condra, and zones containing Schwagerina cf. S. providens Thompson and Hazzard and Triticites cf. T. ventricosus (Meek and Hayden), according to Dott (1955, p. 2254). These zones are separated by several hundred feet of beds in which no fusulinids have been 
found; therefore, the exact position of the systemic boundary is unknown.

The base of the Permian System in north-central Nevada is placed within the overthrust Havallah Formation in an interval bracketed by the Middle Pennsylvanian fusulinids, Pseudostaffella sp. and Fusulinella sp., and the Permian assemblage of Schwagerina sp., Schwagerina or Parafusulina sp., Parafusulina sp., and Pseudofusulinella(?) sp. (L. G. Henbest and R. C. Douglass, written commun. to Ralph Roberts, 1953).

The upper part of the Ely Limestone in east-central Nevada is regarded as of Wolfcamp age (Hose and Repenning, 1959, p. 2170-2171; Langenheim and others, 1960, p. 154). The base of the Permian System is generally fixed at a disconformity below the first appearance of Wolfcamp fossils in the Ely.

The base of the Permian System in southernmost Nevada is placed at the contact of the Pakoon Limestone, a dolomitic limestone containing Pseudoschwagerina, Schwagerina, "Rugofusulina," and Triticites, with the underlying Callville Limestone, as described by McNair (1951, p. 525), which is less dolomitic and contains Virgil forms of Triticites. In other parts of southern Nevada the base of the Permian lies somewhere within the Tippipah Limestone. In this paper it is placed at the base of Unit C of M. S. Johnson and D. E. Hibbard (1957, p. 360), which, according to R. C. Douglass (p. 362 in the same paper), is the lowest unit of the Tippipah containing fossils suggestive of Wolfcamp age.

In the Bird Spring Formation, in both southern Nevada and in southern California, the Pennsylvanian-Permian boundary is determined by fusulinid zones. In Nevada the boundary is placed between the Triticites zone and the Schwagerina (Pseudofusulina) zone. Here the faunal break coincides with an upward change from thick-bedded limestone and dolomite to thin-bedded shaly limestone (Longwell and Dunbar, 1936, p. 1202). In two sections in California the boundary is placed at the lowest appearance of Wolfcamp fusulinids. In Inyo County various forms of Triticites and Pseudofusulina mark the base, whereas in San Bernardino County Pseudoschwagerina and many other fusulinids indicate the base.

Within the Keeler Canyon Formation in Inyo County, Calif., the systemic boundary is placed at a faunal change from Pennsylvanian species of Triticites to Permian species of Triticites and Pseudofusulina (Merriam, C. W., and Hall, 1957, p. 6).

In northwestern Washington, detrital beds overlie Pennsylvanian limestone (W. R. Danner, written commun., 1959). The base of the Permian System is tentatively placed at the base of the detrital unit.

In Blaine County, Idaho, Bostwick (1955, p. 947) indefinitely located the base of the Permian below certain Wolfcamp fusulinids and above Pennsylvanian forms.

\section{PALEOTECTONIC IMPLICATIONS}

In many places throughout the region, marine deposition continued with little or no break from Pennsylvanian to Permian time. However, in northeastern and southwestern Nevada and northern California the Permian System lies unconformably on beds which range in age from Ordovician to Middle Pennsylvanian. In many places the age of the rocks under the Permian System is unknown or too uncertain to be shown on the paleogeologic map. Points of unconformity which extend from southwestern to northeastern Nevada probably record the encroachment of Permian seas on remaining ridges of the Antler orogenic belt (Roberts and others, 1958, p. 2825). Large local deposits of coarse detrital material of Permian age along the east border of Eureka County indicate that parts of these ridges remained above sea level throughout Permian time.

A Late Pennsylvanian upheaval in Elko and White Pine Counties and some adjacent parts of Utah resulted in deposition of sediments of Wolfcamp age on Middle Pennsylvanian beds (Dott, 1955, p. 2278; Steele, 1960, p. 98).

\section{INTERVAL A}

\section{FORMATIONS INCLUDED AND UPPER BOUNDARY OF INTERVAL A}

Table 2 shows the formations included in interval $A$ and the upper boundary chosen for the interval.

In the Carlin Canyon area of Elko County, Nev., interval A consists of the upper part of the Strathearn Formation of Dott (1955, p. 2248) and overlying strata described by Fails $(1960$, p. 1696). The upper boundary of rocks of Wolfcamp age as established by Fails is between rock containing fusulinids uncertainly identified as either Schwagerina youngquisti or Schwagerina wallsensis and rock containing the coral Leonardophyllum distinctum.

In the Piñon Range of southwestern Elko County, limestone and coarse detrital beds containing Wolfcamp fusulinids and other fossils have been mapped by J. F. Smith, Jr., and K. B. Ketner. The contact between intervals $\mathrm{A}$ and $\mathrm{B}$ has not yet been determined.

The Antler Peak Limestone ranges in age from Late Pennsylvanian to Early Permian (Roberts and others, 1958, p. 2843); an indefinite thickness is assigned to 
TABLE 2.-Formations and upper boundary of interval $A$ in the West Coast region

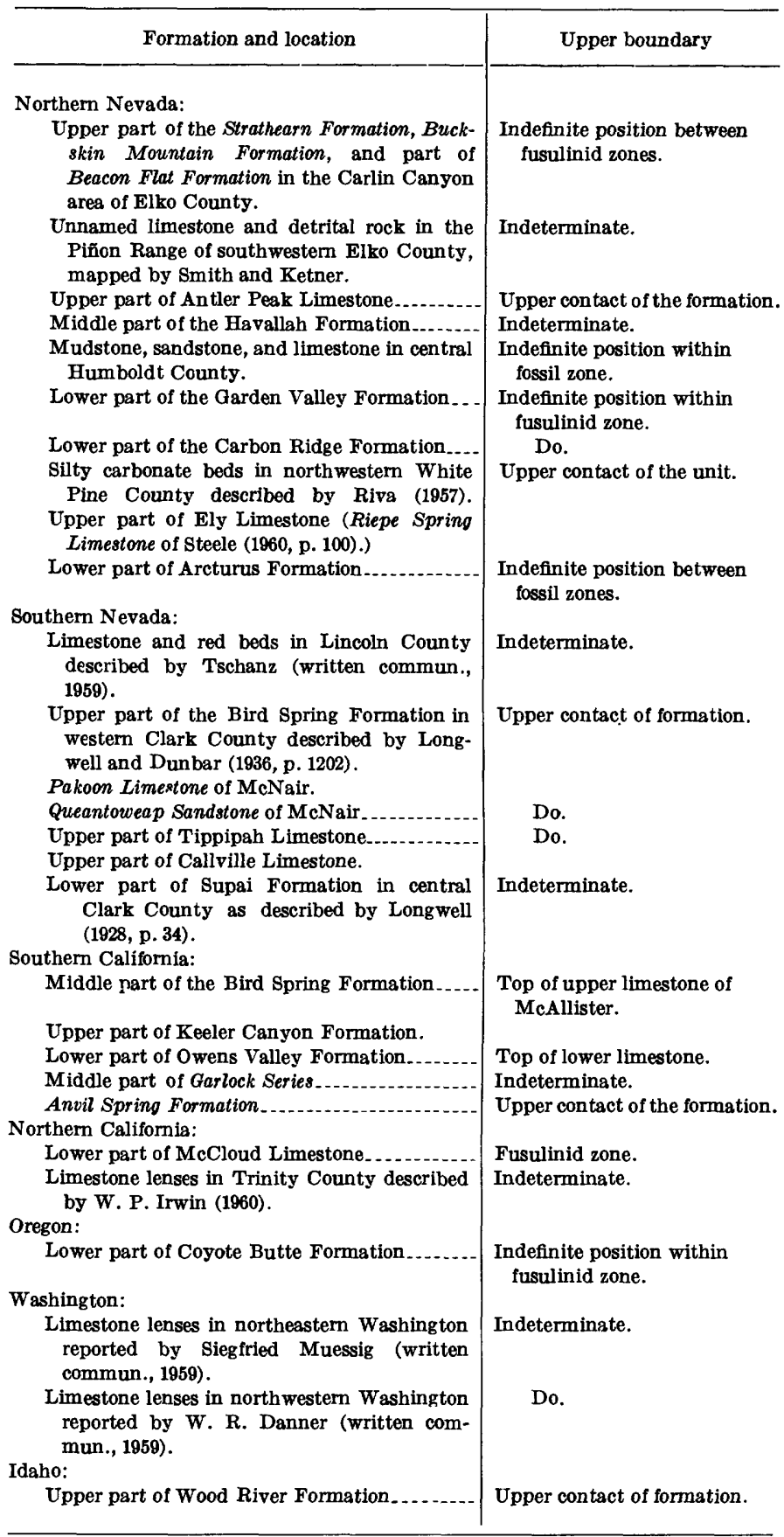

interval A. The top of the formation is considered to be the upper boundary of interval A, although some beds may be of Leonard age.

The Havallah Formation is part of an overthrust sheet in north-central Nevada. In northern Lander County it contains a fauna of Middle Pennsylvanian and Leonard age (Roberts and others, 1958, p. 2848). On the map of interval A, strata of Wolfcamp age are assumed to occur in the Havallah of northern
Lander County and elsewhere. The top, bottom, and thickness of interval $\mathbf{A}$ are indeterminate.

Rocks of probable Wolfcamp age in Humboldt County are of two facies: muddy carbonate rocks probably equivalent to the autochthonous Antler Peak Limestone and mainly detrital rocks thrust into the area from a considerable distance.

Parts of the Carbon Ridge and Garden Valley Formations in southern Eureka County, Nev., are assigned to interval $A$. The Garden Valley was probably thrust from the west (Nolan and others, 1956 , p. 68). Although the presence of beds of Wolfcamp and Leonard age is indicated by fusulinids and other fossils (Nolan and others, 1956, p. 65, 68), contacts between rocks of the two ages have not been exactly located.

In northwestern White Pine County, Nev., unit A of Riva (1957) is assigned to interval $\mathbf{A}$ on the basis of the fusulinids it contains.

Elsewhere' in White Pine County interval A includes the upper part of the Ely Limestone above a widely recognized disconformity, and part of an overlying interbedded sandstone and limestone sequence, best known as the Arcturus Limestone. The upper part of the Ely Limestone was called Riepe Spring Limestone by Steele (1960, p. 100). The name Arcturus Limestone can be applied to all Permian beds above the Ely Limestone that cannot be confidently assigned to other well-established formations. It is used in this way here and is assigned to intervals A, B, and C. Parts of the Arcturus assigned wholly or in part to interval $\mathbf{A}$ have been called Rib Hill Formation (Pennebaker, 1932, p. 164; Langenheim and others, 1960, p. 149), Riepetown Sandstone, Pequop Formation, and Ferguson Springs Formation (Steele, 1960, p. 93). The upper contact of rocks of Wolfcamp age has not been definitely located on the basis of fossils, but is between 1,100 and 2,200 feet above the Ely Limestone, according to Langenheim and others (1960, p. 154).

Sandy limestone beds of Wolfcamp age in northern Lincoln County, described by C. M. Tschanz (written commun., 1959), are assigned to interval A. The thickness of these beds cannot be accurately determined as beds of Wolfcamp age are not readily separable from those of Pennsylvanian and Leonard age that are lithologically similar.

Red beds in southern Lincoln County, Nev., described by Tschanz, are included in interval $A$. Neither the upper nor the lower boundary of interval A has been determined here.

In southernmost Nevada the Pakoon Limestone and overlying Queantoweap Sandstone of McNair 
(1951, p. 524) are included in interval A. His Pakoon Limestone is probably equivalent to the upper part of the Callville and Bird Spring Formations to the west. His Queantoweap Sandstone is probably part of the Supai of others. The contact between the Queantoweap and overlying Hermit Shale is the upper boundary of interval A. In central Clark County, the "Supai Formation" of Longwell (1928, p. 34) is divided between intervals $A$ and $B$. The "Supai" as used in that area included the uppermost part of the Supai Formation and the Hermit Shale of the western Grand Canyon area, of Wolfcamp and Leonard age, respectively.

In southern Nevada and southern California, part of the Bird Spring Formation is considered to be of Wolfcamp age. The upper contact of rocks of Wolfcamp age in western Clark County, Nev., was placed by Longwell and Dunbar (1936, p. 1202), on the basis of preliminary examination of fusulinids, at about the middle of a 2,950-foot sequence of limestone. In this publication the upper contact of interval $\mathbf{A}$ is moved up to the base of the overlying unit called "Supai" by Longwell and Dunbar, but thought to be Hermit Shale (McKee, 1939, p. 314). This position coincides with the top of the upper limestone unit of the Bird Spring of McAllister (1956).

Impure limestone in the upper part of the Keeler Canyon Formation in Inyo County, southern California, is assigned to interval $\mathbf{A}$ on the basis of certain fusulinids (Merriam, C. W., and Hall, 1957, p. 6). Its thickness is unknown owing to the indefinite position of the base of the Permian System. The lower limestone unit of the overlying Owens Valley Formation of Merriam and Hall $(1957$, p. 6) is also assigned to interval $\mathrm{A}$ on the basis of fusulinids. Its thickness is about 1,000 feet.

An indefinite thickness of the Garlock Series in Kern County is assigned to interval $\mathbf{A}$ on the basis of Schwagerina identified by C. W. Merriam. The only fossils obtained were collected from a thin zone 12,000 feet above the base of the series and 24,000 feet below the top. The series consists of volcanic, cherty, detrital, and carbonate rocks. Unlike the volcanic units in some other thick siliceous series of Permian rocks in the west, the volcanic parts of this series are low in the sequence.

In San Bernardino County, Calif., the entire Anvil Spring Formation of B. K. Johnson $(1957$, p. 382) is assigned to interval $\mathrm{A}$, although the lower part is possibly of Pennsylvanian age.

The McCloud Limestone of Shasta County, Calif., is of Wolfcamp and Leonard age. Fusulinids 500980 feet above the base of the McCloud probably bracket the Wolfcamp-Leonard boundary (Thompson, M. L., and others, 1946, p. 22).

In Trinity County of northwestern California, limestone lenses interbedded with slate, greenstone, and chert are tentatively assigned to interval $\mathbf{A}$ on the basis of fusulinids identified by Henbest (in Irwin, 1960, p. 26). The thickness of beds of Wolfcamp age is unknown.

In Crook County, Oreg., the Coyote Butte Formation of C. W. Merriam and S. A. Berthiaume (1943, p. 156) is assigned Wolfcamp and Leonard age, but the boundary between rocks of Wolfcamp and Leonard age cannot be fixed by the fusulinid assemblage present.

In northeastern Washington, limestone lenses of Wolfcamp age in a thick detrital series were reported by J. W. Skinner (written commun. to C. O. Dunbar, 1958). Wolfcamp and Leonard faunas were identified by R. C. Douglass (Siegfried Muessig, written commun., 1959). The relations of dated rocks to each other and to the remainder of the section is not clear, according to Muessig, and therefore the thickness of interval A cannot be given.

In northwestern Washington, on Black Mountain, Whatcom County, limestone beds of Wolfcamp age are in a section of detrital rocks of unknown thickness (W. R. Danner, written commun., 1959; J. W. Skinner, written commun. to C. O. Dunbar, 1958).

\section{THICKNESS AND LITHOFACIES TRENDS}

Interval $\mathbf{A}$ in eastern Nevada and southern California attains thicknesses of at least 2,500 feet. Coarse detrital beds in interval $\mathbf{A}$ in southwestern Elko County and the absence of interval $\mathbf{A}$ along the Antler orogenic belt suggest that the interval thins rapidly to the vanishing point near the boundary between Lander and Eureka Counties. West of this tectonic belt, interval A increases to unknown thicknesses probably comparable to or greater than those in eastern Nevada. In the western area, data on thickness and lithofacies trends and paleogeography are obscured by thrust faulting. Overthrust rocks were deposited an unknown distance generally westward of their present location. An original site of deposition in western Nevada was suggested by Roberts, Hotz, Gilluly, and Ferguson (1958, p. 2846).

A belt of volcanic, cherty, and siliceous detrital rocks extends from northern Washington to southern California. The close juxtaposition of rocks of this belt with carbonates in southern California indicates either a very abrupt facies change or large-scale faulting. 
In Clark County, Nev., red beds grade westward into marine limestone.

\section{PALEOTECTONIC IMPLICATIONS}

The West Coast region is divided into three paleotectonic parts: an eastern miogeosyncline, a western eugeosyncline, and an intervening tectonic land (Antler orogenic belt) bordered by aprons of detritus. In southern and northern California and northwestern Washington there were probably other tectonically active lands shedding detrital sediments, but their positions are unknown.

The miogeosyncline occupied eastern Nevada and part of southern California. Fine-grained detritus that was spread throughout eastern Nevada, within a sequence composed largely of carbonate rock, was undoubtedly supplied at least in part by the Antler orogenic belt west of the miogeosyncline. Judged by the presence of red beds, southeastern Nevada may have been emergent during parts of later Wolfcamp time.

A segment of the Antler orogenic belt in central Nevada had sufficient relief to shed very coarse detrital sediments eastward into southwestern Elko County and fine to medium detrital material westward into the Havallah sea. The northward and southward extent of the orogenic belt in Wolfcamp time is unknown, but detrital rock in the Wood River Formation of south-central Idaho indicates a possible extension.

The tectonic behavior of a vast region west of the Antler orogenic belt and extending from beyond northern Washington at least to southern California is little known. The character of the sparsely exposed Permian rocks indicates that this region was covered by a sea in which were deposited sediments derived from tectonic lands and great quantities of volcanic material extruded from subaerial or submarine vents. Chert was formed, and local deposits of limestone, some possibly of reef origin, suggest the existence of shoals. These rocks crop out at scattered localities along a curved belt that may outline the eugeosyncline, and they are an almost inseparable part of a terrane that includes similar eugeosynclinal rocks of Carboniferous and Triassic ages.

\section{INTERVAL B}

\section{FORMATIONS INCLUDED AND UPPER BOUNDARY} OF INTERVAL B

Table 3 shows the formations included in interval $B$ and the upper boundary chosen for the interval.

Limestone of Leonard age in the Carlin Canyon area of Elko County was described by Fails (1960, p. 1697). The upper boundary, as established by
TABLE 3.-Formations and upper boundary of interval $B$ in the West Coast region

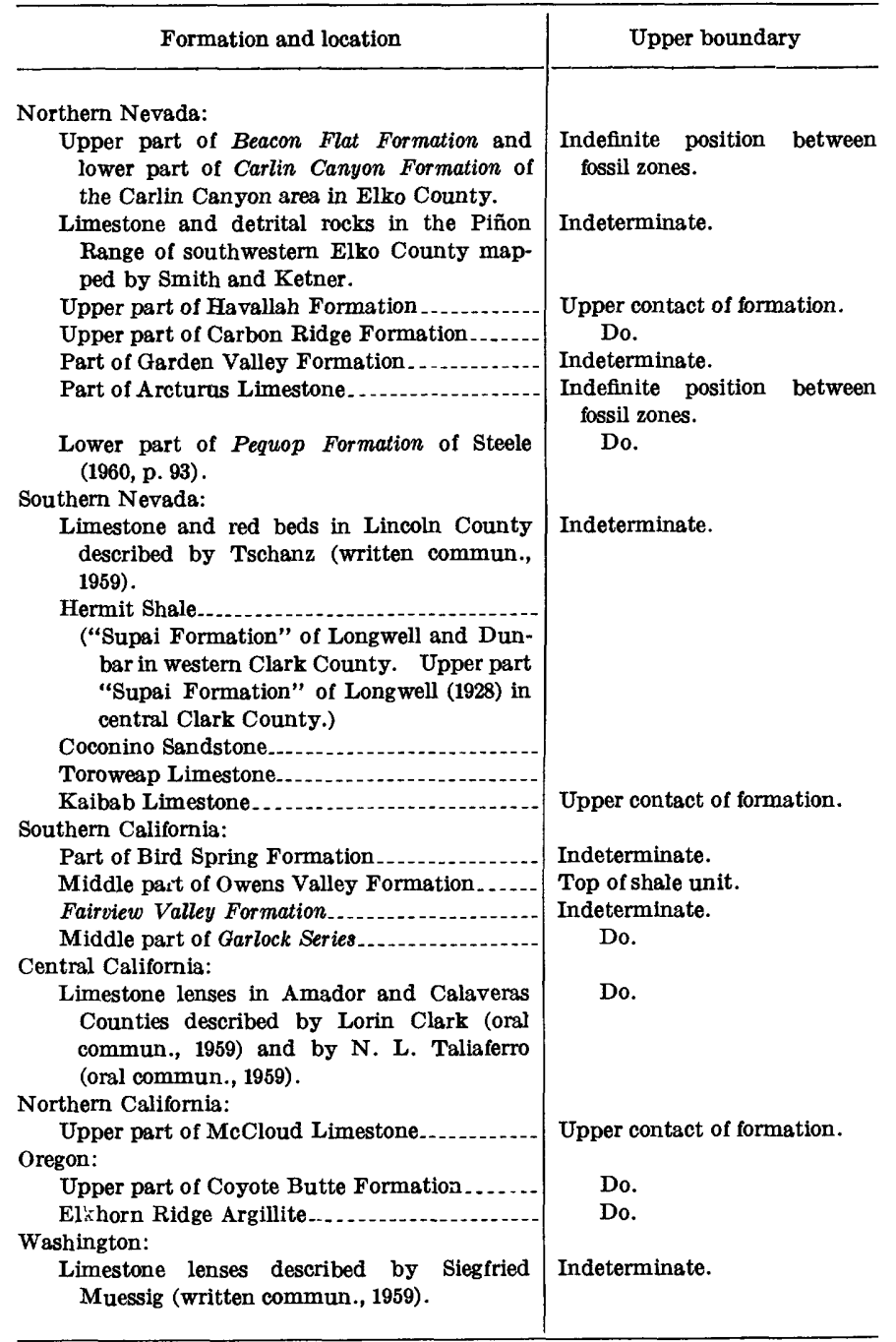

Fails, is between occurrences of the Leonard pelecypod Nuculana obesa and the Guadalupe Aviculopecten vanvleeti. Although the upper boundary of rocks of Leonard age as thus determined is within a lithologic unit, the boundary approximately coincides with a change from rather pure limestone of Leonard age to cherty limestone of Guadalupe age.

In north-central Nevada the upper part of the Havallah Formation is considered to be of Leonard age (Roberts and others, 1958, p. 2848). However, owing to structural complexity, the thickness cannot be accurately determined.

In southern Eureka County, Nev., the Carbon Ridge Formation and the partly equivalent Garden Valley Formation contain beds of Leonard age (Nolan and others, 1956 , p. 65, 68). The upper contact of the Carbon Ridge is considered to be the boundary of interval B, but the Garden Valley con- 
tains beds that are probably younger than Leonard. The exact stratigraphic position is indeterminate. The Garden Valley Formation is thought to be a more western facies of the Permian than the Carbon Ridge and to have been thrust an unknown distance, generally eastward, from its site of deposition (Nolan and others, 1956, p. 68).

In White Pine County, interbedded sandstone, limestone, and evaporites of the Arcturus Limestone, paleontologically identified by Steele to be of Leonard age, are included in interval B. The names $\mathrm{Rib} \mathrm{Hill}$ Formation (Pennebaker, 1932, p. 163) and Pequop Formation (Steele, 1960, p. 93) have been applied to beds included in interval $B$.

Permian limestone in northern Lincoln County described by C. M. Tschanz (written commun., 1959) is assigned partly to interval $\mathrm{B}$ because he correlated the unit with beds of Wolfcamp and Leonard age in Eureka and Nye Counties.

In eastern Clark County the Hermit Shale, Coconino Sandstone, Toroweap Formation, and Kaibab Limestone (McNair, 1951, p. 527) are assigned to interval B. The lower boundary of the interval is conventionally established at the base of the Hermit Shale, and the upper boundary, at the top of the Kaibab Limestone.

In western Clark County both the "Supai" and Kaibab Formations of Longwell and Dunbar (1936. p. 1203) are assigned to interval B. The "Supai" of Longwell and Dunbar was considered by E. D. McKee (oral commun., 1960) to be the Hermit Shale.

In southern California the upper part of the Bird Spring Formation, as represented in the southwest corner of the Ubehebe Peak quadrangle, contains beds of Leonard age according to L. G. Henbest (in McAllister, 1956). Their upper contact with beds of possible Guadalupe age is indefinite, and their thickness is unknown.

Farther south, in San Bernardino County, the Bird Spring Formation may contain beds of Leonard age in addition to beds of known Wolfcamp age (Thompson, M. L., and others, 1946, p. 39).

Part of the Fairview Valley Formation of Bowen (1954, p. 36) is tentatively assigned to interval B. The formation contains limestone fragments bearing fossils as young as Wolfcamp and is overlain by the Triassic(?) Sidewinder Volcanic Series. The upper part of the formation is probably of Guadalupe and Ochoa age and is included in interval C-D.

The middle shaly part of the Owens Valley Formation of C. W. Merriam and W. E. Hall (1957, p. 6 ) in Inyo County is included in interval B on the basis of its fossils. The upper contact is placed at the disconformity on top of the shaly beds.

Part of the Garlock Series of Dibblee (1952, p. 18) is tentatively assigned to interval B. A zone of fossils, including Schwagerina, 12,000 feet above the base studied by Merriam is correlated with the lower part of the McCloud Limestone. Because only one fossiliferous zone is known, the thickness of interval B is indeterminate.

Permian fusulinids have been collected from lenses of limestone in thick sequences of slate, chert, and volcanic rock of unknown age in Amador and Calaveras Counties, Calif. (Lorin Clark, oral commun., 1959 ; N. L. Taliaferro, oral commun., 1959). The fusulinids may be of Leonard and possibly Word age as suggested by Henbest and Douglass (Clark, oral commun., 1959).

The upper part of the McCloud Limestone in the middle part of northern California is assigned to interval $\mathrm{B}$, in accordance with the age assignment by Thompson, Wheeler, and Hazzard (1946, p. 23). The upper boundary of the interval is at the contact between the McCloud Limestone and the Nosoni Formation.

The upper part of the Coyote Butte Formation of C. W. Merriam and S. A. Berthiaume (1943, p. 156) in central Oregon is assigned to interval B. This formation is directly overlain by Triassic beds, according to Merriam and Berthiaume (1943, p. 156), but was believed by John Harbaugh (oral commun., 1959) to be overlain by younger Permian chert beds. The upper boundary of beds of Leonard age is not firmly established; therefore, the thickness of interval $B$ in this area is indefinite. The combined Coyote Butte and overlying chert beds are about 1,800 feet thicka maximum thickness for the interval.

The Elkhorn Ridge Argillite, formerly thought to be of probable Pennsylvanian age (Gilluly, 1937, p. 14), contains Leonard fusulinids (M. L. Thompson, in Taubeneck, 1955 p. 97).

Limestone lenses in a thick sequence of volcanic rock, argillite, gray wacke, quartzite, conglomerate, and chert in northeastern Washington contain fusulinids (Siegfried Muessig, written commun., 1959), which were dated as Wolfcamp to Leonard by R. C. Douglass. Part of this sequence is assigned to interval $\mathrm{B}$, but the total thickness of the interval is unknown.

\section{THICKNESS AND LITHOFACIES TRENDS}

In eastern Nevada interval B attains a maximum thickness of 3,070 feet. Like interval A, interval $B$ in eastern Nevada probably thins abruptly westward against the ridge of the Antler orogenic belt. 
However, evidence in the form of conglomerates is not as abundant in interval $\mathrm{B}$ as in intervals $\mathrm{A}$ or $\mathrm{C}$. Westward from the Antler orogenic belt, interval B consists of detrital rocks thrust an unknown distance from the west. The thickness of interval B in northwestern Nevada is uncertain, but it may well exceed thicknesses east of Antler orogenic belt. Volcanic rocks are confined to a belt along the west coast. Red beds at the base of the interval in southern Nevada persist a short distance westward into California, where marine limestone takes their place.

\section{PALEOTECTONIC IMPLICATIONS}

The threefold paleotectonic division of the West Coast region into miogeosyncline, tectonic land, and eugeosyncline seems as valid for Leonard time as it does for Wolfcamp time. However, relief on the Antler orogenic belt seems to have been more subdued during Leonard time, as suggested by the lack of large amounts of conglomerate of Leonard age. The presence of evaporites and red beds indicates that part of southern and eastern Nevada continued to be recurrently emergent during early Leonard time. The absence of interval B rocks in northwestern Washington might indicate Leonard uplift in the area or, more likely, might merely be due to lack of data. Late Leonard or early Guadalupe orogeny in northwestern Nevada is discussed under interval C-D.

\section{INTERVAL C-D \\ FORMATIONS INCLUDED AND UPPER BOUNDARY OF INTERVAL C-D}

Table 4 summarizes the formations included in interval C-D and the nature of the upper boundary chosen for the interval.

The upper 800. feet of Permian limestone (Fails, 1960 , p. 1700) in the Carlin Canyon area of northern Nevada is assigned in this report to interval C-D. Erosion has removed an additional unknown thickness of higher Permian beds. The limestone in this area, in common with that in other formations assigned to interval $\mathrm{C}-\mathrm{D}$, contains many beds and nodules of chert but no phosphate.

In the Piñon Range of southwestern Elko County, Nev., rocks of Guadalupe age-chert-pebble conglomerate and limestone-lie disconformably on Mississippian strata. Because upper parts of the Permian beds are faulted and covered by Tertiary beds, the thickness cannot be estimated.

In southeastern Eureka County, coarse detrital rocks at Carbon Ridge and Tyrone Gap were assigned a Guadalupe age by Steele $(1959$, p. 112 ; oral commun., 1960) on the basis of fusulinids. This age
TABLE 4.-Formations and upper boundary of interval $C-D$ in the West Coast region

\begin{tabular}{|c|c|}
\hline Formation and location & $\begin{array}{l}\text { Nature of upper boundary } \\
\text { of interval } C \rightarrow D\end{array}$ \\
\hline Northern Nevada: & \multirow{6}{*}{$\begin{array}{l}\text { Upper erosional contact of } \\
\text { the formation. } \\
\text { Indeterminate. } \\
\text { Do. } \\
\text { Upper contact of the forma } \\
\text { tion. } \\
\text { Indeterminate. }\end{array}$} \\
\hline $\begin{array}{l}\text { Part of the Carlin Canyon Formation in the } \\
\text { Carlin Canyon area of Elko County de- } \\
\text { scribed by Fails (Fails, 1960, p. 1700). }\end{array}$ & \\
\hline $\begin{array}{l}\text { Limestone and conglomerate in the Piñon } \\
\text { Range of southwestern Elko County mapped } \\
\text { by Smith and Ketner. }\end{array}$ & \\
\hline $\begin{array}{l}\text { Detrital rocks in southeastern Eureka County } \\
\text { described by Steele (1959). }\end{array}$ & \\
\hline Edna Mountain Formation & \\
\hline $\begin{array}{l}\text { Limestone and chert-pebble conglomerate in } \\
\text { central Humboldt County described by Will- } \\
\text { den (written commun., 1958). }\end{array}$ & \\
\hline Koipato Formation & \multirow{3}{*}{$\begin{array}{l}\text { Upper contact of the forma- } \\
\text { tion or base of beds con- } \\
\text { taining Triassic fossils. } \\
\text { Indeterminate. } \\
\text { Upper contact of formation. }\end{array}$} \\
\hline $\begin{array}{l}\text { Beds of Guadalupe age in White Pine County } \\
\text { described by Knight (1956, p. 775). }\end{array}$ & \\
\hline Gerster Formation & \\
\hline Southern Nevada: & \multirow{17}{*}{ Upper contact of formation. } \\
\hline $\begin{array}{l}\text { Pablo Formation } \\
\text { Diablo Formation.... }\end{array}$ & \\
\hline $\begin{array}{l}\text { Southern California: } \\
\text { S }\end{array}$ & \\
\hline $\begin{array}{l}\text { Uppermost part of the Bird Spring Formation } \\
\text { Upper part of the Owens Valley Formation... }\end{array}$ & \\
\hline Upper part of the Fairview Valley Formation... & \\
\hline Central California: & \\
\hline Limestone in Calaveras County.... & \\
\hline $\begin{array}{l}\text { Northern California: } \\
\quad \text { Nosoni Formation }\end{array}$ & \\
\hline Dekkas Andesite............. & \\
\hline Reeve Meta-andesite............... & \\
\hline Robinson Formation & \\
\hline Oregon: & \\
\hline $\begin{array}{l}\text { Unnamed chert above Coyote Butte Forma- } \\
\text { tion. }\end{array}$ & \\
\hline $\begin{array}{l}\text { Clover Creek Greenstone..................... } \\
\text { Idaho: }\end{array}$ & \\
\hline Lower part of Seven Devils Volcanics.... & \\
\hline Washington: & \\
\hline $\begin{array}{l}\text { Leach River Formation of Canada and lime- } \\
\text { stone lenses in northwestern Washington de- } \\
\text { scribed by Thompson, Wheeler, and Danner } \\
\text { (1950). }\end{array}$ & \\
\hline
\end{tabular}

assignment is tentatively accepted and used in this publication. The units are included in interval C-D.

The Edna Mountain Formation (Roberts and others, 1958 , p. 2843) is assigned to interval C-D on the basis of brachiopods considered by J. Steele Williams to be approximately equivalent to those in the upper part of the Phosphoria Formation. The Edna Mountain Formation lies with angular unconformity on rocks ranging from Cambrian to Pennsylvanian. Permian deformation is indicated.

The Koipato Formation ranges from Guadalupe to Triassic age. Guadalupe age is indicated by the presence of Helicoprion and by the unconformable relation of the Koipato to the Havallah. Triassic age is indicated by an ammonite fauna near the top 
of the formation (N. J. Silberling, oral commun., 1958). An indefinite thickness is assigned to interval C-D. The Koipato is part of a western sequence of upper Paleozoic rocks. It may have been emplaced by thrust faulting an unknown distance from the west (Roberts and others, 1958, p. 2846).

In southwestern Nevada the Pablo and Diablo Formations are assigned to interval $\mathrm{C}-\mathrm{D}$. The Diablo is considered to be Guadalupe on the basis of a fauna characteristic of the Phosphoria Formation (Ferguson and others, 1954). The Pablo Formation is assigned to interval C-D because it gradationally overlies the Diablo and is cut by pre-Triassic intrusive rocks (Ferguson and Cathcart, 1954).

In White Pine County, beds assigned a Guadalupe age by R. L. Knight (1956, p. 775) and the Gerster Formation (Steele, 1960, p. 93) are assigned to interval $\mathrm{C}-\mathrm{D}$.

In Inyo County, Calif., the uppermost part of the Bird Spring Formation contains fusulinids vaguely suggestive of Guadalupe age (McAllister, 1956).

The upper part of the Owens Valley Formation in Inyo County (Merriam, C. W., and Hall, 1957, p. 6) is assigned to interval $\mathrm{C}-\mathrm{D}$ on the basis of a fauna including Punctospirifer pulcher (Meek) and Spirifer pseudocameratus (Girty), which are considered to be of Guadalupe age.

In San Bernardino County, Calif., the Fairview Valley Formation of Bowen $(1954$, p. 36) and the overlying Hodge Volcanic Formation are imprecisely dated, but some beds of Guadalupe age are probably included in the 16,000 feet of volcanic rock, conglomerate, and limestone constituting these formations. The uppermost part of the Fairview Valley Formation is tentatively assigned to interval $\mathrm{C}-\mathrm{D}$.

In Calaveras County, Calif., an isolated limestone fault block among Jurassic rocks contains fusulinids which, according to L. G. Henbest and R. C. Douglass, indicate Leonard and possibly Guadalupe age (Lorin Clark, oral commun., 1959).

In Shasta County, Calif., the Nosoni Formation (Thompson, M. L., and others, 1946, p. 23) and the overlying Dekkas Andesite (Albers and Robertson, 1961, p. 29) are assigned to interval C-D on the basis of fusulinids. The Dekkas interfingers with the underlying Nosoni according to Coogan (1957) and, in its upper part, with the Bully Hill Rhyolite and possibly with the Middle and Upper Triassic Pit Shale (Albers and Robertson, 1961, p. 26).

In northeastern California the Reeve Meta-andesite and overlying Robinson Formation are assigned to interval C-D. The Reeve contains fusulinids suggesting Guadalupe age (John Harbaugh, oral com- mun., 1959). The Robinson Formation has been correlated with the Nosoni Formation (Girty, in Diller, 1908, p. 27), which is now thought to be of early Guadalupe age.

In Crook County, the Coyote Butte Formation is considered to be of Wolfcamp and Leonard age on the basis of fusulinids, but its brachiopods indicate the possible presence of Guadalupe beds (Cooper, G. A., 1957a, p. 13). Above the Coyote Butte and beneath Triassic beds is 900 feet of chert (John Harbaugh, oral commun., 1959) that may belong to interval C-D.

In eastern Oregon the Clover Creek Greenstone of Gilluly (1937) is assigned to interval $\mathrm{C}-\mathrm{D}$ because it contains a Permian fauna and overlies the Elkhorn Ridge Argillite of Leonard age. As is commonly true with volcanic formations, exact thicknesses cannot be assigned specific epochs. The Clover Creek should probably be correlated with part of the Seven Devils Volcanics of eastern Oregon and western Idaho.

In western Idaho the Seven Devils Volcanics, mapped by Wagner (1945, p. 4) and by Cook (1954, p. 3 ), is partly of Permian age and partly of late Triassic age. This assignment is based on fossils collected in Adams County, Idaho, by R. S. Cannon and identified by J. S. Williams and S. W. Muller (written commun., to R. S. Cannon, 1939, 1942). Part of the collection indicates equivalence to the Phosphoria Formation, according to Williams, and therefore part of the enclosing rocks is assigned to interval C-D.

Correlation is difficult in most volcanic rocks; accordingly, not all rocks called Seven Devils and other formations such as the Casto Volcanics, correlated on the basis of lithology, may be properly assignable to interval C-D. Hence, only the localities where dating has been possible are indicated on the map of interval $\mathrm{C}-\mathrm{D}$.

The very late Permian fusulinid Yabeina packardi was found in a waterworn cobble from central Oregon and described by M. L. Thompson and H. E. Wheeler (1942, p. 702). Although the bedrock site from which the cobble originally came is unknown, it can be assumed to be near where the cobble was found. This site is shown on the map of interval C-D (I450 , pl. 5A).

Other fusulinids of very late Permian age have been reported from northwestern Washington (Thompson, M. L., and Wheeler, 1942, p. 703; Thompson, M. L., and others, 1950, p. 46, 48; W. R. Danner, written commun., 1959). They are in limestone lenses in thick sequences of otherwise undated siliceous sedimentary and volcanic rocks. The pale- 
ontological reports on these fusulinids imply postGuadalupe age.

In northeastern Washington, rocks of Guadalupe age have been reported by J. W. Skinner (written commun. to C. O. Dunbar, 1958). In the same general area, beds containing fusulinids of which the age according to Douglass is "probably late Leonard or possibly even younger" were reported by Siegfried Muessig (written commun., 1959). These beds are assigned to interval C-D. No thickness and few lithologic data are available.

\section{THICKNESS AND LITHOFACIES TRENDS}

Westward coarsening of detritus and the absence of occurrences in the vicinity of the Lander-Eureka County line indicate that interval C-D, like interval A, thins abruptly to the vanishing point against the east side of the Antler orogenic belt. Marine detrital and volcanic rocks of eastern Pershing County and vicinity west of the orogenic belt are of unknown but generally great thickness, probably exceeding the thickness of interval C-D east of the orogenic belt. Most of these rocks, according to Roberts and others (1958, p. 2849), were thrust an unknown distance from the west.

The Kaibab Limestone in southeastern Nevada is assigned to the Guadalupe Series by some geologists (Steele, 1959; McNair, 1951). However, following McKee's usage, the Kaibab is here assigned to interval $\mathrm{B}$, and no rocks in southeastern Nevada are assigned to interval $\mathrm{C}-\mathrm{D}$.

Volcanic rocks extend as far as Idaho and central Nevada, much farther eastward than those of earlier intervals.

\section{PALEOTECTONIC IMPLICATIONS}

In Guadalupe and Ochoa time, as during earlier intervals, the West Coast region was divisible into miogeosyncline, tectonic land, and eugeosyncline, but there were important differences between major structures of these ages and those of the two preceding. The miogeosyncline persisted in northeastern Nevada and, perhaps for a time, in the southeastern part of the State. The trend of isopachs (I-450, pl. 5) suggests this; however, positive evidence of interval C-D in southeastern Nevada is not known. Rocks of interval B are directly overlain by Lower Triassic marine beds in southern Nevada, and if interval C-D once existed there, it has been eroded from a broad upwarp of late Guadalupe to earliest Triassic age.

The presence of extensive conglomerates of Guadalupe age near the east border of Eureka County indicates that the Antler orogenic belt retained or regained considerable relief in Guadalupe and Ochoa time. However, by the end of the Permian it was probably reduced to a chain of low islands which may have persisted locally into Triassic time. Guadalupe marine sediments were deposited in an area in southwestern Nevada (the southern part of the Antler orogenic belt) which had formerly been elevated.

In late Leonard time or early Guadalupe time northwestern or north-central Nevada was the scene of a brief orogenic episode, in which the Havallah Formation of Pennsylvanian to Leonard age was deformed. This rock was later overlain with angular unconformity by the Koipato Formation of Guadalupe to Triassic age. Whether this orogenic event took place before or after the Havallah was thrust to its present location in north-central Nevada is uncertain (N. J. Silberling and R. J. Roberts, written commun., 1960).

Volcanism, which had been feeble during earlier Permian time, probably reached a maximum in Guadalupe and Ochoa time. Some areas in Nevada, California, Oregon, and Idaho received their first Permian volcanic deposits late in Permian time, and most of these volcanic rocks are thick and extensive.

\section{TOTAL THICKNESS OF PERMIAN ROCKS}

The thickness of the Permian System is accurately known in only a few areas. Available information indicates general thickening westward in eastern $\mathrm{Ne}-$ vada to a maximum of more than 9,000 feet, then an abrupt thinning against the Antler orogenic belt. West of the belt, accurate measurements of thickness are too few to establish trends. The thickness in the inferred eugeosyncline is probably as great as that in the miogeosyncline, or greater in places.

\section{GEOLOGIC UNITS DIRECTLY ABOVE PERMIAN SYSTEM UNITS ABOVE THE PERMIAN}

Lower Triassic rocks (interval A of the Triassic System) overlie the Permian in an arcuate belt extending from northeastern Nevada southwestward through central and southwestern Nevada and southeastern California and back eastward into southern Nevada.

Deposition may have continued without interruption from Permian to Triassic time in two places within the West Coast region. In southwestern $\mathrm{Ne}-$ vada, the Permian Diablo Formation grades without apparent break into the Lower Triassic Candelaria Formation, according to B. M. Page (oral commun., 1959). The two formations are separated by 
an unconformity representing a brief hiatus (N. J. Silberling, written commun.,.1961). In north-central Nevada, the mainly Permian Koipato Formation contains earliest Triassic fossils near the top (N. J. Silberling, written commun., 1959). Elsewhere lowest Triassic beds have not been recognized.

Middle Triassic rocks lie directly on Permian only in northwestern Nevada and possibly in northern California.

The Permian in Washington, Oregon, and adjacent parts of Idaho is overlain by Upper Triassic rocks.

In northeastern Washington, Permian strata are overlain by Upper Triassic eugeosynclinal rocks ( $R$. L. Parker, oral commun., 1960). These Triassic rocks were not reported in the Triassic folio (McKee and others, 1959).

Triassic rocks have not been reported in much of the middle part of eastern Nevada, or in central
California where Permian rocks are known. In central California the next younger rocks known are of Jurassic age and in the middle part of eastern Nevada of Cretaceous and Tertiary ages. In both areas, Triassic rocks may yet be discovered.

\section{PALEOTECTONIC IMPLICATIONS}

Evidently much of the West Coast region was uplifted near the end of Permian time. The general absence of angular unconformity or of deep erosion below Triassic beds suggests, however, that the Permian sediments may not have been raised much above sea level before deposition of Lower to Upper Triassic sediments.

The Antler orogenic belt of central Nevada may have briefly persisted in Triassic time in the form of a chain of islands, as indicated by local occurrences of Lower Triassic conglomerates. 


\section{REFERENCES CITED AND INDEX}





\section{REFERENCES CITED}

Adams, J. E., 1929. Triassic of west Texas: Am. Assoc. Petroleum Geologists Bull., v. 13, no. 8, p. 1045-1055.

1944, Upper Permian Ochoa series of Delaware Basin West Texas and southeastern New Mexico: Am. Assoc. Petroleum Geologists Bull., v. 28, no. 11, p. 1596-1625.

Adams, J. E., and Frenzel, H. N., 1950, Capitan barrier reef, Texas and New Mexico: Jour. Geology, v. 58, no. 4, p. 289312.

Adams, J. E., Frenzel, H. N., Rhodes, M. L., and Johnson, D. P., 1951, Starved Pennsylvanian Midland Basin: Am. Assoc. Petroleum Geologists Bull., v. 35, no. 12, p. 2600-2607.

Adams, J. E., and others, 1939, Standard Permian section of North America: Am. Assoc. Petroleum Geologists Bull., v. 23 , no. 11, p. 1673-1681.

Adams, J. E., and Rhodes, M. L., 1960, Dolomitization by seepage refiuxion: Am. Assoc. Petroleum Geologists Bull., v. 44, no. 12, p. 1912-1920.

Adkins, W. S., 1924, Geology and mineral resources of McLennan County : Texas Univ. Bull. 2340, 202 p.

Adkison, W. L., 1960, Subsurface cross section of Paleozoic rocks from Barber County, Kansas, to Caddo County, Oklahoma : U.S. Geol. Survey Oil and Gas Inv. Chart OC-61.

Agatston, R. S., 1954, Pennsylvanian and Lower Permian of northern and eastern Wyoming: Am. Assoc. Petroleum Geologists Bull., v. 38, no. 4, p. 508-583.

1957; Pennsylvanian of the Wind River Basin, in Wyoming Geol. Assoc. Guidebook 12th Ann. Field Conf., southwest Wind River Basin, 1957 : p. 29-34.

Albers, J. P., and Robertson, J. F., 1961, Geology and ore deposits of east Shasta copper-zinc district, Shasta County, Calif. : U.S. Geol. Survey Prof. Paper 338, 107 p. [1962].

Albritton, C. C., Jr., 1938, Stratigraphy and structure of the Malone Mountains, Texas: Geol. Soc. America Bull., v. 49, no. 12 , pt. 1, p. 1747-1806.

Albritton, C. C., Jr., and Smith, J. F., 1965, Geology of the Sierra Blanca area, Hudspeth County, Texas: U.S. Geol. Survey Prof. Paper 479, 131 p.

Alderman, A. R., and Skinner, H. C. W., 1957, Dolomite sedimentation in the south-east of South Australia: Am. Jour. Sci., v. 255, no. 8, p. 561-567.

Alexander, R. G., Jr., and Clark, E. W., 1954, Drilling of the Johns Valley, Upper Valley, and Muley Creek structures [Utah], in Intermountain Assoc. Petroleum Geologists Guidebook 5th Ann. Field Conf., Salt Lake City, 1954: p. 103-109.

Allen, J. E., and Balk, Robert, 1954, Mineral resources of Fort Defiance and Tohatchi quadrangles, Arizona and New Mexico: New Mexico Bur. Mines and Mineral Resources Bull. 36, 192 p.

Allen, J. E., Jones, S. M., and others, 1951, Preliminary stratigraphic section, Capitan quadrangle, in Roswell Geol. Soc. Guidebook 5th Field Gonf., Capitan-Carrizozo-Chupadera Mesa region, 1951.
Allspach, H. G., 1955, Geology of a part of the south flank of the Seminoe Mountains, Carbon County, Wyoming: Wyoming Univ., unpub. M.S. thesis.

American Commission on Stratigraphic Nomenclature, 1961, Code of stratigraphic nomenclature: Am. Assoc. Petroleum Geologists Bull., v. 45, no. 5, p. 645-665.

Amsbury, D. L., 1958, Geologic map of Pinto Canyon area, Presidio County, Texas : Texas Univ. Bur. Econ. Geology [Geol.] Quad. Map 22 [1959].

Anderman, G. G., 1955, Geology of a portion of the north flank of the Uinta Mountains in the vicinity of Manila, Summit, and Daggett Counties, Utah, and Sweetwater County, Wyoming: Princeton Univ., Ph. D. thesis, 658 p. Available from University Microfilms, Inc., Ann Arbor, Mich.

Ashley, W. H., 1948, Geology of the Kennaday Peak-Pennock Mountain area, Carbon County, Wyoming: Wyoming Univ., unpub. M.A. thesis.

Asquith, D. O., 1958, Geology of a portion of the Sangre de Cristo Range northwest of Cuchara Camps, Colorado, in Kansas Geol. Soc. Guidebook 22d Field Conf., south-central Colorado, 1958 : p. 138-152.

Baars, D. L., 1962, Permian system of the Colorado Plateau: Am. Assoc. Petroleum Geologists Bull., v. 46, no. 2, p. 149218.

Baas Becking, L. G. M., Kaplan, I. R., and Moore, Derek, 1960, Limits of the natural environment in terms of $\mathrm{pH}$ and oxidation-reduction potentials: Jour. Geology, v. 68, no. 3, p. 243-284.

Bachman, G. O., 1953, Geology of a part of northwestern Mora County, New Mexico: U.S. Geol. Survey Oil and Gas Inv. Map OM-137.

1960, Southwestern edge of late Paleozoic landmass in New Mexico, in Short papers in the geological sciences: U.S. Geol. Survey Prof. Paper 400-B, p. B239-B241.

Bachman, G. O., and Hayes, P. T., 1958, Stratigraphy of Upper Pennsylvanian and Lower Permian rocks in the Sand Canyon area, Otero County, New Mexico: Geol. Soc. America Bull., v. 69, no. 6, p. 689-700.

Baker, A. A., 1936, Geology of the Monument Valley-Navajo Mountain region, San Juan County, Utah: U.S. Geol. Survey Bull. 865,106 p.

1946, Geology of the Green River Desert-Cataract Canyon region, Emery, Wayne, and Garfield Counties, Utah: U.S. Geol. Survey Bull. 951, 122 p.

1947, Stratigraphy of the Wasatch Mountains in the vicinity of Provo, Utah: U.S. Geol. Survey Oil and Gas Inv. Preìm. Chart 30.

Baker, A. A., and Reeside, J. B., Jr., 1929, Correlation of the Permian of southern Utah, northern Arizona, northwestern New Mexico, and southwestern Colorado: Am. Assoc. Petroleum Geologists Bull., v. 13, no. 11, p. 1413-1448.

Baker, A. A., and Williams, J. Steele, 1940, Permian in parts of Rocky Mountain and Colorado Plateau regions: Am. Assoc. Petroleum Geologists Bull., v. 24, no. 4, p. 617-635. 
Baker, C. L., 1920, Contributions to the stratigraphy of eastern New Mexico: An. Jour. Sci., 4th ser., v. 49, p. 99-126.

- 1946, Geology of the northwestern Wind River Mountains, Wyoming: Geol. Soc. America Bull., v. 57, no. 6, p. 565-596.

- 1947, Deep borings of western South Dakota: South Dakota Geol. Survey Rept. Inv. 57, 112 p.

1948, Additional well borings in South Dakota [supp. to Rept. Inv. 57]: South Dakota Geol. Survey Rept. Inv. 61, $40 \mathrm{p}$.

—_ 1951, Well borings in South Dakota, 1948-1950: South Dakota Geol. Survey Rept. Inv. 67, 67 p.

Baker, D. A., 1958, Subsurface geology of southwestern Pawnee County, Oklahoma: Oklahoma Univ., unpub. M.S. (G.E.) thesis, $46 \mathrm{p}$.

Baltz, E. H., and Bachman, G. O., 1956, Notes on the geology of the southeastern Sangre de Cristo Mountains, New Mexico, in New Mexico Geol. Soc. Guidebook 7th Field Conf., southeastern Sangre de Cristo Mountains, New Mexico, 1956 : p. 101.

Barkley, C. J., and Gosman, R. F., 1958, Donkey Creek area, Crook County, Wyoming, in Wyouning Geol. Assoc. Guidebook 13th Ann. Field Conf., Powder River Basin, 1958: p. 174-179.

Barlow, J. A., 1950, Geology of the LaPrele Creek-Box Elder Creek area, Converse County, Wyouning: Wyouning Univ., unpub. M.A. thesis.

- 1953, The geology of the Rawlins uplift, Carbon County, Wyoming: Wyoming Univ., unpub. $\mathrm{Ph}$. D. thesis.

Barnes, V. E., Cloud, P. E., Jr., Dixon, L. P., Folk, R. L., Jonas, E. C., Palner, A. R., and Tynan, E. J., 1959, Stratigraphy of the pre-Simpson Paleozoic subsurface rocks of Texas and southeast New Mexico: Texas Univ. Pub. 5924, 2 v., $836 \mathrm{p}$.

Barnett, V. H., 1914, The Douglas oil and gas field, Converse County, Wyoming: U.S. Geol. Survey Bull. 541-C, p. 49-88.

Barr, F. T., 1957, Paleontology and stratigraphy of the Pennsylvanian and Permian rocks of Ward Mountain, White Pine County, Nevada: California Univ., Berkeley, unpub. M.A. thesis.

Bass, N. W., 1939, Verden sandstone of Oklahoma-an exposed shoestring sand of Permian age: Aın. Assoc. Petroleun Geologists Bull., v. 23, no. 4, p. 559-581.

1958, Pennsylvanian and Permian rocks in the southern half of the White River uplift, Colorado, in Rocky Mtn. Assoc. Geologists, Symposium on Pennsylvanian rocks of Colorado and adjacent areas, 1958: p. 91-94.

Bass, N. W., and Northrop, S. A., 1950, South Canyon Creek dolomite member, a unit of Phosphoria age in Maroon formation near Glenwood Springs, Colorado: Am. Assoc. Petroleum Geologists Bull., v. 34, no. 7, p. 1540-1551.

Bates, R. L., 1942, The oil and gas resources of New Mexico: New Mexico School Mines Bull. 18, 320 p.

_ 1955, Perıno-Pennsylvanian formations between Laramie Mountains, Wyoming, and Black Hills, South Dakota : Ain. Assoc. Petroleum Geologists Bull., v. 39, no. 10, p. 19792002.

Bates, R. L., Wilpolt, R. H., MacAlpin, A. J., and Vorbe, Georges, 1947, Geology of the Gran Quivira quadrangle, New Mexico: New Mexico Bur. Mines and Mineral Resources Bull. 26, $52 \mathrm{p}$.

Bauer, E. J., 1952, Geology of the Wagonhound Creek area, Carbon County, Wyoming: Wyoming Univ., unpub. M.A. thesis.
Beede, J. W., 1914, The Neva limestone in northern Oklahoma, with relnarks upon the correlation of the vertebrate fossil beds of the State: Oklahoma Geol. Survey Bull. 21, 37 p.

Beede, J. W., and Christner, D. D., 1926, The geology of Foard County : Texas Univ. Bull. 2607, p. 18-53.

Beede, J. W., and Kniker, H. T., 1924, Species of the genus Schwagerina and their stratigraphic significance: Texas Univ. Bull. 2433, 96 p. [1925?].

Beekly, A. L., 1915, Geology and coal resources of North Park, Colorado: U.S. Geol. Survey Bull. 596, 121 p.

Berg, R. R., 1956, Subsurface stratigraphy of the pre-Niobrara formations in the Shirley and Laranie Basins, Wyoming, in Wyoming stratigraphy, pt. 1: Wyouning Geol. Assoc., Nomenclature Comm., p. 77-83.

Bergstrom, J. R., 1950, Geology of the east portion of Casper Mountain and vicinity: Wyoming Univ., unpub. M.A. thesis.

Berryhill, H. L., Jr., 1963, Geology and coal resources of Belmont County, Ohio: U.S. Geol. Survey Prof. Paper 380, $113 \mathrm{p}$.

Berryhill, H. L., Jr., Colton, G. W., de Witt, Wallace, Jr., and Johnston, J. E., 1956, Geologic inap of Allegany County [Maryland]: Maryland Dept. Geology, Mines, and Water Resources.

Berryhill, H. L., Jr., and de Witt, Wallace, Jr., 1955, Revised correlation of Koontz coal and Pennsylvanian-Permian boundary in Georges Creek Basin, Allegany County, Maryland: Ain. Assoc. Petroleum Geologists Bull., v. 39, no. 10, p. 2087-2090.

Berryhill, H. L., Jr., and Swanson, V. E., 1962, Revised stratigraphic nomenclature for Upper Pennsylvanian and Lower Permian rocks, Washington County, Pennsylvania, in Short papers in geology, hydrology, and topography: U.S. Geol. Survey Prof. Paper 450-C, p. C43-C46.

Berryman, R. J., 1942, Geology of the Deer Creek-Little Deer Creek area, Converse County, Wyoming: Wyoming Univ., unpub. M.A. thesis.

Bissell, H. J., 1952, Stratigraphy and structure of northeast Strawberry Valley quadrangle, Utah : Am. Assoc. Petroleum Geologists Bull., v. 36, no. 4, p. 575-634.

Bissell, H. J., and Childs, O. E., 1958, The Weber formation of Utah and Colorado, in Rocky Mtn. Assoc. Geologists, Symposium on Pennsylvanian rocks of Colorado and adjacent areas, 1958: p. 26-30.

Blackstone, D. L., Jr., 1956, Introduction to the tectonics of the Rocky Mountains, in Am. Assoc. Petroleum Geologists Rocky Mtn. Sec., Geol. Rec., Feb. 1956: p. 3-19.

Blackwelder, Eliot, 1911, A reconnaissance of the phosphate deposits in western Wyoming: U.S. Geol. Survey Bull. 470-H, p. $452-481$.

- 1918, New geological formations in western Wyoming: Washington Acad. Sci. Jour., v. 8, p. 417-426.

Blanchard, W. G., Jr., and Davis, M. J., 1929, Permian stratigraphy and structure of parts of southeastern New Mexico and southwestern Texas: Am. Assoc. Petroleun Geologists Bull., v. 13, no. 8, p. 957-995.

Blanpied, B. W., and Hazzard, R. T., 1944, Field and wildeat developments in south Arkansas in 1942: Am. Assoc. Petroleum Geologists Bull., v. 28, no. 3, p. 326-332.

Boardman, D. C., 1942, The Minnelusa formation in the Rapid Canyon area, Black Hills, South Dakota : Iowa State Univ., unpub. M.S. thesis.

Bogart, L. E., 1953, The Hueco (Gym) limestone, Luna County, New Mexico : New Mexico Univ., unpub. M.S. thesis, 91 p. 
Bolin, E. J., and Petsch, B. C., 1954, Well logs in South Dakota east of Missouri River: South Dakota Geol. Survey Rept. Inv. 75, $95 \mathrm{p}$.

Bolyard, D. W., 1959, Pennsylvanian and Perinian stratigraphy in Sangre de Cristo Mountains between La Veta Pass and Westcliffe, Colorado: Am. Assoc. Petroleuın Geologists Bull., v. 43, no. 8 , p. 1896-1939.

Böse, Eınil, 1917, The Perıno-Carboniferous aınınonoids of the Glass Mountains, west Texas, and their stratigraphical significance: Texas Univ. Bull. 1762, $241 \mathrm{p}$.

Bostwick, D. A., 1955, Stratigraphy of the Wood River formation, south-central Idaho: Jour. Paleontology, v. 29, no. 6, p. 941-951.

Bowen, O. E., Jr., 1954, Geology and inineral deposits of Barstow quadrangle, San Bernardino County, California : California Div. Mines Bull. 165, p. 7-185.

Bowles, C. G., and Braddock, W. A., 1960, Solution breccias in the upper part of the Minnelusa sandstone, South Dakota and Wyoming [abs.]: Geol. Soc. America Bull., v. 71, no. 12 , pt. 2 , p. 2032.

Bowman, E. C., 1950, Stratigraphy and structure of the Orient area, Washington : Harvard Univ., unpub. $\mathbf{P h}$. D. thesis.

Boyd, D. W., 1956, Permian sedimentary facies, central Guadalupe Mountains, New Mexico: Columbia Univ., Ph. D. thesis, 167 p. Available from University Microfilms, Inc., Ann Arbor, Mich.

1958, Permian sedimentary facies, central Guadalupe Mountains, New Mexico: New Mexico Bur. Mines and Mineral Resources Bull. 49, $100 \mathrm{p}$.

Brady, F. H., 1931, Minnelusa formation of Beulah district, northwestern Black Hills, Wyoıning: Am. Assoc. Petroleum Geologists Bull., v. 15, no. 2, p. 183-188.

- 1958, Evaporite deposits in the Minnelusa formation in the Sundance-Beulah area, Crook County, Wyoming, in Wyouning Geol. Assoc. Guidebook 13th Ann. Field Conf., Powder River Basin, 1958 : p. 45-47.

Brady, R. T., 1949, Geology of the East Flank of the Laramie Range in the vicinity of Federal and Hecla, Laramie County, Wyoming: Wyoming Univ., unpub. M.A. thesis.

Bretz, J. H., 1949, Carlsbad Caverns and other caves of the Guadalupe block, New Mexico: Jour. Geology, v. 57, no. 5, p. 447-463.

Bridges, L. W., and DeFord, R. K., 1961, Pre-Carboniferous Paleozoic rocks in central Chihuahua, Mexico: Am. Assoc. Petroleum Geologists Bull., v. 45, no. 1, p. 98-104.

Briggs, L. I., Jr., 1958, Evaporite facies: Jour. Sed. Petrology, v. 28 , no. 1 , p. $46-56$.

Brill, K. G., Jr., 1942, Late Paleozoic stratigraphy of Gore area, Colorado: Am. Assoc. Petroleum Geologists Bull., v. 26, no. 8, p. 1375-1397.

— 1944, Late Paleozoic stratigraphy, west-central and northwestern Colorado: Geol. Soc. America Bull., v. 55, no. 5, p. 621-656.

1952, Stratigraphy in the Permo-Pennsylvanian zeugogeosyncline of Colorado and northern New Mexico: Geol. Soc. Annerica Bull., v. 63, no. 8, p. 809-880.

Brinkmann, Roland, 1954, Abriss der Geologie, v. 2 of Historische Geologie : 7th ed., Stuttgart, Ferdinand Enke, 359 p.

Broin, T. L., 1957, Stratigraphy of the Lykins formation of eastern Colorado: Colorado Univ., Ph. D. thesis, $256 \mathrm{p}$. Available from University Microfilms, Inc., Ann Arbor, Mich.

Brongersma-Sanders, Margaretha, 1948, The importance of upwelling water to vertebrate paleontology and oil geology:
Koninkl. Nederlandse Akad. Wetensch., Afd. Natuurk., Verh., sec. 2, v. 45, no. 4, $112 \mathrm{p}$.

Brooks, B. G., 1957, The geology of the Wheatland Reservoir area, Albany County, Wyoming: Wyoming Univ., unpub. M.A. thesis.

Brown, W. H., 1939, Tucson Mountains, an Arizona basin range type: Geol. Soc. America Bull., v. 50, no. 5, p. 697-760.

Bruce, C. L., 1954, Correlation chart, southeastern New Mexico, Guadalupe Mountains area, in New Mexico Geol. Soc. Guidebook 5th Field Conf., southeastern New Mexico, 1954: p. 41.

Bryant, D. G., 1957, Geology of the Gray Horse area, Osage County, Oklahoina : Oklahoma Univ., unpub. M.S. thesis, $118 \mathrm{p}$.

Bryant, D. L., 1955, Stratigraphy of the Permian system in southern Arizona: Arizona Univ., $\mathrm{Ph}$. D. thesis, 224 p. Available from University Microfiluns, Inc., Ann Arbor, Mich.

Bryant, D. L., and McClyınonds, N. E., 1961, Permian Concha limestone and Rainvalley formation, southeastern Arizona : Am. Assoc. Petroleum Geologists Bull., v. 45, no. 8, p. $1324-1333$.

Buehler, K. M., 1947, Freezeout Creek fault, Baca County, Colorado: Am. Assoc. Petroleun Geologists Bull., v. 31, no. 10, p. 1863-1868.

Bunte, A. S., 1939, Subsurface study of Greenwich pool, Sedgwick County, Kansas: Am. Assoc. Petroleum Geologists Bull., v. 23, no. 5, p. 643-662.

Burbank, W. S., 1930, Revision of geologic structure and stratigraphy in the Ouray district of Colorado, and its bearing on ore deposition: Colorado Sci. Soc. Proc. v. 12, no. 6, p. 151-232.

Burk, C. A., 1954, Subsurface correlation along the southern margin of the Wind River and Powder River Basins, Wyoming, in Wyoming Geol. Assoc. Guidebook 9th Ann. Field Conf., Casper area, 1954 : chart, in pocket.

1956, Subsurface stratigraphy of the pre-Niobrara formations in the Wind Basin, central Wyoming, in Wyoming stratigraphy, pt. 1: Wyouning Geol. Assoc., Noinenclature Comm., p. 23-33.

Burk, C. A., and Thomas, H. D., 1956, The Goose Egg formation (Perıno-Triassic) of eastern Wyoming: Wyoming Geol. Survey Rept. Inv. 6, 11 p.

Butters, R. M., 1913, Permian or "Permo-Carboniferous" of the eastern foothills of the Rocky Mountains in Colorado: Colorado Geol. Survey Bull. 5, pt. 2, p. 61-94.

Cady, W. M., 1960, Stratigraphic and geotectonic relationships in northern Vermont and southern Quebec: Geol. Soc. America Bull., v. 71, no. 5, p. 531-576.

Callahan, J. T., and Cushman, R. L., 1955, Geology and groundwater supplies of the Fort Wingate Indian School area, McKinley County, New Mexico: U.S. Geol. Survey Circ. $360,12 \mathrm{p}$.

Campbell, C. V., 1956, The Phosphoria formation on the southeastern Big Horn Basin, Wyoming: Stanford Univ., Ph. D. thesis, 203 p. Available from University Microfilms, Inc., Ann Arbor, Mich.

Campleell, M. R., 1904, Description of the Latrobe quadrangle [Pennsylvania] : U.S. Geol. Survey Geol. Atlas, Folio 110.

Caplan, W. M., 1954, Subsurface geology and related oil and gas possibilities of northeastern Arkansas: Arkansas Research Devel. Commn., Div. Geology Bull. 20, 124 p.

Carey, B. D., 1950, Geology of the eastern part of Flat Top anticline, Albany and Carbon Counties, Wyoming: Wyoming Univ., unpub. M.A. thesis. 
Carlson, C. E., 1949, Areal geology and stratigraphy of the Red Fork-Powder River area, Johnson County, Wyoming: Wyoming Univ., unpub. M.A. thesis.

Carmody, R. A., Huffman, Arch, Reed, E. C., Grohskopf, J. G., Workman, L. E., and Tippie, F. E., 1941, Geologic crosssection from the Granite Ridge in southern Nebraska to the Salem field in Illinois, in Kansas Geol. Soc. Guidebook 15th Ann. Field Conf., central and northeastern Missouri and adjoining area in Illinois, 1941: facing p. 120.

Carter, J. A., Jr., 1954, The geology of the Pearsonia area, Osage County, Oklahoma : Oklahoma Univ., unpub. M.S. thesis.

Case, E. C., 1919, The environment of life in the late Paleozoic in North America; a paleogeographic study: Carnegie Inst. Washington Pub. 283, 273 p.

Caussey, D. E., 1957, Homann field, in Herald, F. A., ed., Occurrence of oil and gas in West Texas: Texas Univ. Bur. Econ. Geology Pub. 5716, p. 145-147.

Cave, H. S., 1954, The Capitan-Castile-Delaware Mountain problem, in New Mexico Geol. Soc. Guidebook 5th Field Conf., southeastern New Mexico, 1954 : p. 117-124.

Cheney, T. M., 1957, Phosphate in Utah and an analysis of the stratigraphy of the Park City and the Phosphoria formations, Utah-a preliminary report; Utah Geol. and Mineralog. Survey Bull. 59, 54 p.

Cheney, T. M., and Sheldon, R. P., 1959, Permian stratigraphy and oil potential, Wyoming and Utah, in Intermountain Assoc. Petroleum Geologists Guidebook 10th Ann. Field Conf., Wasatch and Uinta Mountains transition area, 1959: p. $90-100$.

Cheney, T. M., Sheldon, R. P., Waring, R. G., and Warner, M. A., 1954, Stratigraphic sections of the Phosphoria formation in Wyoming, 1951: U.S. Geol. Survey Circ. 324, $22 \mathrm{p}$.

Cheney, T. M., Smart, R. A., Waring, R. G., and Warner, M. A., 1953, Stratigraphic sections of the Phosphoria formation in Utah, 1949-51: U.S. Geol. Survey Circ. 306, 40 p.

Christiansen, F. W., 1951, A summary of the structure and stratigraphy of the Canyon Range, in Utah Geol. Soc. Guidebook, no. 6, Canyon House and Confusion Ranges, Millard County, Utah, 1951 : p. 5-18.

Chronic, B. J., Jr., 1960, Late Paleozoic paleontology in the northern Paradox Basin, in Four Corners Geol. Soc. Guidebook 3d Field Conf., Paradox Basin fold and fault belt, 1960 : p. 80-85.

Clapp, F. G., 1907a, Description of the Amity quadrangle [Pennsylvania] : U.S. Geol. Survey Geol. Atlas, Folio 144.

- 1907b, Description of the Rogersville quadrangle [Pennsylvania] : U.S. Geol. Survey Geol. Atlas, Folio 146.

Clark, D. L., and Stokes, W. L., 1956, Preliminary survey of Triassic rocks in eastern Great Basin [Nevada-Utah] : Am. Assoc. Petroleum Geologists Bull., v. 40, no. 7, p. 16861692.

Clarke, F. W., 1924, The data of geochemistry: 5th ed., U.S. Geol. Survey Bull. 770, $841 \mathrm{p}$.

Clifton, R. L., 1942, Invertebrate faunas from the Blaine and the Dog Creek formations of the Permian Leonard series: Jour. Paleontology, v. 16, no. 6, p. 685-699.

- 1944, Paleoecology and environment inferred for some marginal middle Permian marine strata [Kansas-OklahomaTexas] : Am. Assoc. Petroleum Geologists Bull., v. 28, no. 7, p. 1012-1031.

Cohee, G. V., 1960, Series subdivisions of Permian System: Am. Assoc. Petroleum Geologists Bull., v. 44, no. 9, p. 15781579.
Cohee, G. V., Macha, Carol, and Holk, Margery, 1951, Thickness and lithology of Upper Devonian and Carboniferous rocks in Michigan: U.S. Geol. Survey Oil and Gas Inv. Chart oC-41.

Cohee, G. V., chm., and others, 1961, Tectonic map of the United States, exclusive of Alaska and Hawaii: U.S. Geol. Survey and Am. Assoc. Petroleum Geologists, 2 sheets [1962].

Collet, L. W., 1935, The structure of the Alps : $2 d$ ed., London, Arnold and Co., 304 p.

Collier, A. J., 1920, Anticlines near Maverick Springs, Fremont County, Wyoming: U.S. Geol. Survey Bull. 711-H, p. 149171.

Collins, J. B., 1947, Sulbsurface geologic cross-section from Trego County, Kansas, to Cheyenne County, Colorado: Kansas Geol. Survey Oil and Gas Inv. Prelim. Cross Section 5, 6 p.

Condit, D. D., 1919, Relations of late Paleozoic and early Mesozoic formations of southwestern Montana and adjacent parts of Wyoming: U.S. Geol. Survey Prof. Paper 120-F, p. 111-121.

1924, Phosphate deposits in the Wind River Mountains, near Lander, Wyoming: U.S. Geol. Survey Bull. 764, 39 p.

Condit, D. D.,.Finch, E. H., and Pardee, J. T., 1928, Phosphate rock in the Three Forks-Yellowstone Park region, Montana : U.S. Geol. Survey Bull. 795-G, p. 147-209.

Condra, G. E., 1935, Geologic cross section, Forest City, Mo., to Du Bois, Nebr. : Nebraska Geol. Survey Paper 8, $23 \mathrm{p}$.

Condra, G. E., and Reed, E. C., 1935, The Permo-Pennsylvanian section of the Hartville area of Wyoming: Nebraska Geol. Survey Paper 9, 46 p.

__ 1943, The geological section of Nebraska : Nebraska Geol. Survey Bull. 14, 82 p.

Condra, G. E., Reed, E. C., and Scherer, O. J., 1940, Correlation of the formations of the Laramie Range, Hartville uplift, Black Hills, and western Nebraska : Nebraska Geol. Survey Bull. 13 (revised ed., Bull. 13A, 1950), 52 p.

Condra, G. E., Schramm, E. F., and Lugn, A. L., 1981, Deep wells of Nebraska : Nebraska Geol. Survey, $2 d$ ser., Bull. 4, 288 p.

Coogan, A. H., 1957, Stratigraphy and correlation of the Permian Nosoni and Dekkas Formations, Shasta County, California [abs.] : Geol. Soc. America Bull., v. 68, no. 12, pt. 2, p. 1821.

Cook, E. F., 1954, Mining geology of the Seven Devils region: Idaho Bur. Mines and Geology Pamph. 97, 22 p.

Cooper, C. G., and Ferris, B. J., 1957, TXL field, Ector County, Texas, in Herald, F. A., ed., Occurrence of oil and gas in West Texas: Texas Univ. Bur. Econ. Geology Pub. 5716, p. 358-368.

Cooper, G. A., 1953, Permian faunal studies in the Glass Mountains, Texas, in West Texas Geol. Soc. Guidebook, Spring Field Trip, Chinati Mountains, Presidio County, Texas, 1953 : p. 70-76.

- 1957a, Permian brachiopods from central Oregon: Smithsonian Misc. Colln., v. 134, no. 12, 79 p.

$1957 \mathrm{~b}$, Study of the Wolfcamp and related faunas of the Glass Mountains, Texas, in Soc. Econ. Paleontologists and Mineralogists Guidebook, Permian Basin Section, Wolfcamp of the Glass Mountains and the Permian Basin, 1957 : p. 8-12.

1960, Remarks on brachiopods, in Dunbar, C. O., and others, Correlation of the Permian formations of North America : Geol. Soc. America Bull., v. 71, no. 12, pt. 1, p. 1768-1772.

Cooper, G. A., and Arellano, A. R. V., 1946, Stratigraphy near Caborca, northwest Sonora, Mexico: Am. Assoc. Petroleum Geologists Bull., v. 30, no. 4, p. 606-611. 
Cooper, H. T., 1951, Geology of the western Seminoe Mountains, Carbon County, Wyoming: Wyoming Univ., unpub. M.A. thesis.

Cooper, J. C., 1952, Rattlesnake oil and gas field, San Juan County, New Mexico, in Four Corners Geol. Soc. Symposium [1st], Four Corners region : p. 75-82.

Crawford, R. D., 1913, Geology and ore deposits of the Monarch and Tomichi districts, Colorado: Colorado Geol. Survey Bull. 4, 317 p.

Cressman, E. R., 1955, Physical stratigraphy of the Phosphoria formation in part of southwestern Montana: U.S. Geol. Survey Bull. 1027-A, p. 1-31.

Cressman, E. R., Wilson, W. H., Tandy, C. W., and Garmoe, W. J., 1953, Stratigraphic sections of the Phosphoria formation in Montana, 1949-50: U.S. Geol. Survey Circ. 302, 23 p.

Cross, A. T., 1958, Fossil flora of the Dunkard strata of eastern United States, in Sturgeon, M. T., The geology and mineral resources of Athens County, Ohio: Ohio Div. Geol. Survey Bull. 57, p. 191-197.

Cross, A. T., and Schemel, M. P., 1956, Geology of the Ohio River Valley in West Virginia : West Virginia Geol. Survey Repts., v. 22, pt. 1, 149 p.

Cross, A. T., Smith, W. H., and Arkle, Thomas, Jr., 1950, Field guide for the special conference on the stratigraphy, sedimentation, and nomenclature of the Upper Pennsylvanian and Lower Permian strata (Monongahela, Washington, and Greene series) in the northern portion of the Dunkard Basin of Ohio, West Virginia, and Pennsylvania, 1950 : privately printed, $104 \mathrm{p}$.

Cross, C. W., and Howe, Ernest, 1905, Red beds of southwestern Colorado and their correlation: Geol. Soc. America Bull., v. 16, p. $447-498$.

Cross, C. W., and Spencer, H. S., 1900, Geology of the Rico Mountains, Colorado: U.S. Geol. Survey 21st Ann. Rept., pt. 2, p. 7-165.

Crowley, A. J., 1955, A structural history of northwestern Colorado and parts of northeastern Utah, in Intermountain Assoc. Petroleum Geologists Guidebook 6th Ann. Field Conf., northwest Colorado, 1955 : p. 53-55.

Dake, C. L., 1920, The pre-Moenkopi (pre-Permian?) unconformity of the Colorado Plateau: Jour. Geology, v. 28, no. 1, p. 61-74.

Dane, C. H., 1935, Geology of the Salt Valley anticline and adjacent areas, Grand County, Utah: U.S. Geol. Survey Bull. $863,184 \mathrm{p}$.

1948, Geologic map of part of eastern San Juan Basin, Rio Arriba County, New Mexico: U.S. Geol. Survey Oil and Gas Inv. Prelim. Map 78.

Darrah, W. C., 1935, Permian elements in the fossil flora of the Appalachian province; 1 . Taeniopteris: Harvard Univ. Bot. Mus. Leaflets, v. 3, no. 9, p. 137-148.

Darton, N. H., 1901, Preliminary description of the geology and water resources of the southern half of the Black Hills and adjoining regions in South Dakota and Wyoming : U.S. Geol. Survey 21st Ann. Rept., pt. 4b, p. 489-599.

1908, Paleozoic and Mesozoic of central Wyoming: Geol. Soc. America Bull., v. 19, p. 403-470.

- 1910, A reconnaissance of parts of northwestern New Mexico and northern Arizona : U.S. Geol. Survey Bull. 435, $88 \mathrm{p}$.

__ 1922, Geologic structure of parts of New Mexico: U.S. Geol. Survey Bull. 726-E, p. 173-275.

1925, A résumé of Arizona geology : Arizona Univ. Bull. 119, Geol. Ser. 3, 298 p.
Darton, N. H., 1928, "Red Beds" and associated formations in New Mexico, with an outline of the geology of the State: U.S. Geol. Survey Bull. 794, 356 p.

Darton, N. H., and others, 1910, Laramie-Sherman Folio [Wyoming] : U.S. Geol. Survey Geol. Atlas, Folio 173. 1915, The Santa Fe route, with a side trip to the Grand Canyon of the Colorado, pt. C. of Guidebook of the Western United States: U.S. Geol. Survey Bull. 613, 200 p.

Darton, N. H., Stephenson, L. W., and Gardner, J. A., 1937, Geologic map of Texas: U.S. Geol. Survey. Abstract in Geol. Soc. America Bull., v. 44, pt. 1, p. 82, 1933.

Davidson, D. F., Smart, R. A., Peirce, H. W., and Weiser, J. D., 1953, Stratigraphic sections of the Phosphoria formation in Idaho, 1949, part 2: U.S. Geol. Survey Circ. 305, 28 p.

Davis, H. E., chm., and others, 1953, North-south cross section through Permian basin of West Texas: West Texas Geol. Soc., Strat. Problems Comm.

Davis, L. V., 1955, Geology and ground water resources of Grady and northern Stephens Counties, Oklahoma: Oklahoma Geol. Survey Bull. 73, 184 p.

Davis, S. H., Jr., 1952, The stratigraphy and structure of the Sheep Mountain area, Converse County, Wyoming: Iowa State Univ., unpub. M.S. thesis.

DeFord, R. K., and others, 1951, Apache Mountains of TransPecos Texas, in West Texas Geol. Soc. Guidebook, Fall Field Trip, West Texas and eastern New Mexico, 1951: 56 p.

DeJong, Gerard, 1959, The subsurface geology of Blaine County, Oklahoma : Oklahoma Univ., unpub. M.S. thesis, 82 p.

Dibblee, T. W., Jr., 1952, Geology of the Saltdale quadrangle, California: California Div. Mines Bull. 160, p. 7-43.

Dillé, G. S., 1930, Minnelusa of Black Hills of South Dakota : Am. Assoc. Petroleum Geologists Bull., v. 14, no. 5, p. 619623.

Diller, J. S., 1908, Geology of the Taylorsville region, California : U.S. Geol. Survey Bull. 353, 128 p.

Dobbin, C. E., Hoots, H. W., and Dane, C. H., 1928, Geology and oil and gas possibilities of the Bell Springs district, Carbon County, Wyoming: U.S. Geol. Survey Bull. 796-D, p. 171-201.

Dobrovolny, Ernest, Summerson, C. H., and Bates, R. L., 1946, Geology of northwestern Quay County, New Mexico: U.S. Geol. Survey Oil and Gas Inv. Prelim. Map 62.

Donegan, Ben, and DeFord, R. K., 1950, Ochoa is Permian : Am. Assoc. Petroleum Geologists Bull., v. 34, no. 12, p. 23562359.

Donnell, J. R., 1954, Tongue of Weber sandstone in Maroon formation near Carbondale and Redstone, northwestern Colorado: Am. Assoc. Petroleum Geologists Bull., v. 38, no. 8, p. 1817-1821.

Donner, H. F., 1936, Geology of the McCoy area, Eagle and Routt Counties, Colorado: Michigan Univ., unpub. Sc. D. thesis.

Dott, R. H., Jr., 1955, Pennsylvanian stratigraphy of Elko and northern Diamond Ranges, northeastern Nevada: Am. Assoc. Petroleum Geologists Bull., v. 39, no. 11, p. 2211-2305.

Douglass, R. C., 1960, Late Pennsylvanian and Early Permian fusulinids of northeastern Nevada [abs.] : Geol. Soc. America Bull., v. 71, no. 12, pt. 2, p. 1852-1853.

Dunbar, C. O., 1939, Permian fusulines from Sonora [Mexico] : Geol. Soc. America Bull., v. 50, no. 11, p. 1745-1759. 1940, The type Permian ; its classification and correlation : Am. Assoc. Petroleum Geologists Bull., v. 24, no. 2, p. 237281.

1942, Artinskian series : Am. Assoc. Petroleum Geologists Bull., v. 26, no. 3, p. 402-409. 
Dunbar, C. O., chm., and others, 1960, Correlation of the Permian formations of North America: Geol. Soc. America Bull., v. 71 , no. 12 , pt. 1 , p. $1763-1806$.

Dutro, J. T., Jr., 1961, Correlation of the Arctic Permian, in Short papers in the geologic and hydrologic sciences: U.S. Geol. Survey Prof. Paper 424-C, p. C225-C228.

Eardley, A. J., 1951, Structural geology of North America : New York, Harper \& Bros., 624 p.

Eargle, D. H., 1960, Stratigraphy of Pennsylvanian and Lower Permian rocks in Brown and Coleman Counties, Texas : U.S. Geol. Survey Prof. Paper 315-D, p. 55-77, pls. 25-30.

Eckel, E. B., and others, 1949, Geology. and ore of the La Plata district, Colorado : U.S. Geol. Survey Prof. Paper 219, 179 p.

Edson, F. C., 1945, Subsurface geologic cross section from Ford County to Wallace County, Kansas: Kansas Geol. Survey Oil and Gas Inv. Prelim. Cross Section 1.

1947, Subsurface geologic cross section from Ford County, Kansas, to Dallam County, Texas: Kansas Geol. Survey Oil and Gas Inv. Prelim. Cross Section 3.

Edwards, J. D., 1958, Areal geology of the northeast Mangum area : Oklahoma Univ., unpub. M.S. thesis, 96 p.

Ehring, T. W., 1957, The Murray formation (Permian) Nevada: Southern California Univ., unpub. M.A. thesis.

Elam, J. G., 1957, Abell field, Pecos and Crane Counties, Texas, in Herald, F. A., ed., Occurrence of oil and gas in West Texas: Texas Univ. Bur. Econ. Geology Pub. 5716, p. 1-11.

Elston, D. P., and Landis, E. R., 1960, Pre-Cutler unconformities and early growth of the Paradox Valley and Gypsum Valley salt anticlines, Colorado, in Short papers in the geological sciences: U.S. Geol. Survey Prof. Paper 400-B, p. B261B265.

Elston, W. E., 1956, Reconnaissance geology of the Virden quadrangle, Grant, and Hidalgo Counties, New Mexico [abs.] : Geol. Soc. America Bull., v. 67, no. 12, pt. 2, p. 1691-1692.

- 1957, Geology and mineral resources of Dwyer quadrangle, Grant, Luna, and Sierra Counties, New Mexico: New Mexico Bur. Mines and Mineral Resources Bull. 38, $86 \mathrm{p}$.

- 1958, Burro uplift, northeastern limit of sedimentary basin of southwestern New Mexico and southeastern Arizona : Am. Assoc. Petroleum Geologists Bull., v. 42, no. 10, p. 2513-2517.

Emigh, G. D., 1958, Petrography, mineralogy, and origin of phosphate pellets in the Phosphoria formation : Idaho Bur. Mines and Geology Pamph. 114, 60 p.

Epis, R. C., 1956, Geology of the Pedregosa Mountains, Cochise County, Arizona: California Univ., Ph. D. thesis, 263 p. Available from University Microfilms, Inc., Ann Arbor, Mich.

Evans, Noel, 1931, Stratigraphy of Permian beds of northwestern Oklahoma [with discussion by Horace L. Griley and Sherwood Buckstaff] : Am. Assoc. Petroleum Geologists Bull., v. 15, no. 4, p. 405-439.

Evans, O. F., 1949, The origin of the Verden sandstone of Oklahoma : Jour. Sed. Petrology, v. 19, no. 2, p. 87-94.

Fails, T. G., 1960, Permian stratigraphy at Carlin Canyon, Nevada: Am. Assoc. Petroleum Geologists Bull., v. 44, no. 10, p. 1692-1703.

Farquhar, O. C., 1957, The Precambrian rocks of Kansas : Kansas Geol. Survey Bull. 127, pt. 3, p. 49-122.

Faul, Henry, 1961, History of intrusion and metamorphism in the Appalachians and in the Urals [abs.]: Geol. Soc. America Spec. Paper 68, p. 176.

Fenneman, N. M., 1905, Geology of the Boulder district, Colorado: U.S. Geol. Survey Bull. 265, 101 p.
Fenneman, N. M., 1938, Physiography of eastern United States : New York, McGraw-Hill Book Co., 714 p.

Fenoglio, A. F., 1957, Geology of northeastern Payne County, Oklahoma : Oklahoma Univ., unpub. M.S. thesis, 84 p.

Fentress, G. H., Kinsey, Vail, Murphy, Ed, Simpson, John, and Wing, Richard, 1958, Stratigraphic cross section of Paleozoic rocks in eastern Colorado: Rocky Mtn. Assoc. Geologists.

Ferguson, H. G., and Cathcart, S. H., 1954, Geologic map of the Round Mountain quadrangle, Nevada: U.S. Geol. Survey Geol. Quad. Map GQ-40.

Ferguson, H. G., and Muller, S. W., 1949, Structural geology of the Hawthorne and Tonopah quadrangles, Nevada: U.S. Geol. Survey Prof. Paper 216, 55 p.

Ferguson, H. G., Muller, S. W., and Cathcart, S. H., 1954, Geologic map of the Mina quadrangle, Nevada: U.S. Geol. Survey Geol. Quad. Map GQ-45.

Ferguson, H. G., Muller, S. W., and Roberts, R. J., 1951a, Geologic map of the Winnemucca quadrangle, Nevada: U.S. Geol. Survey Geol. Quad. Map GQ-11.

1951b, Geology of the Mount Moses quadrangle, Nevada: U.S. Geol. Survey Geol. Quad. Map GQ-12.

Ferguson, H. G., Roberts, R. J., and Muller, S. W., 1952, Geologic map of the Golconda quadrangle, Nevada : U.S. Geol. Survey Geol. Quad. Map GQ-15.

Feth, J. H., 1948, Permian stratigraphy and structure, northern Canelo Hills, Arizona: Am. Assoc. Petroleum Geologists Bull., v. 32, no. 1, p. 82-108.

Fettke, C. R., Stephenson, R. C., and Tiguor, E. M., 1946, Oil and gas developments in the north Strabane area, Washington County, Pennsylvania: Pennsylvania Geol. Survey, 4th ser., Bull. M-28, 62 p.

Finks, R. M., Yochelson, E. L., and Sheldon, R. P., 1961, Stratigraphic implications of a Permian sponge occurrence in the Park City formation of western Wyoming: Jour. Paleontology, v. 35, no. 3, p. 564-568.

Fisher, H. C., Jr., 1956, Surface geology of the Belford area, Osage County, Oklahoma: Oklahoma Univ., unpub. M.S. thesis, $96 \mathrm{p}$.

Flawn, P. T., 1956, Basement rocks of Texas and southeast New Mexico: Texas Univ. Pub. 5605, 261 p.

1959, Devils River uplift, in West Texas Geol. Soc. Guidebook, Geology of the Val Verde basin, 1959: p. 74-78.

Flawn, P. T., and Diáz-Gonzalez, T. E., 1959, Problems of Paleozoic tectonics in north-central and northeastern Mexico: Am. Assoc. Petroleum Geologists Bull., v. 43, no. 1, p. 224 230.

Flawn, P. T., Goldstein, August, Jr., King, P. B., and Weaver, C. E., 1961, The Ouachita System: Texas Univ. Bur. Econ. Geology Pub. 6120, 401 p.

Fontaine, W. M., and White, I. C., 1880, The Permian or upper Carboniferous flora of West Virginia and southwestern Pennsylvania : Pennsylvania Geol. Survey, 2d, Prof. Paper, $143 \mathrm{p}$.

Foster, D. I., 1958. Summary of the stratigraphy of the Minnelusa formation, Powder River Bașin, Wyoming, in Wyoming Geol. Assoc. Guidebook 13th Ann. Field Conf., Powder River Basin, 1958 : p. 39-44.

Foster, R. W., 1959, Precambrian rocks of the Sacramento Mountains and vicinity, in Permian Basin Section, Soc. Econ. Paleontologists Mineralogists, Roswell Geol. Soc. Guidebook, Joint Field Conf., Sacramento Mountains of Otero County, N. Mex., 1959: p. 137-153. 
Francis, D. R., 1956, Jurassic stratigraphy of the Williston Basin area [summ.], in North Dakota Geol. Soc. Williston Basin Symposium, 1st Internat., Bismarck, 1956 : p. 179185.

Francis, Wilfred, 1954, Coal-its formation and composition: London, Edward Arnold, Ltd., $567 \mathrm{p}$.

Freie, A. J., 1930, Siedimentation in the Anadarko Basin: Oklahoma Geol. Survey Bull. 48, 80 p.

Frenzel, H. N., 1958, Permo-Pennsylvanian problems on the south side of the Permian Basin, in San Angelo Geol. Soc. Guidebook, The base of the Permian-a century of controversy, 1958: p. 57-61.

Frenzel, H. N., and Mundorff, M. J., 1942, Fusulinidae from the Phosphoria formation of Montana: Jour. Paleontology, v. 16 , no. 6, p. 675-684.

Fulkerson, D. H., 1951, Geology of a part of the west flank of the Big Horn Mountains north of Bigtrails, Washakie County, Wyoming: Wyoming Univ., unpub. M.A. thesis.

Galley, J. E., 1958, Oil and geology in the Permian Basin of Texas and New Mexico, in Weeks, L. G., ed., Habitat of oila symposium: Am. Assoc. Petroleum Geologists, p. 395-446.

Gardner, L. S., 1944, Phosphate deposits of the Teton Basin area, Idaho and Wyoming: U.S. Geol. Survey Bull. 944-A, p. 1-36.

Gardner, L. S., Hendricks, T. A., Hadley, H. D., and Rogers, C. P., Jr., 1946, Stratigraphic sections of Upper Paleozoic and Mesozoic rocks in south-central Montana: Montana Bur. Mines and Geology Mem. 24, 100 p.

Gates, Olcott, 1950, Geology of the west side of the Gore Range near Radium, Colorado : Colorado Univ., unpub. M.S. thesis.

Gianella, V. P., and Larson, E. R., 1960, Marine Permian at Black Rock, Nevada [abs.] : Geol. Soc. America Bull., v. 71, no. 12 , pt. 2 , p. 2061.

Giddings, $H$. J., 1935, The geology of a portion of the Laramie Basin lying north of Como anticline, Albany County, Wyoming : Wyoming Univ., unpub. M.A. thesis.

Gillerman, Elliot, 1958, Geology of the central Peloncillo Mountains, Hidalgo County, New Mexico, and Cochise County, Arizona: New Mexico Bur. Mines and Mineral Resources Bull. 57, $152 \mathrm{p}$.

Gilluly, James, 1937, Geology and mineral resources of the Baker quadrangle, Oregon: U.S. Geol. Survey Bull. 879, 119 p.

1956, General geology of central Cochise County, Arizona : U.S. Geol. Survey Prof. Paper 281, 169 p.

Gilluly, James, Cooper, J. R., and Williams, J. Steele, 1954, Late Paleozoic stratigraphy of central Cochise County, Arizona : U.S. Geol. Survey Prof. Paper 266, 49 p.

Gilluly, James, and Reeside, J. B., Jr., 1928, Sedimentary rocks of the San Rafael Swell and some adjacent areas in eastern Utah: U.S. Geol. Survey Prof. Paper 150-D, p. 61-110.

Girty, G. H., 1908, The Guadalupian fauna: U.S. Geol. Survey Prof. Paper 58, 651 p.

Gist, J. G., 1957, Geology of the north Freezeout Hills and adjacent areas, Carbon and Albany Counties, Wyoming: Wyoming Univ., unpub. M.A. thesis.

Gordon, Mackenzie, Jr., and Merriam, C. W., 1961, Late Permian ammonoids in the Inyo Range, California, and their significance, in Short papers in the geologic and hydrologic sciences: U.S. Geol. Survey Prof. Paper 424-D, p. D238D239.

Gorton, K. A., 1953, Geology of the Cameron Pass area, Grand, Jackson, and Larimer Counties, Colorado, in Wyoming Geol. Assoc. Guidebook 8th Ann. Field Conf., Laramie Basin, Wyoming, and North Park, Colorado, 1953 : p. 87-98.
Gould, D. B., 1935, Stratigraphy and structure of Pennsylvanian and Permian rocks in Salt Creek area, Mosquito Range, Colorado: Am. Assoc. Petroleum Geologists Bull., v. 19, no. 7, p. 971-1009.

Green, D. A., 1936, Permian and Pennsylvanian sediments exposed in central and west-central Oklahoma [with discussion] : Am. Assoc. Petroleum Geologists Bull., v. 20, no. 11, p. 1454-1475.

Gregory, H. E., 1917, Geology of the Navajo country-a reconnaissance of parts of Arizona, New Mexico, and Utah : U.S. Geol. Survey Prof. Paper 93, 161 p.

- 1938, The San Juan country, a geographic and geologic reconnaissance of southeastern Utah: U.S. Geol. Survey Prof. Paper 188, 123 p.

Creig, P. B., Jr., 1959, Geology of Pawnee County, Oklahoma : Oklahoma Geol. Survey Bull. 83, 188 p.

Gries, J. P., 1956, Tectonics of the Black Hills [South DakotaWyoming], in Am. Assoc. Petroleum Geologists Rocky Mtn. Section Geol. Rec. : p. 109-118.

Griggs, R. L., and Hendrickson, G. E., 1951, Geology and groundwater resources of San Miguel County, New Mexico: New Mexico Bur. Mines and Mineral Resources Ground-Water Rept. 2, 121 p.

Grimsley, G. P., 1907, Ohio, Brooke, and Hancock Counties : West Virginia Geol. Survey County Rept., 378 p.

1910, Pleasants, Wood, and Ritchie Counties : West Virginia Geol. Survey County Rept., 352 p.

Griswold, W. T., and Munn, M. J., 1907, Geology of oil and gas fields in Steubenville, Burgettstown, and Claysville quadrangles, Ohio, West Virginia, and Pennsylvania : U.S. Geol. Survey Bull. 318, $196 \mathrm{p}$.

Gudim, C. J., 1956, Subsurface stratigraphy of the pre-Niobrara formations along the eastern margin of the Great Divide and Washakie basins, Wyoming, in Wyoming stratigraphy, pt. 1: Wyoming Geol. Assoc., Nomenclature Comm., p. 69-75.

Haff, J. C., and Kiersch, G. A., 1955, Crushed stone and manufactured aggregate, in Mineral resources, Navajo-Hopi Indian Reservations, Arizona-Utah: Tucson, Arizona Univ. Press, v. 3, p. 27-60.

Hale, W. E., 1955, Geology and ground-water resources of Webster County, Iowa: Iowa Geol. Survey Water-Supply Bull. $4,257 \mathrm{p}$.

Hallgarth, W. E., 1959, Stratigraphy of Paleozoic rocks in northwestern Colorado: U.S. Geol. Survey Oil and Gas Inv. Chart OC-59.

1962, Upper Paleozoic rocks exposed in Straight Wash Canyon, San Rafael Swell, Utah: Am. Assoc. Petroleum Geologists Bull., v. 46, no. 8, p. 1494-1501.

Ham, W. E., Merritt, C. A., and Frederickson, E. A., 1957, Field conference on geology of the Wichita Mountain region in southwestern Oklahoma, May 2-4, 1957 : Oklahoma Geol. Survey Guidebook 5, $58 \mathrm{p}$.

Hardie, C. H., 1958, The Pennsylvanian rocks of the northern Hueco Mountains [New Mexico], in West Texas Geol. Soc. Guidebook, Franklin and Hueco Mountains, Texas, 1958: p. 44-45.

Harley, G. T., 1934, The geology and ore deposits of Sierra County, New Mexico: New Mexico School Mines Bull. 10, $220 \mathrm{p}$.

Harlow, George, 1956, Stratigraphy and structure of the Spruce Mountain area, Elko County, Nevada: Washington Univ., Seattle, unpub. M.S. thesis. 
Harrington, F. I., 1954, Stratigraphy and structure of the northern two-thirds of the Hot Springs quadrangle, South Dakota : Iowa State Univ., unpub. M.S. thesis.

Harrison, J. W., 1938, Pennsylvanian stratigraphy of the Laramie Range, southeastern Wyoming: Wyoming Univ., unpub. M.A. thesis.

Harshbarger, J. W., and Repenning, C. A., 1954, Water resources of the Ohuska Mountains area, Navajo Indian Reservation, Arizona and New Mexico: U.S. Geol. Survey Circ. 308, 16 p.

Hattin, D. E., 1957, Depositional environment of the Wreford megacyclothem (Lower Permian) of Kansas: Kansas Geol. Survey Bull. 124, $150 \mathrm{p}$.

Hay-Roe, Hugh, 1957, Geologic map of Wylie Mountains and vicinity, trans-Pecos, Texas: Texas Univ., unpub. Ph. D. thesis.

Hayes, P. T., 1957, Geology of the Carlsbad Caverns East quadrangle, New Mexico: U.S. Geol. Survey Geol. Quad. Map GQ-98.

1959, San Andres limestone and related Permian rocks in Last Chance Canyon and vicinity, southeastern New Mexico: Am. Assoc. Petroleum Geologists Bull., v. 43, no. 9, p. 2197-2213.

1964, Geology of the Guadalupe Mountains, New Mexico: U.S. Geol. Survey Prof. Paper 446, $69 \mathrm{p}$.

Hayes, P. T., and Koogle, R. L., 1958, Geology of the Carlsbad Caverns West quadrangle, New Mexico-Texas: U.S. Geol. Survey Geol. Quad. Map GQ-112.

Hazzard, R. T., Spooner, W. C., and Blanpied, B. W., 1947, Notes on the stratigraphy of the formations which underlie the Smackover limestone in south Arkansas, northeast Texas, and north Louisiana: Shreveport Geol. Soc. 1945 Reference Rept., v. 2, p. 483-503.

Heisey, E. L., 1949, Geology of the east Ferris Mountains, Carbon County, Wyoming: Wyoming Univ., unpub. M.S. thesis.

Hemsell, C. C., 1939, Geology of Hugoton gas field of southwestern Kansas: Am. Assoc. Petroleum Geologists Bull., v. 23, no. 7, p. 1054-1067.

Henbest, L. G., 1958, Pennsylvanian-Permian boundary in northcentral Texas, in The base of the Permian-a century of controversy, San Angelo Geol. Soc. Guidebook, 1958: p. 3851.

Henbest, L. G., and Read, C. B., 1944, Stratigraphic distribution of the Pennsylvanian Fusulinidae in a part of the Sierra Nacimiento of Sandoval and Rio Arriba Counties, New Mexico : U.S. Geol. Survey Oil and Gas Inv. Prelim. Chart 2.

Hennen, R. V., 1909, Marshall, Wetzel, and Tyler Counties : West Virginia Geol. Survey County Rept., 654 p.

1911, Wirt, Roane, and Calhoun Counties: West Virginia Geol. Survey County Rept., $573 \mathrm{p}$.

Hennen, R. V., and Reger, D. B., 1913, Marion, Monongalia, and Taylor Counties: West Virginia Geol. Survey County Rept:, $844 \mathrm{p}$.

Hensley, F. S., Jr., 1956, Some microfossils of the Pennsylvanian-Permian Casper formation along the west flank of the Laramie Range, Albany County, Wyoming: Wyoming Univ., unpub. M.A. thesis.

Herman, George, and Sharps, S. L., 1956, Pennsylvanian and Permian stratigraphy of the Paradox Salt Embayment [Colorado Plateau], in Intermountain Assoc. Petroleum Geologists 7th Ann. Field Conf., Geology and economic deposits of east central Utah, 1956: p. 77-84.

Hester, R. J., and Holland, R. R., 1959, Structure of the Puckett fleld, Pecos County, Texas, in West Texas Geol. Soc. Guide book, Val Verde basin, 1959 : p. 87-92.
Hewitt, C. H., 1958, Precambrian geology of the northern Big Burro Mountains and Redrock area, Grant County, New Mexico [abs.] : Geol. Soc. America Bull., v. 69, no. 12, pt. 2, p. 1730.

Heylmun, E. B., Jr., 1958, Paleozoic stratigraphy and oil possibilities of Kaiparowits region, Utah: Am. Assoc. Petroleum Geologists Bull., v. 42, no. 8, p. 1781-1811.

Hickok, W. O., 4th, and Moyer, F. T., 1940, Geology and mineral resources of Fayette County, Pennsylvania: Pennsylvania Geol. Survey, 4th ser., Bull. C-26, 530 p.

Hills, R. C., 1900, Description of the Walsenburg quadrangle [Colo.] : U.S. Geol. Survey Geol. Atlas, Folio 68.

Hoffmeister, W. S., and Staplin, F. L., 1954, Pennsylvanian age of Morehouse formation of northeastern Louisiana: Am. Assoc. Petroleum Geologists Bull., v. 38, no. 1, p. 158-159.

Holmes, Arthur, 1947, The construction of a geological time scale: Geol. Soc. Glasgow trans., v. 21, pt. 1, p. 117-152.

Hopper, R. H., 1947, Geologic section from the Sierra Nevada to Death Valley, California : Geol. Soc. America Bull., v. 58 , no. 5 , p. $393-432$.

Horberg, C. L., 1949, Geomorphic history of the Carlsbad Caverns area, New Mexico: Jour. Geology, v. 57, no. 5, p. 464-476.

Hose, R. K., 1955, Geology of the Crazy Woman Creek area, Johnson County, Wyoming : U.S. Geol. Survey Bull. 1027-B, p. 33-118.

Hose, R. K., and Repenning, C. A., 1959, Stratigraphy of Pennsylvanian, Permian, and Lower Triassic rocks of Confusion Range, west-central Utah : Am. Assoc. Petroleum Geologists Bull., v. 43, no. 9, p. 2167-2196.

Hoyle, L. E., 1948, Subsurface geology of the Shawnee Lake area, western Pottawatomie County, central Oklahoma: Oklahoma Univ., unpub. M.S. thesis, 46 p.

Huddle, J. W., and Dobrovolny, Ernest, 1945, Late Paleozoic stratigraphy of central and northeastern Arizona: U.S. Geol. Survey Oil and Gas Inv. Prelim. Chart 10.

Huffington, R. M., 1951, Geologic section in Humble Oil and Refining Company's Reynolds Cattle Company "B" No. 1, in West Texas Geol. Soc. Guidebook, Fall Field Trip, Apache Mountains of Trans-Pecos Texas, 1951: p. 47-49.

Hughes, P. W., 1952, Stratigraphy of Supai formation, Chino Valley area, Yavapai County, Arizona: Am. Assoc. Petroleum Geologists Bull., v. 36, no. 4, p. 635-657.

Hull, J. P. D., Jr., 1957a, Petrogenesis of Permian Delaware Mountain sandstone, Texas and New Mexico: Am. Assoc. Petroleum Geologists Bull., v. 41, no. 2, p. 278-307.

1957b, Slick-Urschel Oil Co. No. 1 Mary Decie-Sinclair, in Soc. Econ. Paleontologists and Mineralogists, Permian Basin Section, Guidebook, Wolfcamp of the Glass Mountains and the Permian basin [New Mexico-Texas], 1957: p. 96-98.

Hunt, C. B., assisted by Averitt, Paul, and Miller, R. L., 1953, Geology and geography of the Henry Mountains region, Utah: U.S. Geol. Survey Prof. Paper 228, 234 p.

Hunt, V. G., and O'Connor, J. P., Jr., 1954, Developments in east Texas in 1953 : Am. Assoc. Petroleum Geologists Bull., v. 38, no. 6, p. 1196-1207.

Imbrie, John, Laporte, L. F., and Merriam, D. F., 1959, Beattie limestone facies and their bearing on cyclical sedimentation theory, in Kansas Geol. Soc. Guidebook 24th Ann. Field Conf., Kansas, 1959 : p. 69-78.

Imlay, R. W., 1939, Paleogeographic studies in northeastern Sonora [Mexico] : Geol. Soc. America Buil., v. 50, no. 11, p. 1723-1744. 
Imlay, R. W., 1940, Lower Cretaceous and Jurassic formations of southern Arkansas and their oil and gas possibilities: Arkansas Geol. Survey Inf. Circ. 12, 64 p.

1943, Jurassic formations of Gulf region [of North America including United States, Mexico, and Cuba] : Am. Assoc. Petroleum Geologists Bull., v. 27, no. 11, p. 1407-1533.

Imlay, R. W., Cepeda, Edmundo, Alvarez, Manuel, Jr., and Díaz-Gonzalez, T. E., 1948, Stratigraphic relations of certain Jurassic formations in eastern Mexico: Am. Assoc. Petroleum Geologists Bull., v. 32, no. 9, p. 1750-1761.

Imlay, R. W., and Williams, J. S., 1942, Late Paleozoic age of Morehouse formation of northeastern Louisiana: Am. Assoc. Petroleum Geologists Bull., v. 26, no. 10, p. 1672-1673.

Irwin, W. P., 1960, Geologic reconnaissance of the northern Coast Ranges and Klamath Mountains, California, with a summary of the mineral resources: California Div. Mines Bull. 179, 80 p.

Israelsky, M. C., 1949, Oscillation chart [from foraminifera in oil well, Terrebonne Parish, Louisiana] : Am. Assoc. Petroleum Geologists Bull., v. 33, no. 1, p. 92-98.

Jackson, R. L., 1951, Stratigraphic relationships of the Supai formation of central Arizona: Plateau [Flagstaff, Ariz.], v. 24, no. 2, p. 84-91.

Jenkins, C. E., 1950, Geology of the Bates Creek-Corral Creek area, Natrona County, Wyoming: Wyoming Univ., unpub. M.A. thesis.

Jewett, J. M., 1939, Shallow aquifers in eastern Kansas : Kansas Acad. Sci. Trans., v. 42, p. 339.

- 1941, The geology of Riley and Geary Counties, Kansas: Kansas Geol. Survey Bull. 39, 164 p.

Jicha, H. L., Jr., 1954, Geology and mineral deposits of Lake Valley quadrangle, Grant, Luna, and Sierra Counties, New Mexico: New Mexico Bur. Mines and Mineral Resources Bull. 37, 93 p.

Jicha, H. L., and Lochman-Balk, Christina, 1958, Lexicon of New Mexico geologic names-Precambrian through Paleozoic: New Mexico Bur. Mines and Mineral Resources, Bull. $61,137 \mathrm{p}$.

Joesting, H. R., and Byerly, P. E., 1958, Regional geophysical investigations of the Uravan area, Colorado: U.S. Geol. Survey Prof. Paper 316-A, p. 1-17 [1959].

Johnson, B. K., 1957, Geology of a part of the Manly Peak quadrangle, southern Panamint Range, California: California Univ., Pubs. in Geol. Sci., v. 30, no. 5, p. 353-423.

Johnson, J. H., 1929, Contribution to the geology of the Sangre de Cristo Mountains of Colorado: Colorado Sci. Soc. Proc., v. 12, no. 1, p. 3-21.

Johnson, M. E., 1925, Greensburg quadrangle, mineral resources : Pennsylvania Geol. Survey, 4th ser., Topog. and Geol. Atlas 37, $162 \mathrm{p}$.

-1929, Pittsburgh quadrangle, geology and mineral resources: Pennsylvania Geol. Survey, 4th ser., Topog. and Geol. Atlas 27, 236 p.

Johnson, M. S., and Hibbard, D. E., 1957, Geology of the Atomic Energy Commission Nevada proving grounds area, Nevada : U.S. Geol. Survey Bull. 1021-K, p. 333-384.

Johnson, O. H., Jr., 1958, The Monroe uplift: Gulf Coast Assoc. Geol. Socs. Trans., v. 8, p. 24-32.

Jones, C. L., 1954, The occurrence and distribution of potassium minerals in southeastern New Mexico, in New Mexico Geol. Soc. Guidebook 5th Field Conf., southeastern New Mexico, 1954 : p. 107-112.
Jones, T. S., 1953, Stratigraphy of the Permian basin of west Texas: [New York, John Wiley \& Sons] West Texas Geol. Soc., $63 \mathrm{p}$.

Jones, T. S., chm., and others, 1949, East-west cross section through Permian basin of west Texas: West Texas Geol. Soc. Strat. Problems Comm.

Jongmans, W. J., chm., 1952, Round table conference on stratigraphic nomenclature: Congrès pour l'avancement des études de stratigraphic et de géologie du Carbonifère, $3 d$. Comptes Rendu, v. 1, p. 13-14.

Juilfs, J. D., 1953, A stratigraphic correlation and lithofacies study of the Pennsylvanian and Permian sediments in the subsurface of southcentral and southwestern Nebraska: Nebraska Univ., unpub. M.S. thesis.

Kansas Geological Society, 1938, Guidebook 12th Ann. Field Conf., Front Range of Rocky Mountains, Colo., 1938: 110 p. 1940, Guidebook 14th Ann. Field Conf., western South Dakota and eastern Wyoming, 1940: $162 \mathrm{p}$.

—_ 1955, Guidebook 18th Ann. Field Conf., southwestern Kansas, 1955 : $118 \mathrm{p}$.

Kansas Geological Society Study Group Committee, 1949, Northsouth electric log cross section from Nebraska to Oklahoma along sixth principal meridian showing Lower Permian through Cambrian Systems: Kansas Geol. Soc., 1 sheet. 1950, West-east [electric log] cross section, southern Kansas: Kansas Geol. Soc., 1 sheet.

Kansas Geological Survey, 1937, Geologic map of Kansas, prepared under the direction of R. C. Moore and K. K. Landes.

Karpinsky, A. P., 1889, Über die Ammoneen der Artinsk-Stufe und einige mit denselben verwandte carbonische formen: St. Petersbourg Acad. Sci. Mem., 7th ser., v. 37, no. 2, 104 p.

Kay, G. M., 1947, Geosynclinal nomenclature and the craton: Am. Assoc. Petroleum Geologists Bull., v. 31, no. 7, p. 1289-1293.

- 1951, North American geosynclines: Geol. Soc. America Mem. 48, 143 p.

Kazakov, A. V., 1937, The phosphorite facies and the genesis of phosphorites, in Sci. Inst. Fertilizers and Insecto Fungicides Trans. : Internat. Geol. Cong., 17th, Leningrad 1937, Pub. 142, p. 95-113.

1938, Phosphorite beds and the genesis of natural phosphates; chemical and geologic factors in the formation of phosphate deposits : Soviet Geology, v. 8, no. 6, p. 33-47.

Keefer, W. R., 1957, Geology of the Du Noir area, Fremont County, Wyoming: U.S. Geol. Survey Prof. Paper 294-E, p. 155-221.

Keener, M. H. L., 1957, Dollarhide field, Andrews County, Texas, and Lea County, New Mexico, in Herald, F. A., ed., Occurrence of oil and gas in West Texas: Texas Univ. Bur. Econ. Geology Pub. 5716, p. 87-96.

Kellett, Betty, 1932, Geologic cross section from western Missouri to western Kansas, showing detailed correlation of Permian Big Blue series and Pennsylvanian [with classification of lower Permian and Pennsylvanian systems of Kansas and Nebraska], in Kansas Geol. Soc. Guidebook 6th Ann. Field Conf., 1932 : p. 95-97.

1943, Permian ostracodes: Jour. Paleontology, v. 17, no. 6, p. 615-628.

1951, Geologic cross section from western Missouri to western Kansas, showing detailed correlation of Permian Big Blue series and Pennsylvanian [Revised], in Kansas Geol. Soc. Guidebook 6th Ann. Field Conf. : p. 95-97.

Kelley, V. C., 1949, Geology and economics of New Mexico ironore deposits: New Mexico Univ. Geology, Pub. 2, 246 p. 
Kelley, V. C., 1958, Tectonics of the region of the Paradox Basin [Colorado Plateau], in Intermountain Assoc. Petroleum Geologists Guidebook 9th Ann. Field Conf., 1958: p. 31-38.

Kelley, V. C., and Bogart, L. E., 1952, Gym limestone, New Mexico: Am. Asssoc. Petroleum Geologists Bull., v. 36, no. 8, p. 1644-1648.

Kelley, V. C., and Wood, G. H., Jr., 1946, Lucero uplift, Valencia, Socorro, and Bernalillo Counties, New Mexico: U.S. Geol. Survey Oil and Gas Inv. Prelim. Map OM-47.

Kentta, Harold, and Abrassart, C. P., 1952, Surface cross section of the Phosphoria formation, southeast Big Horn Basin, in Wyoming Geol. Assoc. Guidebook 7th Ann. Field Conf., southern Big Horn Basin, Wyoming, 1952: p. 54.

King, P. B., 1930, Descriptive geology, pt. 1 of The geology of the Glass Mountains, Texas: Texas Univ. Bull. 3038, 167 p. [1931].

1932, Limestone reefs in the Leonard and Hess formations of Trans-Pecos Texas : Am. Jour. Sci., 5th ser., v. 24, p. 337354.

1934, Permian stratigraphy of Trans-Pecos Texas: Geol. Soc. America Bull., v. 45, no. 4, p. 692-798.

1937, Geology of the Marathon region, Texas: U.S. Geol. Survey Prof. Paper 187, 148 p.

1942, Permian of west Texas and southeastern New Mexico, pt. 2 of DeFord, R. K., and Lloyd, E. R., eds., West Texas-New Mexico-a symposium: Am Assoc. Petroleum Geologists (Bull., v. 26, no. 4, p. 535-763.

1948, Geology of the southern Guadalupe Mountains, Texas: U.S. Geol. Survey Prof. Paper 215, 183 p. [1949].

- 1949, Regional geologic map of parts of Culberson and Hudspeth Counties, Texas: U.S. Geol. Survey Oil and Gas Inv. Prelim. Map 90.

- 1965, Geology of the Sierra Diablo region, west Texas: U.S. Geol. Survey Prof. Paper 480, 185 p.

King, P. B., and Flawn, P. T., 1953, Geology and mineral deposits of pre-Cambrian rocks of the Van Horn area, Texas: Texas Univ. Pub. 5301, 218 p.

King, P. B., King, R. E., and Knight, J. B., 1945, Geology of the Hueco Mountains, El Paso, and Hudspeth Counties, Texas: U.S. Geol. Survey Oil and Gas Inv. Prelim. Map OM-36.

King, R. E., 1930, Faunal summary and correlation of the Permian formations, with description of Brachiopoda, pt. 2 of the Glass Mountains, Texas : Texas Univ. Bull. 3042, 245 p. [1931].

- 1939, Geological reconnaissance in northern Sierra Madre Occidental of Mexico: Geol. Soc. America Bull., v. 50, no. 11, p. 1625-1722.

- 1945, Stratigraphy and oil-producing zones of the pre-San Andres formations of southeastern New Mexico, a preliminary report: New Mexico Bur. Mines and Mineral Resources Bull. 23, 31 p.

King, R. E., and others, 1944, Geology and paleontology of the Permian area northwest of Las Delicias, southwestern Coahuila, Mexico: Geol. Soc. America Spec. Paper 52, 172 p.

King, R. H., 1947a, Phosphate deposits near Lander, Wyoming: Wyoming Geol. Survey Bull. 39a, 84 p.

1947b, Sedimentation in Permian Castile Sea [United States] : Am. Assoc. Petroleum Geologists Bull., v. 31, no. 3, p. $470-477$.

King, W. R., Jr., chm., and others, 1956, East-west cross section-Comanche County, Kansas, to Baca County, Colorado : Liberal, Kansas, Liberal Geol. Soc. Cross Section 1.
Kinney, D. M., 1955, Geology of the Uinta River-Brush Creek area, Duchesne and Uintah Counties, U.tah : U.S. Geol. Survey Bull. 1007, 185 p.

Klemme, H. D., 1949, The geology of Sixteen Mile Creek area, Montana : Princeton Univ., unpub. $\mathrm{Ph}$. D. thesis.

Klepper, M. R., Honkala, F. S., Payne, O. A., and Ruppel, E. T., 1953, Stratigraphic sections of the Phosphoria formation in Montana, 1948: U.S. Geol. Survey Circ. 260, 39 p.

Klepper, M. R., Weeks, R. A., and Ruppel E. T., 1957, Geology of the southern Elkhorn Mountains, Jefferson and Broadwater Counties, Montana: U.S. Geol. Survey Prof. Paper 292, 82 p.

Knight, R. L., 1956, Permian fusulines from Nevada : Jour. Paleontology, v. 30, no. 4, p. 773-792.

Knight, S. H., 1929, The Fountain and the Casper formations of the Laramie Basin; a study on genesis of sediments: Wyoming Univ. Pub. Sci. Geology, v. 1, no. 1, p. 1-82.

1960 , Cross-lamination and local deformation in the Casper sandstone, southeast Wyoming, in Geol. Soc. America Guidebook, Guide to geology of Colorado, 1960 : p. 228-229.

Koenig, A. A., Jr., 1952, Geology of the Troublesome Creek Basin, Carbon County, Wyoming: Wyoming Univ., unpub. M.A. thesis.

Kottlowski, F. E., 1958, Pennsylvanian and Permian rocks near Late Paleozoic Florida Islands [New Mexico], in Roswell Geol. Soc. Guidebook 11th Field Conf., Hatchet Mountains and Cooks Range-Florida Mountain areas, 1958: p. 79-87. 1959, Real wildcat country-Pennsylvanian of southwest New Mexico: Oil and Gas Jour., v. 57, no. 16, p. 148-151. 1960, Summary of Pennsylvanian sections in southwestern New Mexico and southeastern Arizona: New Mexico Bur. Mines and Mineral Resources Bull. 66, $187 \mathrm{p}$.

Kottlowski, F. E., and others, 1956, Stratigraphic studies of the San Andres Mountains, New Mexico: New Mexico Bur. Mines and Mineral Resources Mem. 1, 132 p.

Krebs, C. E., 1911, Jackson, Mason, and Putnam Counties : West Virginia Geol. Survey, 387 p.

Kroenlein, G. A., 1939, Salt, potash, and anhydrite in Castile formation of southeast New Mexico: Am. Assoc. Petroleum Geologists Bull., v. 23, no. 11, p. 1682-1693.

Krumbein, W. C., and Garrels, R. M., 1952, Origin and classification of chemical sediments in terms of $\mathbf{p H}$ and oxidationreduction potentials: Jour. Geology, v. 60, no. 1, p. 1-33.

Krumbein, W. C., and Sloss, L. L., 1951, Stratigraphy and sedimentation: San Francisco, W. H. Freeman \& Co., 497 p.

Kuehnert, H. A., 1954, Huntington anticline, Emery County, Utah, in Intermountain Assoc. Petroleum Geologists Guidebook 5th Ann. Field Conf., Salt Lake City, Utah, 1954: p. 94-95.

Kuellmer, F. J., 1954, Geologic section of the Black Range at Kingston, New Mexico: New Mexico Bur. Mines and Mineral Resources Bull. 33, 100 p.

Kulp, J. L., 1959, Geological time scale [abs.] : Geol. Soc. America Bull., v. 70, no. 12, pt. 2, p. 1634. 1961, Geologic time scale : Science, v. 133, p. 1105-1114.

Kulstad, R. O., Fairchild, P. W., and McGregor, D. J., 1956, Gypsum in Kansas: Kansas Geol. Survey Bull. 113, 110 p.

Kummel, Bernhard, 1954, Triassic stratigraphy of southeastern Idaho and adjacent areas: U.S. Geol. Survey Prof. Paper 254-H, p. 165-194.

Kunkel, R. P., 1958, Permian stratigraphy of the Paradox basin [Colorado-Utah], in Intermountain Assoc. Petroleum Geologists Guidebook 9th Ann. Field Conf., Paradox basin, 1958: p. 163-168. 
Lamborn, R. E., 1930, Geology of Jefferson County [Ohio] : Ohio Geol. Survey, 4th ser., Bull. 35, 304 p.

Landes, K. K., and Keroher, R. P., 1942, Mineral resources of Phillips County [Kansas]: Kansas Geol. Survey Bull. 41, pt. 8, p. 277-312.

Lang, W. T. B., 1935, Upper Permian formation of Delaware Basin of Texas and New Mexico: Am. Assoc. Petroleum Geologists Bull., v. 19, no. 2, p. 262-270.

- 1939, Salado formation of the [Texas and New Mexico] Permian basin: Am. Assoc. Petroleum Geologists Bull., v. 23, no. 10, p. 1569-1572.

Langenheim, R. L., Jr., Barr, F. T., Shank, S. E., Stensaas, L. J., and Wilson, E. C., 1960, Preliminary report on the geology of the Ely No. 3 quadrangle, White Pine County, Nevada, in Intermountain Assoc. Petroleum Geologists Guidebook 11th Ann. Field Conf., east central Nevada, 1960 : p. 148-156.

Latta, B. F., 1948, Geology and ground-water resources of Kiowa County, Kansas: Kansas Geol. Survey Bull. 65, 151 p.

Laudon, L. R., and Bowsher, A. L., 1941, Mississippian formations of Sacramento Mountains, New Mexico: Am. Assoc. Petroleum Geologists Bull., v. 25, no. 12, p. 2107-2160.

Lavington, C. S., and Thompson, W. O., 1948, Post-Mississippian stratigraphy: Colorado School Mines Quart., v. 43, no. 2, p. 36-52.

Lawson, D. E., 1949, Geology of the West Ferris Mountains, Carbon County, Wyoming: Wyoming Univ., unpub. M.A. thesis.

LeBlond, R. E., 1957, Wheeler field, Ector and Winkler Counties, Texas, in Herald, F. A. ed., Occurrence of oil and gas in West Texas: Texas Univ. Bur. Econ. Geology Pub. 5716, p. 401-409.

Lee, Wallace, 1949, Subsurface geologic cross section from Barber County to Saline County, Kansas: Kansas Geol. Survey Oil and Gas Inv. 8, $16 \mathrm{p}$.

1953, Subsurface geologic cross section from Meade County to Smith County, Kansas: Kansas Geol. Survey Oil and Gas Inv. 9, $23 \mathrm{p}$.

1956, Stratigraphy and structural development of the Salina basin area : Kansas Geol. Survey Bull. 121, $167 \mathrm{p}$.

Lee, Wallace, Leatherock, Constance, and Botinelly, Theodore, 1948, The stratigraphy and structural development of the Salina Basin of Kansas: Kansas Geol. Survey Bull. 74, $155 \mathrm{p}$.

Lee, Wallace, and Merriam, D. F., 1954, Preliminary study of the structure of western Kansas: Kansas Geol. Survey Oil and Gas Inv. 11, 23 p.

Lee, Wallace, Nickell, C. O., Williams, J. S., and Henbest, L. G., 1938, Stratigraphic and paleontologic studies of the Pennsylvanian and Permian rocks in north-central Texas: Texas Univ. Pub. 3801, 252 p.

Lee, W. T., 1927, Correlation of the geologic formations between east-central Colorado, central Wyoming, and southern Montana: U.S. Geol. Survey Prof. Paper 149, 80 p.

Lehner, R. E., and others, 1961, Preliminary geologic map of Eureka County, Nevada: U.S. Geol. Survey-Mineral Inv. Field Studies Map MF-176.

LeRoy, L. W., 1946, Stratigraphy of the Golden-Morrison area, Jefferson County, Colorado : Colorado School Mines Quart., v. 41, no. 2, 115 p.

Lewis, F. E., 1941, Position of San Andres group, west Texas and New Mexico: Am. Assoc. Petroleum Geologists Bull., v. 25, no. 1, p. 73-103.

Ley, R. H., 1957, Pecos Valley field, Pecos and Ward Counties, Texas, in Herald, F. A., ed., Occurrence of oil and gas in
West Texas: Texas Univ. Bur. Econ. Geology Pub. 5716, p. 262-270.

Likharev, B. K., 1959, O granitsakh i osnovnom delenii Permskor sistemy [On the boundaries and principal division of the Permian system] : Soviet Geology, no. 6, p. 13-30.

Lindeblad, E. E., 1957, Block 47 field, Crockett County, Texas, in Herald, F. A., ed., Occurrence of oil and gas in West Texas: Tex. Univ. Bur. Econ. Geology Pub. 5716, p. 47-49.

Lisman, R. A., 1957, Brushy Top field, Sutton County, Texas, in Herald, F. A., ed., Occurrence of oil and gas in West Texas: Texas Univ. Bur. Econ. Geology Pub. 5716, p. 57.

Lloyd, E. R., 1949, Pre-San Andres stratigraphy and oil-producing zones in southeastern New Mexico, a progress report: New Mexico Bur. Mines and Mineral Resources Bull. 29, $79 \mathrm{p}$.

Lochman-Balk, Christina, 1958, The Capitol Dome section, Florida Mountains [N. Mex.], in Roswell Geol. Soc. Guidebook 11th Field Conf., Hatchet Mountains and Cooks RangeFlorida Mountain areas, 1958 : p. 46-52.

Longwell, C. R., 1925, The pre-Triassic unconformity in southern Nevada: Am. Jour. Sci., 5th ser., v. 10, p. 93-106.

- 1928, Geology of the Muddy Mountains, Nevada, with a section through the Virgin Range to the Grand Wash Cliffs, Arizona : U.S. Geol. Survey Bull. 798, 152 p.

Longwell, C. R., and Dunbar, C. O., 1936, Problems of Pennsylvanian Permian boundary in southern Nevada: Am. Assoc. Petroleum Geologists Bull., v. 20, no. 9, p. 1198-1207.

Longwell, C. R., Miser, H. D., Moore, R. C., Bryan, Kirk, and Paige, Sidney, 1925, Rock formations in the Colorado Plateau of southeastern Utah and northern Arizona: U.S. Geol. Survey Prof. Paper 132-A, p. 1-23.

Love, J. D., 1954, Tentative diagrammatic correlation of Tensleep, Amsden, Casper, and Hartville formations in Wyoming, in Wyoming Geol. Assoc., Guidebook 9th Ann. Field Conf., Casper area, Wyoming, 1954: in pocket.

Love, J. D., Henbest, L. G., and Denson, N. M., 1953, Stratigraphy and paleontology of Paleozoic rocks, Hartville area, eastern Wyoming: U.S. Geol. Survey Oil and Gas Inv. Chart OC-44.

Lukert, L. H., 1949, Subsurface cross sections from Marion County, Kansas, to Osage County, Oklahoma: Am. Assoc. Petroleum Geologists Bull., v. 33, no. 2, p. 131-152.

Lynn, J. R., 1947, Geology of the north margin of the Reshaw Hills, Platte County, Wyoming: Wyoming Univ., unpub. M.A. thesis.

Lyon, D. L., 1956, Geology of the north flank, eastern Bridger Range, Hot Springs County, Wyoming: Wyoming Univ., unpub. M.A. thesis.

Lyons, J. B., Jaffe, H. W., Gottfried, David, and Waring, C. L., 1957, Lead-alpha ages of some New Hampshire granites: Am. Jour. Sci., v. 255, no. 8, p. 527-546.

McAllister, J. F., 1956, Geologic map of the Ubehebe Peak quadrangle, California : U.S. Geol. Survey Geol. Quad. Map GQ-95.

McCauley, V. T., 1956, Pennsylvanian and Lower Permian of the Williston Basin, in North Dakota Geol. Soc., Williston Basin Symposium, 1st Internat., Bismarck, 1956; p. 150-164.

McClymonds, N. E., 1957, The stratigraphy and structure of the Waterman Mountains, Pima County, Arizona: Arizona Univ., unpub. M.S. thesis.

McCue, J. J., 1953, Facies changes within the Phosphoria formation in the southeast portion of the Big Horn Rasin, Wyoming: Wyoming Univ., unpub. M.A. thesis. 
McCurdy, H. R., 1941, Pennsylvanian and Permian stratigraphy along the eastern flank of the Laramie Range, southeastern Wyoming: Wyoming Univ., unpub. M.A. thesis.

McDavid, J. D., 1953, Geology of the Muddy Creek area, Carbon County, Wyoming: Wyoming Univ., unpub. M.A. thesis.

McGookey, D. P., 1952, Pennsylvanian and Early Permian stratigraphy of the southeast portion of the east flank of the Laramie Range, Wyoming and Colorado: Wyoming Univ., unpub. M.A. thesis.

McKee, E. D., 1938, Environment and history of the Toroweap and Kaibab formations of northern Arizona and southern Utah : Carnegie Inst. Washington Pub. 492, 268 p.

1939, Studies on the history of Grand Canyon Paleozoic formations: Carnegie Inst. Washington Year Book 38 for 1938-39, p. 313-314.

- 1940, Three types of cross-lamination in Paleozoic rocks of northern Arizona: Am. Jour. Sci., v. 238, no. 11, p. 811824.

1945, Small-scale structures in the Coconino sandstone of northern Arizona: Jour. Geology, v. 53, no. 5., p. 313-325. _- 1947, Paleozoic seaways in western Arizona: Am. Assoc. Petroleum Geologists Bull., v. 31, no. 2, p. 282-292.

1951, Sedimentary basins of Arizona and adjoining areas : Geol. Soc. America Bull., v. 62, no. 5, p. 481-505.

- 1952, Uppermost Paleozoic strata of northwestern Arizona and southwestern Utah, in Utah Geol. Soc. Guidebook 7, Cedar City, Utah, to Las Vegas, Nevada, 1952: p. 52-55.

- 1954a, Permian stratigraphy between Price and Escalante, Utah, in Intermountain Assoc. Petroleum Geologists Guidebook 5th Ann. Field Conf., Portions of high plateaus and adjacent canyon lands, central and south-central Utah, 1954 : p. 21-24.

$1954 \mathrm{~b}$, Stratigraphy and history of the Moenkopi formation of Triassic age: Geol. Soc. America Mem. 61, 133 p.

McKee, E. D., Oriel, S. S., and others, 1967, Paleotectonic maps of the Permian System: U.S. Geol. Survey Misc. Geol. Inv. Map I-450.

McKee, E. D., and others, 1956, Paleotectonic maps of the Jurassic system : U.S. Geol. Survey Misc. Geol. Inv. Map I-175, 6 p., 9 pls.

1959, Paleotectonic maps of the Triassic system: U.S. Geol. Survey Misc. Geol. Inv. Map I-300, 33 p., 9 pls. [1960].

McKee, E. D., and Sterrett, T. S., 1961, Laboratory experiments on form and structure of longshore bars and beaches, in Peterson, J. A., and Osmond, J. C., eds., Geometry of sandstone bodies: Am. Assoc. Petroleum Geologists Spec. Pub., p. 13-28.

McKelvey, V. E., Armstrong, F. C., Gulbrandsen, R. A., and Campbell, R. M., 1953, Stratigraphic sections of the Phosphoria formation in Idaho, 1947-48: U.S. Geol. Survey Circ. 301, pt. 2, 58 p.

McKelvey, V. E., and others, 1953, Stratigraphic sections of the Phosphoria formation in Wyoming, 1947-48: U.S. Geol. Survey Circ. 210, 35 p.

McKelvey, V. E., Swanson, R. W., and Sheldon, R. P., 1953, The Permian phosphorite deposits of western United States: Internat. Geol. Cong., 19th, Algiers 1952, Comptes rendus, sec. 11, pt. 11, p. 45-64.

McKelvey, V. E., Williams, J. S., Sheldon, R. P., Cressman, E. R., Cheney, T. M., and Swanson, R. W'., 1956, Summary description of Phosphoria, Park City, and Shedhorn formations in western phosphate field : Am. Assoc. Petroleum Geologists Bull., v. 40, no. 12, p. 2826-2863.
- 1959, The Phosphoria, Park City, and Shedhorn formations in the western phosphate field: U.S. Geol. Survey Prof. Paper 313-A, p. 1-47.

McKnight, E. T., 1940, Geology of a rea between Green and Colorado Rivers, Grand and San Juan Counties, Utah: U.S. Geol. Survey Bull. 908, 147 p.

McLaughlin, T. G., 1954, Geology and ground-water resources of Baca County, Colorado: U.S. Geol. Survey Water-Supply Paper 1256, 232 p.

McLellan, R. D., 1927, The geology of the San Juan Islands : Seattle, Wash., Washington Univ. Geology Pub., v. 2, 185 p.

McLennan, Lamar, Jr., and Bradley, H. W., 1951, Spraberry and Dean sandstones of West Texas: Am. Assoc. Petroleum Geologists Bull., v. 35, no. 4, p. 899-908.

McMannis, W. J., 1955, Geology of the Bridger Range, Montana : Geol. Soc. America Bull., v. 66, no. 11, p. 1385-1430.

McMath, V. E., 1958, Geology of the Taylorsville area, Plumas County, California : California Univ., Ph. D. thesis. Available from University Microfilms, Inc., Ann Arbor, Mich.

McNair, A. H., 1951, Paleozoic stratigraphy of part of northwestern Arizona: Am. Assoc. Petroleum Geologists Bull., v. 35, no. 3, p. 503-541.

Maher, J. C., 1945, Structural development of Las Animas arch, Lincoln, Cheyenne, and Kiowa Counties, Colorado: Am. Assoc. Petroleum Geologists Bull., v. 29, no. 11, p. 16631667.

1946, Subsurface geologic cross section from Ness County, Kansas, to Lincoln County, Colorado: Kansas Geol. Survey Oil and Gas Inv., Prelim. Cross Section 2, 13 p.

1947, Subsurface geologic cross section from Scott County, Kansas, to Otero County, Colorado : Kansas Geol. Survey Oil and Gas Inv., Prelim. Cross Section 4, $11 \mathrm{p}$.

—_ 1948, Subsurface geologic cross section from Baca County to Yuma County, Colorado: Kansas Geol. Survey Oil and Gas Inv., Prelim. Cross Section 6, 11 p.

1953, Permian and Pennsylvanian rocks of southeastern Colorado: Am. Assoc. Petroleum Geologists Bull., v. 37, no. 5, p. 913-939.

1954, Lithofacies and suggested depositional environment of Lyons sandstone and Lykins formation in southeastern Colorado: Am. Assoc. Petroleum Geologists Bull., v. 38 , no. 10 , p. $2233-2239$.

1958, Stratigraphic classification and correlation of Paleozoic rocks in southeastern Colorado, in Kansas Geol. Soc. Guidebook 22d Field Conf., south-central Colorado, 1958: p. 51-77.

Maher, J. C., and Collins, J. B., 1952, Correlation of Permian and Pennsylvanian rocks from western Kansas to the Front Range of Colorado: U.S. Geol. Survey Oil and Gas Inv. Map OC-46.

Mansfield, G. R., 1927, Geography, geology, and mineral resources of part of southeastern Idaho: U.S. Geol. Survey Prof. Paper 152, $453 \mathrm{p}$.

Mapel, W. J., 1954, Geology and coal resources of the Lake De Smet area, Johnson County, Wyoming: U.S. Geol. Survey Coal Inv. Map C-23.

Maravich, M. D., 1941, Geology of Freezeout Mountain-Gold Mountain area, Carbon County, Wyoming: Am. Assoc. Petroleum Geologists Bull., v. 25, no. 5, p. 883-897.

Marshall, C. H., 1940, Geology of the Hazelton area, Big Horn Mountains, Wyoming: Iowa State Univ., unpub. M.S. thesis.

Martens, J. H. C., 1945, Well-sample records: West Virginia Geol. Survey Rept., v. 17, 889 p. 
Mason, B. H., 1958, Principles of geochemistry : 2d ed., New York, John Wiley \& Sons, $310 \mathrm{p}$.

Masters, K. E., 1955, Geology of the Prague area, Lincoln and Pottawatomie Counties, Oklahoma : Oklahoma Univ., unpub. M.S. thesis, 37 p.

- 1957, Geology of the Prague area, Lincoln and Pottawatomie Counties, Oklahoma: Shale Shaker [Oklahoma City, Okla.], v. 7, no. 5, p. 8, 10, 13-16, 19-20.

Maughan, E. K., and Wilson, R. F., 1960, Pennsylvanian and Permian strata in southern Wyoming and northern Colorado, in Geol. Soc. America Guidebook, Guide to geology of Colorado, 1960 : p. 34-42.

Mears, Brainerd, Jr., 1950, Cenozoic faults, gravels, and volcanics of Oak Creek Canyon, Arizona: Columbia Univ., Ph. D. thesis. Available from University Microfilms, Inc., Ann Arbor, Mich.

Merriam, C. W., and Berthiaume, S. A., 1943, Late Paleozoic formations of central Oregon: Geol. Soc. America Bull., v. 54, no. 2, p. 145-171.

Merriam, C. W., and Hall, W. E., 1957, Pennsylvanian and Permian rocks of the southern Inyo Mountains, California: U.S. Geol. Survey Bull. 1061-A, p. 1-15.

Merriam, D. F., 1955, Jurassic rocks in Kansas: Am. Assoc. Petroleum Geologists Bull., v. 39, no. 1, p. 31-46.

- 1957, Notes on the Permian Stone Corral formation of central and western Kansas: Compass [Provo, Utah], v. 34, no. 4, p. 267-277.

1958, Preliminary regional structural contour map on top of the Stone Corral formation (Permian) in Kansas: Kansas Geol. Survey Oil and Gas Inv. 17.

Merriam, D. F., and Atkinson, W. R., 1955, Tectonic history of the Cambridge arch in Kansas: Kansas Geol. Survey Oil and Gas Inv, 13, $28 \mathrm{p}$.

Merriam, D. F., and Goebel, E. D., 1954, The geology of the Norton oil field, Norton County, Kansas: Kansas Geol. Survey Bull. 109, pt. 9, p. 125-152.

Miller, A. K., 1945, A Permian ammonoid from Sonora [Mexico] : Jour. Paleontology, v. 19, no. 1, p. 22.

Miller, A. K., and Furnish, W. M., 1940, Permian ammonoids of the Guadalupe Mountain region and adjacent areas: Geol. Soc. America Spec. Paper 26, 242 p.

Miller, A. K., Furnish, W. M., Jr., and Clark, D. L., 1957, Permian ammonoids from western United States: Jour. Paleontology, v. 31, no. 6, p. 1057-1068.

Miller, A. K., and Garner, H. F., 1953, Permian ammonoid zones of the West Texas region, in West Texas Geol. Soc. Guidebook, Spring Field Trip, Chinati Mountains, Presidio County, Texas, 1953 : p. $64-69$.

Miller, A. K., and Thomas, H. D., 1936, The Casper formation (Pennsylvanian) of Wyoming and its cephalopod fauna: Jour. Paleontology, v. 10, no. 8, p. 715-738.

Miller, D. N., Jr., 1955, Petrology of Pierce Canyon red beds, Delaware basin, Texas and New Mexico: Texas Univ., unpub. Ph. D. thesis.

Miser, H. D., 1924, Geologic structure of San Juan Canyon and adjacent country, Utah: U.S. Geol. Survey Bull. 751-D, p. 115-155.

1954, Geologic map of Oklahoma: U.S. Geol. Survey.

Mitchell, J. G., 1953, Pre-Cretaceous stratigraphy of the Denver Basin, in Moore, C. A., ed., Third subsurface geological symposium proc., Oklahoma Univ., 1953: p. 82-94.

Mixon, R. B., Murray, G. E., Díaz-Gonzalez, T. E., 1959, Age and correlation of Huizachal group (Mesozoic), State of Tam- aulipas, Mexico: Am. Assoc. Petroleum Geologists Bull., v. 43 , no. 4 , p. $757-771$.

Mohr, C. L., 1939, Subsurface cross section of Permian from Texas to Nebraska : Am. Assoc. Petroleum Geologists Bull., v. 23, no. 11, p. 1694-1710.

Moore, G. W., 1959, Alteration of gypsum to form the Capitan limestone of New Mexico and Texas [abs.]: Geol. Soc. America Bull., v. 70, no. 12, pt. 2, p. 1647.

- 1960, Origin and chemical composition of evaporite deposits : U.S. Geol. Survey open-file report, $174 \mathrm{p}$.

Moore, J. H., 1944, Fullerton pool, Andrews County, Texas: Am. Assoc. Petroleum Geologists Bull., v. 28, no. 10, p. 15411542.

Moore, R. C., 1931, Pennsylvanian cycles in the northern Mid. Continent region: Illinois Geol. Survey Bull. 60, p. 247-257. - 1932, A reclassification of the Pennsylvanian system in the northern Mid-continent region, in Kansas Geol. Soc. Guidebook 6th Ann. Field Conf., Kansas, Missouri, and Nebraska, 1932 : p. 79-98.

- 1940, Carboniferous-Permian boundary : Am. Assoc. Petroleum Geologists Bull., v. 24, no. 2, p. 282-336.

1949, Rocks of Permian(?) age in the Colorado River Valley, north-central Texas: U.S. Geol. Survey Oil and Gas Inv. Map 80 .

1950, Late Paleozoic cyclic sedimentation in central United States : Internat. Geol. Cong., 18th, Great Britain 1948, Rept., pt. 4, p. 5-16.

- 1959, Geological understanding of cyclic sedimentation represented by Pennsylvanian and Permian rocks of northern Midcontinent region, in Assoc. Am. State Geologists, Kansas Field Conf., 1959: p. 46-55.

Moore, R. C., Frye, J. C., Jewett, J. M., Lee, Wallace, and O'Connor, H. G., 1951, The Kansas rock column: Kansas Geol. Survey Bull. 89, 132 p.

Moore, R. C., Jewett, J. M., and O'Connor, H. G., 1951, Rock formations of Chase County, pt. 1 of Geology, mineral resources, and ground-water resources: Kansas Geol. Survey [Rept.], v. 11, p. 1-16.

Moore, R. C., and Mudge, M. R., 1956, Reclassification of some Lower Permian and Upper Pennsylvanian strata in northern Mid-Continent: Am. Assoc. Petroleum Geologists Bull., v. 40, no. 9, p. 2271-2278.

Moore, R. C., chm., and others, 1944, Correlation of Pennsylvanian formations of North America : Geol. Soc. America Bull., v. 55, no. 6, p. 657-706.

Morgan, B. R., 1958, Geology of southwestern Lincoln County, Oklahoma: Oklahoma Univ., unpub. M.S. thesis, 129 p.

Morgan, H. J., Jr., 1952, Paleozoic beds south and east of Ouachita folded belt: Am. Assoc. Petroleum Geologists Bull., v. 36, no. 12 , p. 2266-2274.

Morgan, J. K., 1951, Geology of the Otter Creek area, Washakie County, Wyoming: Wyoming Univ., unpub. M.A. thesis.

Mudge, M. R., 1949, The pre-Quaternary stratigraphy of Riley County, Kansas : Kansas State Univ., unpub. M.S. thesis.

- 1956, Sandstones and channels in Upper Pennsylvanian and Lower Permian in Kansas: Am. Assoc. Petroleum Geologists Bull., v. 40, no. 4, p. 654-678.

1957, Permian-Pennsylvanian boundary in Kansas, in Kansas Geol. Soc. Guidebook 21st Field Conf., eastern Kansas: p. 113-118.

Mudge, M. R., and Burton, R. H., 1959, The geology of Waubaunsee County, Kansas: U.S. Geol. Survey Bull. 1068, 210 p. 
Mudge, M. R., Matthews, C. W., and Wells, J. D., 1958, Geology and construction material resources of Morris County, Kansas : U.S. Geol. Survey Bull. 1060-A, p. 1-61.

Mudge, M. R., Walters, C. P., and Skoog, R. E., 1959, Geologic construction material resources of Nemaha County, Kansas: U.S. Geol. Survey Bull. 1060-D, p. 179-256.

Mudge, M. R., and Yochelson, Ellis, 1962, Stratigraphy and paleontology of the uppermost Pennsylvania and lowermost Permian rocks in Kansas: U.S. Geol. Survey Prof. Paper 323, 213 p. [1963].

Mullens, T. E., 1960, Geology of the Clay Hills area, San Juan County, Utah : U.S. Geol. Survey Bull. 1087-H, p. 259-336.

Muller, S. W., Ferguson, H. G., and Roberts, R. J., 1951, Geologic map of the Mount Tobin quadrangle, Nevada: U.S. Geol. Survey Geol. Quad. Map GQ-7.

Munn, M. J., 1912, Description of Claysville quadrangle [Pennsylvania] : U.S. Geol. Survey Geol. Atlas, Folio 180.

Murchison, R. I., 1841, First sketch of some of the principal results of a second geological survey of Russia : Philos. Mag., 3d ser., v. 19, p. 417-422.

Murphy, J. P., 1957, White and Baker-Walker field, in Herald, F. A., ed., Occurrence of oil and gas in West Texas: Texas Univ. Bur. Econ. Geology Pub. 5716, p. 410-414.

Murray, F. E., 1957, Geology of the Nowood area, Washakie County, Wyoming: Wyoming Univ., unpub. M.A. thesis.

Murray, H. F., 1958, Pennsylvanian stratigraphy of the Maroon trough, in Rocky Mtn. Assoc. Geologists, Pennsylvanian rocks of Colorado and adjacent areas-a symposium: p. 47-58.

Myers, A. J., 1959, Geology of Harper County, Oklahoma : Oklahoma Geol. Survey Bull. 80, 108 p.

Myers, D. A., Stafford, P. T., and Burnside, R. J., 1956, Geology of the late Paleozoic Horseshoe atoll in west Texas: Texas Univ. Pub. 5607, 113 p.

Nakayama, Eugene, 1955, Geology of southeastern Payne County, Oklahoma: Oklahoma Univ., unpub. M.S. thesis, 68 p.

Needham, C. E., and Bates, R. L., 1943, Permian type sections in central New Mexico: Geol. Soc. America Bull., v. 54, no. 11, p. 1653-1667.

Newell, N. D., 1948, Key Permian section, Confusion Range, western Utah: Geol. Soc. America Bull., จ. 59, no. 10, p. 1053-1058.

1957, Paleoecology of Permian reefs in the Quadalupe Mountains area, in Ladd, H. S., ed., Treatise on marine ecology and paleoecology: Geol. Soc. America Mem. 67, p. 407-436.

Newell, N. D., and Kummel, Bernhard, Jr., 1942, Lower EoTriassic stratigraphy, western Wyoming and southeast Idaho: Geol. Soc. America Bull., v. 53, no. 6, p. 987-995.

Newell, N. D., Rigby, J. K., Fischer, A. G., Whiteman, A. J., Hickox, J. E., and Bradley, J. S., 1953, The Permian reef complex of the Guadalupe Mountains region Texas and New Mexico-a study in paleoecology: San Francisco, W. H. Freeman \& Co., 236 p.

Noble, L. F., 1922, A section of the Paleozoic formations of the Grand Canyon at the Bass trail: U.S. Geol. Survey Prof. Paper 131-B, p. 23-73.

1927, A section of the Kaibab limestone in Kaibab Gulch, Utah: U.S. Geol. Survey Prof. Paper 150-C, p. 41-60 [1928].

Nolan, T. B., 1930, Paleozoic formations in the Gold Hill quadrangle, Utah: Washingtion [D.C.] Acad. Sci. Jour., v. 20, no. 17 , p. $421-432$.
Nolan, T. B., Merriam, C. W., and Williams, J. S., 1956, The stratigraphic section in the vicinity of Eureka, Nevada: U.S. Geol. Survey Prof. Paper 276, 77 p.

Norling, D. L., 1958, Geology and mineral resources of Morgan County, Ohio: Ohio Div. Geol. Survey Bull. 56. 131 p.

Norris, R. P., 1951, The origin and sedimentation of Wilson Canyon, Caddo County, Oklahoma: Kansas Univ., unpub. M.S. thesis, $83 \mathrm{p}$.

Northrop, S. A., Sullwold, H. H., Jr., MacAlpin, A. J., and Rogers, C. P., Jr., 1946, Geologic maps of a part of the Las Vegas Basin and of the foothills of the Sangre de Cristo Mountains, San Miguel and Mora Counties, New Mexico: U.S. Geol. Survey Oil and Gas Inv. Prelim. Map 54.

Norton, G. H., 1939, Permian red beds of Kansas: Am. Assoc. Petroleum Geologists Bull., v. 23, no. 12, p. 1751-1819.

Oborne, H. W., 1938, Guide to field study of the rocks exposed along the Front Range of the Rocky Mountains in Colorado, pt. 2 of Kansas Geol. Soc. Guidebook 12th Ann. Field Conf., Front Range of the Rocky Mountains, Colorado, 1938: p. 38-57.

O'Connor, H. G., 1953, Rock formations of Lyon County, pt. 1 of Geology, mineral resources, and ground-water resources of Lyon County, Kansas: Kansas Geol. Survey [Rept.], v. 12, p. 5-24.

O'Connor, H. G., Goebel, E. D., and Plummer, N. V., 1953, Mineral resources of Lyon County, pt. 2 of Geology, mineral resources, and ground-water resources of Lyon County, Kansas : Kansas Geol. Survey [Rept.], v. 12, p. 24-35.

O'Connor, H. G., Jewett, J. M., and Smith, R. K., 1951, Mineral resources of Chase County, pt. 2 of Geology, mineral resources, and ground-water resources: Kansas Geol. Survey [Rept.], v. 11, p. 16-28.

Oklahoma Geological Survey, 1917, A discussion of the oil and gas fields and undeveloped areas of the State, by counties, pt. 2 of Petroleum and natural gas in Oklahoma : Oklahoma Geol. Survey Bull. 19, 536 p.

O'Malley, F. W., Davidson, D. F., Hoppin, R. A., and Sheldon, R. P., 1953, Stratigraphic sections of the Phosphoria formation in Idaho, 1947-48, pt. 3: U.S. Geol. Survey Circ. 262, $43 \mathrm{p}$.

Oppel, T. W., 1959, The Pennsylvanian-Permian contact in lower Fresnal Canyon Sacramento Mountains, New Mexico, in Permian Basin Section, Soc. Econ. Paleontologists Mineralogists, Roswell Geol. Soc. Guidebook, Joint Field Conf., Sacramento Mountains of Otero County, New Mexico, 1959: p. 186-195.

Oriel, S. S., and Mudge, M. R., 1956, Problems of lower Mesozoic stratigraphy in southeastern Colorado, in Rocky Mtn. Assoc. Geologists Guidebook, Geology of the Raton Basin, Colorado, 1956 : p. 19-24.

Osborne, W. C., 1957, Keystone field, Winkler County, Texas, in Herald, F. A., ed., Occurrence of oil and gas in West Texas : Texas Univ. Bur. Econ. Geology Pub. 5716, p. 156-171.

Osterwald, F. W., and Dean, B. G., compilers, 1958, Preliminary tectonic map of western Nebraska and northwestern Kansas showing the distribution of uranium deposits: U.S. Geol. Survey Mineral Inv. Field Studies Map MF-129.

Otte, Carel, Jr., 1954, Late Pennsylvanian and early Permian stratigraphy of the northern Sacramento Mountains, Otero County, New Mexico: California Inst. Technology, unpub. $\mathrm{Ph}$. D. thesis, $245 \mathrm{p}$.

1959, Late Pennsylvanian and early Permian stratigraphy of the northern Sacramento Mountains, Otero 
County, New Mexico: New Mexico Bur. Mines and Mineral Resources Bull. 50, 111 p.

Page, L. R., and Adams, J. E., 1940, Stratigraphy, eastern Midland basin, Texas, in DeFord, R. K., and Lloyd, E. R., eds., West Texas-New Mexico-a symposium: Am. Assoc. Petroleum Geologists Bull., v. 24, no. 1, p. 52-64.

Paige, Sidney, 1916, Description of the Silver (Yity quadrangle, New Mexico : U.S. Geol. Survey Geol. Atlas, Folio 199.

Partridge, L. R., 1949, The (Permian) Phosphoria and (Triassic) Dinwoody formations, northern Big Horn Basin, Wyoming and Montana: Wyoming Univ., unpub. M.A. thesis.

Pederson, S. L., 1953, Stratigraphy of the Casper and Fountain formations of southeastern Wyoming and north central Colorado: Wyoming Univ., unpub. M.A. thesis.

Pennebaker, E. N., 1932, Geology of the Robinson (Ely) mining district in Nevada; a preliminary report on the primary monzonite prophyry intrusive ore bodies and how they are formed: Mining and Metallurgy, v. 13, no. 304, p. 163-168.

Pennington, Jack, Jr., 1947, Stratigraphy and structure of the Horse Draw area, Albany and Platte Counties, Wyoming: Missouri Univ., unpub. M.A. thesis.

Peterson, J. A., Gosman, R. F., and Swanson, R. W., 1954, Stratigraphic sections of the Phosphoria formation in Montana, 1951 : U.S. Geol. Survey Circ. 326, 27 p.

Peterson, M. L., 1956, Subsurface stratigraphy of the pre-Niobrara formations along the eastern margin of the Powder River Basin, Wyoming, pt. 1 of Wyoming stratigraphy: Wyoming Geol. Assoc. Nomenclature Comm., p. 43-48.

Pettijohn, F. J., 1949, Sedimentary rocks : New York, Harper \& Bros., 526 p.

Phillips, F. C., 1947, Oceanic salt deposits : Quart. Rev. [London Chem. Soc.], v. 1, p. 91-111.

Pierce, W. G., 1947, quoted in Curry, W. H., Norton, George, Reinhart, P. W., Spalding, R. W., and Maebius, J. B., Road $\log$ Greybull to Cody via Shell Canyon and Dayton-Kane Road, in Wyoming Geol. Assoc. Guidebook 2d Ann. Field Conf., Bighorn Basin, 1947 : p. 35-37.

1948, Geologic and structure contour map of the BasinGreybull area, Big Horn County, Wyoming: U.S. Geol. Survey Oil and Gas Inv. Prelim. Map 77.

Plummer, F. B., and Scott, Gayle, 1937, Upper Paleozoic ammonites in Texas: Texas Univ. Bull. 3701, pt. 1, p. 1-516.

Poole, F. G., 1957, Paleo-wind directions in late Paleozoic and early Mesozoic time on the Colorado Plateau as determined by cross-strata [abs.] : Geol. Soc. America Bull., v. 68, no. 12, pt. 2, p. 1870.

1962, Wind directions in late Paleozoic to middle Mesozoic time on the Colorado Plateaus, in Short papers in geology, hydrology, and topography: U.S. Geol. Survey Prof. Paper 450-D, p. D147-D151.

Pownell, L. D., 1957, Surface geology of northwestern Lincoln County, Oklahoma: Oklahoma Univ., unpub. M.S. thesis, $65 \mathrm{p}$.

Praetorius, H. W., 1956, Stratigraphy of the (Permian) Phosphoria formation of northwestern Colorado and northeastern Utah : Colorado Univ., unpub. M.S. thesis.

Pray, L. C., 1949, Pre-Abo deformation in the Sacramento Mountains, New Mexico [abs.] : Geol. Soc. America Bull., v. 60, no. 12 , pt. 2 , p. 1914-1915.

-1954 , Outline of the stratigraphy and structure of the Sacramento Mountain escarpment, in New Mexico Geol. Soc. Guidebook 5th Field Conf., southeastern New Mexico, 1954: p. $92-107$.
Pray, L. C., Stratigraphic and structural features of the Sacramento Mountain escarpment, New Mexico, in Permian Basin Section, Soc. Econ. Paleontologists Mineralogists, Roswell Geol. Soc. Guidebook, Joint Field Conf., Sacramento Mountains of Otero County, New Mexico, 1959: p. 86-130.

1960, Compaction in calcilutites [abs.] : Geol. Soc. America Bull., v. 71, no. 12, pt. 2, p. 1946.

Pray, L. C., and Allen, J. E., 1956, Outlier of Dakota (?) strata, southeastern New Mexico: Am. Assoc. Petroleum Geologists Bull., v. 40, no. 11, p. 2735-2740.

Pray, L. C., and Otte, Carel, Jr., 1954, Correlation of the Abo formation of south-central New Mexico [abs.] : Geol. Soc. America Bull., v. 65, no. 12, pt. 2, p. 1296.

Privrasky, N. C., and others, 1958, Preliminary report on the Goose Egg and Chugwater formations in the Powder River Basin, Wyoming, in Wyoming Geol. Assoc. Guidebook 13th Ann. Field Conf., 1958 : p. 48-55.

Rall, R. W., and Rall, E. P., 1958, Pennsylvanian subsurface geology of Sutton and Schleicher Counties, Texas: Am. Assoc. Petroleum Geologists Bull., v. 42, no. 4, p. 839-870.

Ramírez M., J. C., and Acevedo C., Francisco, 1957, Notas sobre la geología de Chihuahua: Asoc. Mexicana Geólogos Petroleros Bol., v. 9, nos. 9, 10, p. 583-770.

Raney, D. C., 1957, Oates field, Pecos County, Texas, in Herald, F. A., ed., Occurrence of oil and gas in West Texas: Texas Univ. Bur. Econ. Geology Pub. 5716, p. 237-238.

Ransome, F. L., 1915, The Tertiary orogeny of the North American Cordillera and its problems, in Problems of American geology : New Haven, Yale Univ. Press, p. 287-376.

1916, Some Paleozoic sections in Arizona and their correlation : U.S. Geol. Survey Prof. Paper 98-K, p. 133-166.

Read, C. B., 1944, Geology and Upper Paleozoic stratigraphy in portions of northeastern New Mexico: Tulsa Geol. Soc. Digest, v. 13, p. 36-44 [1945].

- 1950, Stratigraphy of the outcropping Permian rocks around the San Juan Basin, in New Mexico Geol. Soc. Guidebook 1st Field Conf., San Juan Basin, New Mexico and Colorado, 1950: p. 62-66.

1951, Stratigraphy of the outcropping Permian rocks around the San Juan Basin, in New Mexico Geol. Soe. Guidebook 2d Field Conf., south and west sides of San Juan Basin, New Mexico and Arizona, 1951 : p. 80-84.

Read, C. B., and others, 1944, Geologic map and stratigraphie sections of Permian and Pennsylvanian rocks of parts of San Miguel, Santa Fe, Sandoval, Bernalillo, Torrance, and Valencia Counties, north-central New Mexico: U.S. Geol. Survey Oil and Gas Inv. Prelim. Map 21.

Read, C. B., and Wanek, A. A., 1961, Stratigraphy of outeropping Permian rocks in parts of northeastern Arizona and adjacent areas : U.S. Geol. Survey Prof. Paper 374-H, p. H1-H10.

Read, C. B., Wood, G. H., Wanek, A, A., and Mackie, P. R., 1949, Stratigraphy and geologic structure in the Piedra River Canyon, Archuleta County, Colorado: U.S. Geol. Survey Oil and Gas Inv. Prelim. Map 96.

Reed, E. C., 1938, Correlation of formations drilled in the Midland Forster well near Fremont, Nebr. : Nebraska Geol. Survey Paper 13, $20 \mathrm{p}$.

1955, Correlation of the Permo-Pennsylvarian rocks of the Black Hills with the northern Mid-Continent region [South Dakota-Nebraska], in North Dakota Geol. Soc. Guidebook 3d Field Conf., South Dakota Black Hills, 1955 : p. 44-47. 
Reeside, J. B., Jr., and Bassler, Harvey, 1922, Stratigraphic sections in southwestern Utah and northwestern Arizona: U.S. Geol. Survey Prof. Paper 129-D, p. 53-77.

Reeves, Frank, 1928, The carbon-ratio theory in the light of Hilt's Law: Am. Assoc. Petroleum Geologists Bull., v. 12, no. 8 , p. $795-823$.

Reger, D. B., 1916, Lewis and Gilmer Counties: West Virginia Geol. Survey Rept., 660 p.

Reiche, Parry, 1938, An analysis of cross-lamination; the Coconino sandstone: Jour. Geology, v. 46, no. 7, p. 905-932. 1949, Geology of the Manzanita and North Manzano Mountains, New Mexico: Geol. Soc. America Bull., v. 60, no. 7, p. 1183-1212.

Renick, B. C., 1981, Geology and ground-water resources of western Sandoval County, New Mexico: U.S. Geol. Survey Water-Supply Paper 620, 117 p.

Rich, J. L., 1921, A probable buried mountain range of early Permian age east of the present Rocky Mountains in New Mexico and Colorado: Am. Assoc. Petroleum Geologists Bull., v. 5, no. 5, p. 605-608.

Rich, Mark, 1956, Geology of the southern portion of the Pancake Summit quadrangle, Nevada: Southern California Univ., unpub. M.A. thesis.

Richards, P. W., 1955, Geology of the Bighorn Canyon-Hardin area, Montana and Wyoming: U.S. Geol. Survey Bull. 1026, $93 \mathrm{p}$.

Richardson, A. L., 1950, Geology of the Mayoworth region, Johnson County, Wyoming: Wyoming Univ., unpub. M.A. thesis.

Richardson, G. B., 1903, The upper red beds of the Black Hills: Jour. Geology, v. 11, p. 365-393.

1904, Report of a reconnaissance in Trans-Pecos Texas, north of the Texas and Pacific Railway: Texas Univ. Mineralog. Survey Bull. 9, 119 p.

Rigby, J. K., 1957, Some submarine mass movements [Texas and Utah] [abs.] : Geol. Soc. America Bull., v. 68, no. 12, pt. 2, p. 1872.

Ritzma, H. R., 1951, Paleozoic stratigraphy, north and west fiank of the Sierra Madre, Wyoming-Colorado, in Wyoming Geol. Assoc. Guidebook 6th Ann. Field Conf., south-central Wyoming, 1951 : p. 66-69.

1955, Early Cenozoic history of the Sand Wash Basin, northwest Colorado, in Intermountain Assoc. Petroleum Geologists Guidebook 6th Ann. Field Conf., Salt Lake City, Utah, 1955 : p. 36-40.

Riva, J. F., 1957, Geology of a portion of the Diamond Range, White Pine County, Nevada: Nevada Univ., unpub. M.S. thesis.

Rix, C. C., 1953a, Geology of the Chinati Mountain quadrangle, in West Texas Geol. Soc. Guidebook, Spring Field Trip, Chinati Mountains, Presidio County, Texas, 1953 : p. 1-3. 1953h, Road log, Chinati quadrangle trip, in West Texas Geol. Soc. Guidebook, Spring Field Trip, Chinati Mountains, Presidio County, Texas, 1953 : p. 8-20.

1953c, Geology of the Chinati Peak quadrangle, Presidio County, trans-Pecos Texas: Texas Univ., unpub. Ph. D. thesis.

Roberts, R. J., 1951, Geologic map of the Antler Peak quadrangle, Nevada : U.S. Geol. Survey Geol. Quad. Map GQ-10.

Roberts, R. J., Hotz, P. E., Gilluly, James, and Ferguson, H. G., 1958, Paleozoic rocks of north-central Nevada: Am. Assoc. Petroleum Geologists Bull., v. 42, no. 12, p. 2813-2857.

Robinson, H. H., 1913, The San Franciscan volanic field, Arizona : U.S. Geol. Survey Prof. Paper 76, 213 p.
Rogers, H. D., 1858, The geology of Pennsylvania, a government survey : Philadelphia, v. 1, 586 p. ; v. 2, 1046 p.

Romer, A. S., 1952, Late Pennsylvanian and early Permian vertebrates of the Pittsburgh-West Virginia region, in Fossil vertebrates of the Tri-State area : Carnegie Mus. Annals, v. 33, p. 47-112.

1958, The Texas Permian redbeds and their vertebrate fauna, in Westoll, T. S., ed., 1958, Studies on fossil vertebrates: The Athlone Press, London Univ., p. 157-179.

Rooney, L. F., 1956, A stratigraphic study of the Permian formations of part of southwestern Montana: Indiana Univ., $\mathrm{Ph}$. D. thesis, $150 \mathrm{p}$. Available from University Microfilms, Inc., Ann Arbor, Mich.

Ross, C. A., 1959a, The type Wolfcamp Series (Permian) Glass Mountains, Texas: Yale Univ., Ph. D. thesis. Available from University Microfilms, Inc., Ann Arbor, Mich.

1959b, The Wolfcamp Series (Permian) and new species of fusulinids, Glass Mountains, Texas : Washington [D.C.] Acad. Sci. Jour., v. 49, no. 9, p. 299-316.

1960, Fusulinids from the Hess Member of the Leonard Formation, Leonard Series (Permian), Glass Mountains, Texas: Cushman Found. Foram. Research Contr., v. 11, pt. 4, p. 117-133.

Roswell Geological Society, 1953, North-south correlation section, western flank of Permian Basin, southeastern New Mexico.

- 1958, North-south stratigraphic section, northwest shelf to Delaware basin, southeastern New Mexico.

Roth, R. I., 1949, Paleogeology of the Panhandle of Texas: Geol. Soc. America Bull., v. 60, no. 10, p. 1671-1688.

1955, Paleogeology of Panhandle of Texas: Am. Assoc. Petroleum Geologists Bull., v. 39, no. 4, p. 422-443.

Ruzhentsev, V. E., 1936, New data on the stratigraphy of the Carboniferous and lower Permian of the Orenburg and Aktiubinsk districts [Russia] : Problems Soviet Geology, no. 6, p. 470-506.

- 1955, Fundamental stratigraphical assemblages of ammonoids in the Permian system: Izv. Akad. nauk SSSR, no. 4, p. 120-132.

Sabins, F. F., Jr., 1957, Stratigraphic relations in Chiricahua and Dos Cabezas Mountains, Arizona: Am. Assoc. Petroleum Geologists Bull., v. 41, no. 3, p. 466-510.

Sahl, H. L., 1952, Geology of the Soap Creek dome, Big Horn County, Montana : Nebraska Univ., unpub. M.S. thesis.

Sanders, C. W., Jr., 1934, Geology of Two Buttes dome in southeastern Colorado: Am. Assoc. Petroleum Geologists Bull., v. 18 , no. 7 , p. $860-870$.

Savre, W. C., 1954, Stratigraphy, igneous rocks, mineral deposits, and structure of a portion of the southwestern Bear Lodge Mountains, Crook County, Wyoming: Iowa State Univ., unpub. M.S. thesis.

Schaeffer, F. E., 1960, Stratigraphy of the Silver Island Mountains, in Utah Geol. Soc. Guidebook 15th Ann. Field Conf., Silver Island Mountains, Box Elder and Tooele Counties, Utah, and Elko County, Nevada, 1960: p. 15-113.

Scherer, O. J., and Condra, E. C., 1940, Section of Minnekahta, Opeche, and Minnelusa formations, Redbird Canyon, secs. 16 and 17, T. 3 S., R. 1 E., Custer County, South Dakota, in Kansas Geol. Soc. Guidebook 14th Ann. Field Conf., western South Dakota and eastern Wyoming, 1940 : p. 45.

Schoenfelt, C. E., 1938, Oil and gas development in eastern Colorado, in Kansas Geol. Soc. Guidebook 12th Ann. Field Conf., Front Range of Rocky Mountains, Colorado, 1938: p. 91-102. 
Scobey, w. B., chm., Stratigraphic Problems Committee, 1951, North-south cross section through Permian basin of West Texas : West Texas Geol. Soc.

Scott, G. L., Jr., and Ham, W. E., 1957, Geology and gypsum resources of the Carter area, Oklahoma: Oklahoma Geol. Survey Circ. 42, 64 p.

Scott, G. R., Foster, F. W., and Crumpton, C. F., 1959, Geology and construction-material resources of Pottawatomie County, Kansas: U.S. Geol. Survey Bull. 1060-C, p. 97-178.

Scott, K. R., Hayes, W. E., and Fietz, R. P., 1961, Geology of the Eagle Mills formation: Gulf Coast Assoc. Geol. Socs. Trans., v. 11, p. 1-14.

Scruton, P. C., 1953, Deposition of evaporites : Am. Assoc. Petroleum Geologists Bull., v. 37, no. 11, p. 2498-2512.

Sears, J. D., 1956, Geology of Comb Ridge and vicinity north of San Juan River, San Juan County, Utah: U.S. Geol. Survey Bull. 1021-E, p. 167-207.

Sears, J. D., Hunt, C. B., and Hendricks, T. A., 1941, Transgressive and regressive Cretaceous deposits in southern San Juan basin, New Mexico: U.S. Geol. Survey Prof. Paper 193-F, p. 101-121.

Sharps, S. L., 1955, Correlation of pre-Mancos, post-Weber formations, northwestern Colorado, in Intermountain Assoc. Petroleum Geologists Guidebook 6th Ann. Field Conf., northwest Colorado, 1955 : p. 16-17.

Shaw, E. W., and Munn, M. J., 1911, Description of the Burgettstown-Carnegie quadrangles, Pennsylvania : U.S. Geol. Survey Geol. Atlas, Folio 177.

Sheffer, B. D., 1951, Geology of the western Alcova area [central Wyoming] : Wyoming Univ., unpub. M.A. thesis.

Sheldon, R. P., 1957, Physical stratigraphy of the Phosphoria formation in northwestern Wyoming: U.S. Geol. Survey Bull. 1042-E, p. 105-185.

1959, Geochemistry of uranium in phosphorites and black shales of the Phosphoria formation: U.S. Geol. Survey Bull. 1084-D, p. 83-115.

Sheldon, R. P., Cressman, E. R., Carswell, L. D., and Smart, R. A., 1954, Stratigraphic sections of the Phosphoria formation in Wyoming, 1952 : U.S. Geol. Survey Circ. 325, 24 p.

Sheldon, R. P., Waring, R. G., Warner, M. A., and Smart, R. A., 1953, Stratigraphic sections of the Phosphoria formation in Wyoming, 1949-50 : U.S. Geol. Survey Circ. 307, 45 p.

Sheldon, R. P., Warner, M. A., Thompson, M. E., and Peirce, H. W., 1953, Stratigraphic sections of the Phosphoria formation in Idaho, 1949, pt. 1: U.S. Geol. Survey Circ. $304,30 \mathrm{p}$.

Sheridan, D. S., 1950, Permian, Triassic, and Jurassic stratigraphy of the McCoy area, west-central Colorado: Colorado Univ., unpub. M.A. thesis.

Sherlock, R. L., 1948, The Permo-Triassic formations; a world review: London, Hutchinson's Sci. and Tech. Pubs., 367 p.

Shoemaker, E. M., and Newman, W. L., 1959, Moenkopi formation (Triassic? and Triassic) in salt anticline region, Colorado and Utah: Am. Assoc. Petroleum Geologists Bull., v. 43 , no. 8 , p. 1835-1851.

Shortridge, C. G., 1953, The geological relationship of water loss and gain problems on Battle Creek near Hermosa, South Dakota : South Dakota School Mines and Technology, unpub. M.S. (G.E.) thesis.

Shreveport Geological Society, 1947, Reference report, 1945, on certain oil and gas fields of north Louisiana, south Arkansas, Mississippi, and Alabama: Shreveport, La., Shreveport Photo Copy Co., v. 2, 503 p.
Shumard, B. F., 1858, Notice of new fossils from the Permian strata of New Mexico and Texas: St. Louis Acad. Sci. Trans., v. 1, p. 290-297 [1860].

Sidwell, Raymond, and Warn, G. F., 1953, Pennsylvanian and related sediments of Upper Pecos Valley, New Mexico: Am. Assoc. Petroleum Geologists Bull., v. 37, no. 5, p. 975-1013.

Singewald, Q. D., 1942, Stratigraphy, structure, and mineralization in the Beaver-Tarryall area, Park County, Colorado: U.S. Geol. Survey Bull. 928-A, p. 1-44.

Skinner, H. C. W., 1960, Formation of modern dolomitic sediments in South Australian lagoons [abs.] : Geol. Soc. America Bull. v. 71, no. 12, pt. 2, p. 1976.

Skinner, J. W., 1940, Upper Paleozoic section of Chinati Mountains, Presidio County, Texas, in DeFord, R. K., and Lloyd, E. R., eds., West Texas-New Mexico symposium : Am. Assoc. Petroleum Geologists Bull., v. 24, no. 1, p. 180-188.

1946, Correlation of Permian of west Texas and southeast New Mexico: Am. Assoc. Petroleum Geologists Bull., v. 30, no. 11, p. 1857-1874.

Skinner, J. W., and Wilde, G. L., 1955, New fusulinids from the Permian of. west Texas: Jour. Paleontology, v. 29, no. 6, p. 927-940.

Smart, R. A., Waring, R. G., Cheney, T. M., and Sheldon, R. P., 1954, Stratigraphic section of the Phosphoria formation in Idaho, 1950-51: U.S. Geol. Survey Circ. 327, 22 p.

Smith, C. T., 1954, Geology of the Thoreau quadrangle, McKinley and Valencia Counties, New Mexico: New Mexico Bur. Mines and Mineral Resources Bull. 31, $36 \mathrm{p}$.

Smith, C. T., and Budding, A. J., 1959, Reconnaissance geologic map of Little Black Peak fifteen-minute quadrangle, east half : New Mexico Bur. Mines and Mineral Resources Geol. Map 11.

Smith, L. E., Hosford, G. F., Sears, R. S., Sprouse, D. P., and Stewart, M.D., 1952, Stratigraphic sections of the Phosphoria formation in Utah, 1947-48: U.S. Geol. Survey Circ. 211, 48 p. [1953].

Smith, R. E., 1957, Geology and ground-water resources of Torrance County, New Mexico: New Mexico Bur. Mines and Mineral Resources Ground-Water Rept. 5, 186 p.

Smith, R. K., and Anders, E. L., Jr., 1951, The geology of the Davis Ranch oil pool, Wabaunsee County, Kansas: Kansas Geol. Survey Bull. 90, pt. 2, p. 13-52.

Smith, W. D. P., and Allen, J. E., 1941, Geology and physiography of the northern Wallowa Mountains, Oregon: Oregon Dept. Geology and Mineral Industries Bull. 12, $64 \mathrm{p}$.

Smith, W. H., 1948, Geology of Newport Township, Washington County, Ohio: Ohio Geol. Survey Rept. Inv. 5, 7 p.

Snelson, Sigmund, 1957, The geology of the northern Ruby Mountains and the East Humboldt Range, Elko County, northeastern Nevada: Washington Univ., Ph. D. thesis, 268 p. Available from University Microfilms, Inc., Ann Arbor, Mich.

Society of Economic Paleontologists and Mineralogists, Permian Basin Section, 1957, Guidebook, Wolfcamp of the Glass Mountains and the Permian basin [New Mexico-Texas], 1957: $98 \mathrm{p}$

Sonnenberg, F. P., Rader, M. T., and Clement, J. H., 1952, Electric and lithologic cross-section from Norcanols Ogema to Weller-Bush-Weisman, in Billings Geol. Soc. Guidebook 3d Ann. Field Conf., Black Hills-Williston Basin, 1952: in pocket.

South Dakota Geological Survey, 1946, Logs of some deep wells in western South Dakota : Revised ed., South Dakota Geol. Survey Rept. Inv. 4, 108 p. 
Spooner, W. C.; 1935, Oil and gas geology of the Gulf coastal plain in Arkansas: Arkansas Geol. Survey Bull. 2, $474 \mathrm{p}$.

Stafford, P. T., 1959, Geology of part of the Horseshoe atoll in Scurry and Kent Counties, Texas: U.S. Geol. Survey Prof. Paper, 315-A, p. 1-20.

1961, Geology of the Cross Plains quadrangle, Brown, Callahan, Coleman, and Eastland Counties, Texas: U.S. Geol. Survey Bull. 1096-B, p. 39-72.

Stauffer, C. R., and Schroyer, C. R., 1920, The Dunkard Series of Ohio: Ohio Geol. Survey, 4th ser., Bull. 22, 167 p.

Stead, F. L., and Waldschmidt, W. A., 1953, Regional significance of the Pump Station Hills, in West Texas Geol. Soc. Guidebook, Fall Field Conf., Sierra Diablo-Guadalupe-Hueco areas of Trans-Pecos, Texas, $1953:$ p. 71-77.

Steed, R. H., 1954, Geology of Circle Cliffs anticline [Utah], in Intermountain Assoc. Petroleum Geologists Guidebook 5th Ann. Field Conf., Salt Lake City, Utah, 1954: p. 99-102.

Steele, Grant, 1959, Stratigraphic interpretation of the Pennsylvanian-Permian systems of the eastern Great Basin: Washington Univ., Ph. D. thesis. Available from University Microfilms, Inc., Ann Arbor, Mich.

1960, Pennsylvanian-Permian stratigraphy of east-central Nevada and adjacent Utah, in Intermountain Assoc. Petroleum Geologists Guidebook 11th Ann. Field Conf., eastcentral Nevada, 1960 : p. 91-113.

Stehli, F. G., 1954, Lower Leonardian Brachiopoda of the Sierra Diablo [Texas] : Am. Mus. Nat. History Bull., v. 105, p. 257-358.

Steven, T. A., 1954, Geology of the Northgate fluorspar district, Colorado: U.S. Geol. Survey Mineral Inv. Field Studies Map MF-13.

Stevenson, J. J., 1876, Report of progress in Greene and Washington district of the bituminous coal fields of western Pennsylvania : Pennsylvania Geol. Survey, 2d, Rept. K, 419 p.

Stevenson, R. H., 1958, Subsurface geology of northwest Canadian County, Oklahoma: Oklahoma Univ., unpub. M.S. thesis, $74 \mathrm{p}$.

Stewart, J. H., 1959, Stratigraphic relations of Hoskinnini member (Triassic?) of Moenkopi Formation on Colorado Plateau: Am. Assoc. Petroleum Geologists Bull., v. 43, no. 8, p. $1852-1868$.

Stiles, E. R., Roper, F. C., and McCammon, J. H., 1955, Val Verde basin cross sections [Texas], in San Angelo Geol. Soc., Geological contributions, 1955: San Angelo, Tex., p. 82-83, cross sections in pouch.

Stipp, T. F., 1947, Paleozoic formations near Cody, Park County, Wyoming: Am. Assoc. Petroleum Geologists Bull., v. 31, p. 274-281.

Stipp, T. F., and Haigler, L. B., 1956, Preliminary structure contour map of a part of southeastern New Mexico showing oil and gas development: U.S. Geol. Survey Oil and Gas Inv. Map OM-177.

Sturgeon, M. T., and others, 1958, The geology and mineral resources of Athens County, Ohio: Ohio Div. Geol. Survey, Bull. 57, 600 p.

Sullivan, C. R., and Raasch, G. O., 1938, Geologic cross-section, western Kansas and eastern Colorado, in Kansas Geol. Soc. Guidebook 12th Ann. Field Conf., Front Range of Rocky Mountains, Colo., 1938: p. 77-81.

Sverdrup, H. U., Johnson, M. W., and Fieming, R. H., 1942, The oceans, their physics, chemistry, and general biology: New York, Prentice-Hall, 1087 p.
Swain, F. M., Jr., 1944, Stratigraphy of Cotton Valley beds of northern Gulf Coastal Plain: Am. Assoc. Petroleum Geologists Bull., v. 28, no. 5, p. 577-614.

Swanson, R. W., Carswell, L. D., Sheldon, R. P., and Cheney, T. M., 1956: Stratigraphic sections of the Phosphoria formation, 1953: U.S. Geol. Survey Circ. 375, 30 p.

Swanson, R. W., Cressman, E. R., Jones, R. S., and Replogle, B. K., 1953, Stratigraphic sections of the Phosphoria formation in Montana, 1949-50, pt. 2: U.S. Geol. Survey Circ. 303, 21 p.

Swanson, R. W., Lowell, W. R., Cressman, E. R., and Bostwick, D. A., 1953, Stratigraphic sections of the Phosphoria formation in Montana, 1947-48: U.S. Geol. Survey Circ. 209, $31 \mathrm{p}$.

Swineford, Ada, 1955, Petrography of Upper Permian rocks in south-central Kansas : Kansas Geol. Survey Bull. 111, 179 p.

Tait, D. B., and others, 1962, Artesia group of New Mexico and west Texas: Am. Assoc. Petroleum Geologists Bull., v. 46, no. 4, p. 504-517.

Taubeneck, W. H., 1955, Age of the Elkhorn Ridge argillite, northeastern Oregon: Northwest Sci. [Pullman, Wash.], v. 29 , no. 3, p. 97-100.

Taucher, L. M., 1953, Geology of the Cookstove basin area, Big Horn County, Wyoming: Wyoming Univ., unpub. M. A. thesis.

Taylor, R. C.,.1953, The geology of the Foraker area, Osage County, Oklahoma: Oklahoma Univ., unpub. M.S. thesis, $108 \mathrm{p}$.

Thomas, C. R., McCann, F. T., and Raman, N. D., 1945, Mesozoic and Paleozoic stratigraphy of northwestern Colorado and northeastern Utah: U.S. Geol. Survey Oil and Gas Inv. Prelim. Chart 16.

Thomas, H. D., 1934, Phosphoria and Dinwoody tongues in lower Chugwater of central and southeastern Wyoming: Am. Assoc. Petroleum Geologists Bull., v. 18, no. 12, p. 1655-1697. 1939, comment on Williams, J. Stewart, 1939, "Park City" beds on southwest fiank of Uinta Mountains, Utah: Am. Assoc. Petroleum Geologists Bull., v. 23, no. 8, p. 1249 1250.

1940, Pennsylvanian and Permian stratigraphy of central and southeastern Wyoming, in Kansas Geol. Soc. Guidebook 14th Ann. Field Conf., western South Dakota and eastern Wyoming, 1940 : p. 90, 121-126.

-1948, Summary of Paleozoic stratigraphy of the Wind River Basin, Wyoming, in Wyoming Geol. Assoc. Guidebook 3d Ann. Field Conf., Wind River Basin, 1948: p. 79-95.

Thomas, H. D., Thompson, M. L., and Harrison J. W., 1953, Stratigraphy of the Casper formation, pt. 1 of Fusulinids of the Casper formation of Wyoming: Wyoming Geol. Survey Bull. 46, p. 5-14.

Thompson, M. L., 1942, Pennsylvanian system in New Mexico: New Mexico School of Mines Bull. 17, 90 p.

- 1946, Permian fusulinids from Afghanistan : Jour. Paleontology, v. 20, no. 2, p. 140-157.

1954, American Wolfcampian fusulinids: Kansas Univ. Paleont. Contr. [14], Protozoa, art. 5, 225 p.

Thompson, M. L., and Wheeler, H. E., 1942, Permian fusulinids from British Columbia, Washington, and Oregon: Jour. Paleontology, v. 16, no. 6, p. 700-711.

Thompson, M. L., Wheeler, H. E., and Danner, W. R., 1950, Middle and Upper Permian fusulinids of Washington and British Columbia : Cushman Found. Foram. Research Contr., v. 1 , pts. $3-4$, p. $46-63$. 
Thompson, M. L., Wheeler, H. E., and Hazzard, J. C., 1946, Permian fusulinids of California : Geol. Soc. America Mem. $17,77 \mathrm{p}$.

Thompson, R. M., and White, V. L., 1952, Geology of the Conant Creek-Muskrat Creek area, Fremont County, Wyoming: U.S. Geol. Survey open-file map.

Thompson, W. O., 1937, Original structures of beaches, bars, and dunes: Geol. Soc. America Bull., v. 48, no. 6, p. 723-751. 1938, Selected cross section, Deer Creek southwest of Littleton, Jefferson County, Colorado, in Oborne, H. W. Guide to field study of the rocks exposed along the Front Range of the Rocky Mountains in Colorado, in Kansas Geol. Soc. Guidebook 12th Ann. Field Conf., Front Range of Rocky Mountains, Colorado, 1938: p. 43.

- 1949, Lyons sandstone of Colorado Front Range: Am. Assoc. Petroleum Geologists Bull., v. 33, no. 1, p. 52-72.

Thompson, W. O., and Kirby, J. M., 1940, Cross section from Colorado Springs to Black Hills showing correlation of Paleozoic stratigraphy, in Kansas Geol. Soc. Guidebook 14th Ann. Field Conf., western South Dakota and eastern Wyoming, 1940 : p. 142-146.

Thompson, W. O., and Oborne, H. W., 1938, Selected cross sections, in Oborne, $\mathrm{H}$. W., Guide to field study of the rocks exposed along the Front Range of the Rocky Mountains in Colorado, in Kansas Geol. Soc. Guidebook 12th Ann. Field Conf., Front Range of Rocky Mountains, Colorado, 1938: p. 38-57.

Thompson, W. O., and Quam, L. O., 1938, Selected cross sections [D, E, F], in Oborne, H. W., Guide to field study of the rocks exposed along the Front Range of the Rocky Mountains in Colorado, in Kansas Geol. Soc. Guidebook 12th Ann. Field Conf., Front Range of Rocky Mountains, Colorado, 1938 : p. 54-56.

Tomlinson, C. W., and McBee, W. D., Jr., 1959, Pennsylvanian sediments and orogenies of Ardmore district, Oklahoma, in Petroleum geology of southern Oklahoma-a sympossium : Ardmore Geol. Soc., v. 2, p. 3-52.

Tomlinson, C. W., Moore, R. C., Dott, R. H., Cheney, M. G., and Adams, J. E., 1940, Classification of Permian rocks: Am. Assoc. Petroleum Geologists Bull. v. 24, no. 2, p. 337-358.

Tonking, W. H., 1957, Geology of Puertecito quadrangle, Socorro County, New Mexico: New Mexico Bur. Mines and Mineral Resources Bull. 41, 67 p.

Tooker, E. W., and Roberts, R. J., 1961, Stratigraphy of the north end of the Oquirrh Mountains, Utah, in Geology of the Bingham mining district and northern Oquirrh Mountains: Utah Geol. Soc. Guidebook to the geology of Utah, no. 16, p. 17-35.

Totten, R. B., 1956, General geology and historical development, Texas and Oklahoma panhandles: Am. Assoc. Petroleum Geologists Bull., v. 40, no. 8, p. 1945-1967.

Tourtelot, H. A., 1953, Geology of the Badwater area, central Wyoming: U.S. Geol. Survey Oil and Gas Inv. Map OM-124.

Trotter, J. F., 1954, Geology of the Nowood Creek-Ten Sleep area, Washakie County, Wyoming: Wyoming Univ., unpub. M.A. thesis.

Tschanz, C. M., Laub, D. C., and Fuller, G. W., 1958, Copper and uranium deposits of the Coyote district, Mora County, New Mexico: U.S. Geol. Survey Bull. 1030-L, p. 343-398.

Tschanz, C. M., and Pampeyan, E. H., 1961, Preliminary geologic map of Lincoln County, Nevada : U.S. Geol. Survey Mineral Inv. Field Studies Map MF-206.

Tyrrell, W. W., Jr., 1957, Geology of the Whetstone Mountain area, Cochise and Pima Counties, Arizona: Yale Univ.,
Ph. D. thesis, 64 p. Available from University Microfilms, Inc., Ann Arbor, Mich.

Udden, J. A., 1904, The geology of the Shafter silver mine district, Presidio County, Texas: Texas Univ. Mineral Survey Bull. 8, 60 p.

1917, Notes on the geology of Glass Mountains : Texas Univ. Bull. 1753, p. 3-59.

1924, Laminated anhydrite in Texas: Geol. Soc. America Bull., v. 35, p. 347-354.

Udden, J. A., Baker, C. L., and Böse, Emil, 1916, Review of the geology of Texas : Texas Univ. Bull. 44, $178 \mathrm{p}$.

Untermann, G. E., and Untermann, B. R., 1954, Geology of Dinosaur National Monument and vicinity, Utah-Colorado: Utah Geol. Mineralog. Survey Bull. 42, 228 p.

Van den Bark, Edwin, 1957a, Embar field, Andrews County, Texas, in Herald, F. A., ed., Occurrence of oil and gas in West Texas: Texas Univ. Bur. Econ. Geology Pub. 5716, p. 110-115.

1957b, North Goldsmith field, Ector County, Texas, in Herald F. A., ed., Occurrence of oil and gas in West Texas: Texas Univ. Bur. Econ. Geology Pub. 5716, p. 230-233.

Van Horn, Richard, 1957, Bedrock geology of the Golden quadrangle, Colorado: U.S. Geol. Survey Geol. Quad. Map GQ103.

Veronda, G. R., 1951, Summary report on the geology of the Big Sandy area, Carbon County, Wyoming, in Wyoming Geol. Assoc. Guidebook 6th Ann. Field Conf., south-central Wyoming, 1951 : p. 117-121.

Vertrees, C. D., Atchison, C. H., and Evans, G. L., 1959, Paleozoic geology of the Delaware and Val Verde basins, in West Texas Geol. Soc. Guidebook, Field Trip, Val Verde basin, 1959 : p. 64-73.

Verville, G. J., 1957, Wolfcampian fusulinids from the Tensleep sandstone in the Big Horn Mountains, Wyoming: Jour. Paleontology, v. 31, p. 349-352.

Vestal, J. H., 1950, Petroleum geology of the Smackover formation of southern Arkansas: Arkansas Research Devel. Comm. Div. Geology Inf. Circ. 14, 19 p.

Vinson, M. C., 1959, Brown-Bassett field, Terrell County, in West Texas Geol. Soc. Guidebook, Field Trip, Val Verde basin, 1959 : p. 85-86.

Vosburg, D. L., 1954, Geology of the Burbank-Shidler area, Osage County, Oklahoma: Oklahoma Univ., unpub. M.S. thesis, $110 \mathrm{p}$.

Wagner, W. R., 1945, A geological reconnaissance between the Snake and Salmon Rivers north of Riggins, Idaho: Idaho Bur. Mines and Geology Pamph. 74, 16 p.

Walcott, C. D., 1880, The Permian and other Paleozoic groups of the Kanab Valley, Arizona: Am. Jour. Sci., 3d ser., v. 20, no. 117, p. 221-225.

Walter, J. C., Jr., 1953, Paleontology of Rustler formation, Culberson County, Texas: Jour. Paleontology, v. 27, no. 5, p. 679-702.

Walters, Richard, 1953, Geology of Independence Mountain area, North Park, Colorado: Wyoming Univ., unpub. M.A. thesis.

Walton, P. T., 1954, Teasdale anticline, Wayne County, Utah, in Intermountain Assoc. Petroleum Geologists Guidebook 5th Ann. Field Conf., Salt Lake City, Utah, 1954: p. 98.

Wanless, H. R., Belknap, R. L., and Foster, Helen, 1955, Paleozoic and Mesozoic rocks of Gros Ventre, Teton, Hoback, and Snake River Ranges, Wyoming: Geol. Soc. America Mem. 63, 90 p. 
Wanless, H. R., and Shepard, F. P., 1936, Sea level and climatic changes related to late Paleozoic cycles: Geol. Soc. America Bull., v. 47, no. 8, p. 1177-1206.

Warren, W. C., 1955, Introduction to field trip, in Soc. Econ. Paleontologists and Mineralogists, Permian Basin Section, Guidebook, Guảdalupe Mountains, 1955: p. 11-14.

Watson, R. N., and Bentz, F. P., 1957, Martin field, Andrews County, Texas, in Herald, F. A., ed., Occurrence of oil and gas in West Texas: Texas Univ. Bur. Econ. Geology Pub. 5716, p. 183-189.

Webb, J. H., 1942, The geology of an area southwest of Douglas, Converse County, Wyoming: Oklahoma Univ., unpub. M.S. thesis.

Weeks, W. B., 1938, South Arkansas stratigraphy with emphasis on the older Coastal Plain beds: Am. Assoc. Petroleum Geologists Bull., v. 22, no. 8, p. 953-983.

Weichman, B. E., 1958, Stratigraphy of the Phosphoria formation in the southern portion of the Wind River Basin, Wyoming: Wyoming Univ., unpub. M.A. thesis.

Weimer, R. J., 1949, Geology of the Whiskey Gap-Muddy Gap area, Wyoming: Wyoming Univ., unpub. M.A. thesis.

Weller, J. M., 1956, Argument for diastrophic control of late Paleozoic cyclothems: Am. Assoc. Petroleum Geologists Bull., v. 40, no. 1, p. 17-50.

1957, Paleoecology of the Pennsylvanian Period in Illinois and adjacent States, in Ladd, $H$. S., ed., Treatise on marine ecology and paleontology : Geol. Soc. America Mem. 67, v. 2, p. 325-364.

Welsh, J. E., 1953, Geology of Sheep Mountain-Delaney Butte area, North Park, Colorado, in Wyoming Geol. Assoc. Guidebook 8th Ann. Field Conf., Laramie Basin, Wyoming, and North Park, Colorado, 1953 : p. 99-100.

Wengerd, S. A., and Strickland, J. W., 1954, Pennsylvanian stratigraphy of Paradox salt basin, Four Corners region, Colorado and Utah: Am. Assoc. Petroleum Geologists Bull., v. 38, no. 10, p. 2157-2199.

West, A. E., 1955, Surface geology of northeastern Lincoln County, Oklahoma : Oklahoma Univ., unpub. M.S. thesis, $53 \mathrm{p}$.

West Texas Geological Society, 1950, Guidebook, Field Trip, Sierra Blanca region, Franklin Mountains, Texas, 1950: $68 \mathrm{p}$.

1952, Guidebook, Spring Field Conf., Marathon Basin, Brewster and Pecos Counties, Trans-Pecos Texas, 1952: $78 \mathrm{p}$.

- 1953, Guidebook, Fall Field Conf., Sierra DiabloGuadalupe-Hueco areas of Trans-Pecos Texas, 1953: $91 \mathrm{p}$. — 1957, Guidebook, Field Conf., Glass Mountains [Texas], 1957 : $39 \mathrm{p}$.

1959 , Geology of the Val Verde basin and field trip guidebook, $1959: 118 \mathrm{p}$.

White, C. D., 1903, Permian elements in the Dunkard fiora [abs.] : Geol. Soc. America Bull., v. 14, p. 538-542.

1929, Flora of the Hermit shale, Grand Canyon, Arizona : Carnegie Inst. Washington Pub. 405, 221 p.

White, G. W., 1947, Waynesburg coal in Harrison and northern Belmont Counties, Ohio, and revision of Dunkard (Permian) boundary: Ohio Geol. Survey Rept. Inv. 1, 4 p.

White, I. C., 1891, Stratigraphy of the bituminous coal fields in Pennsylvania, Ohio, and West Virginia: U.S. Geol. Survey Bull. 65, 212 p.

Wilder, F. A., 1902, Geology of Webster County: Iowa Geol. Survey Ann. Rept., 1901, v. 12, p. 63-191.
Wilder, F. A., 1924, Gypsum ; its occurrence, origin, technology, and use, with special chapters devoted to gypsum in Iowa : Iowa Geol. Survey Ann. Repts., 1917, 1918, v. 28, p. 47-537.

Willhour, R. R., 1958, Structure and stratigraphy of a part of the Front-Laramie Range foothills in northern Colorado and southern Wyoming : Colorado Univ., unpub. M.S. thesis.

Williams, H. L., 1958, The importance of fusulines in the study of Pennsylvanian stratigraphy, in San Angelo Geol. Soc. Guidebook, The base of the Permian [Texas]-A century of controversy, $1958:$ p. 62-72.

1959, Paleozoic paleontology of the Delaware and Val Verde basins [Texas], in West Texas Geol. Soc. Guidebook, Field Trip, Val Verde basin, 1959: p. 96-97.

Williams, J. Steele, 1938, Pre-Congress Permian conference in the U.S.S.R.: Am. Assoc. Petroleum Geologists Bull., v. 22, no. 6, p. 771-776.

1954, Problem of boundaries between geologic systems: Am. Assoc. Petroleum Geologists Bull., v. 38, no. 7, p. 16021605.

Willis, Robin, 1929, Preliminary correlation of the Texas and New Mexico Permian: Am. Assoc. Petroleum Geologists Bull., v. 13, no. 8, p. 997-1031.

Willis, R. P., 1953, Geologic map and cross sections of the Porcupine Creek area, Big Horn County, Wyoming: Wyoming Univ., unpub. M.A. thesis.

Wilpolt, R. H., MacAlpin, A. J., Bates, R. L., and Vorbe, Georges, 1946, Geologic map and stratigraphic sections of Paleozoic rocks of Joyita Hills, Los Pinos Mountains, and northern Chupadera Mesa, Valencia, Torrance, and Socorro Counties, New Mexico: U.S. Geol. Survey Oil and Gas Inv. Prelim. Map 61.

Wilpolt, R. H., and Wanek, A. A., 1951, Geology of the region from Socorro and San Antonio east to Chupadera Mesa, Socorro County, New Mexico: U.S. Geol. Survey Oil and Gas Inv. Prelim. Map OM-121.

Wilson, J. A., 1959, Stratigraphic concepts in vertebrate paleontology : Am. Jour. Sci., v. 257, no. 10, p. 770-778.

Wilson, P. C., 1954, Pennsylvanian stratigraphy of the Powder River Basin, Wyoming, and adjoining areas: Washington State Coll., unpub. Ph. D. thesis.

Winters, S. S., 1963, The Supai Formation (Permian) of eastern Arizona : Geol. Soc. America Mem. 89, 99 p.

Wood, G. H., Jr., Johnson, R. B., and Dixon, G. H., 1957, Geology and coal resources of the Starkville-Weston area, Las Animas County, Colorado: U.S. Geol. Survey Bull. 1051, $68 \mathrm{p}$.

Wood, G. H., Jr., and Northrop, S. A., 1946, Geology of Nacimiento Mountains, San Pedro Mountains, and adjacent plateaus in parts of Sandoval and Rio Arriba Counties, New Mexico: U.S. Geol. Survey Oil and Gas Inv. Prelim. Map OM-57.

Wood, G. H., Jr., Northrop, S. A., and Griggs, R. L., 1953, Geology and stratigraphy of Koehler and Mount Laughlin quadrangles and parts of Abbott and Springer quadrangles, eastern Colfax County, New Mexico: U.S. Geol. Survey Oil and Gas Inv. Map OM-141.

Woodward, T. C., 1957, Geology of Deadman Butte area, Natrona County, Wyoming: Am. Assoc. Petroleum Geologists Bull., v. 41, no. 2, p. 212-262.

Work, P. M., 1931, The stratigraphy and paleontology of the Minnelusa Formation of the southern Black Hills of South Dakota : Iowa Univ., unpub. M.S. thesis. 
Wyoming Geological Association, Nomenclature Committee (Burk, C. A., chm.), 1956, Subsurface stratigraphy of the pre-Niobrara formations in Wyoming, pt. 1 of Wyoming stratigraphy : 97 p.

Yochelson, E. L., 1956, Euomphalacea, Trochonematacea, Pseudophoracea, Anomphalacea, Craspedostromatacea, and Platyceratacea, pt. 1 of Permian Gastropoda of the southwestern United States: Am. Mus. Nat. History Bull., v. 110, p. 173276.

York, H. F., 1954, Geology of the Elk Mountain anticline, North Park, Colorado: Wyoming Univ., unpub. M.A. thesis.

Young, Addison, 1960, Paleozoic history of the Fort StocktonDel Rio region, west Texas, in Aspects of the geology of Texias-a symposium: Texas Univ. Pub. 6017, p. 87-109.
Zakis, W. N., 1950, Geology of the east flank of the Big Horn Mountains near Dayton, Sheridan County, Wyoming: Wyoming Univ., unpub. M.A. thesis.

Zeller, R. A., Jr., 1958, Road log, Deming to the Big Hatchet Mountains via Wilma and Hachita, New Mexico. Return to Deming via Hachita and Columbus, in Roswell Geol. Soc. Guidebook 11th Field Conf., Hatchet Mountains and Cooks Range-Florida Mountains areas, 1958: p. 7-24.

Zieglar, D. L., 1955, Pre-Piper post-Minnekahta "red beds" in the Williston Basin, in North Dakota Geol. Soc. Guidebook 3d Field Conf., South Dakota Black Hills, 1955: p. 49-55. 1956, Pre-Piper post-Minnekahta "red beds" in the Williston Basin [summ.; 1955 pub. revised and enlarged], in North Dakota Geol. Soc., Williston Basin Symposium, 1st Internat., Bismarck, 1956 : p. 170-178. 


\section{INDEX}

[Italic page numbers indicate major references. All stratigraphic names are indexed in roman type: use of italics and quotation marks for some names in the text is explained on

Abo Formation, Arizona and western New Mexico......... 208, 209, 210, 212, 213, 214

northeastern New Mexico and TexasOklahoma Panhandles ............- 69, 71 west Texas Permian basin region......... 39,44

Abo reef...................................... 44

Abo reef trend.................................. 41

Absaroka Range....... 129

Adams County, Colo., interval B......... 111

Adams County, Idaho, interval C-D.......- 236

Admiral Formation.

Admire Group.

Alibates Dolomite Lentil.................... 75,76

Allegany County, Md.......................

Allegheny Mountain section, Appalachian

Plateaus province. ................

Allegheny Plateau. province

Allegheny region, defined........ 1

Alta Formation.

Altuda Formation.

Amador County, Calif., interval B ........... 234

Amarillo uplift. ............... 65, 68, 69,71,74,78

Ammonites............................. 30, 34

Ammonoid............... 40,53

Amos Wash Member, Supai Formation. ... 210

Amphibian fossils. ........... 5

Amsden Formation.

Anadarko basin, northeastern New Mexico and Texas-Oklahoma Panhandles. 65 , $68,69,71,72,74,78,79$

Oklahoma. $85,86,88,89,90,91,92$

Ancestral Front Range, central Midcontinent region.

eastern Wyoming, eastern Montana, and the Dakotas.............. 133, 137, 138, 150

western Colorado, southern Utah, and northwestern New Mexico....... 175, $179,180,186,189,192,193,196,197$

Ancestral Julesburg basin.................... 141 Ancestral Rocky Mountains, central Midcontinent region

eastern Wyoming, eastern Montana, and the Dakotas.......

northeastern New Mexico and TexasOklahoma Panhandles.......... 71, 74,77

west Texas Permian basin region....... 44, 45, 51 western Colorado, southern Utah, and northwestern New Mexico........- 196

Ancestral Uncompahgre highland . . ...... 189 Ancestral Wichita Mountains. Anhydrite. See Evaporite deposits.

Antler orogenic belt. . . . . .......... 230, 233, 235, 238 Antler Peak Limestone.......... 230, 231 Anvil Spring Formation........... 232 Apishapa-Sierra Grande uplift . . . ...... 104, 106, 115 Apishapa uplift, central Midcontinent region,

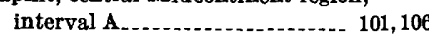

central Midcontinent region, interval B ... 111 $112,113,115$

interval C-D ................ 115 lower boundary of Permian ............ 97,98 paleotectonic implications, paleogeology. thickness trends of Permian rocks. . page VI of the preface]

Page

Blaine of Texas Bone Spring flexure........................ 40,45, 47 Bone Spring I imestone, Arizona and western New Mexico west Texas Permian basin region ........ 32 , $37,38,40,43$

Brachiopods. Bravo dome, New Mexico........ 65, 67, 68, 70,71, 74 Brewster County, Tex., tectonic features.... 58 Briggs Formation. . . . ..................... 38, 40,43 Briscoe County, Tex., interval D........... 78 Brook Creek Group. . ................ 133, 134, 140 Brown dolomite.

Brownville Limestone Member, Wood Siding

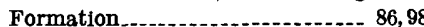

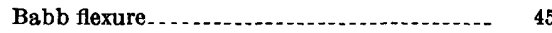

Baca County, Colo., interval A interval C-D

Bailey County, Tex., carbonate rocks....... 78 Precambrian rocks. . . Balmorhea Ranch........................... 29

Barneston I.imestone Basin environments, interval $B$, west Texas Permian basin region............... 43,44 interval $\mathbf{C}$, west Texas Permian basin region . .

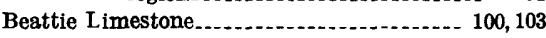
Beaver County, Okla., interval C. ......... 76,80

Beaver County, Utah, interval A ......... 181, 182 Pennsylvanian rocks. . . .......... 175, 181, 182, 194 thickness of Permian rocks. . .............. 194

Beaver Dam Mountains.................... 181

Beaverhead County, Mont., interval A....... 158

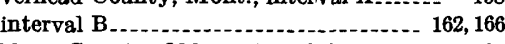
Beckham County, Okla., interval A......... 87 interval $B$. 88 Beeman Formation. 204 Bell Canyon Formation................. 46, 47 Belle Plains Formation.................... 39 Bergen Shale Member, Lykins Formation.. 115, 144 Bernal Formation, Arizona and western New Mexico northeastern New Mexico and Texas-Oklahoma Panhandles............... 72, 75 Big “A” Member, Supai Formation......... 210, 214 Bighorn Basin ............... 132, 140, 144, 146, 148, 150 Bighorn Mountains. . . . .................. 129, 140, 144 Billings County, N. Dak., interva-1B....... 141 Bird Spring Formation......... 210, 230, 232, 234, 236 Bisbee Group........ 223 Bissett Conglomerate............................. 60 Black Hills, S. Dak. . . . 129, 132, 133, 134, 140, 144, 148 Black Hills basin ....... 150 Black Hills uplift. Black Mountain............................... 232 Blaine County, Idaho, lower boundary of Permian Blaine County, Okla., interval A Blaine Formation, central Midcontinent region $\ldots \ldots \ldots$............... 109, 110,112,114 eastern Wyoming, eastern Montana, and the Dakotas.

northeastern New Mexico and Texas-Oklahoma Panhandles ................. 72,73

Blaine Gypsum, Oklahoma west Texas Permian basin region.......... 39, 48
Brushy Canyon Formation........ 46, 47, 51 Bully Hill Rhyolite. . . . . .

Bursum Formation .......................... 68,208

\section{C}

Caballos Novaculite

Calaveras County, Calif., interval B........... 234

interval C-D .............................. 236

California, formations and upper boundary, interval A...................... 231

formations and upper boundary, interval B. interval C-D

formations underlying Permian............ 229 Callipteris arizonae........................... 215 Callville Formation.... . . . ........... 207, 210, 213, 232 Callville Limestone................... 176, 179, 209, 230 Cambridge arch. ........................ 106 Candelaria Formation.................... 237

Canyon Series Capitan I,imestone..................... 47, 52,58 Capitan reef . .

Carbon Ridge, Nev....... Carbomita Carlsbad Caverns

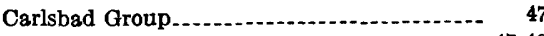
Carlsbad Limestone........................... 47,48

Carrizo Mountain-Van Horn area, Texas..... 29 Carter County, Okla., thickness trends....... 92 Cassa Group. . . ....................... 109,112, 134, 140 Casper Formation...... 129, 132, 133, 134, 137, 138, 143 Casper Sandstone............................. 140 Cassia County, Idaho, interval A.......... 158 Cassville Shale Member, Washington Formation, fossil plants. . ............

Castile Formation............... 48, 51, 53, 54, 55, 56 Cedar Creek anticline.

Cedar Hills Formation. .................. 114

Cedar Hills Sandstone......................... 109

Cedar Hills Sandstone Member, Hennessey Shale

Centennial Range. .......................... 164 Central Basin platform, west Texas Permian basin, interval $A$. . . ..... 32, 33, 34, 35, 36
Carbon Ridge Formation ............ Cedar Mesa Sandstone Mem, 181,182, 183, 184, 185, 187 
Central Basin platform-Continued

west Texas Permian basin, interval B

$39,41,45$

interval C.................. 47, 48, 49, 50, 52 interval D............................ 54

paleotectonic implications....... 28, 29,30,58

Pennsylvanian and older rocks. . .. 21, 22, 26

Triassic and younger rocks.......... 59

Central Cordilleran foreland

Central Kansas basin ....................... 117, 120

Central Kansas uplift. . . . .

Central Midcontinent region, defined....... 97

Chaffin Limestone Member, Thrifty Formation (Cisco Group)

Chalk Bluff Formation..................... 75

Charleston thrust.

Chase County, Nebr., interval A ............ 101

tectonic features............................. 117

Chase Group, central Midcontinent region . _ . 99,

$100,104,106$

northeastern New Mexico and Texas-

Oklahoma Panhandles.......... 69

Oklahoma 86

Chaves County, N. Mex., interval A........ 211

Cherry Canyon Formation............ 41,46,47,52

Cherry County, Nebr., interval B.......... 113

Precambrian rocks..................... 97

Cheyenne County, Colo., interval A....... 101

Cheyenne Formation .................... $\quad 120$

Chickasha Formation $\quad 89,90$

Chihuahua, Mexico.......... 21, 53

Chinati Mountains, west Texas Permian basin, interval A . . . west Texas Permian basin, interval B.... 38, $40,43,45$ interval C..................... 47,50,51 paleotectonic implications............- 29 Pennsylvanian and older rocks.... 21, 26, 27 Permian rocks exposed. ............ 59

Triassic and younger rocks

Chinle Formation.

Choza Formation

Chugwater Formation

Cibolo Formation................... 32, 34, 38, 40,43

Cleneguita Formation. ............ 26,29

Cimarron Anhydrite.

Cimarron County, Okla., interval C.

tectonic elements......... 68

Cimarron uplift

Cisco Group................................... 86

Cisco Series. . . . ................ 22, 25,67

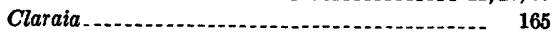

Clare County, Mich., thickness of Permian rocks ....... 7

Clark County, Nev., interval A . ......... 232, 233

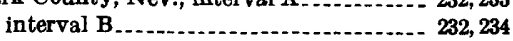

Clear Fork Group..................... 38, 39, 44, 72

Climate, Allegheny region......................

Clinate during deposition of interval $\mathbf{A}$, eastern Wyoming, eastern Montana, and the Dakotas... 138

Cloud Chief Formation..................... 90,91

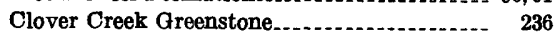

Clyde Formation........................ 39

Coahuila, Mexico

Coal beds.

Allegheny region. . .

key units, Dunkard Group........... 2

Cochran County, Tex., Precambrian rocks... 65

Coconino Sandstone, Arizona and western New Mexico.............. 215, 218

West Coast region

western Colorado, southern Utah, and northwestern New Mexico......... 183,

$184,187,189,190$

Coleman Junction Limestone Member, Putnam Formation.......... 34, 39, 69, 86 Colfax County, N. Mex., interval C...... 76 Colina Limestone...... 209, 210, 213, 215
Collapse breccias, Hartville and Casper Formations Collingsworth County, Tex., interval C.... 76 Colorado trough.................... 175, 180,183, 186 Comanche Series............................ 58

Concha Limestone........ 215, 218, 219

Confusion Range............................. 158, 160, 196

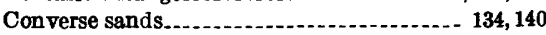

Corals............... 183

Cordilleran geanticline...................... 157

Cordilleran geosyncline ................. 168, 207, 216

Cordilleran miogeosyncline........ 203

Cottle County, Tex interval B

interval C....... 76

Cotton Valley Group.......... 15

Cotylosaurs.

Council Grove Group. ........ 69,86,99,100,104, 106

Coyote Butte Formation. ................. 232, 234

Crestone Conglomerate Member, Sangre de Cristo Formation.....................

Cretaceous and younger rocks, Oklahoma...

Crinoids.

Crockett Counts, Tex, interval $\mathrm{C}$

Ozona arch

Permian rocks exposed

Crok County, Oreg intervals $A$ and $B$ interval C-D.........................

Crosby County, Tex., Pennsylvanian rocks. -

Crowley County, Colo., interval B.......... pre-Permian rocks......................... 26

Curry County, N. Mex., interval B....... 71, 74 interval C............................. 76 interval D 78

Cutler Formation, Arizona and western New Mexico._..._._._. 209, 210, 213, 215, 218 western Colorado, southern Utah, and northwestern New Mexico......... 175, $180,183,184,186,188,195,196$

Cutoff shale

\section{D}

Dakota Formation.

Dakota Sandstono

Dalhart basin . .

Dawes County, Nebr., interval C-D........ 116

Dawson County, Tex., interval A........... 32

Day Creek Dolounite.................... 115, 117, 145

De Baca County, N. Mex., interval A _....... 69 interval $B$.

pre-Permian rocks............................

De Chelly Sandstone Member, Cutler Formation, Arizona and western New Mexico

western Colorado, southern Utah, and northwestern New Mexico ........ 184, 187,189

Deaf Smith County, Tex., interval D . .....- 78 Dean Sandstone....................... 30, 32, 34, 38 Deer Mountain Red Shale Meinber, Hueco Limestone Defiance positive element...................... 207,

Dekkas Andesite $212,213,214,216,219$

Delaware basin, west Texas Permian basin, interval A ....... 32, 34, 35, 36, 37, 208, 211 west Texas Permian basin, interval B ... 37, $38,40,41,42,43,44,45,216$ interval $C \ldots \ldots \ldots$........... 46,47,49,50,51, 52 interval $D$............................... 53,54,56 interval C-D......................... 219 lower boundary of Permian........... 27 Northwestern shelf.............. 203, 204, 214 paleotectonic inplications. .......... 28, 29 Pennsylvanian and older rocks. ... 21, 24, 25 thickness of Permian rocks. . ......... 57,58 Delaware Mountain Group....... 40, 41,46, 47, 48, 51 Delaware Mountains...................... 37, 40

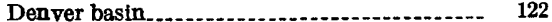
Dopositional environments, Allegheny region.

interval A, Arizona and western New Mexico.

eastern Wyoming, eastern Montana, and the Dakotas.

central Midcontinent region northeastern New Mexico and TexasOklahoma Panhandles.

Oklahoma

west Texas Permian basin region western Colorado, southern Utah, and northwestern New Mexico

interval $\mathrm{B}$, Arizona and western New Mexico.

central Midcontinent region

eastern Wyoming, eastern Montana, and the Dakotas

Middle Rocky Mountains and northeastern Great Basin.

northeastern New Mexico and TexasOklahoma Panhandles............

Oklahoma

west Texas Permian basin region.....

western Colorado, southern Utah, and northwestern New Mexico.........

interval C, northeastern New Mexico and Texas-Oklahoma Panhandles....

west Texas Permian basin region.....

interval C-D, central Midcontinent

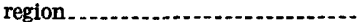

eastern Wyoming, eastern Montana, and the Dakotas.

Middle Rocky Mountains and north eastern Great Basin.

Oklahoma

western Colorado, southern Utah, and northwestern New Mexico.........

interval D, northeastern New Mexico and Texas-Oklahoma Panhandles.....

west Texas Permian basin region.....

Des Moines Series.......... mian basin region . .

sources, interval $C$, west Texas Permian basin region. ........................

Devils River uplift ........................... 27

Dewey Lake Redbeds............. 53, 54, 56, 76, 77, 78 Diablo Formation........................ 236, 237 Diablo platform, west Texas Permian basin . 21, $26,29,36,37,43,45,58$

Diamond Creek Sandstone Dictyoclostus bassi ..................... 40, 187, 190, 215 Dimple Limestone. . . . 23 Dinwoody Formation ...... 145, 146, 150, 164, 165, 168 Dockum Group, Arizona and western New Mexico. - 223

central Midcontinent region ............. _ 116, 122 northeastern New Mexico and TexasOklahoma Panhandles........ . 76, 77, 79

west Texas Permian basin region....... 54, 58, 60 Doddridge County, W. Va., interval A........

Dog Creek Shale, central Midcontinent region. ................... 110,112, 114

eastern Wyoming, eastern Montana, and the Dakotas...................................

northeastern New Mexico and TexasOklahoma Panhandles........... 72

Otlahoma 89,90

west Texas Permian basin region. ......... 39, 48 Dolores Formation. .......................... 196 Douglas Creek arch. . . . . Doxey Shale Member, Quartermaster Formation.

Dragoon Mountains......................... 213 Drinkard Sandy Member, Yeso Formation.- $\quad 39$ Duncan Sandstone. . . . . . . ................ 88, 89, 90 Dundy County, Nebr., interval A .......... 101 Dunkard basin.................... 
Page

Dunkard Group.

$1,2,3,5$

cyclic character

$4,5,6$

E

Eagle County, Colo., interval C-D. 181

Pennsylvanian rocks 177,196 Eagle Mills Formation. Earp Formation................... 204, 209, 213, 214 Eastern shelf, west Texas Permian basin, interval A.............. 33, 34, 35, 37 west Texas Permian basin, interval B.- 39 , $41,42,44,45,48$

interval C....... 48,50,52 interval D............................. 54 paleotectonic implications. . ........... 30, 58 Pennsylvanian and older rocks. ... 21, 22, 27 Quaternary rocks...................... 58 Ector County, Tex., interval A

Eddy County, N. Mex., interval A.......... 69

interval $B . . . . . . .41,71,72$ interval $\mathbf{C}$

post-Permian rocks.

59

235

El Paso, Tex. .

E1 Reno Group.................. 39, 41, 89

Elbert County, Colo., interval B............. 111

Elephant Canyon Formation........ 181, 182, 184, 185

Elk City Member, Quartermaster Formation.. $\quad 90$

Elkhorn Ridge Argillite. ..................... 234

Elko County, Nev., interval A ............... 232

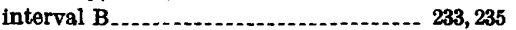
lower boundary of Permian

Ellenburger Group.

Ellsworth County, Kans., interval A _....... 106

Ely Limestone. . . . . . . . . . . . . . 175, 181, 230, 231

Embar Formation......................... 144

Emery County, Utah, interval A ............. 183

Empire Mountains............................. 213

Entrada Sandstone.

Environmental relations, Allegheny region. . - 5

Epitaph Dolomite

Ervay Carbonate Rock Member, Park City Furmation........... 144, 145, 148, 164, 165

Ervay Tongue 132

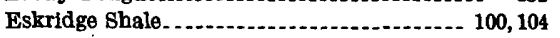

Esplanade Sandstone Member, Supai Formation............................ 181

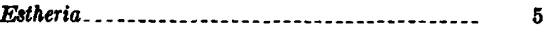

Eugeosyncline, West Coast region........... 233

Eureka County, Nev., interval A........... 231, 232

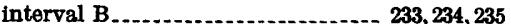
interval C-D.............................. 237 pre-Permian paleotectonic implications... $\quad 230$

Evaporite deposits, Arizona and western New Mexico, interval A. .............. 212, 213 Arizona and western New Mexico, inter-

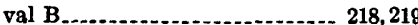

central Midcontinent region, interval A _ 100,101 interval $B . . . . . . .-109,110,111,112,113,114$ interval C-D.................... 115, 116, 117

eastern Wyoming, eastern Montana, and the Dakotas, interval A . . ........ 133, $134,136,137,138$

interval B.. $140,141,143$ interval $C-D$ Gulf Coast region, interval A........ 13, 14, 15 Michigan basin and Iowa.

northeastern New Mexico and TexasOklahoma Panhandles, interval A. $\quad 69$ interval $B$....... 71, 72 interval C................ 75 interval $D \ldots \ldots \ldots . . . \ldots 7,78,78$ Oklahoma, interval A . .

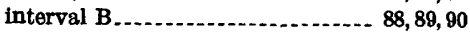
interval C-D......................... 90, 91

West Coast region, interval B ............ 234 west Texas Permian basin region, interval B.................... $39,42,43,44,48$ interval C...................... 47, 48,50, 51

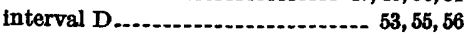

Evaporite deposits-Continued western Colorado, southern Utah, and northwestern New Mexico........ 195 interval A.................. 185 interval B.......... 186, 180 interval C-D.

Fairview Valley Formation................. 234, 236 Falcon Limestone Member, Lykins Formation. . . ............................. 115, 14

Fallon County, Mont., interval B........... 141 Faulting, Powder River Basin Ferguson Springs Formation.

Finlay Mountains...................... 38,40,43 Finney County, Kans., interval B........... 112 First Bone Spring sand....................... 32, 38 Fish fossils.

Five Point Limestone Member, Janesville Limestone Member, Barneston

Florence Limestone Member, Barneston
Limestone...................... 100

Florida Island positive element.............. 213, 214 Florida Range.................................. 204 Flowerpot Shale_............. 39, 48, 72, 88, 89, 90, 109 Floyd County, Tex., interval D.............. 78 Fluvial-delta plains, Allegheny region......... 5 Foard County, Tex., interval B.............. 44 Foraker Limestone . ............... 98, 100, 101, 103, 105 Forelle Limestone, central Midcontinent region . . ......................... 115, 116 eastern Wyoming, eastern Montana, and the Dakotas........... 132, 144, 145, 148

western Colorado, southern Utah, and northwestern New Mexico....... 190, 192

Forest City basin

Fort Apache Limestone Member, Supai Formation_........ 209, 210, 215

Fort Dodge, Iowa

Fort Dodge Formation.

Fort Riley Limestone Member, Barneston Limestone............

Fort Stockton high.

Fossils, A bo Formation

Admiral Formation

Allegheny region.-.-.

Bird Spring Formation.

Bone Spring Limestone......................

Bursum Formation.

Callville Limestone.

Cibolo Formation

Eagle Mills Formation

Foraker Limestone...... 100, 10

Fort Apache Limestone Member, Supai Formation..

Gaptank Formation

Garlock Series.

Gerster Formation........................... 190

Hess Limestone Member, Leonard Formation

Hueco Limestone.

Ingleside Formation.

interval $\mathbf{A}$, central Midcontinent region.-

interval B, Harquahala Mountains, Arizona...

West Coast region

interval C-D, West Coast region . ......... 236

Kaibab Limestone..................... 187, 190

Koipato Formation

Leonard Formation.

Madera Formation........................ 67

Magdalena Formation....................... 23

Maroon Formation

Owens Valley Formation.................. $\quad 236$

Pakoon Limestone............................ 230

Park City Formation....................... 190

Pease River Group.

Rustler Formation . .

San Andres Limestone
Fossils-Continued

Sangre de Cristo Formation . ............ 67, 183

Spraberry Sandstone

Strathearn Formation. ............... 229, 230

Strawn Series............................... 24

Tessey Limestone.

Verden Sandstone Member, Marlow Formation.

Washington Formation........................

Weber Sandstone........................... 183

White Rim Sandstone Member, Cutler Formation 187

Wolfeamp Formation

Wolfcamp Iiimestone ................... 34

Wreford Limestone...................... 104

Fountain Formation. . . ......... 97, 100,110,111, 129 Four Corners area

Franklin Mountains............................ 23, 34 Franson Member, Park City Formation...... 140 , $144,145,160,164$

Freezeout Tongue, Chugwater Formation . . 144, 145 Freezeout Shale. . . Fremont County, Colo Front Range.

Front Range, ancestral, central Midcontinent

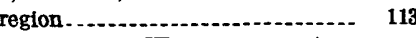
ancestral, eastern Wyoming, eastern Montana, and the Dakotas....... 133,

$137,138,150$

western Colorado, southern Utah, and northwestern New Mexico _.. 175 $179,180,186,189,192,193,196,197$

Fullerton sandstone. . . . .................. 39 Funston Limestone................ 104 Fusselman Dolomite. . . . Fusulina...................................... 67 Fusulinella sp. . ............................... 230 Fusulinids_. 23, 24, 25, 27, 29, 30, 32, 34, 37, 40, 69, 98, 100

Gaptank Formation.................. 24, 26, 28, 29, 30

Garber Sandstone............................ 89 Garden Valley Formation. ................ 231, 233 Garfield County, Colo., interval C-D.... .. 190, 191 Garfield County, Utah, interval A . . ....... 183, 186

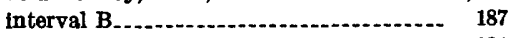

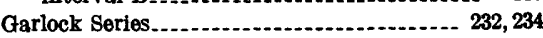
Gastropods ............................... 56, 67, 91 Gateway, Colo., subsidence near............. 195 Georges Creek basin..

Gerster Formation. ..................... 164, 190, 236 Gilboy Sandstone Member, Monongahela Formation...................................

Gilliam Formation.

Gilliam Limestone. . . ......................... 47

Glance Conglomerate........................ 223

Glass Mountains, west Texas Permian basin region, interval A. .......... 30,33, 35, 36

west Texas Permian basin region, interval B............................. 37, 44,45

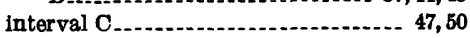
interval D.......................... 53,54,57 lower boundary of Permian ........... 26 paleotectonic implications. ............. 28, 60

Pennsylvanian and older rocks. ....... 23, 24

Permian rocks exposed. . ............. 59 Glass Mountains escarpment. Glendo Shale................ 116, 132, 140, 144, 148, 160 Glendo Shale Member, Goose Egg Formation_ 164 Glennon Limestone Member, Lykins Formation. .......................... 115, 145 Glorieta Sandstone, Arizona and western New Mexico........................... 215, 218

northeastern New Mexico and TexasOklahoma Panhandles......... 71, 72, 74

west Texas Permian basin region...... 38, 39, 40 Goat Seep Limestone........................ 47, 48, 52 Gobbler Formation......................... 204 
Goose Egg Formation, eastern Wyoming, eastern Montana, and the Dakotas... 140, $144,145,150$

Middle $R_{\text {ocky }}$ Mountains and northeastern Great Basin ............... 160 $162,163,164,166$

Grand Canyon Grand County, Colo., interval C-D......... 191

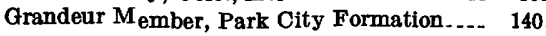
158,160 Grandeur Tongue, Park City Formation....- 158 Grant County, N. Mex., pre-Permian rocks.- 204 ,

Gravelly Range........... 164 Grayburg Formation........ 47, 48, 52,75 Green River basin........................ 162,166

Greene County, Pa., interval A ........... 3

Greene County Group......... 2

Greene Formation.......... 2,3

Gros Ventre Range. 160

Guadalupe Mountains . . . . . . . . . . . . 50, 55

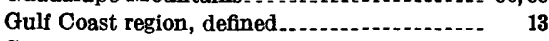

Gunnison Hills, Ariz...................... 213

Gypsum. See Evaporite deposits.

H

Hale County, Tex., interval D

Halgaito Tongue, Cutler Formation........- 181

Halite. See Evaporite deposits.

Hamilton County, Kans., interval A .....-.- 104 interval B............. 111

Hardeman basin....................... 67, 69, 71,74

Harmon basin. See Hollis basin.

Harmon County, Okla., interval C-D...... 91

Harper Siltstone.................................. 114

Harquahala Mountains................. 200, 215

Harriman Shale Member, Lykins Formation_ 112,

Hart Limestone Member, Stratford Forma115,144

Hartville Formation...- 129, 132, 133, 134, 137, 140, 143 Hartville uplift............... 129, 132, 133, 134, 137, 140 Havallah Formation................. 230, 231, 233, 237 Haymond Formation........................... 24 Haystack Gypsum Member, Blaine Gypsum. 88 Helicoprion................................. 235 Hempstead County, Ark., Triassic rocks..... 13 Hennessey Shale. ... . . 88, 89,90 Henry Mountains....... 196

Herington dolomite.................. 68, 69

Herington Limestone Member, Nolans Limestone..................... 87, 100

Hermit Shale_..................... 182, 215, 232, 23 Hermosa Formation................ 175, 177, 179, 207 Hess Limestone Member, Leonard Formation. 30, 37 Hidalgo County, N. Mex., interval A .......... 211

Hobbs channel. ............ 58

Hodge Volcanic Formation................. 236

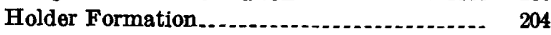

Hollis basin . . ........... 71, 74, 85, 86, 87, 88, 89, 90, 92

Horn fault.............

Horquilla Limestone........... 204

Horseshoe atoll........................... 22, 27, 28, 36

Hoskinnini Member, Moenkopi Formation... 190

Hovey anticline. $\quad 41$

Hovey channel ................................. 58

Howard County, Tex., Pennsylvanian rocks..

Hudspeth County, Tex., interval B ......... 38

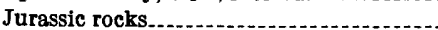

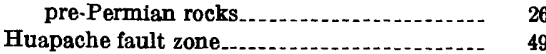

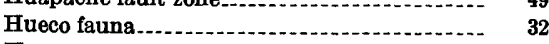

Hueco Limestone, Arizona and western New Mexico............ 208, 209, 210, 212, 214 northeastern New Mexico and TexasOklahoma Panhandles

west Texas Permian basin region.... 30, 32, 34, 38
Page

Hueco Mountains..................... 23, 26, 32, 34, 214

Huerfano County, Colo, interval A ......... 101

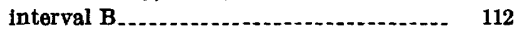
Hugoton embayment.............. 72, 98, 106, 114,117 Humboldt County, Nev., interval A . ........ 231

\section{I}

Idaho, formations underlying Permian...... . interval A.

229

interval C-D.

231

Ingleside Formation.

98,100

Interval A, Allegheny region paleotectonic implications. ............. sources and environments of deposition. structural framework

thickness trends

thal Midcontinent region............... environments of deposition............. lithofacies trends.

paleotectonic implications

sources of detritus

thickness trends.

upper boundary Wyoming, eastern Montans, and the Dakotas....................

sources and environments of deposition.

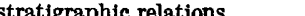

thickness trends....................

Middle Rocky Mountains and northeastern Great Basin. .............

northeastern New Mexico, formations in cluded......................................

northeastern New Mexico and TexasOklahoma Panhandles...........

lithofacies trends. ....................

paleotectonic implications. .............

thickness trends

Oklahoma

Texas-Oklahoma Panhandles, formations included..

lithofacies trends

paleotectonic implications.

thickness trends.

upper boundary

west Texas Permian basin region. ........

lithofacies trends. ....................

paleotectonic implications

sources and environments of deposition.

thickness trends

upper boundary
western Colorado, southern Utah, and northwestern New Mexico.........

lithofacies trends.......................

paleotectonic implications. . .

sources and environments of deposition

thickness trends.........

Interval B, Arizona and western New Mexico

A rizona and western New Mexico, paleotectonic implications. sition

structural framework

thickness trends.......................

central Midcontinent region...............

lithofacies trends. . ......................

paleotectonic implications. . ........... sources and environments of depo-

thickness trends.
Interval B-Continued tions included

Interval $C$, northeastern New Mexico and

Interval C-D A rizona and western New eastern Wyoming, eastern Montana, and the Dakotas.................-...-

lithofacies trends..........................

paleotectonic implications. ...........

sources and environments of deposi-

tion

thickness trends...............................

Middle Rocky Mountains and northeastern Great Basin

northeastern New Mexico, formations included.

northeastern New Mexico and TexasOklahoma Panhandles

lithofacies trends.

paleotectonic implications.

sources and environments of deposition thickness trends.

Oklahoma

paleotectonic implications..........-

sources and environments of deposition.

thickness trends.

Oklahoma Panhandle and northeastern part of Texas Panhandle, forma-

West Coast region.

lithofacies trends

paleotectonic implications. ............

thickness trends

upper boundary

lithofacies trends.

paleotectonic implications.

sources and environments of deposi-

tion -

thickness trends

upper boundary

western Colorado, southern Utah, and northwestern New Mexico..........

lithofacies trends.

paleotectonic implications sources and environments of deposition.

stratigraphic relations. . .

thickness trends......................... Texas-Oklahoma Panhandles.....

shelf areas, west Texas Permian basin region, formations included........

west Texas Permian basin region..........

lithofacies trends.

paleotectonic implica lons. ............sources and environments of deposition.

thickness trends

upper boundary

central Midcontinent region

eastern Wyoming, eastern Montana, and the Dakotas.

lithofacies trends.

paleotectonic implications. ............. sources and environments of deposition ....................................... thickness trends

Middle Rocky Mountains and northeastern Great Basin............... lithofacies trends. -

paleotectonic implications............. sources and environments of deposition.

thickness trends Oklahoma

West Coast region 
Interval C-D-Continued

western Colorado, southern Utah, and northwestern New Mexico......... environments of deposition............

formations included.

lithofacies trends..........................

paleotectonic implications. . . ..............

stratigraphic relations..................

thickness trends........................

Interval D, northeastern New Mexico and Texas-Oklahoma Panhandles. west Texas Permian basin region. .........

Inyo County, Calif., interval A.............. interval $B$.

interval C-D.

lower boundary of Permian.

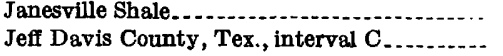
Johnson County, Nebr., interval A............ 101

Joyita positive element....................... 204, 207 Julesburg basin.......................... 114, 14f, 148 Julesburg basin, ancestral..................... 141 Jurassic and younger rocks, Gulf Coast region. 15

\section{K}

Kaibab Formation. . .

Kaibab Limestone, Arizona and western New Mexico................... 215, 218, 219,223 Middle Rocky Mountains and northeastern Great Basin. ........... 160

West Coast region.................... 234, 237 west Texas Permian basin region........ 41 western Colorado, southern Utah, and northwestern New Mexico......... 187,

Kansas basin 106,114

Kansas Permian basin................... 103, 104, 114

Karst topography ........................... 223

Keeler Canyon Formation.............. 230, 232

Kent County, Tex., Pennsylvanian rocks.... 24

Kern County, Calif., interval A............. 232

Keyes dome..

Kimble County, Tex., Permian rocks exposed.

Kingoceras.................................... 53

Kiowa County, Colo., interval A........ 100, 101 interval B............ 111

Klowa Formation................. 120

Klowa Shale Member, Purgatoire Formation.- 92

Kirkman Limestone............................ 158

Kit Carson County, Colo., interval B. ....... 111

Koipato Formation.................... 235, 237, 238

\section{L}

Laborcita Formation........................ 208

Lacustrine deposits, Allegheny region. .......

Lakes, Allegheny region......................

Lamar Limestone Member, Bell Canyon Formation......................... 47,

Lamb County, Tex., interval D

Precambrian rocks...................... 65, 68

Lance Creek field............................... 134

Lander County, Nev., interval A.......... 231, 232

Lane County, Kans., interval B.............. 112

Laramide thrust belt.

Laramie Basin ............... 129, 140, 144, 146, 148, 150

Laramie Range.......... 128, 132, 133, 134, 137, 140,141

Las Animas arch............. 88, 101, 104, 106, 114, 117

Las Animas County, Colo., interval A...... 101 interval B..................... 111, 112 Ordovician and Silurian rocks........... 97

Lea County, N. Mex., interval A ........... 69 interval $B$................... 40, 41, 71, 72 Lee, Wallace, quoted........ 106 Lenox Hills Formation..................... $\mathbf{3 0}$

Leonard Formation. . .

Leonard Series.

Leonardophyllum distinctum ............... 230
Page

Lincoln County, Colo., interval B

Lincoln County, Nev., interval A............

interval $\mathbf{B}$........................................

Lincoln County, N. Mex., Pedernal positive lement.........

Lingula permiana

Lithofacies trends, interval A, Allegheny region.

interval A, central Midcontinent region.and the Dakotas....................

Middle Rocky Mountains and northeastern Great Basin ..............

northeastern New Mexico and TexasOklahoma Panhandles............. Oklahoma.

West Coast region

west Texas Permian basin region..... western Colorado, southern Utah, and northwestern New Mexico.........

interval $B$, central Midcontinent region. eastern Wyoming, eastern Montana, and the Dakotas.

Middle Rocky Mountains and north eastern Great Basin................

northeastern New Mexico and TexasOklahoma Panhandles.

Oklahoma........

West Coast region.

west Texas Permian basin region.

western Colorado, southern Utah, and northwestern New Mexico.........

interval C, northeastern New Mexico and Texas-Oklahoma Panhandles.....

west Texas Permian basin region.....

interval $\mathrm{C}-\mathrm{D}$, eastern Wyoming, eastern Montana, and the Dakotas.......

Middle Rocky Mountains and northeastern Great Basin...............

Oklahoma.

West Coast region

western Colorado, southern Utah, and northwestern New Mexico.........

interval $D$, northeastern New Mexico and Texas-Oklahoma Panhandles......

west Texas Permian basin region..... Little Medicine Tongue, Dinwoody Formation.

Louann Formation.

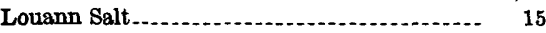

Love County, Okla., thickness trends...... 92

Lower boundary of Permian, Allegheny region.

Arizona and western New Mexico

central Midcontinent region............

eastern Wyoming, eastern Montana, and the Dakotas

Gulf Coast region

Middle Rocky Mountains and northeastern Great Basin.

northeastern New Mexico

Oklahoma

Texas-Oklahoma Panhandles.

West Coast region

west Texas Permian basin region

western Colorado, southern Utah, and northwestern New Mexico.........

Lubbock County, Tex., interval A.......... 36

Lueders Limestone............................ 39

Luna County, N. Mex., pre-Permian rocks.-- 204

Lykins Formation.- 109, 111, 112, 115, 117, 122, 144, 14

Lyon County, Kans., interval A . .......... 104

Lyons Sandstone. ............... 109,111, 114, 140, 187

M

McCloud Limestone..................... 232, 234

Mackentire Tongue, Woodside Formation _. 160, 164
Page

Macrotaeniopteris magnifolia................. 13

Madera Formation....................... 67, 204

Madera Limestone ................... 175, 177, 179, 207

Madison Limestone.......................... 132

Madison Range............ 164

Magdalena Formation

Magdalena Group.......... 67, 204

Malone Formation. ....... 58,60

Malone Mountains...................... 38, 40,43, 58

Mannington Sandstone Member, Washington Formation....................... $\mathbf{3}$

Marathon, Tex............................. 29, 32

Marathon sequence

Marfa basin, west Texas Permian basin, interval $A$ west Texas Permian basin, interval B... 38, $40,41,43,45$

interval C..................... 47, 50, 51, 52

lower boundary of Permian........ 27

Pennsylvanian rocks.................... 21, 26

Marginal reef, environments, interval $B$ west Texas Permian basin region..

interval $\mathrm{C}$, west Texas Permian basin region.

Marion County, Kans. Nemaha anticline

Marion County, W. Va., interval A..........

Marlow Formation............... 88, 90,81

Maroon Formation........................... 177, $179,180,181,183,184,190,191,193,196$

Martin County, Tex., Pennsylvanian rocks_. 24 Matador arch......................... 65, 68, 71, 74

Meade Ṕeak Pho phatic Shale Member, Phosphoria Formation............

Meade Peak Phosphatic Shale Tongue, Phosphoria Formation.

Mecosta County, Mich., Permian rocks.....

Medicine Bow Range............................

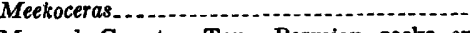

Menard County, Tex., Permian rocks exposed

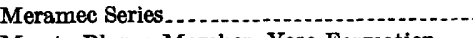

Meseta Blanca Member, Yeso Formation.....

Middle Rocky Mountain and northeastern Great Basin region, defined........ 157

Midland basin, west Texas Permian basin interval $A \ldots \ldots . . . . . . . . . .32,33,34,36,37$

west Texas Permian basin, interval B...- 38 , $40,41,42,43,44,45$

interval $\mathrm{C}$ interval $D$ lower boundary' of Permian............ 27 paleotectonic implications.......... 28, 58, 60 Pennsylvanian and older rocks...- 21,24, 25 Permian rocks exposed................. 59 Millard County, Utah, interval C-D......... 192 Mima Grande Formation...._...... 47, 50 Minnekahta Limestone........... 111, 112, 114, 140,141 Minnelusa Formation . ....................... 129 $132,133,134,137,140,143,14$

Minturn Formation. Miogeosyncline, West Coast region............ 233 Missouri Series................................ 97 Mitchell County, Tex., Pennsylvanian rocks. 24 Moenkopi Formation. ............... 60, 191, 196, 221 Moffat County, Colo., Colorado trough..... 180, 192 Monongalia County, W. Va., interval A..... 3 Monongahela Formation..................... Monongahela Series. ............... Montague County, Tex., interval A......... 36 Montoya Limestone......................... 26 Monument upwarp. . . . Monument Valley.............................. 189 Moore County, Tex., Cimarron uplift........- 68 Mora County, N. Mex., Pennsylvanian rocks. 67 Moran Formation . Morehouse Formation...................... 13, 14, 15 Morgan County, Colo., interval B........... 111 Morgan Formation...................... 180 Morris County, Kans., interval A ........... 104 
Page

Morrison Formation ..................... 60, 120, 122 Morton County, Kans., interval C-D........- 115 Motley County, Tex., interval C.............. 76

\section{$\mathbf{N}$}

Naco Group.................................. 207, 209 Nautiloids

67

Neal Ranch Formation

Nemaha anticline .................... 98, 106, 117

Nemaha County, Kans., interval A .......... 101

Nemaha ridge................................. 104

Neospirifer................................ 190, 191

Neva Limestone Member, Grenola Limestone- 100

Nevada, formations and upper boundary, interval A

formations and upper boundary, interval B.....................................

interval C-D formations underlying Permian New Water Mountains, Ariz ................ 209, 215 Ninnescah Shale.................. 88, 109, 110, 112, 113 Nippewalla Group......................... 111,112 Noble County, Okla., interval A ............ 87 Nolans Limestone....................... 87, 100,10 North Canadian River.............. 80 North Kansas basin .......................... 100 Northeast Colorado Permian basin........... 104 Northern shelf, west Texas Permian basin..... 38 Northwestern shelf, west Texas Permian basin $\ldots \ldots \ldots$ 21,

$22,30,32,33,34,36,37,39,45,58$

Delaware basin, west Texas Permian basin............ 203, 204, 208, 214, 215

Nosoni Formation ........................ 234, 236

Nowood Member, Park City Formation ...... 134, 140,141

Nucla, Colo., fault near..................... 195

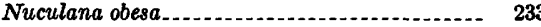
Nye County, Nev., interval B................ 234

Ochoa Series. $53,54,75,76$ Ogallala Formation Oketo Shale Member, Barneston Limestone_- $\quad 100$ Oklahoma region, defined. . . Oklahoma shelf Opeche Shale_.............. 112, 132, 136, 140, 141, 143 Oquirrh Formation........................ 157, 158 Oquirrh Range.............................. 158 Organ Rock Member, Cutler Formation..... 181, $182,183,185,186,187$ Oregon, formations and upper boundary, interval $A$

formations and upper boundary, interval B.................................. 233 interval C-D

formations underlying Permian 229 Orogrande basin ................... 204, 208, 211, 212 Osage County, Kans., interval B........ 113 Ostracodes.............................. 5, 183

Otero County, Colo., interval B............- 111

Otero County, N. Mex., Pedernal positive element 68

Ouachita-Marathon structural belt_.......-. 21 $27,35,36,37,45,60$

Ouachita Mountains...................... 13 Ouachita structural belt ................ 13,14 Owens Valley Formation............... 232, 234, 236 Owl Canyon Formation................. 109 $111,134,136,140,141,143$

Owl Creek Mountains................... 129 Ozona arch

Pablo Formation. 236 Pakoon Formation.

Pakoon Limestone $181,230,231$
Paleogeology, Allegheny region.

central Midcontinent region

eastern Wyoming, eastern Montana, and the Dakotas.

Gulf Coast region

Middle Rocky Mountains and northeastern Great Basin. . ..........

northeastern New Mexico and TexasOklahoma Panhandles.............

Oklahoma.

West Coast region.

West Texas Permian basin region

western Colorado, southern Utah, and northwestern New Mexico........

Paleotectonic implications, Arizona and western New Mexico.................

basins and troughs, west Texas Permian basin region.

central Midcontinent region ............

eastern Wyoming, eastern Montana, and the Dakotas.

interval $A, A l l e g h e n y$ region central Midcontinent region........... eastern Wyoming, eastern Montana, and the Dakotas...................

Middle Rocky Mountains and northeastern Great Basin...............

northeastern New Mexico and TexasOklahoma Panhandles.

Oklahoma.

West Coast region...................... west Texas Permian basin region..... western Colorado, southern Utah, and northwestern New Mexico.......

interval $\mathrm{B}$, Arizona and western New Mexico........................ central Midcontinent region.-...-...-eastern Wyoming, eastern Montana, and the Dakotas.....................

Middle Rocky Mountains and northeastern Great Basin. ..............

northeastern New Mexico and TexasOklahoma Panhandles.

Oklahoma

West Coast region west Texas Permian basin region..... western Colorado, southern Utah, and northwestern New Mexico.......-.

interval C, northeastern New Mexico and Texas-Oklahoma Pazhandles...

west Texas Permian basin region.....

interval C-D, eastern Wyoming, eastern Montana, and the Dakotas......

Middle Rocky Mountains and northeastern Great Basin .

Oklahoma.................................

West Coast region.................... western Colorado, southern Utah, and northwestern New Mexico.......

interval D, west Texas Permian basin region

Middle Rocky Mountains and northeastern Great Basin

northeastern New Mexico and TexasOklahoma Panhandles.............

Oklahoma.

Ouachita-Marathon structural belt, west Texas Permian basin region.......

paleogeology, central Midcontinent re gion

eastern Wyoming, eastern Montana, and the Dakotas...................

northeastern New Mexico and TexasOklahoma Panhandles.............

Oklahoma............................

West Coast region......................

platforms, west Texas Permian basin region.
Page

106

138

158

71

233

186

218

114

143

162

74

90

189

77

52

148

168

91

237

193

56

168

79

27

98

18

68

86

230

29
Paleotectonic implications-Contin'ed shelves, west Texas Permian basin region. units overlying P.ermian, Allegheny region.

Arizona and western New Mexico central Midcontinent region

Gulf Coast region.

Middle Rocky Mountains and northeastern Great Basin.......

Oklahoma.

West Coast region.

western Colorado, southern Utah and northwestern New Mexico...

units underlying Permian, Allegheny region.

Middle Rocky Mountains and north eastern Great Basin................ western Colorado, southern Utah, and northwestern New Mexico

west Texas Permian basin region......... 58,60

western Colorado, southern Utah, and northwestern New Mexico........- 194

Palo Duro basin......... 65, 67, 68, 69, 70,71, 74, 76, 79

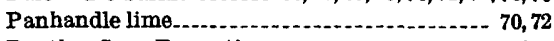
Panther Seep Formation...................... 204 Paradox basin .................... 177, 179, 180, 195, 212 Paradox Formation.............................. 177

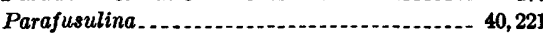
rothi

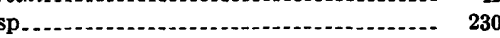
Park City Formation, eastern Wyoming, eastern Montana, and the Dakotas..... 132, 134, 140, 141, 143, 144, 145

Middle Rocky Mountains and northeastern Great Basin.... 158, 160, 165, 166

western Colorado, southern Utah, and northwestern New Mexico......... 183, $184,187,189,190,191,193$

Park County, Colo., interval A............... 183 Parmer County, Tex., interval D............ 78 Pawnee County, Nebr., interval A ............ 101 Pease River Group ............... 38, 39, 41, 43, 44, 48 Pecos, N. Mex............. 67 Pecos arch.

Pedernal Hills.

Pedernal positive element, Arizona and western New Mexico........... 204, $211,212,214,219$

northeastern New Mexico and TexasOklahoma Panhandles........ 65,
$67,68,71,74,76,79$

west Texas Permian basin region.. 21, 26, 36, 45 Pedregosa basin.......................... 200 Pedregosa trough. Pelecypods. Pelycosaurs.

Pennsylvanian and older rocks, Arizona and western New Mexico.

central Midcontinent region

eastern Wyoming, eastern the Dakotas . . . . . . . . . . . . . northeastern New Mexico and TexasOklahoma Panhandles.

Oklahoma -

West Coast region..

western Colorado, southern Utah, and northwestern New Mexico.

Pennsylvanian rocks, Middle Rocky Mountains and northeastern Great

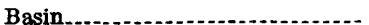

Monongahela Formation..................

Morehouse Formation, west Texas Permian basin region...................

west Texas Permian basin region.

Pequop Formation. . . . Permian carbonate member, Cutler Forma- 
Permian rocks, Eastern United States and lowa

Perrinites..... hilli.

Pershing County, Nev., interval C-D........

Phillips County, Colo., interval B.............

Phosphoria Formation, eastern Wyoming, eastern Montana, and the Dakotas.

Middle Rocky Mountains and northeastern Great Basin. ................ 158 $160,162,163,164,165,166,168$

West Coast region

western Colorado, southern Utah, and northwestern New Mexico....... 184, 191

Plerce Canyon Redbeds

Pine Salt ............................ 144, 145, 148, 150

Piñon Range....................... 230

Pinto Canyon Formation................ 38, 40, 43, 47

Pipeline Shale Member, Brushy Canyon Formation....... 40,47

Pit Shale................... 236

Placer de Guadalupe........................ 21,45

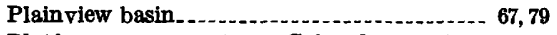

Platform area, eastern Colorado, western Nebraska, and southeastern Wyoming ......................... 105

Platform environments, interval B, west Texas Permian basin region.............. 44

Pleurophorus

Plympton Formation, Confusion Range..... 158, $160,164,188,190$

Polydiexodina mexicana....................... 53 Pontotoc Group.......................... 86, 87 Post Oak Conglomerate Member, Wichita

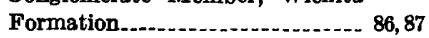

Pottawatomie County, Kans., interval A.... 101

Powder River Basin.... 132, 138, 140,144, 146, 148, 150

Powwow Conglomerate Member, Hueco Limestone................... 26, 29, 32, 208

Presidio, Tex

Presidio County, Tex., interval $\mathrm{B} . . . \ldots . . . . . .38,43$

Pre-Pennsylvanian rocks, west Texas Permian basin region

Productus (Dictyoclostus bassi)

Prowers County, Colo., interval A.......... 100

Pseudofusulina...................... 88, 230

Pseudofusulinella sp.......................... $\quad 230$

Pseudoschwagerina_................. 26, 30, 37, 98, 230

Pseudoschwagerina Assemblage Zone........... 32

Pseudoschwagerinids........................... 30

Pseudostaffella sp............................... 230

Pueblo County, Colo., interval B........... 112

Pueblo Formation... 30,33

Pump Station Hills........................... 26

Punctospirifer pulcher......................... 236

Purgatoire Formation. .................. 92

Putnam Formation................... 30, 33, 39, 69, 86

Q

Quadrant Quartzite_......... 157 Quartermaster Formation. .......... 75, 90, 91, 145 Quay County, N. Mex., interval B......... 71 Queantoweap Sandstone.................. 181, 186, 231 Queen Formation............................. 47 Queen Sandstone...... 48 Quitman Mountains .......................... 38, 58

\section{$\mathbf{R}$}

Rainvalley Formation..... 215,223

Ralston Creek Formation _ 120,122

Randall County, Tex., interval D ........... 78 Raton basin........... 115 Red Cave, Clear Fork Group.............. 72 Red Eagle Limestone......................... 100 Red marker mudstone, Wyoming and South Dakota.......... 132,133

Redwall Limestone.......................... 207, 208, 212 Reeve Meta-andesite ..................... 236
Reeves County, Tex., fault. interval B.

interval $D$

References cited.

Relay Creek Dolomite Beds

Reptile fossils

Retort Phosphatic Shale Member, Phosphoria Formation............... 145, 163, 164, 16

Retort Phosphatic Shale Tongue, Phosphoria Formation

Rex Chert Member, Phosphoria Formation.. 160

Rib Hill Formation. .................... 231, 234

Rico Fcrmation.

Riepe Spring Limestone..................... 181, 231

Riepetown Sandstone

Rio Arriba County, N. Mex., Pennsylvanian rocks.

Rio Blanco County, Colo., interval C-D... 191

Pennsylvanian rocks................. 177, 183

Rio Grande trench.......................... 58

Ritchie County, W. Va., interval A......... 3

Robinson Formation.

Rocky Mountains, ancestral, eastern Wyoming, eastern Montana, and the Dakotas...................................

ancestral, northeastern New Mexico and Texas-Oklahoma Panhandles... $71,74,77,99,106$ west Texas Permian basin region.... 44

western Colorado, southern Utah, and northwestern New Mexico.- 196

Roosevelt County, N. Mex., interval A...... 69

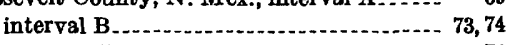
interval $C \ldots \ldots$

interval $D$

Precambrian rocks..... 65, 68 Ross Mine Formation................... 47, 50 Rowe-Mora basin. 65

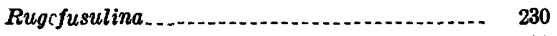
Rush Springs Sandstone.................. 90, Rustler Formation............. 53, 54, 56, 75, 76, 77, 78

\section{s}

Sacramento Mountains, N. Mex............ 34, 204, 208. 213, 214

St. Louis Limestone...-

Ste. Genevieve Limestone. 7

Salado Formation............ 48, 53, 54, 56, 76, 77, 78 Salina basin.......................... 98, 106, 117

Saline County, Kans., interval A .............. 106

interval B................ 113

Salt Basin......... 59

Salt Plain Formation......................... 109, 114

San Andres Limestone, Arizona and western New Mexico............. 214, 215, 218, 219

northeastern New Mexico and TexasOkiahoma Panhandles ......... 71, 72,75 west Texas Permian basin region......... 38, $40,47,48,50,52$

San Andres Mountains........................ 204 San Angelo Sandstone.................... 39,40,44 San Bernardino County, Calif., interval A... 232 interval B..................................... 234 interval C-D

lower boundary of Permian............... 230

San Juan basin........... 175, 180, 184, 203, 212, 213 San Juan County, N. Mex., Pennsylvanian rocks

San Juan County, Utah, interval B .......... 188 interval C-D................................ 193

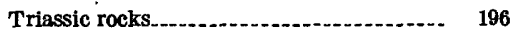
San Juan Mountains. ......................... 175 San Luis highland...................... 175, 186, 196 San Luis positive element. . .................. 212,213 San Rafael Swell.
Sangre de Cristo Formation, northeastern New Mexico and Texas-Oklahoma Panhandies ............ 67, 69, 70, 71, 74, 76

western Colorado, southern Utah, and northwestern New Mexico......... 177, $179,181,183,184,193,196$ Sangre de Cristo Mountains................ 106, 183 Santa Fe County, N. Mex., interval C....... 75 Quaternary rocks Satanka Shale_._ 109, 111, 134, 136, 140, 141, 144, 190, 192 Saude Formation.................. 136, 145, 150, 152 Scherrer Formation............................ 215 Schoolhouse Sandstone..... 177, 179, 183, 184, 187, 189 Schleicher County, Tex., interval B.......... 41 Schwagerina. ......................... 30, 69, 183, 232, 234 providens... wallsensis_................................ 230 youngquisti............................... 230 sp. ............................................ 230 Second Bone Spring sand.................... 32, 38 Sedgwick basin Sedgwick County, Colo., interval B........ 111 Selden anticline. ............................... 114 Seven Devils Volcanics......................... 236 Seven Rivers Formation................ 47, 75, 76 Seymour Formation........................... 41, 59

Shasta County, Calif., intervals A and B..... 232 interval C-D............................ 236 Shattuck Member, Queen Sandstone......... 48 Shedhorn Sandstone......... 158, 160, 162, 164, 166, 168 Sheffield channel .................. 38, 40, 43, 45, 50, 52 Shelf environments, interval $B$, west Texas Permian basin region..............

Shelf evaporites, interval $C$, west Texas Permian basin region..............

Sherman County, Tex., Cimarron uplift...... 68

Sidewinder Volcanic Series................- 234

Sierra County, N. Mex., pre-Permian rocks . - 204

Sierra del Cuervo.............................. 21 Sierra Diablo........................... 23, 26, 37, 38 Sierra Grande arch......... 65, 67, 68, 70, 71, 74, 76, 79 Sierra Grande uplift....................... 98, 99, 113 Sierra Madre.............................. 129 Simpson Group.............................. 26 Sinbad Limestone Member, Moenkopi Formation.

Sioux County, Nebr., interval C-D......... 116

Siouxana arch.............................. 104 Siouxia_.................. 105, 113 Siouxia uplift.................................. 99 Socorro County, N. Mex., interval B...... 216, 218 pre-Permian rocks....................... 204 Sonora, Mexico Sonoran geosyncline................. 203, 215, 216, 218 Source areas, Allegheny region.................. Sources and environments of deposition, interval A, Allegheny region............ Arizona and western New Mexico.... eastern Wyoming, eastern Montana, and the Dakotas.

northeastern New Mexico and TexasOklahoma Panhandles.............

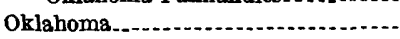
west Texas Permian basin region..... western Colorado, southern Utah, and northwestern New Mexico.........

interval B, Arizona and western New Mexico................................... central Midcontinent region............ eastern Wyoming, eastern Montana, and the Dakotas.................

Middle Rocky Mountains and northeastern Great Basin. northeastern New Mexico and TexasOklahoma Panhandles............ Oklahoma west Texas Permian basin region....western Colorado, southern Utah, and northwestern New Mexico..........
4

137

70

88
36

185

216 113 162

74 90
45 
Sources and environments of deposition-Con. interval C, northeastern New Mexico and Texas-Oklahoma Panhandles..... west Texas Permian basin region..... interval C-D, central Midcontinent region ........... and the Dakotes

Middle Rocky Mountains and northeastern Great Basin.................

Oklahoma

interval $D$, northeastern New Mexico and Texas-Oklahoma Panhandles........................-...-.

west Texas Permian basin region.....

Sources of detritus, interval A, central Midcontinent region.

South Canyon Creek Member, Maroon Formation............... 190, 191, 193 Southern shelf, west Texas Permian basin...- 50 Southern Utah basin................... 203 Spearfish Formation............. 116, 122, 144, 145, 150 Spirifer pseudocameratus................. 236 Spiriferina pulchra........................ 160,166 Spirorbis Spraberry Sandstone....... 34, 38, 44, 45 Starved-basin facies......................... 28 State Bridge Formation . .-. 177, 180, 190, 191, 193, 196 Stearns Shale................................ 104 Stephens County, Okla., interval C-D ..... 90 Stone Corral Formation..... 88, 101, 109, 111, 112, 113 Strain Shale Member, Lykins Formation ...- $\quad 115$ Stratford Formation............ 87 Strathearn Formation..................... 229, 230 Stratigraphic relations, Gulf Coast region.... 14 interval A, Allegheny region.............. eastern Wyoming, eastern Montana, and the Dakotas interval $B$, eastern Wyoming, eastern Montana, and the Dakotas........

Middle Rocky Mountains and northeastern Great Basin.............-

western Colorado, southern Utah, and northwestern New Mexico .........

interval C-D, eastern Wyoming, eastern Montana, and the Dakotas......-. western Colorado, southern Utah, and northwestern New Mexico 190

Strawn Limestone.......................... 25, 27

Strawn Series .......................... 22, 24, 28

Structural framework, interval A, Arizona and western New Mexico.............. 211

interval B, Arizona and western New Mexico............................... 216

Sumner Group...._- 110

Sundance Formation........................ 122

Supai Formation, Arizona and western New Mexico...... 207,208, 209,210,213,214, 215

West Coast region......................... 232, 234 western Colorado, southern Utah, and northwestern New Mexico......... 181,

184,186

Sutton County, Tex., interval B............. 41

lower boundary of Permian............... 27

Permian rocks exposed. . .

Swamps, Allegheny region................ 5

Swineford, Ada, quoted...................... 117

\section{T}

Taloga Formation.................. 115, 117, 145 Tamaulipas, Mexico............. 15

Tansill Formation.............. 47, 48, 49, 53, 75, 76 Tenderfoot Member, Moenkopi Formation_-- 190 ,

Tensleep Sandstone .... 129, 133, 134, 137, 138, 143, 157 Terrell County, Tex., Permian rocks exposed.- 59 Tesnus Formation......... 23, 27 Tessey Limestone, Ochoa Series........ 48, 53, 54, 55 Texas County, Okla., interval C...... 76
Thickness trends, Arizona and western New

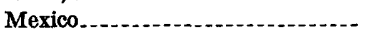
central Midcontinent region eastern Wyoming, eastern Montana, and the Dakotas

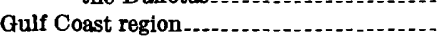
interval $\mathrm{A}$, Allegheny region

Arizona and western New Mexico.... central Midcontinent region.......... eastern Wyoming, eastern Montana, and the Dakotas.

Middle Rocky Mountains and northeastern Great Basm. ........... northeastern New Mexico and TexasOklahoma Panhandles............

Oklahoma.-.........................

West Coast region........................

west Texas Permian basin region...

western Colorado, southern Utah, and northwestern New Mexico...-.-.--

interval B, Arizona and western New Mexico.

central Midcontinent region

eastern Wyoming, eastern Montana, and the Dakotas..................

Middle Rocky Mountains and northeastern Great Basin..............

northeastern New Mexico and TexasOklahoma Panhandles.

Oklahoma.............................

West Coast region.

west Texas Permian basin region...-

western Colorado, southern Utah, and northwestern New Mexico

interval C, northeastern New Mexico and Texas-Oklahoma Panhandles.....

west Texas Permian basin region.....-

interval C-D, central Midcontinent region.....

eastern Wyoming, eastern Montana, and the Dakotas..................

Middle Rocky Mountains and northeastern Great Basin............

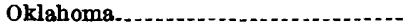

West Coast region...................

western Colorado, southern Utah, and northwestern New Mexico.........

interval D, northeastern New Mexico and Texas-Oklahoma Panhandles...---

west Texas Permian basin region.....

Middle Rocky Mountains and northeastern Great Basin............... northeastern New Mexico and TexasOklahoma Panhandles............

Oklahoma

west Texas Permian basin region.

western Colorado, southern Utah, and northwestern New Mexico-....... 193

Third Bone Spring sand................ 30, 32, 34, 38 Thomas County, Kans., interval A...... 104 Threemile Limestone Member, Wreford Limestone........................... 104 Tippipah Limestone.......... 230 Tobosa basin ............................ 28, 29, 30 Toroweap Formation....... 184, 186, 189, 215, 218, 234 Torrance County, N. Mex., interval B....... 216 interval $C . . . . . . . . . . . . . . . . . .75,76$

Pedernal positive element.

Quaternary rocks_........................ 79 Tosi Chert Member, Phosphoria Formation.. 163, 164,165

Tosi Chert Tongue, Phosphoria Formation. 144, 145 Transitional rocks, Washington Formation... Triassic and younger rocks, absence, Allegheny region.

Arizona and western New Mexico......

central Midcontinent region.

eastern Wyoming, eastern Montana, and the Dakotas.
Triassic and younger rocks-Continued

Middle Rocky Mountains and northeastern Great Basin

northeastern New Mexico and TexasOklahoma Panhandles.

West Coast region

west Texas Permian basin region.

Triassic rocks, western Colorado, southern Utah, and northwestern New Mexico.

Trinity County, Calif., interval A...........

Trinity Group................ 41, 92

Triticites ......... 30, 67, 183, 230

cullomensis............................... 229

ventricosus.

Tubb sand .

Tubb zone.

Tularosa basin.

Tyron

Uddenites

Uinta Mountain anticline.

Uinta Mountains..................... 160, 168, 183, 192

Uncompahgre highland........ 175 , $179,185,189,192,193,197$

Uncompahgre Plateau...................... 186

Uncompahgre positive element...... 180, 207, 212, 213

Uncompahgre-San Luis highland ..........-. 186

Uncompahgre trough ......... 175, 180, 184, 185, 186, 194

Upper Barren Group......................... 2

Upper Barren Series..............................

Upper Washington Limestone................. 2

Val Verde area, Texas. Val Verde County, Tex., Permian rocks exposed........................................

Val Verde geosyncline............................. Val Verde trough, west Texas Permian basin, interval $A$................... 34, 35, 36, 37 west Texas Permian basin, interval B .... $\quad 37$ $38,40,41,43,44$ interval C lower boundary of Permian paleotectonic implications. .......... 28, 29, 58 Pennsylvanian rocks. ............ 21, 23, 24,25

Vale Formation. . ....................... 39

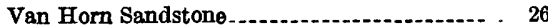
Verden Sandstone Member, Marlow For-

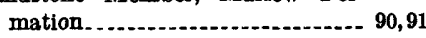

Victorio flexure $\quad 41,45$ Victorio Peak Limestone. ............ 37, 38, 40,41, 44 Vidrio Limestone Member, Word Formation. .........................................

Virgil Series

\section{W}

Waagenoceras dieneri........................ 221 Wabaunsee County, Kans., interval A....... 104

Wasatch Range. . .

Washington (State), formations and upper boundary, interval A interval $B$.

interval $\mathrm{C}-\mathrm{D}$

\begin{tabular}{ll}
235 \\
\hline
\end{tabular}

formations underiying Permian......... 229 Washington County, Colo., interval B.....-. 111 Washington County, $\mathrm{Pa}$., interval $\mathrm{A} . . . . . . . . \quad 2$ Washington County, Utah, interval A.......- 184 Washington County Group.................. 2 Washington Formation.................. 2,3 Wayne County, Utah, interval A........... 183, 185

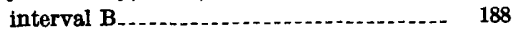
Waynesburg coal bed.......................... 2,3,5 Waynesburg Sandstone Member, Washington Formation...................... 2,3

Weber Quartzite.................... 157 Weber Sandstone........... 158, 177, 179, 181, 183, 184 Webster County, Iowa, Permian rocks......... 7 
Weld County, Colo., interval B.

Page Wellington Formation, central Midcontinent region......... 101,109, 110,112,113,120 northeastern New Mexico and TexasOklahoma Panhandles........... 70,72 Oklahoma............. 87,88,89,90 Wells Formation

Werner Formation. .................... 13, 14,15 West Coast region, defined. . ............. 229 West Texas Permian basin, relation to Matador arch.

West Texas Permian basin region, defined..-- 21 Wet Mountains................ 98,99, 106, 113,117, 120 Whatcom County, Wash., interval A......-. 232 Wheeler County, Tex., interval B. thickness, Permian rocks..

Whetstone Mountains

White Canyon, Utah.

White Mountain Plutonic-Volcanic Series...
White Pine County, Nev., interval A......

Page

interval $B$

interval $C-D$.

paleotectonic implications..... 230

White Rim Sandstone Member, Cutler Formation......... 183, 184, 187, 189, 190, 195

White River Plateau.

Whitehorse Formation. .............. 117

Whitehorse Group............... 48, 73, 75, 89, 90

Whitehorse Sandstone................... 115, 116, 144

Wibaux County, Mont., interval B........... 141

Wichita Formation...................... 86, 87

Wichits Group................... 30, 38, 39, 69, 71, 72

Wichits Mountains......... 68, 85, 86, 87, 88, 89, 90,92

ancestral. ............................ 52

Wichita positive element

Wichits ridge................................ $\quad 89$

Williston basin......... 137, 140,141,145, 146, 148, 150

Wind River Basin............................. 134, 140

Wind River Range............................ 160
Page

Wolf Camp Hills.

Wolfcamp Formation................... 28, 30, 33, 35

Wolfcamp limestone..................... 32, 34

Wolfcamp Series............................ 34

Wood River Formation. . . .............. 233

Wood Siding Formation....... 86, 98

Woodford Shale

Woodside Formation........... 160, 163, 164, 166, 168

Word Formation.............. 40, 47, 50

Wreford Limestone........................ 100, 103

Wyoming lineament.......................... 150

\section{$\mathbf{Y}$}

Yabeina packardi............................. 236

Yates Formation.

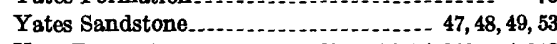

Yeso Formation......... 44, 69, 71, 72,74, 209, 214, 218

$\mathbf{Z}$

Zuni positive element....... 207,212,213,214, 216,219 